\title{
الغير في التنفيذ الجبري وحمايته هن أثاره
}

\author{
shel \\ د / طلعـت يـوسـف خاطـر \\ أستاذ قانون المرافعات المساعد \\ كليتالحقوقـ جامعت المنصورة
}




\section{هقدمة}

اتجهت التشريعات المختلفة إلى الحماية السابقة للغير علي صدور الحكم، وذلك

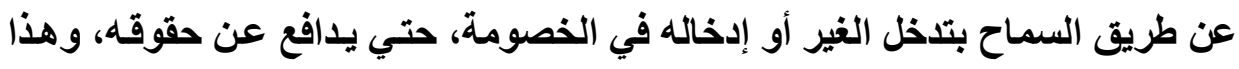

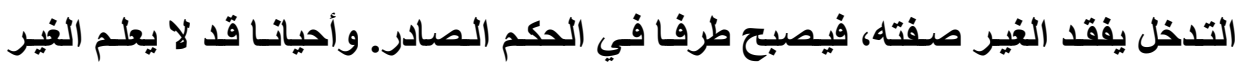

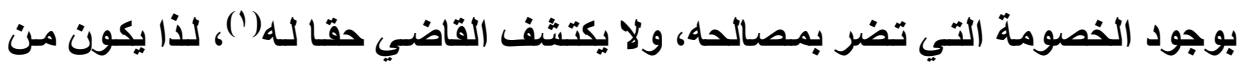

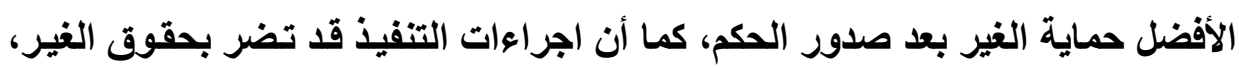
فيلزم حماية الغير أثناء التنفيذ الجبري.

تقتصر آثار التنفيذ كقاعدة عامة علي طرفي الحقى في سند التنفيذ، وهما طالب التنفيذ والمنفذ ضده(")، غير أن المشرع عند معالجته لأطراف خصومة التنفيذ(") قد الد

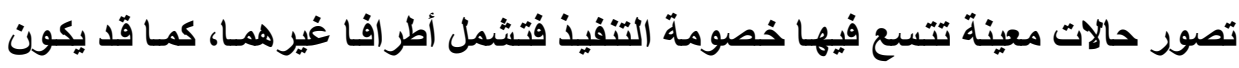
للغير دور في خصومة التنفيذ لوجود علاقة بينه وبين المدين أو لصفة معينة فيه أو

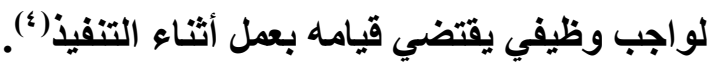

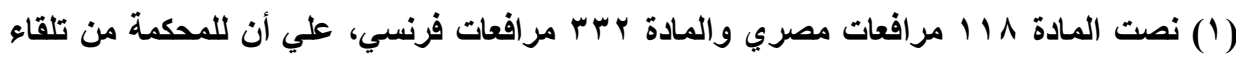
نفسها أن تأمر بإذخال من تري إدخاله لمصلحة العدالة أو لإظهار الحقيقة.

(2) S. GUINCHARD et T. MOUSSA, droit et pratique des voies d'exécution,

D. 2004, $\mathrm{n}^{\circ}$ 100, 31, Cass. 2 civ. 21 janvier 1996, Bull. civ., 11, ${ }^{\circ}$ 24, p. 15.

(ए) د/ أحمد هندي، ود/ أحمد خليل، قانون التنفيذ الجبري، دار المطبوعات الجامعية، 9991، صמז

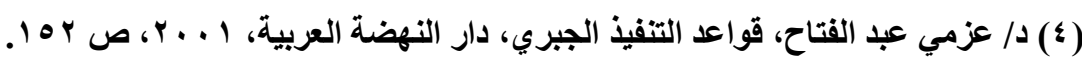


ويجب قانونا حماية الغير أثناء التنفيذ الجبري، ويرجع ذلك إلى مبدأ أساسي

وهو احترام قاعدة الحجية النسبية للسند التنفيذي، فلا يجوز المساس بحقوق شخص لم يكن طرفا في السند التنفيذي، حيث يذهب الفقهـ(') إلى أن السند التنفيذي لا يجوز تنفيذه إلا بين أطر افه الذي صدر فيمـا بينهم، فـلا يفيد الغير ولا يضره، وذلك طبقا للقاعدة الرومانية الثهيرة. Res inter alois judicata aliis nec nocere nec prodesse potest والمـادة 1 ـ 1 من قـانون الإثبـات المصري، وذلك بنصهما علـي أن الأحكام لا تحوز حجيـة الـشيء المحكـوم فيـه إلا فـي نـزاع قـام بـين الخـصوم أنفسـهم دون أن تثتغيـر صفتهم()، وبالتالي فلا يضار الغير من تنفيذ السندات التنفيذية.

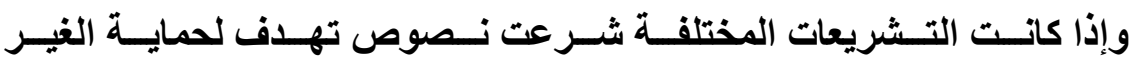
أثنــاء التنفيـ، إلا إنهـا تحتــاج إلـى التحليـل خاصـة في الأحـوال التـي تتشـابك فيهـا

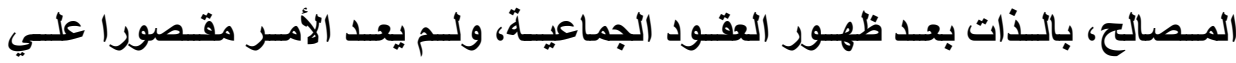
الفرض المبسط الذي يتحدد بنـاء عليهه أطراف التنفيذ والغير في أشـخاص محددين

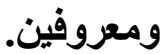

(1) Lacoste paul, De la chose jugee en matrière civile, criminelle et administrative, 3e ed., sirey, 1914, $n^{\circ} 471$, Bonnier, traite théorique et pratique des preuves en droit civile et criminel, t2, 3e éd., paris, $1862, \mathrm{n}^{\circ}$ 877, Constantin Melinesco, Etude sur l'autorité de la chose jugée en matière civile, thèse, Paris, 1913, p. 106, Roger Perrot, "Autorité de la chose jugée au civile sur le civil", Juris classeur de procédure civile, fasc. A.C. proc. Civ., art. 116-148, t 3, Paris, 1955, $n^{\circ} 128$.

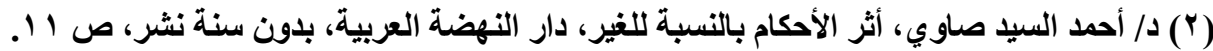




\section{سنشير في هذه الاقدمة إلى النقاط الآتية:}

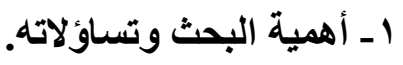

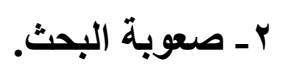

بـ - منهجية وأهداف البحث.

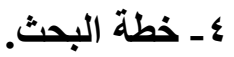

\section{ا - أهميهية الدراسة وتساؤلاتها:}

نظرا لأن الغير قد يضار من تنفيذ السند التنفيذي، وذلتك يرجـع إلى تشـابك

العلاقات القانونية بحيث يصعب فصل بعضها عن بعض، الأمر الذي يترتب عليه إمكانية

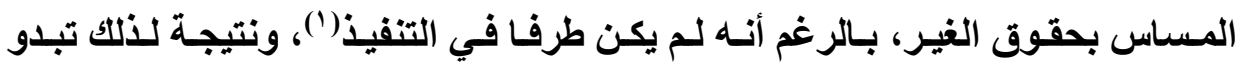

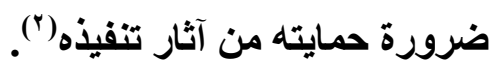

كما قد يضار الغير بسبب خطأ المعاون أثناء إجراء الحجز، حيث يمكن تصور

ثمة خطأ من المعاون بقيامه بالحجز علي مال مملوك للغير، حيث قد يكون هناك خطأ في المعلومات المقدمة من طالب التنفيذ، ولا سيما وأن الحجز قد يقع في غيبة المدين، كما أنه في حالة ما وقع أثناء وجود المدين، فمن المتصور أن يتواطأ مع المعاون أو أن يقوم بالتدليس عليه وتوجيهه إلي توقيع الحجز علي أموال يعلم يقينـا بتعلق حق الغير

(1) الإثارة السابقة، ص ابr I.

(2) Charels Debbasch, Procedure administrative contentieuse et procedure civile, $1962, \mathrm{n}^{\circ} 144$. 
بها، وخاصة أن المنقولات تعتبر محجوزة بمجرد ذكرها في محضر الحجز، ولذلك تبدو أهمية حماية حقوق الغير أثناء التنفيذ الجبري.

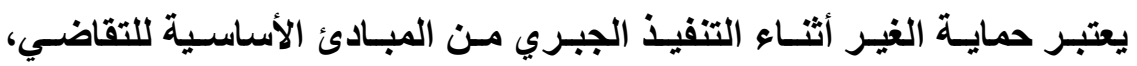
ويتأسس ذلك على قاعدة أصولية قوامها وجوب اطمئنان الغير إلى حمايـة حقوقه، كمـا أن الغير لم يكن ممثلا في السند التنفيذي، ولم يدافع عن حقوقه أثناء تكوين السند، إلي جانب أن السند التنفيذي لا يكون حجة علي غير أطرافه، ولا يجوز التنفيذ إلا علي الأموال المملوكة للمدين، لذا يجب تمكين الغير من الدفاع عن حقوقه إذا مست أثناء إجراءات التنفيذ الجبري.

لقد حدد القـانون إطـار معينـا لممارسـة حق التنفيذ بمـا يحقق المسـاواة بـين أطرافه ويحمي الغير، ويمنـع التعسف أو الإسـاءة في استعماله، حيث كفل لكل مـن أطر افه والغير ضمانات موضوعية وإجرائية. إذا كان متاحا للائن الحجز علي أي مـال من أموال المدين، فإن هذا لا يمنع من مساعلة الدائن إذا تعسف أو أسـاء في استعمال حقه في التنفيذ الجبري، فلا يجوز له القيام بالحجز علي أموال مملوكة للغير. وإدراكا لأهمية حماية الغير أثناء التنفيذ الجبري، فقد حرصت بعض القوانين على تنظيم القواعد والإجراءات التي تحسي حقوق الغير أثنـاء التنفيذ، حيث نظمـت حق الغير في الاعتراض علـي إجـراءات التنفيذ الجبري مـن خـلال الاستشكال في التنفيذ، وإمكانيـة رفع دعوي موضوعية للمطالبة بملكيته للمنقول أو العقار وبطلان

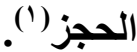

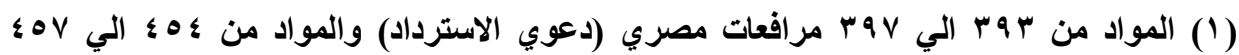

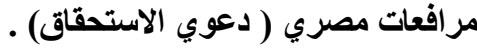


والواقع أن موضوع الغير في التنفيذ الجبري، يزخر بالعديد من التساؤلات التي تبحث عن إجابة، فإنتا لم نجد ـ للأسف ـ دراسة تجيب عن الكثير منها، حيث لا توجد دراسـة تعـالج الموضوع من كافة جوانبه بـالعمق المطلوب، ولذا فإن البحث يقتضى تنـاول العديـ مـن الموضـوعات التـي تتسم بـالغموض، ويطرح العديــ مـن التساؤلات الآتية: مـا هو المقصود بـالغير في التنفيذ الجبري؟ وهل يمكن للشخص أن تكون لـه صفتان في التنفيذ ( غير وطرف في الإجراءات)؟ وهل للغير دور في سير إجراءات

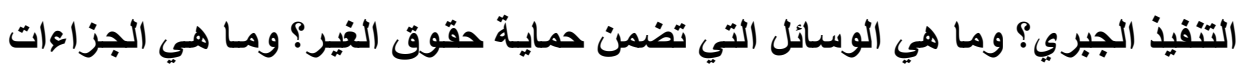
التي تترتب على التعدي علي حقوق الغير أثناء التنفيذ؟ وما هو الوقت الذى يجوز فيهه اعتراض الغير على إجراءات التنفيذ الجبري؟ وهل يمكن الحجز علي أموال مملوكه. للغير كاستثناءً

لاثك أن الإجابة على هذه التساؤلات تقتضى التعرض لبيان المركز القانوني

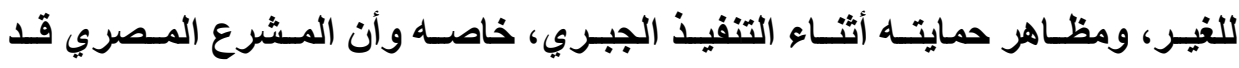
خطا خطوات واسعة نحو حمايـة حقوق الغير أثناء التنفيذ الجبري، فبإذا كـان قد أجـاز التنفيذ علي الغير في بعض الفروض، إلا أنه وضع لله ضمانات تكفل حمايته من تعسف الحاجز، وتمكنه من الدفاع عن أمواله وحقوقه في مواجهة إجراءات التنفيذ الجبري.

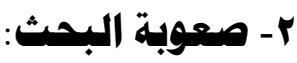

نظرا لتظور العلاقات بين الأشخاص وتعددها وتشعبها، ومع ظهور العقود التي تطول مجموعـات من الأشخاص وتجمعهم علي مصالح مشتركه، أصبح من الصعب حصر الحق في شخص معين أو أثخاص محددين، كما أن الالتزام لم يعد مقصورا علي شخص محدد يمكن أن يكون هو وحده الملتزم بالتنفيذ، ولعل هذا هو مـا دفعنـا إلى 
محاولة التعرض لتلك التطورات، من خلال البحث عن الأشخاص الذين تثبت لهم صفة الأطراف والغير في خصومة التفيذ، حتي لا يضار الغير من إجراعات التنفيذ الجبري، ووسائل حمايته عند المساس بحقوقه.

إذا كانت حماية الغير أثناء التنفيذ الجبري ضرورة منطقية تتفق مع مبادئ العدل والإنصاف، فـإن تـــاول الموضـوع بالبحث والدراسـة ليس مهمـة يسيرة، بـل تعد مـن أصعب الموضوعات التي يتعرض لها الباحث في قانون المرافعات، نظر المـا تثيره من مشكلات في مختلف جوانبها، ولعل نقطة الصعوبة الرئيسية في هذا الموضوع تكمن في تشعب موضوعات مفهوم الغير وحمايته أثناء إجراء التنفيذ الجبري، وعدم اتفـق الفقه في تحديد مفهوم أثر الأحكام بالنسبة للغير (')، فـالبعض يحصر الحجية فيمـا بين أطراف الدعوي والممثلين فيها، ورأي ثـان يعتبر الأحكام حجة في مواجهة الكافـة، ورأي ثالث يفرق بين القضاء الثخصي والقضاء الموضوعي، فالنسبة للأولـي لها حجية نسبية، أما الثانية فالحجية تكون مطلقة، وهذا الامر أثر علي حق الغير أثناء التنفيذي الجبري(ץ)، فقد تمتد حجية الأحكام لأشخاص من الغير. كما أن صعوبة البحث تظهر في أن النظام القانوني للغير لله طبيعة خاصة من حيث دوره في خصومة التنفذ، وعلاقته بأطر اف الخصومة، كما أنه يوجد صعوبة حول حالات التعدي علي حقوق الغير، وإثبات ذلك، ووسائل حمايته، خاصة مع تشعب وتعدد إجراعات التنفيذ الجبري.

(1) د/ بثندي عبدالعظيم أحمد، حماية الغير في قانون ال بثندي مرافعات، رسالة، القاهرة، .99 19، صמג. (Y) د/ أحمد السيد صاوي، أثر الأحكام بالنسبة للغير، المرجع السابق، صY Y Y I. 


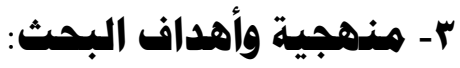

نظرا لتعدد معني الغير في مجـال القانون، واختلافهـ بـاختلاف النظـام المنسوب

إليه، فإن نطاق هذا البحث سوف يقتصر علي حمايـة الغير في مجال التفيذ الجبري، وذلك حتي يكون موضوع البحث مركزا، ويمكن معالجته تفصيلا دون أن يؤدي تشعبه إلى خلل في تناسث هيكله.

ويدور موضوع البحث حول مفهوم الغير ودوره وضماناته في التنفيذ الجبري، ولهذه الإثكالية طبيعة خاصة، وذلك لأن الغير أجنبي عن أطراف التنفيذ، وسوف تعتمد

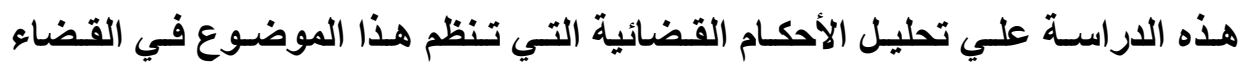
المصري مقارنة ببعض أحكام القضاء الأجنبي، خاصة القضاء الفرنسي، وذلك لأهمية هذه المنهجية في تبيان نقاط القوة والضعف، ثم القيام بمقارنـة هذه الموضوعات في بعض القوانين اعتمادا علي الأدبيات السابقة التي تتاولت هذه الموضوعات. وذلك من أجل استخلاص الإطـار العـام الذي يهيمن عليه،، وسـنتبع المـنهج التحليلي المقـارن، وسنحاول تقيم ضمانات الغير أثناء التنفيذ من الناحية العملية.

\section{وتقتضى دراسة إشكالية الغير في التنفيذ الببري بحث الموضوعات الآتيهة:}

- بيان المركز القانوني للخصوم وللفير في خصومة التنفيذ. - رسم الاطار الأي يبين دور الغير في خصومة التنفيذ. - تحديد الحالات التي تظهر التعدي علي حقوق الغير. - بيان الوسائل القانونية التي تحمي الغير أثناء التنفيذ الجبري وتجنب الإضرار به. - بيان موقف القانون المقارن من حماية الغير أثناء إجراءات التنفيذ. - رسم حدود المسئولية للأطر اف التفيذ في حالة الإضرار بالغير. 
نري أن إثكالية الغير في التنفيذ الجبري تقتضي تحديد صفة الغير والأطراف في التنفيذ الجبري، ودور الغير أثنـاء التنفيذ، ثم بيـان وسـائل حمايته. فنقوم بتقسيم البحث إلى بابين، وفصل تمهيدي علي النحو التالي:

وتقتضى دراسة إشكالية الغير في التنفيذ بمث الموضوعات الآتية:

الفصل التههيدي: صفة أطراف التنفيذ الجبري.

الباب الأول: صفة الغير في التنفيذ الجبري ودوره.

الباب الثاني: حماية الغير في التنفيذ الجبري 


\section{الفصل التمهيدي \\ صفة أطراف التنفيذ الجبري}

لاستجلاء معني الغير بالنسبة للتنفيذ الجبري، يجب تحديل من يكون طرفا في

التنفيذ، إذ علي ضوء هذا التحديد يمكن أن يفهم من يكون غيراً. والواقع أن أطراف التفيذ هم الأشخاص الذين يكون السند التنفيذي حجة في مواجهتهم بنفس صفاتهم

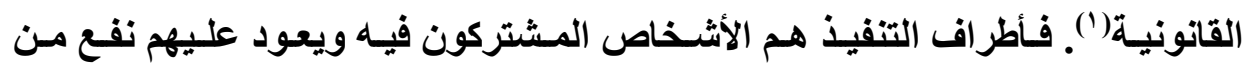
إجراءه أو يتحملون عبئا من ورائه، وينطبق هذا التعريف علي طالب التنفيذ والمنفذ ضده، وخلافهما، ومن يستقيد من السند التنفيذي(). سنشير في هذا الفصل إلى ماهية صفة أطراف التنفيذ، ثم نبحث أنواع الصفة في التنفيذ، وذلك في المباحث الأتية: 


\section{المبحث الأول \\ هاهية صفة أطراف التنفيذ}

سـنعالج في هـا المبحث، تعريـف الصفة في التنفيذ واهميتهـا، وذلـك في

المطلب الأول، أما المطلب الثاني، فيخصص لمعيار الصفة في التنفيذ، وذلك علي النحو التالي:

\section{المطلب الأول \\ تعريف الصفة في التنفيذ الجبري وأهسيتها}

سنشير إلى تعريف الصفة في التنفيذ، ثم نبين أهميته الصفة في التنفيذ، وذلك

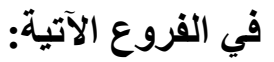

\section{الفرع الأول \\ تعريف الصفة في التنفيذ}

يقصد بالصفة في الدعوي، صساحب الحق في رفع الدعوي أو هو من يحق

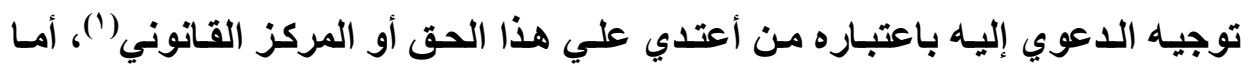
بالنسبة للصفة في التنفيذ فيقصد بها أن يكون طالب التنفيذ صساحب مصلحة شخصية

(1) د/ أحمد هندي، الصفة في التنفيذ، دار الجامعة الجديدة، .... ؟، صب r. 
مباشرة، أي أن يكون هو صاحب الحق أو المركز القانوني المعتدي عليه، والمطلوب

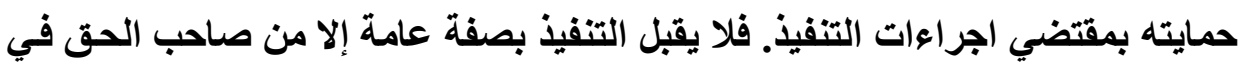
السند التنفيذي (1) أو من ينوب عنه كالوصي أو الوالي ألو الو الوكيل(").

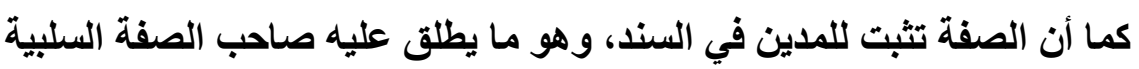

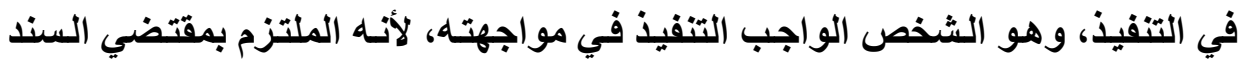
باعتباره الطرف السلبي في التنفيذ.

ويمكن التعرف علي صاحب الصفة في التنفيذ من خلال السند التنفيذي(")، الذي الذي

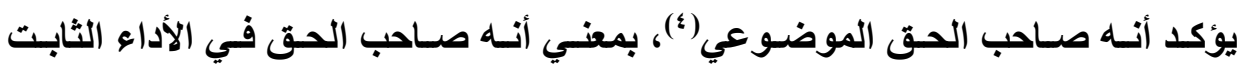

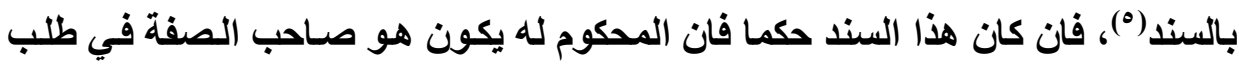
التنفيذ(") والمحكوم عليه صاحب صفة في التنفيذ عليه.

(1) S. GUINCHARD et T. MOUSSA, droit et pratique des voies d'exécution, op. cit., $\mathrm{n}^{\circ}$ 100,31, Cass. 2 e civ. 21 janvier 1996, op cit., 11, $\mathrm{n}^{\circ} 24$, p. 15.

(2) Id. 141.

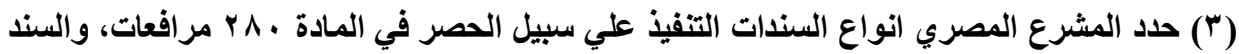

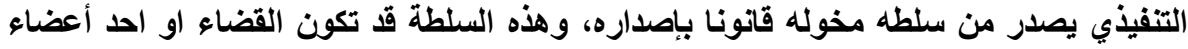

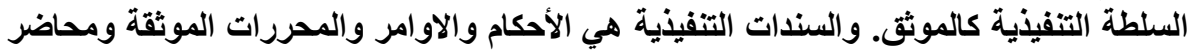

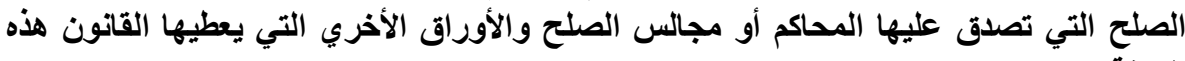

(4) S. GUINCHARD et T. MOUSSA, droit et pratique des voies d'exécution, op. cit., $\mathrm{n}^{\circ} 100.31$.

(0) د/ عبد العزيز خليل بديوي، الوجيز في قواعد وإجراءات التنفيذ الجبري والتحفظي في قانون

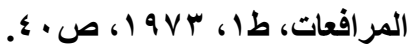

S. GUINCHARD et T. MOUSSA, droit et pratique des voies d'exécution, op. cit., $\mathrm{n}^{\circ} 111,31$.

$$
\text { (†) د/ أحمد هندي، الصفة في التنفيذ، المرجع السابق، صYr. }
$$




\section{الفرع الثاني \\ أهمية الصفة في التنفيذ}

ترجيع العلـة مـن ضـرورة تـوافر الصفة في التنفيـذ، إلـى أن صـاحب الـصفة

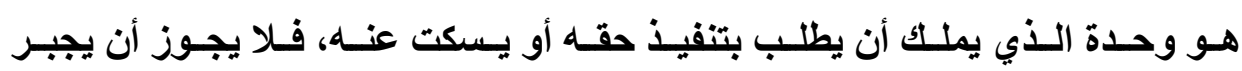

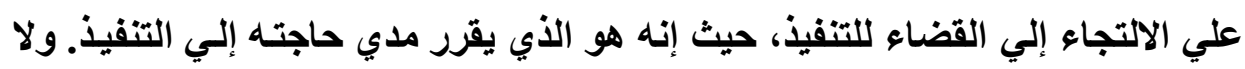

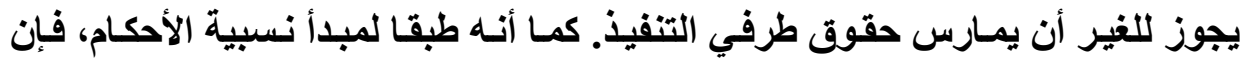
الحكم الصادر في دعوي رفعها غير صـاحب الحق لا تثبت لأحد حقـا ولا علـي أحد التزامسا. كذلك الملتزم في السند هو صـاحب الصفة باعتباره الطرف السلبي الواجب

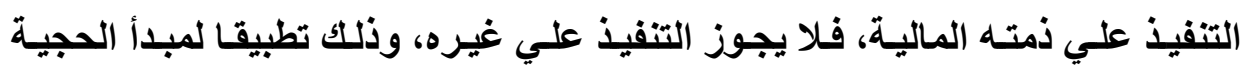
للسندات.

ويكون التنفيذ باطلا إذا بدء التنفيذ من غير صاحب الصفة، بصرف النظر عن

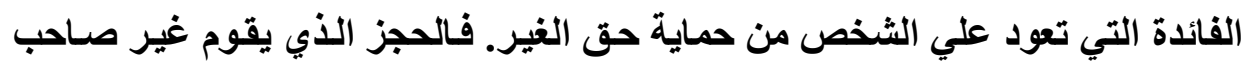

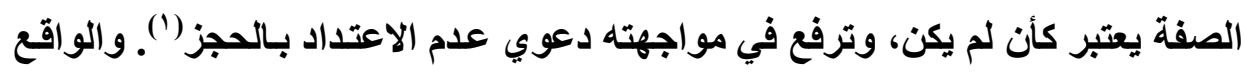
أن مسألة تقدير الصفة مسألة قانون، أي أنها ليست من إطلاقات قاضسي التنفيذ، وإنما

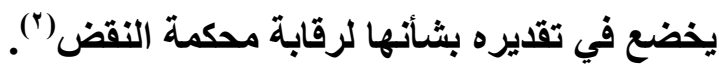

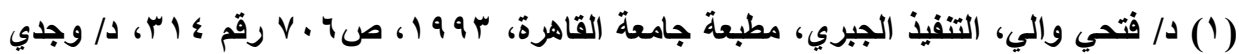

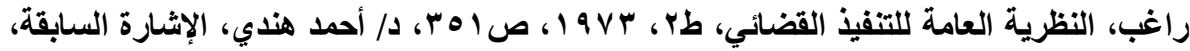


ويري بعض الفقه أن الصفة شرط لقبول اللدعوي أمسام المحكمة، وكذلك تعتبر شرط لقبول اتخـاذ إجراعات التنفيذ(')، فهي شرط لقيـام الحق في التنفيذ(؟)، فالمـادة الثالثة مرافعات تثترط الصفة لقبول أي طلب سواء قدم هذا الطلب في دعوي أو في طعن أو طلب بالتنفيذ.

ونـري أن شـرط الـصفة في التنفيذ شـرط لـصحة الإجـراعات، وهـذا الـشرط

يختلف عن شرط المصلحة اللازم لرفع الدعوي، فهو شرط لقبول الدعوي باعتباره يتعلق بسلطة الالتجاء إلى القضاء. وبنـاء عليها إذا باشـر إجراءات التفيذ غير ذي صـفة كانـت الاجـراءات باطلـة، ويجـوز التمسكك بـالبطلان عـن طريـق المنازعـة في التنفيذ.

\section{الاملب الثاني \\ هميار الصفة في التنفيذ}

سنشبير إلى موقف المشرع المصري والفرنسي من معيار الصفة في التنفيذ، ثم نبين موقف الفقه من معيار الصفة في التنفيذ، والرأي المختار في معيـار الصفة في موي مني التنفيذ، وذلك في الفروع الآتية:

$$
\text { (1) د/ أحمد هندي، الصفة في التنفيذ، المرجع السابق، ص99 ؟. }
$$

(2) S. GUINCHARD et T. MOUSSA, droit et pratique des voies d'exécution, op. cit., $\mathrm{n}^{\circ}$. 111, 21. 


\section{الفرع الأول \\ هوقف المشرع المصري والفرنسي}

نظرا لأن المشرع المصري نص علـي شروط الدعوي في المـادة الثالثة مـن

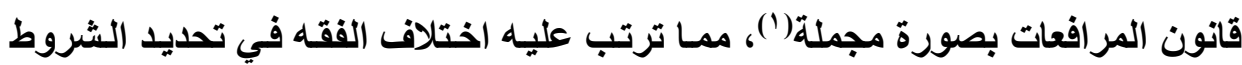
الواجب توافرهـا لقبول الدعوي سـواء الدعوي العاديـة أو دعوي التفيذ، فقد ذهب البعض إلس ضرورة توافر شرطوجود الحق والمصلحة وموضوع النزاع والصفة، بينما ذهب رأي أخر إلي الاكتفاء بالمصلحة(؟)، بينما ذهب رأي إلي أن المصلحة ليست شرطا لقبول الدعوي وإنما هي شرط لوجودهـا، وحدد شروط قبول الدعوي في ثلاثة شروط، وجود الحق والاعتداء عليه وتوافر الصفة. فبإذا توافرت هذه الشروط الثلاثة توافرث المصلحة في الاعوي.

والواقع أن المشرع المصري يركز علي شرط المصلحة لقبول الدعوي ويوجب

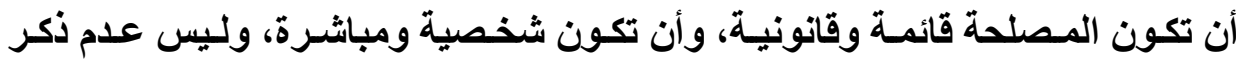

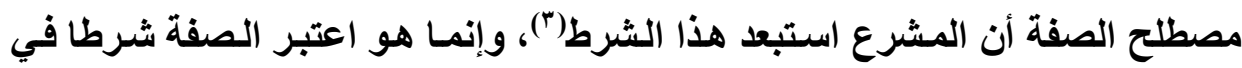

(1) تتص المادة ץ مرافعات علي أنه "لا تقبل أي دعوى كما لا يقبل أي طلب أو دفع استناداً لأحكام

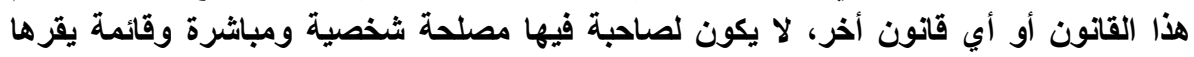

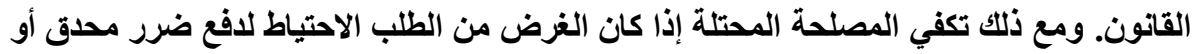
الاستيثاق لحق يخشى زوال دليله عند النزاع فيه".

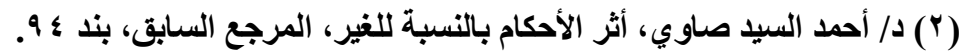

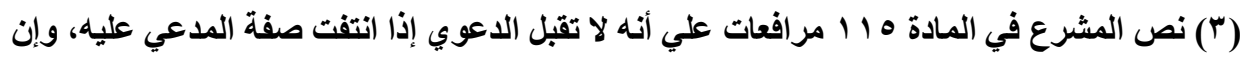

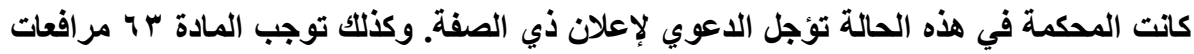

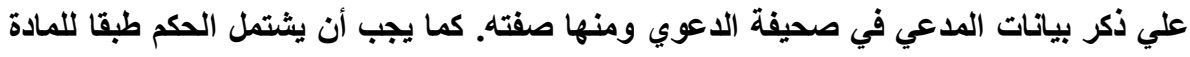

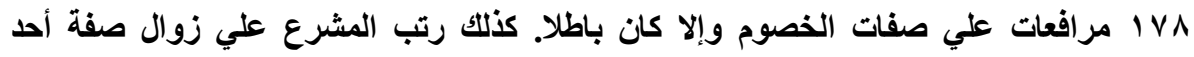

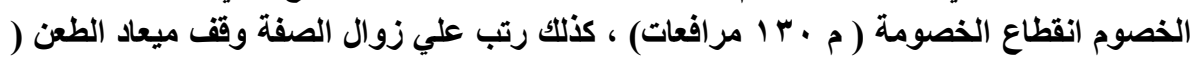

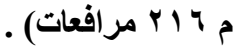


المصلحة، وذلك باشتر اط أن تكون المصلحة (شخصية ومباشرة)، فتوافر المصلحة لا يغني عن توافر شرط الصفة(')

ويالنسبة للقـانون الفرنسي فقد تحدث صراحة عن المصلحة والصفة كشرط لقبول الدعوي، حيث نصت المـادة اب مر افعـات أن اللاعوي تتاح لكل من لـه مصلحة مشروعة لكسب أو لاحض ادعاء مع الأخذ في الاعتبار الأحوال التي يسند القانون فيها حق التقاضي إلى أشخاص محددين لهم وحدهم صفة إثارة أو رد ادعاء، أو لهم صفة في الدفاع عن مصلحة معينة. كمـا أن نص المسادة ب r r مرافعات فرنسي ذكرت أمثلة لعدم قبول الدعوي ومنها تخلف شرط الصفة. ويلاحظ أن المشرع المصري لم يورد نصا عاما لتحديد صاحب الصفة في السند التنفيذي، في مختلف السندات، وإنمـا يوجد نص خـاص بالأحكام باعتبار هـا أهم صور تلكك السندات ويمكن حمله إلى سـائر تلك الصور الاخرى من السندات، حيث نـص المشرع بطريقة عامة وغير مباشرة عن الخصم الأي لله صفة في طلب تنفيذ الحكم(")،

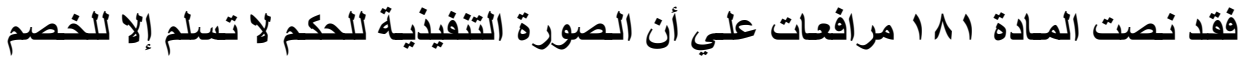
الأي تعود عليه منفعة من تنفيذ الحكم. أما المشرع الفرنسي فقد نص في المـادة ه ؟ ؛ مرافعـات علـي أنـه "يمكن لأي من الخصوم استلام نسخة من الحكم مزودة بالصيغة

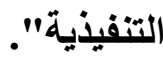

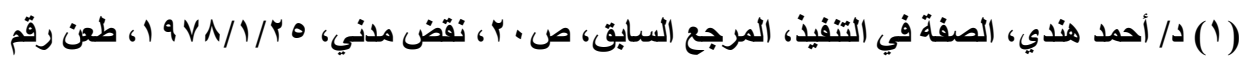

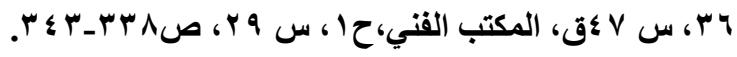

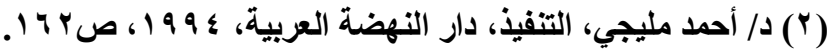




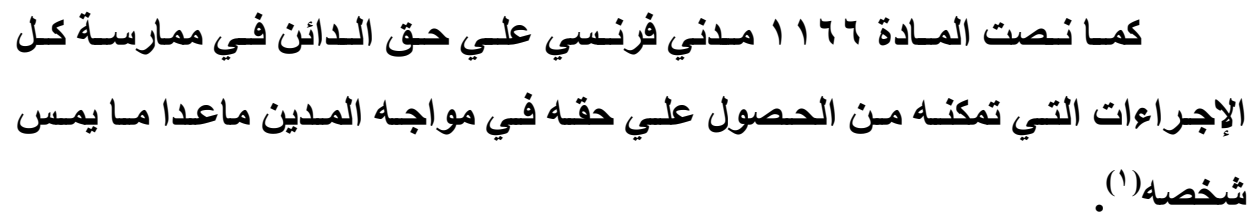

\section{الفرع الثثاني \\ هوقف الفقه هن هميار الصفة في التنفيذ}

اختلف الفقه في تحديد صاحب الصفة في التنفيذ، وذلك علي النحو التالي:

\section{الاتجاه الأول: صاحب الصفة هو صاحب الصلحة في التنفيذ:}

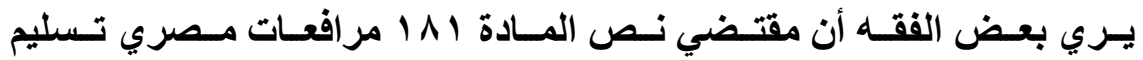
الصورة التفيذ للخصم الذي تعود عليه مصلحة من التفيذ، حيث إن المشرع قصد من

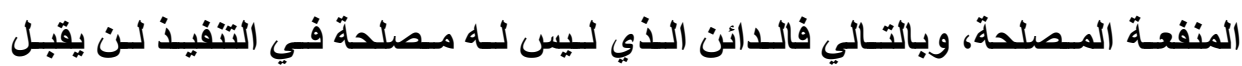
طلبـه في تسلم الصورة التنفيذيـة، وبنـاء علـي ذلـك لا يجـوز للــائن العـادي التنفيـ علي مال المدين المحمل برهن أو امتياز إذا كاتت الحقوق المضمونة بالرهن أو الامتياز

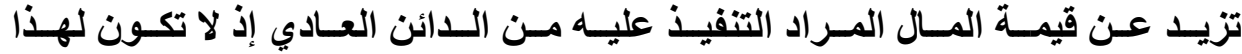
الأخير مصلحة في إجراء التففيذ. كذلك لا يجـوز للدائن مـرتهن متــأخر في المرتبـة التقديم بطلب التفيذ علي أموال المدين، طالما لا تكفي للوفاء بالدائن المتقدم عليه في

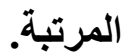

(1) Cass. Civ. 25 septembre 1940, D. 1943, p. 133. Note Carbonnier. 
ومن تطبيقات ذلك ايضا مـا نصت عليه المـادة ب ـ ـ مرافعات التي تجيز لأحد اللائنين أن يطلب من القاضي الإذن له بـالحلول محل الدائن مباشر الإجراءات، وذلك لوجود مصلحة أقوي لله(')

\section{الاتجاه الثاني: صاحب الصفة هو صاحب المنفعة في التنفيذ:}

يري رأي آخر إلي أن المشرع المصري يتحدث عن خصم لله منفعة من تنفيذ الحكم، وذلك في نص المـادة 1 المرافعات، وأنـه لم يستعمل هذا اللفظ في أية مـادة أخري، وأن المنفعة ليست بالتأكيد هي المصلحة، وإلا لكان المشرع استخدم تلك الكلمـة الأخيرة، التي درج علـي استعمالها في مـواد عديدة، لعل أهمها نـص المـادة الثالثة مرافعات، حيث جعل المصلحة مناط الدعوي والطلب والدفع، ويمكن القول أن المشرع قصد أو عمد إلى اختيار تلك الكلمـة، كي يوسـع من دائرة الاشخاص الذين يمكن لهم طلب تنفيذ الحكم، وسائر السندات التنفيذية، فكل شخص تعود عليه منفعة أو فائدة- آيا كاتتـ من جراء التنفيذ، له أن يطلب صورة تنفيذية من السند، حتي يتسنى لله تنفيذه جبرا، والمشرع بذلك المسلك انما استعمل كلمة مرنة لا تحصر صاحب الصفة، في طلب التنفيذ الجبري، فقط في المحكوم له، خلافا لما يذهب إليه البعض من أن الخصم الذي تعود عليه منفعة من تنفيذ الحكم هو المحكوم له، وهو وحدة صاحب الحق في التنفيذ، وأن الصورة لا تسلم لمن لم يكن ماثثلا في الخصومة مهما كاتت صلتة بالدائن("). ونظرا لمرونة وعدم تحديد نص المـادة 1 ا 1 مرافعات، فيمكن القول بأن لأي شخص تعود عليه فائدة من تنفيذ الحكم أن يطلب صورة تنفيذية منه، حتي ولو لم يكن 
طرفا في الدعوي التي صدر فيها الحكم المطلوب تنفيذيـة، أي حتي لـو لـم يكن محكومـا لـه، ويقترب مـن هذا المعنـي نص المـادة الثامنـة مـن قـانون التوثيق: لا تسلم صور المحررات الموثقه إلا لأصحاب الثأن" وإن كـان اصطلاح أصحاب الشأن يمكن حمله علي أطراف المحرر فقط. أما اصحاب المنفعة فلا يتطابق مـع أطراف الدعوي الصادر فيها الحكم أو أصحاب المصلحة والصفة فيها' ') ويلاحظ أن النص الفرنسي قد كان أكثر صراحة وتحديدا، إذ حصر المـادة ه ؟ ؛ مرافعـات استلام الصوة التنفيذيـة ف الخصوم، وبالتـالي فـإن مـن لم يكن خصما في الاعوي ليس له طلب تنفيذ الحكم.

\section{الفرع الثالث}

\section{الرأي الاختار في هميار الصفة}

نلاحظ أن المشرع المصري استخدم لفظة الخصم التي تعود عليه بفائدة، وهذا المغني واسـ، ويمكن أن يثير الكثير من العقبات في الواقع العملي، حيث قد تكون الفائدة اقتصادية فقط، وقد يكون الثخص من الغير ويعود عليه فائدة من التنفيذ، ولا يكون صـاحب الحق الشخص في التنفيذ، فكان مـن الأولـي أن يستخلم المشرع لفظ صاحب الحق المذكور في السند التنفيذي، لأن هنـاك فارقا بين الفائدة وصساحب الحق الشخصي والتي يقصد بها الصفة. في الواقع انتـا لا نسلم بـالرأي الذي يذهب إلي أن الصفة هي ذات المصلحة، ونري أنه لا يمكن الخلط بين شرط الصفة وشرط المصلحة، فشرط الصفة يقصد بـه أن 
الدائن صاحب الحق المذكور في السند، أما شرط المصلحة فيقصد به الفائدة التي تعود عليه من التنفيذ، وهذا الشرط متطلب وفقا للقواعد العامـة، فوفقا للمـادة ب مرافعـات التي تنص علي أنه "لا يقبل أي طلب أو دفع لا يكون لصاحبه فيه مصلحة قائمـة يقرهـا القانون". فإذا لم يكن لطالب التنفيذ مصلحة فلا يقبل طلبه، وبالتالي يقصد بأصحاب الصفة في التنفيذ الأشخاص أصحاب الحق المشتركين فيـه، ويعود عليهم نفـع مـن إجراعاتـه أو يتحملـون عبئـا مـن ورائه، ولا ينطبق هـا التعريف بالطبع علي سلطة التنفيذ أي قاضي التنفيذ ومحضر والغير، وينطبق ذلك علي طرفي السند التنفيذي وهما طالب التنفيذ والمنفذ ضده('). إذن طرفا التنفيذ هما المنفذ (أو طالب التنفيذ) أي الطرف الإيجابي في التفيذ الجبري، والمنفذ ضده، أي الطرف السلبي في التنفيذ الجبري. ويجب أن تتوافر في كل منهمـا شرط يتعلق بوجود الحق في التفيذ (الصفة والمصلحة)، وشرط آخر يتعلق بصحة مباشرة الحق في التنفيذ الجبري، وهو الأهلية(؟).

وفي بعض الأحوال ليس من السهل معرفة مـا إذا كـان طالب الصورة التنفيذيـة هو صاحب الحق في التففيذ لصعوبة ودقة تحديد ما إذا كان ممن تعود عليه منفعة، وقد يدق الأمر ليس فقط علي الكاتب أو الموثق بل علي قاضي التنفيذ نفسه، وسوف نتتبع تحديد ذلك، سواء من ناحية أطراف التنفيذ، أو من ناحية امتداد الصفة في التنفيذ إلى كل من تعود عليه منفعة من تنفيذ الحكم. وذلك في المبحث التالي . 
د/ طلعت يوسف خاطر

العدد rا7 (أغسطس Y.IV) 


\section{البمشث الثاني \\ أنواع الصفة في التنفيذ الببري}

تتنوع الصفة في التنفيذ إلي صفة ايجابية وصفة سلبية، وسنشير إلي ذلك في

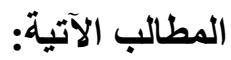

\section{المطلب الأول \\ الصفة الإبمابية في التنفيد الصنابد \\ "طالب التنفيذذ"}

لا شــك فـي أهميـة تحديــ المقصود بالـصفة الإيجابيـة في التنفيـذ، حيـ إن

صاحب هذه الصفة هو الثخص الذي يعطيه القانون سلطة مباشرة إجراءات التتفيذ، وهو الذي لا يتأثر بتصرفات المدين في المـال الذي تم توقيع الحجز عليهه، وهو الذي لوني

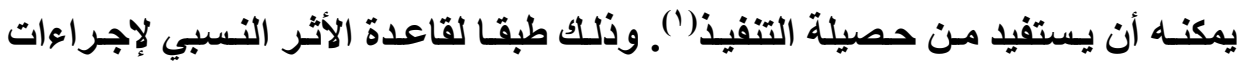

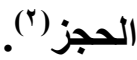

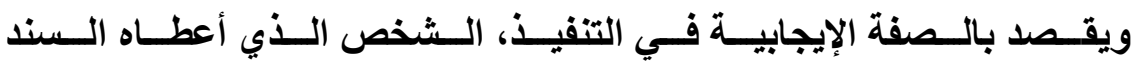

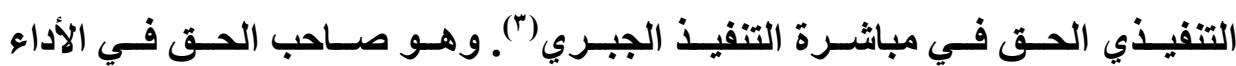

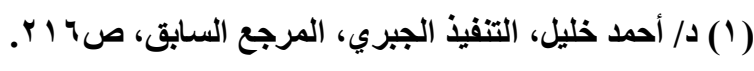

(r) يقصد بقاعدة الأثر النسبي للحجز، أنه لا يستقيد من إجراءات وأثار الحجز إلا من كان طرفا فيها.

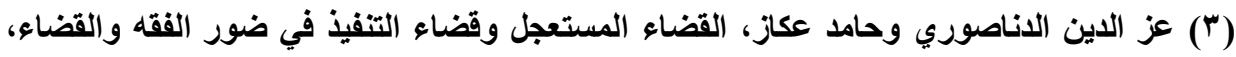

$=$ 
الثابت بالسند التنفيذي (') ويظهر صفته من خلال السند التنفيذي الذي يثبت من لـه

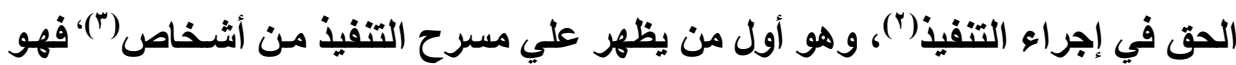

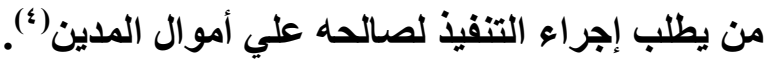

سنشير في هذا المطلب إلى صاحب الصفة الأصلية في السند التنفيذ، ثم نبين امتداد الصفة إلي غيره، وذلك في الفروع الآتية:

\section{الفرع الأول \\ صاحب الصفة الأصلية}

سنشير إلى المقصود بصاحب الصفة الأصلية في السند التنفيذي، ثم نبين شروطه، وذلك في النقاط الآتية:

\section{أولا: الاتصهد بصاحب الصفة الأصلية}

صاحب الصفة الاصلية في التنفيذ تثبت للائن صاحب الحق الموضوعي الثابت

اسمه في السند، حيث نصت المـادة 1 ا أمرافعات علي أن طالب التنفيذ هو الخصم الذي تعود عليه منفعة من تنفيذ الحكم، حيث تقترن الصفة في طلب التنفيذ بالحق مئ

S. GUINCHARD et T. MOUSSA, droit et pratique des voies d'exécution, op. cit., $\mathrm{n}^{\circ}$ 100, 31, Cass. 2 civ. 21 janvier 1996, op cit., 11, $\mathbf{n}^{\circ}$ 24, p. 15.

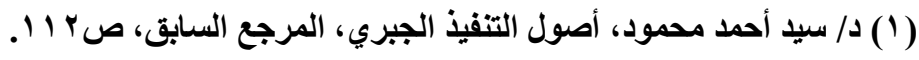

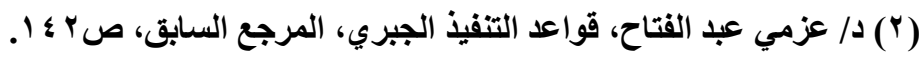

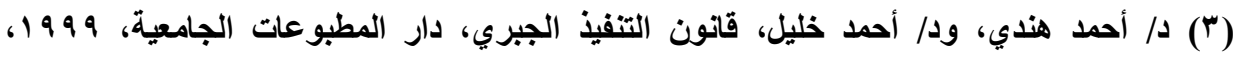


الموضوعي وتلتصق بصاحبه، إذن يشترط في طالب التنفيذ أن يكون خصما في السند

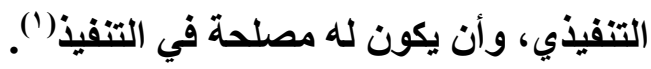

والواقع أن الثخص يعتبر طرفا في التنفيذ حتي لو لم يكن حاضرا في الخصومة بنفسه إذا كان ممثلا في الدعوي عن طريق أحد الخصوم الحاضرين فيها()، أو كـان

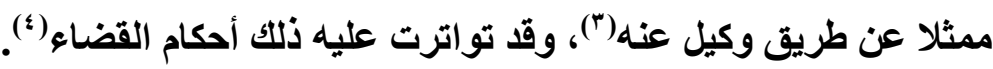

وطالب التنفيذ قد يتسع ليشمل من يتدخل بإرادته أو يختصم في الدعوي، ففي هؤلاء جميعا يعتبر السند التنفيذ حجة لهم(0). ويلاحظ أن العبرة بالخصم الحقيقي في السند التنفيذي، فلو أدخل شخص في خصومة ولم توجه إليه فيها طلبا ما، فإنه لا يصح اعتباره خصما في التنفيذ(')

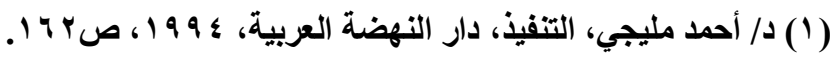

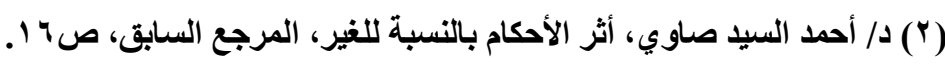

(3) Roger Perrot, "Autorité de la chose jugée au civile sur le civil", op. cit., no 138. S. GUINCHARD et T. MOUSSA, droit et pratique des voies d'exécution, op. cit., $\mathrm{n}^{\circ}$ 141, 19.

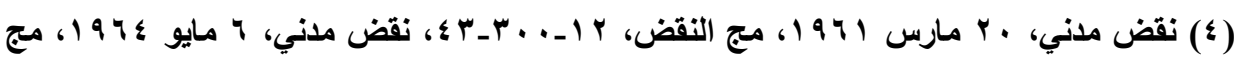

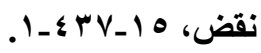

Cass. Civ., 11 decembre 1928, DH, 29,1,51, Cass., 5 juin, 1931, $S .31,1$, 333.

(5) J. Zarzycki, De la demande en justice, Thèse, Caen, 1937, p. 51, Griolet, L'autorité de la chose jugée en matière civile et en matière criminelle, Paris, p. 157.

علي أنه إذا انتقل هذا الحق الموضوعي لغير صاحب الصفة الأصلية، انتقل معه الحق في التنفيذ،

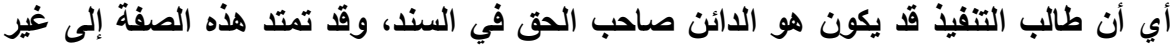
الائن، حيث يمكن أن تمتد إلى خلفه، أو دائنة.

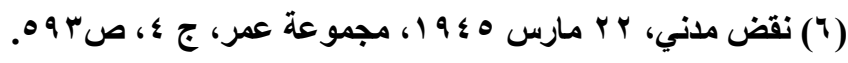


يطلق علي صاحب الصفة الأصلية، اسم طالب التتفيذ(')، وذلك لأن التنفيذ يتم بناء علي طلبه، أو اسم " الدائن"(")، وذلك لأنه صاحب الحق الذي يتضمنه السند

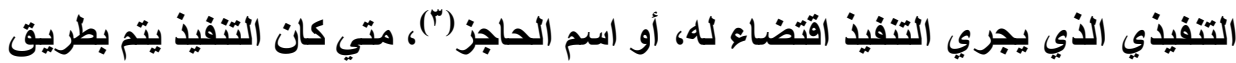

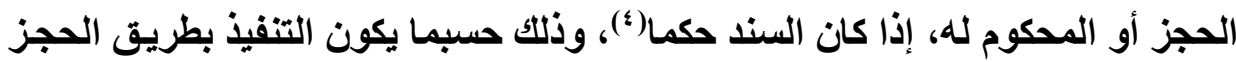
أو بغير ذلك من الطرق كالتنفيذ العيني.

وقد ذهب البعض إلى أن اصطلاح الدائن أو الحاجز مصطلحان لا يخلوان من

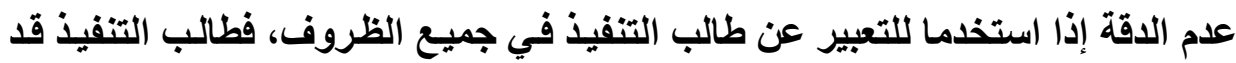
يكون صاحب حق عيني أصلي، وبذلك لا يصدق علي وصف الدائن، وقد يكون التنفيذ

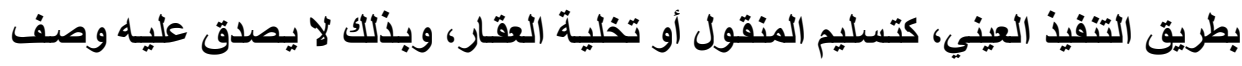

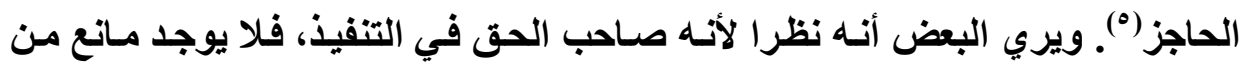

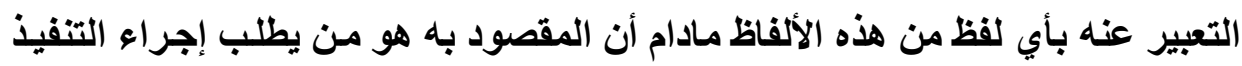

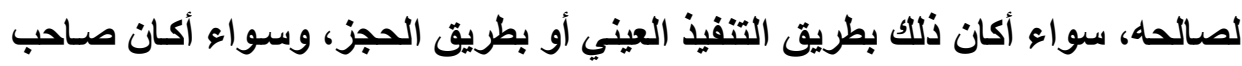

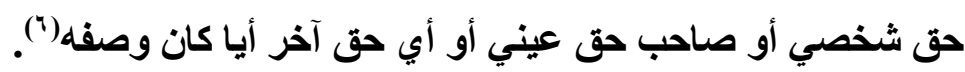

(1) د/ عبد العزيز خليل بديوي، الوجيز في قواعد وإجراءات التتفيذ الجبري والتحفظي في قانون

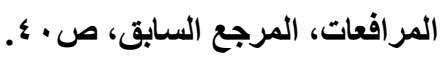

(r) د/ أحمد ابو الوفا، إجراءات التنفيذ بمقتضي قاتون أصول المحاكمات اللبناني الجديد، طب،،مكتبة

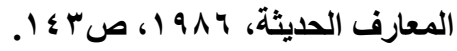

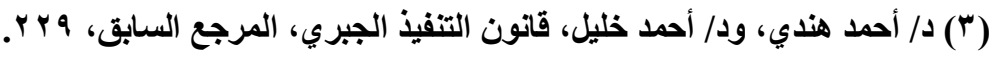

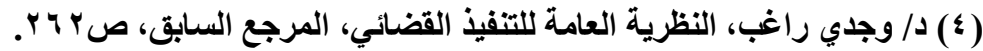

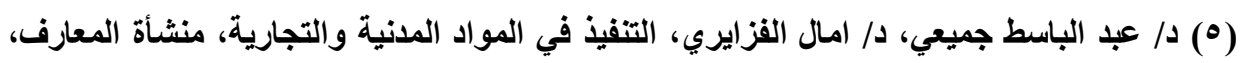

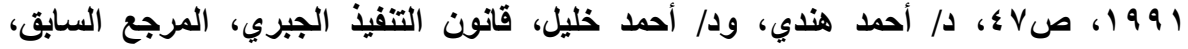


وتثبت الصفة الأصلية في التنفيذ للشخص الذي يؤكد السند أنسه صساحب الحق

الموضوعي(')، وذلك سواء كان هو صاحب الحث الموضوعي في الواقع أم لا، حيث إن

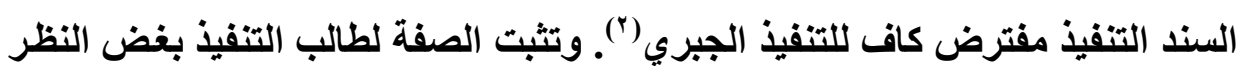
عن كونه دائنا عاديا أو صاحب حق امتيار أو اختصاص أو رهن.

وتثبت صفة طالب التنفيذ للشخص الاعتباري(") كما تثبت للشخص الطبيعي(؛)"،

وقد تثبت الصفة في التنفيذ في بعض الأحوال للتيابة العامـة، وذلك في الأحوال التي يخولها فيها القانون رفع دعوي (•).

(1) S. GUINCHARD et T. MOUSSA, droit et pratique des voies d'exécution, op. cit., $\mathrm{n}^{\circ}$ 100,31, Cass. 2 civ. 21 janvier 1996, op cit., 11, $\mathrm{n}^{\circ}$ 24, p. 15.

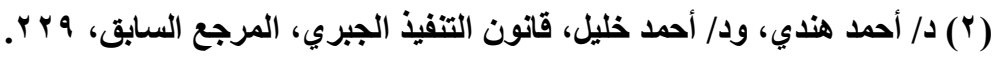

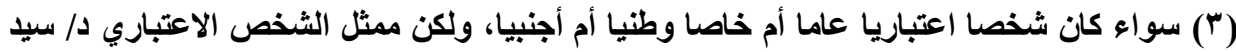

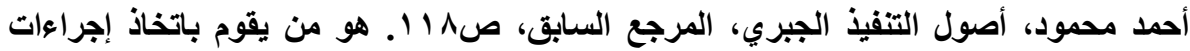
التنفيذ الجبري. فليس بلازم أن يطلب هذا الدائن التنفيذ باسمه، وإنما يمكن أن يطلب التنفيذ نائبا

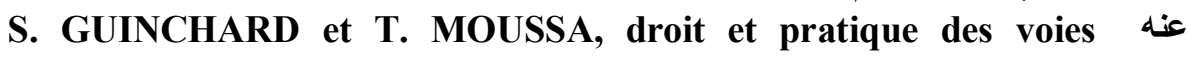

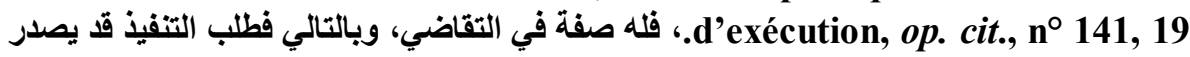

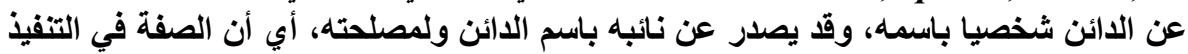

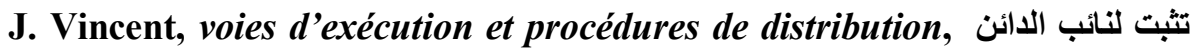
ولو لم يكن محاميا د/ أحمد هندي، ود/ أحمد خليل، قانون

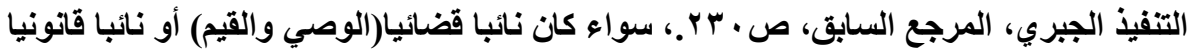

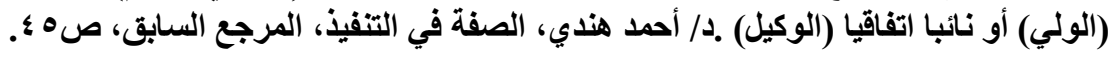

(4) S. GUINCHARD et T. MOUSSA, droit et pratique des voies d'exécution, op. cit., $\mathrm{n}^{\circ}$ 111,21.

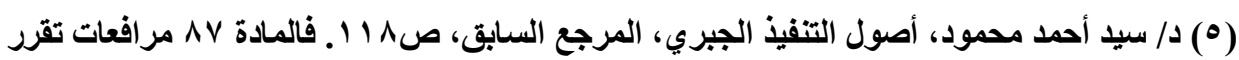

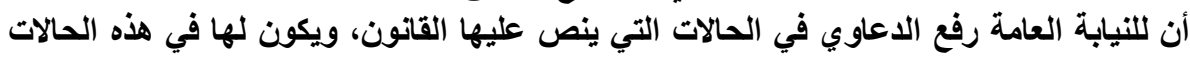

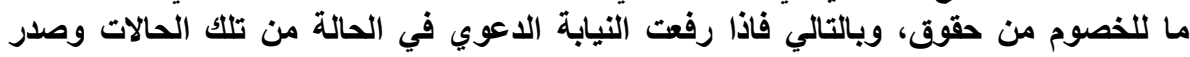

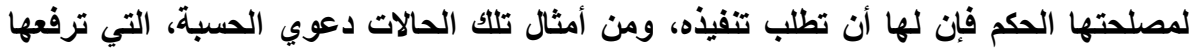
النيابة العامة في مسائل الأحوال الثخصية. 
وقد يتعدد طالب التنفيذ في السند التنفيذ، وذلك في حالة التضامن بين الدائنين،

ويسمي بالتضامن الإيجابي(')، ويؤدي ذلك أن يكون لكل دائن من الدائنين المتعددين أن يطلب المدين بكل الدين، ويكون وفاء المدين لأي من الدائنين مبرئسا لذمته في مواجهة الباقين (مVV9 19 مدني فرنسي) كما يكون لكل دائن الحق في الرجوع علي من قبض الدين منهم لمطالبته بالوفـاء لله بحصته، أي أن الدين ينقسم فيمـا بين الدائنين بقدر

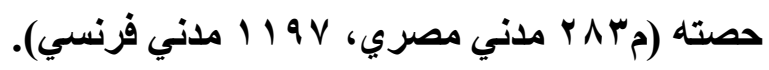

ورغم وحدة الالتزام التضامني، فإن المتضامن يعتبر من الغير بالنسبة للاعوي التي ترفع من أو ضد الباقين بشأن هذا الالتزام(؟). وبالتـالي إذا قام أحد الدائنين برفع دعوي ضد المدين المشترك لمطالبته بالدين أو رفعت دعوي بقصد تبرئـة ذمـة ذلك المدين فإن باقي الدائنين المتضامنين يعتبرون من الغير، ولا يحوز الحكم الصادر في

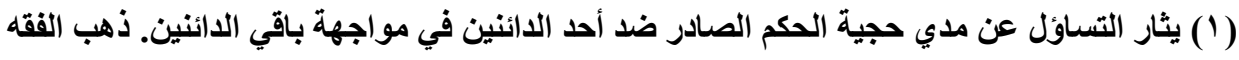

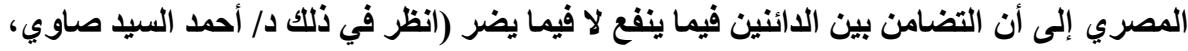

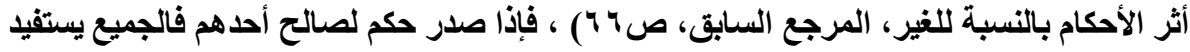

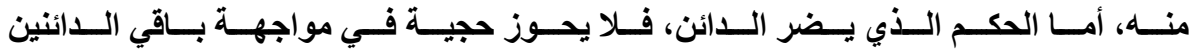

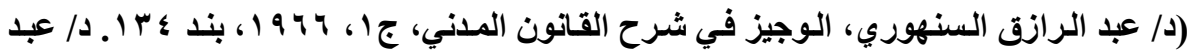

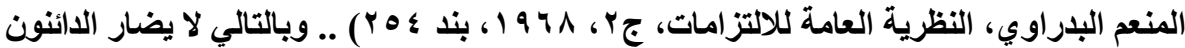

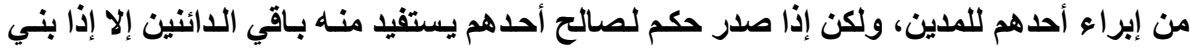

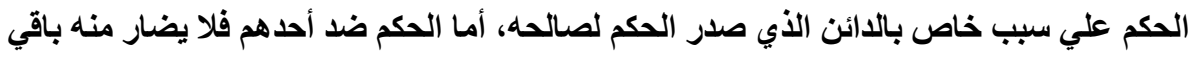

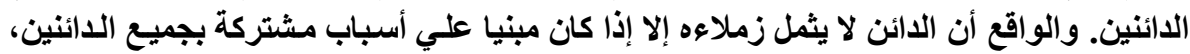

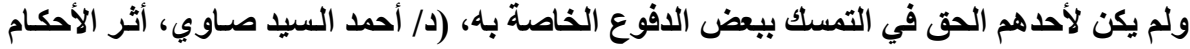

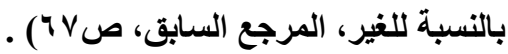

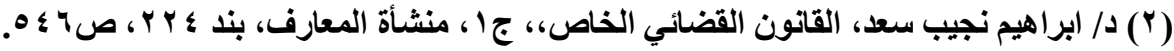


هذه الدعوي حجية الثيع المحكوم فيه بالنسبة لهم ('). وذلك بسبب استقلال الرابطة الموضوعية من حيث أطرافها عن الرابطة الإجرائية، فلا تؤدي وحدة الالتزام إلى صيرورة من لم يرفع الدعوي أو ترفع في مواجهته بشأن الالتزام طرفا في الخصومة الناشئة عنها. وقد ذهب جانب من الفقه الفرنسي إلى ما يسمي بالنيابة الكاملة بين اللائنين، سواء كان الحكم الصادر لصالح أحد أو ضده فيحتج به علي بـاقي الدائنين. بينمـا اتجها رأي آخر إلى نفي النيابة بين الدائنين أمام القضاء(؟) ويثار التساؤل عن مدي حجية السند الصادر في مواجهة بعض الشركاء في حالة الالتزام غير قابل للانقسام(") أو في حالة الشركاء علي الشيوع.

(1) P. Lacoste, De la chose jugée en matière civile, criminelle et administrative, op. cit, $\mathrm{n}^{\circ} 615$.

فلا يحوز الحكم حجية الشئ المحكوم فيه سوي في مواجهة من رفعت منه الدعوي أو رفعت ضده ألهاء

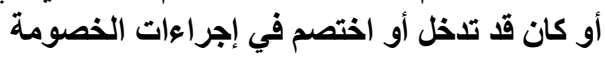

A. Tissier, théorie et pratique de la tierce opposition, thèse paris, $1889, \mathrm{n}^{\circ}$ 120 et 123.

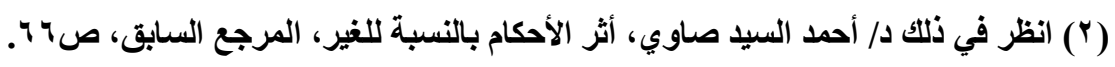

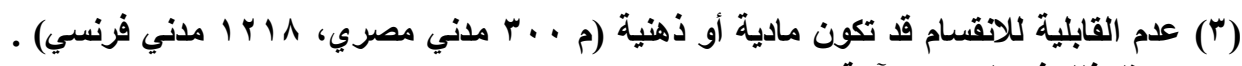
ويتمثل ذلك في الحالات الآتية:

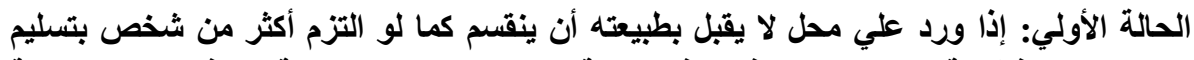

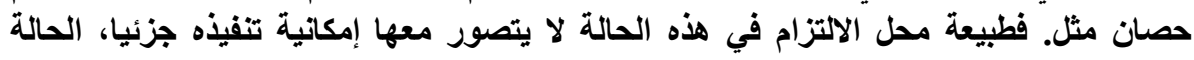

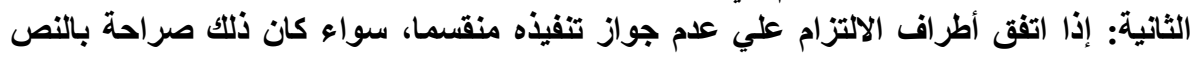

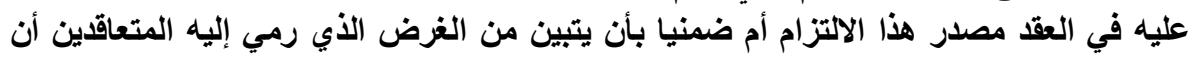

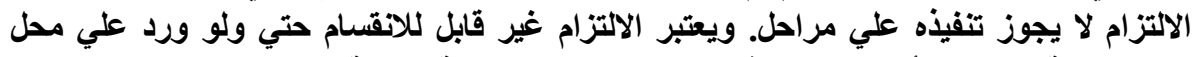

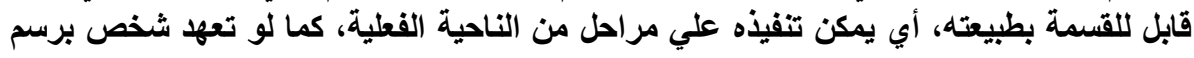


في الواقع لا تؤدي عدم قابلية الالتزام للانقسام إلى استبعاد صفة الغير بالنسبة

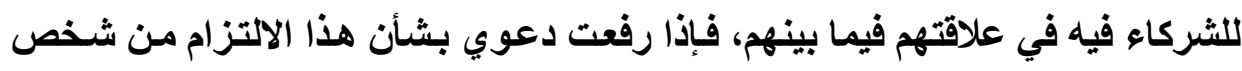
واحد أو بعض الأثخاص فقط من الثركاء فيها- فإن باقي هؤلاء الثركاء يعتبرون من فن

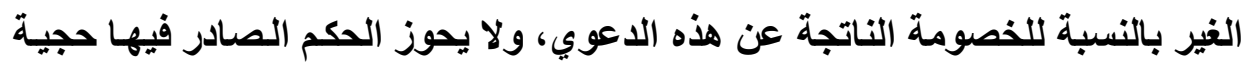

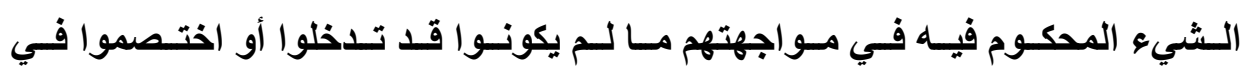

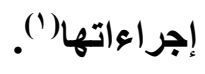

كذلك، فالشركاء علي الشيوع في حقى يقبل القسمة يعتبرون من الغير في

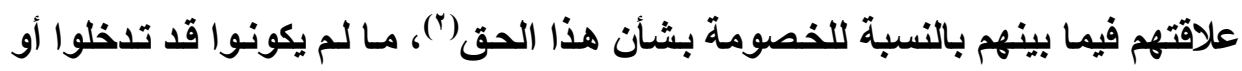

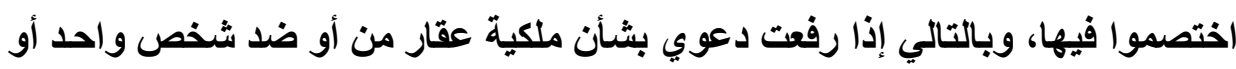

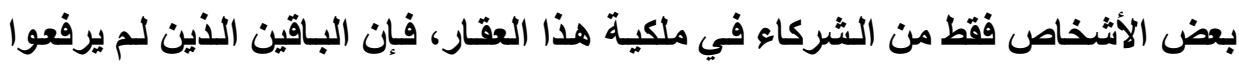

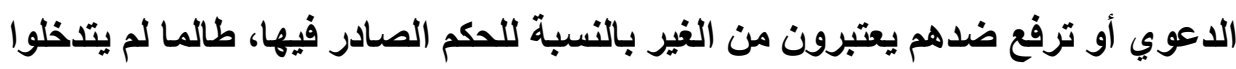

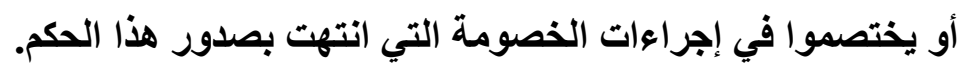
يري جانب من الفقه أن الشركاء في وصيه أو في إرث أو في ملثك، يمثل كل

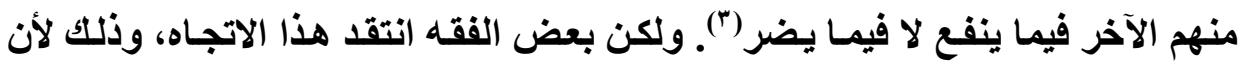

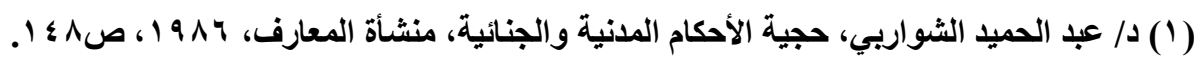

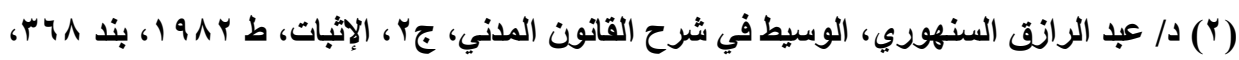

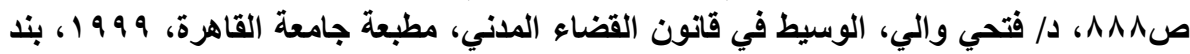

(3) Aubry et Rau, Cours de droit civil français, T, XII, 5 ed, Paris, 1922, p. 422. 
مجرد التقاء المصالح لا ينشئ فيما بين الثركاء في مصلحة نيابة تبادلية أمام القضاء،

ومن ثم يقتصر أثر السند التنفيذي علي من كان طرافا في الخصومة'(')

وتطبيقا لذلك ذهبت بعض الأحكام القضائية إلى أنه ليس في القانون نص يوجب

أن الشركاء في الملك ينوبون عن بعضهم البعض، وبالتالي فالحكم الصادر ضد بعضهم لا يسري علي الاخرين(ّ). وإذا تعدد المضرورين، فإن الحكم الصادر في مواجهة أحدهم لا يكون لله حجة في مواجهة باقي المضرورين.

\section{ثانيا: شروط صاحب الصفة الأصلية}

يشترط لتوافر صاحب الصفة الأصلية الثروط الآتية:

\section{الشرط الأول: ثبوت صفته وقت التنفيذ}

يتعين أن تتوافر الصفة في طالب التنفيذ(") لحظة طلب التففيذ، أي قت مباشرة إجراءات التنفيذ، ويجب أن تستمر حتي انتهاء التنفيذ فلا يكفي أن تكون قائمـة وقت صدور السند وغير قائمسة وقت مباشـرة التنفيذ(؛)، فيجب أن يكون صـاحب الصفة

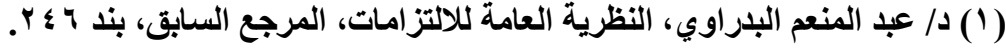

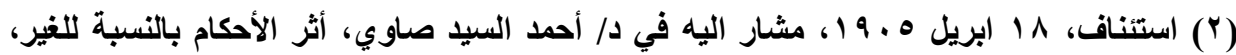

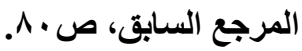

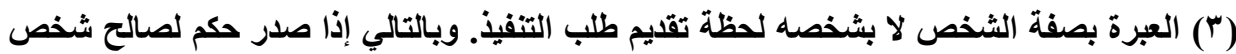

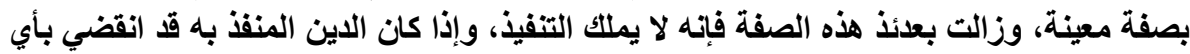

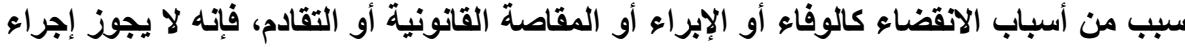
التنفيذ، وذلك بشرط أن يكون سبب الانقضاء لاحقا لصدور الحكم. (§) د/ أحمد هندي، الصفة في التنفيذ، المرجع السابق، ص r ب. 
الأصلية حقه ثابتا في سند تنفيذ مكتمل الأركان والشروط(') وقت اتخاذ إجراعات التنفيذ وإلا كان الحجز باطلا ولا يصححه أن تثبث الصفة في وقت لاحق علي بدء الإجراءات، لأن ذلك لا يصح البطلان(").

\section{يمكن تصور زوال صفة طالب التنفيذ في الفروض الآتية:}

\section{ا - البدى في التنفيذ دون توافر شرط الصفة في طالب التنفيذ:}

إذا بدأت إجراعات التنفيذ دون ثبوت صفة طالب التنفيذ، كسان التنفيذ بـاطلا"(").

وللمــين أن يتمسكك بهـذا الـبطلان (4)، ولغيـره كـذلك ممـن لـه مـصلحة فـي إبطـال هذه الإجراءات كمشتري المـال المحجوز بعد توقيع الحجز الباطل أو الحساجز التـالي الــي يوقع الحجز علـي أمـوال المـدين بعد الحجز الباطل، لأن الحكم بـالبطلان مـن شـأنه أن يحول بينـه وبيلن مزاحمـة الـائن صساحب الحجز الباطل عند توزيع حصيلة

(1) J. Vincent, voies d'exécution et procédures de distribution, op. cit., p.1.

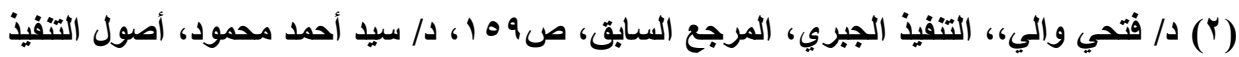

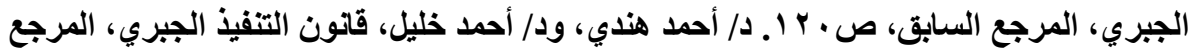

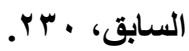
(r) د/ عبد العزيز خليل بديوي، الوجيز في قواعد وإجراءات التبات التفيذ الجبري والتحفظي في قانون

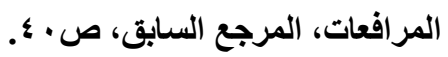

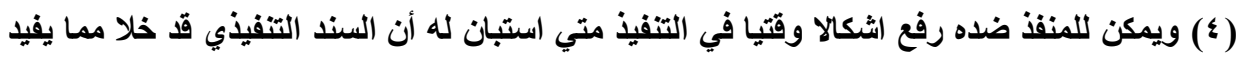

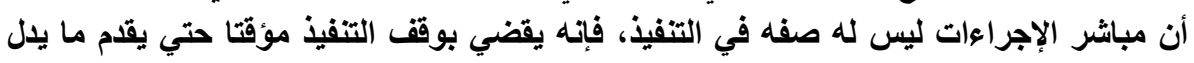
علي صفته.عز الدين الاناصوري وحامد عكاز، القضاء المستعجل وقضاء التهاء التنفيذ في ضور الفئه

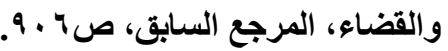

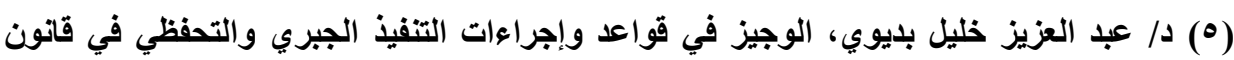

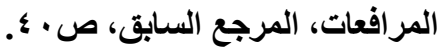


وإذا حدث عارض لطالب التنفيذ قبل البدء في التنفيذ كالوفـاة أو فقدان التمثيل القانوني، فتوجه الإجراءات بواسطة من ينوب عنه، وإلا كانت الإجراءات باطله.

\section{r- ب - زوال الصفة أثناء إجراءات التنفيذ:}

إذا بـأت إجراءات التنفيذ ممـن لـه الصفة، ثـم زالت الصفة بالوفـاة أو فقدان أهليته أو زوال صفة من ينوب عنه، فلا يترتب علي ذلك انقطاع الإجراعات، بل وقفها واستكمالها بالنسبة للورثة أو من يحل محله. بالتالي يكون لمن حل محله الاستمرار في التنفيذ وذلك من اجل تحقيق اقتصادا في الوقت والنفقات(').

\section{الشرط الثاني: اشتراط الأهلية للقيام بالتنفيذ}

اشتراط المشرع توافر الأهلية اللازمة لإجراء التنفيذ(؟)، ويلاحظ أنه لا يشترط توافر أهلية التصرف في طالب التنفيذ، بل يكفي أن تتوافر لله أهلية الإدارة(")، لذلك لألك

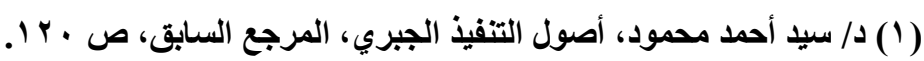

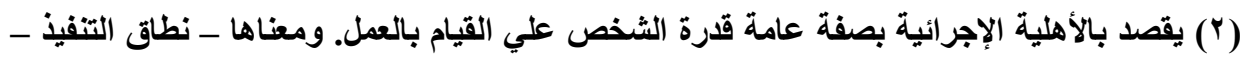

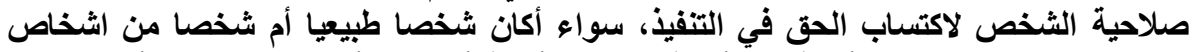

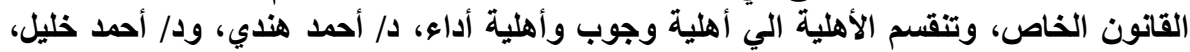

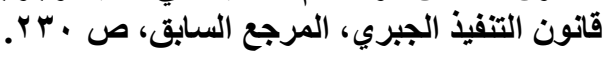

(3) J. Vincent, voies d'exécution et procédures de distribution, op. cit.,. p. 61, no 81., S. GUINCHARD et T. MOUSSA, droit et pratique des voies d'exécution, op. cit., $\mathrm{n}^{\circ} 141,06$.

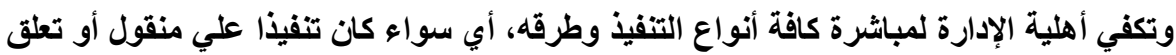

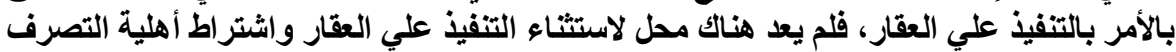

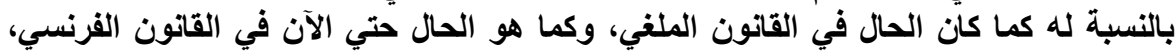

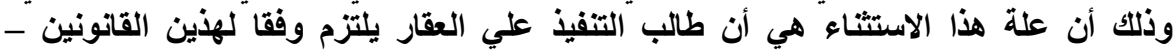

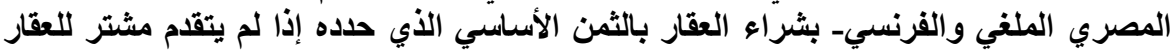

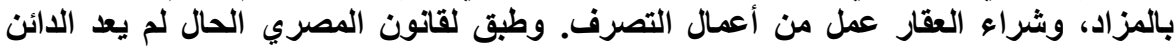

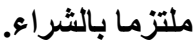


يجوز للقاصر المأذون له بالإدارة طلب التنفيذ،، وذلك أن التنفيذ يرمي إلي قبض الدين،

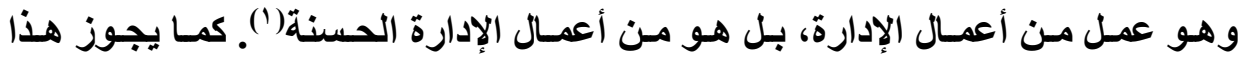

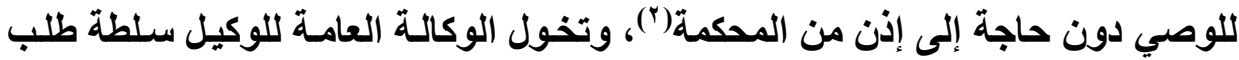

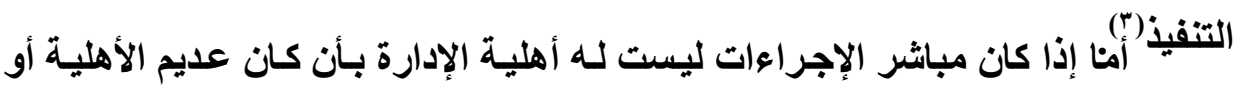
قاصر الم يؤذن له بالإدارة فإن التنفيذ يكون باطلا(').

\section{الفزرع الثانتي \\ اهتداد الصفة إلي غيز صاحب الصفة الأصلية}

تتعدي آثار السند التفيذي إلى غير أطرافه الأصليين، لذا ذهب الفقه إلى بسط نطاق حجية السند التنفيذي خاصة الأحكام إلى غير الأطراف، حيث أمتدت آثار الحكم إلى خلف الخصوم، بل إلى كل شخص كان ممثلا في الدعوي عن طريق أحد أطرافها(ْ).

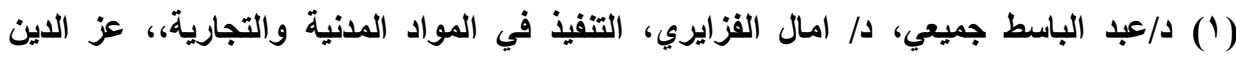

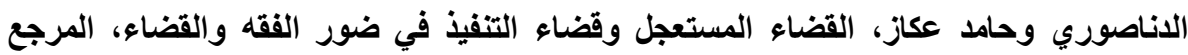

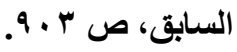

(r) د/ أحمد ابو الوفا، إجراءات التنفيذ بمقتضي قانون أصول المحاكمات اللبناني الجديد، المرجع

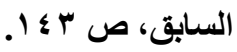

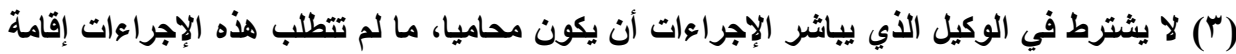
دعوى أمام القضاء، ففي هذه الحالة تتبع القواعد العامة في هذا الصداد. وتكفي أهلية.

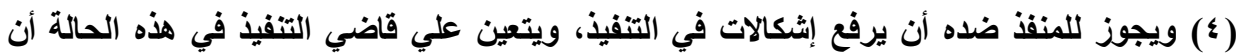

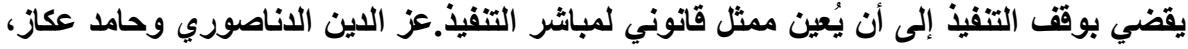

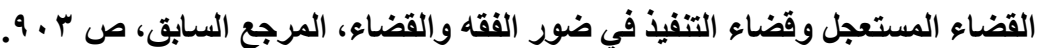

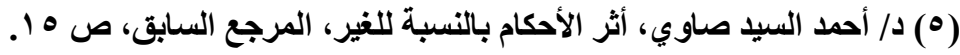


والواقع أن الحق الموضوعي المذكور في السند التنفيذي قد ينتقل إلى شخص آخر غير صاحبه الأصلي، سواء كـان ذلك أثناء حياته أو بعد الوفـاة(')، ويترتب علي ذلك انتقال الصفة في التنفيذ(؟)، وبالتالي لا يشترط أن يكون طالب التنفيذ هو الدائن الذي ورد اسمه في السند التنفيذ إذ قد يحول حقه لغيره، وقد يتوفى فيباشر ورثته التنفيذ، وقد يكون يباشر دائن الدائن التنفيذ(ّ)، في هذه الحالات يكون لمن حل محل الـائن الاصلـي أن يباشـر إجراءات التنفيذ بشرط أن يقوم بـاعلان سـنـ حلولـه محل الاصيل إلي المدين(؛). إذن تثبت الصفة في التنفيذ لمن يستفيد منه حتي ولو كان اسمه غير وارد في السند التنفيذي.

ويري البعض أن من حل قانونا أو اتفاقا محل صاحب الصفة في حقه حل محله فيما اتخذ من إجراعات التتفيذ. فالقاعدة أن الحلول يترتب عليه أن يستكمل المحال له ما بدأه الدائن من إجراعات. وتنقطع الإجراعات بزوال الصفة، ويجب إخطار الخصم الآخر بالصفة الجديدة(0).

(1) د/ عبد العزيز خليل بديوي، الوجيز في قواعد وإجراءات التنفيذ الجبري والتحفظي في قانون

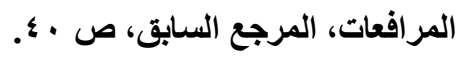

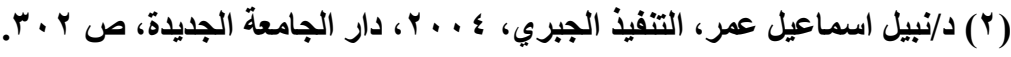

(3) S. GUINCHARD et T. MOUSSA, droit et pratique des voies d'exécution, op. cit., $\mathrm{n}^{\circ} 141,28$

(؛) عز الدين الدناصوري وحامد عكاز، القضاء المستعجل وقضاء التنفيذ في ضور الفقه والقضاء،

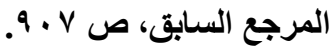

(0) د/ أحمد ابو الوفا، إجراءات التنفيذ بمقتضي قانون أصول المحاكمات اللبناني الجديد، المرجع

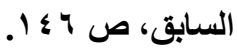


سنشير إلي انتقال الصفة بسبب الخلافة، وانتقالها لعلاقة المديونية، وذلك في

النقاط الآتية:

\section{أولا: انتقال الصفة لوجود الخلافة}

للخلف صفه في طلب التنفيذ بمقتضي السند التنفيذي نفسه الذي كان لصالح سلفه إذا لم يكن هذا الأخير قد طلبه('). وإجراءات التنفيذ التي اتخذها صساحب الصفة الأصلية سوف تنتقل إلى من يخلفه في حقه.

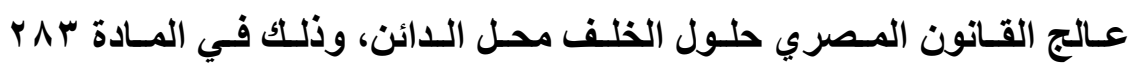
مرافعات، حيث نص علي أن "من حل قانونـا أو اتفاقا محل الدائن يحل محلـه فيمـا اتخذ من إجراءات التنفيذ". وبذلك يتابع من حل محل الدائن إجراعات التنفيذ دون إعـادة مـا تم فيها من إجراءات وعدم انقطاع هذه الإجراءات(؟) فإذا اتخذ صاحب الصفة الأصلية الإجراء، فإن تغير الصفة لا يبطل الإجراءات التي تمت صحيحة، ولا يؤدي إلى انقطاع إجراءات التنفيذ، بل تستمر الإجراءات بمعرفة صساحب الصفة الجديد("). وحكمة ذلك إلك تفادي إعادة إجراعات التنفيذ مرة أخري ممن حل محل الدائن، وذلك من بـاب الاقتصاد في الإجراءات والمصروفات. وهذا الحكم يطبق علي جميع أنواع التفيذ سواء كـان حجزا تنفيذيا أو تحفظيا.

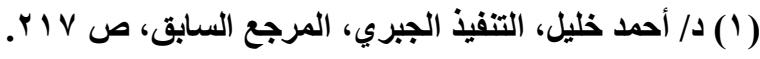

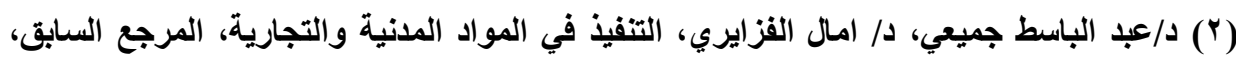
ص.0.

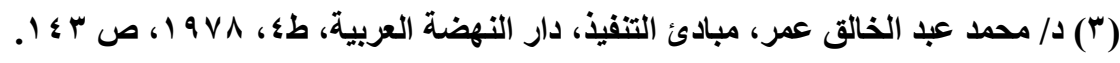


وإذا لـم يكن صساحب الـصفة الجديــ علـي علـم بوجـود إجـراءات التنفيذ، فبان المواعيد التي كاتت سارية في حق صاحب الصفة القديم يقف سريانها، ولا تستأنف إلا بعد إعلان صساحب الصفة الجديل بوجود إجراعات التنفيذ(')، كمـا يجب علي صساحب الصفة الجديا- إن كان يعلم بوجود إجراعات التتفيذ وينوي متابعتها - أن يخطر خصمه بتغيير الصفة، وذلك تفاديا لاستمرار الخصم في اتخاذ الإجراءات في مواجهة من زالت

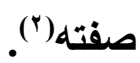
فإذا كـان مباشـر الإجراءات وارثـا يتعين عليه أن يعلن المدين بـالقرار المثبت لوفـاة الـائن ووراثته لـه، وإذا كـان موصسي لـه يعلن المـدين بسند الوصية أو السند المثبت لتسلمه الثيء الموصي به، وإذا كان محالا اليه يعلن المدين بعقد الحوالة، ومع ذلتك لا يلزم هذا الإعلان في حـالات انتقال الحق المحال بـه إلى المحسال إليهه بموافقة المدين، غير أن نفاذ الحوالة بقبول المدين يتحقق به علمه بصفة المحال إليه ولا يلزم إعلانه بها"(ان) وخلف طالب التنفيذ ينقسم إلى خلف عام وخلف خاص، وذلك علي النحو التالي:

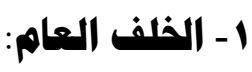

ينتقل الحق في التنفيذ الجبري للخلف العام (مه ؛ ا مدني) نتيجة لوفـاة صـاحب الصفة، ويقصد بهذا الخلف كل من يخلف طالب التنفيذ في ذمته المالية أو حصه شـائعة منها (كالورثة أو الموصي له بحصة شائعه)- حتي ولو لـ يكن اسمه واردا في السند 
التنفيذي، فالحق في التنفيذ الجبري ينتقل كأثر لانتقال الحق الموضوعي كالورثة(1) أو للموصي له بحصه شائعة، وإذا جاز لأحد الورثة أن يطلب تنفيذ السند، فإنهل يشترط أن يوكله باقي الورثة في طلب التفيذ والقبض وذلك حماية لحقوقهم وحتي لا ينفرد أحدهم بالاستئثار بحصيلة التنفيـذ. ويمكن للورثـة جميعـا طلب تتفيذ الحكم الصادر لـصالح مورثهم أو لصالح التركة، لأن الصفة تثبت لمجموع الورثة وليس لوارث بعينه(). وتتحقق الخلافة العامسة في شـأن الشخص الاعتبـاري، كمـا تتحقق في شـأن الثخص الطبيعي، ويحصل ذلك في حالة الاندماج، حيث تنفني الشركة المندمجة، بكل ذمتها الماليةـ أي بكل مـا لها من حقوق ومـا عليها من التزامـاتـ في شركة أخري، سواء كانت موجودة من قبل أم نشأت بعد فنـاء الأولى، فشخصية الشركة المندمجة تزول وتقني في شخصية الثركة الدامجة أو المندمج فيها فهي تصبح خلفـا عامـا لها، فيما لها من حقوق وما عليها من التزامات، وتكون الثركة الدامجة وحدها هي الجهة التي تخاصـم وتختصم في خصوص تلكـ الحقوق والالتزامـات("). وطالمــا أن حقوق الشخص الاعتباري المندمج تؤل إلى الشخص الاعتباري الدامج، فان للأخير أن يطلب بتنفيذ السندات التنفيذية الصادرة لصالح الأول، باعتبار أن الصفة في التنفيذ انتقلت إليه بانتقال الحقوق، وتزول عن الشخص المندمج، باعتبار أنه لم يعد لـه كيان مستقل

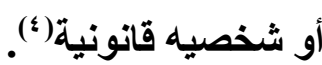

(1)S.GUINCHARD et T. MOUSSA, droit et pratique des voies d'exécution, op. cit., $\mathrm{n}^{\circ} 111,31$.

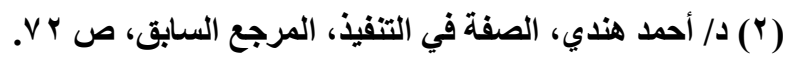

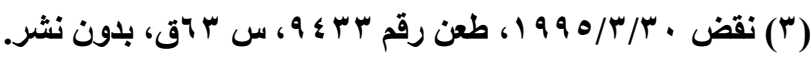

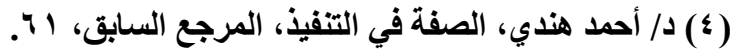


ينتقل الحق في التنفيذ الجبري للخلف الخـاص مـن صـاحب الصفة الأصلية في التنفيذ، ويقصد بهذا الخلف، كل من يتلقى من سـلفه ملكية شـيء محدد أو حق عيني أخر عليه، أو من ينتقل إليه حق شخصي كان سلفه دائنا بـه من قبل، كالمشتري الذي يخلف البائع في ملكيـة المبيع، وكصاحب حق الانتفـاع الذي يعد خلفـا خاصـا لمن تلقي منه هذا الحق، والموصي له بعين معينه أو بحق معين كملكية قطعة أرض أو

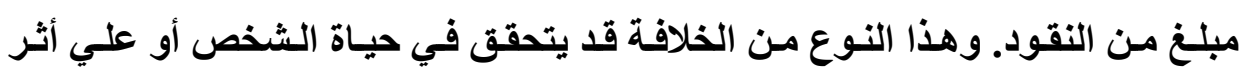

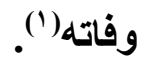

ويلاحظ أن انتقال الحق في التنفيذ إلي الخلف يرجع إلي أن التنفيذ أداة وظيفته لحماية الحق الموضوعي فإنه لا يمكن تحويله مستقلا بل هو ينقل كأثر لحوالة الحق الموضوعي أو التصرف فيه. وبانتقال الحق الموضوعي الثابت بالسند التثفيذي إلى

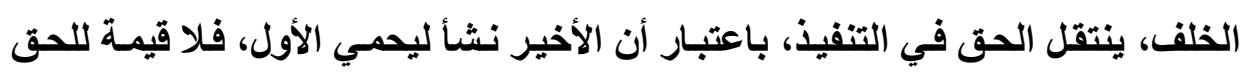
الأي انتقل إلى الخلف إذا لم يتمكن من الحصول عليه، فالخلافة لا تقتصر علي الحق الموضوعي وإنما تثمل أيضا الحق الإجرائسي. فاستخلاف الحق يؤدي إلى استخلاف الصفة (r) (ب)

ويجب بمقتضي المادة 7 ؛ 1 مدني حتي تنتقل الحقوق والالتزامـات الناتجة عن العقد الذي أبرمه السلف إلى خلفه الخاص، أن يكون عقد السلف سـابقا علي التصرف

$$
\begin{aligned}
& \text { (1) د/ أحمد هندي، الصفة في التنفيذ، المرجع السابق، ص س با. }
\end{aligned}
$$

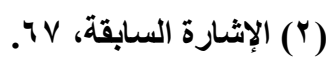


الأي انتقل به الحق إلى الخلف الخـاص، أي سـابقا في إبرامـه علي انتقال الشيء من

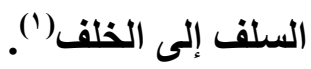

وإذا تعـد خلفـاء صـاحب الـصفة، كـان لكـل مـنهم طلب تنفيـذ السند الـصادر لصالحه، فللموصي له أن يطالب بتنفيذ الحكم الصادر لصالح الموصي، كما أن لكل من تثبث له صفة الخلف الخاص أن يطالب بذلك.

والواقع أن الحق ينتقل إلى الخلف الخاص بالحالـة التي كان عليها وقت تحقق الخلافة، ومن ثم يعتبر الخلف أنـه كـان ممثلا بواسطة سـلفه في كل اللاعاوي السابقة علي انتقال الحق إليه، فيكون الحكم حجة له أو عليه بحسب ما إذا كان الحكم الصادر قـ صدر لصالح سلفه أو ضده(). والأصل يتحدد انتقال الحق في مواجهة الخلف الخـاص، بوقت صدور الحكم، وليس بوقت رفع الدعوي أو بدء إجراعات التنفيذ. ولكن استثناء من ذلك ما نصت عليه المادة ه 1 والمادة VI من قانون الشهر العقاري، فقد نصت الأولى علي وجوب تسجيل الاعاوي العقارية أو التأثير بها، ورتبت الثانية علي ذلك أثرا هاما هو جعل أثر الحكم مستندا إلى تاريخ تسجيل الدعوي أو التأثير بها. وبناء عليه، يعتبر الحكم الصادر في دعوي الاستحقاق المرفوعة علي البائع حجة علي المشتري، إذا كاتت عريضة الدعوي سجلت أو تم التأثير بها قبل تسجيل عقده(").

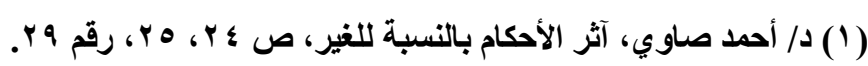

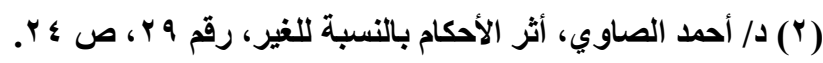

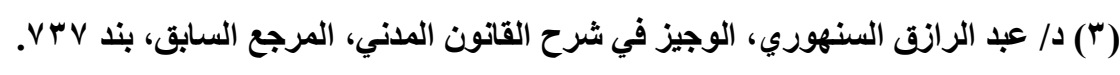


وبالتالي في غير الدعاوي التي أوجب المشرع تشجيل صحيفتها أو التأثير بها، هل تكون العبرة في كون الحكم حجة علي الخلف أم لا؟ وهل تكون بوقت صدور الحكم في مواجهة السلف؟ أم بوقت رفع الدعوي عليه(').

ويري جانب من الفقه، أنه يكفي أن تكون الدعوي رفعت علي السلف قبل انتقال الحق للخلف أو قبل أن يصبح حقه نافذا في مواجهة الغير، حتي لو صدر الحكم فيها بعد ذلك. وحجة اصحاب هذا الرأي، أن الحكم يرتد أثره إلي يوم رفع الدعوي طبقا لمبدأ رجعية أثر الأحكام. ومن ثم يعتبر الخلف ممثُلا بواسطة سلفة من هذا الوقت. فيكون الحكم حجة له أو عليه بحسب مـا إذا كـان لصالح سلفه أو ضده. وقد وجد هذا الرأي صدي كبيرا في ظل القضاء المختلط(؟). والواقع أن هذا الرأي لا يمكن التسليم بـه، وذلك لأنسه من وقت أن يصبح حق الخلف نافذا في مواجهة الغير ينفصل عن سلفه، فانهه لا يمكن القول بـأن السلف يظل بعد هذا الوقت ممثلا له أمام القضاء. وإنما يعتبر من الغير، فلا ينتج الحكم الصادر في مواجهة سلفه بعد ذلك أي أثر بالنسبة له("). ولا أهمية لعلم الخلف عند اكتسابه الحق بوجود دعوي بين سلفه وبين الغير(؛)، كمـا أن خروج الخلف من الدعوي لا يحول دون اعتبار الحكم حجـة عليه، فبإذا رفع شخص دعوي استحقاق علي المشتري مباشرة، فطلب الأخير إدخال البائع في الدعوي

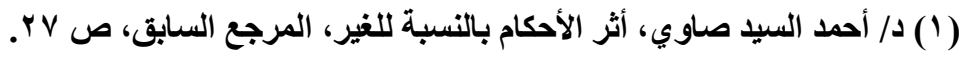

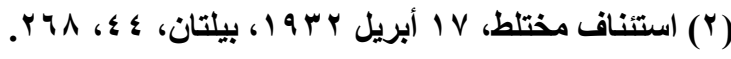

(3) Lacoste paul, De la chose jugee en matrière civile criminelle et administrative, op cit, $\mathrm{n}^{\circ}$ 493-486

$$
\text { (؛) د/ أحمد السيد صاوي، أثر الأحكام بالنسبة للغير، المرجع السابق، ص ^^. }
$$


باعتباره ضامنا، وإخراجه هو من الدعوي، تاركا البائع يتابع الدعوي وحده متحملا عبء الدفاع في مواجهة المدعي، فـالحكم يحوز حجية في مواجهة المشتري سواء

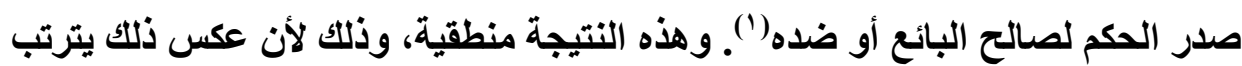
عليه عدم إمكانية حصول رافع دعوي الاستحقاق علي حكم في مواجهة المشتري، لأنسه سيعد إلى الخروج في كل مره من الدعوي ثم يحتج بأنه لم يكن طرفا في الدعوي التي

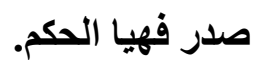

في الواقع لا يمثل الخلف العام أو الخـاص سلفهما، وذلك لان السلف لا يتلقى حقوقه عن الخلف، ومن ثم، فانه لا حجية للأحكام الصادرة في مواجهة الخلف الخـاص قبل مانح الحق، متي كان هذا الأخير لـم يختصم في الدعوي (「). وبالتالي فالحكم الذي يقضي بقبول دعوي الاستحقاق التي يرفعها الغير علي من انتقلت إليه ملكية العقار، دون اختصام البائع، لا يحوز الحجية في مواجهة البائع("). وعلي الخلف أن يثبت للمنفذ ضده صفته، ويتم ذلك عن طريق الإعلان الذي يوجهه إلى المنفذ ضده قبل البدء في التنفيذ، ويبين فيه صفته وسنده وسبب خلافته

(1) Lacoste paul, De la chose jugee en matrière civile criminelle et administrative, op. cit., $\mathrm{n}^{\circ}$ 503-512.

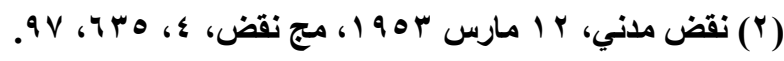

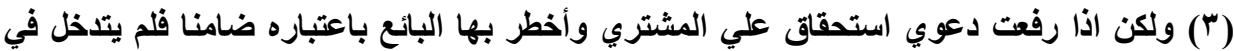

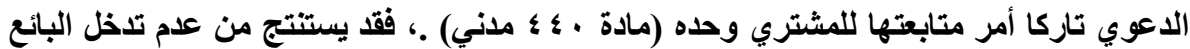

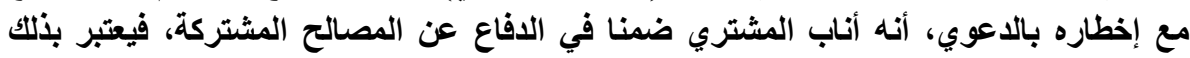

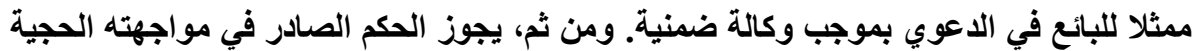
بالنسبة لسلفة البائع سواء صدر الحكم لصالحة أو ضده. 
للـائن الأصلـي(') وللمنفذ ضـده أن يطالبـه بهذا حتـي لا يضطر للوفـاء مـره أخري لاائنه(؟).وعلي الجهة التي تقوم بالتنفيذ أن تتحقق من ذلك، وذلك لأنها غير ملزمـة بعدم القيام بما يطلب منها من اتخاذ إجراءات التنفيذ الجبري إلا لمصلحة صساحب الحق

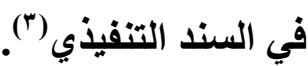

\section{ثانيا: انتقال الصفة بسبب علاقة المديونية}

في الواقع تنتقل الصفة من طالب التنفيذ إلـي دائنة فيمكن لـه مباشرة إجراءات التنفيذ الجبري باعتباره صاحب صفة.

سنشير إلـي أسـاس انتقال الصفة، ووسـائل الدائن في مباشرة حقوق مدينـة،

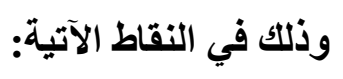

\section{ا - أساس انتقال الصفة إلي دائن طالب التنفيذ:}

يرجع أساس حق الأئن في إجراء التنفيذ بدلا من مدينه صاحب الصفة الاصلية، أن للدائن علي أموال مدينه جميعها ضمان عام، الذي يعبر عن حق كل دائن في التنفيذ علي ما لاي المدين من أموال وقت التنفيذ واستيفاء حقه من المتحصل من البيع جبرا،

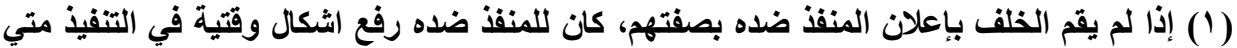
استبان لله أن السند التنفيذ قد خلا مما يفيد أن مباشر الإجراءات ليس له له صفه في التنفيذ أو أنه لم لم

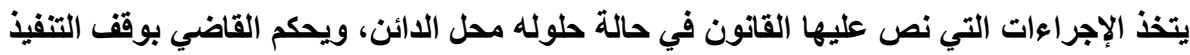

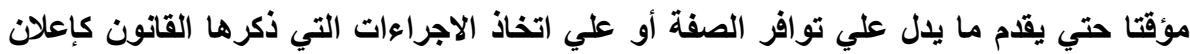

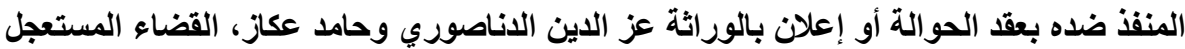

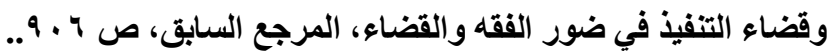

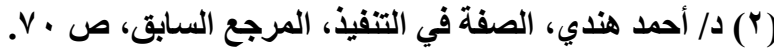

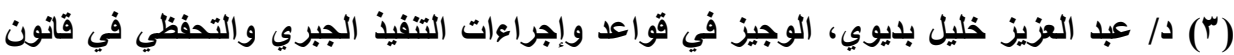

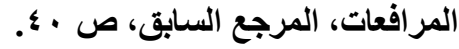


فإذا تصرف المدين في مال من أمواله فخرج من ذمته نقص الضمان العـام للائن ممـا يهدد حقه بالضياع، وبالعكس إذا كسب المدين حقاز زاد ضمانه عند التنفيذ عليه. لذلك فله أن يحتج بعقود المدين لينفذ علي الأموال التي كسبها المدين. لا يعتبر الأئن خلفا لصاحب الصفة، إذ الخلف الخاص يتلقى حقا ثابتا وموجودًا في ذمة السلف، أما الدائن فينشأ له حق في ذمـة المدين صـاحب الصفة دون أن يكون لهذا الحق وجود من قبل، أي لا ينتقل إليه حق من المدين، فالدائن لا يخلف المدين في شيء، أي أن الدائن يعتبر من الغير - بالنسبة للعقود والتصرفات التي يبرمها مدينهـ بمعني أنه لا يعد من الأشخاص الذين تتوافر فيهم صفه المتعاقد أو الخلف، فلا يكتسب من العقد الأي يعقده مدينه حقا ولا يلتزم بما ترتب عليه(').

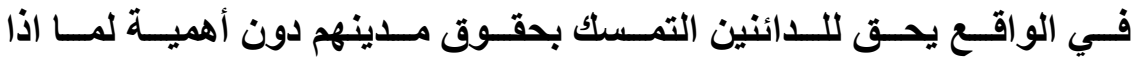
كانـت ديـونهم نسشأت في تـاريخ سـابق علـي السند التنفيذني أو لاحق عليسه. وذلـك يرجـع إلـي الضمان العـام علـي أمسوال مـدينهم، وهـم في ذلتك يشبهون الخلف العسام.

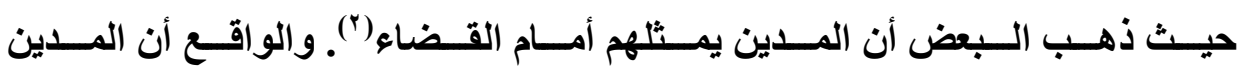

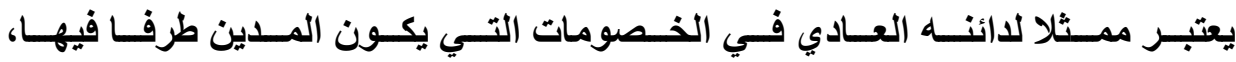

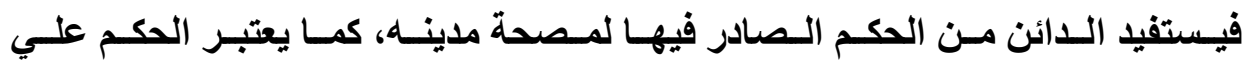
المـدين حجـة علـي دائنـة في حدود مـا يتـأثر بـالحكم حق الـضمان العـام("). ويعتبر

(1) د/ عبد الرازق السنهوري، ا الوسيط في شرح القانون المدني، جr، الإثبات، المرجع السابق،

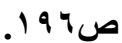

(ץ) د/ أحمد السيد صاوي، أثر الأحكام بالنسبة للغير، المرجع السابق، ص آمأ.

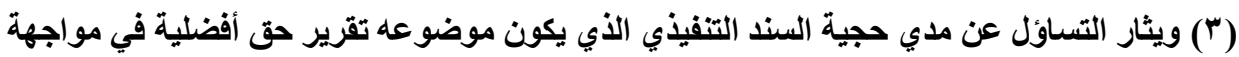
باقي الأنين: ذهب بعض الفقه إلى أن الحكم يحوز في هذه الحالة الحجية في مواجهة بالقي $=$ 
الأننين من الغير (') إذا صدر الحكم بين مدينهم وخصمه نتيجة تصرفات صورية أو تواطؤ للإضرار بحقوقهم، فلا يكون الحكم حجة عليهم()، و إنمسا من حقهم الطعن فيمـا اثبته الحكم بلدعوي مبتدأه.

ويكون الدائن نائبا قانونيا عن المدين في اجراء التنفيذ، وهذه النيابة لمصلحة النائب، وليس لمصحة الأصيل، وإذا صدر الحكم لصالح المدين فإن له صفة في تنفيذه، لأنه هو صـاحب الحق الذي كرسـه الحكم، إلا أن هذه الصفة تثبت كذلك لائنسه، حيث ستعود عليه منفعة من طلب تنفيذ هذا الحكم، إذ من غير المقبول منطقيـا أن تعطي

الاداننين، وحجتهم في ذلك أنه ليس للاائنين العاديين سوي مجرد الضمان علي أموال مدينهم، وهو

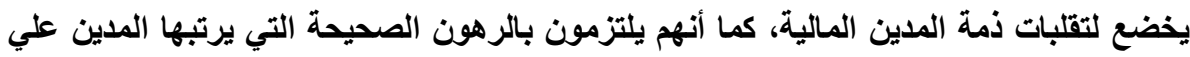

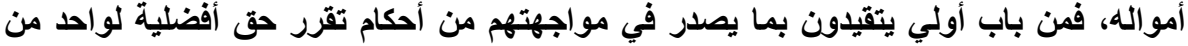
Laurent, principes de droit civile français, T, XX, 3 ed., Paris, 1878, بينهم 104 n. ولكن يري الفقه الراجح أن المدين لا يمثل الدائنين العاديين حينما يتطلق الأمر بتفضيل

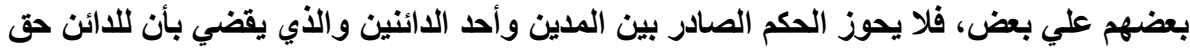

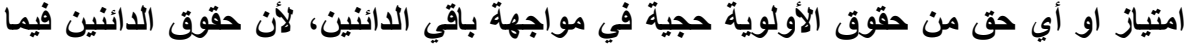

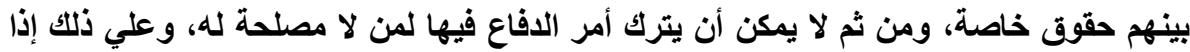

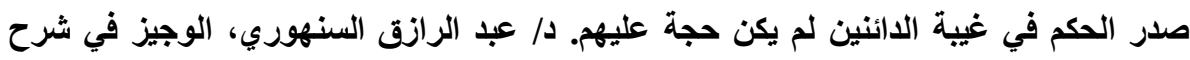

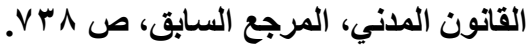

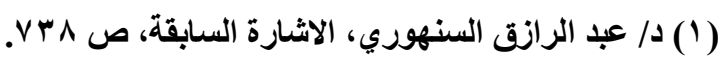

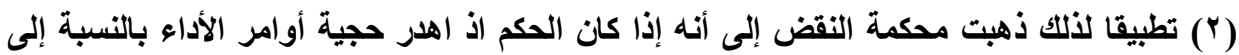

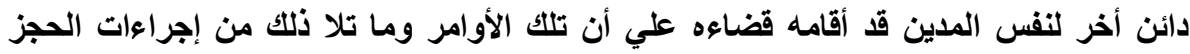

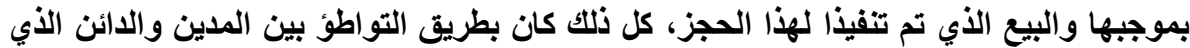

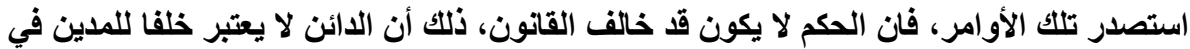

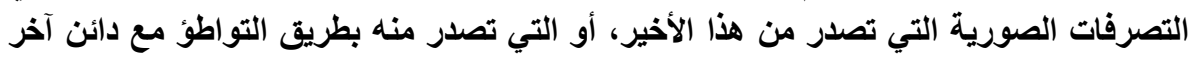

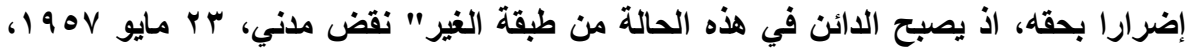

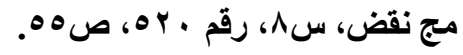


لاائني المدين صفة رفع دعوي للمطالبة بحقوقه ولا تكون لهم صفة في ترجمة الحكم الصادر لصالح مدينهم إلى واقع ملموس (') ويلاحظ أن صفة الدائن في توقيع الحجز التنفيذي هي صفة استثنائية، خوله القانون باسم مدينه ولصالح ذمته المالية، التي تمثنل الضمان لحق الدائن، ممـا يعود علي الائن بالنفع، حسب مفهوم المادة 1 ا 11 مرافعات.

\section{r- وسائل الدائن في الصول همل صاحب الصفة.}

يباشر دائن الدائن إجراءات التففيذ باسم مدينـة ونيابـة عنه في مواجهة المنفذ

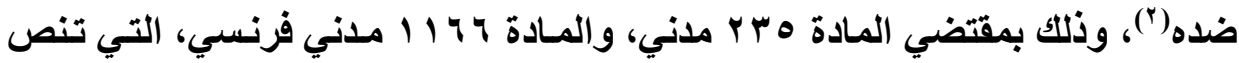
علي أنه لكل دائن ولو لم يكن حقه مستحق الأداء أن يستعمل باسم مدينه جميع حقوق هذا المدين، ما لم يكن متصلا بشخصه(") أو غير قابل للحجز. ويجب إثبات صفة الدائن التي تخول له مباشرة إجراءات(؛)، وإلا كان التنفيذ باطلا(ْ).

$$
\text { (1) د أحمد هندي، الصفة في التنفيذ، المرجع السابق، ص\&ء. }
$$

(2) S. GUINCHARD et T. MOUSSA, droit et pratique des voies d'exécution, op. cit., n' $141,19$.

(3) Id.

(؛) د/ أحمد ابو الوفا، إجراءات التنفيذ بمقتضي قانون أصول المحاكمات اللبناني الجديد، المرجع

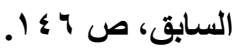

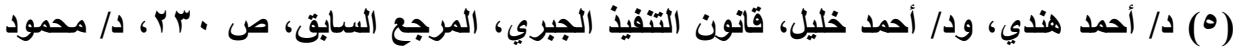

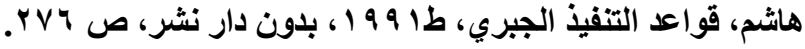


ويستعل الائن حقوق مدينه في تنفيذ السند، بناء علي دعوي غير مباشرة أو بناء علي دعوي مباشرة أو بناء علي حجز ما للمدين لاي الغير، وذلك علي أسـاس مـا يعود عليه من نفع من وراء هذا التنفيذ(')

ويجب حتـي يكـون لـدائن طالـب التنفـذ الحق في مباشـرة إجـراءات التنفيذ

توافر شـروط الـدعوى غير المباثـرة المنصوص عليها في المـادة هبr و ؟بr مـن القانون المدني()، وذلك علي أسـاس إهمـال المدين في المطالبـة بحقـه(r)، وأن يترتب علي عدم استعمال المدين لحقه ضررا بالدائن، ويمكن له اتباع طريق حجز مـا للمدين

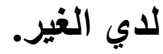

ولا شك في أن حجز ما للمدين لاي الغير قد يحقق مزايا الدعوي غير المباشرة،

ويغني الدائن بالتالي عن رفع الدعوي غير المباشرة، إلا أن ذلك لا يكون دائمسا، إذ إن اجر اء هذا الحجز يفترض أن للمدين حقاـ دينا أو منقولاـ ثابتا في ذمة الغير، ممـا يتيح لدائنه أن يحجز علي حقه في حيازة شخص ثالث. ثم إن حجز مـا للمدين لدي الغير

(1) د/ سيد أحمد محمود، أصول التنفيذ الجبري، المرجع السابق، ص 117 (1).

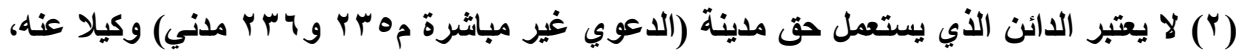

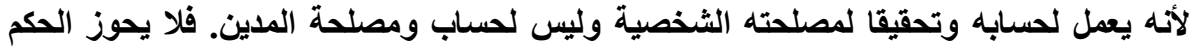

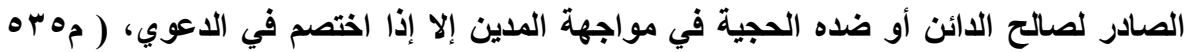

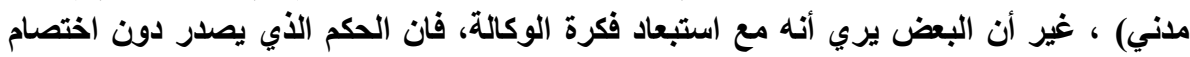

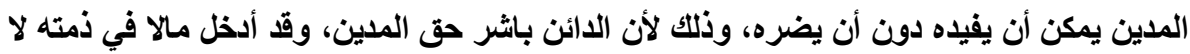
يمكن للغير أن ينتزعه منه. Lacoste paul, De la chose jugée en matière civile, criminelle et administrative,e op. cit., $\mathrm{n}^{\circ} 654$.

(3) S. GUINCHARD et T. MOUSSA, droit et pratique des voies d'exécution, op. cit., n $141,19$. 
مسشاكله، إذ إن إجراءاتـه طويلـه وأطر افـه متعددون، وإذا كـان الـدائن حينمـا يوقعهـه لا يشترط أن يكون حقه لاي مدينة ثابتا بسند تنفيذي، إذ أن حجز ما للمدين لاي الغير هو حجز تحفظي، يمكن للائن الحصول علي إذن من قاضـي التنفيذ مـع تقدير دينها تقديرا مؤقتا ( م P rV مرافعات) إلا أنسه يجب علي الدائن في تلكك الحالةـ حيث لا يكون بيده سند تنفيذي- رفع دعوي بثبوت حقه وصحة حجزه خلال ثمانية أيسم من إعلان الحجز

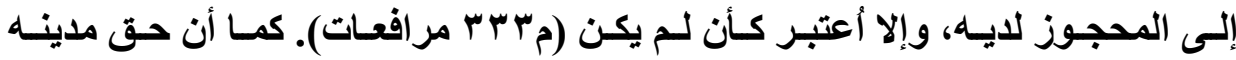
(المحجوز عليه) تجاه مدين المدين (المحجوز لايه) يجب أن يكون ثابتا، إمـا من خلال التقرير بمـا في الأمـة أو نتيجة الحكم في دعوي المنازعة في التقرير، التي يرفعها الحاجز- أي المدين أو دائنهـ كدعوي خاصة يرفعها باعتباره حاجزا، إذ بتوقيعه الحجز يستعمل حقا خاصا به هو حق الحجز، وهو لـه باعتباره حـاجزا أن يلزم المحجوز لايـه بالتقريز بما في ذمته وله بهذه الصفة أن ينازع في تقريزه('). فللـائن طالب التنفيذ أن يستعمل حقوق مدينه في التنفيذ، وذلك إذا تقـاعس صاحب الصفة الأصلية عن طلب تنفيذ السند، فحماية حقوق الأئن لا تقتصر علي منحه صفة رفع دعوي مدينة - باسم المدين- وإنما تمتد إلى إمكانية استعماله لحقوق مدينة المالية. وياخل ضمن هذه الحقوق طلب تنفيذ السندات التنفيذية لصالح المدين. فللدائن أن يوقع الحجز باسم مدينة علي مدين مدينة، سواء كـان حجزا تنفيذيا علي منقول أو علي عقار أو كان حجزا تحفظيا. كما له أن يوقع باسم مدينة حجز ما للمدين لدي الغير، 
وذللك لأن نص المادة ه P مدني نص عام يشمل حق توقيع الحجز كغيره من الحقوق التي لا تتصل بشخص المدين(')

ويمكن للائن أن يحجز علي ما لمدينه في ذمـة مدين ثان، فلا يقصد بحجز مـا للمدين لاي الغير أن نقف عند الحجز علي مدين المدين، وإنمـا يمكن للائن أن يحجز علي مدين مدين المدين، وهو يكون هنـا بمثابـة دائن الحاجز، وهو يباشـر نيابة عن الحاجز وباسمه.

وفي بعض الفروض الخاصـة يمنـح المشرع الصفة الاستثنائية للدائن في أن يرفع دعوي باسمه الشخصي وليس باسم مدينه للمطالبة بحق ناشسئ عن عقد لم يكن طرفا فيه، ولكنه بين المدين ومدين المدين، وهذا استثناء من مبدأ عدم انصراف آثار العقد إلى الغير. علي أن الدعاوي المباشرة بهذه الصفة الاستثنائية، لا تكون إلا بنص

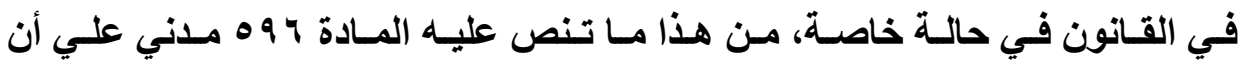
المستأجر من الباطن ملزما بأن يؤدي للمؤجر مباشرة ما يكون ثابتا في ذمته للمستأجر

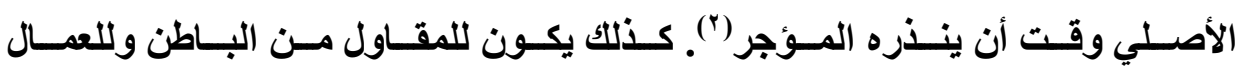
الذين يشتظلون لحساب المقـاول في تنفيذ العـل حق مطالبـة صـاحب العـل مباشـرة

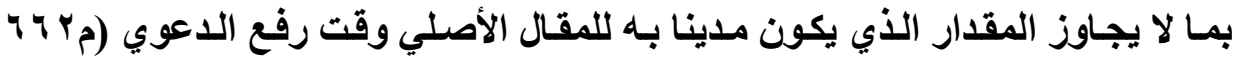

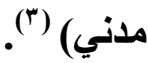

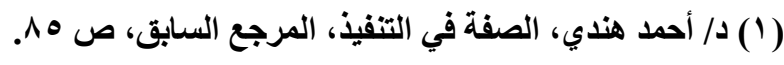

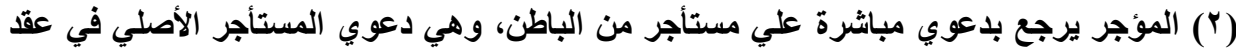

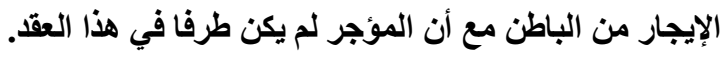

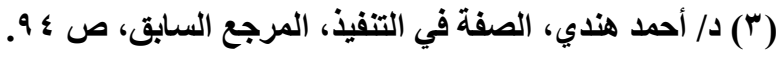


و إذا تعدد دائنو المحكوم لله، فبإن لأي منهم أن يستعمل حقوقه، فلكل دائن أن يرفع الاعوي غير المباشرة علي أن يختصم فيها المدين، ويستفيد جميع الدائنين من نتيجة الحكم في هذه الدعوي، باعتبار أن كسب هذه الدعوي يـخل في ذمـة المدين

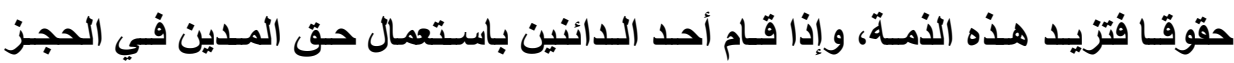
علي مدين المدين، فان الأمر يختلف بحسب طريق الحجز المتبع، فإذا قام دائن المدين بـالحجز علـي مـا لمدينه في ذمـة الغير - أي بطريـق حجز مـا للمـدين لـدي الغيـرفإنه إنما يستعمل طريقا رسمه لـه المشرع، أي يستعمل حقا خاصـا بـه، فهو لا يباشر الحجز باسـم المـدين أو لمـصلحته، وإنمـا باســه هـو ولـصالحه الثخصي، وبالتـالي فـإن الـائن يستأثثر بحصيلة التنفيذ، ولا يشـاركه فيـه بـاقي دائنـي المدين باعتبـار أن الحجز نسبي الأثر، لا يستفيل منه إلا من أجراه. ويجوز لسائر اللائنين أن يشاركوا في الحجز، وعندئذ يقاسمون الدائن الحاجز الأول في حصيلة التنفيذ باعتبارهم أطر افا في

أمـا إذا سـلك الـائن طريق الحجز التنفيذي بطريق الـدعوي الغير مباشـرة أو

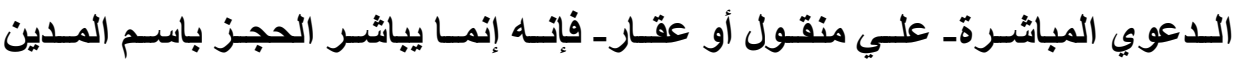
ولمصلحته، حيث أنه يستخدم حقـا خاصـا بالمدين، وبالتـالي فبان المتحصل من التففيذ

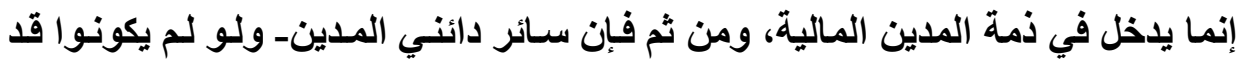
اشتركوا في الحجز- يستفيدون من حصيلة التنفيذ(') لمندين

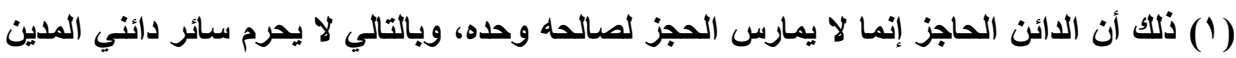

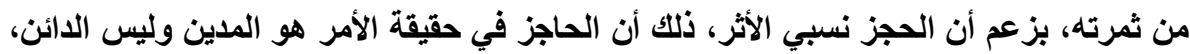

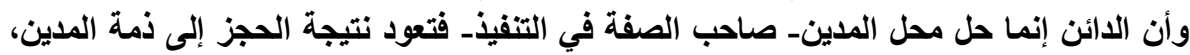

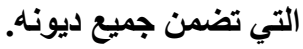




\section{الاطلب الثاني

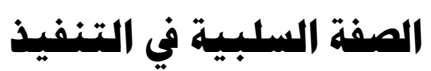

\section{(المنفذ ضده)}

المنفذ ضده هو صاحب الصفة السلبية في التنفيذ، هو الشخص الواجب التفيذ

في مواجهته، فهو الملتزم في السند التنفيذي(')، ولا صعوبة في تحديد صفة المدين، إذ يعني السند التنفيذ بتحديد شخص المدين بالالتزام(؟). فيتعين أن يكون هو الملتزم بالحق موضوع السند، أي مدينا لطالب التنفيذ إلى جانب كونه مالكا للمال الذي يجري التنفيذ عليه("). أي هو من يسمح السند التنفيذي بأن تتخذ إجراعات التنفيذ الجبري ضده، أو أو

$$
\text { بمعني آخر ضد أمواله(؛). }
$$

المنفذ ضده هو الطرف السلبي في التنفيذ الجبري(0)، ويعبر عنه عـادة بلفظ المحجوز عليه، إذا كان التنفيذ حاصلا بطريق الحجز، كما يعبر عنه بلفظ المدين علي تقدير أنه من يجري التنفيذ ضده باعتباره في مقام المدين بالنسبة للعلاقة التنفيذية.

(1) S. GUINCHARD et T. MOUSSA, droit et pratique des voies d'exécution, op. cit., $\mathrm{n}^{\circ}$ 111, 31.

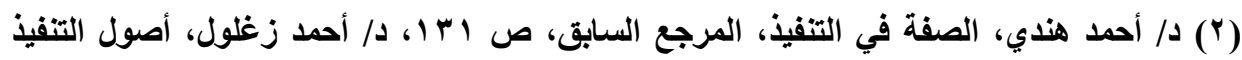

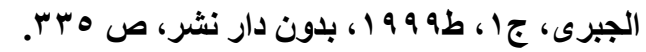

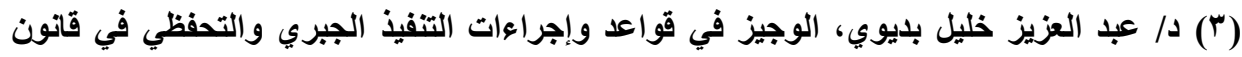

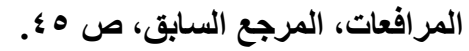

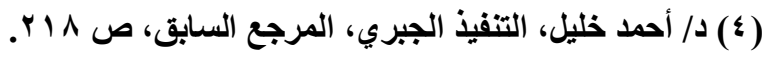

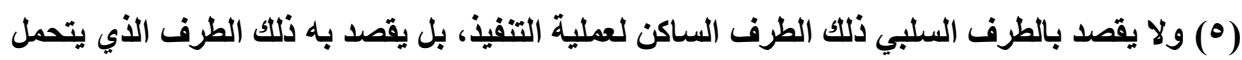

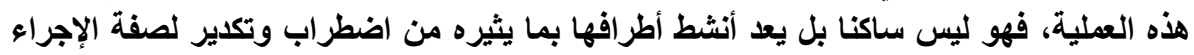
عندما يثير مناز عات التنفيذ. 
ونري أن مصطلح المنفذ ضده هو الأقرب إلى الدقة، وذلك لأن المدين مصطلح عام يطلق علي أي مدين بالتزام، سواء في خصومة التنفيذ أو في العقد، كنلك المحجوز

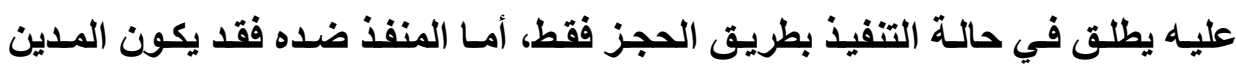

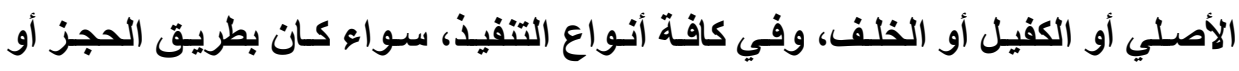

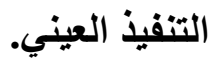
في الواقع صفة المنفذ ضده قد تثبت لشخص آخر غير المدين الأصلي، فيمكن

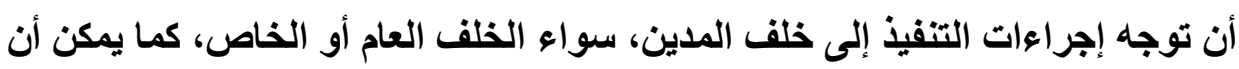
توجه كذلك إلى مدينه، أو كفيله الثخص باعتبار أن هؤلاء يقومون مقام المدين - في لفي

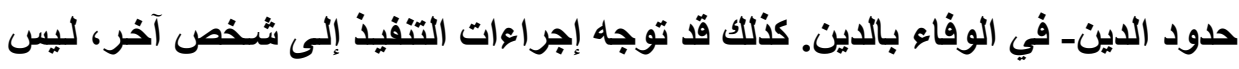
هو المدين وليس مسئولا شخصيا عن الدين، كما هو الكفيل العيني، أو ضد من انتقلت

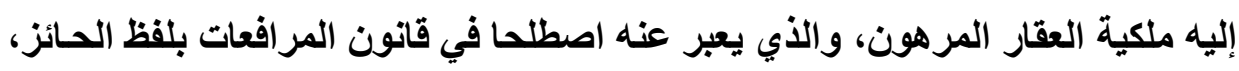

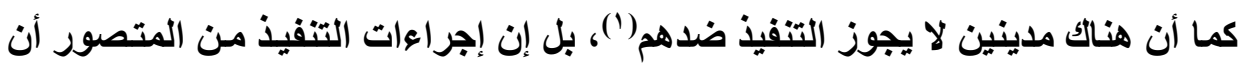

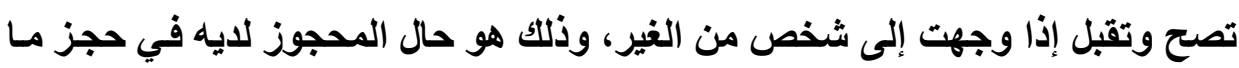

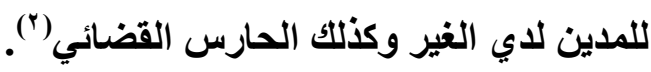
سنثير إلى الصفة الثخصية للمدين في السند، وذلك في الفرع الأول، ثم نعالج

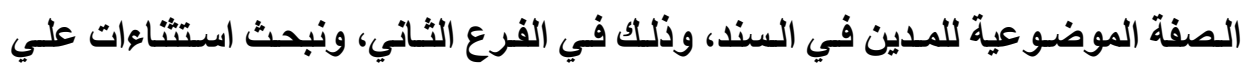
صفه المنفذ ضده، وذلك في الفرع الثالث، وذلك علي النحو التالي:

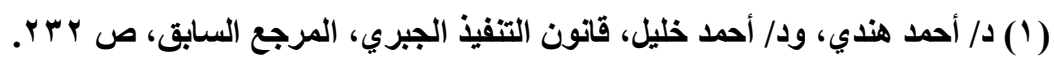

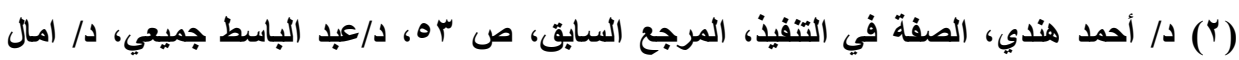

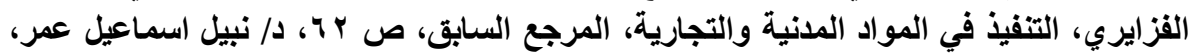

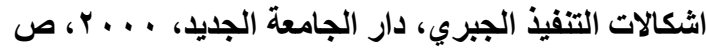




\section{الفرع الأول \\ الصفة الشخصية للمنفذ ضده}

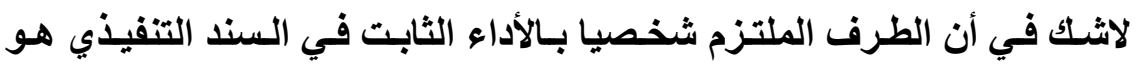

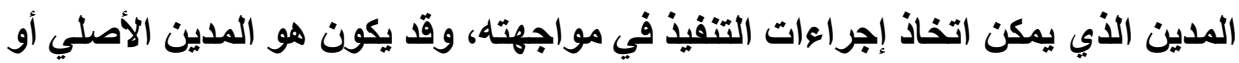

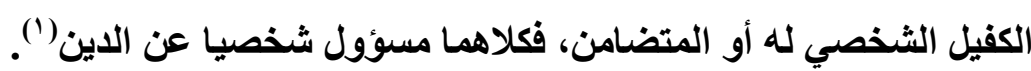
سنشير إلى صفة المدين الثخصي في السند التنفيذ، ثم نبحث صفة الكفيل الثخصي في السند التنفيذ، وذلك في النقاط الآتية:

\section{أولا: المدين الشخصية في السند التنفيذي}

لم يحدد المشرع صراحة المدين المنفذ ضده في التنفيذ الجبري، وإن أمكن

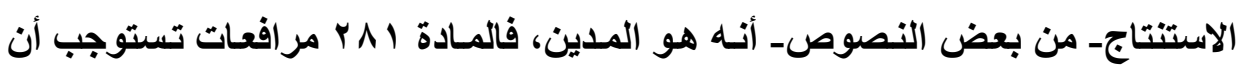

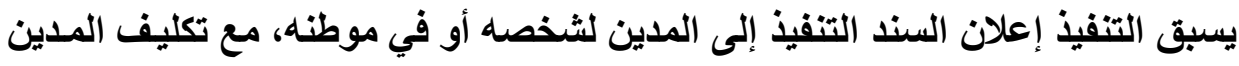

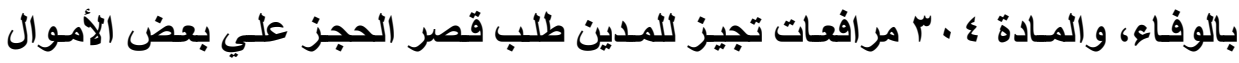

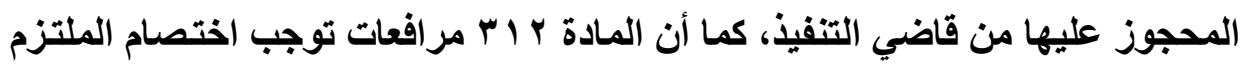
في السند التنفيذي في الإشكال حتي يترتب عليه وقف التنفيذ.

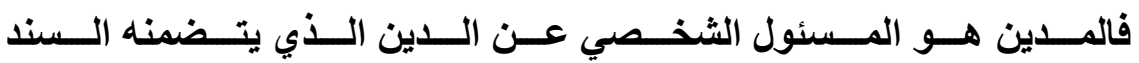

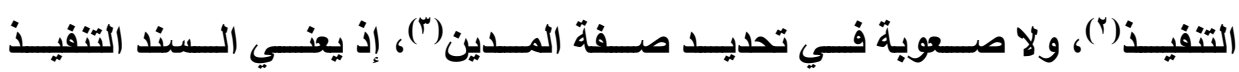

$$
\begin{aligned}
& \text { (1) د/ أحمد خليل، التنفيذ الجبري، المرجع السابق، ص9 آبـ }
\end{aligned}
$$

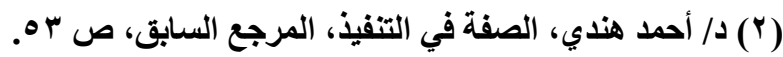

(3) S. GUINCHARD et T. MOUSSA, droit et pratique des voies d'exécution, op. cit., $\mathrm{n}^{\circ} 111,31$. 
بتحديـــــــص المسدين بـالالتزام(') فيتعسين أن يكسون هـو الملتـزم بـالحق موضسوع

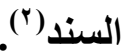

ويلاحظ أن الصفة الثخصية هي التي تبرر الحجز علي جميع أموال المدين(")، ويجب أن تثوافر هذه الصفة عند البدء في التنفيذ وأن تستمر أثناء التنفيذ. فإذا انقضي في فئي التزام المدين لأي سبب، فإن إجراعات التنفيذ يجب أن تتوقف، ويمكن للمدين أن يقدم منازعة في التنفيذ لبطلان إجراءاته لعدم توافر صفة لهه في التنفيذ(؛)، ويمكن التنفيذ

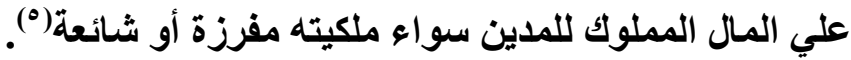

(1) د/ أحمد هندي، الصفة في التنفيذ، المرجع السابق، ص ابرا، د/ أحمد زغلول، أصول التتفيذ

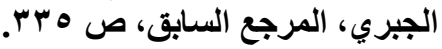

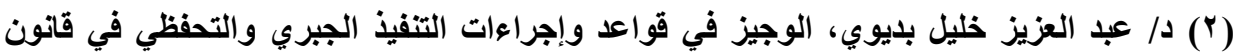

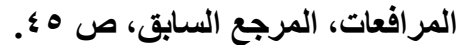

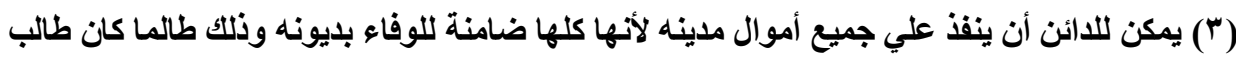

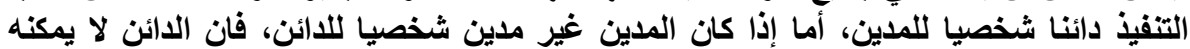

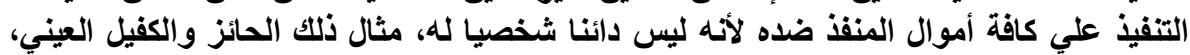

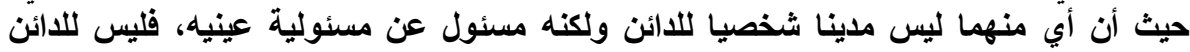

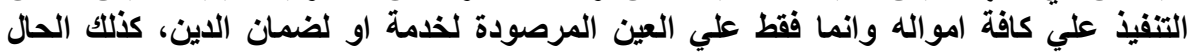

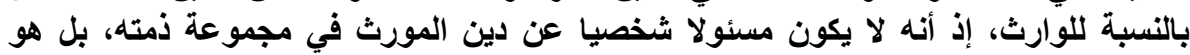
مسئول فقط مسئولية مالية في حدود التركة.

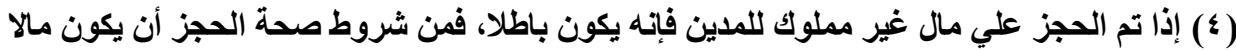

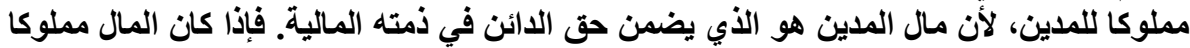

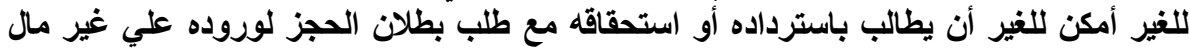

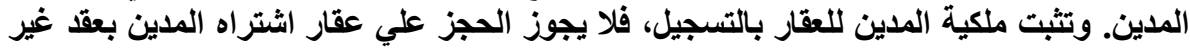

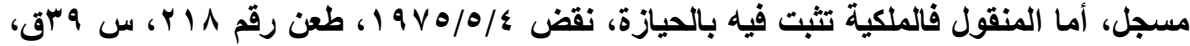

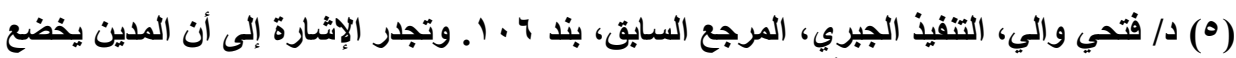

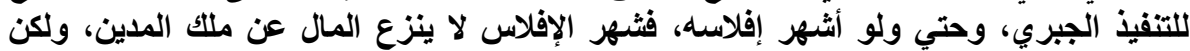

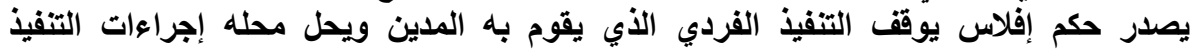

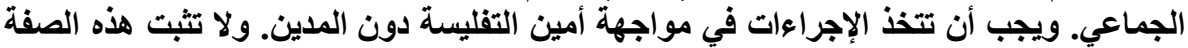

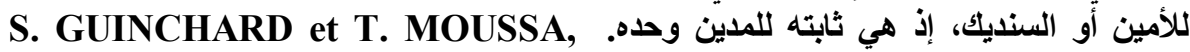
.droit et pratique des voies d'exécution, op. cit., $n^{\circ} 141,15$ 
الواقع أنسه لا يترتب علي زوال صفة المنفذ ضده عدم انقطاع سير إجراءات التنفيذ، فقد ذهبت محكمة النقض إلى أنـه "في اجراءات التنفيذ لا يحدث أي انقطاع للخصومة إذا توفي المنفذ ضده أو زالت صفة نائبه بعد بدء التنفيذ، وانمـا يجب توجيه الإجراءات علي تحقق هذه الحالة إلى نائبة، أو إلي المنفذ ضده إذا كانت قد اكتملت

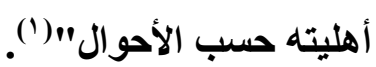

إذا زالـت صـفة المنفـذ ضـده أو زالـت صـفة مـن كـان يمثــه قبـل البـأ فـي التنفيذ أو قبل إتمامه، فيجب إعـادة الإعلان من يمثله(؟)، حتي لو سبق إعلان المنفذ ضده(")

وإذا بـأت بعد الإجراءات في مواجهة ممثل القاصر ثم بلـغ سن الرشـد أثنـاء

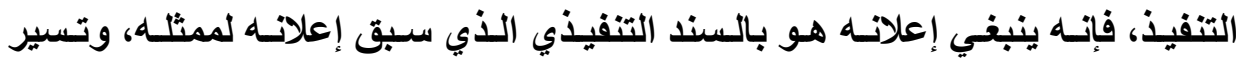
الإجراعات في مواجهتهـ فبإذا لـم تعلن لـه الأوراق بصفته الجديدة لا يعد خصما في

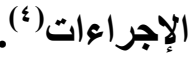

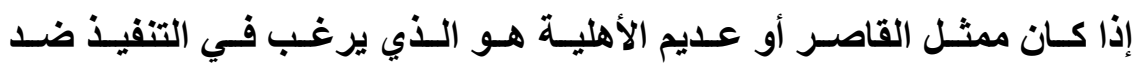
القاصـر فإنـه وجب عليـه أمسا أن يعتزل الوصـاية ويطلب مسن المحكمـة تعيبين وصسي بـلا منـه أو يطلب مـن المحكمة تعيين وصسي لخصومة التفيذ ليتخذ الإجراعات في

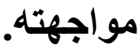

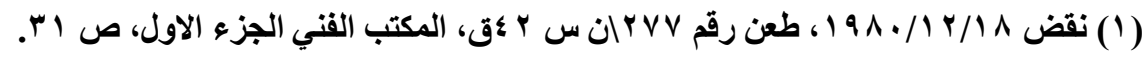
(2) S. GUINCHARD et T. MOUSSA, droit et pratique des voies d'exécution, op. cit., n $111,31$. 
وإذا توقـع الحجـز بعـد مـوت المسين أو فقـده للأهليـة أو بعـد زوال صـفة مسن كـان يباشــر الإجـراءات نيابـة عنـه، دون إعـلان الـسند التنفيـذ، كـان الحجـز بـاطلا لـيس لأن اجراءات التنفيذ ترد عليهـا الانقطـاع، بـل لأن كـل إجـراء لا يعـد صـيحا إلا إذا اتخـذ فـي مواجهـة ذي الـصفة، وبشرط أن تتـوافر لايـهـ الاهليـة التـي يوجبهـا

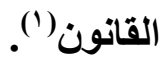

وإذ اتخذت إجراءات التنفيذ ضد شخص ليس له صفة كاتت الإجراعات باطلة)(؟)،

ولهـا يجب علـي الـائن أن يوجه الإجراءات في مواجهة صـاحب الصفة. ونـري أن البطلان يتعلق بالنظام العام. فيجوز لأي خصم طلب البطلان، ويمكن للقاضي أن يحكم باه من تلقاء نفسه.

ويختلف مركز المنفذ ضده عن مركز المدعي عليه الخصومة العادية، ذلك أن الخصومة تتصل بادعـاء معين يراد تحقيقه، ولهذا يجب دعوة المدعي عليه لإبـاء دفاعه، أما في التنفيذ فيتعلق الأمر بحق مؤكد يراد اقتضاؤه جبرا عن المدين، ولهذا فلا

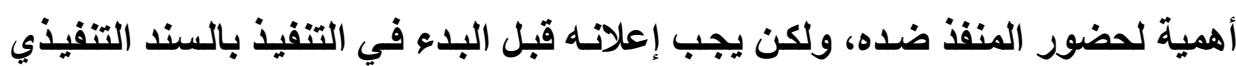
وبعزم دائنه علي التنفيذ(").

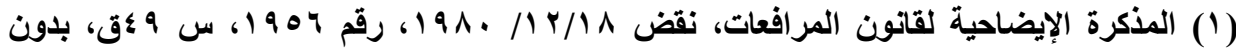

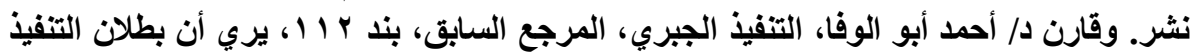

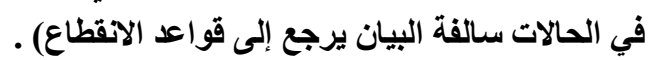

(2) Cass. 2e civ., 26 mars 1997, Rev. Duissiers, 1997, 1001. 
وإذا تعدد المدنيين، ولم يوجد بينهم تضامن فتوجه الاجراءات لكل مدين علي حده(')، أمسا إذا تعدد المدنيين وكان بينهم تضامن(") ورفعت الدعوي عليهم كلهم أو علي بعضهم واختصم البعض الأخر، فللائن أن ينفذ علي أي منهم بكل الدين. ولكن لا يجوز التنفيذ ضد احد المدنيين المتضامنين لـم يتناولـه السند التنفيذي لأن النيابـة فيمـا

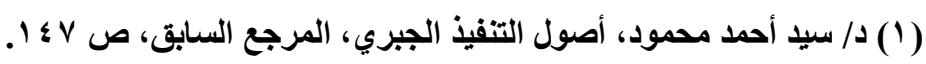

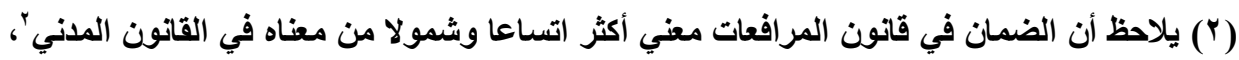

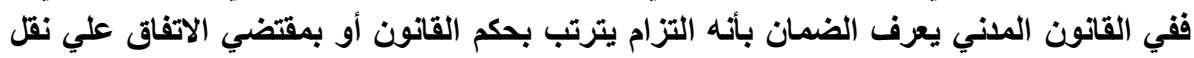

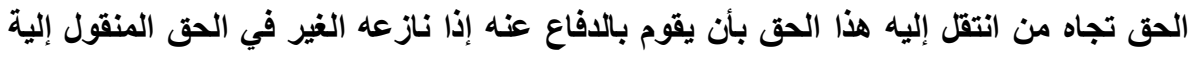

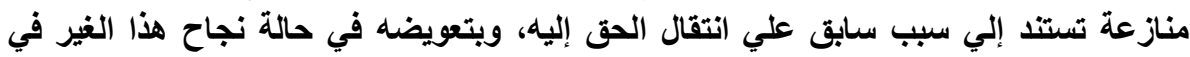

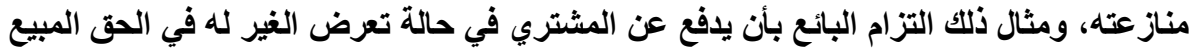

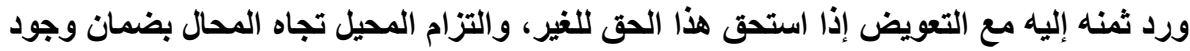

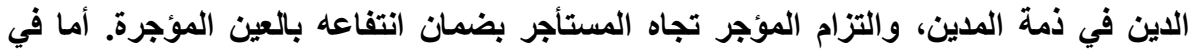

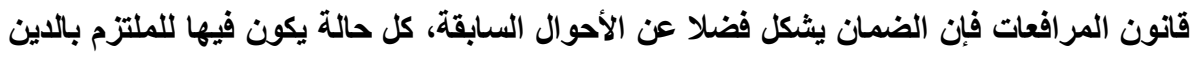

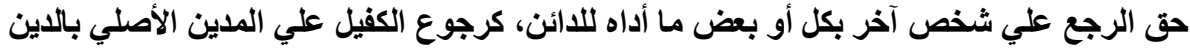

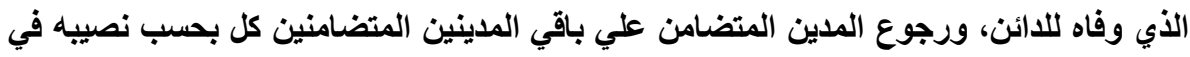

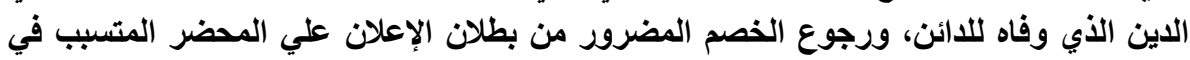

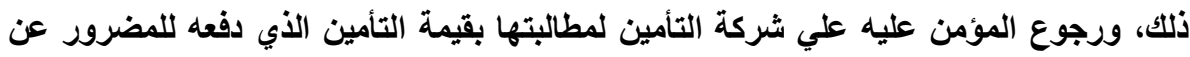

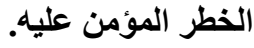

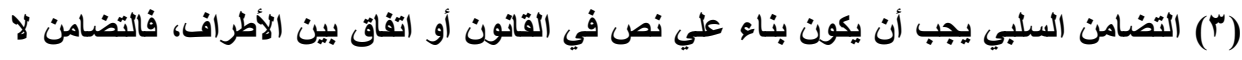

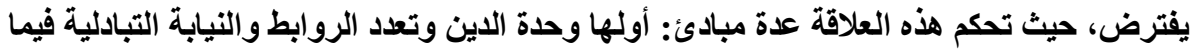

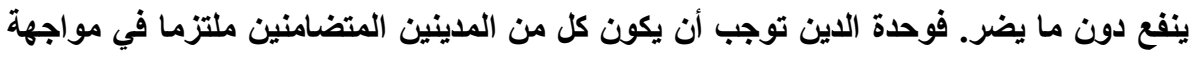

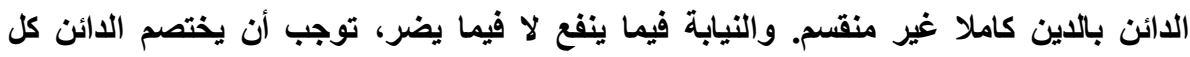

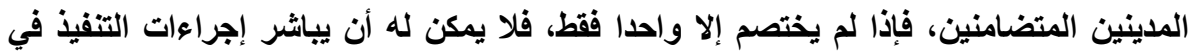

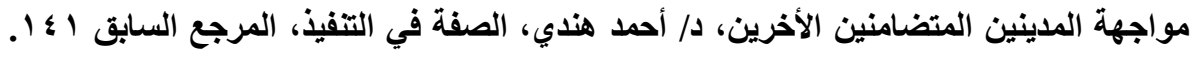

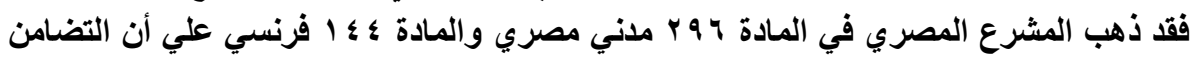

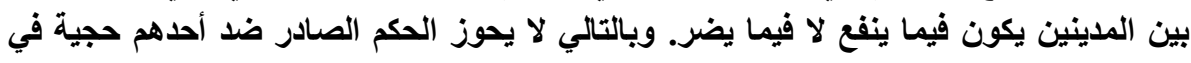
مواجهة الباقين طالما يضر هم. 
في الواقع التضامن السلبي يؤدي إلى أن يكون للدائن الحق في مطالبة أي

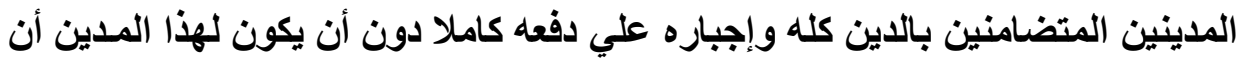

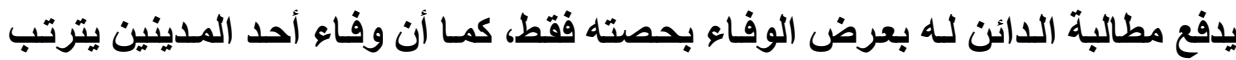

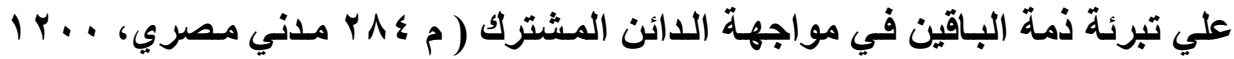

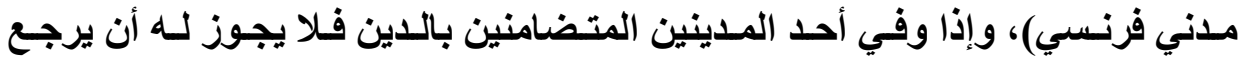

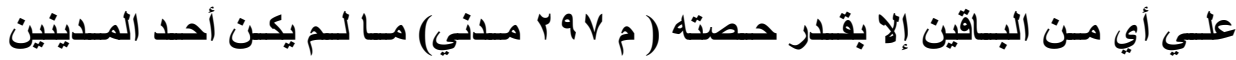
المتضامنين هو وحده صاحب المصلحة في الدين، ففي هذه الحالة يتحمل هذا المدين الدين كله نحو الباقين ( م 9 9 V مدني) كمـا لو كان أحد المدينين هو المدين الحقيقي والباقي مسئولين أمام الدائن كمدينين متضامنين، وتنطبق أحكام الكفالة في علاقتهم

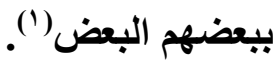

أجـاز القـانون لـصاحب الـضمانـ فـي حالـة اختصامه للـضامن- أن يطلـب

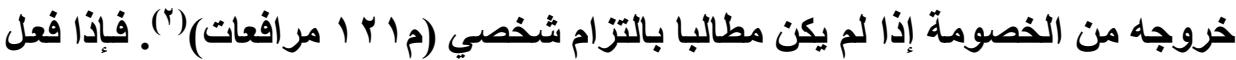
ذلكك فإنه يكون قد وافق ضمنا علي ترك الدفاع في الخصومة للضامن، وميع ذلكت

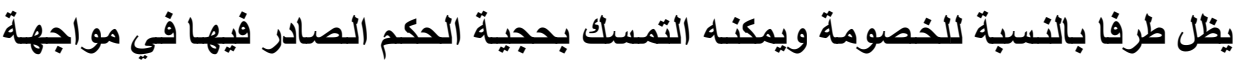
الخصوم الآخرين، كما يمكن لهؤلاء الخصوم التمسكك بهذا الحجية في مواجهته(").

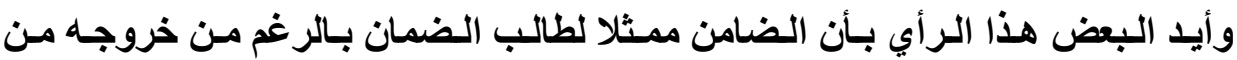

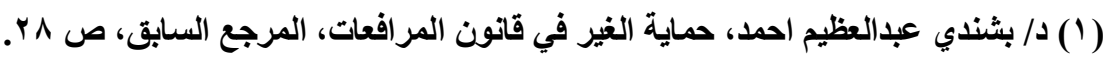

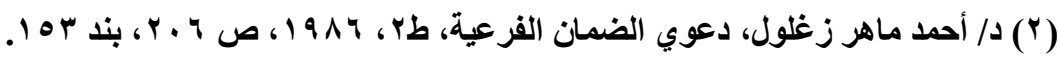

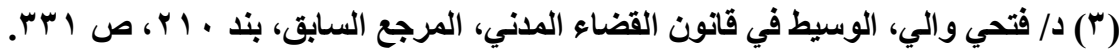


الخصومة، وبالتـالي يحوز الحكم الـصادر في اللـعوي حجيـة الشيء المحكوم فيـه

بالنسبة له (') - 20

ويري جانب من الفقه أن خروج صاحب الضمان من الخصومة يعتبر تركا لها

ويفقده صفة الطرف فيها(؟). فبالرغم من أن الضامن يلتزم بتعويض صاحب الضمان إذا

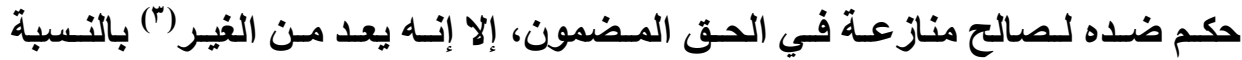

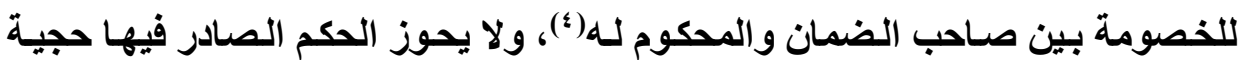

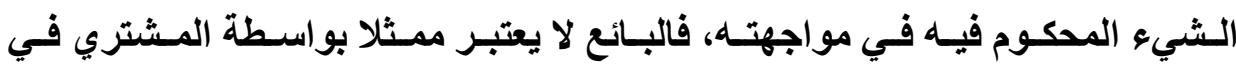

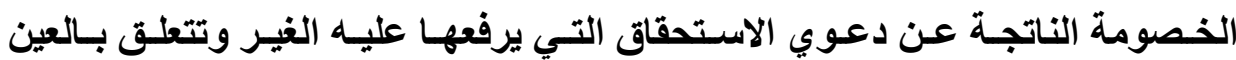

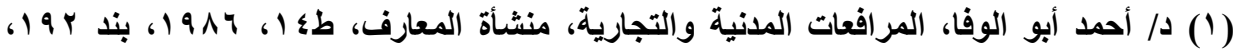

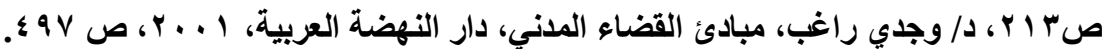

(2) E. Garsnnet et Ch. Cezar-Bru, « traite théorique et pratique de procédure civile ", sirey, 1913, $\mathrm{n}^{\circ} 594$, p. 229.

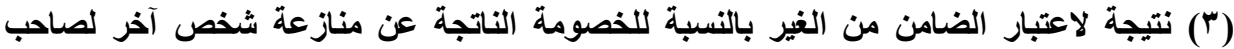

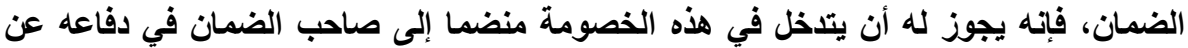

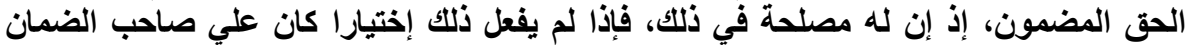

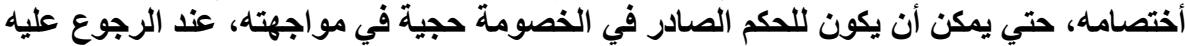

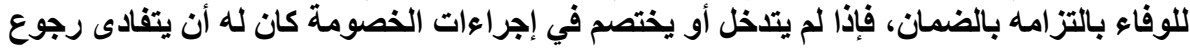

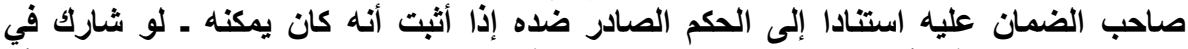

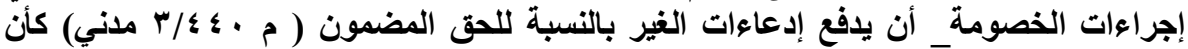

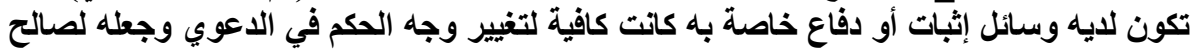

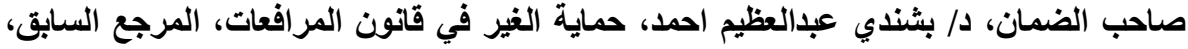

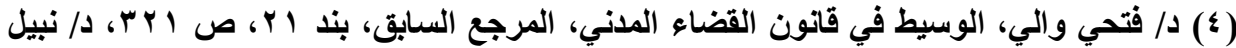

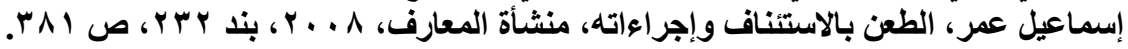


المباعة(')، إلى جانب أن الكفيل لا يمثله المـين في الخصومة بينه وبين الـائن()، ونفس الشيء بالنسبة للمؤمن فيما يتصل بالخصومة بين المؤمن عليه والمضرور(").

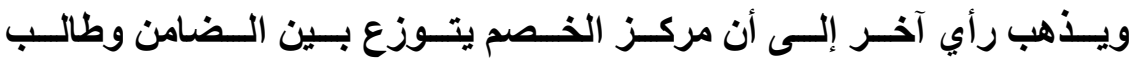

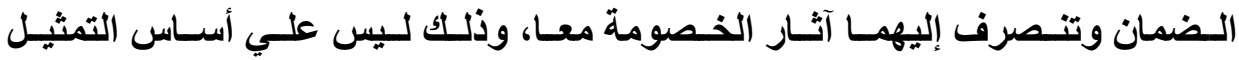
الإجرائي، ولكن علي أسساس فكرة الحلول الإجرائس. وذلك لأن فكرة التمثيل الإجرائسي تــطلم بـبعض العقبـات القانونيـة، حيـث إن الـضامن يباثـر إجـراءات الخـصومة باعتباره خصما فيها وليس مجرد طرف في الإجراءات، وينفذ الحكم في مواجهته، كما لا يوجـ مـصدر للتمثيـل لا قـانوني ولا اتفـاقي (๕). وتعدد أطراف الالتزام غيـر القابـل للانقسام، يستوي في ذلك الـائنون والمـنيون، ولكل دائن أن يطالب المدين بـأداء الالتز ام كاملا.

ويثـار التساؤل هـل الحكم الـصادر ضـــ الشركة يـصلح للتنفيذ ضـــ الشريك المتضامن؟ في الواقع قد اختلف الرأي بشأن هذه الإشكالية، حيث يتجه رأي إلى عدم جواز الحجز علي الشريك لدين علي الشركة طالمـا كـان الدين علي الشركة(ْ)، ويتجهـ

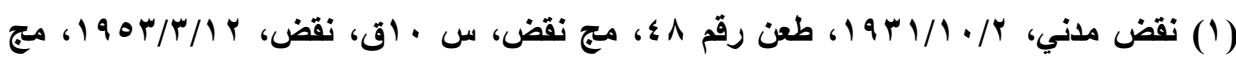

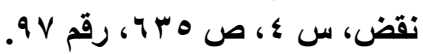

(2) N. FRICERO, "tierce opposition, ency". D. Rep. proc. Civ., 2e ed. T. 3, no 105.

(3) P.D. Madec, L'autorité de la juge jugée et l'assureur en matière civile, thèse Rennes 1976.

$$
\text { (؛) د/ بشندي عبدالعظيم احمد، حماية الغير في قانون المر افعات، المرجع السابق، صه r. }
$$

(5) Cass. 2e civ, 19 mai 1998, Bull. civ., 11, n 161, D., 1998, 405, RTD, civ., 1998, p. 750, obs. R. Perrot.

$=$ 
الرأي الغالب إلى إمكان هذا التنفيذ، وليس للشريك أن يدفع في مواجهة دائن الثركة بالتفيذ علي مال الشركة أولال')، فهو بمثابة كفيل متضامن تظليبا لمقتضيات العدالة، وهذا خلاف للوضع في التضامن بين المدينين، فهو تضامن إجباري بنص القانون، و هي قاعدة موضوعية لا تقبل الاليل علي عكسها، وهي تتعلق بالنظام العام.

ويجب علينا أن نفرق في مسئولية الثريك بين المسئولية شخصية والتضامنية، فإذا كان مسئولا شخصيا جاز التنفيذ عليه، ويمكن التنفيذ عليه بكافة ديون الشركة،

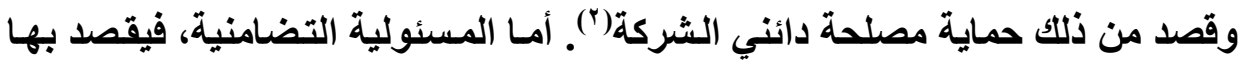

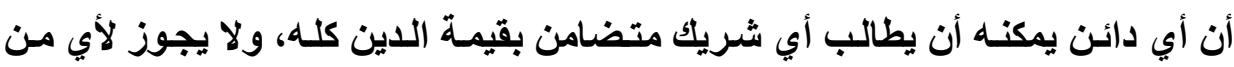
الشركاء أن يدفع في مواجهة دائن الشركة بالتجريد. أي تجريد الشركة من أموالها أولا، ولا بالتقسيم بين الشركاء المتضامنين. ولا يجوز للائن الشريك أن يحجز علي أموال الثركة حتي ولو كانت شركه تضامن(")،ويثار التساؤل عن مركز المسئولين عن التهن

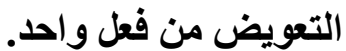

إذا اثـترك أكثر مـن شخص في ارتكاب فعل ضــار، جريمـة أو شبه جريمـة، وترتب علي ذلك حدوث ضرر بشخص آخر، فِإن كل من تسبب في هذا الضرر يعتبر

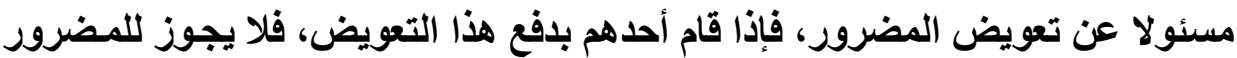

ذهبت محكمة النقض المصرية إلى أنه إذا صدر حم ضد شركة فلا يجوز التنفيذ على أموال

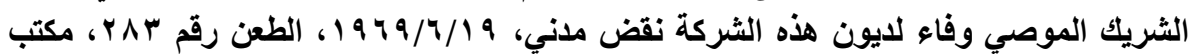

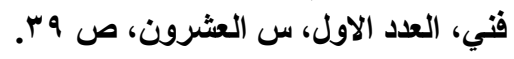

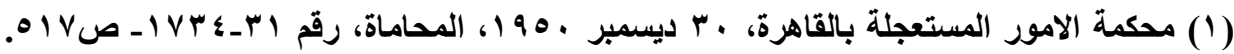

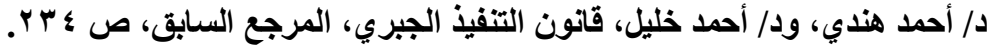

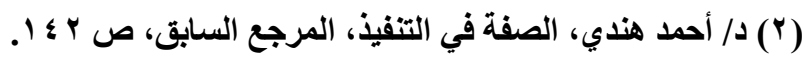
(3) Cass. 2 civ., 26 oct. 1999, RTD, civ., 2000, p. 167. 
أن يطالب الباقين، لأنه ليس له أن يحصل علي التعويض عن الضرر الذي لحق بـه إلا مرة واحدة فقط، ولكن يظل كل من هؤلاء المشتركين في الفعل الضار من الغير بالنسبة

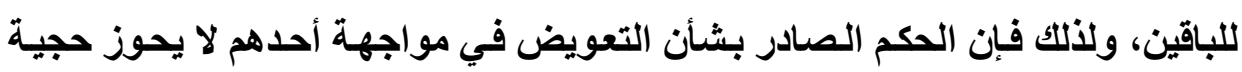

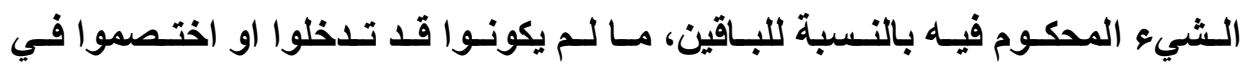

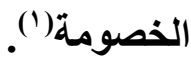

إذن فصفة الغير ذات طابع إجرائي بحت، ولذلك فهي تشتقل عن علاقة الشخص بالنسبة لموضوع النزاع. وقد نص المشرع المصري علي هذه المسألة في المـادة 979 مدني علي أنهه" إذا تعدد المسئولون عن عمل ضـار، كـانوا متضامنين في التزامهم بتعويض الضرر

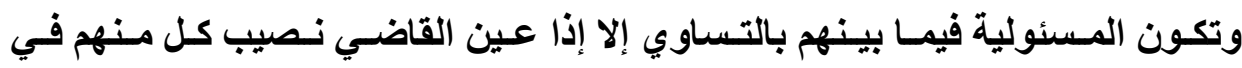
التعويض" وبالتالي يطبق أحكام تضامن المدنيين علي هذا الفرض. ولا يمكن الرجوع علي الضامن، إذا أثبت الضامن أن الصكم الصادر في الدعوي

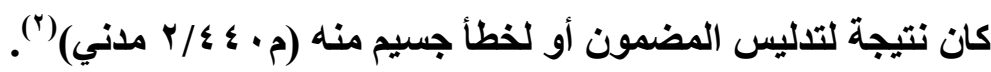
ويثار التساؤل عن حجية السند التفيذي في مواجهة الأطراف في حالة السند

(1) إذا ارتكب أحد الأثخاص فعلا ضارا ترتب عليه حدوث ضرر بأكثر من شخص، فئلفئ هؤلاء

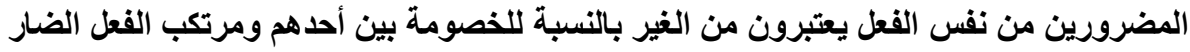

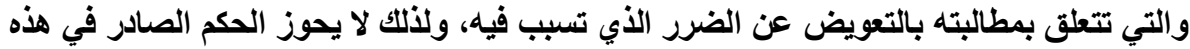

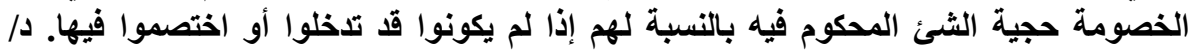

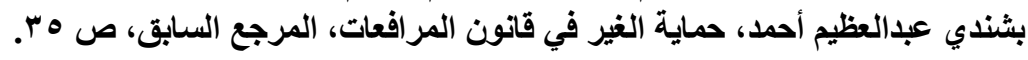

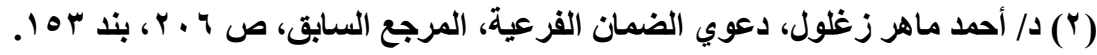




\section{اختلف الفقه في الاجابة علي هذا التساؤل علي النحول التالي:}

الاتجاه الاول: يري البعض أن الدائنين أو المدنيين في التزام لا يقبل التجزئسة

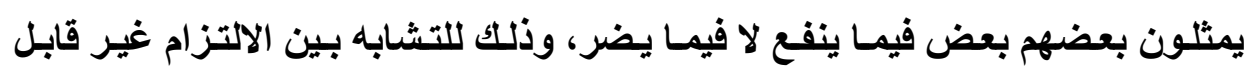
للانقسام والالتزام التضامني (')

الرأي الثـاني: يري أن السند يحوز الحجية في مواجهة كل الأطراف، سواء

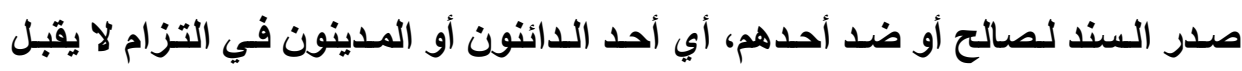

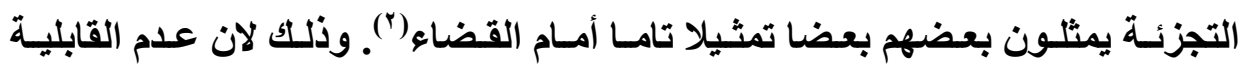

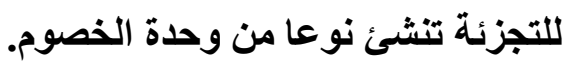

الرأي الثالـ: بينمـا ذهب رأي آخر إلى أن السند التنفيذي في مواجهة أحدا

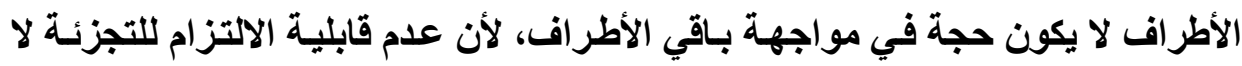

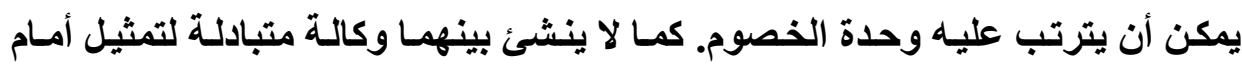
القضاء. لان ترابطهم ليس بسبب رابطة الالتزام المشترك بل بسبب محل الالتزام غير

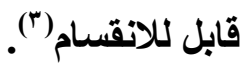

في الواقع إذا تعدد الدائنون أو المدينون في التزام لا يقبل التجزئة، ترتب علي

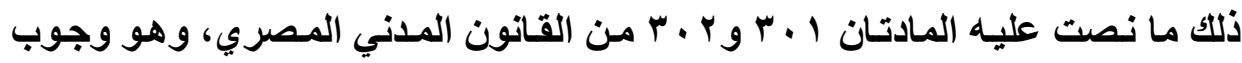

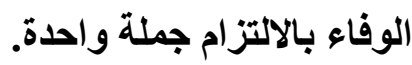

(1) Aubry et Rau, Cours de droit civil français, op. cit, p. 419.

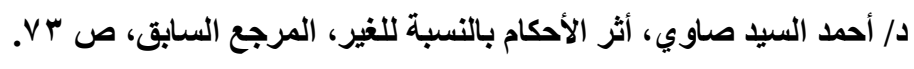

(2) Tiddeier, note au Rev. Trim. Civ. 1906, p. 644.

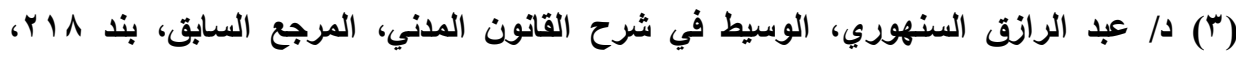

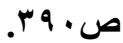




\section{ثانيا: صفة الكفيل الشفصي}

إذا كـان الـائن ينفـذ بحقه تجـاه المـدين الأصلـي لأنـه مسئول مسئولية شخصية

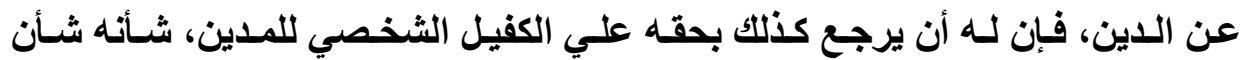
المدين، لأنـه مسئول شخصيا عن الدين، كمـا يمكن لـه أن ينفـذفي مواجهة المـدين

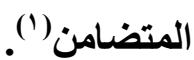

فقد ذهبت محكمـة النقض المصرية إلى أن "ليس في القـانون مـا يمنـع مـن مسئولية مدينين متعددين عن دين واحد تضامن هؤلاء المدينين في الدين... وللائن التنفيذ به كله قبل أيهما"(")

يقصد بالكفيل الشخصي للمنفذ ضده، من يتعه للائن بـأن يفي بـالالتزام إذا لم يوفي به المدين نفسه ( م VVY مدني). فالكفيل يضم ذمته المالية إلى ذمـة المدين في ضمان دين الدائن. فأصبح الضمان العام يرد علي المدين وكفيل المدين أيضا. وينشأ عقد الكفالة بين الدائن في الالتزام الأصلي وبين الكفيل، أما المدين في الالتزام الأصلي فليس طرفا في عقد الكفالة. وإلى جاتب الضمان العقدي، فإن هناك الضمان التقصيري أو ضمان العدوان، الذي يقوم كلما أرتكب شخص فعلا يمثل إخلالا بواجب قانوني، حيث

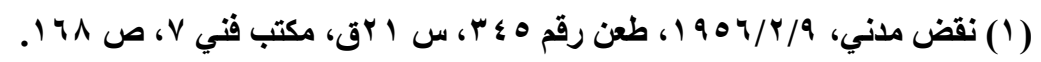

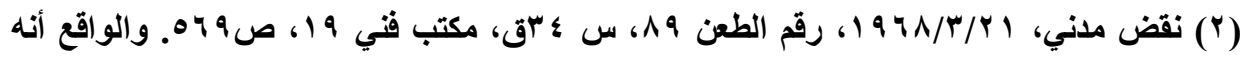

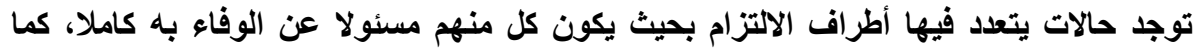

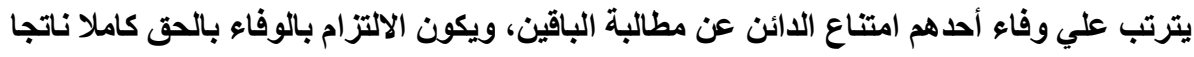

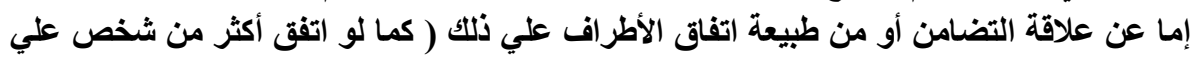

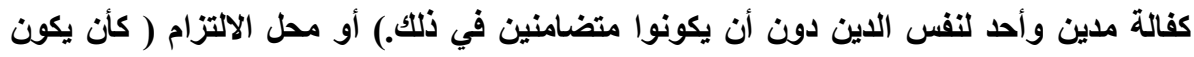
الالتزام غير قابل للقسمة) أو نتيجة حكم قضائي. 
لا يوجد عقد بين الطرفين أو كان العقد باطلا، كما إذا أصيب أحد ركاب سيارة في حادث تصادم بينها وبين سيارة أخري (')، وهو دائمسا التزام بتعويض الضرر، وسواء كـان تعويضا نقديا أو تعويضا عينيا"(

ويتضمن التزام الكفيل أن يفي بالتزام المدين الأصلي إذا لم يف به المدين نفسه.

فيلتزم بصفة احتياطيـة. لـلك فمن العدل إلا يطالبه الدائن بالدفع قبل أن يرجع علي المدين الأصلي بهذا الدين(") فإذا حصل الدائن علي حم يثبت حقه، فإنه يستطيع تنفيذ هذا الحكم سواء ضد المدين أو ضد الكفيل، فكلاهما تثبت له صفة المنفذ ضده. علي أنه يجب علي الدائن أن ينفذ أولا ضد المدين، بأن يجرد المدين من أمواله قبل التنفيذ علي الكفيل، لأن التزامه تابع لالتزام المدين، وهو مدين احتياطي للائن. ويمكن للكفيل أن يدفع بتجرد إذا نفذ عليه أولا (م V^^مدني)، فليس من العدل أن يري الكفيل أموالهه تنزع منه، بينما أموال المدين قائمـة لا تمس. وللكفيل أن يدفع بـالرجوع علي المدين أولا. وهذا دفع إجرائي وهو ليس دفعـا بعدم القبول، ولكنهـ دفع يعيب علي الدائن أنـه أخطأ في اتباع إجراعات المطالبة بدينه. وهو من قبيل الدفع ببطلان إجراءات المطالبة بالدين. ويقصد بالدفع الرجوع رفع دعوي يطالب المدين أولا، فلا يكفي أن يعذر الدائن المدين حتي يحق لهه أن يرجع علي الكفيل بعد ذلك. ويجوز للدائن أن يتخذ إجراءات تحفظية علي أموال الكفيل الشخصي كالتوقيع الحجز التحفظي(؛).

(1) Cass. 2e civ., 26 mars 1997, op. cit., $\mathrm{n}^{\circ} 111,31$.

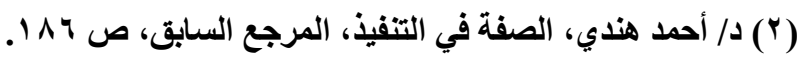

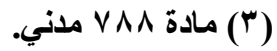

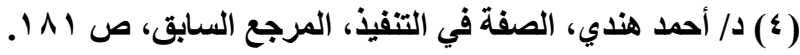


وإذا تعدد الكفلاء لدين واحد، وكانوا قد كفلوا مدينا واحدا، بعقد واحد، ولم يكن فيما بينهم تضامن، فأن الدين يقسم بينهم ولا يجوز للائن أن يطالب كل كفيل إلا بقدر نصيبه في الكفالة('). فلا يجوز للائن أن يطالب أي من الكفلاء بكل الدين، وإذا لم يذكر تحديد لنصيب كل كفيل في الدين فـأن الدين ينقسم علي الكفلاء بحسب عددهم. وإذا اعسر أحدهم فإن الدائن هو الذي يتحمل حصة هذا المعسر، ويقع التقسيم بقوة القانون. ويكون للكفيل الحق في الرجوع علي المدين بما وفاه، ويلتزم الدائن بتسليمه مستتدات

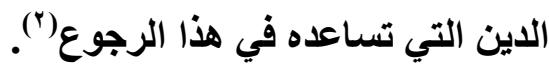

\section{الفرع الثاني}

\section{الصفة الموضووية لامنفذ ضده}

الأصل أن التفيذ لا يجري إلا في مواجهة المدين صاحب الصفة الشخصية، لأنه الملتزم بالأداء الثابت في السند التفيذي، ولكن قد ينتقل مال المدين لشخص آخر، فهنـا يجوز التنفيذ في مواجهـة مـن انتقل إليـه المسال، إذ تتـوافر الصفة الموضـوعية في الشخص الذي انتقل إليه المال محملا بحق لـائن يملك سندا تنفيذيا، ويتمثل ذلك في خلف المنفذ ضده، وفي الكفيل العيني.

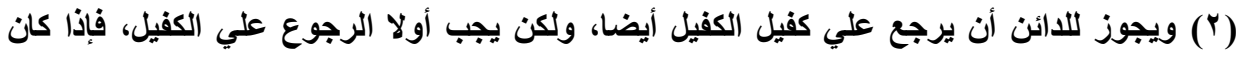

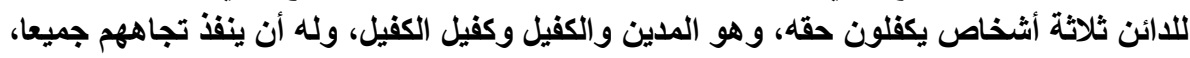

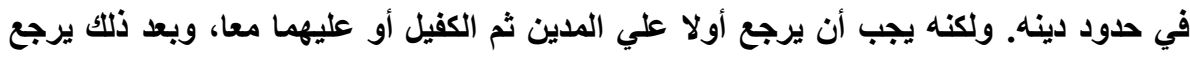

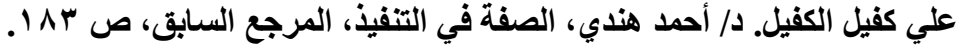




\section{سنشير إلى أصحاب الصفة الموضوعية في النقاط التالية: أولا: الصفة الموضومية النشأة بسبب الخلافة}

يقصد بخلف المنفذ ضـده، الأشخاص الذين يتلقون مـال عن سـالفهم محمـلا

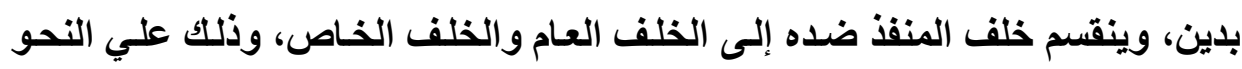
التالي:

ا - الغلف العام للمنفذ ضده:

يقصد بالخلف العام، من تلقي مال من السف، باعتباره وارثا لـه أو موصي لـه

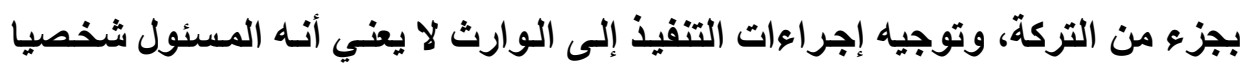

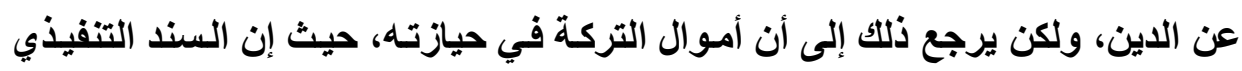

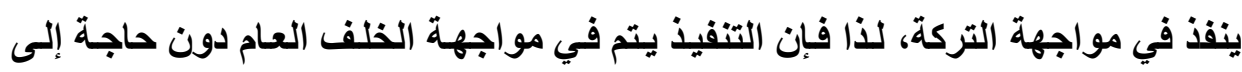

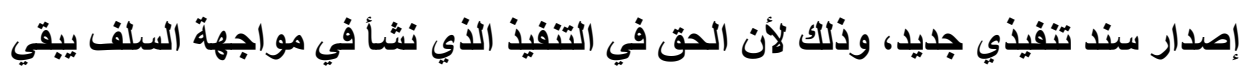
كما هو في مواجهة الخلف، حيث يوجه التنفيذ إلى مـال السلف، لأن الخلف تلقي مـالا من السلف مثقلا بحق يخول الائن حق تتبع مال السلف والحصول علي حقه من ثُمنهـه.

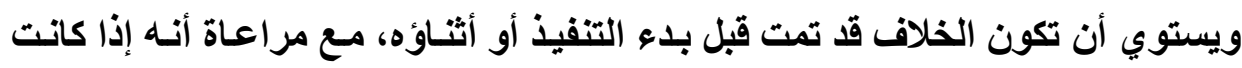

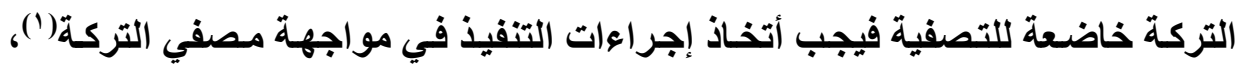
وفقا لنص المادة ه ه وما بعدها من القانون المدني. وقد ذهبت محكمة النقض المصرية إلى أنه "إذا كـان الحكم المطعون فيه قد

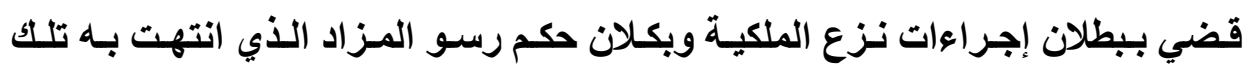


الإجراءات وذلك استنادا إلى أن البنكــ الطاعن- لم يتخذ الاجراءات الصحيحه وأنـه لم يعلم الورثه جميعا بما يتخذه من إجراعات ودون أن يكون لهم من يمثلهم قانونـا أو يملك التحدث عن التركه، فإن النزا في صورته هذا يكون غير قابل للتجزئه ويجب لكي يكون الطعن بـالنقض مقبولا شكلا في هذه الحالة ان تتخذ بالنسبة إلى جميع الخصوم فيه. إجراءات الطعن التي أوجبها القانون فبإذا بطل الطعن بالنسبة لاحدهم واصبح الحكم نهائيا بالنسبة إليه بطل تعبا بالنسبة للجميع"(1').

وفي حالة تعدد الورثة، فهل يجوز اتخاذ إجراعات التفيذ في مواجهة بعضهم؟ تنص المادة \& ؟ مر افعات علي أنه إذا توفي المدين قبل البدء في التنفيذ أو قبل إتمامه فلا يجوز التنفيذ قبل ورثته إلا بعد مضي ثمانيـة أيسام من تـاريخ إعلانهم بالسند التنفيذي، ويجوز قبل انقضاء ثلاثتة أثـهر من تـاريخ وفـاة المدين أن تعلق الأوراق المتعلقة بالتنفيذ إلى ورثثه جملة في آخر موطن لمورثهم بغير بيان أسمائهم وصفاتهم. يستفاد من ظاهر النص أنه يجب علي الدائن مباشرة إجراعات التنفيذ في مواجهة كافة

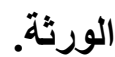

نري أن الأئن يملك اتخاذ إجراءات التنفيذ الجبري في مواجهة بعض الوارث في حدود نصيبهم في التركة، فبإذا كـان هذا النصيب يكفي للوفاء بالدين، فِإن الموفي بالدين من الوارثة يملوك الرجوع علي باقي الورثنة في حدود نصيب كل واحد منهم. وإذا لم يكن نصيبه يكفي للوفاء بالدين، فإن الدائن يملك توجيه الإجراعات في مواجهة 
باقي الورثة. وما نصت عليه المادة ؟ ^ مرافعات يهدف إلى إعلان الورثة بوجد سند تنفيذي في مواجهة التركة(')

والواقع أن الخلف يفترض أنه كان حاضر ا في الدعاوي التي كان سلفهم حاضرا فيها، ومن ثم يستفيدون من الأحكام التي صدرت لصالحه(ז)، كمـا يضارون منها، في حدود تركة مـورثه ("). إعمـالا لقاعدة لا تركه إلا بعد سداد الديون. فالسند التنفيذي يكون حجة في مواجهة الخلف في حدود ما تلقاه عن سلفه(")، وبالتالي فحقوق الخلف الخاصة لا يمكن التنفيذ عليها(ْ).

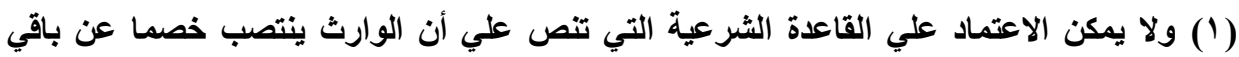

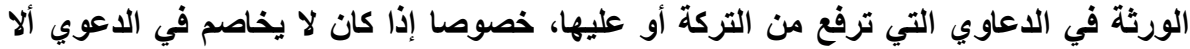

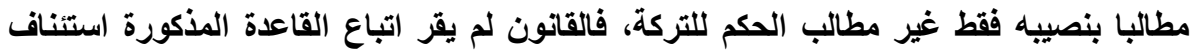

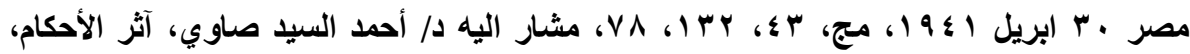

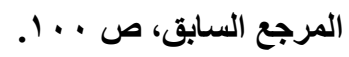

(r) د/ عبد الرازق السنهوري، الوسيط في شرح القانون المدني، ا، مصادر الالتزام، ؛ ؟ 9 1، بند

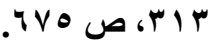

(3) Roger Perrot"Autorité de la chose jugée au civile sur le civil", op. cit., no 143' Lacoste paul, De la chose jugée en matière civile, criminelle et administrative, op. cit., no. 482.

(4) S. GUINCHARD et T. MOUSSA, droit et pratique des voies d'exécution, op. cit., $\mathrm{n}^{\circ} 111,31$.

د/ عبد الرازق السنهوري، الوسيط في شرح القانون المدني، 1، مصادر الالتزام، المرجع السابق، بند

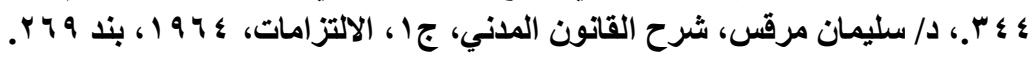

(5) Laurent, principes de droit civile français, op. cit, n. 96. 


\section{r - r الخاف الخاص للمنفذ ضده:}

يقصد بالخلف الخالص من انتقل إليه حق مـالي من المدين محمـلا بـدين، وهذا الحق ينتقل إلى الخلف الخاص بالحالة التي كان عليها لحظة انتقاله إليه، فيجوز للائن التنفيذ بحقه تجاه الخلف الخاص مثل المحال عليه الدين(')، والمشتري(") والموصي له له

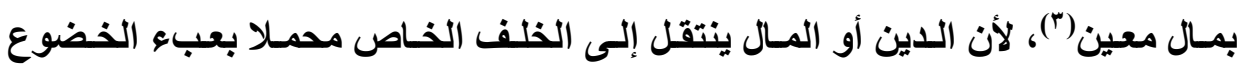

للتنفيذ(")، حيث تثبث الصفة الموضوعية للخلف الخاص باتتقال المال اليه. يشترط للتفيذ في مواجهة الخلف الخـاص أن يكون حق طالب التففيذ نافذا في مواجهته، فإذا لم يكن نافذا، فِإن الخلف الخـاص يعتبر من الغير. ومن أجل بيـان

(1) بمجرد حوالة الاين، أصبح المحال اليه ذات صفة موضوعية في التنفيذ الجبري، وبالتالي للائن

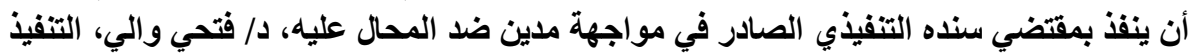

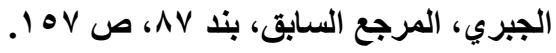

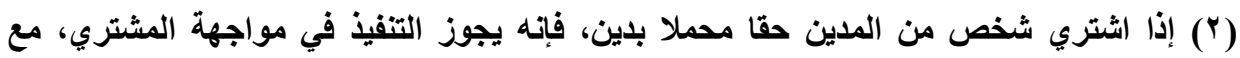

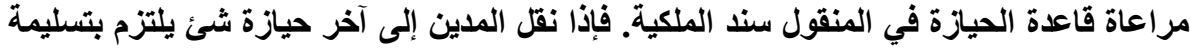

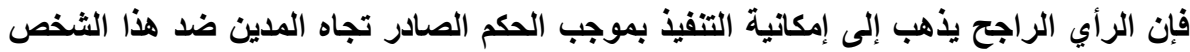

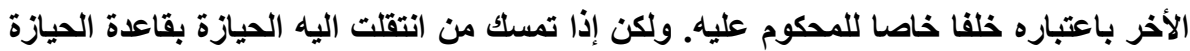

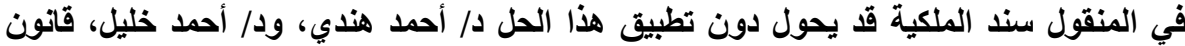

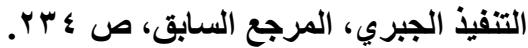

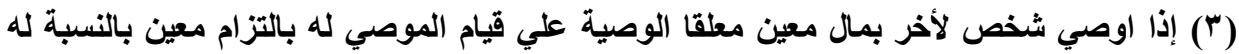

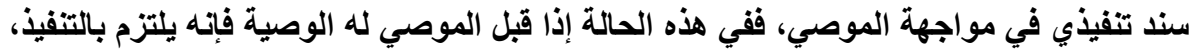

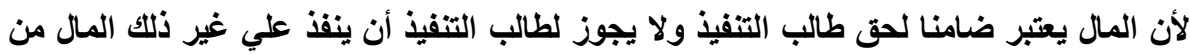

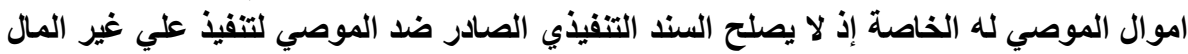

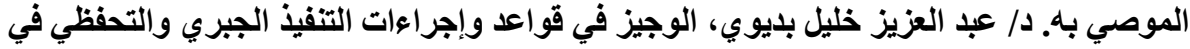

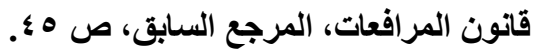

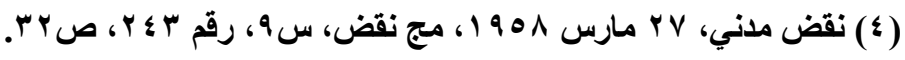


مـدي اعتبـار الخلف الخـاص مـن الغير أم لا بالنسبة للسند التفيذ يجب التفرقة بـين فرضين:

الفرض الأول: إذا كان هذا السند قد صدر قبل انتقال الحق إلى الخلف أو قبل أن يصير هذا الانتقال نافذا في مواجهة الغير: هذا الفرض يقتضي إذا صدر السند قبل انتقال الحق إلي الخلف الخاص، أو إذا كان السند قد صدر قبل أن يصبح حق هذا الخلف ناقذا في مواجهة الغير لعدم استكمال الشروط القانونيـة التـي يتطلبهـا القـانون في بعض الاحوال لتفـاذ الحق في مواجهـة

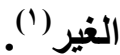

في هذه الحالة يتلقى الخلف من الحق بكل عناصره الإيجابية والسلبية التي كـان بها في يل سلفه، وتنفذ السندات في مواجهته(؟)، ولا يجوز لله دفع بعدم الاحتجـاج بها. ولا يجوز له الاعتراض عليها، إلا إذا أمكنه التجرد من تبعيته للسلف، بأن يستند في اعتر اضه إلي حق خاص به لم يتلقه عن السلف بمقتضي الخلافة، وكأن بطلب بـالحق

(1) Lacoste paul, De la chose jugée en matière civile, criminelle et administrative, op. cit., no 485

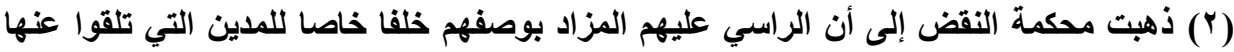

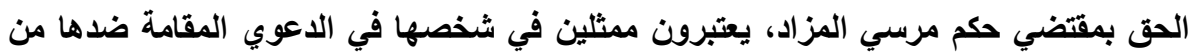

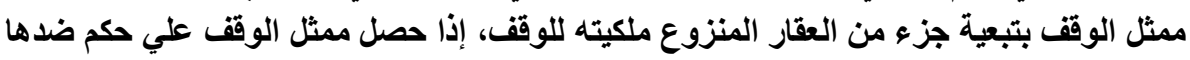

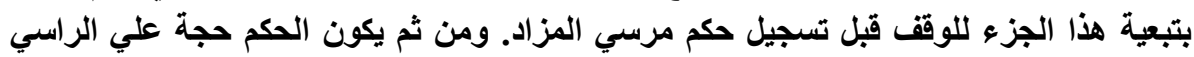

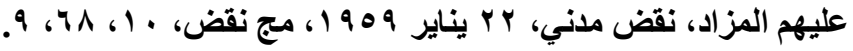


د/ طلعت يوسف خاطر

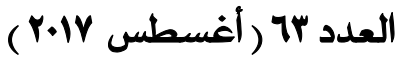

استنادا إلى وسـائل خاصه بـه، أو يشبت أن الحكم قد بنـي علي غش السلف أو تواطئه علي الإضرار بحقوق خلفه الخاص(').

في حقيقة الامر، يشترط لامتداد أثر السند إلي الخلف الخـاص أن يصدر قبل

انتقال الشيء إليه، لا يكفي رفع الدعوي قبل انتقال المال اليه(؟).

الفرض الثاني: إذا كان هذا السند قد صدر في مواجهة السلف بعد أن صسار

انتقال الحق إلى الخلف ناقذ في مواجهة الغير:

ففي هذا الفرض لا يحتج بـه في مواجهة هذا الخلف، ويمكنه الاعتراض عليه دون حاجـة إلى إثبـات غش سلفه("). وذلك لأن هذا السند لـ يكن ينطبق بالنسبة لـه

قواعد الخلافة، كما أن السلف قد فقد صفته في الدعوي بثأن هذا الحق منذ انتقاله إلى الخلف، وأصبح هذا الأخير هو المعنـي بالـدفاع عنـه، فِإذا لـم يختصم أو يتـذل في إجراعات الخصومة، فإنه يظل من الغير بالنسبة للحكم، ولا يكون لهذا الحكم أثر في مواجهته إلا باعتباره دليلا إثبات عكسه عن طريق الاعتراض عليه(؛).

(1) Cass. Civ. 11 Javier 1977, Gaz pal., 1977, 2, 455, note JV. Tib civ. Rhone, 13 mai 1927, DP, 1929, 2, p. 54.

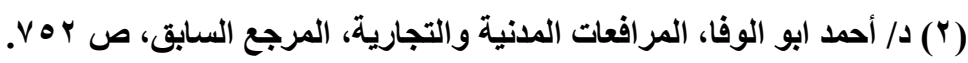

(3) Cass. Civ. 20 November 1969, Bull. Civ., 1969, 3, n 741, D. 1971. Somm. 131. Tirb. Civ. Chateaudon 9 juin 1945, D. 1946, p. 203.

(4) Rrolond H., " chose jugée et tiers opposition », thèse Lyon, LGDJ, 1958, $n^{\circ}$ 332, p. 387, Cass. Civ, 30 mars 1858, D.P., 1858, I, 164, Tirb civ, Seine, 17 septembre, 1941, Rev. Loyers 1942, p. 59,A. tissier, théorie et pratique de la tierce opposition, thèse paris, op. cit, n. 101, p. 171. 
وبالتتالي إذا صدر الحكم بعد انتقال الحق للخلف أو بعد نفاذه في مواجهة الغير،

فان الخلف يعتبر من الغير بالنسبة لما يصدر في مواجهة سلفه من أحكام متعلقة بهذا الحق(')، وتطبيقا لذلك قضت محكمة النقض بأن البائع لا يمثل المشتري فيما يقوم علي العقار المبيع من نزاع بعد تسجيل عقد البيع، ومن ثم فـان الحكم الصادر ضد البائع باعتباره غير مالك للعين المبيعه لا يعتبر حجة علي المشتري الذي سجل عقد شرائه قبل صدور هذا الحكم ولم يختصم في الدعوي(). والحكم الذي ينكر علـي الواهب ملكيـة العقـار الموهوب لا يحوز الحجيـة في مواجهة الموهوب له إذا صدر بعد تسجيل عقد الهبة(").

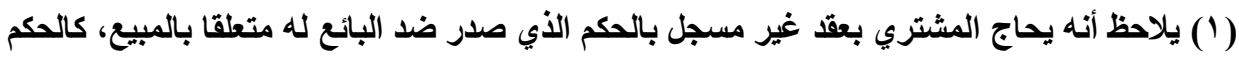

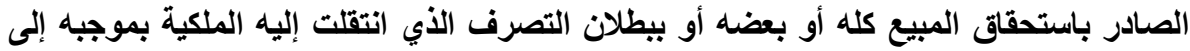

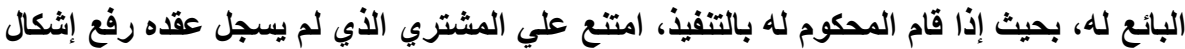

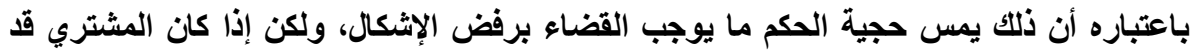

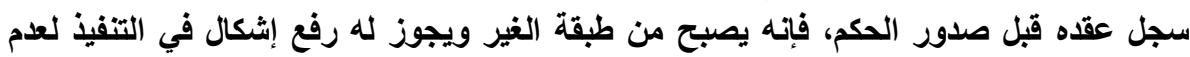

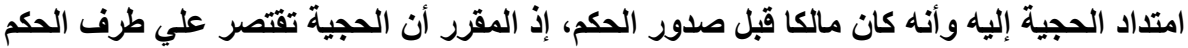

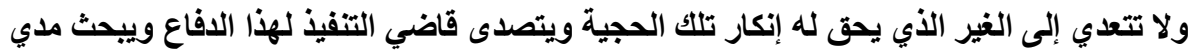

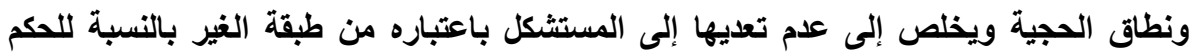

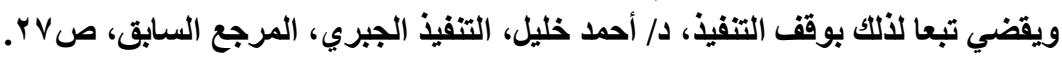

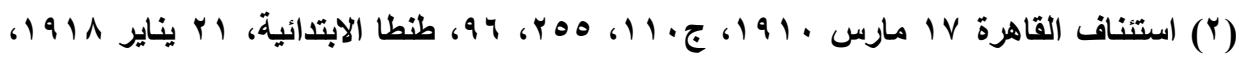

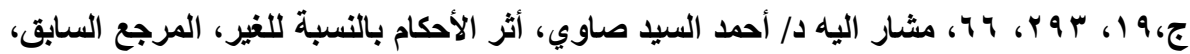
ro

(3) Lacoste paul, De la chose jugée en matière civile, criminelle et administrative, op. cit., $\mathrm{n}^{\circ} 485$. 


\section{ثانيا: الصفة الموضوعية الناشئة عن الكفالة العينية:}

تثبت الصفة الموضوعية للكفيل العينـي(')، وهو الذي يكون لـه صفه المنفذ

ضده(†)، ويقصد بالكفيل العيني، كل شخص يقدم عقـارا لـه ضمانا لدين علـي شخص آخر، فهو كل شخص رهن عقارهـ رهنـا رسميا أو حيازيـا- ضمانا لدين علي شخص آخر، فهذا الثخص ليس مدينا أو مسئولا شخصيا عن الدين، فهو كفيل عيني وليس شخصيا، لأنه لا يضم ذمته المالية إلى ذمة المدين الأصلي، ولكن لـه صفه موضوعية في التنفيذ، لأن الكفيل العيني لا يسأل عن الدين المضمون إلا في حدود العقار الذي قام برهـة(")، دون غيره من الأموال الخاصـة بـه("). فيتم الحجز علي العين التي رهنها الكفيل دون أن يكون ملزما بصفة شخصية(ْ)، وفي هذه الحالة أيضا تتوافر الصفة في مواجهته، فضلا عن توافرها في المنفذ عليه، باعتباره مالكا للعقار المحمل بالتأمين العيني الأي يجري التنفيذ عليه. إذ أن الكفيل هو أيضا ملتزم بمقتضي السند التنفيذي

(1) وتبع في الحجز علي عقار الكفيل العيني علي النحو التالي: أولا: تكليف المدين بالوفاء، ثانيا:

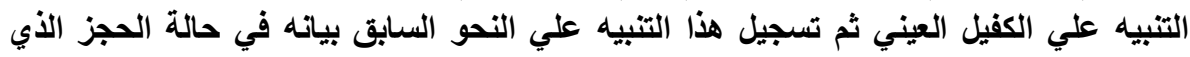

يجري علي عقار مملوك للمدين.

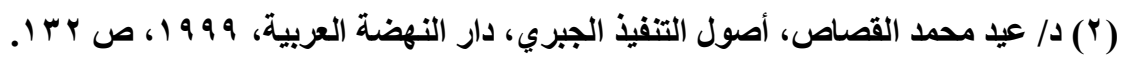

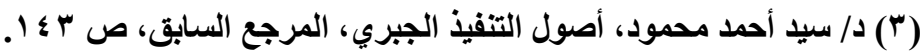

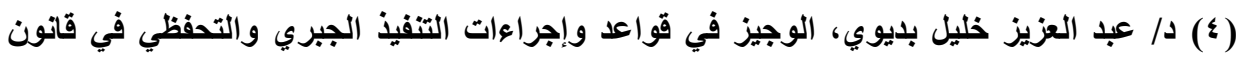

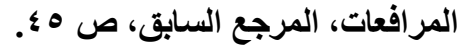

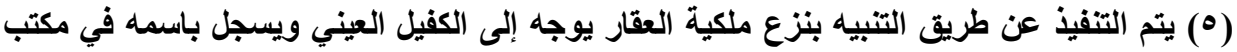

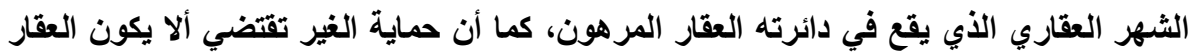

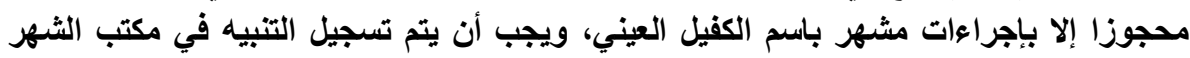

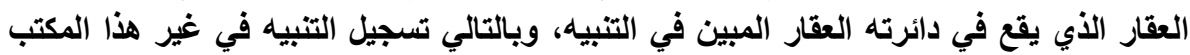
يجعله ليس له اثز ولا يحتج به فلي الغير الذي تم التصرف إليه في العقار. 
الذي يلتزم المـدين المكفول بمقتضاه. فالكفيـل لا يعد مـن الغير ويجـوز التنفيذ في

والكفيل العيني لا يعد خلفا للمنفذ ضده(؟)، فهو كفيل عيني ولا ينتقل إليه مال من

المدين، بالإضـافة إلى أن ملكيته للعقار لا تجعله خلفـا. كمـا أن وصف الحسائز بـالمعني الذي حدده القانون غير منطبق عليه، فهو ذو صفة في التنفيذ بشرط أن يكون السند التفيذي صادرا ضده هو، وذلك حتي يمكن التنفيذ عليه بالإضـافة للمدين إلـي المدين

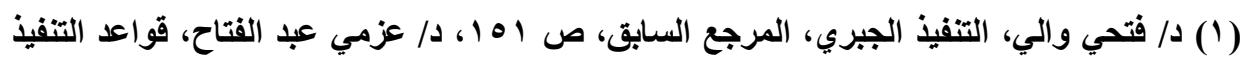

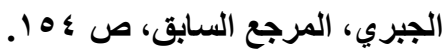

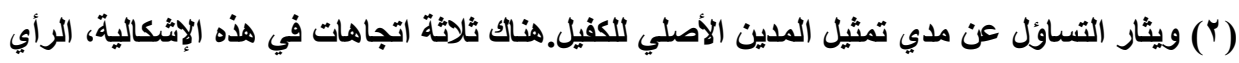

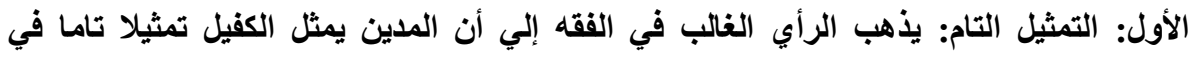

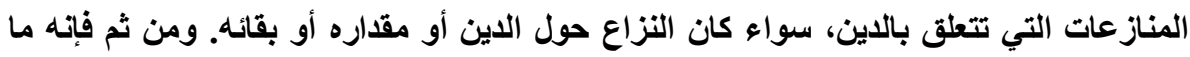

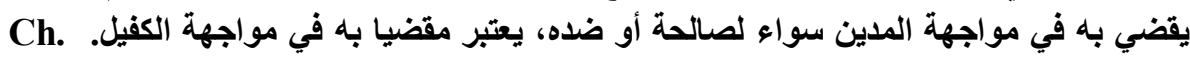
Beudant, le droit civile français, $T$ 10, 5e éd, $n^{\circ} 209$. CA Grenoble, 18 الاجاه

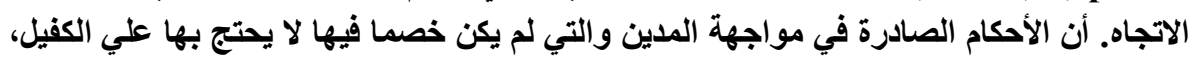

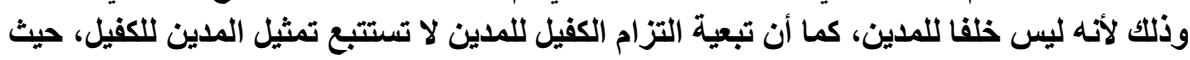

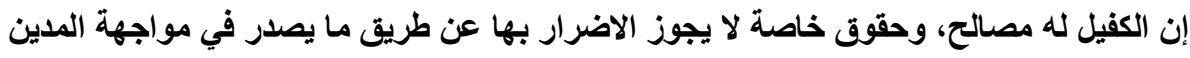

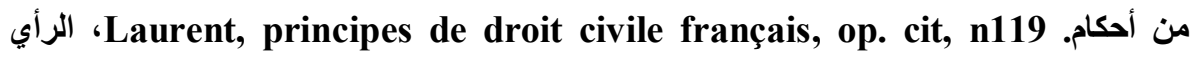

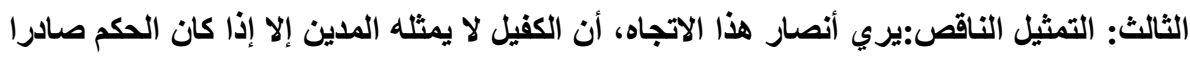

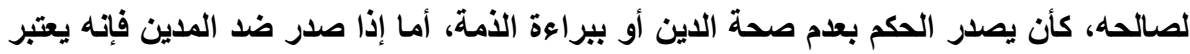

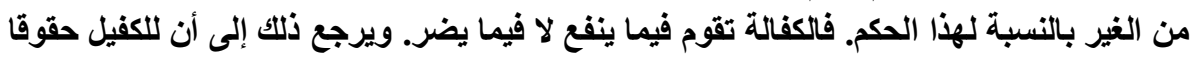

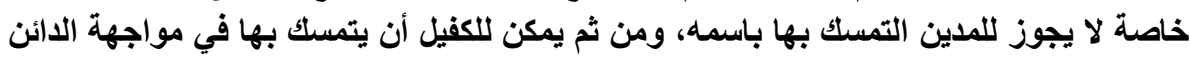

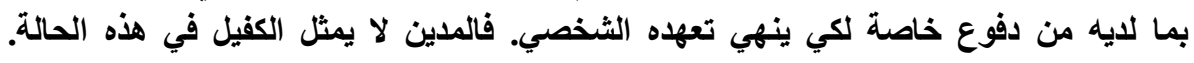
.Aubry et Rau, Cours de droit civil français, op. cit., p. 415 
المكفول('). ويتكون السند التنفيذي في هذه الحالة من السند التنفيذي الذي للاائن ضد المدين بالإضافة إلى عقد الرهن.

يذهب رأي في الفقه إلى أن المدين يعتبر من الغير بالنسبة للأحكام التي تصدر لصالح الكفيل، التي تبرع الكفيل لأسباب خاصة بالكفالة، أما الأحكام التي تتعلق بالدين مثل نكول الائن عن حلف اليمين فحمم لصالح الكفيل فإنه يستفيد منها(؟). وقد نـصت المـادة . ه . 1 مدني علي أنسه " إذا كـان الراهن شخصا آخر غير المدين، فلا يجوز التنفيذ علي ماله إلا مـا رهن من هذا المـال ولا يكون لـه حق الدفع بتجريد المدين ما لم يوجد اتفاق يقضي بغير ذلك" وتنص المادة اهـ ـ ـ مدني علي أنه " للائن بعد التنبيه علي المدين بالوفاء أن ينفذ بحقه علي العقار المرهون ويطلب بيعه في المواعيد وفقا للأوضاع المقررة في قانون المرافعات، وإذا كان الرهن شخصا غير المدين جاز له أن يتفادى أي إجراء موجه إليه إذا هو تخلى عن العقار المرهون وفقا للأوضاع وطبقا للأحكام التي يتبعها الحائز في تخليه العقار ".

في الواقع ليس للكفيل العيني حق التطهير، لأن التطهير سلطة منحها المشرع للحائز، يمارسها وفق إراداته، فهو الذي يحدد وقت التطهير وشروطه. بغرض أن يدفع للـائنين المـرتهنين مبلغـا مساويا للقيمـة الحقيقة للعقـار المرهون وليس وفـاء كافـة ديونهم، كما أنه ليس للكفيل العيني الدفع بالتجريد، بأن يجبر الدائنين علي الرجوع أولا

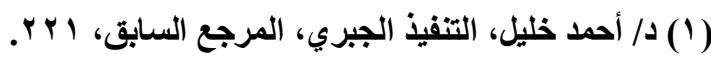

(2) Lacoste paul, De la chose jugée en matière civile, criminelle et administrative, op. cit., $\mathrm{n}^{\circ} 638$. 
علي مال المدين، المسئول شخصيا عن الدين، وذلك لأن العقار الكفيل مرهون لخدمة الدين (')

وحقيقة الأمر، مسئولية الكفيل العيني عن الدائن مسئولية عينية تختلف عن مسئولية الحسائز في أن مسئوليته العينية هو الذي أنشأها برضـائه(؟)، أمسا مسئولية الحسائز فقد نشأت بقوة القانون، كأثر مترتب علي انتقال ملكية العقـار المرهون إلى ذمته، كما أن الكفيل العيني ليس أجنبيا عن الدائن المرتهن، فهو طرف في عقد الكفالة الأي يربطهما معا. في الواقع الكفيل والحائز لا يكونون مدينين ولا يضمنان الدين بكل أموالهما. فالحجز ينصب علي العقار الذي في يد الحائز أو الكفيل العيني. ولكن يلاحظ أن الكفيل العيني يقدم العقار بإرادته لضمان حقهه قبل غيره، علي عكس الحائز الذي ينتقل إليه العقار محملا بالتأمين دون أن يكون له يد في ترتيبه. و إذا حـدث وأن تــصرف الكفيـل العينـي فـي العقــار قبـل التنفيـــ عليـه، فإنــه يمكن لدائن المدين أن يتبع العقار تحت يـ الحسائز الجديد(")، لأن رهنه يخوله ذلكك. ويجب علي الدائن أن يوجه الإجراءات إلى الحائز الجديد، وبذلك يقوم الدائن بالحصول

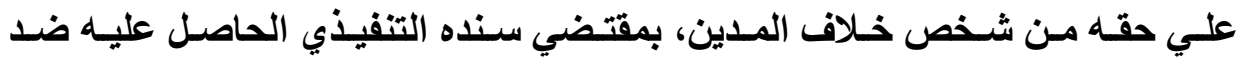

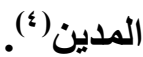

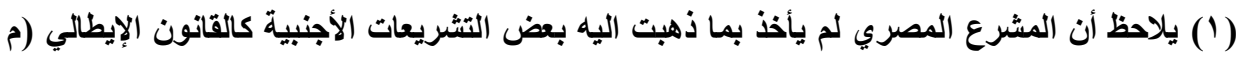

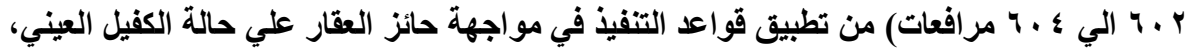
ذلك أن حائز العقار انتقلت إليه ملكية العقار من المدين، أما عقار الكفيل لم يكن مملوكا للمدين.

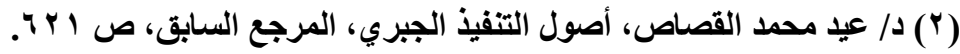

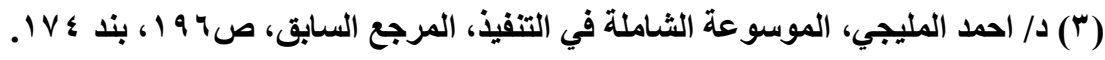

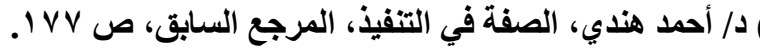




\section{الفرع الثالث \\ استثثناءات علي صفة المنفذ ضده}

قد يكون الشخص مدينا شخصيا للائن، ولا يملك هذا الأخير مباشرة إجراءات التنفيذ الجبري في مواجهته، وذلك يرجع إلى وجود حصانة قضائية تمنع من إجراء

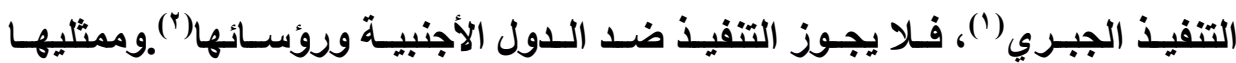
الابلوماسيين")، وذلـك لأن لهوولاء الأثـخاص حصانة، وهـي تنصب علـي الشخص وعلي صفته وتصرفاته، وقد نظمت هذه الحصانة بمعاهدة فيينا التي أبرمت تحت رعاية

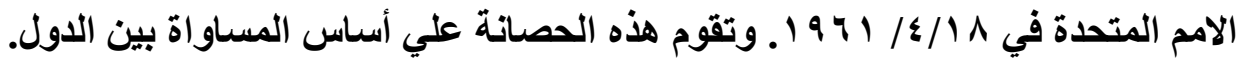
ولا يجـوز الحجز ضـــ هيئة الأمـم المتحدة وفروعهـا ووكالاتهـا، وكذلك الأمـر بالنسبة للمنظمـات الدوليـة العالميـة أو الإقليميـة أو المتخصسة وفروعهـاووكلائهـا وممثليها وموظفيها ومندوبي الدول لايها، وذلك احترامـا لحصانة التفيذ التي تقررهـا قواعد القـانون الدولي وأعرافـه خصوصا اتفاقيـة فيينـا للعلاقـات الدبلوماسية، وذلك باسـتثناع المعـاملات المدينـة والتجاريـة أو المهنيـة خـارج النطـاق الرســي، والإرث والتركات، أو الديون الشخصية، فتخضع للتنفيذ وكذلك إذا تم التنازل صراحة ومحددا عن الحصانة القضائية التنفيذية الدولية. والتنازل عن الحصانة في مرحلة دعوي الحكم يفيا التنازل عن حصانة التنفيذ لمصلحة الخصم من تنازل لصالحة"(؛).

(1) S. GUINCHARD et T. MOUSSA, droit et pratique des voies d'exécution, op. cit., $\mathrm{n}^{\circ} 152,05$.

(2) Cass. 8 decembre 1995, Bull. civ., $n^{\circ}$ 14, p. 13.

(3) CA Paris, 10 avril 2001, JCP,G, 2001, 11, p.1051.

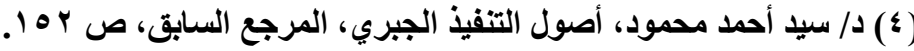


نصت المـادة VA مدني علـي أن الأموال العامـة المملوكة للاولة والمخصصة للمنفعة العامة لا يجوز التصرف فيها، وبالتالي لا يجوز الحجز عليها. وهذه الأموال

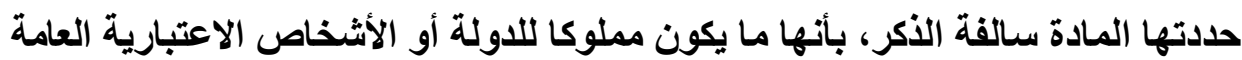

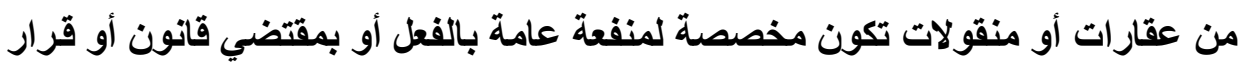

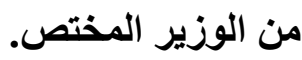
وقـ ذهبت محكمـة الـقضض إلـي أن "إضـفاء الـصفة العامـة علـي الجمعيـات

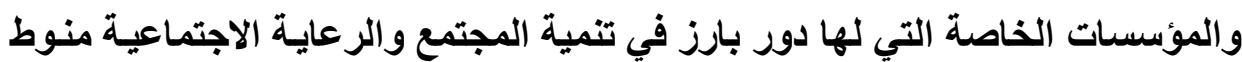

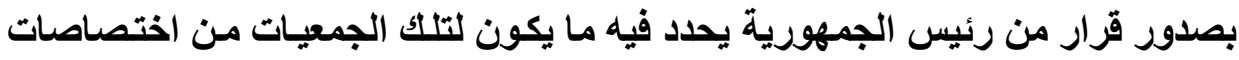

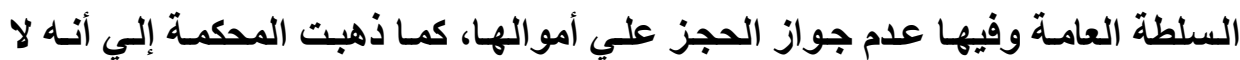
يجوز الحجز علي الجمعية التي يثبت لها الصفة العامة سواء بالنسبة لمديونيتها للغير أو لا حد أعضائها، أي عدم جواز الحجز علي أموالها تحت يدها التها او تحت يد الغير بـأي صورة من صور الحجوز التحفظية او التنفيذية"(1). فقد نص القانون الفرنسي علي عدم جواز التنفيذ علي أموال الأثخاص العامـة، وذلك علي أساس وجوب الثقة بيسار الدولة واستعدادها للوفاء بديونها. وكذلك حماية التهاية الأشخاص الخزنة العامة من المفاجآت التي قد تترتب علي تتفيذ الأحكام جبرا عليهاب("). وقد ذهبت محكمة النقض الفرنسية في حكم لها إلى أنه لا يجوز الحجز علي

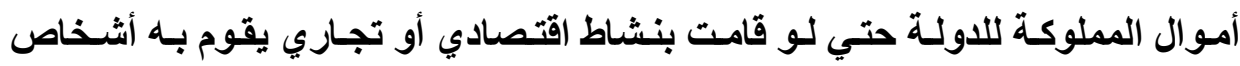

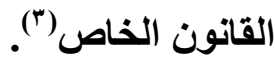

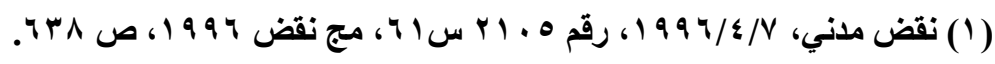
(r) د/ عبد العزيز خليل بديوي، الوجيز في قواعد وإجراءات التنفيذ الجبري والتحفظي في قانون

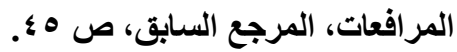

(3) Cass. Civ., 14 mars 1984, JCP, G, 1984, 11, 205, obs. Synvet. 
بالنسبة للأمسوال الخاصـة المملوكـة للاولـة فقد ثـار الخـلاف حـول مـدي جـواز

التنفيذ عليها. فقا اختلف الفقه والقضاء، حول مدي جواز الحجز عليها، حيث ذهب البعض إلي عدم جواز الحجز علي الأموال الخاصـة للاولـة(')، علي اعتبار أن الدولـة

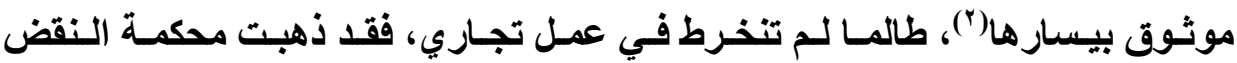
الفرنسية إلى علم جواز الحجز علي أموال أثخاص القانون العام بصرف النظر عن الأنشطة التي يقوم بها الشخص الاعتباري، سواء أنشطة صناعية أم تجارية("). ولكن ذهب رأي آخر إلي جواز الحجز علي هذه الأموال(؛). حيث ذهبت محكمة اسـتنـاف فرســاي الفرنسـية(ْ). إلـى جـواز الحجـز علـي الأمسوال الخاصـة للشخص الاعتباري، حيث قصرت عدم الحجز علي الأموال العامة التي تبرر تمكن المرفق العام من الاستمرار في العمل. وقد أيدات ذلك محكمة النقض الفرنسية في بعض أحكامها،

(1) د/ أحمد هندي، الصفة في التنفيذ، المرجع السابق، ص ع با ا، د/ أحمد ابو الوفا، اجراءات التنفيذ،

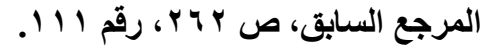

(ץ) د/ احمد ابو الوفا، اجراءات التنفيذ، بمقتضي قانون أصول المحاكمات اللبناني الجديد، المرجع

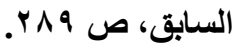

(3) La Cour de Cassation y a mis fin en refusant toute possibilité de saisie a l'encontre des personnes morales de droit publique " même exerçant une activité indcistrielle et commercial, que ce soit a raison de leur activite relevant du domaine prive. Cass. 1 re civ., 21 decembre 1987, bull. civ.,1, n 346, jcp, 1989,11, 21183, obs., Icod, RTD civ., 1989, p. 145, obs., Perrot.

(؛) د/ فتحي والي، التنفيذ الجبري، المرجع السابق، ص 4717 1، د/ عزمي عبد الفتاح حسن، قواعد

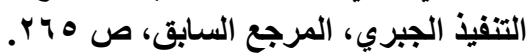

(5) CA Versailles, 2 juin 1986, D., 1987, p. 86, obs. prevault. 
د/ طلعت يوسف خاطر

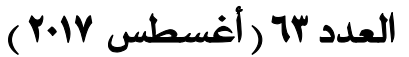

حيث ذهبت إلى جواز الحجز علي أموال الشخص الاعتبـاري العـام طالمـا يقوم بنشاط

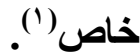

\section{وهن جانبا نؤيد هذا الرأي، وذلك للآتي:}

I - أن خضوع الدولة للقانون يستوجب خضوعها لأحكام القضاء، وهذا يتطلب تنفيذ

الأحكام الصادرة من القضاء تنفيذا جبريا علي أموال الدولة الخاصة.

r ـ أن صالح الدولة يقتضي قبولها التنفيذ الجبري حتي لا يحجم الأفراد عن التعامل

$$
\text { مع الدولة. }
$$

ويلاحظ أن الحجز التحفظي لا يكون جـائز ضد الدولة، وذلك لأنه لا يتصور أن

يخشي الدائن فقده لضمانه العام ومن ثم يطلب الحجز التحفظي علي أموال الدولـة.

و إنما يمكن الحجز التنفيذي علي العقـارات أو المنقولات المملوكة للاولتة والمخصصة

للمنفعة الخاصة بالدولة، وكذلك يجوز حجز ما للمدين لدي الغير.

في الواقع قبول الدول اللجوء إلى التحكيم يعتبر تنازلا ضمنيا عن الحصانة في

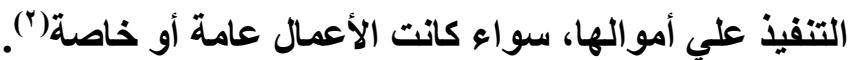

(1) La Cour énonce en effet que les biens des organisme publics distincts de

l état étranger peuvent être saisis "lorsqu'ils font partie d un patrimoine que celui-ci affecte a une activité principale relevant du droit prive ». Cass. 11 re civ., 1 re octobre 1985, JCP G, 1986, 11, 20566, obs., synvet, Cass., 1 re civ., 15 juillet 1999, D., 1999, ir, p. 230. Cass. 1 re civ., 27 janv. 1998, procedur av. 1998, $\mathrm{n}^{\circ} 83$.

(2) Cass. 1re civ., 6 juil. 2000, JCP, G, 2001, 11, 10512. 
في الواقع هنـاك مبـادئ أو طرق عامـة يمكن مـن خلالهـا معرفـة مـا إذا كـان لشخص ما الحق في طلب التنفيذ الجبري لحكم أو لأي سند تنفيذي آخر، ولعل أهم هذه المبادئ ما جاءت به نصوص المواد / 1 ا مرافعات، حيث تسلم الصورة التنفيذية لمن

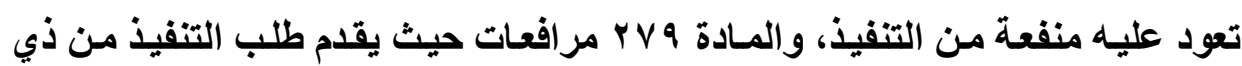
الشأن متـي سـلم السند للمحضر، بالإضـافة إلى المـادة الثالثة مر افعـات حيث تشترط المصلحة الشخصية المباشرة لقبول أي طلب، إذا ياخل تحت هذا المفهوم طلب التثفيذ الجبري('). إذن طالب التنفيذ هو الدائن الأصلي وخلقه و دائنوه.

وبالنسبة للمنفذ ضده، فقد يكون ذات صفة شخصية كالمدين الشخصي والكفيل الشخصي والمدين المتضامن، وقد يكون له صفة موضوعية في التنفيذ، بسبب وجود المال تحت يده، مثل الخلف العام والخـاص، والكفيل العيني، ولا يحتج السند التتفيذي لئي علي الخلف إذا ثبت أن الحكم صدر نتيجة غش السلف له أو كاتت له وسـائل خاصـة بـه لم يستمدها من هذا السلف، لأنه في هذه الحالات قد تجرد من رابطة الخلافة، وبالتـالي يمكنه تفادي الاحتجاج بالحكم في مواجهته كأي شخص من الغير ذي مركز مستقل عن الخصوم. وقد يكون الثخص مدينا، ومع ذلك لا يجوز التتفيذ عليه، وذلتك بسبب وجود حصانة في اتخاذ اجراعات التنفيذ عليه. 


\section{الباب الأول \\ صفة الغير في التنفيذ ودوره}

الغير في التنفيذ الجبري هو من ليس طرفا في الحق في التنفيذ(')، ولكنه قـ

يكون ملزما بالاشتراثك في إجراءات التنفيذ الجبري، وهذا الاثتراك يفرضه القانون

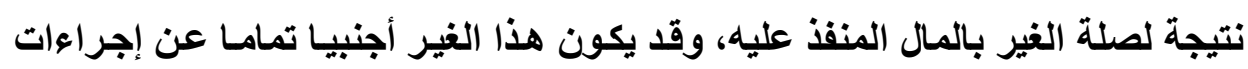
التنفيذ.

سنعالج صفة الغير في التنفيذ، وذلك في الفصل الأول، ونبحث دور الغير في التنفيذ، وذلك في الفصل الثاني، وذلك علي النحو التالي: 


\section{الفصل الأول \\ صفة الغير في التنفيذ الجبري}

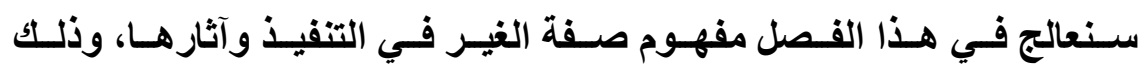

في المبحث الأول، ثم نبين اتساع نطاق الغير في التنفيذ الجبري وذلكت في المبحث

الثاني.

\section{المبحث الأول \\ هفهوم صفة الغير وآثارها}

مـصطلح الغير مـن الـصطلحات القانونيـة ذات المعـاني المتعدد والمتغيـرة،

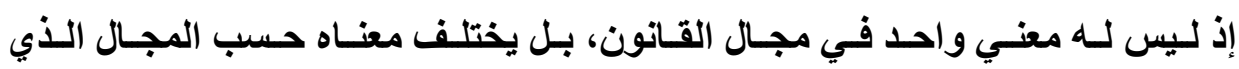

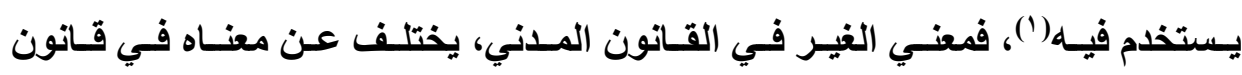

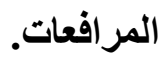

سنشير في هذا المبحث إلى تعريف صفة الغير، والأثر الذي يترتب علي صفة

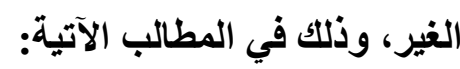

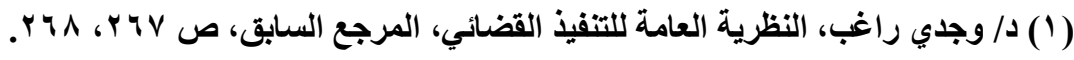




\section{المطاب الأول \\ تعريف صفة الغير في التنفيذ الجبري}

سنـشير إلسى تعريـف صـفة الغير في فقـهـ المرافعـات، ثم نسعي إلـى التحديــ

المنضبط لمعني الغير في التنفيذ الجبري، وتمييز صفة الغير عن أطراف التنفيذ، وذلك

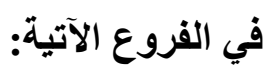

\section{الفرع الأول \\ تعريف صفة الغير في فقه المرافعات}

الواقع أن المشرع المصري والفرنسي لم يورد تعريفا للغير في مجال الإجراءات

خاصة في خصومة التنفيذ(')، وذلك يرجع إلي أن فكرة الغير في مجال القانون من أكثر الموضوعات صعوبة في ضبطها، وتحديد معناها، وذلك لأنه من المصطلحات الوظيفية في علم القانون فهو موجود في كل فروع القانون(†)، لذلك يجب تحديد معني الغير بالنسبة إلى فرع معين للقانون، إذ يصعب إطلاق هذا المعني أو استخدامه بصفة واحدة في جميع الحالات. فاصطلاح الغير في مجال الإجراءات يختلف عن معنـاه في القانون المدني، خاصة في آثار العقود أو الصورية أو ثبوت التاريخ، فهي ليست ذات مدلول واحد في جميع الحالات، حيث يختلف معني الغير بـاختلاف فروع القانون، وحتي في داخل الفرع الواحد، فِإن هذا المدلول يختلف أيضا بـاختلاف النظام القانوني المـراد

(1) J. VINCENT et G. GUIMCHARD, procedure civile, 26ed, Dalloz, 2001, p. 416.

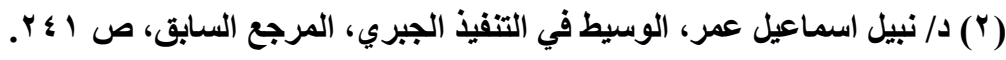


استخذامه فيه(')، وبصفة عامة فإن الغير هو كل من ليس طرفا في العلاقة القانونية أو

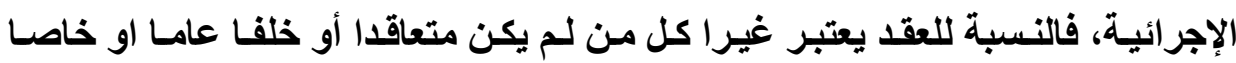

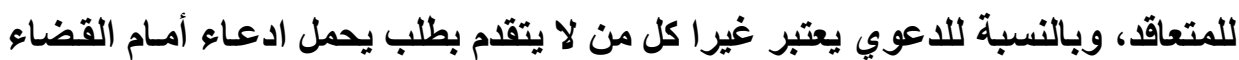
وكل من لا يوجه إليه مثل هذا الطلب(")

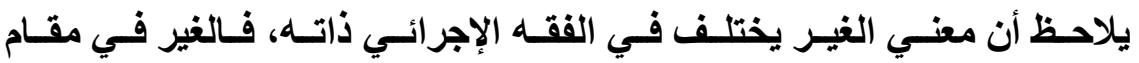

آثار الحكم غيره في خصومة التنفيذ("). حيث يختلف بالنسبة للخصومة العادية"(4).

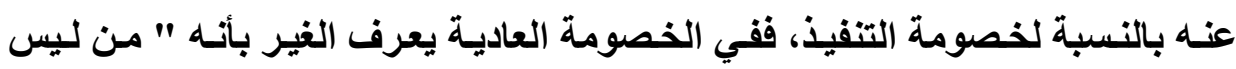

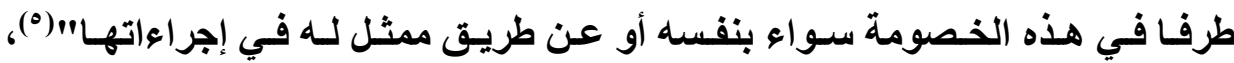

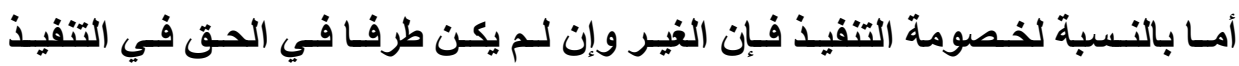

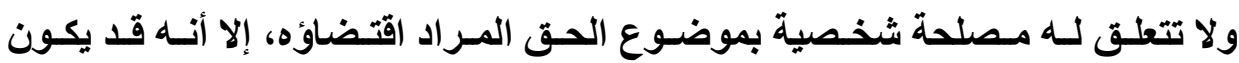

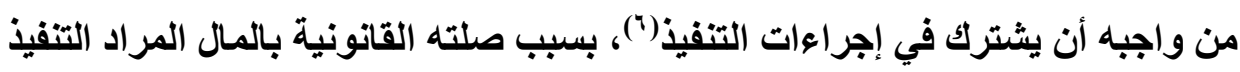

(1) G. CUNNY, des tiers, thèse Nancy, 1889, p. 20, J. M. AUSSEL, essai sur la notion de tiers en droit civile français, thèse Montpellier, 1951, p. 50.

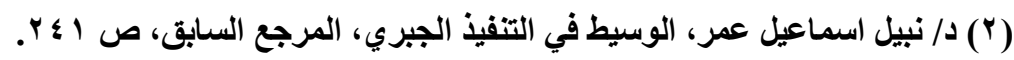

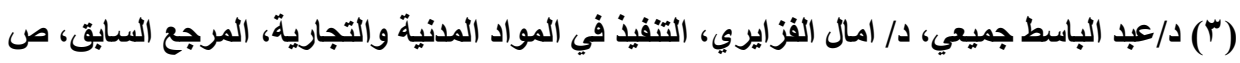

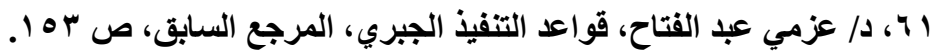

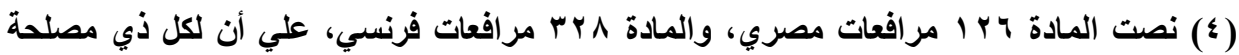

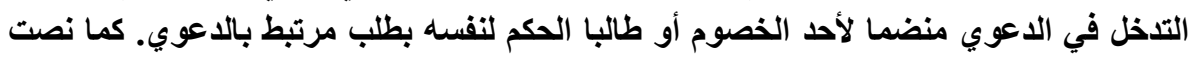

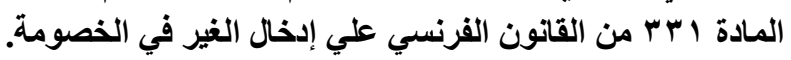

(5) R. Coutant, des créanciers chirographaires considères comme tiers, thèse Paris, 1906, p. 8, J. Vincent et s. Guinchard, procédure civile, D., 26 éd., 2001, n. 354.

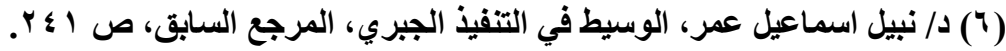


عليه(') كالمحجوز لايه، أو ما له من صفة وظيفية كالحارس القضائي وكاتب المحكمة

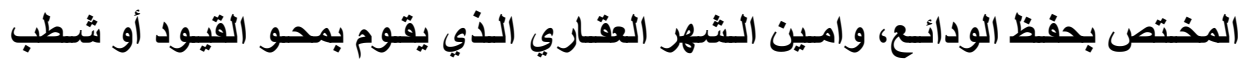

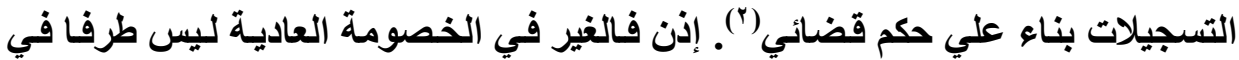

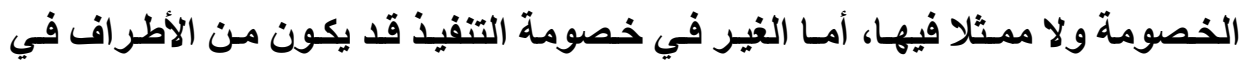

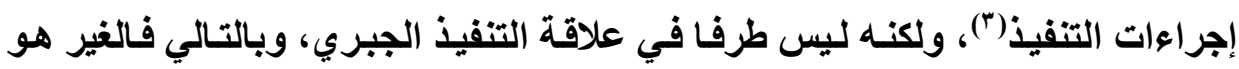

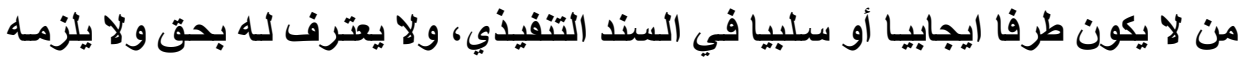

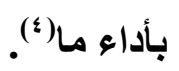

ذهب البعض إلى أن الغير هو الذي ليس لله مصلحة شخصية بموضوع الحق

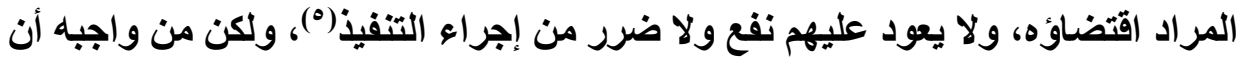

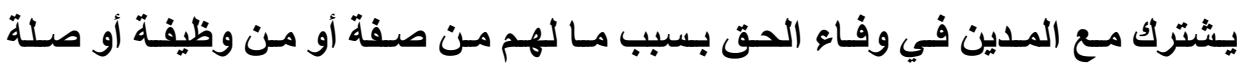

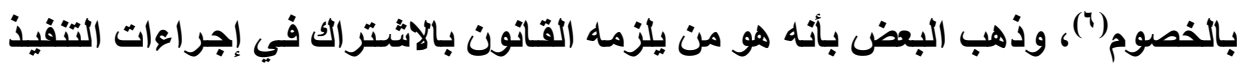

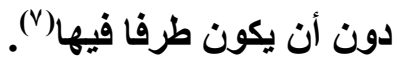

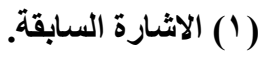
(ץ) د/عبد الباسط جميعي، د/ امال الفزايري، التنفيذ في المواد المدنية والتجارية، المرجع السابق،

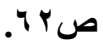

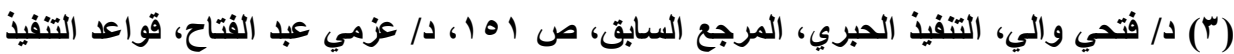

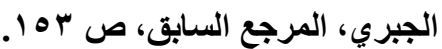

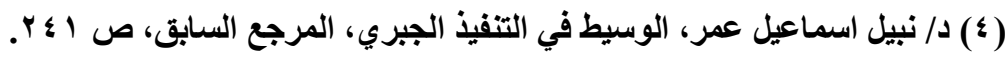

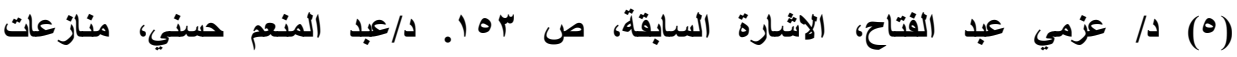

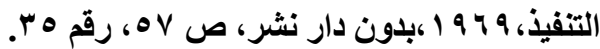

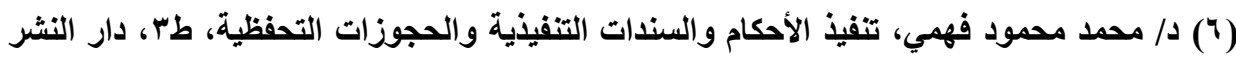

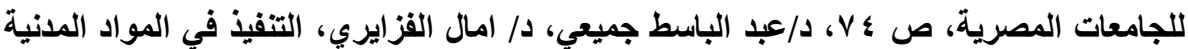


ورغم أن الغير ليس طرفا من أطراف الحق في التنفيذ (طالب التنفيذ ومن يحل

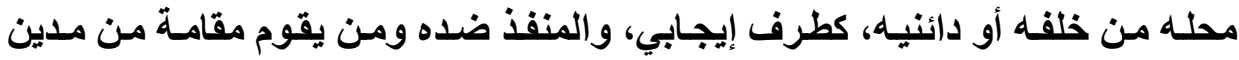

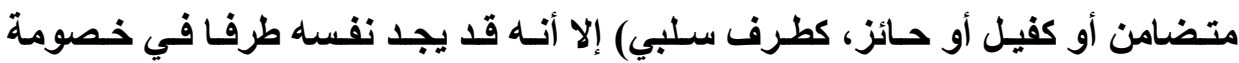

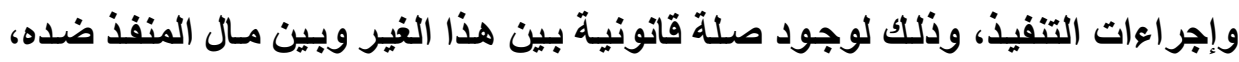
وصلته هذه بالمال المراد التنفيذ عليه تقتضي إدخاله في إجراءات التنفيذ، ويعد من هذه الزاوية طرفا في خصومة التنفيذ، ويعتبر المحجوز لايه صورة مثالية للغير في التنفيذ، بجانب الحارس القضائي (1).

فطبقا لهذا الاتجاه الغير في التنفيذ هو من ليس طرفا في الحق الموضوعي

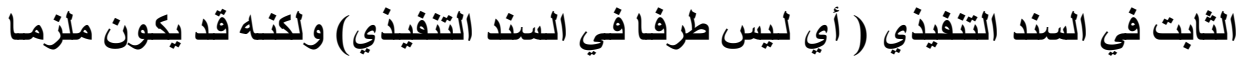
قانونا بالاشتراك في إجراءات التتفيذ دون أن تكون له مصلحة فيه. وقد يكون الغير شخصا طبيعيا كالحارس أو المحضر وكاتب المحكمة وأمين

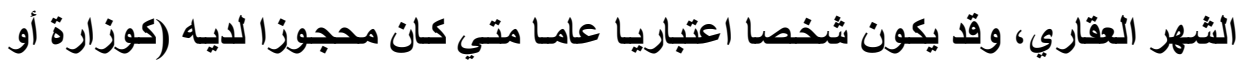

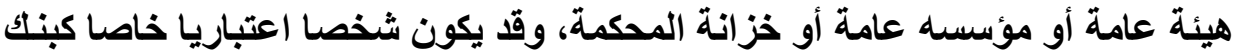

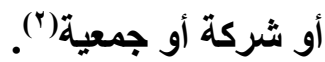
وبنـاء علـي ذلكت لا يعد مـن الغير طبقـا لهـذا الاتجـاه، مـن لـم يلزمسه القـانون بالاشتراك في اجراءات خصومة التنفيذ، كمن يدعي ملكية المنقول أو العقار المحجوز، التهاء فهو يعترض - اختياريا ودون ان يوجه إليه أي اجراء ـ سير اجراءات التيات التفيذ مدعيا

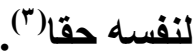

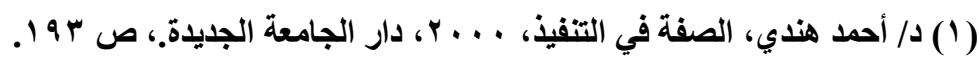

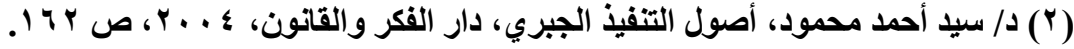

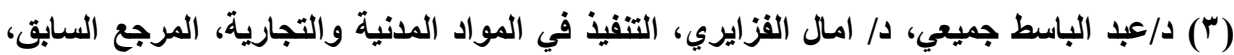

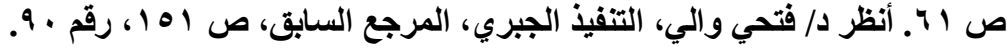


في واقع الامر لا نتفق مع هذا الرأي، لأنه قصر معني الغير علي المشنرك في اجراءات التنفيذ بحكم القانون، دون مراعاة أن صفة الغير تطلق علي أي شخص اجنبي عن التفيذ، ليس لله مصلحه شخصية بموضوع الحق ولا يعود عليه نفع ولا ضرر. وهذا يطلق علي الغير الاجنبي عن التنفيذ. لذا سنحاول في الفرع الثاني تحديد معني منضبط للغير.

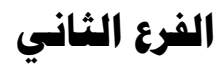

\section{هماولة عن تحديد منضبط لمعني الغير في التنفيذ الجبري}

لتحديــ معنسي الغير في التنفيذ الجبري، سـنعالج أسـاس فكرة في الغير في التنفيذ، ومعيار الغير في التنفيذ، والتمييز بين الغير وأطراف التنفيذ، وذلك في النقاط

\section{أولا: أساس فكرة الغير في التنفيذ الجبري:}

يرجع أساس صفة الغير في التنفيذ إلى أن السند التنفيذي يتضمن الوجهات الآتية:

\section{الوجه الأول: القوة المزهمة للسند التنفيذي:}

في الواقع بمجرد صدور السند التنفيذي يحوز قوة ملزمه لأطرافه، وليس تجاه

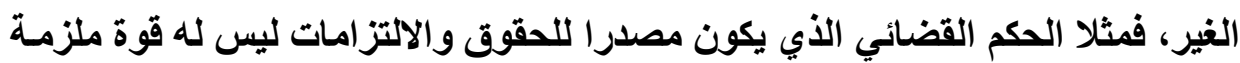
إلا تجاه أطراف النزاع محل الحكم، لاتهم كـانوا مـاثلين أو ممثلين فيها، وقدموا أدلتهم ودفوعهم، وهذا الحكم لا يرتب أثرا تجاه الغير، فلا يمكن أن ينشئ حقوقا أو التزامـات

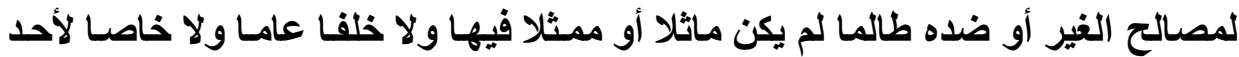
أطراف النزاع، وهذا ما يقصد به نسبية أثر الحكم(').

(1) د/ سيد أحمد محمود، ود/ يوسف يوسف أبو زيد، التقاضي بقضية وبدون قضية في المواد المدنية

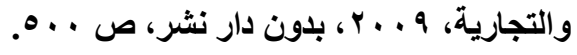


وبالتالي لو احتج علي الغير بآثار الحكم فيمكن لله أن يدفعها بقاعدة نسبية أثر الثر الثرادي

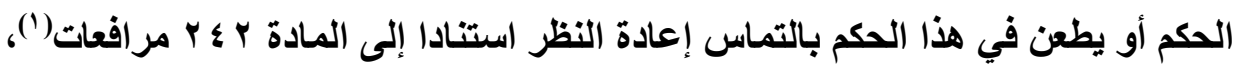

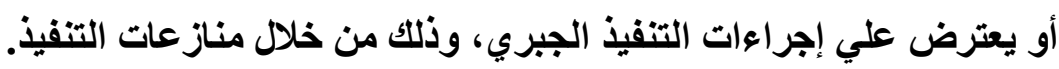

\section{الوجه الثاني: القوة الثبوتية للسند التنفيذي:}

في الواقع يعد السند التنفيذي بالنسبة لأطرافه ورقة رسمية ملزمة لهم، فالحكم

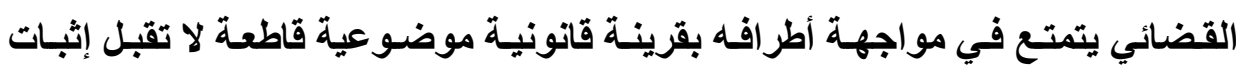

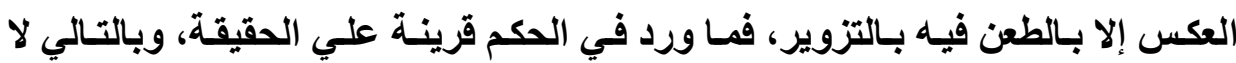
يجوز قبول دليل ينقض حجية الحكم بالنسبة لأطر افه(").

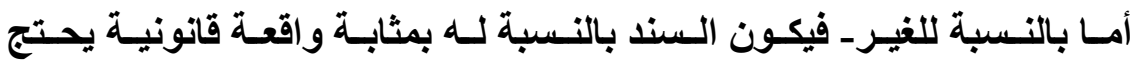

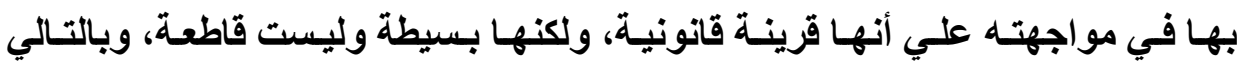
يمكنه الاعتراض عليها بكافة طرق الاعتراض، أي يمكنه إثبات عكس ما جاء في السند

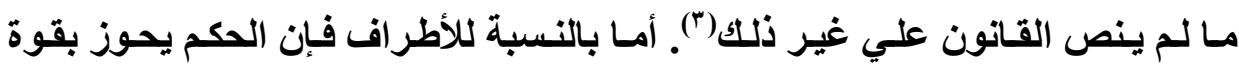

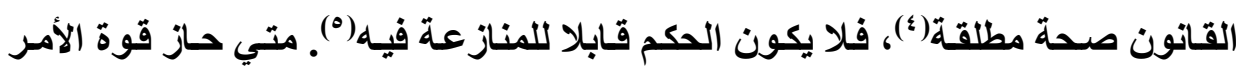
المقضي.

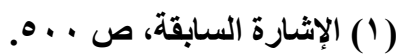

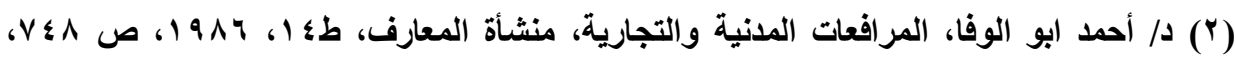

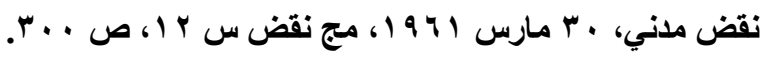

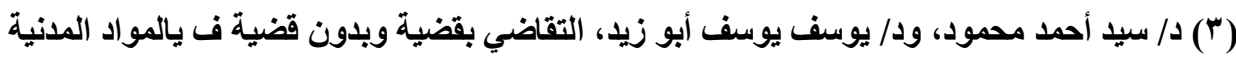

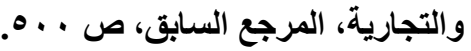

(§) دا عبد المنعم الشرقاوي، الوجيز في المرافعات المدنية والتجارية، مكتبة النهضة المصرية،

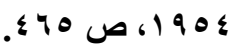

(5) J. Foyer, De l'autorité de la chose juge en matière civile essai de l'une définition, thèse, 1954, p. 320 
وعلي ذلك نصت المادة 1 ـ 1 اثبات بالنسبة للأحكام القضائية علي أن" الأحكام

التي حازت قوة الأمر المقضي تكون حجة فيما فصلت فيه من الحقوق ولا يجوز قبول دليل يـقضض هذه الحجيـة". إذن الأحكـام القضائية تحـوز الحجيـة التـي تلـزم أطرافهـا

\section{الوجه الثالث: القوة التنفيذية للسند التنفيذي:}

يقصد بـللك أن السند التنفيذي يمكن صساحبه من التنفيذ الجبري علـي أمسال المدين رغما عن إرادته بواسطة السلطة العامة في الدولة(؟)، وينطبق ذلك علي جميع السندات التنفيذية، سواء كان حكمـا أو أمرا أو محررا موثقا. وبالتـالي لا يستفيد من التنفيذ غير أطرافـه، أمسا الغيـر فهو خـارج نطـاق هـذه العلاقـة المـذكورة فـي السنــ التنفيذي، فهو شخص أجنبي عن أطراف السند التنفيذي، وبالتـالي فهو أجنبي عن

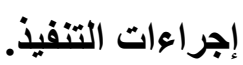

والهـف الأسـاسي من اتخـاذ إجراعات التنفيذ الجبري هو التحفظ علي أموال المدين تمهيدا لبيعها في المزاد العلني واقتضاء الدائنين حقوقهم من هذه الأمسوال، والعدالة تقتضي أنه لا يجوز بيع ملك الغير لدين علي المدين(")، فـأموال المدين هي الضامنة لحقوقه، ولا يجوز لله أن يثري علي حساب شخص آخر، عن طريق تسديد ديونه بواسطة أموال الغير، وهذه القاعدة الأصولية، تعتبر حقا من حقوق الانسان.

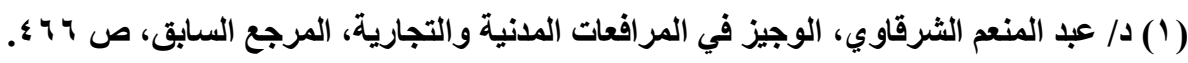

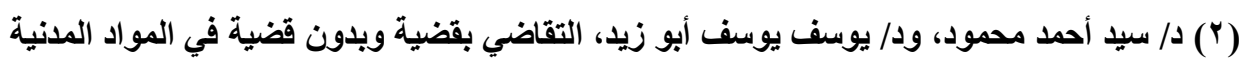
والتجارية، المرجع السابق، ص ه9 هـ ؛.

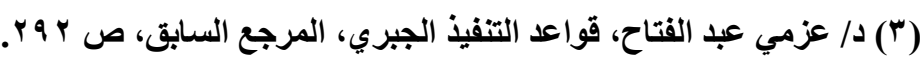


وبالتالي يستفيد الغير من مبدأ حجية السند لأطرافه فقط، حيث إن القانون لـم يتجاهل حق الغير الذي يلحقه الضرر من التنفيذ علي أمواله لايون ليس مسئولا عنها، وبالتالي للغير الحق في الاعتراض علي الدائن الذي يوقع الحجز علي منقولات مملوكة للغير، ويكون المـدين مجرد حسائز لها لمجرد كونـه مستأجرا أو مستتعيرا أو مودعـا عنده، وقد تكون المنقولات المحجوزة محمله بحق خـاص للغير كـأن يكون لـه حق هـ انتفاع عليها، وهذا الانتفاع يتعارض مـع بقاء هذه الأموال محجوزة ومـا يقتضيه هذا مسن بيعها وتسليمها إلى مـن يشتريها بـالمزاد العلتـي. فللغير رفع دعوي اسـترداد المنقـولات المحجـوز أو اســـقاق العقــار المحجـوز عليـه، أو الاعتـراض علـي قائمــة

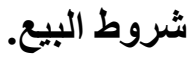

\section{ثانيا: هميار الغير في التنفيذ:}

بصفة عامـة يتحـد الغير بطريقة سلبيه، حيـ أنـه ليس طرفـا في الحق في التنفيذ، فمعني ذلك أنه ذو صفة سلبية محايده، فتحديده لا يتم إلا بطريق الاستبعاد، أي من خلال نفي صفة الطرف(')، وقد بحثنا أطراف السند التنفيذ فيمـا سبق في الفصل التمهيدي.

يقصد بالغير بالمعني العام هو من ليس طرفا في العمل القانوني الذي أنجز أو في العلاقة القانونية (العقد أو الخصومة أو الحكم) التي نشأت بين آخرين حيث تحكمها 
تعتمد فكرة الغير علي مدي تمثيله في السند التنفيذي، فكل شخص ليس طرفا

في السند التنفيذي يعد من الغير(')، ولذا اتجه بعض الفقه إلى محاولـة مد مجـال حجية

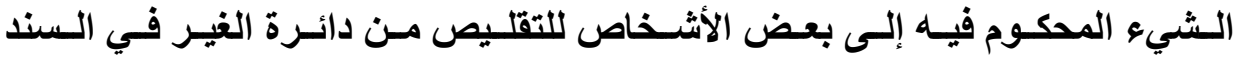
التتفيذي ()وذلك لأن السند التنفيذي يتميز بالحجية النسبية()، ويقصد بذلك أن السند لا يكون حجة إلا علي أطرافه فقط (؛). إذن يتحدد أطر اف التنفيذ الجبري طبقا لمضمون السند التنفيذي، وبالتالي فكل شخص ليس له مصلحة في السند التنفيذي يعتبر اجنبيا بالنسبة للتنفيذ الجبري، سواء كان هذا السند حكما أو أمر أو محضر صلح أو أي سند تنفيذي نص عليه القانون. سنشير إلى أنواع الغير في التنفيذ، ثم نبين معيار الغير في التنفيذ، وذلك علي

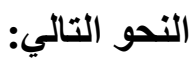

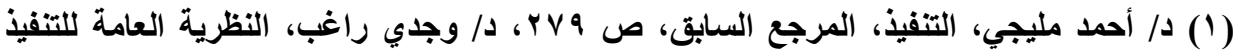

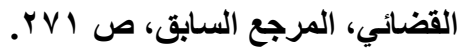

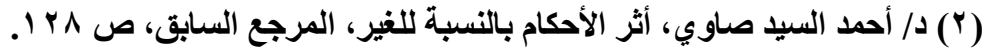

(3) Lacoste paul, De la chose jugee en matriere civile, 3e, Paris 1914, $n^{\circ} 471$, Bonnier, traite theorique et pratique des preuves en droit civile et criminel, op. cit., $\mathrm{n}^{\circ}$ 877, Constantin Melinesco, Etude sur I autorite de la chose jugee en matiere civile, these, Paris, 1913, p. 106, Roger Perrot, Juris classeur de procedure civile, Autorite de la chose jugee au civile sur le civil, fasc. A.C. proc. Civ., art. 116-148, t 3, Paris, 1955, n 128.

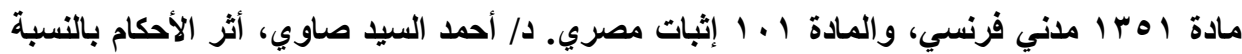

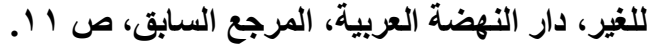

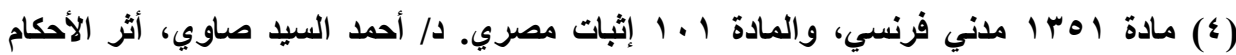

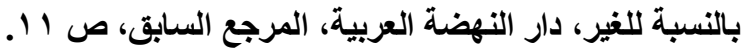




\section{( أ ) أنواع الغير في التنفيذ:}

في الواقع ينقسم الغير في التنفيذ الجبري إلى نوعين:

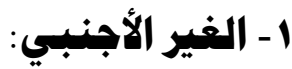

الغير الأجنبي في خصومة التنفيذ هو من لا توجد له أي علاقة بإجراعات التنفيذ ولا بالحق في التنفيذ، وذلك لأنه ليس شخصا في التتفيذ، والأصل أن كل من ليس طرفا في السند التفيذي يعتبر من الغير الأجنبي عن إجراعات التنفيذ الجبري، إلا أنها من الغير من ينازع في التنفيذ الجبري مدعيا لنفسه حقا يتعلق بمحل التنفيذ، كما لو أدعي ملكيـة المـال المحجـوز، وإن كـان هـذا أيضـا لـيس طرفـا في التتفيذ لأنسه غيـر ملـزم بالاشتراك في إجراءات التنفيذ، ولا يساهم في سير اجراعات التنفيذ، ولكنه يثير عارضا

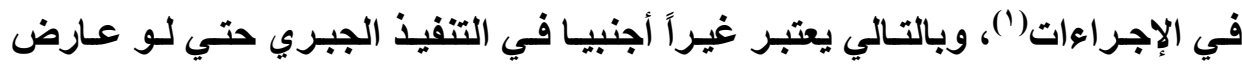

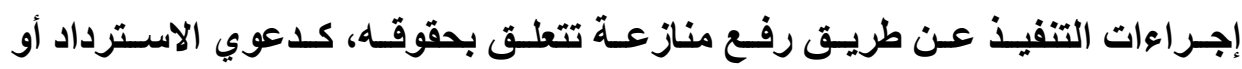
الاسـتحقاق، حيث أنـه لـم يفرض عليـه القـانون واجبـا محددا اثتـاء إجراعات التنفيـ الجبري.

استقر الرأي في العصر الحديث عدم جواز الحكم علي شـص دون تمكينه من

الافاع عن حقوقه والرد علي ادعاءات خصمة؛ وعدم الحجز علي أي مـال غير مملوك للمدين، فيجب حماية حقوق الغير خاصة بعد صدور السند التنفيذي. لأنه مـن الظلم أن 
تضار حقوق الغير دون أن تتاح لهم سبيل الدفاع عنها(')، حيث أنه لم يتمكن الغير من تقديم أدلة الإثبات الخاصة به في الخصومة، ليضعها أمسام المحكمة، وبالتالي لا يجوز أن يضار من إجراعات التنفيذ الجبري. r- الغير الطرف في إجراءات التنفيذ قد يكون الشخص من الغير، ولكنـه ملتزم طبقا لأحكام القانوني بالمشـاركة في إجراءات التنفيذ، ويرجـع اشـتراكه هذا الغير في الإجراءات إلـي صلة بالمسال المراد

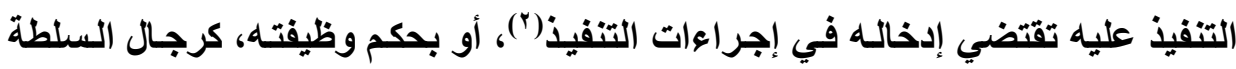
العامة. فإذا كان الغير بصفه عامة هو من ليس طرفا في الحق في التنفيذ(")، فان الغير بالنسبة لإجراءات التتفيذ كل شخص وإن لم يكن ملزما بالحق الجاري التنفيذ اقتضاء لله إلا أن صلته بالمال المراد التنفيذ عليه تقتضي إدخاله في إجراءات التنفيذ، ويعد طرفا في خصومة التتفيذ(") في الواقع نص المشرع المصري في المادة ه ب مر بافعات علي معني الغير في التنفيذ وهوي كل من تنشأ بينه وبين المدين علاقة دائنيه يلتزم بموجبها بالوفاء بما في حيازته للأخير، فيعتبر من الغير، الوكيل والحسارس والناقل والمودع لايه والمستأجر

(1) H. MOTULSKY, Le droit naturel dans la pratique jurisprudentielle, le respect des droits de la défense, mélanges ROUBIER, 1961, T2, P. 175 ET S

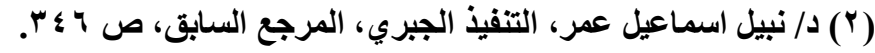

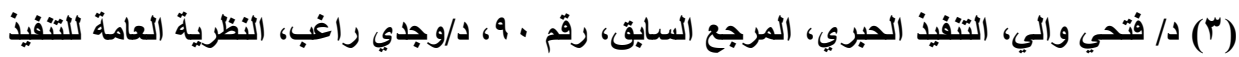

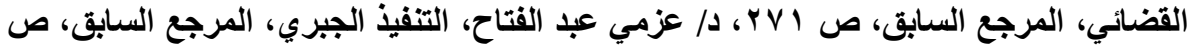


ورب العمل والبنك بالنسبة للودائع والحساب الجـاري، إذ يلتزم هؤلاء بالوفاء للدائنهم بما في حيازتهم، ويخضع الحجز لاي هؤلاء لإجراء حجز ما للمدي لاي الغير. يلاحظ أن فكر الغير هـي فكرة سـلبية، ورغم ذلـك يجب أن يكون طرفـا في خصومة التنفيذ، ولكنه ليس طرفا إيجابيا أو سلبيا في التنفيذ، والقاعدة أنه لا يجوز

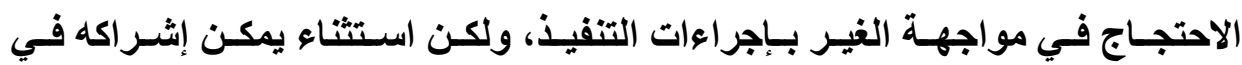
الإجراءات إذا توافرت فيه شروط معينة(')، كما في حالة حجز ما للمدين لاي الغير. فيلاحظ أن الغير في هذا الفرض لـه صفه مركبـه، فهو ليس طرفا في السند التنفيذي، وهو طرف في خصومة التنفيذ، حيث يمكن أن توجه إليه إجراعات التنفيذ الجبري، ويقوم طالب التنفيذ باتخـاذ إجراعات التفيذ في مواجهته الذي يصلح في

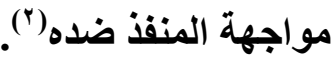

\section{(ب) همعيار الغير في التنفيذ:}

نري أن معيار الغير في التنفيذ الجبري يعتمد أساسا علي الإطار الآتي:

\section{ا - ألا تعود علي الغير فائدة هن السند التنفيذي:}

يلاحظ أن معيار صفة الغير تعتمد علي مدي المصلحة التي تعود علي الشخص في السند التنفيذي(")، فالغير هو شخص أجنبي ليس لـه مصلحة في السند التنفيذي، فهو لا يحتج عليه بأي التزام في السند التنفيذي، وليس لـه حق فيه، ولكن يمكن أن

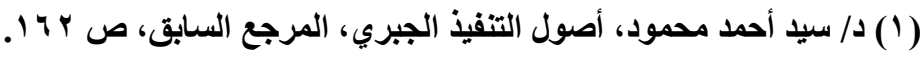

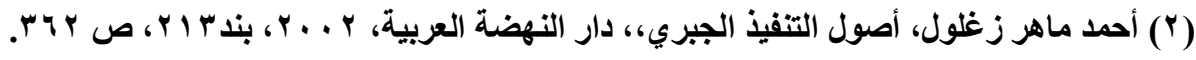

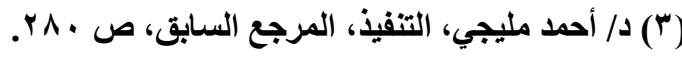


يلزمه القانون بالاشتراك في إجراءات التفيذ الجبري، وذلك بسبب مـا لله من صفه أو من وظيفه أو صلة الخصوم. فيجب ألا تكون للغير مصلحة شخصية في موضوع الحق المراد اقتضاؤه ولا يعود عليه من إجراء التنفيذ نفع ولا ضرر('). إذن تحقق صفة الغير مرتبط بغياب صفة الخصم في خصومة التنفيذ، ويترتب علي ذلكك ارتباط هذه الصفة بمعطيات محددة سواء من حيث الوقتـ كمـا في حالـة الخلف الخاص الذي نفذ حقه في مواجهة الكافة قبل الدعوي، فيعد من الغير بالنسبة للحكم المتلعق بالوصيةــ أو نوع التففيذ ـكما في التنفيذ علي عقار، فالحائز للعقار يعد من الغير- أو من حيث الأثخاص، وبالتالي فهذه الصفة ليست مطلقة ولكنها نسبية إذ توجد في وقت معين وبالنسبة لنوع معين مـن الحجـوزات، وفي مواجهة اشـخاص معينين، فصفة الغير تتحقق للشخص طالمـا لم يكن طرفـا في السند التنفيذي أو تعود عليه مصلحة منه، وإن كان يمكن أن يقوم بعمل يتعلق بإجراءات التنفيذ، كما في حالة حجز مـا للمدين للدي الغير، فـالغير هنـا ملتزم ببعض الواجبـات، مثل التقرير بمـا في الأمة. ولكنه هنا ليس طرفا في السند التنفيذ. ويثار التساؤل عن مدي تغير صفة الشخص من خصم إلى الغير في خصومة

في الواقع قد يتعدد أطراف الحكم وقيام البعض بـالطعن والغـاء الحكم بالنسبة للبعض في الطعن غير عادي، بحيث كانت خصومة التنفيذ قد بدأت بين جميع الأطراف في السند التنفيذي، فإنـه يرتب علـي ذلتك زوال صفة الخصم في إجراعات التنفيذ، ويصبح بالتالي من الغير، متي ألغي الحكم الخاص به. (1) د/ أحمد هندي، الصفة في التنفيذ، المرجع السابق، ص • 19 . 
بل في داخل الخصومة الواحدة قد توجد عدد من الروابط، وتتحدد صفة الغير بالنسبة لرابطة معينة دون أن يعني ذلك تحقق نفس الصفة لذات الشخص بالنسبة للروابط الأخرى، فمثلا حينما يطلب شخص من الغير التذخل في الخصومة، ويحكم بعدم قبول تلخله فإنه يظل محتفظا بصفته هذه بالنسبة للخصومة الأصلية التي يريد التدخل فيها، فإنه يعتبر طرفا محكوما عليه بالنسبة لطلب التدخل، ويجوز لـه استئناف الحكم القاضي بعدم قبول تلدخله.

كذلك فإن مجرد طلب إدخال ضـامن لا يترتب عليه أن يصير الضامن طرفا في الخصومة الأصلية، وذلك لأن هذا الطلب لا ينشئ رابطة إجرائية سوي بين الضامن وطالب الضمان(')، لا يصير الضامن طرفا في الخصومة الأصلية، وبالتـالي يعتبر من الغير بالنسبة للحكم في الاعوي الأصلية.

r- ألا يكون الشخص طرفا في المق الثابت في السند التنفيـذي (r)، ولا هسسئولا عنه (")

الغير ليس الطرف الإيجابي ( طالب التنفيذ) أو الطرف السلبي (المنفذ ضده) ولا خلقهمـا العـام أو الخـاص ولا كفيـل شخصي، ولا كفيـل عينـي (؛)، فهؤلاء أطراف في

(1) Cass. Civ., 9 avril 1970, D., 1970, p. 585.

(r) د/ اسامة أحمد شوقي المليجي، د/ احمد السيد صاوي، الإجراءات المدنية للتنفيذ الجبري،

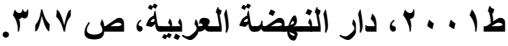

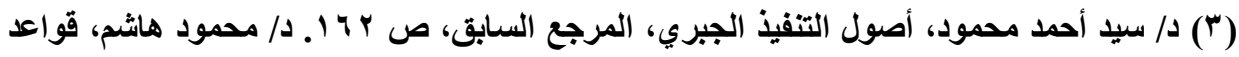

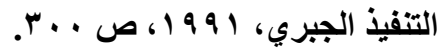

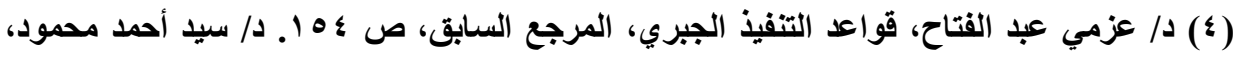

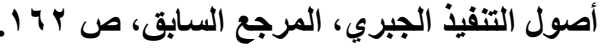


التنفيذ'(') فيحب لتوافر صفة الغير في شخص معين بالنسبة للتنفيذ، بـالرغم مسن اشتراكه في الإجراءات، ألا يكون طرفا في الحق في التنفيذ، أي من لم يكن طرفا في السند التنفيذ سواء كان حكما أو غير حكم، فأن كان حكما وجب ألا يكون من بين من فن فئ يعتبر الحكم القضائي حجة عليهم، وإن كـان السند محررا موثقا فيجب ألا يكون الثخص ممن ينتج العقد آثاره في مواجهتهم (").

\section{r- قد يكون الغير هلزها بالاشتراك في التنفيذ"):}

قد يلزم القانون الغير بالاشتراك في إجراءات التنفيذ، وذلك لوجود علاقة أو صلة قانونية بمال المنفذ ضده بسبب حيازته لهذا المال أو سلطته عليه تقتضي إدخاله

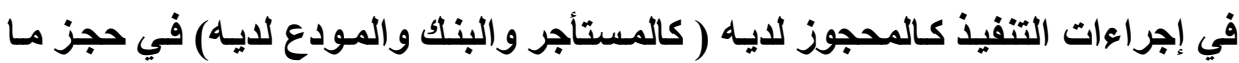
للمدين لاي الغير أو الحارس القضائي علي عقار أو منقول صدر حكم بتسلميه إلى

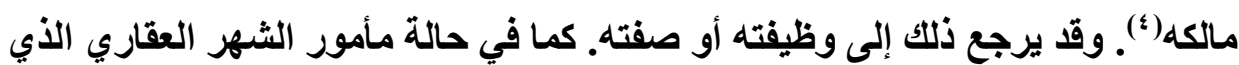
يقوم بمحو القيد أو شطب التسجيل بنـاء علي حكم قضائي. وأيضا كاتب المحكمـة الحختص بحفظ الودائع وكذلك الحارس القضائي(ْ). وقد يتعدد الغير في الحجز، ويكون كل واحل مستقلا عن الآخر ، وله كيان قانوني قائم بذاته(").

(1) د/ اسامة أحمد شوقي المليجي، احمد السيد صاوي، الإجراءات المدنية للتفيذ الجبري، طا ـ. . ؟، دار النهضة العربية، ص

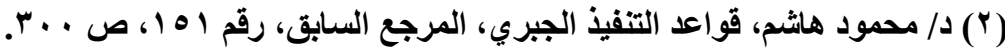

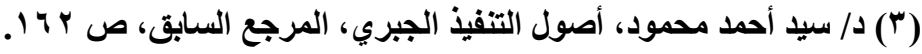

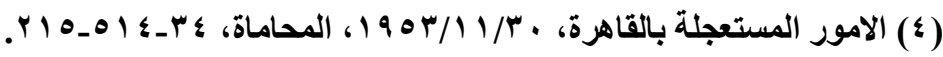
(0) د/ عزمي عبد القتاح، قواعد التنفيذ الجبري، المرجع السابق، ص

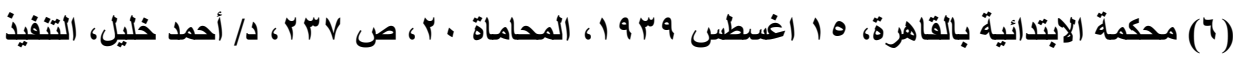

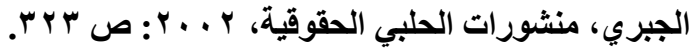


المحجوز لايـه ليس مدينا ولا مسئولا بصفة شخصية عن الدين، ولكنه في الغالب هو مدين المدين، وتباثر الإجراءات ضده('). بسبب هذه الصفة.

\section{الفرع الثالث}

\section{التـيـيز بين الغير وأطراف السند التنفيذي النافي}

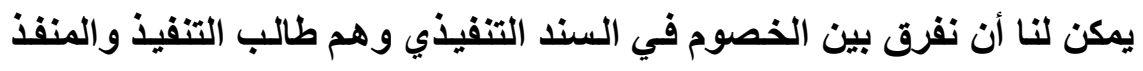

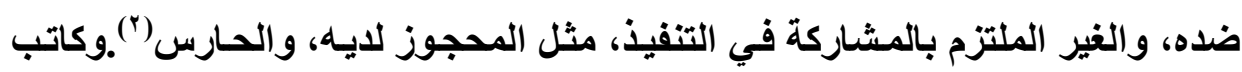

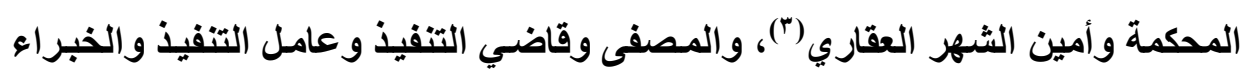

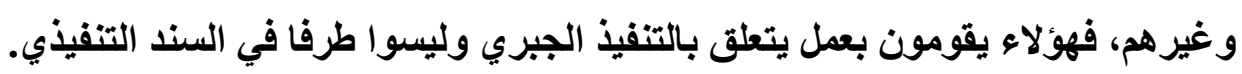
سنثير إلي تمييز الغير عن طالب التنفيذ، وتمييزه عن المنفذ ضده، وذلك في النقاط الآتية:

\section{أولا: تمييز الغير عن طالب التنفيذ:}

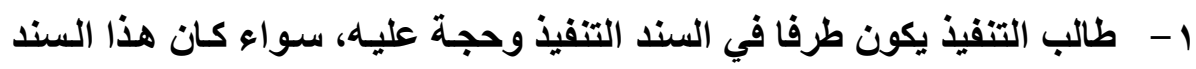

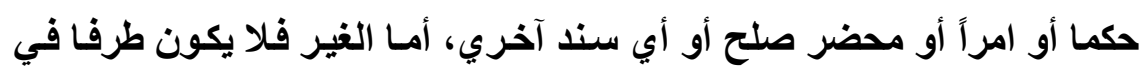
هذا السند ولا حجة عليه.

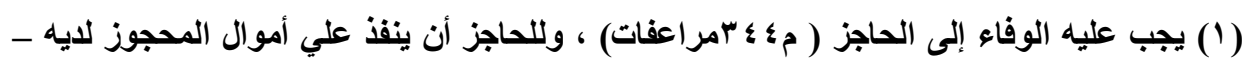

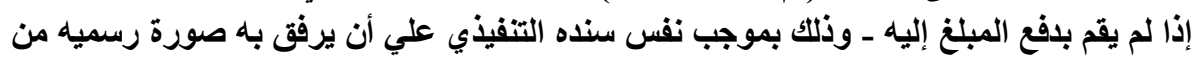
تقرير المحجوز لايه.

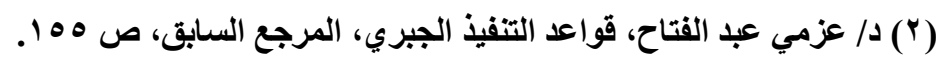

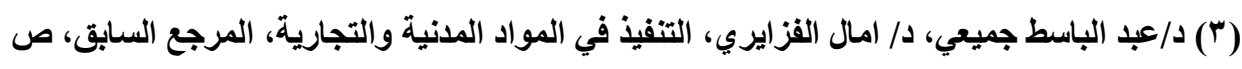


r - طالب التنفيذ تقع عليه واجبات ولـه حقوق بمقتضي إجراعات التنفيذ، فيجب عليه مباشرة إجراعات التثفيذ بدون تعسف، وله الحق في عدم نفـاذ تصرفات المـدين بعد توقيع الحجز علي المسال، أمسا الغير فهو خـارج خصومة التنفيذ، فالأصل ليس لله حقوق وليست عليه أي التزامسات بمقتضي خصومة التنفيذ، ولكن إذا كان ملتزما بالمشاركة في إجراءات التفيذ مثنل حجز مـا للمدين لدي الغير، فهو لا يستفيل ولا يضار من إجراءات التنفيذ، ولكنه يعاون فقط. r- إذا أضر طالب التنفيذ من سوع نية الغير وتعسفه، فله الحق في طلب التعويض بوسائل خاصة نص عليها المشرع مثل دعوي الالزام الشخصي ضد المحجوز لايه، أما إذا أضر الغير من إجراعات التنفيذ بأن تم الحجز علي ماله، فله وسائل نص عليها المشرع لدفع هذا الضرر، مثل رفع دعوي استرداد المنقولات المحجوزة أو دعوي استحقاق بالنسبة للعقارات.

\section{ثانيا: التمييز بين الغير والمنفذ ضده:}

1- هن حيسث الصفة: المنفذ ضده هو الطرف السلبي في التنفيذ الجبري، فهو المدين في السند التنفيذي، أما الغير، فهو لا يمثل السند التنفيذي أي حجة عليه. r- هن حيث الالتراهات والهقوق: المدين تقع عليه التزامات وله حقوق بمقتضي السند التنفيذي، حيث يلتزم بعدم التصرف في ماله بعد وقوع الحجز عليه، كمـا أن له الحق في الإثكال في التنفيذ ورفع دعوي موضوعيه إذا كان هنـاك بطلان في إجراءات التنفيذ الجبري، أما الغير، فهو خـارج نطاق خصومة التنفيذ، فلا يقع عليه التزامـات وليس لـه أي حقوق، ولكن إذا كـان ملتزمـا بالاشـتراك في 
خصومة التنفيذ، فتكون عليه التزامات، مثل التقرير بما في ذمة في حالة حجز ما للمدين لادي الغير. r- هن حيث الأهلية: يجب توافر أهلية الاختصام وأهليه التقاضي في المنفذ ضده، حتي يمكن مباشرة إجر اءات التنفيذ الجبري في مواجهته، ولكن بالنسبة للغير إذا اضير من إجراءات التنفيذ الجبري فيمكن أن يرفع دعوي ولا يشترط فيه

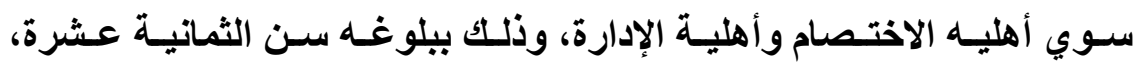
وبالتالي لا يشترط أهليه التقاضي، وذلك لأنه يطالب بحقوقه.

\section{المطاب الثاني \\ الآثار المترتبة علي صفة الغير في التنفيذ}

يترتب علي الصفة الغير في التنفيذ بعض الأثار التي تتمثل في عدم جواز الحجز علي أمواله، ولكن استثناء من ذلك يجوز الحجز علي أموال الغير في بعض الفروض، وسنثير إلى ذلك في الفروع الآتية:

\section{الفرع الأول عدم جواز الحجز علي أهوال الغير}

نظرا لأن الغير ليس طرفا في التنفيذ، فلا يجوز الحجز علي أمواله، ويرجع أسـاس ذلك إلى أنسه يشترط لصحة محل الحجز أن يكون المـال مملوكـا للمدين، لأن 
المدين يضمن التزاماته بالأموال المملوكة له وليس بأموال الغير(')، وذلك لأن التنفيذ علي مال الغير يعتبر اعتداء علي حقه، ويترتب بطلان التنفيذ في حالة المساس بحقوق الغير، لأنه لا يجوز بيع ملك الغير(") ويجب أن تثبت ملكية المدين لحظة بلدء التتفيذ، فإذا دخل المـال في ذمـة المدين بعد بدء إجراءات التفيذ كان الحجز باطلا، فالحجز علي المال غير مملوك للمدين يكون باطلا حتي ولو أصبح مملوكا له أثنـاء التنفيذ(")، كمـا إذا تم الحجز علي عقار اشتراه المدين بعقد غير مسجل(")، فالحجز يقع باطلا ولا يصح هذا البطلان تسجيل العقد بعد بدء الإجراءات إذ ليس للتسجيل أثر رجعي، إذ وفقا لقانون الشهر العقاري لا يعتبر العقار مملوكا لهذا المشتري إلا بالتسجيل، وقبل ذلك الوقت تعتبر العقارات علي ملك البائع والمشتري مجرد حائز، فلا يتحقق شرط ملكيته المدين، وهذا من شأنه أن يصيب الدائن بأضرار فادحه خاصة إذا لم يكن لاي المدين المنقولات أو المبالغ الكافية لسداد دينه، فيصبح أمام دائن صساحب حق عـاجز عن الحصول علي حقه من مدين موسر، وهذا وضع شـاذ ومنتقد، خاصة أنه أصبح من الصعب والمكلف تسجيل العقود شراء العقـارات، فالغالب أن يكتفـي الأفـراد بـالعقود الابتدائيـة تهربـا مـن الرسـوم الباهظـة والإجراءات المعقدة التي يستلزمها التسجيل.

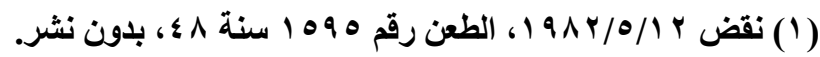

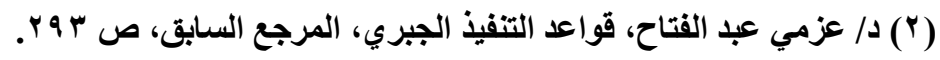

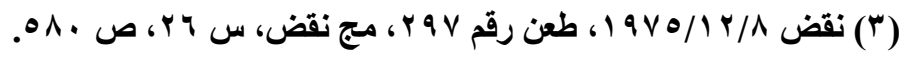

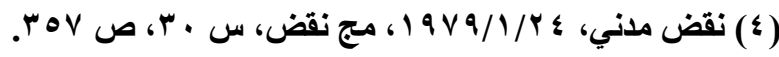


إذاز زالت هذه ملكية المدين للمال بعد الحجز بأثر رجعي(')، كما في حالة الحجز علي عقـار مملوك للمدين ثم زالت عنه ملكيته بسبب فستخ التصرف الذي تملك بـه المال(†)، يصبح الحجز باطلا لوقوعه علي ملك الغير.

والتففيذ يرد علي الأمسوال الحاضرة في ذمـة المدين عند بدء التنفيذ، فهو لا يتناول الأموال الموجودة قبل هذا إذا كانت قد زالت عن ذمـة المدين قبل بــ التتفيذ، وانتقلت إلى الغير، كمـا لا يتــاول الأموال المستقبلية باستثناء الثمسار وملحقات المـال

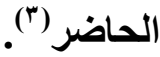
ويالتالي لا يجوز لائن الثريك الحجز علي مال الذي قدمسه الشريك كحصة في الشركة، وذلك لأن المال ياخل في ذمـة الشركة، ولو كـان الشريك هو الذي قدم المـال للشركة كحصة في رأس مالها(؛).وبالتالي تكون من الغير. أيضا لا يجوز لاائن الشركة الحجز علـي الأمـوال الخاصـة للشريك الموصس. أمسا الشريك المتضامن فيجوز لـائن الشركة الحجز علـي أموالـه الخاصـة لأنها ضـامنة للوفـاء بـيون الشركة، وقــ ذهب القضاء الفرنسي إلى جواز توقيع الحجز علي حصة الشريك، وذلك بإجراءات حجز مـا للمدين لدي الغير(•)

(1) د/ أحمد خليل، التفيذ الجبري، المرجع السابق، ص ؟ب با.

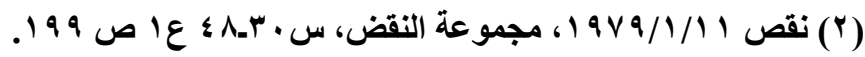

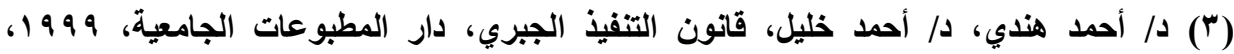

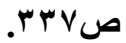

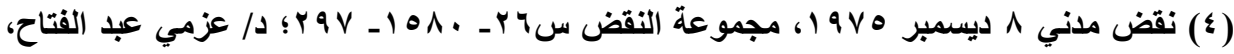

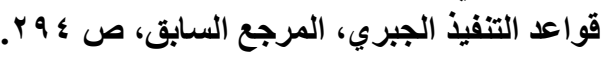

(5) CA Paris, 1re ocotbre 1928, syr., 1929. 1, p. 31. 
كذللك لا يجوز الحجز علي أمسوال مملوكـة لأحـ الزوجين لاستيفاء دين علي الزوج الآخر، أو علي أبنائسه أو العكس، فالصلة الوثيقة التي قد تربط بين شخصينكالزوجية أو الأبوة- لا تلغي استقلال الأمة المالية لكل منهما' '. ولا يجـوز للـائن الوصسي أن يحجز عليـه تحت يــ المحكمـة الحسبية باعتبـار القاضي مدينا لوصية وأن أموالا مودعه خزانة المحكمة، لأن المحاكم الحسبية لا تمثل القاصر وليست أمينة علي أمواله وانما هي رقيبة علي أعمال الأوصياء. ولا يجوز لائن المستحق في الوقف أن يحجز عليه تحت يـ مديني الوقف مثل مستأجري أعيانه، لأن الوقف شخصية معنويـة مستقلة عن شخصية المستحقين فيه، فالمستحق ليس دائنا لمستأجر الأعيان الموقوفة، ولكن يجوز الحجز علي نـاظر الوقف بصفته هذه تحت يا مستأجري أعيانه.

كما أنه لا يجوز الحجز علي مال النائب لدين علي الأصيل، حيث يلتزم الأصيل بأداء الديون المترتبة في ذمته بناء علي تصرف النائب عنها، وبالتالي لا يجوز الحجز الا علي مال مملوك للأصيل وليس النائب(). ولا يجوز الحجز علي مرتب المستخدم في المحل التجاري تحت يل صراف المحل لأن مدين المدين هو صـاحب المحل فيجب أن يوقع الحجز تحت يده هو. 


\section{الفرع الثاني \\ استثناء جواز التنفيذ علي أهوال الغير}

إذا كانت القاعدة عدم جواز إجراء التنفيذ إلا في مواجهة الملتزم بالسند التنفيذ، إلا أنه استثناء من هذه القاعدة، يمكن إجراء التنفيذ في مواجهة شخص غير ملتزم بالسند التنفيذي (')

ويرجـع جواز الحجز في مواجهة الغير إلي وجود امتيـار للمؤجر، وذلك في

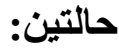

\section{الحالة الأولي: العجز علي المنقولات المملوكة للفير الموجودة بالعين المؤجرة.}

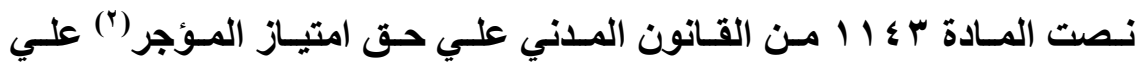
المنقولات التي يضعها المستأجر في العين المؤجرة، ولو كاتت هذه المنقولات مملوكة لغير المدين، كما لو كانت مملوكة لزوجة المستأجر أو للغير.

ويرجع أساس الحجز علي منقولات الغير، أنه لما كان امتياز المؤجر يقوم علي فكرة الرهن الضمني لضمان الأجرة، ومن ثم فلا يشترط في المنقولات الموجودة بالعين أن تكون مملوكة للمستأجر، فيرد لامتياز عليها لو كانت مملوكة للغير، مـادام المؤجر كان حسن النية وقت دخولها بالعين المؤجرة أي لا يعلم بـأن للغير حقا عليها، وحسن

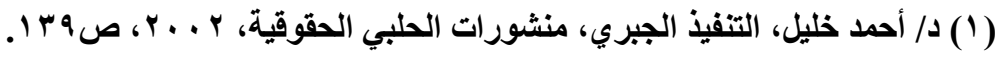

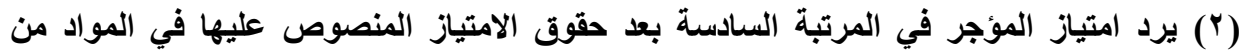

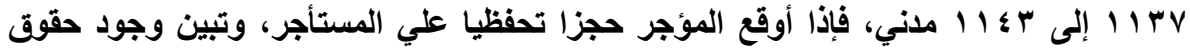

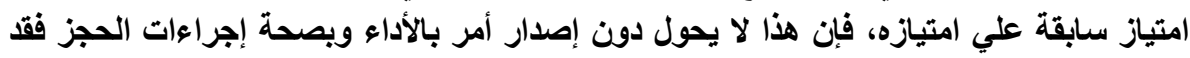

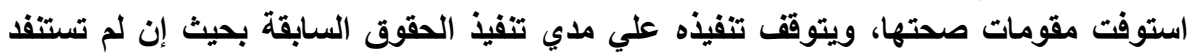
حصيلة التتفيذ كلها، كان للمؤجر التنفيذ علي الباقي. 
النية مفترض، وعلي من يدعي خلافه إثبات سوء النية المؤجر، أي علمه بملكية الغير للمنقولات وقت دخولهـا العين (')، وذلكـ دون الإخـلال بالأحكـام المتعلقـة بـالمنقولات

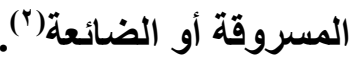
وقد ذهبت محكمة النقض إلى أنسه يشترط ألا يكون المؤجر عالمـا بـأن مـا حجز عليه ليس مملوكا للمستأجر أو المستأجر من الباطن ويجوز استخلاص هذا العلم- من ظروف الدعوي وملابساتها- فإذا استـل الحكم علي علم مالكا الأرض بـأن الحاصلات المحجـوزة ليست مملوكـة للمستأجر مسن البـاطن بـأن العين المـؤجرة جـرن لا تـتـج محصولا وإنما هيئت لينقل إليها سكان العزبة محصولاتهم لارسها فيكون قد استخلص ذلك استخلاصا سائغا("). فيجـب للحجـز علــي منقــولات الموجـود بــالعين المسؤجرة، تــوافر عناصـر

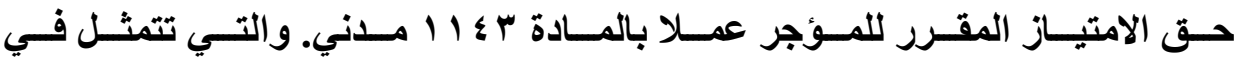

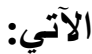

ا - أن يكمون الحاجز هؤجرا للهقار: يـشترط أن يكـون العـاجز مــؤجرا للعقــار وقـت الحجـز، ســواء كــان هـو المالك أو صاحب حق انتفاع أو مؤجر من الباطن، وأيا كـان الغرض الذي تم من أجلهـه التأجير.

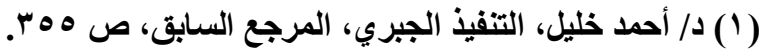

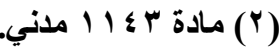

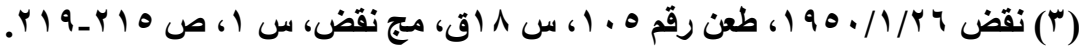


ويجـب أن ينـصب الإيجـار علـي العقــار، سـواء كــان أرض بنــاء او أرضـــا زراعيـة، ولكـن إذا كـان الــائن مـؤجرا لمنقـول، فـلا يملـك توقيـع الحجـز التحفظـي،

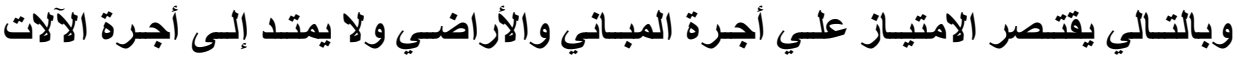

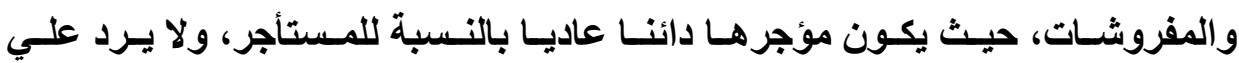
المنقولات حق امتياز. إذا تصرف المستأجر في المنقولات الخاضعة لامتيـاز المؤجر لشخص حسن النية فإن هذا لا يتملكها بالحيازة إلا إذا انقضي شهر علي علم المؤجر بخروجها من العين دون أن يحجزها حجزا استحقاقي عملا المادة 9 مه مدني. r- أن يكون المدين المطلوب الهجز عليه مستأجراً: يشترط أن يكون المحجوز عليه مستأجرا، وذلك بوجود علاقة إيجاريه مع طالب الحجز، كما يستوي أن يكون مستأجرا أصليا أو من الباطن. وطبقا لنص المسادة VIV مرافعات فالحجز علي المنقولات لادي المدين المستأجر من البـاطن يعد بمثابة حجزين في وقت واحد، أحدهما علي المنقولات الموجودة في العين المؤجرة، والثاني علي مـا تحت يده من أجرة. وللحجز علـي المنقولات المملوكـة للمستأجر مسن البـاطن، يجب التفرقـة بين

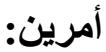
الأول: إذا كان المأجر قد اشتزط عدم الإيجار من الباطن. ففـي هـذه الحالـة يجـوز الحجـز علـي هـذه المنقــولات المتواجـدة فـي العـين حتـي ولـو كانــت مملوكـة للغيـر، وذلــك للوفـاء بكافـة حقـوق المسـتأجر الأصـلـي، ولا يحاج في مواجهة المؤجر بالإيجار من الباطن، فيثبت لـه الامتيـاز علي المنقولات 
الموجودة بـالعين ولـو كانت مملوكـة للمستأجر مـن البـاطن، فمنقولات المستأجر مـن الباطن تضمن الأجرة المستحقة من غير أن تحدد بقيمة الإيجار من الباطن، إلا إذا ثبت علم المـؤجر وقـت دخـول المنقـولات العـين المـؤجرة أنهـا ليست مملوكـة للمستأجر

الأصلي.

الثاني: إذا سمح المؤجر بالإيجار هن الباطن، فلا يجوز للمؤجر أن يحجز علي هذه المنقولات الموجودة في العين المؤجرة إلا ضمانـا لقدر من حقوق المؤجر يعادل مـا يكون مستحقا للمستأجر الأصلي في ذمـة المستأجر من الباطن(')، ففي هذه الحالة لا يكون للمؤجر الأصلي امتياز علي منقولات المستأجر من البـاطن إلا بقدر مـا يكون هذا مدينا به للمستأجر الأصلي وقت إنذاره (مادة ج وه مدني)(؟) r- أن يكون الدين الذي يتم المبز بمقتضاه هن الديون التـي يضشنها حـق

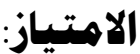

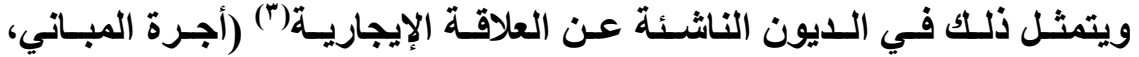

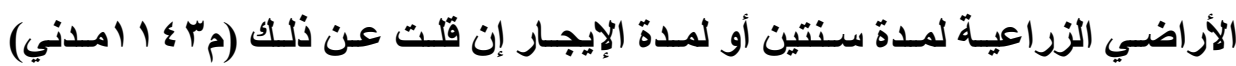

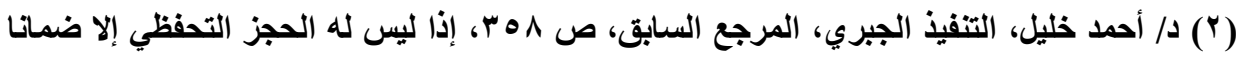

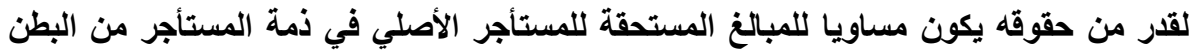

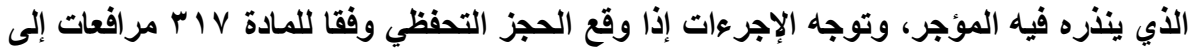

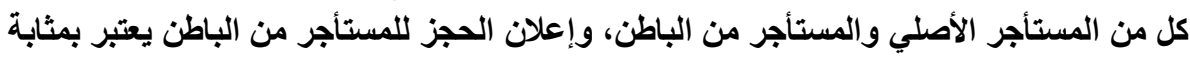

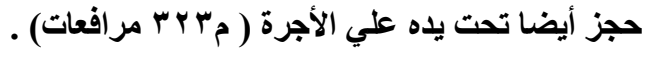

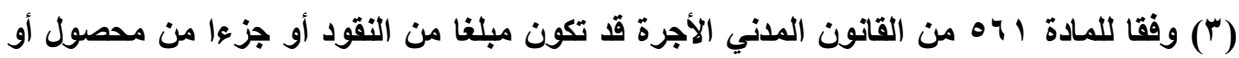

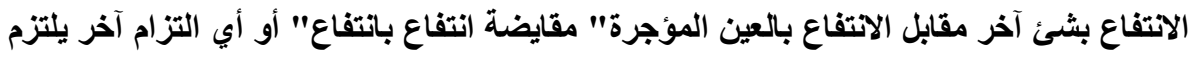

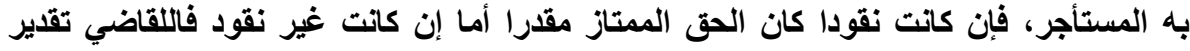
$=$ 
والتعـويض المسـتحق للمـؤجر لعـــم وفــاء المسـتأجر بالالتزامــات الناشـــة عـن عقد الإيجـار)، ويجب أن يكـون الحق محقق الوجـود وحسال الأداء، ومعين المقـدار

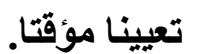

كما يرد الامتياز علي المبالغ الأخرى المستحقة بسبب عقد الإيجـار كـالتعويض المستحق للمؤجر عن تلف العين المؤجرة أو عن استعمال في غير الغرض الذي أعدت لله أو عن فسخ الإيجار أو عن عدم الوفاء بأي التزام آخر كعدم المحافظة علي الأشجار المغروسة بحديقة المسكن. ولا يرد الامتياز علي المجوهرات والحلي ولا علي النقود والسندات، فهي لا تعتبر منقولات جهزت بها العين المؤجرة ( م ^^ه مدني)، إذن الحجز لا يجري علي أي مال بل يجب أن يكون واردا علي منقولات مملوكة للمدين أو للغيـر وموجـوده بــالعين المـؤجرة (ســواء أكانــت منقـولات ماديـة أو ثــرات أو

المبلغ الذي يعتبر مقابلا للانتفاع بالعين المؤجرة فيكون هذا المبلغ هو الحق الممتاز، ولا يثبت

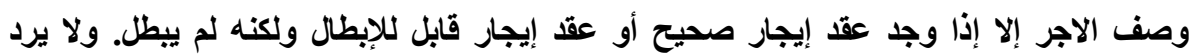

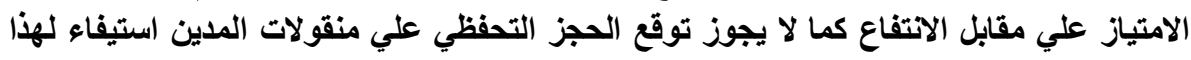

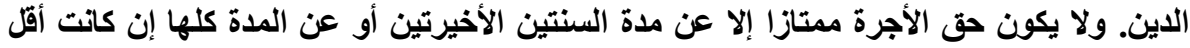

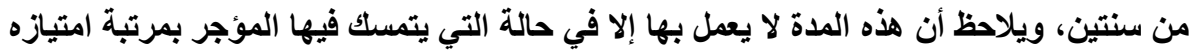

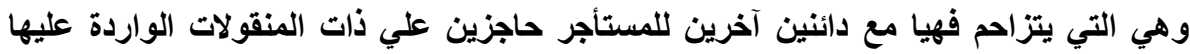

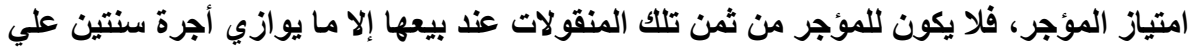

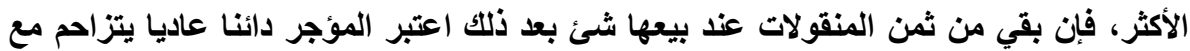

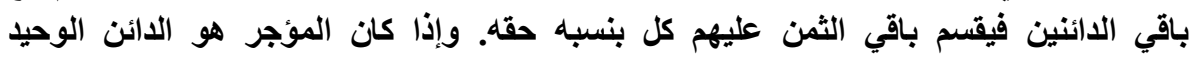

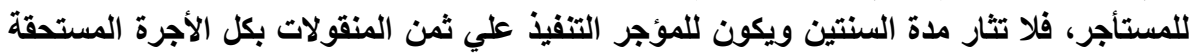

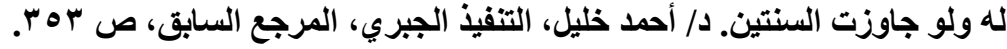


ويثار التساؤل عن مدي وجود امتيـار للمؤجر علي منقولات المملوكة للزوجة مع وجود قرينة علي ملكية الزوجة للمنقولات. الاتجاه الأول: عدم الاعتداد بالقرينة في هواجهة المؤجر: يـري بعض الفقـهـ أن للمـؤجر الامتيـاز عــي منقـولات الزوجيـة، سـواء علــم

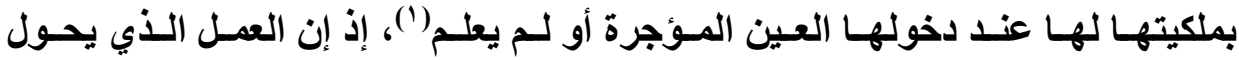
دون هذا الامتياز هو المتعلق بمنقولات الغير ولم يكن يعلم بملكية الغير لها. فقرينة المنقولات الزوجيـة ملتك للزوجـة ـ مسلمة أو غير مسلمة لا يعتد بهـا في مواجهة المؤجر.

\section{الاتجاه الثاني: الاحتجاج بالقرينة في هواجهة المؤجر:}

ذهب هذا الاتجاه إلي أنه يمكن أن يحاج المؤجر بهذه القرينة إذا قامت الزوجـة بإخطاره قبل إدخالها لمنقولاتها العين المؤجرة بملكيتها لها، وبعدم تحملها بامتيـازه، ويكون لها إخراجها في أي وقت، ولا الحق للمؤجر الحجز عليها، أمـا إن لـم تقم بهذا الإخطار، أو قامت به بعد دخول المنقولات العين المؤجرة، فقد أقام القانون قرينة علي امتداد امتياز المؤجر إلى هذه المنقولات، وتلكك قرينة قانونية قاطعة لا يجوز إثبات مـا يخالفها ومـن ثم يتعين رفض دعوي الزوجة باسترداد هذه المنقولات ولكن يتعين الفصل في ملكيتها أولا حتي إذا مـا ثبت ملكيتها للزوجة احتفظت بحقها بعد ذلك في الرجوع بقيمتها علي زوجها بدعوي الإثراء بلا سبب، أنه أثري بقدر ما برئت ذمته من 


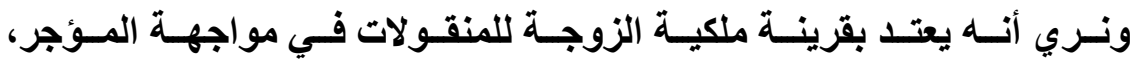

وعلي المـؤجر أن يثبت عدم علمها بهذه القرينـة. وبالتـالي إذا علـم المـؤجر بملكيـة الزوجة للمنقولات، فلا يجوز له الحجز عليها، حتي لو لم تصرح الزوجـة بأنها مالكة

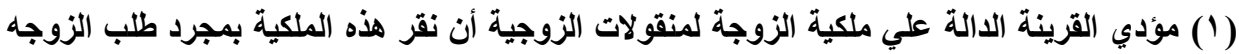

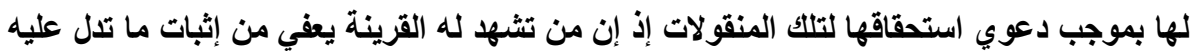

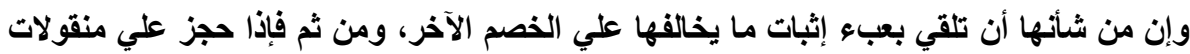

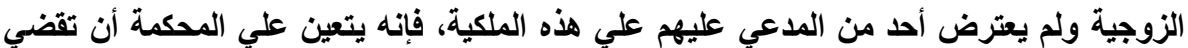

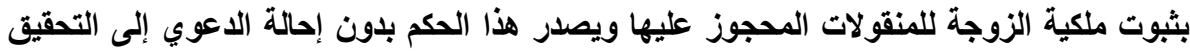

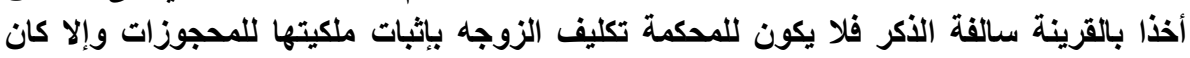

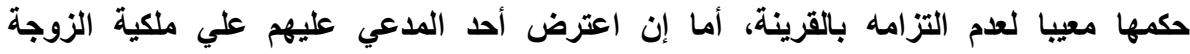

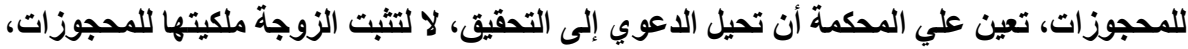

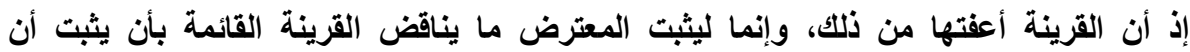

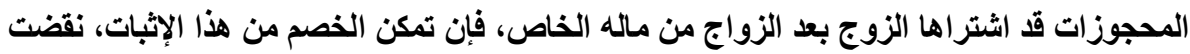

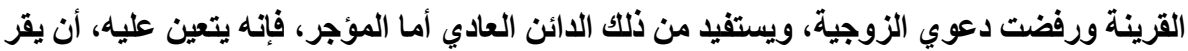

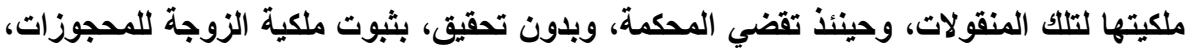

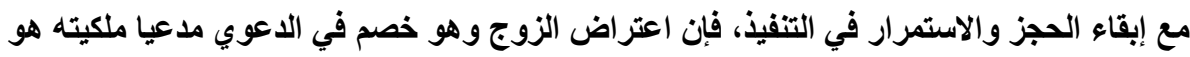

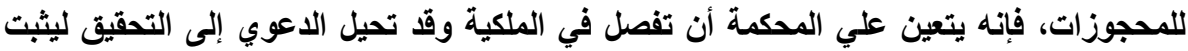

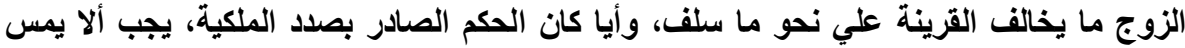

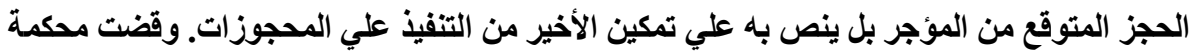

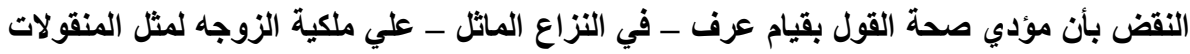

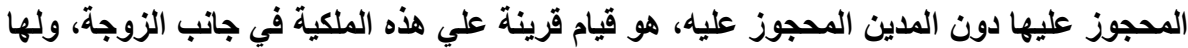

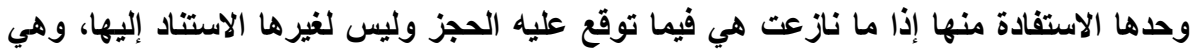

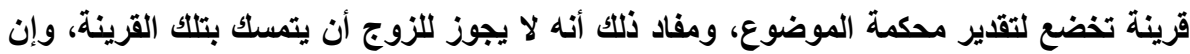

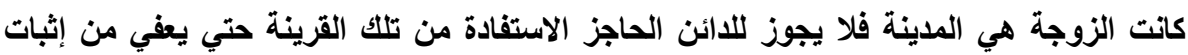

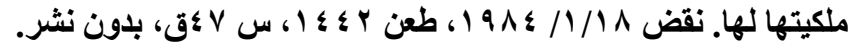


ويثار التساؤل عن مدي حق المؤجر في تتبع المنقولات إذا خرجت من العين

يلاحظ أنه رغبة من المشرع في تقوية ضمان المؤجر في الحصول علي حقه،

فإنه لـم يكتف بمنحسه امتيـازا علـي المنقولات الموجودة في العين المؤجرة كمـا منحسه الحق في الحجز التحفظي علي هذه الأمسوال. إلـي جانب ذلك للمؤجر حق تتبع هذه المنقولات إذا نقلت دون علمه من العين المؤجرة خلال ثلاثين يوماً من نقلها. فقد نصت المـادة V ا مرافعـات علي أنه يجوز للمؤجر أن يوقع الحجز التحفظي إذا كاتت تلك المنقولات والثمرات والمحصولات قد نقلت بدون رضـائه من العين المؤجرة مـالم يكن قـ مضي علي نقلها ثلاثون يوماً. وق ذهب القانون الفرنسي إلى أنه يجب إعلان السند التنفيـي للمحجوز لايـه خـلال ^ ايـام مـن بـد الحجز التحفظي علـي المحجوز لديـه، ويترتب علي مخالفة ذلك البطلان (')، كمـا يمكن للغير أن يـدفع بعدم الزامـه بدفع قيمـة الاين إذا وفي بحقوق المدين المحجوز عليه().

فيمكن للمؤجر حق التتبع للمنقولات في أي يد تكون، ويلاحظ أن المشرع اعتبر الحجز الأي يوقعه المؤجر علي منقولات المستأجر الأصلي أو المستأجر من الباطن بعد

(1) CA Paris, 11 oct. 2007, RG no. 07/01209. Dalloz, 20015, Cass. 2 civ. 15 janv. 2009, Bull. Civ. 11, n $^{\circ}$ 199, procedures 2009 comm., 80 obs. S. Piedelievre, Cass. Civ. 5 juill. 2000, D. 2001, 722, RTD civ., 2000, 903, obs. Perrot, R. Perrot et Thery, saisie attribution, ob. Cit.,714.

(2) Cass. Avis, 21 juin 1999, Bull. Civ. ${ }^{\circ}$ 5, D. affaires 1999, 1247, obs. P. julien, Rev. huiss. 1999, 683, note Dahan, Cass. Com, 13 oct. 1998, D. 1998, IR, 250. 
نقل هذه المنقولات من العين المؤجرة بما له من حق تتبعها في الميعاد القانوني بمثابـة

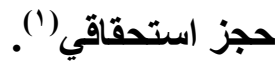

\section{ويشترط لممارسة حق التتبع الشروط الآتية:}

الـــشرط الأول: أن تكــون المنقــولات موجــودة بــالعين المـؤجرة ذاتهــا أو

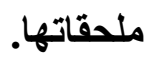

الشرط الثاني: أن يتم النقل بغير رضاء المؤجر أي خفية أو تم نقلها عنوة. الشرط الثالـ: أن يتم الحجز في مواجهة المستأجر الأصلي والمستأجر من الباطن خلال · ب يوما من تاريخ نقلها من العين المؤجرة بدون رضاه.

الشرط الرابع: ألا يكون بالعين المؤجرة أموال تكفي لضمان حق الامتياز المقرر له، و إلا له حق توقيع الحجز التحفظي علي المنقولات التي نقلت من العين المؤجرة

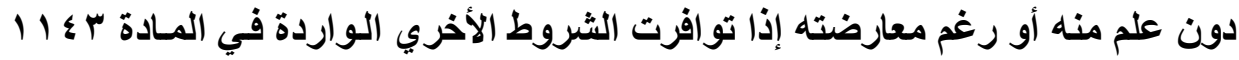
مدني ( بما له من حق تتبع عليها)، فيمـا لا يضر بحقوق الغير حسن النية علي هذه الأموال إلا إذا وقع عليها حجزا استحقاقي في الميعاد القانوني، فيبقي الامتياز قائمـا لمدة ثُلاث سنوات مـن تـاريخ نقلها ولـو أضر بحق الغير مـا لم تكن قد بيعت هذه المنقولات إلى مشتر حسن النية في سوق عام أو في مزاد علني أو لمن يتجر في مثلها، فعلي المؤجر رد الثمن إلى المشتر في هذه الحالة. 


\section{الحالة الثانية: المنقولات الموجودة بالفندق:}

لصاحب القندق حق امتياز بالمبالغ المستحقة لله في ذمته النزيل علي الأمتعة التي أحضرها النزيل في القندق ولو كاتت مملوكة لغير النزيل. بشرط ألا يكون صساحب القندق علي علم بملكية الغير لها (ع ؛ 11 مدني).

وفي هذه الحالة يقوم الدائن ببيع الأمتعة او المنقولات واقتضاء حقه في الأجرة من ثمن هذه الأثياء. ويجب للحجز علـي منقولات الغير في هذه الحالـة، أن يكون الحسجز صـاحب فندق، وأن يكون المحجوز عليه نزيلا في الفندق، وأن يكون الحجز لضمان قيمة الأجرة.

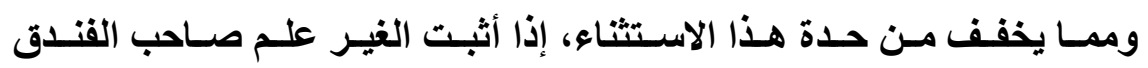

بملكيـة الغيـر للمنقـولات، فـلا يجـوز الحجز علـي هذه المنقولات، كـلكت لا يجـوز لـه

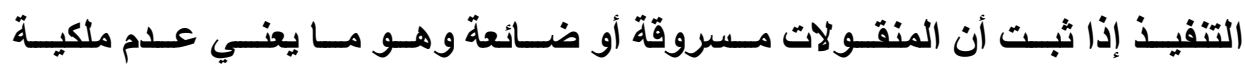

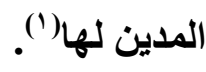

مـن الواضـح أن هذه الاستثنـاءات لا تخـل بالقاعدة العامـة وهي وجـوب ورود الحجز علي مال مملوك للمدين، وذلك حتي يمكن التصرف فيه بـالبيع الجبري تصرفا نافذا في حق مالكة.

إذا تـم الحجز علـي مـال مملوكـه للغير في غير الحسالات الاستثنائية، فـان هذا الحجز يكون باطلا، حيث إن مقتضيات العدالة تستوجب أن كل تنفيذ يمس بحقوق الغير 
يكون بـاطلا(')، فـاذا جري علـي مـال الغير يستطيع أن يرفع دعوي استرداد المسال

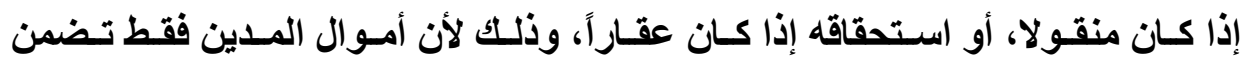

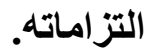




\section{المبحث الثاني \\ نطاق الغير في التنفيذ الجبري}

يتسع نطاق فكر الغير في التنفيذ الجبري، فتظهر في إجراءات التنفيذ في حالة

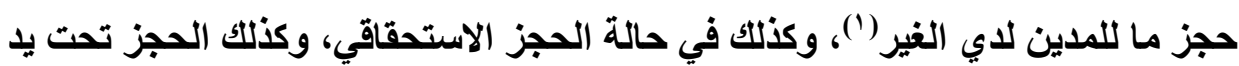

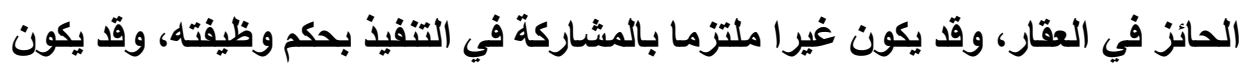
هذا الغير شخصا طبيعيا أو اعتباريا"). ويمكن لنا تقسيم الغير في اجراءات التنفيذ الجبري إلى: الغير الذي لهه صله

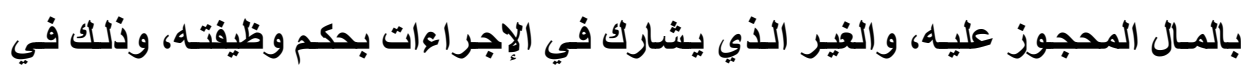

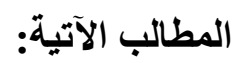

\section{المطلب الأول \\ الغير الذي له صله بهال المنفذ ضده}

يتمثل هذا الغير الذي لـه صلة بالمسال في المحجوز لايه، والحائز في الحجز

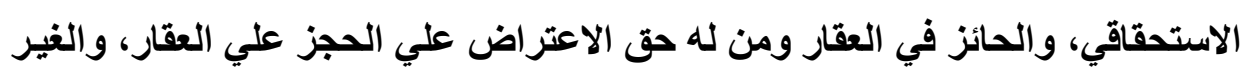

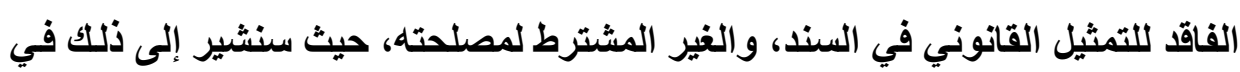

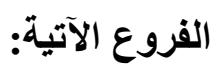

(1) Cass. Com. 25 juin 1996, D. 1996, p. 615, obs. Derrida, Cass. Com. 22 avril 1997, D. 1997, p. 371, obs. Drrida. S. GUINCHARD et T. MOUSSA, droit et pratique des voies d'exécution, op. cit., $\mathbf{n}^{\circ}$ 161-22.

(2) S. GUINCHARD et T. MOUSSA, droit et pratique des voies d'exécution, op.cit., n¹61-13. 


\section{الفرع الأول \\ الغير الحجوز لديه}

سنشير إلى تعريف الغير المحجوز لايه،، والشروط الواجب توافرهـا فيه، وذلك

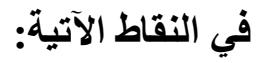

\section{أولاً: تعريف الغير المجوز لديه:}

يقصد بالغير المحجوز لايه، من يكون في ذمته حقوق أو في حيازته منقولات للمنفذ ضده، فهو مدين المدين(')، حيث أعطي المشرع السلطة للائن في ممارسة حجز علي حقوق مدينه أو منقولاته التي في ذمة الغير أو في حيازته()، بهرف منع الغير من

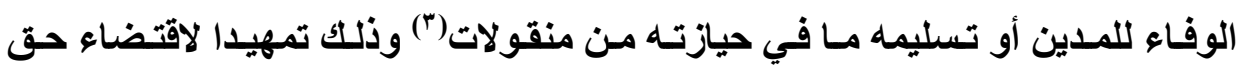
الحاجز من ثمن المال المحجوز عليه بعد بيعه(؛) فهذا الحجز هو الإجراء الذي يستطيع

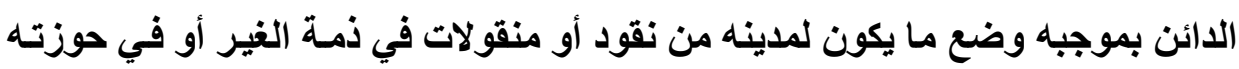

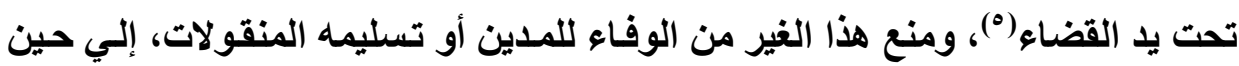

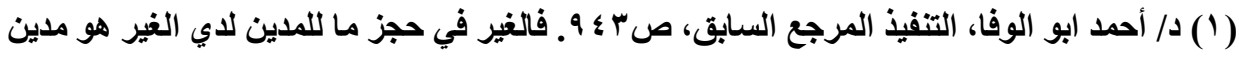

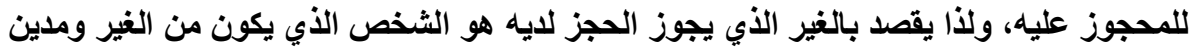

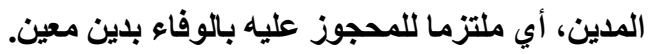

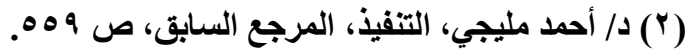

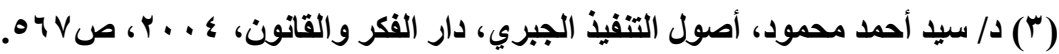

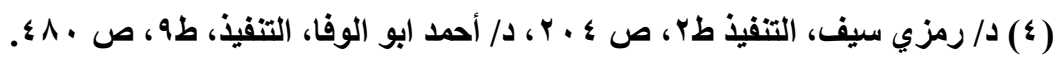

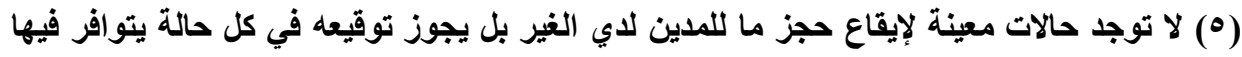

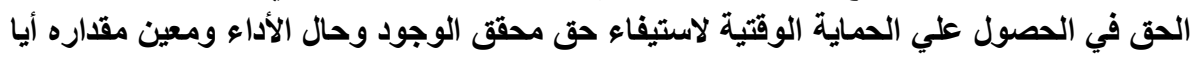

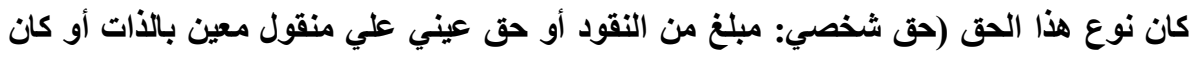
حقا يجيز لصاحبة تتبع المنقولات في يد حائزها) وأيا كان سبب هذا هذا الدين هلين هو معاملة مدنية أو الو $=$ 
اتخـاذ الـائن الإجـراءات التـي تخولـه اقتضاء حقـه مـن المـال المحجـوز أو مـن الثمن المتحصل بعد بيعه(')، وييرر حق طالب التنفيذ في الحجز علي أموال مدينه لدي الغير بمـا لـه من حق الضمان العـام علـي أموال مدينـه(؟). ويجب أن يكون المنقول المـادي مملوكـا للمدين وقت الحجز أو للمدين حق في ذمـة الغير حتي ولو كـان غير معين

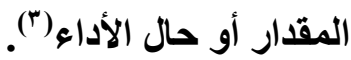

وقد حددت محكمة النقض الفرنسية الغير بأنه الشخص الذي لـه علاقة قانونية بالمنفذ ضده، وذلك بقولها

La cour de cassation fancaise a defini du tiers saisi, personne qui "se trouve dans un rapport de droit avec le debiteur et a qui la mesure... pratique impose des obligations" ${ }^{(4)}$.

تجارية. وغنصر الاستعجال في حجز ما للمدين لاي الغير مفترض ولا يلزم إثباته وليس علي

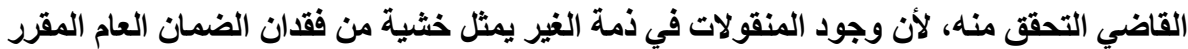
للائن علي أموال المدين. د/ سيد أحمد محمود، أصول التنفيذ الجبري، دار دار الفكر والقانون،

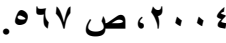

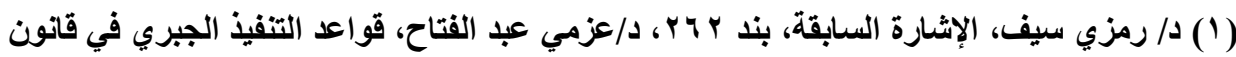

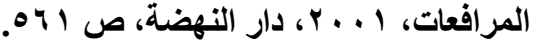

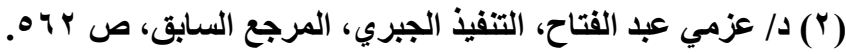

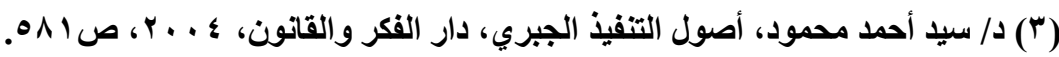

(4) Cass. 24 janvier 1994, Bull. Civ., n 4. 
ويلاحظ أن أطراف خصومة التنفيذ في هذا الفرض ثلاثة، الحاجز وهو الدائن، والمحجوز عليه وهو المدين ومحجوز لايه وهو مدين المدين، حيث إن هذا النوع من الحجز لا يتضمن فقط العلاقة التقليدية في كل الحجوز، التي تتمثل في طالب التنفيذ والمنفذ ضده، بل ينطوي علي رابطتين قانونيتين، الأولي: تثضمن العلاقة بين الحسجز والمحجوز عليه، وسببها هو الحق الذي يكون للحاجز، والذي يبرر اللجوء إلي توقيع الحجز، والرابطة الثانية: وتجمع بين المحجوز عليه والغير المحجوز لايه، وسبيها هو الحق الذي يكون للمحجوز عليه في ذمة المحجوز لايه، وهو الذي ينصب عليه حجز ما للمدين لاي الغير.

والواقع أن الغير يكون هو الخاضـع لإجراءات التنفيذ الجبري، مـع أنـه ليس المدين، وليس مسئولا عن ديـن الـائن، وإن كـان هوـ في الغالبـ مدين المدين، أي المحجوز لايه في حجز ما للمدين لاي الغير. فالمدين هو المحجوز عليه لا تباشر ضده إجراءات التففيذ، وإنما تباشر هذه ضد المحجوز لايه، فهو الأي يعلن أولا بأمر قاضسي التنفيذ بالحجز، وعليه التزام بعدم الوفاء بما في يده إلى دائنة المحجوز عليه، ويلتزم

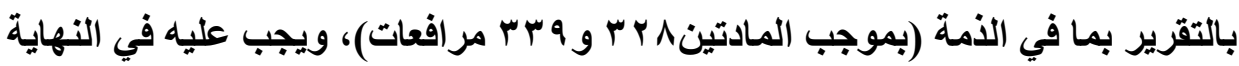
دفع المبلغ إلى الحاجز (م ع ؛ ب مرافعات). ويثار التساؤل حول ممارسة الدائن لحقه في حجز ما لمدين لاي الغير، هل يعد من قبيل استعمال الدائن لحق مدينة؟ في حقيقة الأمر يري الفقـه أن هنـاك اختلاف من حيث الهدف والشروطوالآثار بين حجز مـا للمدين لدي الغير واستعمال الدائن لحق مدينة المنصوص عليه في المـادة 7711 من القانون المدني، حيث إن المقصود من حجز ما للمدين لاي الغير استيفاء حق الحاجز مباشرة من الحق المحجوز عليه، أمسا استعمال الدائن لحق مدينه فلا يهذف به إلا مجرد إدخال الحق الذي لـم يستعمله مدينها. 
في أمسوال هذا المسين لكي يكون ضـمانا لسائر الـائنين، ويستفيد مسن قيـام الـائن باستعمال حقه مدينه كافة الدائن حتي ولو لم يتلخلوا معه، كما أن حق الدائن في حجز ما للمدين لاي الغير حق مستقل في ذاته عن حق الائن في استعمال حقوق مدينة. إلـي جانب ذلك لا يشترط قـانون المرافعـات مـا اشترطه القـانون المدني لقيـام الدائن لحجز ما للمدين للدي الغير، حيث اشترط القـانون المدني عدم استعمال المدين لحقه، وأن يسبب عدم الاستعمال في إعساره أو يزيــ فيه. كمـا أن الحجز يمنـع علي المدين التصرف في أمواله في ذمة الغير، ويمنع الغير من الوفاء للمدين بأمواله، أمـا في حالة استعمال الـائن لحقوق مدينة، فلا يمتنـع علـي المدين التصرف في حقهـ ولا علي مدين المدين الوفاء له بمطلوبة، بل يجوز للمدين أن يتنازل عن حقه، وفي هذه الحالة لا يملك الأئن إلا مباشرة الدعوي التي تهذف إلي عدم نفاذ تصرف المدين.

\section{ثانيا: الشروط الهاجب توافرها في الغير المجوز لديه} يشترط في الغير في حجز ما للمدين لاي الغير الثروط الآتية:

\section{الشرط الأول: استقلال شخصية الغير عن المدين:}

فلا يجوز أن تكون بين الغير والمدين رابطة تبعيـة، فبإذا كـان الشخص تابعـا للمدين، فلا تتوافر فيه صفة الغير، فالصراف الذي يعمل علي خزينـة في محل يملكه. المدين لا يعتبر من الغير، ونفس الحكم بالنسبة للبواب والخـادم، علي العكس من ذلك فإن الشخص يعتبر مـن الغيـر إذا كانـت لـه الثخصية القاتونيـة المستقلة (') علـي المنقولات أو النقود التي استلمها من المدين. 
ولا يمكن إعطاء صفة الغير إلا للشخص الذي يكون الشيء المحجوز بحوزته بموجب أهلية خاصـة ومستقلة تجـاه المدين المحجوز عليه، فيجب ألا تكون شخصية الطرف الثالث مندمجة مع شخصية المدين (').

وبناء علي ذلك لا يعتبر من الغير الشخص الذي يحوز لحساب المدين وليست له حيـازة مستقلة، والتي يحق للمـين أن يسترد المسال في أيـة لحظة دون اللجوء إلى القضاء. مثال ذلك العلاقة بين رب العمل وأمين صندوقه، فمن حق رب العمل أن يتناول من الصندوق شخصيا ما يشاء من مال، وعلي عكس ذلك، فإن المصرف المودعة لايـه مبالغ باسم شخص معين، إذا امتنعا عن تسليمها إليه فلا يمكنه الحصول عليها إلا بحكم قضائي.

\section{الشرط الثاني: أن يكون للغير سلطات هستقلة علي المنقولات التي يحوزها:} يقــد بـذلك أن يكـون للغيـر سـلطات خاصـة ومسـتقلة علـي المنقـولات التـي

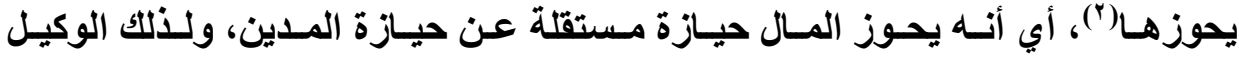
والمستأجر والمـودع لايسه وأمسين النقل والحسارس والموصسي لـه والقيم يعدون مـن

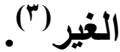

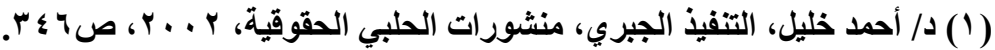

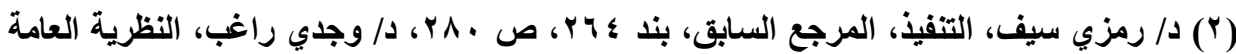

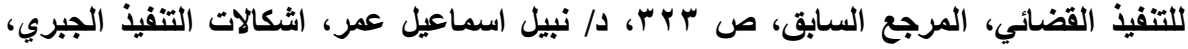


يقصد بالسلطات الخاصة والمستقلة تلكك التي يكون مصدر ها نصا في القانون يخوله إياها تسليم المنقول للغير، أو عقدا بين المدين والغير (')، حيث إن وجود رابطة بين حائز المنقول والمحجوز عليه تؤدي إلى عدم جواز الحجز عليهه بإجراءات حجز

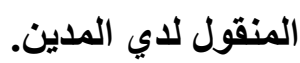

ولا يعد من الغير من ليست لله حيازة مستقلة عن حيازة المدين، فمن يكون خاضعا للمدين خضوع التابع للمتبوع كالخادم والبواب والصر اف والسائق، لا يعد من الغير، فالأموال التي تحت ايديهم تحجز بطريق الحجز علي أموال المدين. الشرط الثالث: سيطرة الغير علي المال بما يمول دون اسيطرة المدين:

يجب أن يكون الغير مسيطراً علي المال سيطرة تحول دون سيطرة المدين علي المسال()، حيث إن الغير هو مـن تكون لـه سبطرة مباشـرة علـي المسال الذي يحوزه، وبالتالي المودع لايه والسنديك بالنسبة لمـا يحوزه من أموال التقليسة والمحضر بمـا تحت يده من نقود لأحد الخصوم يعدون من الغير، أمسا الخـادم والبواب فلا يعدون من الغير.

ويلاحظ أن الغير الذي لله سلطة علي الشئ تمنع المحجوز عليه من الاتصال بـه إلا عن طريقه ( كالمستأجر والمودع لايه، أو الحارس أو الوكيل أو الوصي أو القيم أو 
البنك أو المحضر والمستعير والسنديك، المصفي القضائي('). أمسا إذا كـان تابعا للمدين

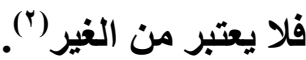

\section{الشرط الرابع: أن يكون في ذهة الغير هال جائز العجز عليه:}

والأمـوال التـي يجـوز حجزهـا بطريـق حجز مـا للمـدين لـدي الغير هـي حقوق

المـدين، أي أن الحجز يـرد علـي محل الحقوق التي تكون للمدين لـدي الغير، وهذه الحقوق قد تكون نقودا أو منقولات مادية مثل الأثاث والمفروشات والبضائع التي تكون بين يدي هذا الغير والتي يلتزم بتسليمها أو بردهـا للمدين، وقد ينصب الحجز علي أوراق مالية أو تجارية في حيازة الغير.

طبقا لنص المـادة ه P مرافعات يجوز للائن أن يحجز علي مـا يكون لمدينه لاي الغير من المبالغ أو الديون ولو كاتت مؤجلة أو معلقه علي شرط، ومـا يكون من الأعيان المنقولة في يد الغير، وبالتالي فيمكن أن يقع الحجز علي دين في ذمـة الغير أو علي منقول مادي، ويجوز الحجز علي الديون (راتب أو أجر الموظف أو العامل) ولو كاتت مؤجلة (أجل قانوني أو قضائي أو اتفاقي) أو معقلة علي شرط (مه ؛ ب مرافعات). فهذا الحجز يتناول كل ما يكون للمحجوز عليه من منقولات في يد المحجوز لايسه أو مـا ينشأ له من ديون في ذمته(") بعد ذلك إلى وقت التقرير بما في ذمته (مه Y مر مرافعات). ولا يشترط في الدين أن يكون محقق الوجود ولا معين المقدار ولا واجب الأداء في

(1) S. GUINCHARD et T. MOUSSA, droit et pratique des voies d'exécution, op. cit., $\mathrm{n}^{\circ} \mathbf{1 6 2 . 2 5}$ et $\mathrm{s}$.

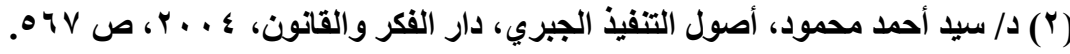

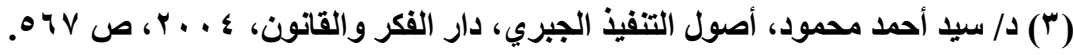


الحسال(')، وبالتــالي يعـد مـن الغيـر المستعير والمـودع لايسه، والمسستأجر والوصسي

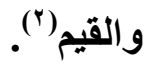

أما إذا كان العقار في يد الغير، فيحجز بالإجراعات التي رسمها القانون بـالحجز

$$
\text { علي العقار ولو كان في حيازة الغير. }
$$

في الواقع ثار الجدال في الفقه بالنسبة للأموال التي يضعها شخص في خزانـة لاي البنك حول إمكانية اعتبار البنك شخصا من الغير، وبالتالي يجوز توقيع هذا الحجز

$$
\text { تحت يده ام لاب }
$$

ذهب بعض الفقه إلى أن العقد المبرم بين البنك والعميل هو عقد أجـارة للخزانـة

لا عقد وديعة، كمـا أن للعميل حريـة الاتصال بخزانته فهو يعد حائزا لمحتوياتها، لأن البنك لا يعلم شيئـا عن محتويـات الخزانـة وبالتـالي لا يستطيع إعطاء التصريح بمـا في ذمته، ولا يعد البنك مدينا بما فيها، وهذا مما أدي ببعض الفقهاء إلي القول بعدم جواز توقيع حجز عليها بطريق حجز مـا للمدين للدي الغير، لأن البنك لا يملك تقديم تقرير حول محتويات الخزانة("). وإجازة الحجز علي البنك تثبه إجـازة الحجز علي منقولات المستأجر تحت يد المؤجر، وهذا لم يقل به أحد)". فقد ذهب هذا الرأي إلى عدم جواز

(1) ويجوز حجز الأسهم الاسمية تحت يد الثركة المصدرة لها بطريق الحجز ما للمدين لاي الغير.

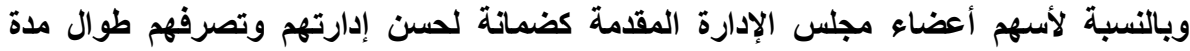

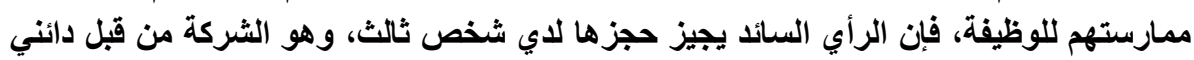

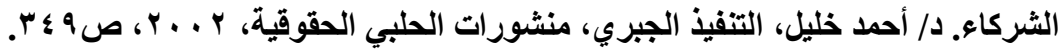

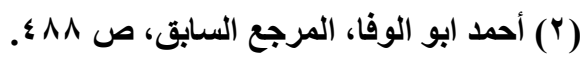

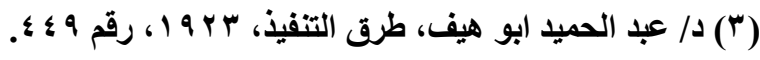

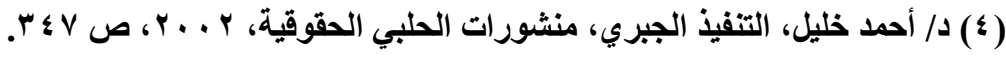


الحجز التحفظي علي الأمسوال الموجودة في خزانـة مستأجره من البنك، وإنمـا يجوز إلقاء الحجز التنفيذي عند المدين نفسه، لأن حائز محتويـات الخزانـة هو العميل نفسه أي المدين الاصلي. ويأخذ القانون اللبناني بهذا الرأي، في المادة VIV V، حيث نص علي أن الحجز الواقع علي أموال محفوظة في خزانة المحكمة استأجرها المدين من أحد المصارف أو علي أموال معروضهـ في معرض عام، فعلي مـأمور التنفيذ أن يعين في الحال مدي المصرف أو مدير المعرض حارسـا لها، وتتنهي الحراسة عند استلام دائرة التنفيذ الأموال المحجوزة (1) بينما ذهب رأي آخر في الفقه إلي أن الطريق الواجب الاتباع في الحجز هو حجز مـا للمدين لاي الغير، أي تحت يد البنك، اعتبار البنتك شخصا ثثلاثـا لأنه يحوز الخزانة، وحيازته مستقلة عن حيازة المحجوز عليه، إذا يجب أن يعتد بمن لله الحيـازة الفعلية للشيء، فالحائز الفعلي هو البنك، وبـإعلان البنك يجب عليهه منـع المدين من الوصول إلي الخزنة، ويتضمن التقرير بما في الأمة أن يشير إلي رقم الخزنة(؟).

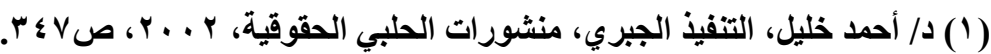

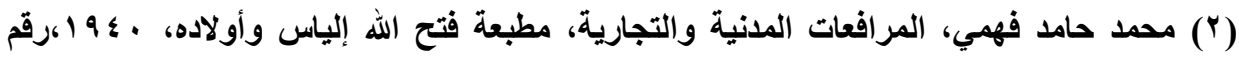

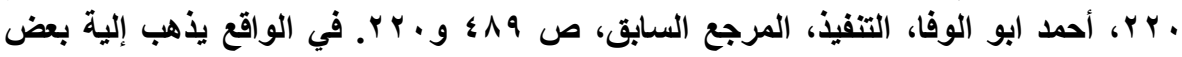

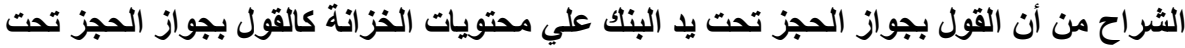

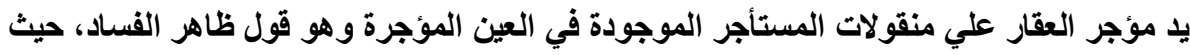

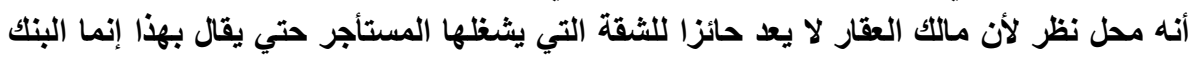

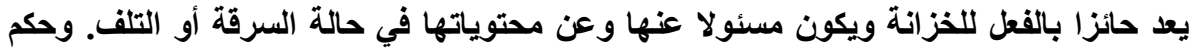

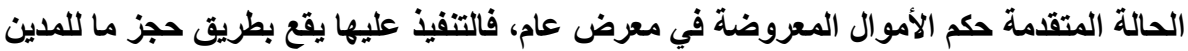

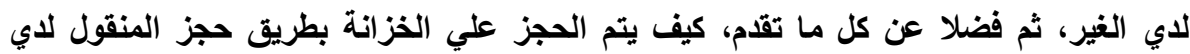

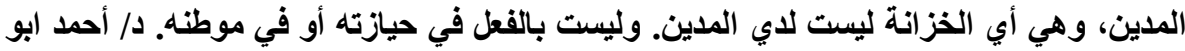

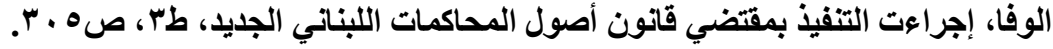




\section{الفرع الثاني \\ الغير في الحجز الاستحقاقى}

سنشير إلي تعريف الحجز الاستحقاقي، ومفهوم الغير في هذا الحجز، وذلك في

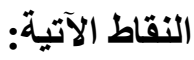

\section{أولا: تعريف العجز الاستمقاقي:}

يجيز القانون لمالك المنقولات أو لمن له حق عيني عليه أو حق في الحبس أن

يوقع الحجز الاستحقاقي عليه عند حائزه، وذلك بهدف التحفظ عليه تحت يـ الحائز، حتي يتمكن من استرداده إذا حكم له بحقه، وهذا الحجز نتيجة لما للمالك في الحق في تتبع المنقول في يـ الحسائز (')، فـالحجز الاستحقاقي عبـارة عن وضع المـال تحت يـا القضاء لعدم قرة المدين علي التصرف فيه إضرار بحق الدائن، فهو صوة من صور الحجز التحفظي، ولكنها تختلف عن غيره من أنواع الحجوز التحفظية، حيث يتم الحجز علي المال في يا شخص من الغير.

ويرجـع أسـاس هذا الحجز أن الحسجز لـه حق عينـي (ملكية أو انتفـاع أو حق

حبسه أو غيره) يخولـه تتبـع المنقول، لذا فهو الحجز الذي يوقعهه مالكك المنقول أو صاحب حق عيني آخر عليه يخوله تتبعه أو صاحب الحق في الحبس في يد من يحوزه تمهيدا لتسلمه( (ن) ويثار التساؤل عن مدي اقتصار توقيع هذا الحجز من المالك فقط.

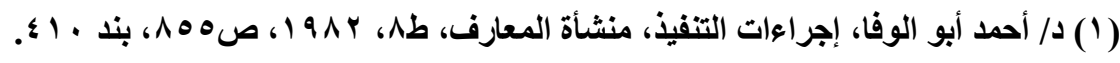

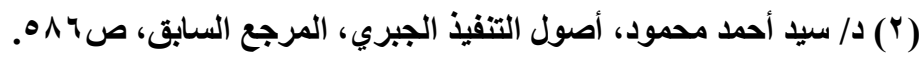




\section{في الواقع اختلفت كلمة الفقه في الإجابة علي هذا التساؤل، وذلك علي النحو التالي:}

الاتجاه الأول: يري جاتب من الفقه أن هذا الحجز يجوز توقيعه من المالك وذلك عملا بالمادة 1 آ مرافعات، وكذلك يمكن أن يوقع من لكل شخص له الحق في التتبع، مثل صاحب حق الاتتفاع وحق الحبس (')

الاتجاه الثاني: يري بعض الفقه أن هذا الحجز لا يوقع إلا في حالة كان الحساجز

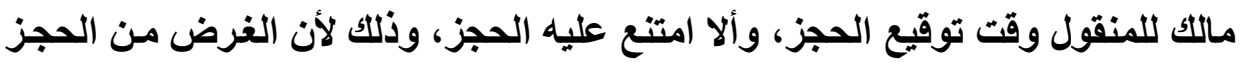

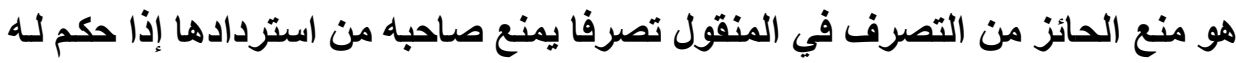
بعد ذلك بملكيتها(")

في الواقع نري أن مجال هذا الحجز أوسع من اشتراط أن يكون الحساجز مالكا فقط، فيمكن مباشرة الحجز في حالة كون الحاجز صاحب الحقى في حبس المنقول أو لـه

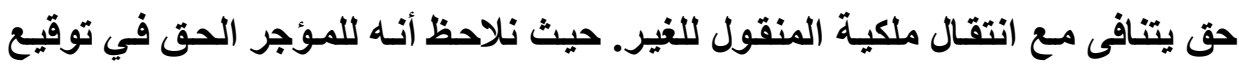
الحجز الاستحقاقي علي المنقولات التي كانت موجودة بـالعين المؤجرة، ولكنها قد

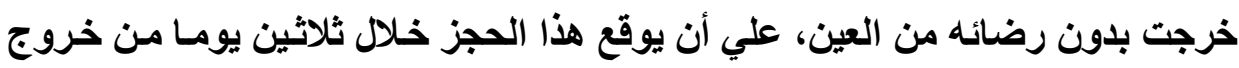
المنقولات، وإذا نقلت إلى العين مؤجرة أخري قدم امتياز المؤجر الأول بشرط إيقاع العجز الاستحقاقي خلال المدة سالفة الذكر. الحجز الاستحقاقي لا يتحول إلـي حجز تتفيذي كباقي الحجوز التحفظيـة، بل

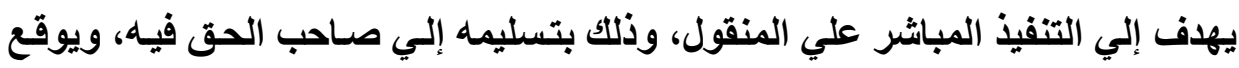

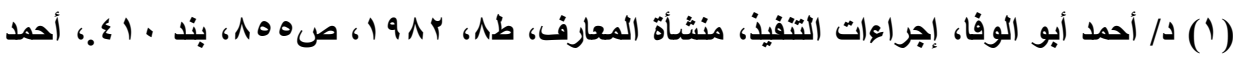

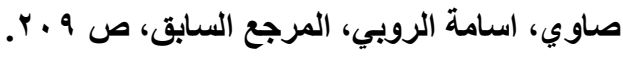

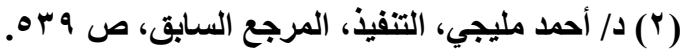


الحجز الاستحقاقي بنفس إجراعات الحجز التحفظي للمنقول لاي المدين، وبالتالي يجب إعلان المدين المحجوز عليه خلال ثمانية أيام علي الأكثر من تـاريخ توقيع الحجز وإلا

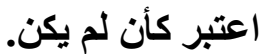

كما يجب علي الحاجز خلال نفس الميعـاد ـ ثمانيـة أيسام علي الأكثر من تـاريخ توقيع الحجز - أن يرفع أمام المحكمة المختصة الدعوي بثبوت الحق وصحة الحجز، وإذا كانت الدعوي بالحق مرفوعة من قبل قدمت دعوي صحة الحجز إلى ذات المحكمة

والحجـز الاســــقاقي في حالـة الحجـز الـــي يوقعـه المـؤجر علـي منقـولات المستأجر، لـه وظيفتـان، وظيفـة الحجز الاستحقاقي، ووظيفة الحجز التنفيذي، حيث يكون ضد كلا من الغير والمستأجر، فيقوم المؤجر بحجزها استحقاقيا في مواجهة الغير الحائز للمنقولات واستردادها من تحت يده بمـا لـه من حق التتبيع، وياعتباره حجزا تحفظيـا مؤديـا لحجز تنفيـذي يوجـه إلى المستأجر المـدين والذي يعتبر مالكـا لهذه المنقولات، ولهذا يجب استصدار الإذن بـالحجز ضـهما ويجب اختصامهما معـا في دعوي صحة الحجز، فإذا استصدر الإذن بالحجز ورفعت دعوي صحة الحجز ضد الغير وحده كنا بصدد حجز استحقاقي لا يصلح للتحول إلى حجز تنفيذي، ووجب للوصل إلى هذه الغاية توقيع حجز آخر علي المنقولات في مواجهة المستأجر، ثم تحويله إلى حجز

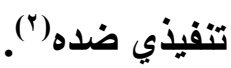




\section{ثانيا: تعريف الغير الحائز في العجز الاستحقاقي:}

خروجا علي القواعد العامة في تحديد المنفذ ضده، فبان التفيذ قد يجري ضد

شخص غير ملتزم شخصيا بالدين، كحائز (') المال، ويقصد بالحائز هو كل شخص انتقل إليه المنقول، دون أن يكون التصرف الذي انتقل إليه بمقتضاه نافذاً في مواجهة طالب الحجز، ويجب أن يكون للحاجز حق التتبع علي المنقول تحث أي با. وتطبيقا لذلك قضي بأن العقود المترددة بين البيع والإيجار يكون للبائع فيها حق توقيع الحجز الاستحقاقي، ما دام محتفظا بالملكية إلي أن يستوفي الثمن، والأمر عكس ذلك إذا لم يحتفظ بالملكية)(؟). وفي الواقع لممارسة الحجز في مواجهة الحائز يجب توافر الثروط الآتية: الشرط الأول: أن يكون للحاجز حق يقتضي التتبع علي المنقول: يشترط لتوقيع الحجز الاستحقاقي أن يكون للحائز حق علي المنقولات، وهذا الحق قد يكون عينيـا (أصليًا: ملكية أو انتفاعًا) أو تبعيًا (امتيـازا أو رهنـا أو حقَا في الحبس) علي المنقول ذاته، يخوله تتبع المنقول، لذا قضي ببطلان الحجز الاستحقاقي الأي وقعه بائع ماكينة حرث بالتقسيط إذا كان قد سلم بالمليكة للمشتري. ولصاحب الحق في الحجز الاستحقاقي أن يوقعه ضد أي شخص- حتي ولو لـم تكن للحاجز علاقة قانونية به كالغاصب الذي يحوز الثيع(").

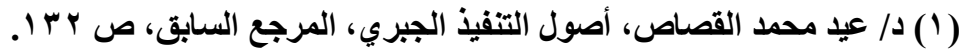

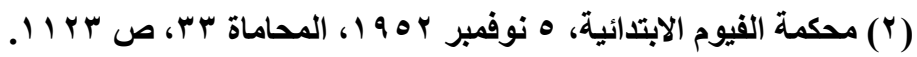

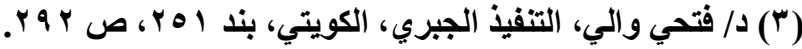




\section{الشرط الثاني: ألا يكون المنقول قد انتقل إلى حائز حسن النية.}

الواقع أنه قد يتمسك الغير الحائز بقاعدة الحيـازة في المنقول سند الملكيـة ممـا يحول دون القيـام بـالحجز الاستحقاقي متـي كـان حسن النيـة('). وبالتـالي يمتـع علي المالك تتبع المنقول بسبب ترتيب حق للغير يمكن أن يحتج به في مواجهته، فبإذا بيعت هذه المنقولات إلي مشتر حسن النية، فيمكن له التمسك بقاعدة الحيازة في المنقول سند الملكية. كما لو بيعت المنقولات لمثتري حسن النية في سوق عام أو في مزاد علني أو ممن يتجر في مثلها.

وينطبق هذا الشرط أيضا في حالة توقع الحجز من المؤجر- للعقار- باعتباره صاحب حق امتياز علي المنقولات والثمرات والمحصولات إذا كانت قد نقلت من العين المؤجرة، حيث إن الأصل هو امتياز المؤجر علي المنقولات ينقضي بنقلها إذا كان النقل قد تم برضاه أو بعلمه أو إذا بقيت في العين المؤجرة منقولات تكفي لضمان الوفاء بمـا يستحق للمؤجر. وفي غير هاتين الحالتين يبقي للمؤجر امتيـازه علي المنقولات رغم نقلها، ويجوز له أن يوقع عليها حجزا استحقاقيا خلال · ب يوما من تاريخ علمـه بنقلها من العين المؤجرة، وذلك بمقتضي ما له من حق التتبع (). كما يجوز للمؤجر في حالة سرقة المنقولات أو ضياعها الحق في استردادها مباشرة أو باسم مستأجر خلال ثـلاث سنوات من السرقة أو الضياع (م هـr مدني) (").

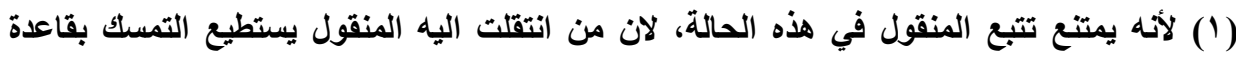

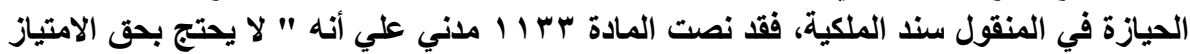

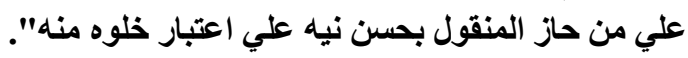

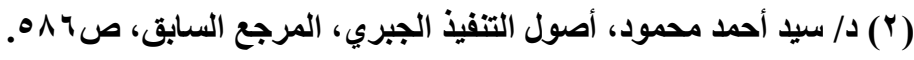

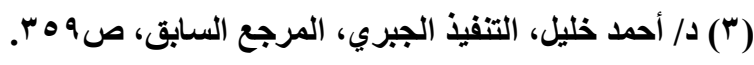




\section{الشرط الثالث: أن يكون بيد طالب العجز سند بمقه}

يجب أن يكون بيده سند تنفيذي ولو كان غير واجب النفاذ متي كان الدين الثابت به(') معين المقدار، فإذا لم يكن بيده سند تتفيذي، فلا يوقع الحجز إلا بإذن من القاضي المختص، ويمكن أن يحصل طالب الحجز علي إذن قاضي التنفيذ بنـاء علي عريضة مقدمة من الحاجز في حالة عدم وجود سند تتفيذي بيده أو كان دينه غير معين المقدار أو معه حكم قضائي غير نهائي غير معين المقدار، ويجوز أن يطلب الإذن بـالحجز من رئسيس الهيئة التـي تنظر دعوي الحق أو أمسام المحكمة المختصة، ويجب أن يشتمل العريضة علي بيان وافي للمنقولات المطلوب حجزها.

(1) التفيذ في مواجهة الغير يتطلب أن يكون بذات السند التفيذي الذي يوجه للمدين ( المنفذ ضده)

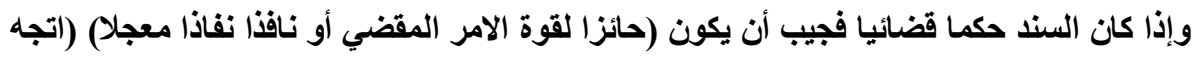

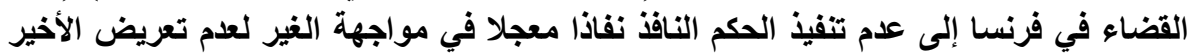

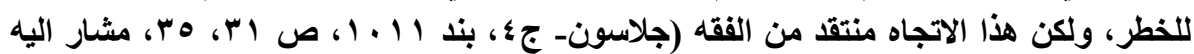

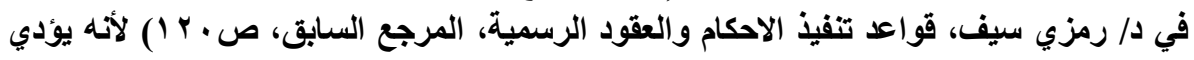

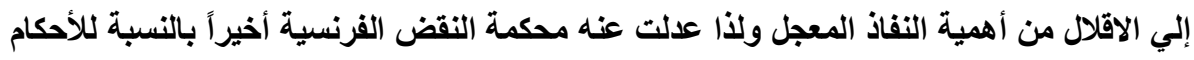

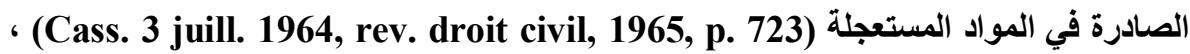

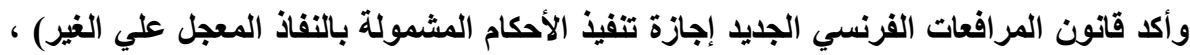

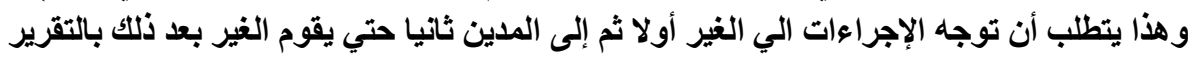

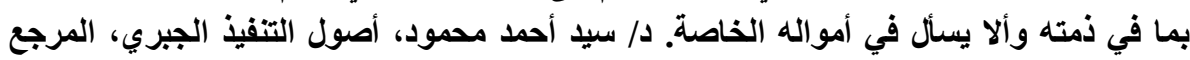

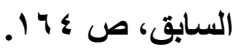




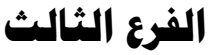

\section{الغير الحائز للعقار وهن له حق يتعارض همع الحجز العقار}

سنثير إلي الغير الحسائز للعقار، ثم نعالج من لله حق الاعتراض علي الحجز

علي العقار، وذلكك في النقاط الآتية:

أولا: الغير الحائز للعقار

سنثير إلي تعريف الغير الحائز للعقار، وشروطه وأساس الحجز في مواجهته،

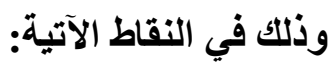

1 - ت تعريف الغير الحائز للعقار:

يجيز القانون للائن المرتهن التفقيذ علي العقار المرهون الذي انتقتت ملكيته

إلى الغير قبل تسجيل تتبيه نزع الملكية، حيث أن العقار قد انتقلت ملكيته إلى الحائز

محملة بحق الرهن المشهر، والأي يجيز لصاحبه تتبع العقار في أي يد تكون (').

يُقصد بحائز العقار هو شخص من الغير ليس مسئولا شخصيا عن الدين، ولكن

انتقلت إليه ملكية عقار محمل بحق عيني تبعي نافذ في مواجهة الغير. أي أن الحائز هو

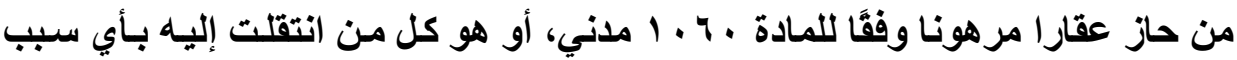

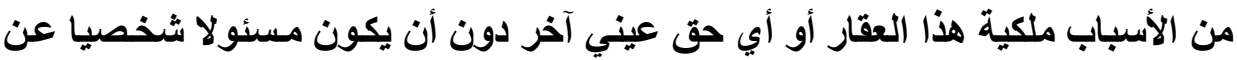

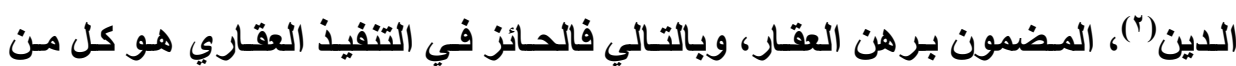

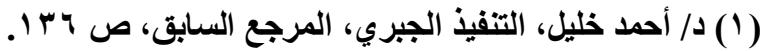

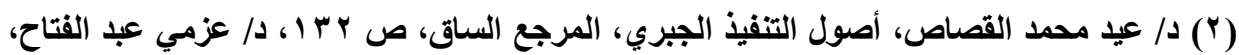

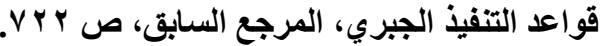

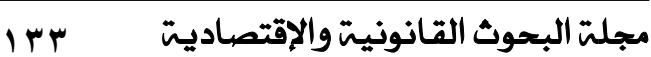


أكتسب حقا عينيا علي عقار مرهون بموجب سند سابق في تسجيله علي تسجيل تنبيه نزع الملكية دون أن يكون مسئولا عن الدين المضمون.

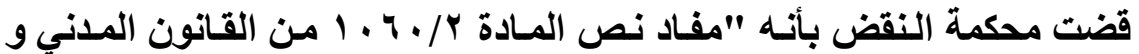

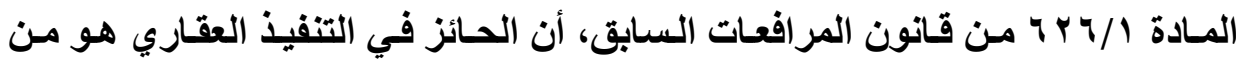
اكتسب ملكية عقار مرهون أو حقاً عينياً عليه يجوز رهنه، وذلكك بموجب سند مسجل سابق في تسجيله على تسجيل تنبيه نزع الملكية دون أن يكون مسئولا شخصيا عن الدين المضمون، وأن إنذار الحائز و ما يترتب على الإنذار وعدمه لا شأن لهـ وعلى ما

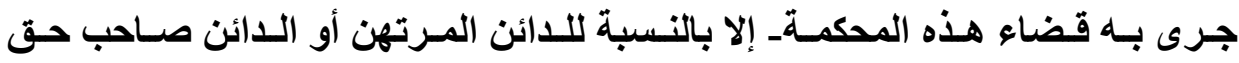
الاختصاص الأى حكمه حكم المرتهن، بما له من حق تتبع العقار في أي يـ يكون، أمسا الدائن العادي، فقكرة الحيازة الواجب إنذار صاحبها منتفيه بالنسبة لـه تمامسا، ذلكك أنـه متى كان المدين قد تصرف في العقار تصرفا شهر قبل تسجيل تنبيه نزع الملكية، فِان التصرف ينفذ في حق هذا الدائن العـادي، ولا يجوز لله وهو لا يملك حقا عينيا على العقار المذكور يحتج به على من تتنقل إليه الملكية، أن يتخذ إجراعات التنفيذ على ذلك العقار الأى خرج من ملكية مدينه"(') - (1) وقد ذهب جاتب من الفقه إلى القول بـأن حائز () العقار ، يدعي ملكيته لا يعتبر

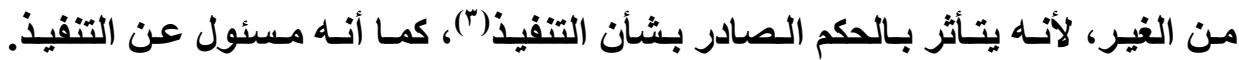

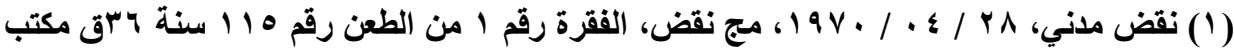

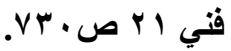

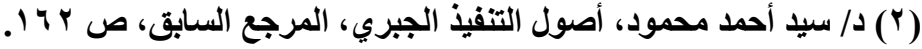

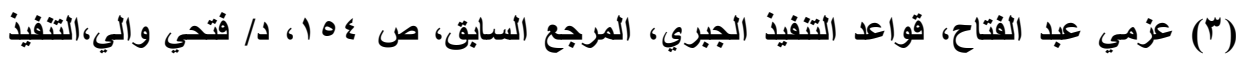

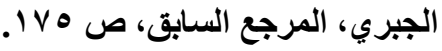


وبالتـالي إذا نقل المـدين الراهن ملكيـة العقـار المرهون إلى شـخص آخر كـان للـائن المرتهن أن ينفذ علي العقار في مواجهة من انتقلت إليهه ملكيةة(')، إذن توجهه إجراءات التنفيذ في هذه الحالة للغير، فتتوافر الصفة في مواجهة الحائز، فضلا عن توافرها في المنفذ عليه. في الواقع انتا لا نتفق مع هذا الرأي، حيث نري أن هؤلاء الأشخاص من الغير، لأنهم ليسوا طرفا في السند التنفيذي، وليس لهم مصلحة في التنفيذ علي أي مسال من أمسوال المدين، وحيث تتـأثر حقوقهم بشأن التنفيذ علـي مـال معين بالـات، ويرجـع ارتباطهم بالتنفيذ إلي كون المال يقع في حيازتهم، فهم من الغير بالنسبة للعلاقة بين طالب التنفيذ والمنفذ ضده.

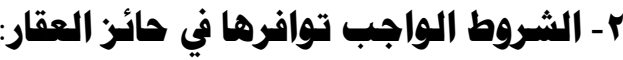

ينبغي أن يكون الغير قد تلقي حقا عينيا علي العقار المرهون يمكن بيعه بـالمزاد العلني، كحق الانتفاع أو الملكية، ويجب أن يكون قد قيد حقه قبل التسجيل بتنبيه نزع الملكية، ويجب أن يكون الغير قد شهر حقه بعد قيد الرهن، فإذا لم يكن قد شـهر حقهـ أصلا فلا يكون حائزا، فالمشتري بعقد غير مسجل لا يكون حائزا، وهذا الحائز غير مسئولا شخصيا عن الدين فهو أجنبي عنه لا تربطه بالدائن أيسة علاقة شخصية، ولكن المسئول عن الدين هو قيمة العقار المرهون، بالتالي لاتمتد المسئولية إلى سائر أموال الحائز وتنقضي باستنفاذ قيمة هذا العقار (†).

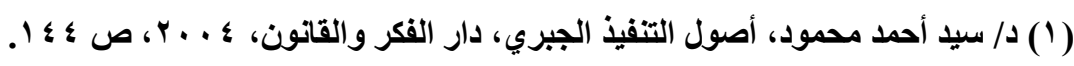

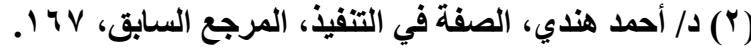




$$
\text { فزذه الشروط تتمثل في الآتي: }
$$

السشرط الأول: أن يكون للـائن حق عيني تبعي علـي عقـار مملـوك لمدينها كالرهن أو الامتياز أو الاختصاص.

السشرط الثـاني: أن يكون حق الدائن صساحب الحق العينـي مشهورا، بحيث يكون ناقذا في حق الغير.

الشرط الثالث: أن يتصرف المدين الراهن في العقار تصرفا من شأنه إمـا نقل

ملكية العقار أو ترتيب حق عيني عليه لصالح الغير من الحقوق التي يجوز حجزهـا وبيعها علـي استقلال، كحق الانتفـاع('). ولذلك لا يعتبر حائزا من تتوافر فيهه شروط الحيـازة القانونيـة أو الماديـة علـي العقار. ولا يعد الدائن المرتهن رهنـا حيازيـا حـائزا للعقار، ولا يعتبر حائزا وارثا المدين، لأن الوارث لا يمتلك التركة إلا بعد سداد الديون. الشرط الرابع: يجب انتقال الملكية للحائز قبل تسجيل تنبيه نزع الملكيـة، ولو بعد إعلانهـ إلي المدين المحجوز عليه، ويرجع ذلك إلـي أن التسجيل حق للحائز بعد تسجيل تنبيه نزع الملكية، يترتب عليه عدم نفاذ حق الغير في مواجهة الدائن الحاجز، ويكون له أن يتابع إجراءات الحجز علي العقار ضد المدين، فلا يلتزم بتوجيه أي إجراء للحائز.

يثار التساؤل عن اشترط انتقال الملكية للغير بطريق العقد حتي يمكن التنفيذ في مواجهته.

(1) ولا يعتبر من الغير من انتقل اليه حق ارتفاق أو حق عيني تبعي. لان هذه الحقوق لا يجوز حجزها وبيعها علي استقلال. 
الواقع أن الفقـه اختلفت كلمـة في حالـة انتقـال الملكيـة للغير لسبب غير العقد المسجل، وقد أثثر التساؤل علي وجه التحديد بثأن انتقال الملكية إلى غير المدين عن طريق التقادم، فذهب رأي إلى أنها لا يعتبر حائزا من تملكك العقار بالتقادم، لأن هذه المليكة لم تثتقل اليه بتصرف من المالك(')، وبينمـا ذهب رأي آخر إلى أن نص المـادة

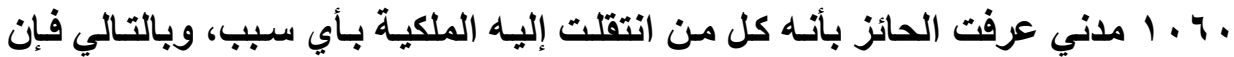
الوصف المتقدم يصدق علـي انتقـال الملكيـة إليـه عن طريت التقــادم، فهذا النص لـم يشترط انتقال الملكية بتصرف من المالك(؟).

الشرط الخاهس : يجب ألا يكون من انتقلت اليهه ملكيـة العقار أو الحق العينـي مسئولا شخصيا عن الدين المضمون بـالرهن، كمـا لو كان مدينا متضامنا مـع المدين

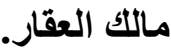

\section{r- أساس الصجز في هواجهة الحائز:}

يرجع أساس التنفيذ في مواجهة الحائز، إلي أن للائن المرتهن حق التتبع الذي

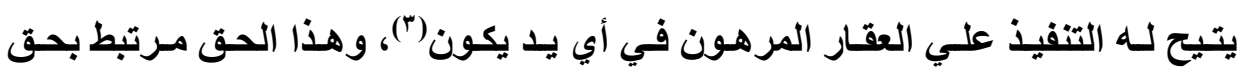
الراهن، خاصة في حالة التصرف في العقار المرهون، ولا يتصور قيام الحقين بدون الآخر وإلا انتقصنا من حق الراهن في الملكية أو من حق المرتهن في الرهن، فللراهن أن يتصرف في ماله وللمرتهن أن يحصل علي حقه من ثمن هذا المـال (مَ • 1 مدني)،

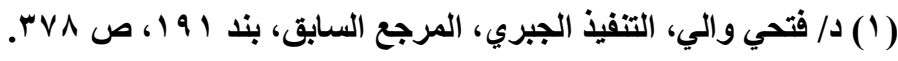

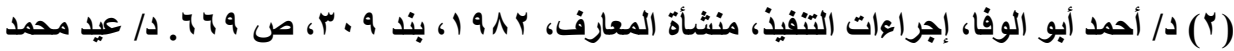

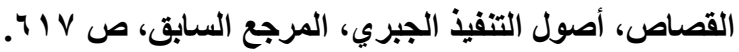


فحق التتبع مظهر من مظاهر نفاذ الرهن في مواجهة الغير، ومترتب علي كون الرهن

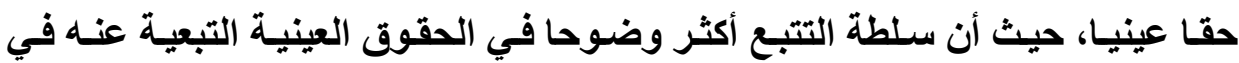
الحقوق العينية الأصلية، ولعل السبب في ذلك أن صاحب الحق العيني التبعي لا يحتفظ

بسلطة التصرف في الثيء محل الحق، وهو ما لا يوجد في الحقوق العينية الأصلية. وإذا كان التتبع من أهم مظاهر الرهن إلا أنه لا يعبر عن جوهره، فجوهر الرهن هو الحق في الأفضلية و التقدم، إذ حق الرهن قد يباثشر دون حاجة إلى تتبع العقار

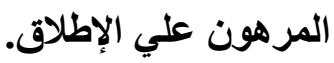

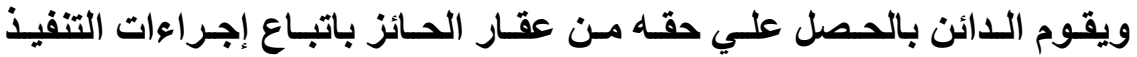
الجبري، علي أنه لا يحتاج إلى استصدار حكم من القضاء للتنفيذ علي الحائز لأن عقد الرهن الرسمي هو نفس الوقت سند تنفيذي- بصفته محررا موثقاـ يمكن بمقتضاه

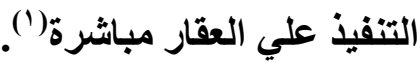

ولأن الحائز قد انتقلت إليه الملكية من المدين تجبـ حماية للغير الذي قد يتعامل

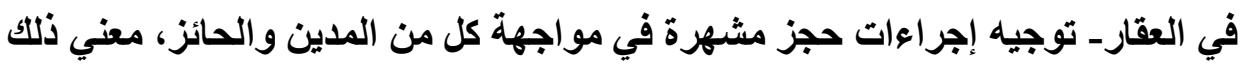

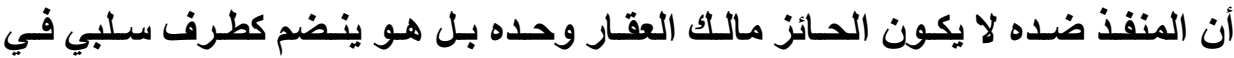

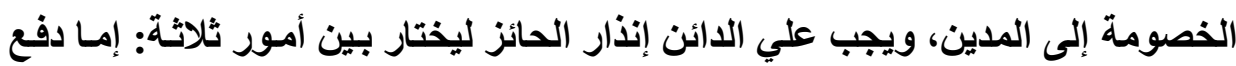

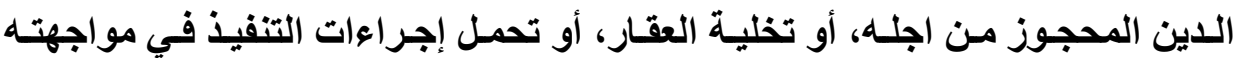

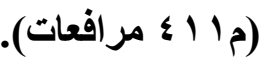

(1) تبدأ إجراءات التنفيذ علي عقار الحائز، بإعلان تتبيه نزع الملكية إلي المدين وتسجيل هذا التتبيه،

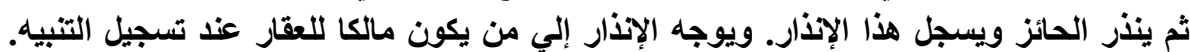

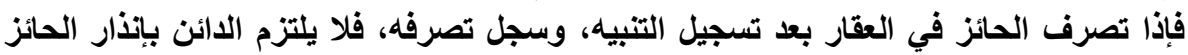
الجديد للعقار. ولا يكون هذا التصرف نافنا في مواجهته 
وللحائز أن يختار تطهير العقار وذلك بعد اتخـاذ مقدمات التنفيذ في مواجهة المدين المنفذ ضده. وتطهير العقـار المرهون لا يفرض علـي الحسائز، ولكنـه هو الذي يعرضه، فالتطهير يعني أن يعرض الحائز علي الدائنين المرتهنين أن يدفع لهم مبلغا مساويا للقيمة الحقيقة للعقار المرهون فهو لا ينتظر حتي تحل آجال الديون فيعرض وفاءهـا، أو يطلب الـائنون استتفاءها، ولكنـه يستطيع بمجرد اكتسابه صفة الحسائز، وقبل أن تحل آجال الديون، أن يعرض تطهير العقار من كل حق مقيد عليه، فـالتطهير سلطة تتميز بعنصر المبادأة من جانب الحائز، فهو وحده الذي يحدد وقت التطهير، ويحدد شروطه التي يدعو الادئنون إلى قبولها' ')

وطالما أن الدائنين لن يحصلوا من العقار علي أكثر من قيمته الحقيقية عند بيعه بـالمزاد العلنـي، فمـن مـصلحتهم قبـول عرض الحسائز وتـوفير الإجـراعات والنفقـات. والعرض الذي يقوم به الحائز ليس هو وفاء ديون الدائنين ولكنه القيمة الحقيقية للعقار ولو لم تكن هذه كاملة لوفاء جميع الديون. ويمكن للاائنين المرتهنين الاعتراض علي عرض الحائز وشروطه للتطهير، لذلك ينبغي أن يكون الحائز معقولا في عرضه. علي أن الحائز يرجع بحقه علي المدين- بما دفعه زيادة علي ما يلتزم به أصلا- إما بالدعوي الثخصية وهي دعوي الإثراء بـلا سبب أو دعوي الضمان، المقررة في المـادة ب ؛ ؛ مـدني، إذا كـان قـــ اكتسب ملكيـة العقـار بطريـق الشراء. وإمـا بـدعوي الحـول محل

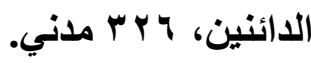




\section{ثانيا: صفة الغير المعترض علي إجراءات العجز علي العقار:}

لقد نصت المادة ب ؟ مر مرافعات علي الأثخاص الأين يجوز لهم الاعتراض علي

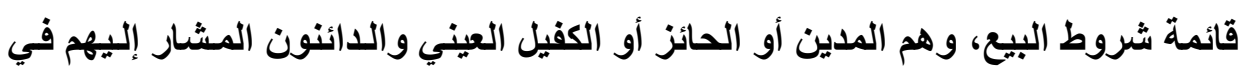
المادة V ا أ ، وهم الدائنون أصحاب الحقوق المقيدة قبل تسجيل التنبيه والائنون الذين

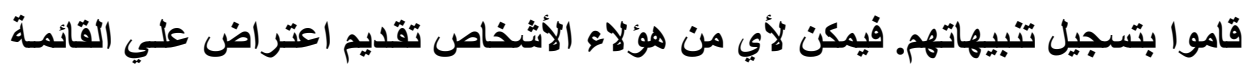

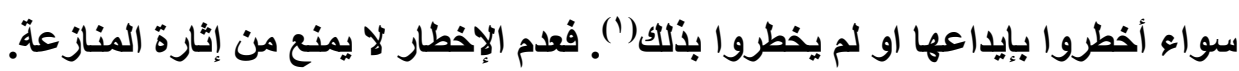
وقد نصت الفقرة الثانية من ذات المادة علي أنه يمكن لكل ذي مصلحة من غير

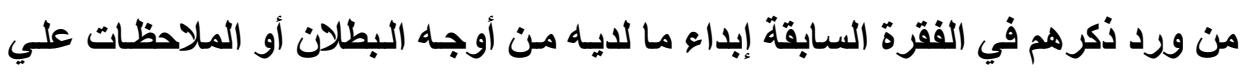
القائمة بطريق الاعتراض عليها أو بطريق التدخل في نظر الاعتراض، من ذلكت من النه يكون دائنا عاديا للمدين او أو من يكون له حق ارتفاق أو حق انتفاع علي العقار او من

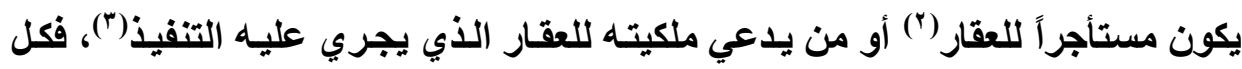
هؤلاء يعتبرون من الغير بالنسبة لإجراءات الحجز علي العقار، يمكن لهم الاعتراض علي قائمة شروط البيع، أو طلب بطلان حكم الراسي المزاد. فنلاحظ أن المشرع لم يطلق العنان للائن مباشر الإجراءات في تحديد شروط

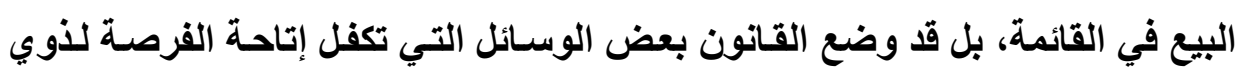

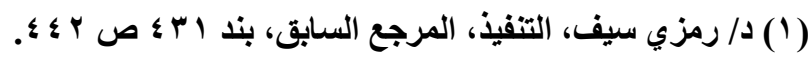

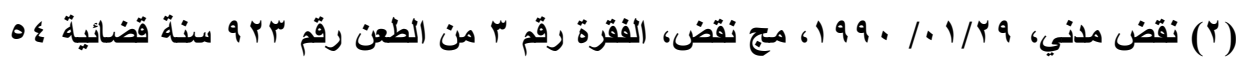

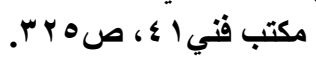

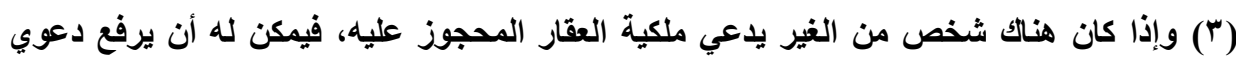

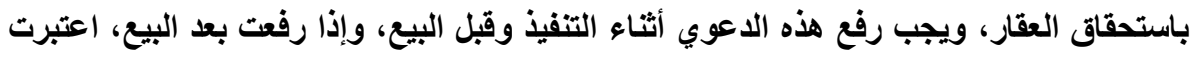


الثأن كي يباثُروا رقابة لاحقة علي مـا قام بـه الدائن من إجراءات، فهيأ لهم السبل

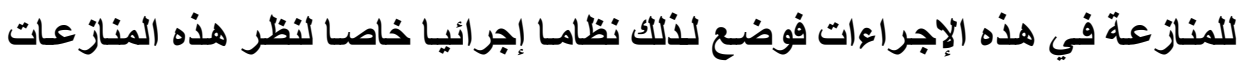
بقصد حماية أطراف خصومة التنفيذ ومن تتعلق مصالحهم بهذه الخصومة، وإذا تم الفصل في هذه الاعتراضات بأحكام نهائية أصبح العقار معدا للبيع وتبدأ مرحلة أخري

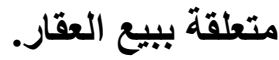
وقد يحدث أن يعتبر الثخص طرفا في التنفيذ وغيرا بصفة أخري، وعندئذ يكون له بصفته الثانية أن يعترض بكل من الصفتين علي قائمسة شروط البيع، كمـا لو كان الثخص وارثا للمدين الذي يجري التتفيذ علي تركته، حيث يعد بهذه الصفة طرفا في

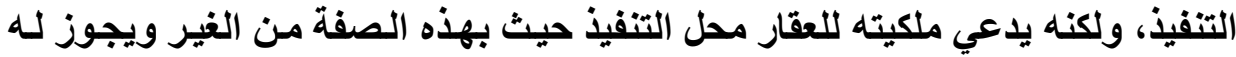
بمقتضاها رفع دعوي الاستحقاق الفرعية'(')

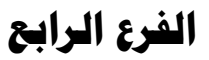 \\ الغير الفاقد تمثيله في السند التنفيذي}

في الواقع الممثل الإجرائي للخصم يعتبر من الغير بالنسبة للخصومة التي يباشر إجراءاتها، ولا يكون للحكم الصادر فيها حجية الثيء المحكوم فيه في مواجهته شخصيا،

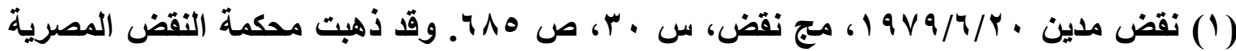

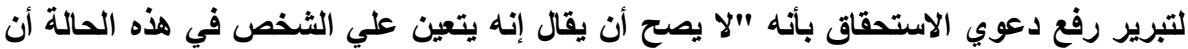

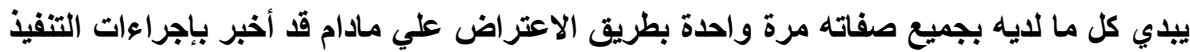
بإحدي هذه الصفات، إذ في ذلك مصادرة لحقه في اتخاذ الوسيلة القانونية المناسبة في الوقت الوقت المناسب ووفقا لكل صفة من صفاته". 
وذلك لأن صاحب الصفة هو الأصيل(') وليس ممثله الإجرائسي(')، فهذا الأخير مجرد وسبط ياشر الإجراءات باسم الأصيل ولمصلحته.

يلاحـظ أن التمثيـل الإجرائسي أو النيابـة فـي التقاضـي قـ أثـــــــــلا كبيـرا

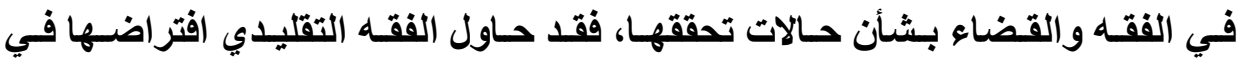
بعض الحالات لتبرير امتداد آثثار الأحكام إلى الغير بمـا يتفق مـع المبدأ التقليدي الذي يقرر نسبية أثر الأحكام، أي اقتصار هذه الآثار علي الخصوم فقط دون أن تمتد إلى

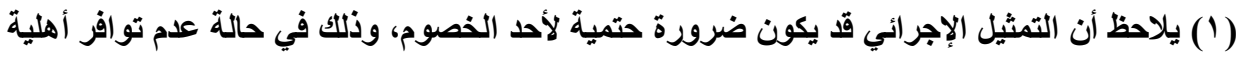

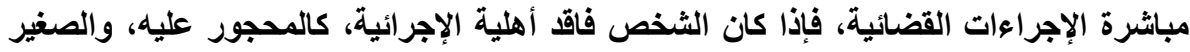

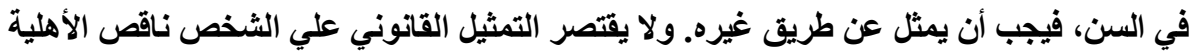

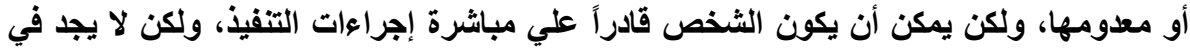

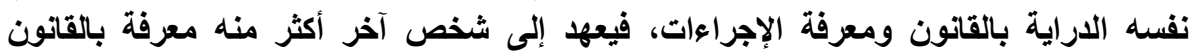

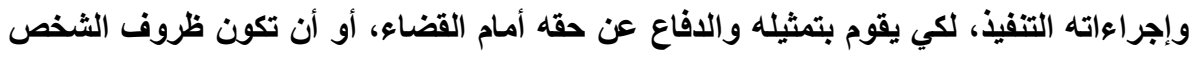

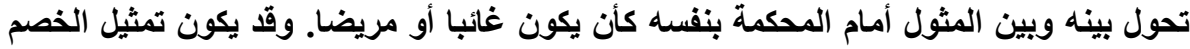

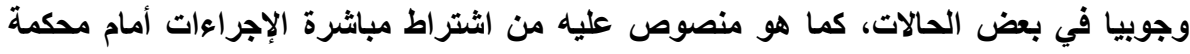

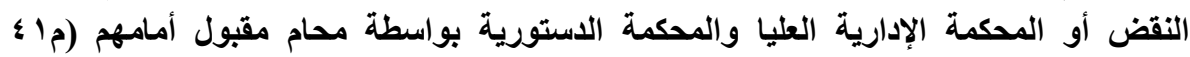

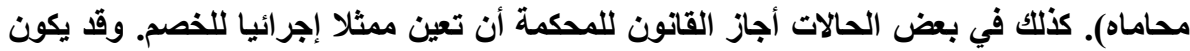

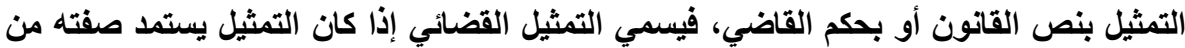

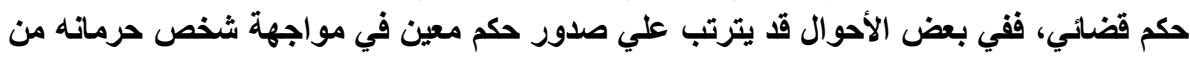

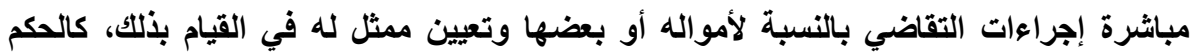
بالإقلاس الذي يترتب عليه قيام السنديك بتمثيل المفلس وجماعة الدائنين بالنسبة لأموال التفليسة.

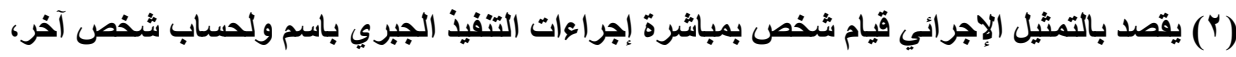

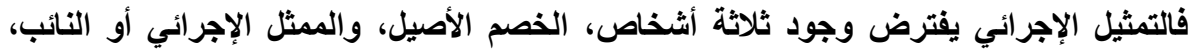

والخصم الأخر في إجراءات التنفيذ. (") د/ احمد صاوي، الغير..، 
وتوجد بعض الحالات التي تنقطع فيها علاقة التمثيل بين الأصيل ومن يمثله، ويصير نتيجة لذلك الأصيل من الغير بالنسبة للآثار المترتبة علي الإجراعات التي قام بها الممثل. ويتمثل ذلك في حالـة غش الممثل أو تواطئه أو تجاوزه حدود التمثيل، أو تعارض مصلحته مع مصلحة الأصيل.

\section{- حالات انقطاع علاقة التمثيل الإجرائي تتمثل في الآتي:}

\section{الحالة الأول: غش الممثل أو تواطؤه:}

تنقطع علاقة التمثيل بين الأصيل ومن يقوم بتمثيله إذا غش الممثل أو تواطأ مع الخصم الآخر علي الإضرار بحقوق موكله، حيث إن من غشك لا يمثلك، ولذلك يصير من الغير لمن قام بتمثيله ولا يحتج في مواجهته بالأحكام الصادرة في مواجهة ممثلـه نتيجة ارتكابه الغش أو التواطؤ من جاتب هذا الممثل (').

فقد نصت المادة إ؛ مرافعات علـي أنـه يعتبر من الغير الشخص الطبيعي أو

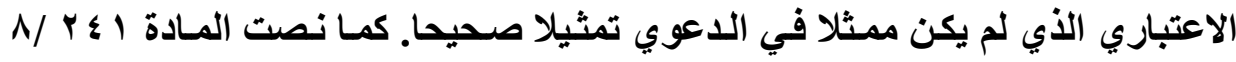
علي اعتبار من الغير "لمن يعتبر الحكم الصادر في الدعوي حجة عليه لم يكن قد أدخل أو تلخل فيها بشرط إثبات غش من كان يمثله أو تواطئه أو إهمالـه الجسيم". وهؤلاء الأثـخاص يفقدوا تمثيلهم في الخصومة نتيجة غش أو تواطؤ أو إهــال جسيم مـن ممثلهم. ويجب إثبات غش أو تواطؤ الممثل، وتقدير ذلك لا يخضع للسلطة التقديريـة لرقابة محكمة النقض(')

(1) R. Perrot, cours de droit judiciaire prive, fasc. 2, paris, p. 733.

(2) Cass. Civ., 28 October 1969, Bull. Civ., 1986, I, no 317. 
وتطبيقا لذلك ذهبت محكمة النقض الفرنسية إلى أن الأصيل يعتبر من الغير إذا

تعرض للغش من جاتب الممثل له (').

وهذا الثرط هو الذي يبرر إدراج هذه الحالة في حالات التمساس إعادة النظر

من الغير، وليس من الخصوم، فعدم التمثيل الصحيح يترتب عليه أن يصير الطرف

الأصلي من الغير بالنسبة للحكم الذي صدر في مواجهة الممثل. ويفترض هذه الحالة أن يكون الشخص ممثلا في الخصومة بنص القانون كالقاصر أو المريض مرضا عقليا، أو بحكم قضائي، كالمحجوز عليه و المفلس، ولكن تمثيله لـم يتم بصورة صحيحة طبقا للقانون.

ويكون التمثيل غير صحيح قانونا إذا قام به شخص آخر غير صاحب الصفة في

مباشرة إجراعات الخصومة باسم الأصيل، كما لو صدر الحكم في مواجهة شخص آخر غير الولي أو الوصي صاحب السلطة في تمثيل القاصر أو السنديك الذي يمثل المفلس او الشخص الذي حدده القانون لتمثيل الثخص الاعتباري.

المالة الثانية: تجاوز حدود صفته الإجرائية:

عقد الوكالة يحدد الإجراءات القضائية نيابـة عن الخصم الأصيل، فبإذا تجـاوز الممثل هذا النطاق فإنه يفقد نيابة عن الخصم الأصيل بالنسبة لهذه الإجراعات الزائدة، ويعتبر الأصيل من الغير بالنسبة للأحكام التي تصدر نتيجة ذلك التجـاوز(٪)، ويمكن

(1) Cass. Civ. 17 novembre 1971, Bull. Civ. 1971, 2, no 316.

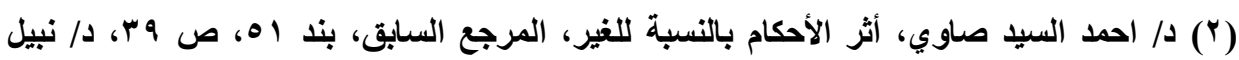

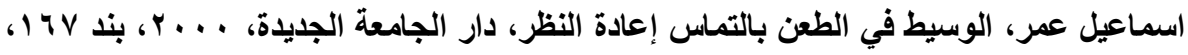


للأصيل أن يجيز الأعمال التي تجاوز فيها الوكيل، ويجب أن تكون الإجـازة قبل صدور

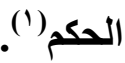

إذن الحكم الصادر في مواجهة الوكيل لا يحوز الحجية في مواجهة الأصيل إذا كان الوكيل قد تجاوز حدود سلطاته المخولة له قانون أو اتفاقا، وتطبيقا لذلك لا يجوز للقيم الاتفاق علي أن التقاضي أمسام المحكمة الجزئية بعينها وتفضل فيهل نهائيا، ففي هذه الحالة يكون متجاوزا حدود سلطاته بتتازله عن حق محجوز عليه في نظر النزاع

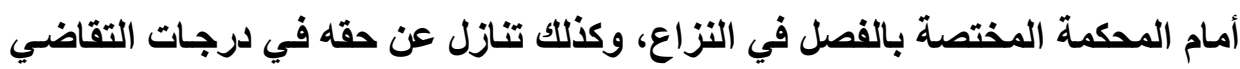
المنصوص عليه في القانون(")

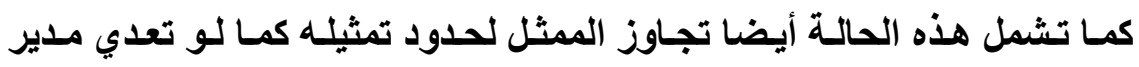

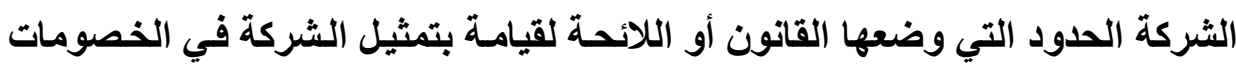

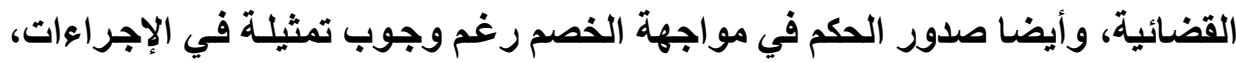

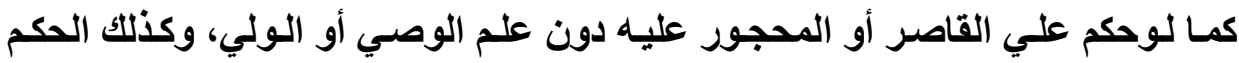
علي الورثة دون قيام مصفي التركة بتمثليهم(").

\section{الحالة الثالثة: تعارض هصلحة الفصم هع هصلحة همثلة:}

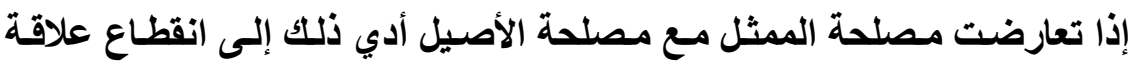
التمثيل، فالشخص لا يمكن أن يمثل مصالح متعارضـة، لأن القول باستمرار التمثيل

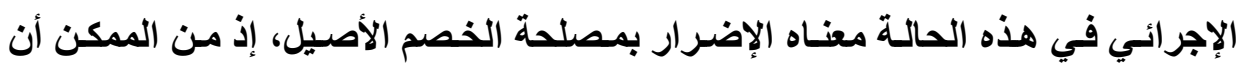
يضحي بمصلحة من يمثله في سبيل تحقيق مصلحتّه

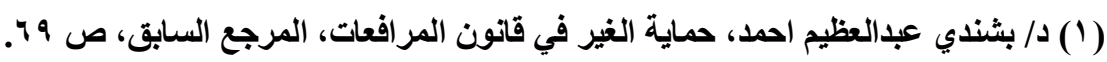

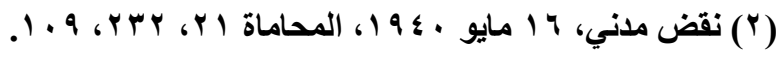

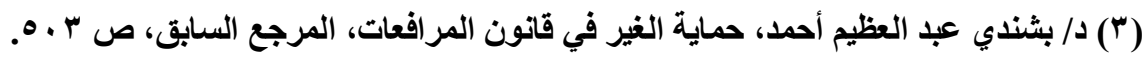


وقد نـصت المسادة بr مـن قـانون الولايـة علـي المسال يجوز للمحكمة أن تعبين وصيا للخصم القاصر إذا تبين أن مصلحته في الخصومة تتعسارض مـع مصلحة مـن

ويرجـع ذلـك إلى أن الوكيل يعمـل باسـم موكلـه ولمـصلحته، فإنـه إذا تعارضـت

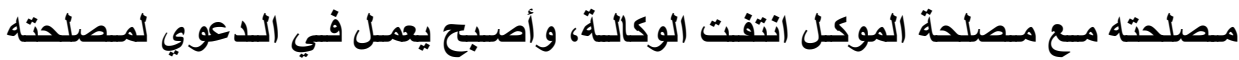
وحسابه هو، ومن ثم تقتصر حجية الحكم عليه وحده دون الموكل(').

\section{الفرع الخاهس}

\section{الاشتراط الصلحة الغير}

لقد أجـاز القانون المدني في العقود الاشـتراط لمصلحة الغير، وبالتـالي يكون للعقد آثار بالنسبة للغير، فقد يحدث في عقد من العقودــ مثل عقد التأمين أو الهبـه أو البيع أو المقاولةـ أن يرتب المتعاقدين حقا لأجنبي عن العقد، وذلك بنص خـاص فيه، وهو ما يسمي بالاشتراط لمصلحة الغير، وهذا الاشتراط يرتب حقا للمنتفع، حق ينشأ مباشرة من عقد الاشتراط دون أن يمر بذمة المشترط، فيصبح المنتفع دائنا به للمتعهد، وهو الذي يطالب بهذا الحق.

فإذا صدر الحكم لمصلحة المنتفع، وفي حالة الاشتر اط لمصلحة الغير، فإن له أن يطالب بتنفيذه، كما تثبت الصفة في تنفيذ حكم المحكمة، كذلك للمشترط، إذا اتضح ذلك من العقد المبرم بينه وبين المتعهد، ويلاحظ أن صفة طالب التفيذ لا تقتصر علي من صدر لصالحة الحكم، وإنما تثبت لكل شخص خوله الأطر اف ذلك(؟).

( (1) د/ أحمد السيد صاوي، أثر الأحكام بالنسبة للغير، دار النهضة العربية، المرجع السابق، ص •؛.

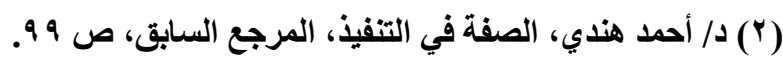


من المتصور أن يتفق المتنـازعون في خصومة التحكيم علي أن حكم التحكيم يكون حجة لهم أو لغيرهم، بحيث أنه يمكن لكل هؤلاء الأشخاص طلب تنفيذ هذا الحكم، إذا صدر لصالحهم. وذلكك يرجع إلى أن التحكيم عمل اتفـاقي في مصدره- إذ يستمد المحكم سـلطاته مـن إرادة الأطراف، وعمل قضائي في آثـارهـ إذ يقوم المحكم بـذات الوظيفـة المنـوط بالقاضـي القيـام بهـا، وهـي الفصل في المنازعـات المعروضـة عليه. بإصدار حمم فيها. وهذه الطبيعة المزدوجة للتحكيم تنعكس علي الصفة في طلب تنفيذ حكم المحكم، فطالمـا أن مصدر التحكيم إرادة الأطراف، فإنـه يكون لهؤلاء الأطراف الاتفاق علي المدي الثخصي للمستفيدين من حكم التحكيم. ويلاحظ أن صفة طلب التفيذ في بعض العقود لا تثبت فقط لأطر اف العقد، وإنما تثبت لشخص من الغير، فيمكن لهذا الشخص من الغير أن يلجـأ إلى التحكيم إذا ورد شرط التحكيم بهذا العقد. والواقع أنه يحق لمن صدر حكم التحكيم لصالحه أن يطلب تنفيذ حكم التحكيم بعد انقضاء ميعاد ستين يوما المقررة لإقامة دعوي البطلان، ولا يوجد مـا يمنـع من إعمـال المادة 11 1 من قانون المرافعات- بصدد تسليم الصورة التنفيذية للأحكام القضائيةـ بحيث تسلم الصورة ط للخصم الذي تعود عليه منفعة من التنفيذ"، فقانون التحكيم لا يمنع من العمل بأحكام قانون المرافعات فيما لم يرد به نص فيه. ويناء علي ذلك فإن الصفة في طلب تنفيذ حكم المحكم تكون لمن صدر الحكم لصالحه، وكذلك لكل شخص تعود عليه منفعة من تنفيذ هذا الحكم، أيضا يمكن ذلك لأي شخص يخوله الاتفاق علي التحكيم، أو العقد المدرج فيه شرط التحكيم' ('. (1) د/ أحمد هندي، الصفة في التنفيذ، المرجع السابق، ص V • 1. 
كما يجوز للخلف العام أو الخـاص لمن اشترط لصالحه أن يطالب بتنفيذ الحكم الصادر لمصلحة سلفه، إذ أن آثار الاتفـق علي التحكيم، لا تنصرف فقط إلى طرفية وإنما تمتد كذلك إلى خلفهم العام والخاص. وأيضا يمكن لدائن المشترط لصالحه طلب التفيذ. فأي من هؤلاء تعود عليهم منفعة أو فائدة من جراء التنفيذ، وبالتالي تثبت لهم الصفة في التنفيذ.

\section{الإطلب الثاني \\ الغير المشارك في إجراءات التنفيذ الببري بمكم وظيفته}

هناك من الغير ما يقوم بالمشاركة في إجراءات التنفيذ الجبري دون أن يكون له أي مصلحة أو صلـه بالـائن أو المدين، ولكن يقوم بالعمل المتعلق بالتنفيذ الجبري بمقتضي وظيفته كقاضي التنفيذ أو معاون التنفيذ(') أو بموجب قرار من قاضسي التنفيذ مثل الحارس علي أموال المدين المحجوز عليه("). سنشير إلي صفة الغير لرجال السلطة القضائية، وصفة الغير لمعاوني قاضسي التنفيذ، وصفة الحارس في التنفيذ.

(1) S. GUINCHARD et T. MOUSSA, droit et pratique des voies d'exécution, op. cit., no 161.

قد أستحدث المشرع المصري في تعديل قانون المرافعات نظام معاون التنفيذ ليحل محل قلم المحضرين

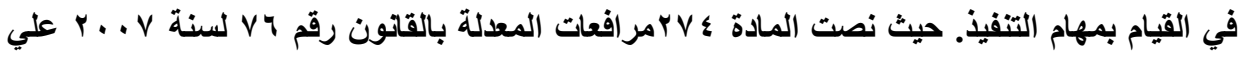
أنه يلحق بالإدارة التنفيذية عدد كاف من معاوني التتفيذ والموظقين يحدد بقرار من وزير العدل قواعد

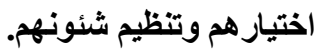

(2) S. GUINCHARD et T. MOUSSA, droit et pratique des voies d'exécution, op. cit., $\mathrm{n}^{\circ}$ 161-24.

د/ عزمي عبد الفتاح، قواعد التنفيذ الجبري، المرجع السابق، ص 100. 


\section{الفرع الأول \\ صفة الغير لقاضي التنفيذ}

تنص المادة §V من قانون المرافعات علي أنه "يجري التنفيذ تحت إثراف إدارة

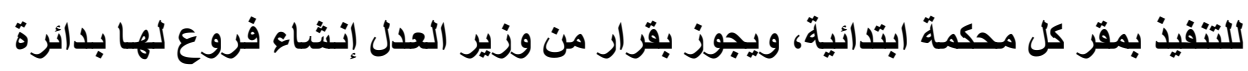
محكمة جزئية. ويرأس إدارة التنفيذ قاضي بمحكمة الاستنناف، ويعاونه عدد كاف من

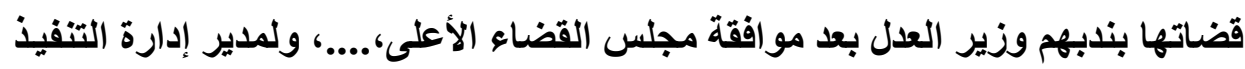
أو من يعاونه من قضاتها إصدار القرارات والأوامر المتعلقة بالتنفيذ".

يري جاتب من الفقهـ أن صفة الغير لا تنطبق علي الأثثخاص الذي يمثلون

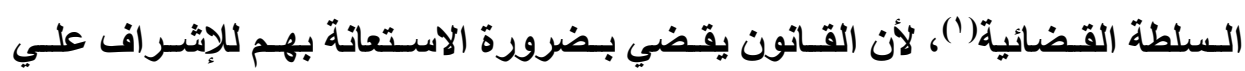

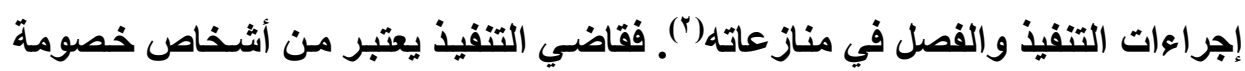

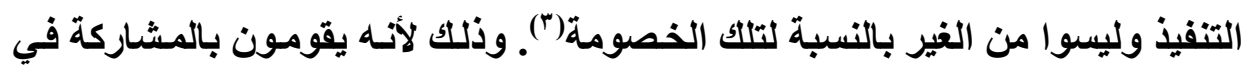
إجراءات التنفيذ بناء علي وظيفته، حيث إن الغير هو من ليس طرفا إيجابيا أو سلبيا

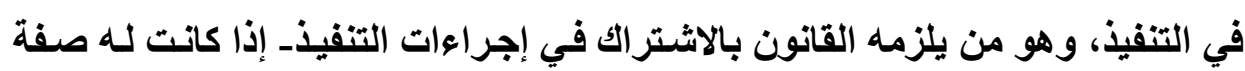

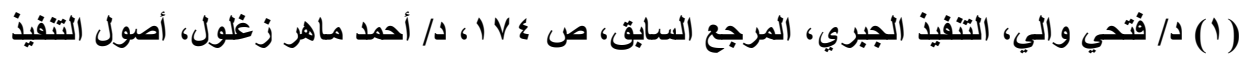

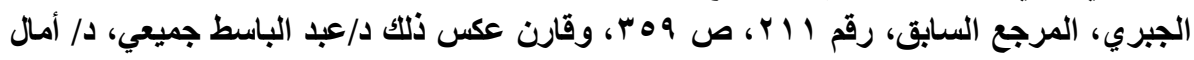

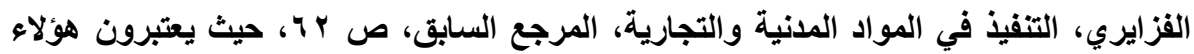

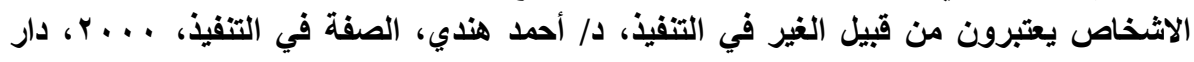

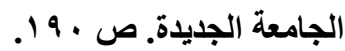

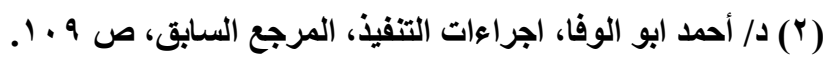

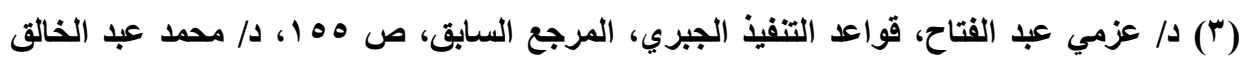

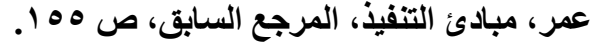


بالنسبة للمال محل التنفيذ- دون أن يكون طرفا فيه أو ممثلا للاولة، كما أنه ليس طرفا في الحق مضمون السند أو مسئولا عنه أو مستفيدا منه (').

و الواقع أنتا لا نتفق مع هذا الرأي، فأعضاء السلطة القضائية المشاركين في

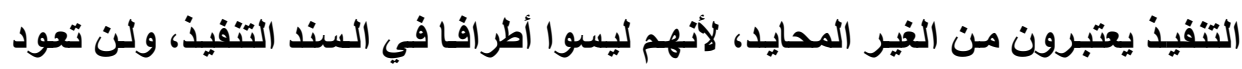

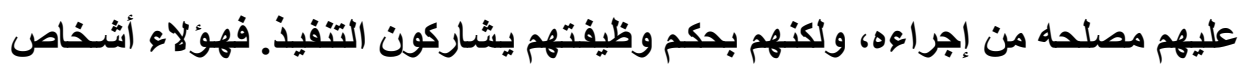

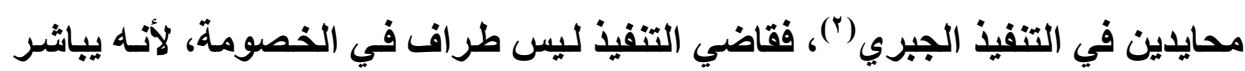
الإجراءات القضائية بسبب وظيفته وليس للحصول علي الحماية لحق من حقوقهم (")،

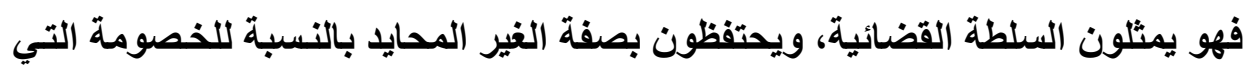
يشارك في إجراءاتها.

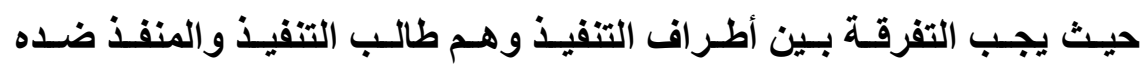
وخلفها، وبين أثخاص التنفيذ، حيث أن أثخاص التنفيذ يتضمنون كل من يثارك في

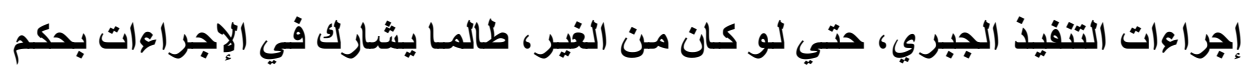

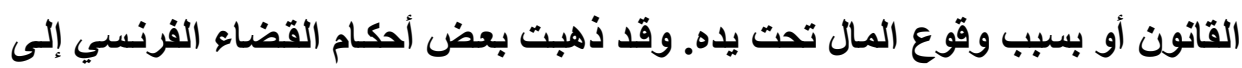

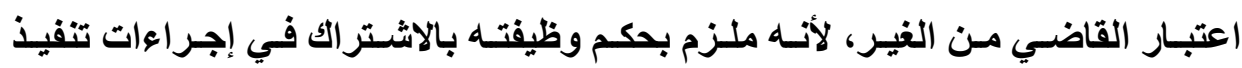




\section{الفرع الثاني \\ صفة الغير لمعاوني قاضي التنفيذ}

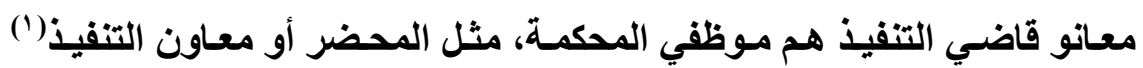
وكاتب المحكمة المختص بحفظ الودائسع، وقد يكون أمين الشهر العقـاري الذي يقوم بمحو القيود أو شطب التسجيلات بناء علي حكم قضائي. اختلف الفقه في مصر حول طبيعة عمل محضر ومعاوني التنفيذ(؟)، حيث ذهب البعض إلي اعتبـاره موظفـا عامـا خاضعا للسلطة التنفيذية، بينما ذهب البعض الآخر إلي اعتباره وكيلاً عن طالب التفيذ، وذهب رأي إلي كونه فرعا من السلطة القضائية

يـري جانب مـن الفقـه أن صفة الغير لا تنطبق علـي الأثـخاص الذي يمثلـون

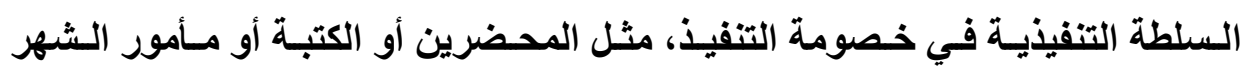
العقاري الأي يقوم بمحو القبد أو شطب التسجيل بناء علي حكم قضائي (r)، لأن القانون

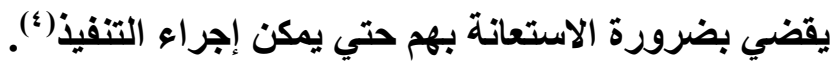

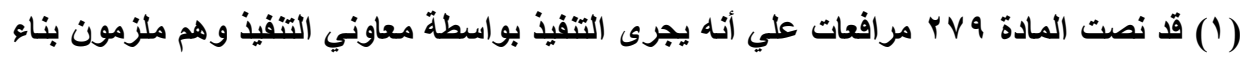

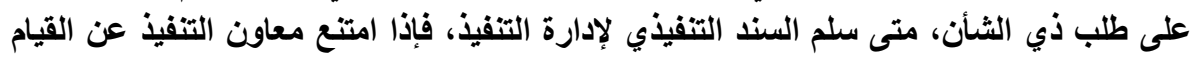

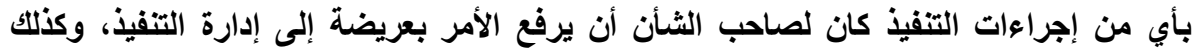

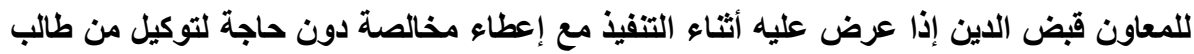

(Y)

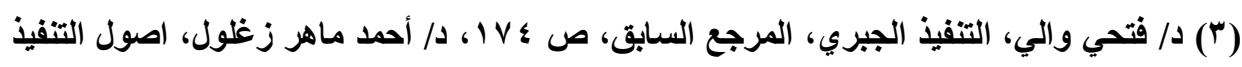

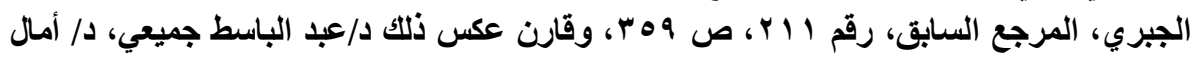

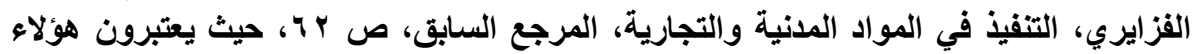

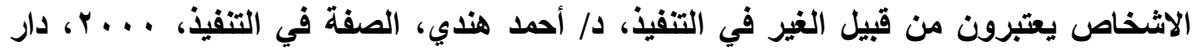

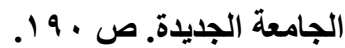

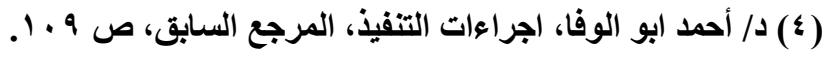


فهؤلاء يعتبرون من أشخاص خصومة التنفيذ وليسوا من الغير بالنسبة لتلكت الخصومة'(') وذلك لأنهم يقومون بالمشاركة في إجراءات التنفيذ بناء علي وظيفتهـا،

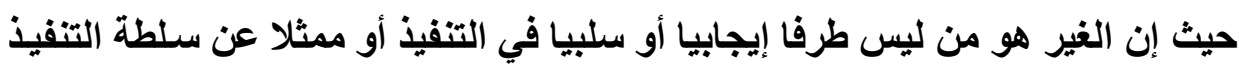

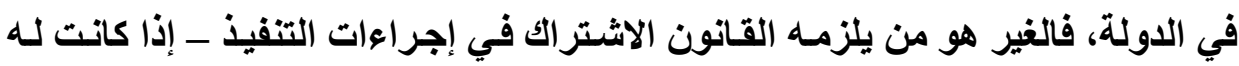

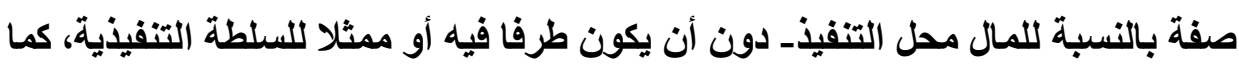

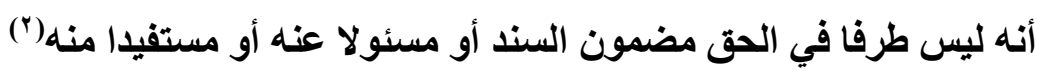
رأي جاتب من الفقه إلي القول بـأن المعاون يعتبر وكيلا عن طالب التنفيذ(")،

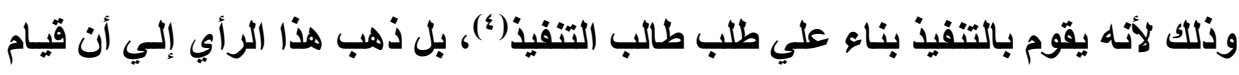

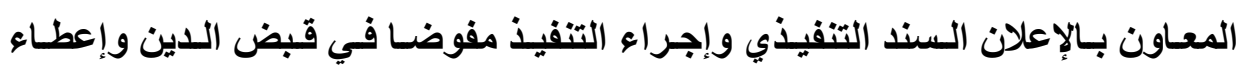
مخالصة مما يستثف منـه أن المقصود من التفويض منح المعاون صفة الوكالـة عن

(1) د/ عزمي عبد الفتاح، قواعد التنفيذ الجبري، المرجع السابق، ص 100، 10، د/ محمد عبد الخالق

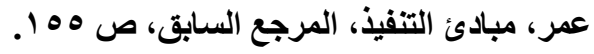

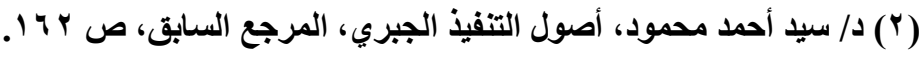

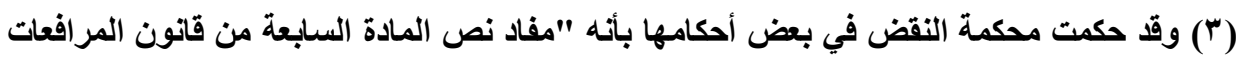

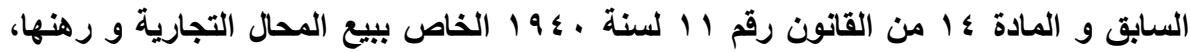

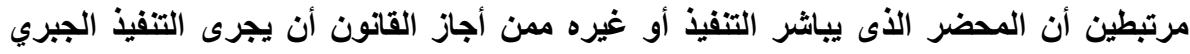

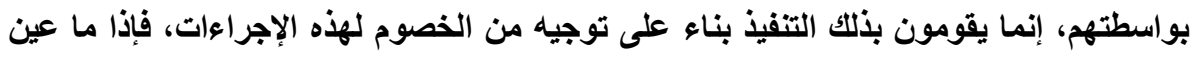

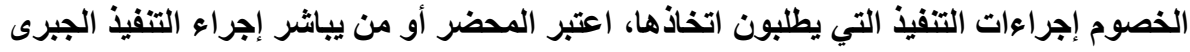

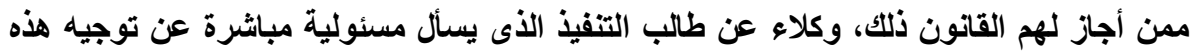

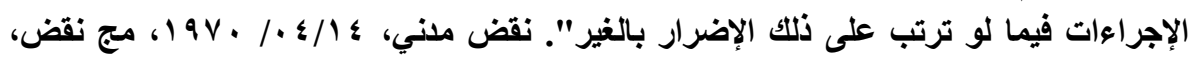

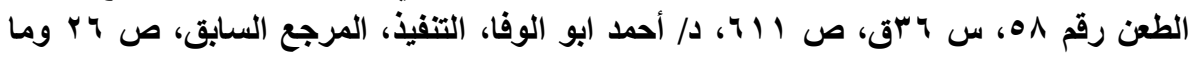


طالب التنفيذ؛ وهذه الصفة ثابتة بحكم القانون طبقا للقواعد العامة بدون حاجة إلي نص

علي ذلك(')

وقد ذهبت بعض أحكام القضاء الفرنسي أن الموظفين العموميين كـالموثقين

والمحضرين الذي يحوزون بعض أموال المتعـاملين، لا يعتبرون من الغير، لأنهم في

حكم الـوكلاء لـيس لهـم سـلطات مستقلة علـي الأمسوال التـي فـي حـوزتهم. كمـا أن شخصيتهم ليست مستقلة عن شخصية المتعاملين معهم (؟).

وقد انتقد الفقهـ الفرنسي هذا الاتجـاه، حيث اعتبر المركز القـانوني لهووّلاء

الموظقين العموميين أقرب إلى مركز المودع لديهم من مركز الوكيل(")، وبالتالي يجب توقيع الحجز تحت أيديهم عن طريـق حجز مـا للمدين للدي الغير، وقد ايـدت بعض المحاكم الفرنسية هذا الاتجاه(؛)

وقد ذهب جاتب من الفقه إلي اعتبار المعاون فرعا من السلطة التفيذية علي أساس أن التنفيذ من وظائفها وليس من مهمة القضاء()، حيث يري أنه يعتبر المعاون موظف عـام يمثل السلطة العامـة في خصومة التنفيذ، ويسنـا إليـه القيـام بأعمـال وإجراعات تتعلق بخصومة التنفيذ(?).

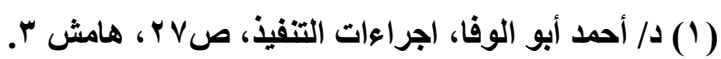

(2) TGI Charts, 13-1-1965, Avoues 1960, la somme juridique, no 3661.

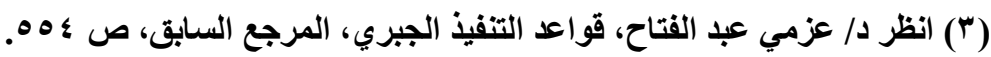

(4) TGI saint auentin, 19-12-1969, soumaine juridique, 1970, avoues, no 5773.

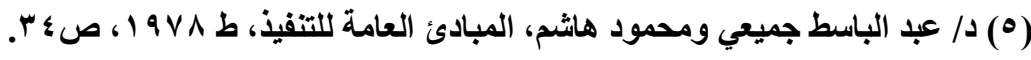

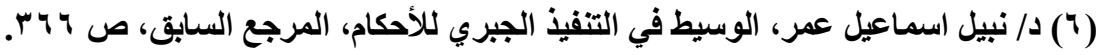


وفي الواقع القول بأن المعاون وكيلا عن طالب التفيذ لا يمكن قبوله،، وذلك لأن عندما يقوم المعاون بمباشرة التنفيذ يعمل بمقتضي واجبه الوظيفي كموظف عام ملتزم تجاه الدولة بالقيام بالتنفيذ(')، وقيام المعاون بالتنفيذ بناء علي طلب طالب التنفيذ ذلك لأن طلب التنفيذ يعد مفترضـا لقيـام المعـاون بالتنفيذ، مثل الطلب القضائي باعتبـاره مفترضا ليقام القاضي بوظيفته، فلم يقل احد بـأن القاضـي وكيل عن المدعي. كمـا أن فكرة الوكالة تقتضي أن يقوم الوكيل بالعمل بنـاء علـي تعليمـات الموكل، بينمـا المعـاون يقوم بالتنفيذ متبعا قو اعد القانون وأوامر قاضي التنفيذ(؟)، ولا يحق لطالب التنفيذ أن

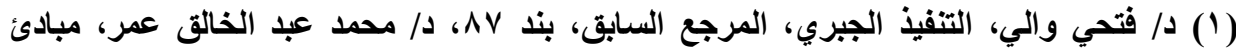

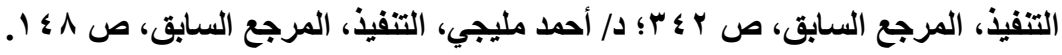

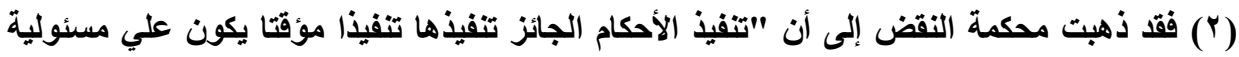

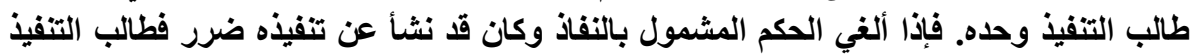

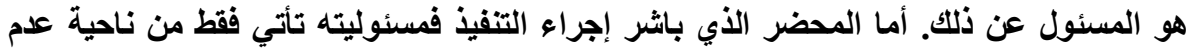

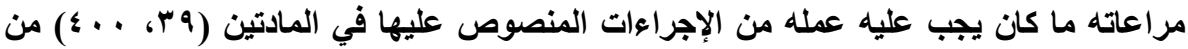

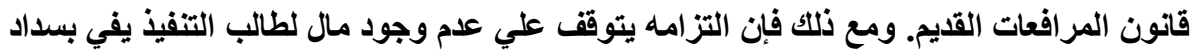

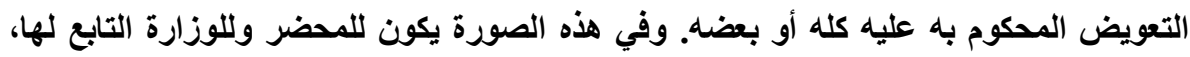

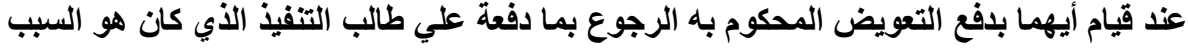

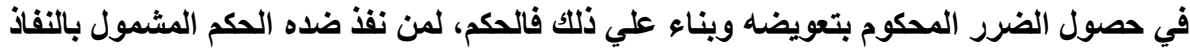

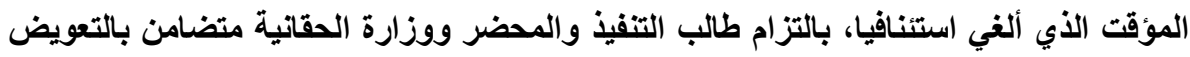

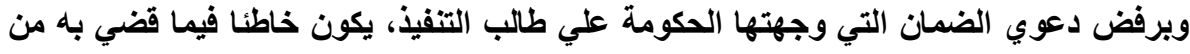

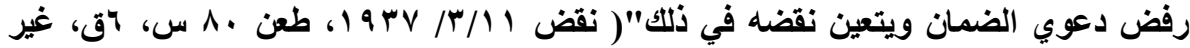

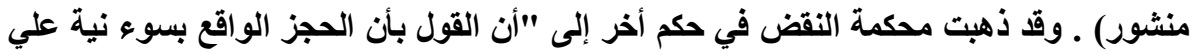

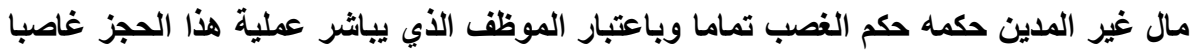

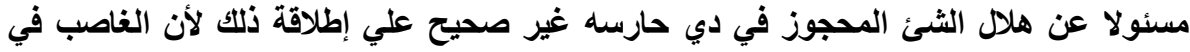

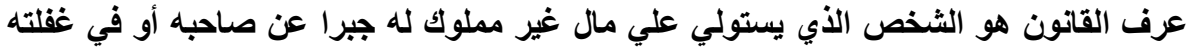

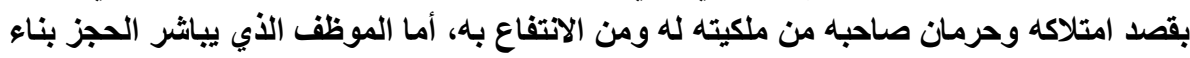

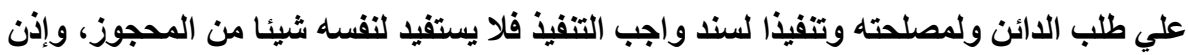
فالحكم باعتباره غاصبا لوضعة الحجز علي شئ يعلم أنه غير مملوك للمدين المطلوب التنفيذ عليه $=$ 
يصدر لـه أوامر. إلـي جانب ذلكك أن المعساون لا يعمل علي المصلحة الخاصـة لطالب التتفيذ وإنما من أجل المصلحة العامة في الحماية التنفيذية)(') ونري أن المعاون يقوم بمعاونة القضاء في تنفيذ الأحكام باعتباره موظفـا عامـا وليس وكيلاً عن طالب التنفيذ، والمعاون لا يقوم بوظيفة قضائية، ولكنه تـابع للسلطة التنفيذ ومعاون للسلطة القضائية في القيام بإجراعات التنفيذ الجبري، فهو من الغير المحايد في التنفيذ الجبري.

والواقع أن معساوني التنفيذ يعتبرون من الغير، وذلك لأنسه ليس لهم مصلحة شخصية في الحق محل التفيذ، بالإضـافة إلى انهم يباشرون عملهم في التنفيذ بحكم

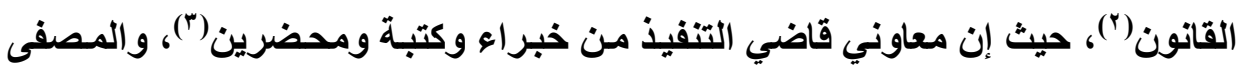

ومساءلته علي هذا الأساس عن هلا المحجوز بدون بيان توافر رابطة السببية بين خطئة والهلال

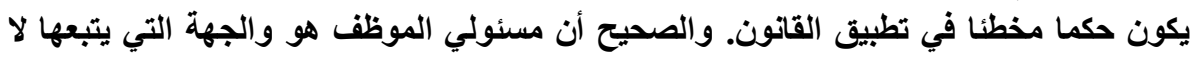

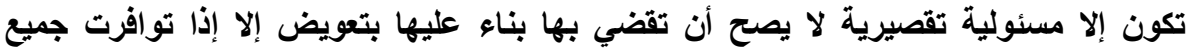

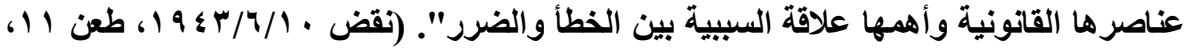

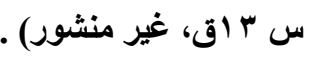

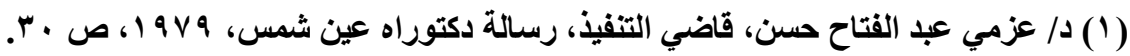

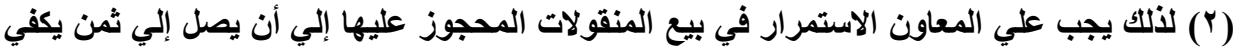

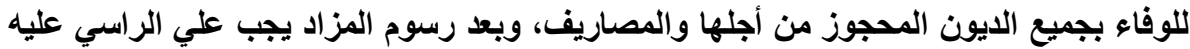

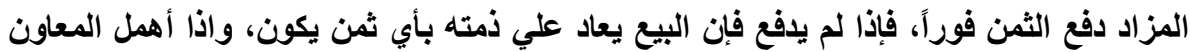

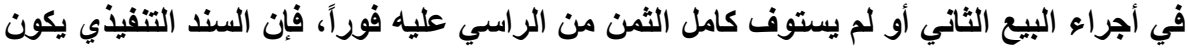
في هذه الحالة هو محضر البيع لرجوع علي المعاون نفسه، وذللك لأنه من الغير المحايد في 
القضائي(')، كل هؤلاء ليسوا أطرافا في الخصومة لأنهم يباشرون الإجراءات القضائية بسبب وظيفتهم وليس للحصول علي الحمايـة لحق من حقوقهم، فهم يمثلون السلطة القضائية، ويحتفظون بصفة الغير(). المحايد بالنسبة للخصومة التي يشاركون في | (إجراء|تها

حيث يجب التفرقة بين أطراف التنفيذ وهم طالب التنفيذ والمنفذ ضده وخلفهما، وبين أشخاص التنفي، حيث إن أشخاص التنفيذ يتضمنون كل من يشارك في إجراءات التنفيذ الجبري، حتي لو كان من الغير، طالمـا يشارك في الإجراعات بحكم القانون أو بسبب وقوع المال تحت يده. وقد ذهبت بعض أحكام القضاء الفرنسي إلى اعتبار القاضسي وأعوانـه من الغير لانهم ملزمون بحكم وظيفتهم أو صفتهم بالاشتراك في إجراءات تنفيذ الحكم(").

\section{الفرع الثالث \\ صفة الحارس في التنفيذ الجبري}

يقصد بالحسارس في التنفيذ الجبري، الشخص الذي يكلفهـ معساون التنفيذ أو قاضي التففيذ بالمحافظة علي المـال المحجوز عليه، ويلتزم هذا الحسارس بالمحافظة علي المال إلى وقت البيع بالمزاد العلمي.

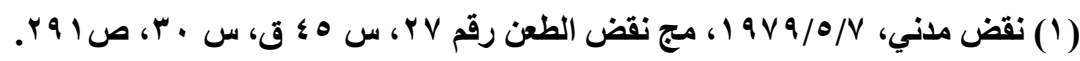
(Y) د/عبد الباسط جميعي، د/ امال الفزايري، التنفيذ في المواد المدنية والتجارية، المرجع السابق،

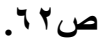

(3) TGI Paris, 17 octobre 1962, D, 1963, p. 125. 
بعد الحجز علي أموال المدين، قد يلزم لحفظها أو لإدارتها تعيين حارس عليها إلي حين بيعها(') فيقوم معاون التفيذ بتعين حارسـا علي الأشياء المحجوزة، حيث يختار هو هذا الحارس إذا لم يأت الحاجز أو المحجوز عليه بشخص مقتدر()، ويجب تعيين المحجوز عليه إذا طلب ذلك إلا إذا خيف التبديد، وكان لذلك أسباب معقولة تذكر في المحضر الحجز(")، وإذا لم يجد المعاون شخص يعينه حارس كلف المدين بالحراسة ولو بغير رضائه إذا كان موجودا في مكان الحجز (؛).

ولا يجوز أن يكون الحارس ممن يعملون في خدمة الحاجز أو المعاون ولا أن

يكون زوجا أو قريبا أو صهرا لأحدهم إلى الدرجة الرابعة، فلا يجوز تعيين المحضر(0) ولا الحساجز حارسـا، وحكمة ذلك هـي المحافظة علـي شـعور المدين وتجنبـا للمتاعب والمشاكسات التي قد تنجم عن ذلتك، وإذا وافق المدين كتابة علي تعيين الحساجز أو أحد أتباعه حارسا، فلا نري ما يمنع من هذا التعيين الذي يصادف هوي لاي المدين صاحب الشأن الذي يثق بخصمه(")، فهذا الحذر مقرر لمصلحة المدين فلـه أن يتــازل عنه،

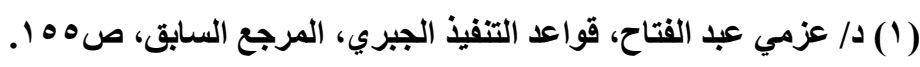

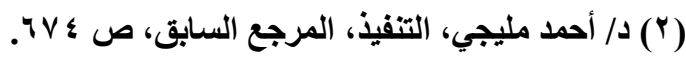

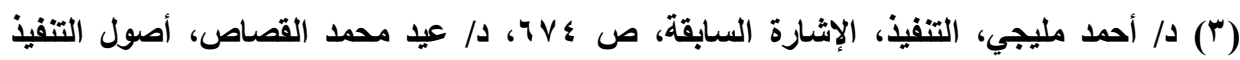

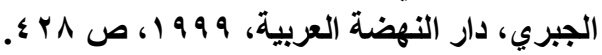

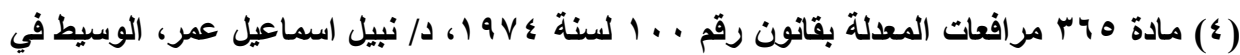

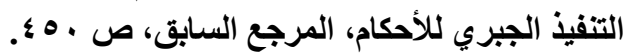

(0) د/ عيد محمد القصاص، أصول التنفيذ الجبري، المرجع السابق، ص و ج ؛ .

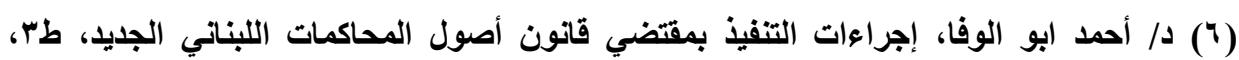


بقبول حراسة الحاجز أو أحد أقاربهه(') ونلاحظ أن القضاء الفرنسي قد قبل أن يعين

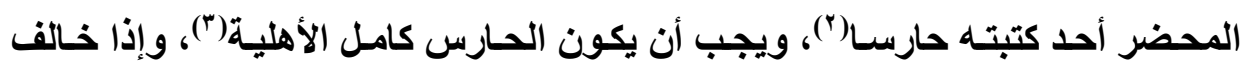

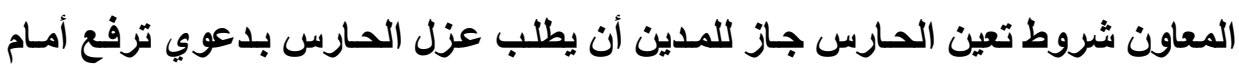

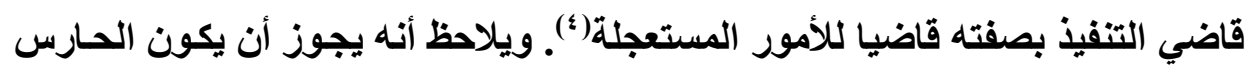
اجنبيا، كما يجوز أن يكون امرأة، ولكن بشرط القدرة وكمال الأهلية(ْ). وإذا عين أحد غير المدين أو الحسائز وجب أن يرتب لـه أجر (") عن حراسته، ويكون لهذا الأجر امتياز المصروفات القضائية علي المنقولات المحجوز عليها، ويقدر البرد

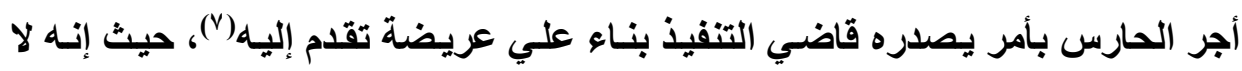

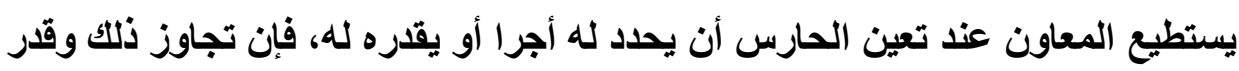

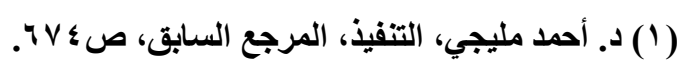

(2) TGI, Paris, 9 juil. 1980, D., 1982, IR, 165, obs., Julien, Cass, civ., 16 juin 1982, D., 1983, p. 237.

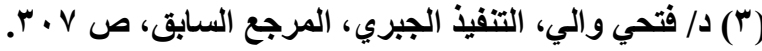

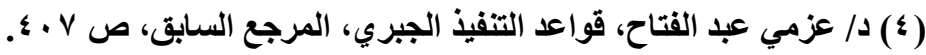

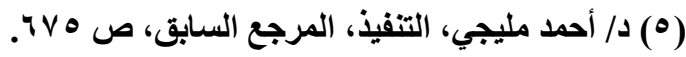

(†) د/ أحمد ابو الوفا، إجراءات التنفيذ بمقتضي قانون أصول المحاكمات اللبناني الجديد، طج، صו מודז

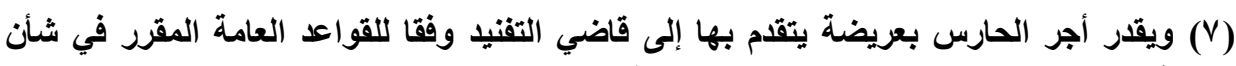

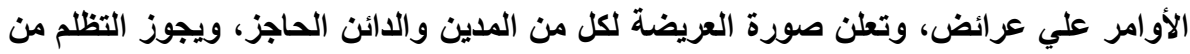

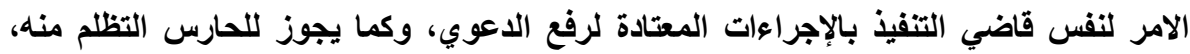

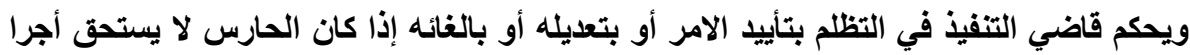

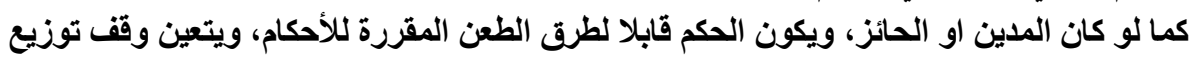

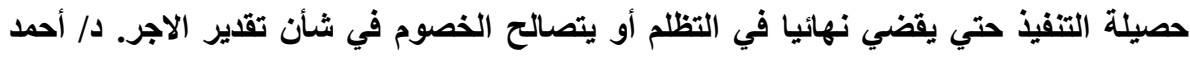

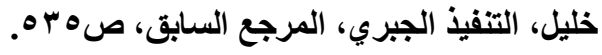


أجر للحارس، فلا يعتد به عند توزيع حصيلة التنفيذ، وفي هذه الحالة إذا قدمت عريضة

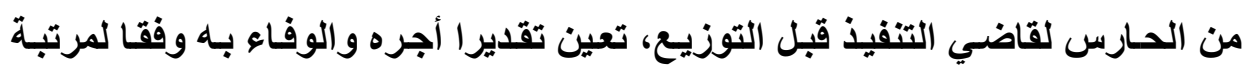
امتيازه التي تعادل المصروفات القضائية، وهذا الأجر سبقا أي حق آخر ولو كان ممتازا و المبالغ المستحقة للخزينة العامـة من ضرائب ورسوم وحقوق أخري وأيضا المبالغ التي صرفت في حفظ المحجوزات. وتتتهي الحراسة بييع الأثشياء المحجوزة بالمزاد العلني، أو الحكم بنقلها من يـ الحارس إلى حارس آخر، الحكم في دعوي الاسترداد برد الأموال إلى المسترد، وفاة الحارس أو عزله أو اعتزاله لأي سبب.

ونري أن الحارس في التنفيذ الجبري متي عينه المعاون أو قاض التنفيذ يعد من

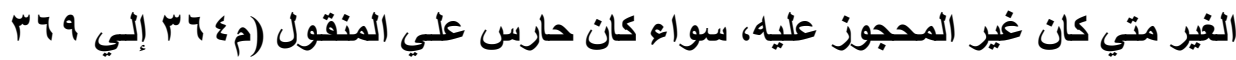

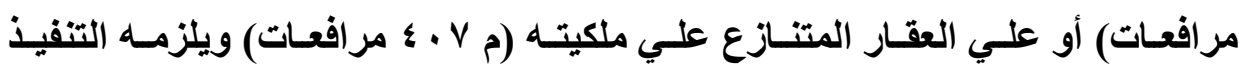

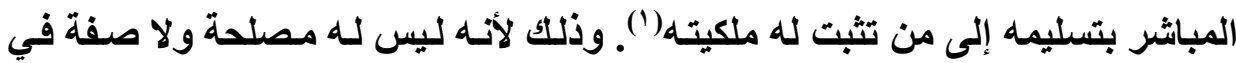
موضوع الحق ولا طرفا في إجراءات التنفيذ. ويلاحظ أن المنازعات التي تتعلق بالحراسة يختص بها قاضي التنفيذ كاستثناء

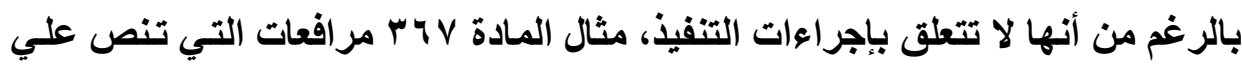

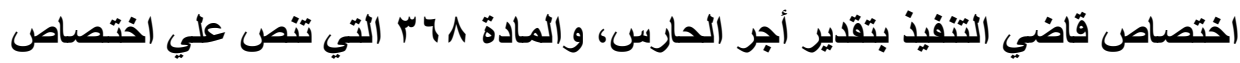

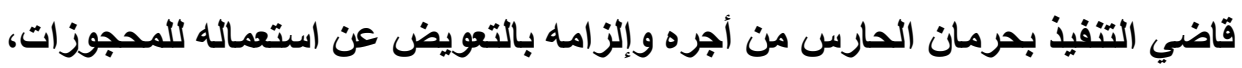
وبمنع الحارس من الإدارة أو الاستغلال أو استبدال غيره به، ونص المادة 9 جب بإعفاء الحارس من الحراسة. (1) د/ سيد أحمد محمود، أصول التنفيذ الجبري، المرجع السبق، ص^^هـ. 
د/ طلعت يوسف خاطر

العدد rا7 (أغسطس Y.IV)

17.

مجلت البحوث القانونيتّ والإقتصاديت 


\section{الفصل الثاني \\ دور الغير في التنفيذ الجبري}

في الواقع المشرعين الفرنسي والمصري قد نظمـا حقوقا وواجبات الغير في

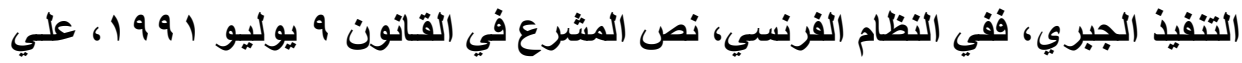
الدور الواضح للغير في التنفيذ الجبري، وكذلك حقوقه وواجباته أثتاء التتفيذ، مميزا

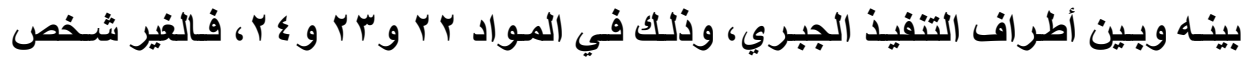
أجنبي عن التنفيذ، ولكنه قد يشارك في إجراءات التنفيذ الجبري(')، وذلك بسبب العلاقة التي تربطه بالأموال التي يحجز عليها الائن، أو قد يؤثر الحجز علي حقوقه، فيتدخل في خصومة التنفيذ(ب).

وفي النظام المصري نص المشرع في قانون المرافعات علي دور الغير في

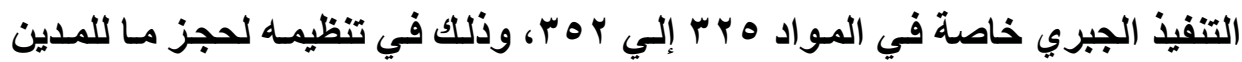
لاي الغير. سنثير إلى الدور السلبي والدور الإيجابي المحايد الذي يقع علي عاتق الغير أثناء التنفيذ الجبري، وذلك في المباحث الآتية:

(1) S. GUINCHARD et T. MOUSSA, droit et pratique des voies d'exécution, op. cit., $\mathrm{n}^{\circ}$ 161-11.

(2) Ibid. nO 161-12. 


\section{المبحث الأول \\ الدور السببي للغير}

يجب علي الغير أن يكون محايدا تجاه طرفي خصومة التنفيذ، وبالتـالي لا يجوز

لـه التعرض لسير إجراعات التنفيذ بـأي صورة من الصور، فيجب أن يلتزم السلبية والحيادية أثناء التنفيذ.

والتعرض قد يكون في صورة التعرض المـادي والتعرض القـانوني، ويلاحظ أن المثرع حاول الحد من سوء نية الغير بوضع قواعد إجرائية تحد من التحايل والكيد في الواقع العملي.

وسنشير التزام الغير بعدم التعرض المـادي وعدم التعرض القـانوني، والجزاء المرتب علي التعرض لإجراعات التنفيذ، وذلك في المطالب الآتية:

\section{المطاب الأول \\ الترام الغير بعدم التعرض المادي لسير \\ إجراءات التنفيذ البمبري}

سنشير إلى مفهوم التعرض المادي، والأساس القانوني لعدم التعرض المـادي، وذلك في الفروع الآتية: 


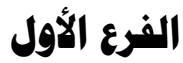 \\ هفهوم عدم التعرض المادي}

يقصد بعدم التعرض المسادي، عدم القيام بـأي عمل ذي أثر إيجابي أو سلبي يضطع به الغير، بحيث يتضمن إنكارا لحق طالب التنفيذ في الحصول علي حقه، فلا

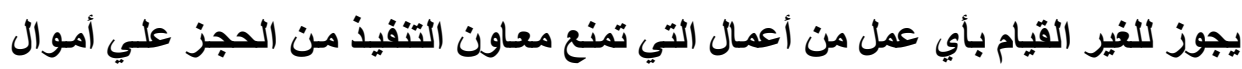
المدين(")، كالمشاركة في تهريب أموال المدين أو إخفائها لايه.

\section{ويمكن لنا تصور التعرض المادي في الصور الآتية:}

ا - الصورة السلبية للتعرض المادي:

يجب علـي الغير أن يلتزم بـالوقوف سـلبا تجـاه طرفي التنفيذ، فمـثُلا يلتزم

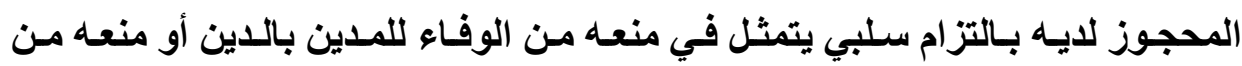
تسليمه ما في حيازته من منقو لات. r- الصور الإيجابية للتعرض المادي: - بائ

قد يكون هذا التعرض المسادي في صورة الإيجابيـة، وذلك بقيام الغير بمنع استعمال أو استغلال المال المحجوز عليه، وقد يقع التعرض علي المـال المحجوز عليه

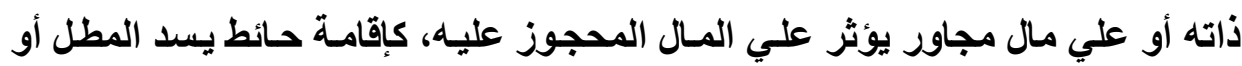
سور يحرم العقار المجوز عليه من حق ارتفاق المرور ممـا يؤثر علي ثُمنه، أو قيام

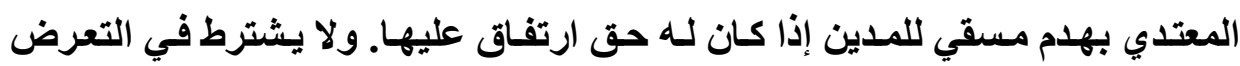


د/ طلعت يوسف خاطر

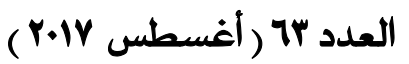

المـادي أن يكون مصحوبا بـالعنف أو إكراه، ويعد العـل تعرضـا ولـو قامـت بـه جهـة

الإدارة أو أي شخص يستند إلي ترخيص من جهة الإدارة.

ويشترط في هذا التعرض أن يكون فيه تأثثير علي المـال المحجوز عليه، بحيث

ينقص من ثمنه لو بيع بالمزاد العلني، ولكن إذا كان التعرض بناء علي سند تنفيذ كحم

قضائي فلا يعد هذا تعرضاً.

\section{الفزرع الثثاني}

\section{الأساس القانوني لعدم التهرض المادي}

ذهب المشرع الفرنسي في قانون المرافعات إلي النص صراحة علي أنها يجب

علي الغير عدم وضع العراقيل أمسام إجراءات التنفيذ الجبري، ويجب عليه أن يتعاون عندما يكون ذلك واجبا عليه، (م ؟ ب من قانون 9 يوليو (99 ( ) وفي حالة امتناعه فيمكن أن يحكم عليه بتعويض الأضرار الناتجة عن تعرضه، وإجباره علي الامتناع عن

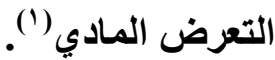

L'article 24 dispose que « les tiers ne peuvent

faire obstacle aux procédure engagées en vue de

l'exécution ou de la conservation de la créance ».

بالنسبة للقانون المصري، فإنه لم ينص علي التزام الغير بعدم وضع العراقيل

أمام اجراعات التنفيذ، ولكن يستفاد من القواعد العامة، حيث يلتزم الغير بعدم التعرض

(1) J. Vincent, voies d execution et procedures den distribution, D., 19 ed, 1999. P11. S. GUINCHARD et T. MOUSSA, droit et pratique des voies d'exécution, op. cit., $\mathrm{n}^{\circ}$ 162.11. S.32 
لسير إجراءات التنفيذ الجبري، وإذا تعرض لإجراءات التنفيذ فيمن اللجوء إلي القضاء للحكم عليه بعدم التعرض مع التعويض إن كان لله وجه. ولـــم يـنظم المـشرع المـصري طريـق خاصــة لمنـع التعـرض المــادي للغيـر إلا في بعض المسائل، حيث نص المشرع المصري في المـادة ـ ب مرافعـات علي الاســعانة برجـال السلطة العامـة لإعانـة منـدوب التففيذ علـي إجـراء التنفيـذ، ولـو باستعمال القوة، وقد حددت المـادة ـ ^ ب مرافعات هذه الصياغة بأنها " علي الجهة التي يناط بها التنفيذ أن تبادر إليه متس طلب منها وعلي السلطات المختصة أن تعين علي إجرائه ولو باستعمال القوه متي طلب منها ذلك". وهي تكتب حرفيا عند تحرير

الصورة التنفيذية. كمـا يمكن لأطر اف الحجز اللجوء إلى قاضـي التنفيذ لمنـع الغير من التعرض للإجراءات الحجز، وذلك عن طريق رفع دعوي مستعجلة، يطلب فيها طالب التنفيذ أو المنفذ ضده منع الغير من التعرض للمال المحجوز عليه.

\section{الامطب الثانبي \\ الالتزام بعدم التعرض القانوني لإجراءات التنفيذ}

سنشير إلـي المقصود بعدم التعرض القـانوني، والأســاس القـانوني لعدم تعرض الغير، وذلك في الفروع الآتية: 


\section{الفرع الأول \\ المقصود بعدم التعرض القانوني}

يقصد بعدم التعرض القـانوني مـن قبل الغير، عدم الاعتراض علي إجراءات التنفيذ الجبري بشكل قانوني(")، كقيام الغير بعمل قانوني يتضمن إنكارًا للحق الائن في الحجز أو لملكية المدين للمسال أو لحق لـه علي المسال قابلا للتنفيذ عليه، وذلك بهدف الكيد، كتوجيه إنذار إلي المدين بإخلاء العقار المحجوز عليه أو بدفع الأجرة، أو قيام الغير بإبرام عقد إيجار أو عقد بيع مع شخص أخر علي العقار محل التنفيذ.

وقد يأخذ التعرض القانوني صورة إجراء قضائي مثل رفع دعاوي الحيـازة علي المدين أو دعوي ملكية، كرفع دعوي استرداد المنقولات المحجوز أو دعوي استحقاق العقار المحجوز عليه، ففي هذه الحالة يمكن للمدين وللادئن الدفع بعدم تعرض الغير لإجراءات التنفيذ، والزامه بالتعويض.

ويختص قاضي التنفيذ بنظر جميع المنازعات بين الغير وطرفي التنفيذ الجبري، حيث ترفع أمامه دعوي الاسترداد للمنقولات()، ودعوي الاستحقاق المتعلقة بالعقار المحجوز عليه(") - (ب)

وقد يظهر التعرض القانوني في شكل رفع استشكال في التنفيذ الجبري، وذلك من أجل وقف تنفيذ السند التنفيذ أو منع الأثر الواقف للاستشكال الثاني المقدم من

(1) S. GUINCHARD et T. MOUSSA, droit et pratique des voies d'exécution, op. cit., $\mathrm{n}^{\circ} 162.13$.

(2) Id.

(3) Ibid. nO 162.27 
المحجوز عليه. فقد يستخدم الغير إشكالات التنفيذ الوقتية بهدف تعطيل سير إجراءات التنفيذ الجبري.

ويلاحظ أن هذه اشكالات الوقتية ومنازعات التنفيذ الموضوعية، تعد من أكثر منازعات التنفيذ استخدامـا في الحياة العملية، سواء من قبل الغير أو من قبل أطراف التنفيذ، لذلك نص المشرع علي قواعد تهدف إلى تحقيق الحمايـة لطرفي التنفيذ وبمـا يتمشى مع ما ترمي إليهه من التوفيق بين المصالح المتعارضـة لطرفي التنفيذ، سواء مصلحة رافع الاعوي والتي تقتضي وقف التنفيذ، ومصلحة الحساجز التي ستضار من وقف التنفيذ الذي سيترتب بقوة القانون بمجرد رفع الأشكال، إذا تبين فيمـا بعد عدم صحة هذه المنازعات، أو أنه لم تستخدم إلا كوسيلة كيدية لعرقلة سير التنفيذ. لذا نص المشرع علي إجراعات تهدف إلى الحد من الكيد، وهذا مـا سنشير اليهه في المطلب

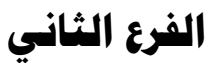 \\ الأساس القانوني لهدم التعرض القانوني}

ذهب المشرع الفرنسي في قانون المرافعات في المادة ؟ ب من القانون ج يوليو 199 19، علي النص صراحة علي الزام الغير بعدم التعرض لإجراعات التنفيذ الجبري، سواء كان تعرض قانونيا أو ماديا. وبالنسبة لقانون المصري، فلم ينص قانون المرافعات صراحة علي التزام الغير بعدم التعرض القـانوني لإجراءات التنفيذ الجبري، ولكن القواعد العامـة توجب علي الغير عدم التعرض لحق أي شخص، حيث أن التعرض القانوني يكون غير مقبول إذا لم 
يكن من ورائه أي فائدة تعود علي الغير، وقد تكون اللدعوي التي يرفعها الغير علي أطراف التنفيذ غير مشروعة إذا كانت تهدف إلي النكاية بأحد الخصوم فقط. فطبقا لنص المادة ץ مرافعات، لا تقبل أي دعوى كمـا لا يقبل أي طلب أو دفع استناداً لأحكام هذا القـانون أو أي قـانون آخر لا يكون لصحابه فيها مـصلحة شخصية ومباشـرة وقائمـة يقرها القانون، والدعوي باعتبارها حقا، تكون غير قانونية وغير مشروعة إذا توافر فيها ما نصت عليه المادة ه من القانون المدني. ويتمثل في الآتي: 1 - إذا لم يقصد بها سوي الإضرار بالغير. r - إذا كاتت المصالح التي يرمي إلي تحقيقها قليلة الأهمية، بحيث لا تتناسب مـع

$$
\text { ما يصيب الغير من ضرر بسببها. }
$$

$$
\text { r- إذا كاتت المصالح التي يرمي إلي تحقيقها غير مشروعة. }
$$

يجب علي الغير الأي اعترف لله المشرع بحق الاعتراض علي التفيذ إذا ما كان ماسا بحقوقه أو مصالحه أو ضارا بهال')، ألا يتعف فيه وألا يضر بأحد أطراف التنفيذ أو يعرقل سيره وإلا تعرض للمسئولية، حيث أن تجاوز الحد المعقول أو المـألوف في المنازعة في التنفيذ يؤدي إلى اعتبار صاحب الحق متعسفا مسيئا، وبالتالي مسئولا عن استعمال الوسائل المتاحة له للدفاع عن حقوقه أو مصالحهـ في غير مـا أعدت لـه أو علي خلاف الغاية التي من أجلها شرعتـ لأن الاتحراف بـالحق عن غايته يقلبه إلى مفسدة أو مخبثةــ وكل شئ يزيد عن حده ينقلب إلى ضدة(؟).

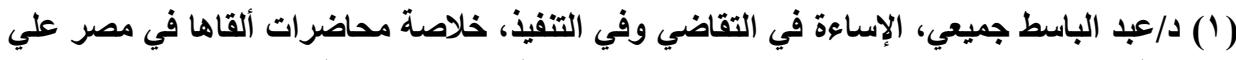

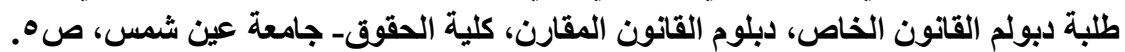

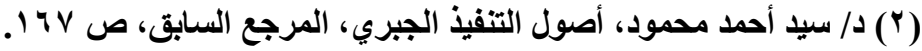




\section{المطاب الثالث \\ الجزاء المترتب علي اعتراض الغير البئ}

الو اقع أنها اذا تعرض الغير لإجراءات التنفيذ بشكل قانوني أو مـادي، فيمكن

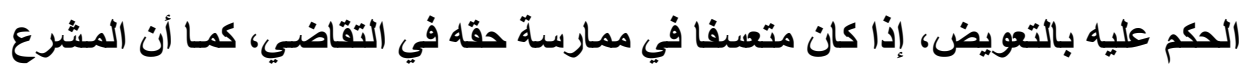

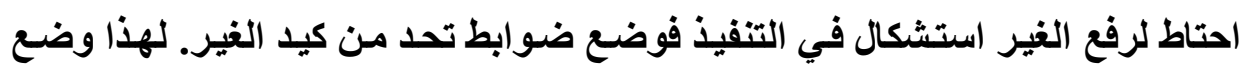

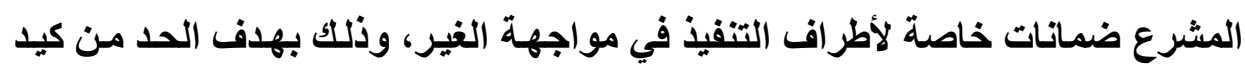
الغير أو تسخيره للإضرار بأحد اطراف الخصومة. فقد نص المشرع علي الزام الغير بالغرامـة والحد من الأثر الواقف لمنازعات التنفيذ المرفوعة من الغير، وسنثير إلى ذلك في الفروع الآتية:

\section{الفرع الأول \\ المكم علي الغير بالغرامة والتعويض}

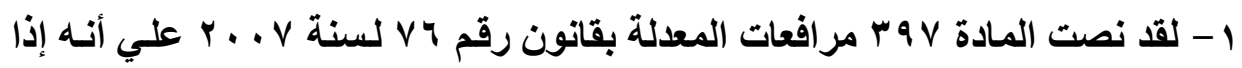
خسر الغير المسترد دعوي الاسترداد جاز الحكم عليه بغرامـة لا تقل عن مـائتي

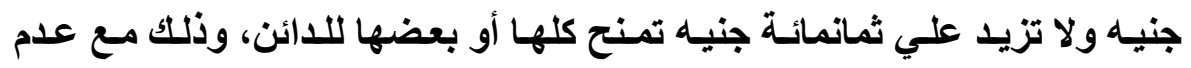
الإخلال بالتعويضات إذا لها وجه. وقد كان النص قبل التعديل الأخير علي أنها إذا خسر الغير طالب الاسترداد دعواه جاز الحكم عليه بغرامة لا تقل عن مائة جنيه ولا

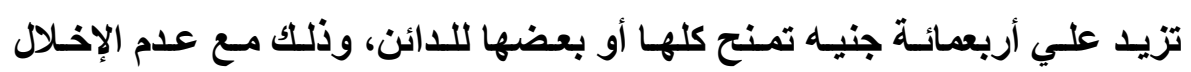

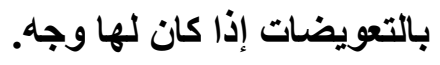


ويهرف المشرع من هذا الجزاء معاقبة المسترد سيئ النية الذي يرفع دعواه

بقصد وقف إجراءات التنفيذ، وبالتالي الحد من دعاوي الاسترداد الكيدية.

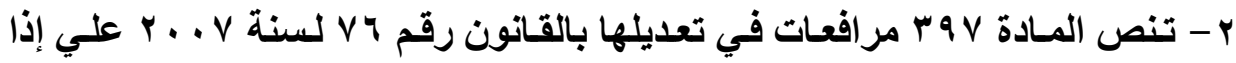

خسر المستثكل دعواه جـاز الحكم عليه بغرامـة لا تقل عن مـائتي جنيـة ولا تزيـا علي ثمانمائة جنية وذلك مع عدم الإخلال بالتعويضات إن كان لها وجه. وذلك للحد من استخدام إشكالات التففيـ كوسيلة للكيد والمماطلـة. ويختص قاضسي التنفيذ بالحكم بهذه التعويضات طالمـا تم التقدم بها بطلب عـارض. أمـا إذا تم التقدم بها بدعوي مبتدأه فإنها تخضع للقواعد العامـة للاختصاص، ولا يختص بها قاضسي التنفيذ.

ويلاحظ أن هذه المسادة قبل تعديلها كانـت تنص علـي انـه إذا خسر المستشكل دعواه جـاز الحكم عليـه بغرامـة لا تقل عن مائسة جنيـة ولا تزيـــ علـي أربعمائـة جنيـة.

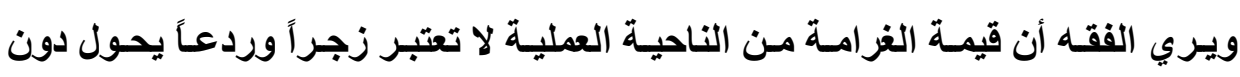
التعسف في استخدام هذا الطريق كوسيلة للمماطلة والتسويف.

\section{الفرع الثاني \\ الهد هن الأثر الواقف لمنازعات التنفيد الوقتية}

- يلاحظ أنه قد يحدث في الواقع العلمي أن يقوم الملتزم في السند من أجل عرقلة التنفيذ أن يوعز لشخص من الغير برفع إثكال في التنفيذ يوقف التفيذ، ثم ينتظر حتي صدور الحكم في الأثكال ويرفع إثكاله هو ليوقف التنفيذ لأنسه لـم يختصم في الإشكال الأول طبقا لنص المادة ب آس/ء مرافعات، ودفعا لهذا التحايل فقد أضيفت 
فقرة جديدة إلي المادة ب ا ب استلزمت ضرورة اختصام الطرف الملتزم في السند التنفيذي إذا كان الإثكال مرفوعا من غيره سواء كان الإثكال قد رفع أمام المعاون أو بالطريق العادي، وقد أوجب النص علي القاضي إذا تبين له أن الملتزم في السند لم يختصم أن يكلف المستشكل باختصامه في ميعاد يحدده، فإذا لم ينفذ مـا أمر بـه فإن للقاضي أن يحكم بعدم قبول الإثكال، ومنح هذه السلطة التقديرية للقاضي لكي يتأكد من جدية الغير، والذي قد لا يتمكن من اختصام الملتزم في السند لسبب خارج

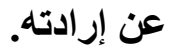

r - والواقع أستحدث قانون المرافعات الحالي حكما جديدا وهو أن الأثكال الذي يثيره الملتزم في السند التنفيذي يعتبر إثكالا أول يوقف التنفيذ إذا لم يكون قد اختصم في الأشكال السابق، وذلك علي أساس سد باب التحايل الذي كثف عنه الواقع العملي، حيث كان طالب التنفيذ يوعز إلي شخص من الغير برفع إشكال قبل أن يرفع الملتزم في السند التنفيذي إثكاله، ثم ينتهي الأثر الواقف لهذا الإشكال، ومن ثم يبدأ التتفيذ أو يستمر، فإذا رفع الملتزم في السند إثكالا فإنه لا يوقف التنفيذ بمجرد رفعها لأنه يعد إثكالا ثانياً' '). ومن أجل ذلك فقد نص المشرع علي أن الإثكال الذي يرفعه الملتزم في السند التنفيذي يوقف التتفيذ علي أساس أن حقيقته هو إشكال أول إذا لم يختصم في الإشكال الأول الأي رفع من قبل. ويلاحظ أن المشرع قد نـص علـي هذه الحمايـة لمسصلحة الملتزم في السند التنفيذي، غير أن السند قد يكون الملتزم فيه شخص وينفذ ضد شخص آخر، مثل الحكم الأي يصدر في مواجهة مستأجر وهمي ويجري في الواقع ضد شخص آخر وهو شـاغل 
العين، وقد يكون الحكم الصادر بصحة ونفاذ عقد بيع وتمكين المشتري من إقامـة بنـاء علي الأرض التي اشتراها ويكون هذا الحكم صـادر بـالتواطؤ بين البائع والمشتري إضرار بحق من له حق ارتفاق علي الأرض المبيعة. ففي هذه الحالة ق يقدم إثكال من ذات الملتزم (وهو خصم وهمي متواطئ مع المحكوم عليه). فإذا استشكل صـاحب حق هق الارتفاق أو شـاغل العين، فـان إثكاله يعد ثانيـا لا يوقف التنفيذ بمجرد رفعه ولا يلزم اختصامه لأنه ليس ملتزما في السند التنفيذي مع أن التنفيذ يجري ضده في الواقع. وقا ذهب الفقه إلي ضرورة تعديل النص بحيث يلغي عبارة الملتزم في السند ويحل محلها عبارة المنفذ ضده دفعا للتواطؤ الذي قد يحدث بين دائن ومدين عن طريق اصطناع خصومة للإضر ار بالغير (') قد نصت المـادة ب اس مرافعـات علي أنـه لا يترتب علـي تقديم أي إثـكال آخر وقف التنفيذ مـا لـم يحكم القاضسي بـالوقف، وبالتـالي فـإن أي أثـكال آخر علـي خـلاف الأشكال الأول لا يترتب علي تقديمه وقف التنفيذ، وذلك لأن المشرع افترض في رافعه

سـوء النيـة والرغبـة في عرقلـة التنفيذ، إذا الإثـكال الثـاني لا يوقف التنفيـذ، إلا أن المشرع تدارك الأمر حيث قد لا يكون رافع الاستشكال سيء النية، ولـه مصلحة مبرره في الوقف، فنص علي أنسه مـا لم يقض قاضـي التنفيذ بوقف التنفيذ، فالوقف في هذه الحالة بحكم القاضي وليس بقوة القانون

r - نص المشرع علي جواز شمول الحكم الصادر لمصلحة طالب التففيذ في منازعات التنفيذ بالنفاذ المعجل القضائي، ويقصد بذلك الأحكام الصادرة في منازعات التنفيذ الموضوعية، ويفترض في هذه الحالة رفع دعوي متعلقة بتنفيذ الحكم ويترتب 
عليها وقف التنفيذ، ثم صدر حكم في هذه المنازعة لصالح طالب التنفيذ. فهذا الحكم يجوز شموله بالنفاذ المعجل، ويجوز شمول الحكم بالنفاذ المعجل في جميع الأحول سواء كان الحكم بعدم قبول المنازعة أو بعدم الاختصاص أو بطلان صحيفتها إلخخ، وذلك لعموم نص القانون('). وحكمة هذا النص محاولة تفادي الآثار المترتبة علي مشاكسة الغير أو المنفذ في إجراءات التنفيذ. ع - اقر المشرع قواعد خاصـة في حالة شطب الإشكال في التنفيذ، حيث قرر جزاء، وهو زوال الأثر الواقف إذا شطبت الدعوي. في واقع الأمر اشكالات التنفيذ الوقتية هي دعوي بـالمعني الفني، وبالتالي كـان من المفروض خضوعها للقواعد العامة المتعلقة بالحضور والغياب المنصوص عليها

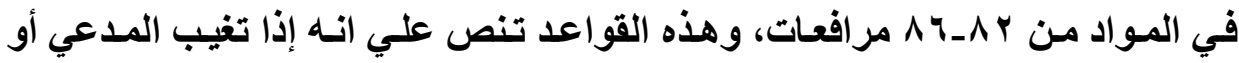
المـدعي عليـه تحكم المحكمة بشطب الدعوي إذا لـم تكن صـالحة للحكم فيها، وتظل الخصومة قائمة بالرغم من الثطب، فإذا مضي علي الشطب ستين يوما ولم يطلب أحد من الخصوم السير فيها أو لم يحضر الطرفان بعد السير فيها تعتبر الدعوي كأن لم تكن وهنا تعتبر الخصومة قد سقطت وتزول إجراءاتها وآثارها. ولو طبقت هذه القواعد علي المنازعة الوقتية يستوجب القول بأن الحكم بشطب الدعوي لا يؤثر علي استمرار وقف التفيذ الذي ترتب علي رفعها، غير أن المشرع رأي أن ذلك يؤدي إلي المماطلة في تنفيذ الأحكام، لذا نص علي حكمـا مخـالف للقواعد العامة مقتضاه أن شطب الأثكال يزيل الأثر الواقف الأي ترتب عليه. 
و الواقع أن نص المادة ؛ اب مر افعات المتعلق بزوال الأثر الواقف بالثطب نص

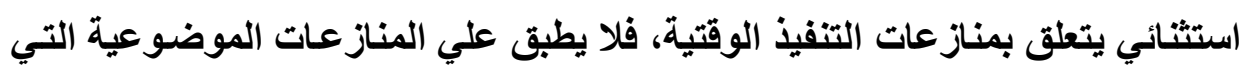
يترتب عليها وقف التنفيذ، إلا إذا نص المشرع علي ذلك بصفة خاصة كنص المسادة ه و ب مرافعات بالنسبة لدعوي استرداد المنقولات المحجوزة. و هذا النص يطبق فقط علي الثطب دون عوارض الخصومة الأخرى مثل الحكم بالوقف لأي سبب من الأسباب، فإذا حكم بعدم الاختصاص بنظر الأثكال والإحالة، فيان الحكم لا يكون له أثر علي وقف التنفيذ، لأن صحيفة الإثكال والأثر الو اقف يظل قائمسا بعد الحكم بعدم الاختصاص والإحالة)' (1) إذا تم تعجيل الأثكال المشطوب قبل انقضاء ستين يومسا، فلا يعود إليه الأثر الو اقف بقوة القانون، بل يجب أن يحكم القاضي بالوقف(") 


\section{المبحث الثاني \\ الدور الإيجابي للغير}

للغير دورا إيجابيا يقوم به أثناء التنفيذ الجبري، حيث نص القانون علي بعض

الالتزامـات الإيجابيـة التـي يقوم بهـا الغير، مثلـ الالتزام بتقديم معلومسات أو بتسبير

الإجراءات والمحافظة علي المال.

سنشير في هذا المبحث إلي التزام الغيز بتقديم معلومـات بشأن المـال المحجوز

عليه، والتزامه بالمحافظة علي المال المحجوز عليه، والتزام بتسبير اجراعات التنفيذ،

وذلك في المطالب الآتية:

\section{الإلب الأول \\ التزام الغير بتقديم هملومات بشأن المال المجهز عليه}

الدائن الحاجز قد لا يعرف أموال المدين بالضبط، لذا يستعين بالغير للإخبار عن

هذه الأموال، ففي النظام الفرنسي يلتزم الغير بالتعاون مع أطراف التنفيذ الجبري، وهذا التززام عـام علـي كـل شـخص مـن الغير (')، فيمكن الاسـتعانة بـالغير لمعرفـة مـوطن المحجوز عليه()، وإذا لم يستجيب الغير، فيمكن الحكم عليه من قاضي التنفيذ بالغرامـة

(1) S. GUINCHARD et T. MOUSSA, droit et pratique des voies d'exécution, op. cit., $\mathrm{n}^{\circ} 162.13$.

(2) Art. 40 de la loi 9 juill. 1991, Ibid. nO 162.20. 
التهديدية بناء علي طلب الحاجز (') ويمكن أعفاء الغير من تقديم معلومـات بنـاء علي أسباب معقوله يقدرها قاضي التنفيذ، ولكن الامتتاع عن تقديم المعلومـات بدون مبرر،

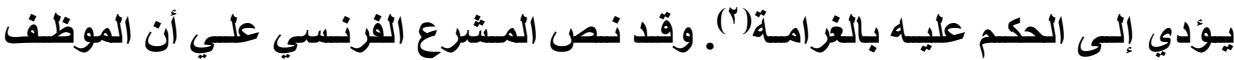
المحجوز لايـه يجب عليه التقرير طبقا للقانون(")، فبإذا كذب()"، فيمكن الحكم عليه

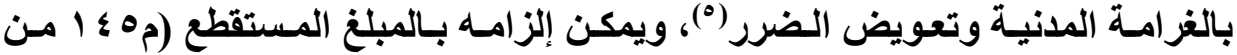
قانون العمل الفرنسي). وكذلك الهيئات التي تعطي معلومـات عن حساب المدين للائن

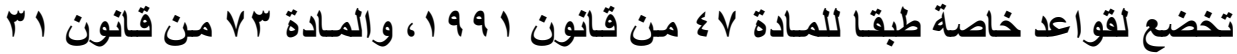

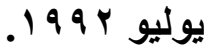

وفي النظـام المصري لا يوجد مثل هـذا المبـدأ، ولكن مـا نص عليـه المشرع

المصري، هو إلزام المحجوز لايه بتقديم المعلومات عن الدين الذي في ذمته للمحجوز عليه، وإلا كـان مسئولا شخصيا عن الدين، وإلزام رجال السلطة التنفيذية بالمعاونـة علي التنفيذ، سواء بتقديم معلومات أو باستعمال القوة عند وجود معارضة في التنفيذ.

(1) S. GUINCHARD et T. MOUSSA, droit et pratique des voies d'exécution, op. cit., $\mathrm{n}^{\circ}$ 162. 32 .

(2) Cass. 2 civ., 2 avril 1997, Bull. civ., II, ${ }^{\circ}$ 107, Cass. 2 civ., 28 janv. 1998, JCP, 1998, no 12, p. 443.

(3) J. Vincent, voies d execution et procedures dendistribution, D., 19 ed, 1999, p. 11, no 17. S. GUINCHARD et T. MOUSSA, Ibid. nO 162.29.

(4) Cass. 2 civ., 22 mars 2001, D. 2002, IR, p. 2102.

(5) S. GUINCHARD et T. MOUSSA, droit et pratique des voies d'exécution, op. cit., $\mathrm{n}^{\circ} 162.32$. 
في الواقع سـح المشرع المصري(') والفرنسي()، للحسجز أن يحجز علي مـا تحت يد الغير من مال أو منقول دون إلزام الحاجز بإثبات ملكية المسال للمدين أو حيازة الغير له، ودون تحديد المال الذي يرد عليه الحجز، وذلك بمجرد الادعاء بوجود مـال للمدين تحت يـ الغير، فيتم توقيع حجز مـا للمدين لـدي الغير("). وقد الزم المشرع المصري والفرنسي الغير المحجوز لايها، بالكشف عن المعلومـات التي تتعلق بالمسال التي تحت يده للمدين (๕) سنشير في هذا المطلب إلى التزام الغير بالتقرير بمـا في الأمـة وذلك في الفرع الأول، أما الفرع الثاني فيخصص لبحث اعفاء الغير من التقرير، ويعالج الفرع الثالث، جزاء الإخلال بواجب التقرير، وذلك علي النحو التالي:

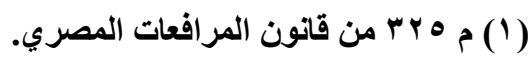

(2) Art. 211/3NCPC.

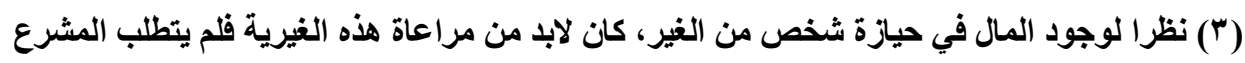

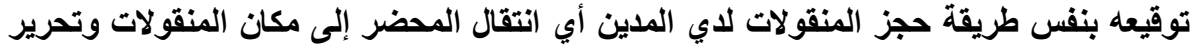

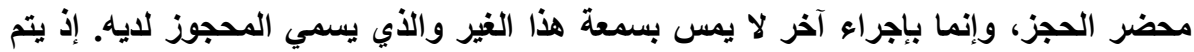

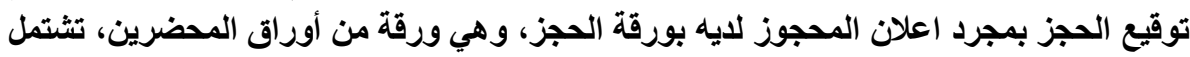

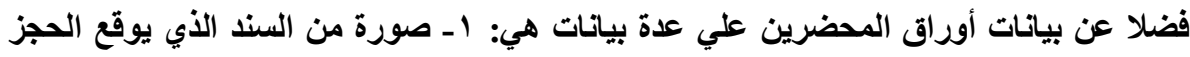

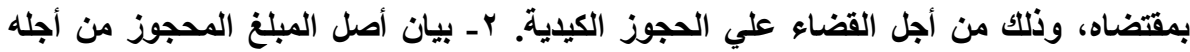

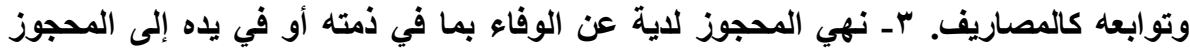

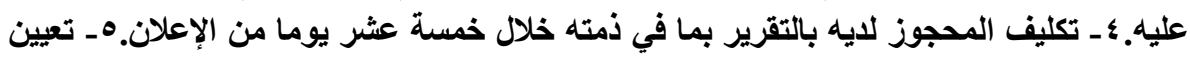

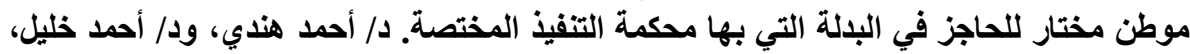

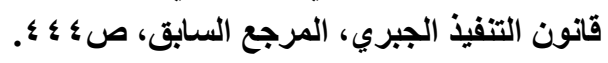

(4) Dedessus-le-Moustier, I obligation de renseignement du tiers saisi dans la saisie attribution, JCP, 1998, p. 106. 


\section{الفرع الأول \\ التزام الغير بالتقرير بما في الذهمة}

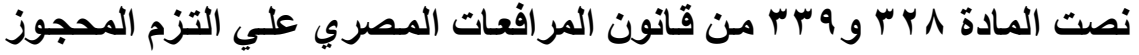

لايه بالتقرير بما في الأمة في خلال خمسة عشرة يومـا من الإعلان الحجز إليه، كما

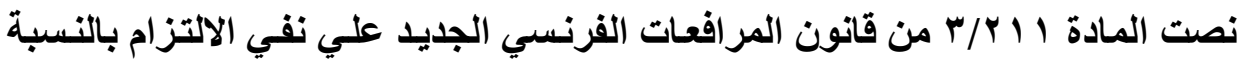
للمحجوز لايسه، ويلاحظ أن القاضسي الفرنسي قد تشدد في هذا الالتزام، حيث الزم المحجوز لايه بتقديم التقرير خلال \& ع ساعة من إعلانه(')، ويلتزم كذلك بالامتـاع عن الوفـاء لدائنـه المحجـوز عليهه بمـا في ذمتـه لـه مـن حقوق، أو تسليمه بمــا لايـه مـن منقولات، وإلا كان مسؤولا مسئولية شخصية عن الوفاء بمطلوب الحاجز. وإذا توفي المحجوز لديه أو فقد أهليته أو زالت صفته أو صفة من يمثله، كـان للحسجز أن يعلن ورثـة المحجوز لايـه، أو من يقوم مقامسه بصورة مـن ورقة الحجز، .

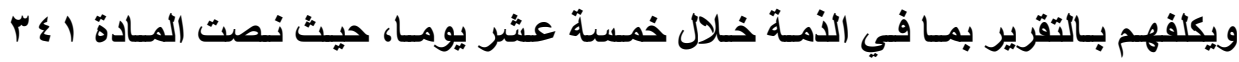
مرافعات علي أنه "إذا توفي المحجوز لايـه أو فقد أهليته أو زالت صفته أو صفة من يمثله كان للحاجز أن يعلن ورثـة المحجوز لايـه أو من يقوم مقامـه بصورة من ورقة الحجز ويكلفه بـالتقرير بمـا في الأمـة خـلال خمسة عشر يومـا". ويفترض هذا النص تحقق سبب الانقطاع بعد إعلان الحجز للمحجوز لايـه إذ تطلب إعلان "صورة" من ورقة الحجز السابق إعلانها للمحجوز لايه. ولكن لو تحقق سبب الانقطاع قبل إعلان الحجز للمجوز عليه، فهذا لا يمنع من إعمال النص، إذ يحل الورثـة ومن في حكمه

(1) TGI Lyon, 22 fevr. 1994, D. 1994, somm. 341 obs. Julien; TGL Rion, 31 janv, 1995, Gaz. Pal. 1995, 2, somm. 382. 
محل المحجوز لايه ممـا يوجب أن توجه الإجراءات إليهم ومنهـا إعلان الحجز، فعدم إعلان الورثة يترتب عليه عدم إلزامهم بالتقرير ('). وإذا حدثت الوفاة بعد انقضاء ميعاد التقرير، فإنه لا يلزم تكليف الورثة ومن في حكمه بالتقرير بما في الأمـة، وإنمـا يجب لاتخاذ إجراءات التنفيذ في مواجتهم، والحجز علي التركة لاستفاء الدين(؟). ومتي أعلن الورثة بالحجز علي نحو ما تقدم وتم تكليفهم بالتقرير بما أصبح في ذمتهم، وجب عليهم القيام بذللك، ولهم تنصيب أحدهم ليقرر عن التركة، ويكفي في هذا التنصيب أن يتوجه أحدهم إلى قلم الكتاب ممثلا للتركة دون حاجـة إلى حضور بـاقي الورثة أو وجود توكيل منهم لمن نصبوه عنهم(") فإن لم يتم الإقرار بما في الأمـة خلال الميعاد المحدد في التكليف، جاز إلزام الورثة بالدين من تركة مورثهم. وإذا توقع الحجز تحت يد الوصي أو القيم ثم زالت صفته بالعزل أو التحي، وقد تزول صفة من يمثله المحجوز لديه، كما لو توقع الحجز تحت يـ مدير شركة أدمجت في أخري، وجب إعلان صورة من ورقة الحجز لمن يحل محله، ويتعين إعلان صورة من ورقة الحجز إلى من أصبحت له الصفة في تمثيل الثركة الدامجة. فإذا تحقق سبب الخلافة، ولم يعلن الورثنة أو من في حكمهم، فِان الإجراءات التاليـة لتحقق بسب تكون باطلة، بمـا في ذلك الحكم الصـادر بـالإلزام، والبطلان هنـا

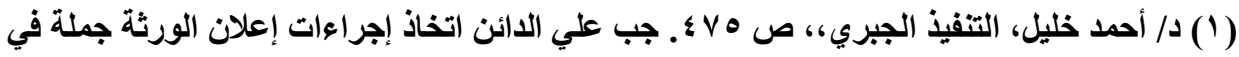

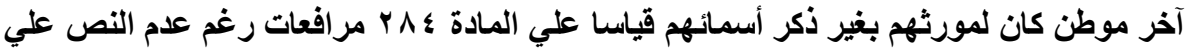

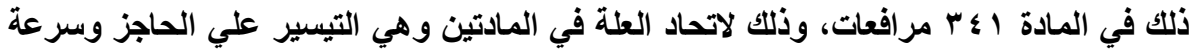

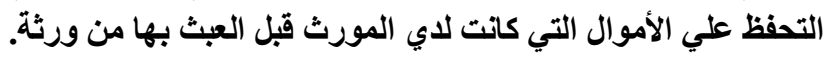

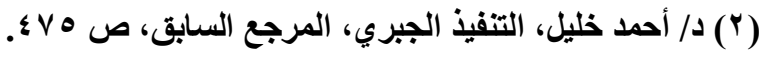

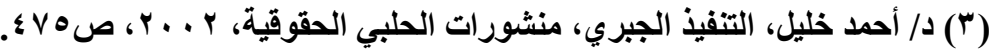


نسبي، مقرر لمصلحة الورثة ومن في حكمه، ويجوز لهم الاعتراض علي إجراءات التنفيذ، برفع دعوي تنفيذ مستعجلة أو موضوعية. سنشير إلى الأساس القانوني لالتزام الغير بالتقرير، ثم نبين مضمون المعلومات محل التقرير، وذلك علي النحو التالي:

\section{أولا: الأساس القانهزي لالتزام الغير بالتقرير:}

الأصل براءة ذمة الغير من أي دين، وعلي من يدعي عكس ذلك الإثبات، فطبقا

للقواعد العامة يقع عبء إثبـات علاقة المديونيـة بين المحجوز عليه والمحجوز لايـه علي عاتق الحاجز باعتباره مدعيا أن للمدين مال لاي الغير، ولكن المشرع يسر الأمر بالنسبة للحاجز، ففرض علي المحجوز لايه التزاما قانونيا بـالتقريز بمـا في ذمته. إذن يلتزم الغير في حجز ما للمدين لدي الغير بتقديم معلومات تتعلق بملكية المدين للمال(')، وذلكك عن طريق تقديم تقرير بما في الأمة، حيث إن الحاجز لا يمكن له أن يعلم بمـا في ذمة الغير من مال للمدين المحجوز عليه(؟).

\section{ونري أن أساس هذا الالتزام يرجع إلى الآتي:}

ا - التسيير علي الحساجز: أن الحاجز لا يملك الوسـائل التي تمكنه من التحقق من

مديونية المحجوز لايه لمدينه المحجوز عليه، كما أن هذا الاخير لا يملك المـال

(1) S. GUINCHARD et T. MOUSSA, droit et pratique des voies d'exécution, op. cit., $\mathrm{n}^{\circ}$ 162.21.

(r) د/ أحمد ابو الوفا، إجراعات التنفيذ بمقتضي قانون أصول المحاكمات اللبناني الجديد، طب،

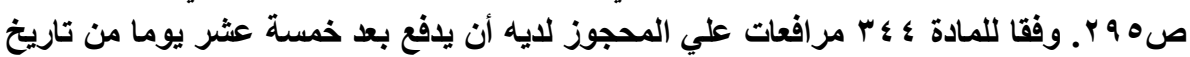

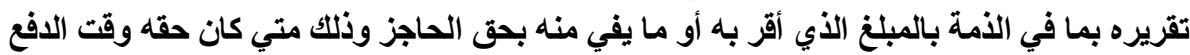

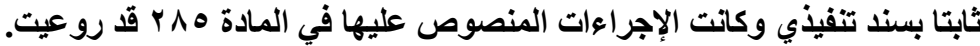


للوفاء للحاجز (')، لذا نص المشرع علي التزام الغير بتقديم المعلومـات من أجل التسيير علي الحاجز ومسـاعدته في الكشف عن حقوق مدينه. إذ أنـه قد أوقع الحاجز الحجز دون تحديد لما يرد عليه، وهو يحتاج إلى هذا التحديد الذي يقدر عليه المحجوز لايه، حتي يقف علي محل الحجز الأي سوف يستوفي منه حقه، إذا يعتبر الحجز واردا علي ما أقر به المحجوز لايه. r - الحاجز يعد من الغير بالنسبة لعلاقة المديونية بين الغير ومدينه: لذا لا يمكن التحقق مـن المديونيـة إلا مـن خـلال التقريـر الملتزم بتقديمـه المحجـوز لايـه، ويمكن للحاجز أن يناقش التقرير، ويطعن في مدي صحته. ب- يلتزم المحجوز لايه بالتقرير حتي لو لم يكن مدينا بأي دين للمحجوز عليه(؟)، وذلـك حتــي يقف الحساجز علـي حقيقـة الظـروف المحيطـة باقتشاء حقـه مـن المحجوز عليه، كان يسرع مثلا إلي الحجز علي مـال آخر، إذن لا يوجد ارتبـاط

(1) V. la chronique annotant les 13 arret, rendue dans ce domaine par la Cour de cassation le 5 juill. 2000, perrot et thery, saisi attribution, la situation du tiers saisi, D. 2001, chron 414.

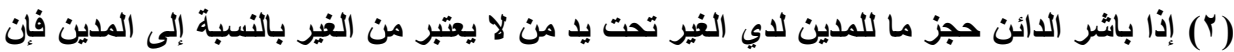

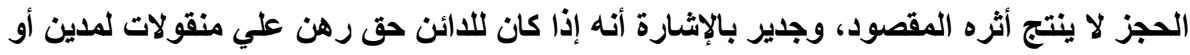

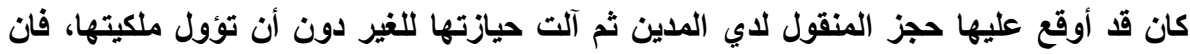

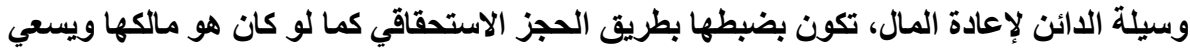

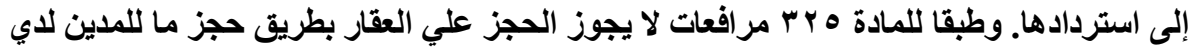

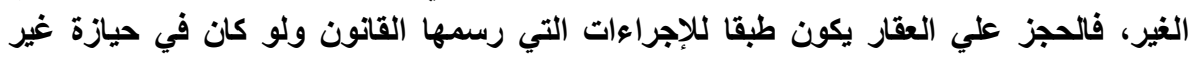

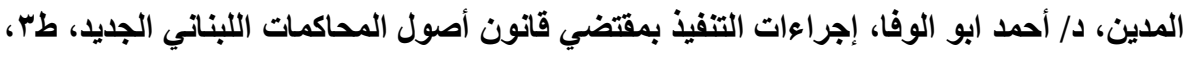

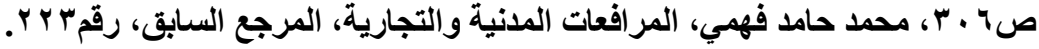


بين التزام المحجوز لايه بالتقرير بمـا في ذمته وبين مديونيته الفعلية للمدين

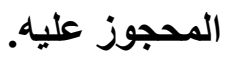

ع - المشرع المصري ألزم المحجوز لايه بالتقرير حتي ولو لـ يكن بيد اللائن سند

تنفيذي)"'، وحتي لو كان الحجز باطلا، ولكن لم يصدر حكم بذلك. ويرجع ذلتك

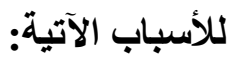

1 أن الالتزام بالتقرير بما في الأمة مستقل عن علاقة المديونية بين المحجوز

لايـه والمحجوز عليه، وكذلك العلاقة بين الحساجز والمحجـوز عليه، لأن

التقريـر يهـدف إلـي تحديد الضمان العسام للـائنين، حيث إن جميع أمسوال

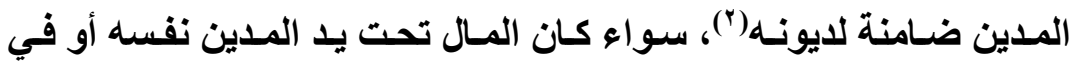

حيازة الغير.

r - رعايـة مـن المشرع لمصلحة الحساجز، حيث إن تقديم التقريز، والمنازعـة

فيه، قد يؤخران الحاجز في اقتضاء حقه بعد حصوله علي السند التفيذي،

فأجـاز لـه في وقت واحد أن يجمـع بين تحقيق مديونيـة المحجوز عليـه،

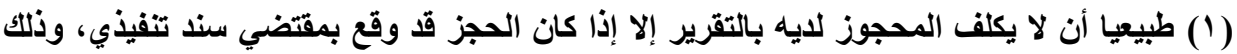

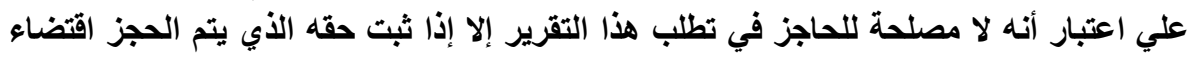
له، ثم قد لا يثبت حقه هذا فيكون تقدير التقرير والمناز لاعة فيه غير مجد ولا فائدة منه.

(2) J. Vincent, voies d'exécution et procédures den distribution, op. cit., p. 24, no 28.

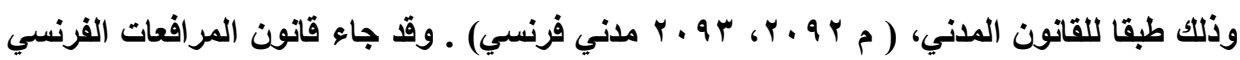

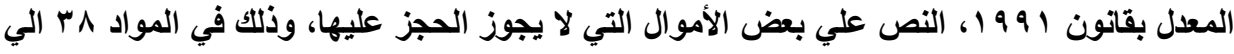

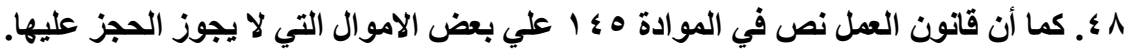


والنظر في مديونية المحجوز لايه، حتي إذا ما ثبت حق في ذمـة المحجوز

عليه، حصل عليه بغير تأخير أو إبطاء(').

\section{ثانيا: هضمون هملومات التقرير بما في الذهة:}

إذا قام الحاجز بإعلان المحجوز لايه بتكليفه بالتقرير بما في ذمته خلال خمسة عشر يوما من إعلانه، أنشأ هذا التكليف التزاما علي عاتق المحجوز لايه وجعله طرفا في عملية التنفيذ، ويلتزم المحجوز لايـه بتقديم التقرير خلال خمسة عشر يومـا من التكليف به سواء تم هذا التكليف في ورقة الحجز أو بموجب ورقة مستقله أعلتت إلى المحجوز عليه فيما بعد.

فيجب علي المحجوز لايه أن يقوم بإيضاح علاقة المديونية التي يدعي الحسجز وجودها بينـهـ أي المحجوز لايـهـ وبين المحجوز عليه()، فيقوم بإيضاح مـا إذا كـان مدينا أم غير مدين، وإذا كان مدينا فما هو مقدار الدين أو مـا هي المنقولات الموجودة تحت يده؟ ومـا إذا كـان هناك حجوزات أخري موقعة تحت يده، ويجب أن يتضمن التقرير كل الحقوق التي تكون للمدين لدي الغير المحجوز لايه، وهذه الحقوق قد تكون نقود أو منقـولات ماديـة مثل الأثـاث والمفروشــات أو البـضائع والتـي يلتـزم بتــليمها أو بردهــا

(1) د/ أحمد ابو الوفا، إجراءات التنفيذ بمقتضي قانون أصول المحاكمات اللبناني الجديد، طس،

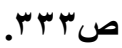

(2) S. GUINCHARD et T. MOUSSA, droit et pratique des voies d'exécution, op. cit., No 162.24 ;CA Paris, 24 Janv. 2002, JCP, 2002, IV, 1444. 
للمدين(') فمضمون التقرير بمـا في الأمـة، الكشف عن حقيقة العلاقة بين المحجوز لايها

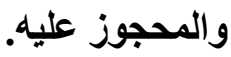

يلاحظ أن العقار لا يمكن حجز بطريق حجز مـا للمدين لدي الغير، حيث يحجز

بالإجراءات التي رسمها القانون بالحجز علي العقار ولو كان في حيـازة الغير، كمـا أنـه لا يتصور الحجز علي ما يكون للمدين في ذمـة الغير من التزام بعدل أو بالامتــاع عن عمل، وانمـا يجوز الحجز علي مبلـغ التعويض الذي يتحول إليـه الالتزام بسبب عدم الوفاع به أو التأخير فيه()

التقرير بما في الذمـة يأخذ شكل محضر يحرر في قلم كتاب المحكمة الجزئية التابع لها موطن المحجوز لايه(")، وفي النظام الفرنسي يرسل التقرير إلى قلم الكتـاب خلال ه 1 يوم من اعلان الغير، ويمكن للائن والمدين أن يطلعوا علي هذا التقرير في قلم الكتاب، ويرسل صورة منه إلى هؤلاء الاشخاص، ويذكر في التقرير البيانات التي تهم الحساجز وأهمها جميع مـا في ذمته من ديون للمجهوز عليه، ويجب أن يتضمن التقريز سبب الدين، هو مصدر التزام المدين، وسواء كسان عقدا أو عملا غير مشروع أو إثراء بـلا سبب أو إرادة منفردة أو نص القـانون، أو مـا في حيازته مـن منقولات، أيضا يجب عليه أن يرفق مـا لديه من مستثدات مؤيده لبياناتـه أو صورا منها مصدقا

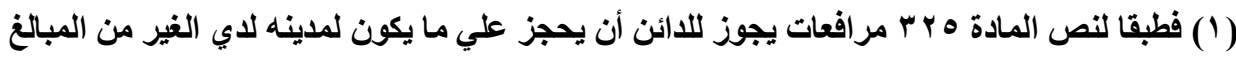
أو الديون ولو كاتت مؤجلة أو معدلة علي شرط وما يكون من للان الأعيان المنقولة في يد الغير.

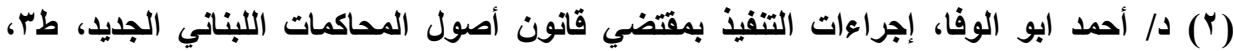

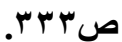

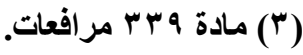


عليها، وإذا لم تكن تربطه بالمحجوز عليه أية رابطة مديونية تكفيه أن يذكر ذلك بصفة عامة، أي يكفيه ذكر عبارة أنه ليس ثمة علاقة مديونية بينه وبين المحجوز عليه. ولا يظتي عن هذا الثكل- محضر في قلم الكتابـ أي شكل آخر، كإقرار في ورقة عرفية أو امـا محضر الإعلان، والحكمة من ذلك هي سد الطريق علي المحجوز لايه

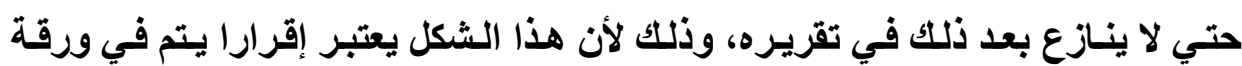
رسمية لا يجوز إثبات عكس ما جاء بها إلا بالطعن بالتزوير (') وإذا كـان المحجـوز لايسه مـصلحة حكوميـة أو غيرهـا مـن الأثــخاص العامـة،

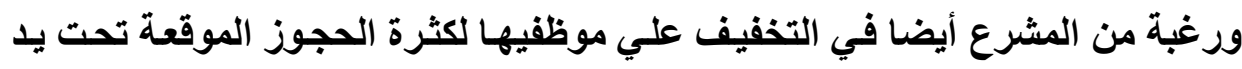
الحكومة، يورد المشرع استثناء علي قاعدة شكل التقرير ويكتفي بثهادة تقام من هذه التها الجهة تتضمن بيانات التقرير وتقوم مقامه، ويلاحظ أن القانون لم يحدد لهذه الجهات ميعادا معينا لتقايم خلال الثهادة("). إذا أقر المحجوز لديه بما في ذمته، أصبح التقرير ملزمسا له، ولا يملك الرجوع

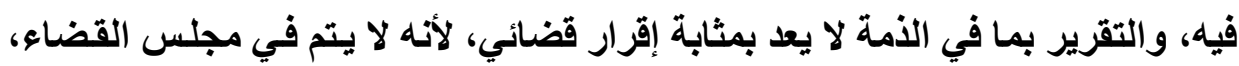
فليس له قوة الإقرار القضائي كليل لا يقبل إثبات العكس. ويلاحظ أن قوة التصريح الملزمة تقتصر علي المقر فقط ولا يمتل إلى المحجوز عليه، الذي يملك بطبيعة الحال

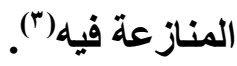

(1) د/ أحمد هندي، د/ أحمد خليل، قانون التففيذ الجبري، المرجع السابق، ص اله ؛.

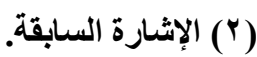
(ए) د/ أحمد ابو الوفا، إجراءات التنفيذ بمقتضي قانون أصول المحاكمات اللبناني الجديد، طس،

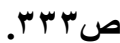




\section{الفرع الثاني \\ الإعفاء هن الالتزام بالتقرير بها في الذهمة}

الهلف من التقرير بمـا في الذمة هو معرفة العلاقة بين الغير المحجوز لديه والمدين المحجوز عليه، بهاف تمكين الدائن من الحصول علي حقه من الأموال التي لهي

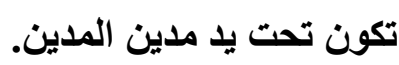

ومنطقيا أن الغير لا يلتزم بهذا التقرير إذا انتفت مصلحة الحاجز في معرفة

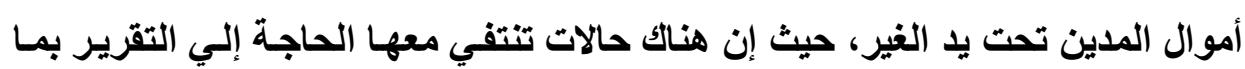

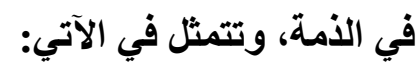

\section{ا- إيداع المجوز لديه ها لديه هن هال خزانة المكمية:}

إذا أودع المحجوز لايهه ـ سواء من تلقاء نفسه أو بناء علي طلب المحجوز

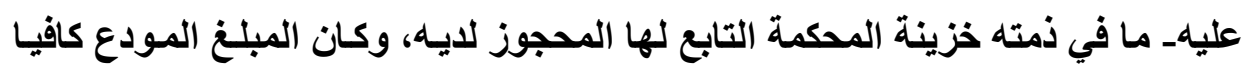
للوفاء بديون الحاجز، فلم يعد للحساجز مصلحة في التقرير بمـا في الأمـة، وإذا لم يكن المبلغ المودع كافيا، ألتزم المحجوز لايه بالتقرير بما في الذمة بالرغم من الإيداع. وإذا تم الإيداع فالحجز سيقي علي المبلغ وفي نفس الوقت لا يترتب عليه زوال

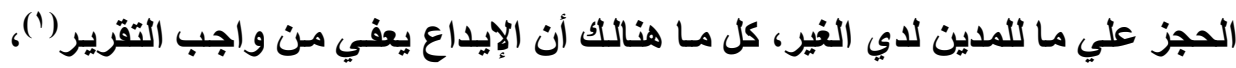

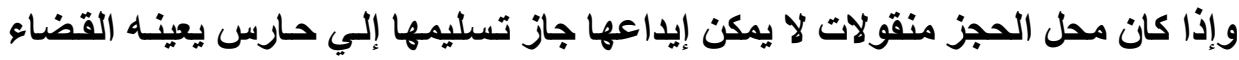
بناء علي طلب يقدم من المحجوز لايه أو المحجوز عليه.

(1) د/ أحمد هندي، د/ أحمد خليل، قانون التنفيذ الجبري، دار المطبوعات الجامعية، 999، ص. n 
ويجب أن يكون الإيـاع مقترنـا ببيـان موقع من المحجوز لايـه بـالحجوز التي وقعت، وأسماء الحاجزين والسندات التي وقعت الحجوز بمقتضاها.

وفـي هـذه الحالـة يـتم إبـلاغ الحساجز والمحجـوز عليـه بإيــاع الأمسوال خزانـة المحكمة أو تسليمها إلي حارس في خلال ثلاثذة أيسام، ويلاحظ أن هذا الإيداع لا يكون مقترنـا بالتخصيص. فإذا وقع حجز جديد علـي المبلغخ المودع فأصبح غير كاف جـاز للحاجز تكليف المحجوز لايه بالتقرير بما في ذمته خلال خمسة عشرة يوما.

\section{r- الإيداع هع التخصيص:}

قد يكون للمحجوز عليه أو للغير مصلحة في عدم معرفة الدائن الحسجز لعلاقة المديونيـة بينهم، لأنها قـ تكون مـن أسرار العدل المهني بين التجـار، لذا يكون من مصلحتهم الإيداع مع التخصيص.

إذا حدث إيداع مع التحصيص من قبل المحجوز لايه أو من غيره طبقا للمـادتين

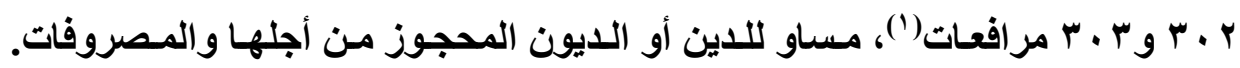
ففي هذه الحالة ليس للحاجز مصلحةـ وقد اختص بمـا أرادـ في الوقوف علي علاقة المديونية التي تربط المنفذ ضده بالغير، ولذلك فإنه فضلا عن إعفاء المحجوز لايسه من واجب التقرير فإنه الحجز نفسه الأي أوقع علي مـا في ذمته للمحجوز عليه يعتبر قد زال وانتقل إلى المبلغ المودع مع التخصيص. وذلك لأنه خصص للحاجز أفقده الحاجة إلي التقرير بما في الأمة.

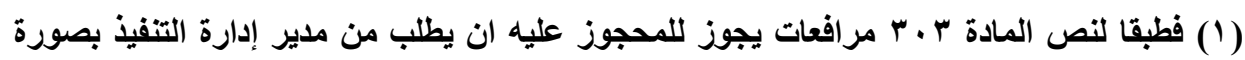

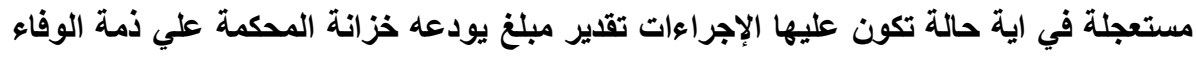




\section{ب- عدم قيام الحاجز بإيداع رسم هضر التقرير:}

أوجب المشرع علي الحاجز أن يقوم بأداء رسم محضر التقرير بمـا في الأمـة،

وذلك حتي يلتزم المحجوز لديه بالقيام بالتقرير. و الحكمة من ذلك أن المحجوز لايه ملزم بالقيام بـالتقرير بمـا في الأمـة حتي ولو كان غير مدين للمحجوز عليه، وهذا التقرير يقتضي دفع رسم عنه. لهذا أوجب المشرع علـي الحساجز أن يقوم بإيـاع

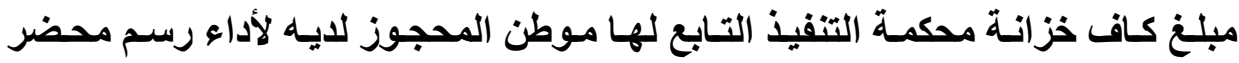
التقرير بما في الذمة، ويؤشر بالإيداع علي أصل الإعلان وصورته. وفي حالة عدم

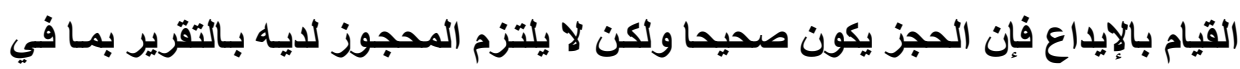

\section{الفرع الثالث \\ جزاء الإخلال بواجب التقرير بها في الذهة}

إذا لم يقام المحجوز لايه التقرير بما في ذمته علي الوجه الذي بينه القانون،

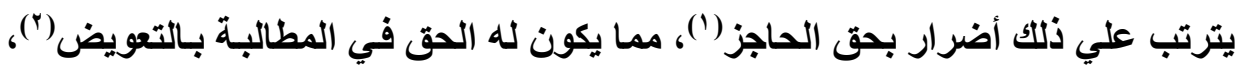
وقد أراد المشرع المصري والفرنسي أن يحمي الحاجز علي نحو أكثر فاعلية، فأعطاه القانون دعوي بإلزام المحجوز لايه شخصيا بدينه، إذا أخل هذا الأخير بواجب التقرير،

(1) S. GUINCHARD et T. MOUSSA, droit et pratique des voies d'exécution, op. cit., $\mathrm{n}^{\circ} 162.13$.

(2) Cass.civ., 2e, 5 juill. 2001,D. 2002, 1304, note Daverat ; TGI, Cherdourg, 8 dec. 1993, D. 1994, 291, note Martin. 
بصرف النظر عن ثبوت ضرر به(')، كما يمكن الحكم علي المحجوز لايه بالتعويض مـع الزامه بدفع غرامه مدنية والتي لا تتجاوز r الاف يورو(؟).

فيثار التساؤل عن ماهية جزاء الاخلال بواجب التقرير بمـا في الأمـة، وشروط تطبيق الجزاء الخـاص الذي نـص عليـه المشرع، وسـائل الحـاجز في إثبـات الإخـلال بـالتقرير بمـافي الأمـة، والحكم بـالجزاع، سـنجيب علـي ذلكت تباعـا، وذلك في النقاط

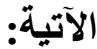
- ماهية جزاء الإخلال بالتقرير. - مروط توقيع الجزاء.

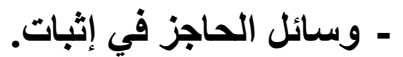

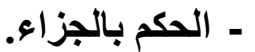

أولا: هاهية جزاء الاخلال بالتقرير:

طبقا لنص المادة || / / من قانون المرافعات الفرنسي الجديد، يلتزم المحجوز لايه بالتقرير بما في الأمة(")، وإذا أخل المحجوز لايه بواجب التقريز، فقد نصت المادة

(1) Art. 511 /5, Cass. Civ. 2e, 5 juill. 2000, D. 2001, 723, obs. Perrot et thery; RTF civ., 2000, 903, obs. Perrot ; perrot et thery, saisie attribution, la situation du tiers saisi, D. 2001, chron, 714.

(2) C. trv. Art. t.3252-10.

(3) S. GUINCHARD et T. MOUSSA, droit et pratique des voies d'exécution, op. cit., $\mathrm{n}^{\circ} 162.32$. 
سالفة الذكر في الفقرة الخامسة علي الزامه بدفع الدين المحجوز من أجله كجزاء(')، بالإضافة إلى التعويض. وبالنسبة للمشرع المصري، لـم يشأ أن يترك جزاء الإخلال بـالتقرير للقواعد العامـة التـي مقتضاها إلزام المحجوز لايسه بتعويض الضرر الناشسئ مـن تقصيره أو إهماله أو غثه، وإنما وضع الجزاء المقرر في المـادة بـ ب مرافعات، ومقتضي هذا الجزاء إلزام المحجوز لايه بلدين الحاجز.

وبالتالي إذا اخل الغير المحجوز لايسه بواجبه القانوني بـالتقرير بمـا في الذمـة

سواء لم يقم به أصلا أو قام به بعد الميعاد أو خالف الحقيقة، تؤدي إلى جواز إلزامـه بالدين المحجوز من أجله كله أو بعضه وبتعويض الحاجز عن الأضرار التي أصابته مع

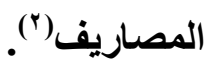

يلاحظ أن الجزاء الأي يجوز للمحكمة أن تقضي بـه عند إخلال المحجوز لايسه بواجب التقرير، لا يشترط للحكم به حدوث ضرر بالفعل للحاجز، فالضرر مفترض في هذه الأحوال. ويصبح المحجوز لايه مدينا شخصيا للدائن وجـاز لـه اقتضاء حقهه جبرا بالتنفيذ علي كافة أمواله، وإذا كان هذا الجزاء مقررا لمصلحة الدائن الحاجز الأي طلب توقيعه، فإن صدور الحكم به لا يمنع حاجزا آخر من طلب توقيعه مرة أخري علي نفس المحجوز لايه، إذا خالف واجب التقرير بما في الأمة بالنسبة له.

(1) J. Vincent, voies d execution et procedures dendistribution, op. cit., p. 11. Cass.civ., 2e, 5 juill. 2001,op cit. ; TGI, Cherdourg, 8 dec. 1993,op. cit. 
يلتزم المحجوز لايـه بواجب التصريح ولـو لـم يكن بيد الحساجز سنـ تنفيذي، وفرض المشرع عليه جزاء إن هو أهل وتراخي في اتخـاذ هذا الإجراء مـع العلم بـأن التقرير لا يفيد ولا يجدي إلا إذا حصل الدائن علي سند ينفذ بمقتضاه، ولعل قسوة المشرع علي المحجوز لايه يبررها سوء نيته الأي يستشف من امتناعه عن التقرير. والواقع أن جزاء الاخلال بالتقرير بما في الأمة هو عقوبة مدنية علي المحجوز لايه، فلا يحكم عليه به إلا في الحدود التي وضعها المشرع، ويلاحظ علي هذا الجزاء

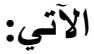
ا - لا يستفيد منه إلا الحاجز الأي رفع الدعوي. r- - تعدد المخالفة بتعدد الحاجزين لما كان حجز يخول الحاجز إلزام المحجوز لايـه بـالتقرير بمـا في ذمته، وهذا الأخير ملزم بهذا الواجب في مواجهة كل حاجز علي حدة، فإنـه يكون لكل منهم حق ذاتي في طلب توقيع هذا الجزاء، ولا يمنـع من توقيع الجزاء سبق الحكم بـه لحساجز

r- لا محل لاختصام المحجـوز عليـه ولا محل لتذخلهـ، اللهـم إلا إذا تعلق التـزاع بحقيقة بيانات التصريح، وما إذا كان المحجوز لايه قد غير الحقيقة. ع ـ تنفيذ الحكم بـالجزاء يـتم وفقـا للقواعد العامـة، باعتبـار المحجـوز لايـه مـدينا ل الحاجز. 


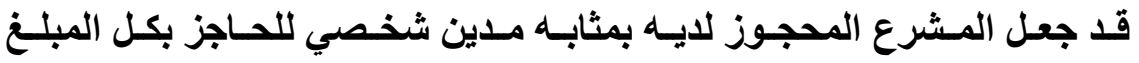
المحجوز من أجله، وذلك عند تراخيه في أداء ما يتطلبه منه القانون، وهذا التنفيذ يعد الدئ وفاء للاين الحاجز علي المحجوز عليه، ولا يعد بمثابة تعويض للحاجز نتيجة غش فئه خصمه أو تدليسه أو تقصيره('). •ـ ـلول المحجوز لايه محل الحاجز.

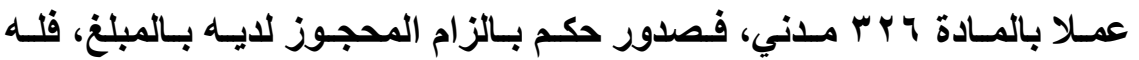

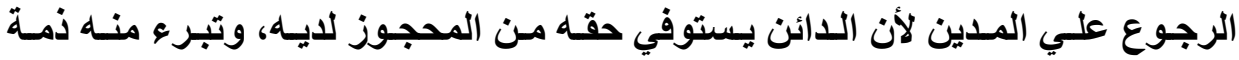

المدين، والرجوع يكون في حدود القدر الزائد علي مقدار الدين الذي في ذمته له(ب)". ثانياً: شروط تطبيق الجزاء: يجب أن يتو افر الثروط حتي يحكم القاضي بالززام المحجوز لايه بالدين: ا - أن تتوافر حالة هن حالات الإخلال بواجب التقرير: حدد المشرع في المسادة ب ؟ ب مرافعات صورا ثلاثثة يمكن أن يأخذها الإخلال بواجب التقرير بما في الأمة، وتتمثل في الاتي: r- r عدم القيام بالتقرير بالشكل المبين في القانون: يتحقق الإخـلال بواجب التقريـر في الصور الثثلاثـة الآتيةـ("): الأول: ألا يقوم المحجوز لايه بالتقرير إطلاقا، والثاني: ألا يقوم المحجوز لايه بالتقرير في الميعاد في الائه

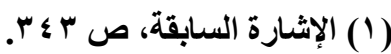

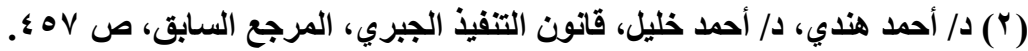

(3) perrot et thery, saisie attribution, la situation du tiers saisi, D. 2001, chron, 714 ; Cass. Civ., 2e, 9 juill. 1986, JCP, 1986, V., 279. 
خلال الخمسة عشر يومـا التالية للتكليف في القـانون المصري وخلال ع ب سـاعة في القانون الفرنسي، وقد خفف القضاء الفرنسي من هذا الالتزام حيث عذر المحجوز لايـه في تقديم التقرير في الميعاد في حالة كان مستلم الاعلان غير مخول بصلاحية تقديم

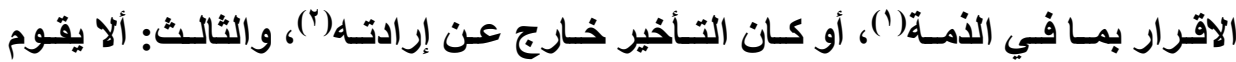
المحجوز لايه بالتقرير في الشكل الذي حدده القانون أي محضر بقلم الكتاب يحتوي علـي البيانـات اللازمـة. وإذا تقدم المحجـوز لايـه بـالتقرير قبـل الحكم بـالحكم عليـه لا

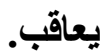

\section{r- التقرير بغير الصقيقة:}

الفـرض في هذه الحالـة أن المحجـوز لايـهـ قـام بـالتقرير في الميعـاد والشكل

المطلوبين قانونا، لكنه من حيث المضمون لـم يـكر - متعددا- حقيقة علاقة المديونية

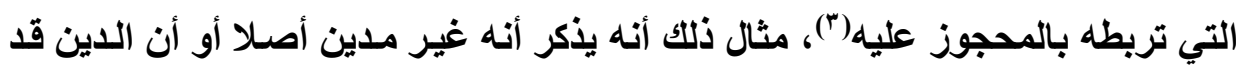
انقضي بالوفاء رغم ثبوت المديونية، أو أن يأكر أنه مدين بمبلغ معين ثبت ذلك أنه أقل

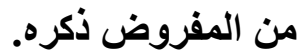

\section{ع- إخفاء الأوراق الواجب إيداعها لتأييد التقرير:}

حتى يمكن التحقق من صحة البيانات التي يذكرها المحجوز لايه، يجب عليه أن

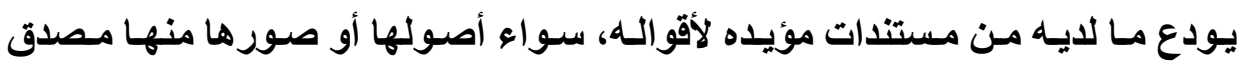

(1) Cass.civ. 2e, 4 oct. 2001, D. 2002, 1304, note Daverat; Cass. Civ. 2 e 16 oct. 2002, JCP, 2002, IV, 2898; Cass. Civ. 2e 15 dec. 2005, JCP. 2006, IV, 1119.

(2) Cass. Civ. 2e,28 janv. 1998, Bull. Civ., II, ${ }^{\circ}$ 35; Cass. Civ. 2 e, 8 sept. 2011, D. 2012, 420, note perrot et thery.

(3) Cass. Civ., 2e, 9 juill. 1986, op. cit. 
عليها، فإذا لم يقدم هذه الأوراق ودون تقديم تفسير مقبول لعدم وجودها فإنه يعتبر مخلا بالواجب الذي يفرضه عليه المشرع.

ويلاحظ أن الصور الثلاثة أتت في التثريع علي سبيل الحصر، فلا يجوز إضافة

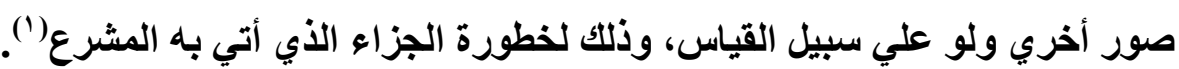
يلاحظ أن المشرع في الصور الثلاثة التي سبق عرضها، يقرر الجزاء ليس فقط

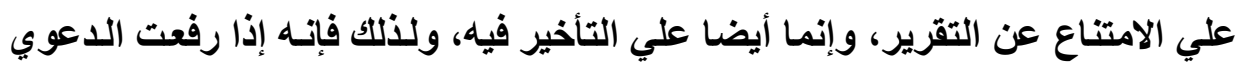
للحكم علي المحجوز لايـه بـالجزاء المقرر فقام المحجوز لايـها بـالتقرير علي الوجهـ

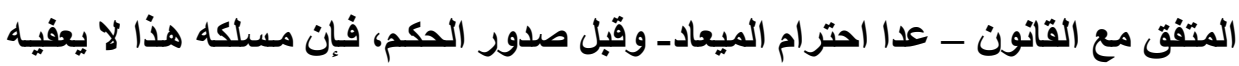

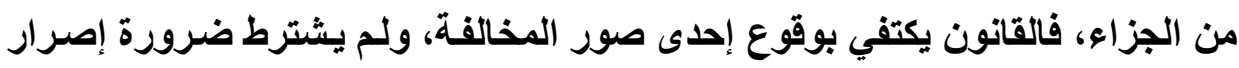

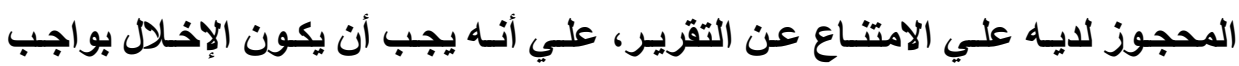
التقرير راجعه إلى سوء نية المحجوز لايه أو نتيجة تواطئه مع المحجوز عليه("). وبالتالي إذا كان تغير الحقيقة راجعا إلى حسن نية المحجوز لديه، اعتقادا منـه

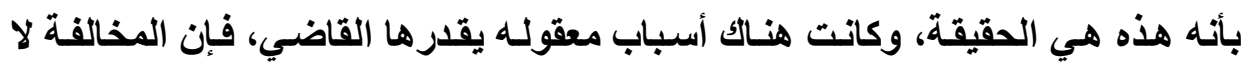
تتحقى في شأنها.

\section{ه- ألا يكون واجب التقرير قد انقضي:}

يجب ألا يكون المحجوز لايه قد أعفي من التقرير أو ألا يكون الحجز قد زال(")،

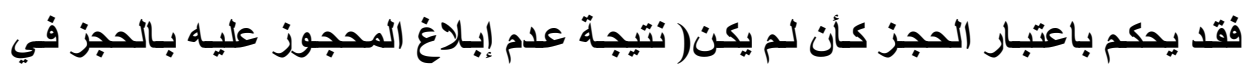
(1) د/ أحمد هندي، د/ أحمد خليل، قانون التنفيذ الجبري، المرجع السابق، صه ه ؛.

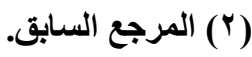

(3) Cass. Civ., 2e, 9 juill. 1986, op. cit. 
الميعاد أو عدم رفع دعوي صحة الحجز في الميعـاد)، أو حكم ببطلانـه لأي سبب كـان (نتيجة تخلف بيان جوهري في ورقة الحجز مثثلا أو لوقوعه علي مـال لا يجوز الحجز عليه) أو بسقوطه ( فالحجز الواقع تحت يد إحدى المصالح الحكومية يجب تجديده في الميعاد و إلا سقط).

إذن صحة الحجز مفترض أساسي لقيام واجب التقرير، ومن ثم لا يكون هنـاك محل لتوقيع الجزاء، إذا لم يكن الحجز صحيحا، كذلك إذا كان الدين انقضي لاي سبب

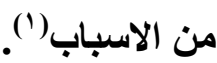

\section{1- أن يتوافر بيد الحاجز سند تنفيدي:}

إذا كان المشرع سمح للائن الحاجز بحجز مـا للمدين للدي الغير بدون اشتراط أن يكون بيده سند مكتمل الثروط()، إلا أنه نص علي وجوب أن يكون بيدي الحاجز سند للحكم بالجزاء، والحكمة من تطلبه أن الجزاء الذي سيوقع هو إلزام المحجوز لديه بالوفاء للحاجز بالدين المحجوز من أجلهه، فإذاذا لم يكن جائزا اقتضاء هذا الدين من المحجوز عليه لعدم وجود سند تنفيذي بعد، فلن يكون منطقيا اقتضاؤه من المحجوز

(1) Id.

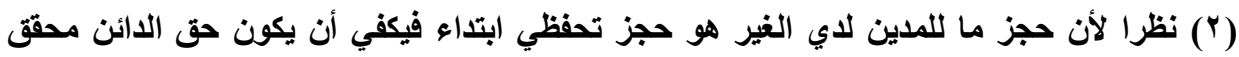

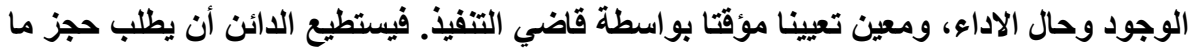

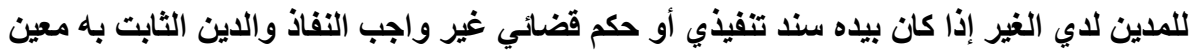

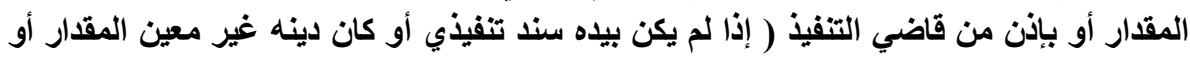

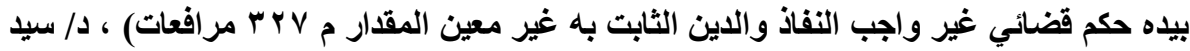

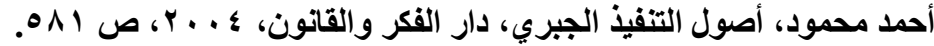




\section{- - أن يكون لدي الحاجز هصلحة في توقيع الحجر:}

عندما يحصل الحساجز علـي حقـه مـن المحجـوز عليـه أو مسن أي طريـق آخر،

لم تعد له مصلحة في إلزام المحجوز لايـه المخل بواجب التقرير بالوفاء لله، بالوفاء

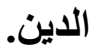

يجب أن يكـون للــاجز مـصلحة في التقريـر، وذلــك لأنسه يعتمــ علـي تقريـر المحجوز لايه في تحديد الدين أو المـال الذي في ذمته المحجوز لايـه، للقيـام بـالحجز علي هذا المال واستفاء حقه.

\section{1- أن يطلب الحاجز هن المكمة توقيع الجزاء:}

فالجزاء الذي نص عليه المشرع لا يقع بقوة القـانون، وإنمـا يجب علـي مـن تقرر لـصالحه أن يطلبهـ في صـورة دعوي موضـوعية ترفع في مواجهة المحجوز لايسه بـالإجراءات المعتـادة أمسام قاضسي التنفيذ، والمحكمة المختصة محليا هي محكمـة التتفيذ التـي يتبعهـا مـوطن المحجوز لايسه. وترفع هـه الـدعوي دون التقيــ بميعـاد

وقد ترفـع الـدعوي مـن المحجـوز عليـه في مواجهـة المحجـوز لايـه، إذ مـن مصلحة المحجـوز عليـه أحيانـا إثبـات حقيقة المديونيـة، فعندها ينكر المحجـوز لايـه كل الحقيقة أو بعضها، فمن مصلحة المحجوز عليه إثبات الحقيقة حتي ولو أدي ذلك إلى حصول الحاجز علي مـا سيثبت من الحقوق، ففي ذلك انقضاء لالتزام المحجوز عليـه أو تخفيـف مـه علـي كل حسال. ويجـوز للمحجـوز عليـهـ رفـع الـدعوي حتـي لـو لـم يحل حقهـ في مواجهة المحجوز لايسه بعد، إذ تكفي المصلحة المحتملـة في هذه

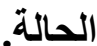




\section{ثالثا: طرق الإثبات في دعوي هسئولية الغير المجوز لديه}

ثار الخلاف بين الفقهاء في طرق الإثبات التي يجوز للدائن الحسجز أن يسلكها في الاعوي التي يرفعها ضد المحجوز لايه بالمنازعة في التقرير بمـا في الأمـة، وذلك الإنك تبعا لما إذا اعتبرنا الحاجز من طبقة الغير أم أنه يستعمل حق مدينة المحجوز عليه(')،

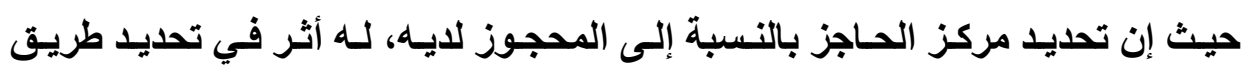
الإثبات. علي حسب طبيعـة دعوي المنازعـة في التقريـر()، هل تعتبر دعوي غير مباشرة؟ أم أنها دعوي خاصة بالحاجز؟ ويمكن أيجاز أراء الفقه في اتجاهين:

الاتجاه الأول: الحاجز من الغير فله استعمال كافة طرق الإثبات(").

$$
\text { الاتجاه الثاني: الائن الحاجز يعتبر من الغير }
$$

يتجه رأي إلى أن الدائن بمجرد توقيع الحجز يعتبر من الغير(؛) بالنسبة للعلاقة بين المحجوز عليه والمحجوز لايسه، فيجوز لله أن يثبت دين المحجوز عليهه في ذمـة المحجوز لايه بكافة طرق الإثبات المقررة قانونا بما في ذلك شههادة الشهود والقرائن حتي لو كان هذا الدين يجاوز نصاب البينة، باعتبار أن الحاجز يستعمل حقا خاصسا بـه،

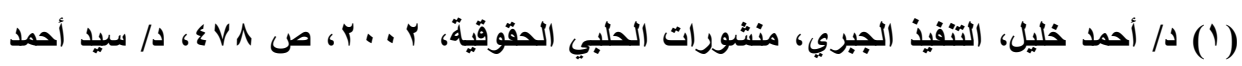

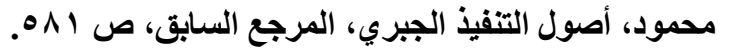

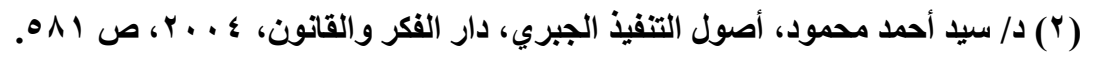

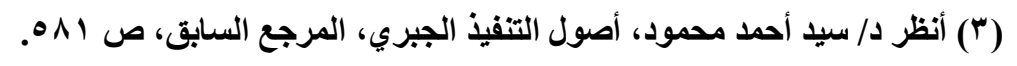

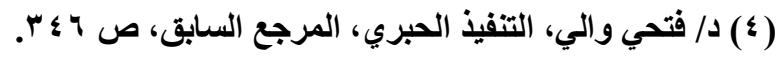


وليس بمدينه المحجوز عليه، ولا يحتج عليه بـالأوراق العرفية المنسوب صدورها للمجوز عليه إلا إذا كانت ثابتة التاريخ قبل الحجز. وقد رؤي أن العمل بهذه القاعدة يقتضي إلزام جميع المدينين بإثبات تاريخ كل أوراق التخالص التي يحصلون عليها من دائنيهم، احتياطا لمجرد احتمسال أن تقع بعد

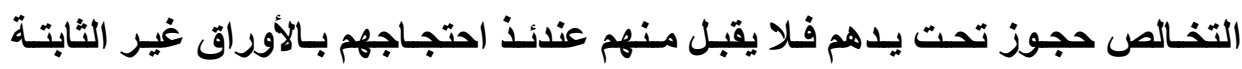
التاريخ، وفي هذا ارهاق وعنت ولهذا يجب القول تيسيرا بالمدينين بإعفاء المحجوز

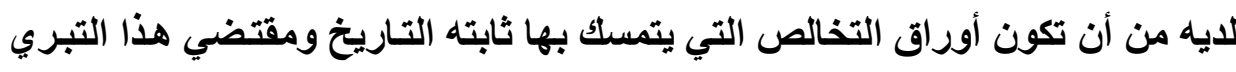

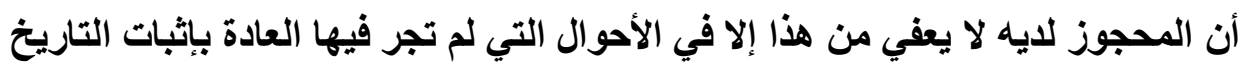

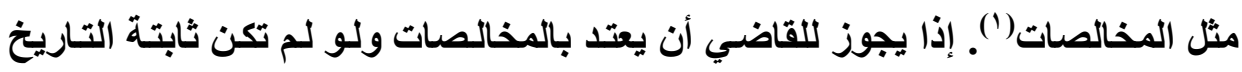

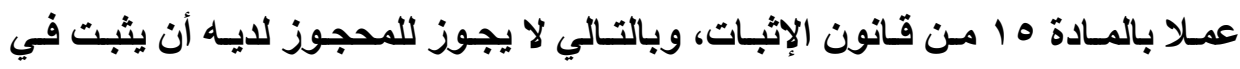
مواجهة الحاجز براعة ذمته بدليل كتابي غير ثابت التاريخ قبل الحجز عملا بالمبادئ

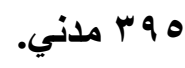

وبالتالي تعد دعوي المنازعة في التقرير المرفوعة من الحاجز دعوي خاصة بالحاجز يرفعها باعتباره حاجزا، ولا يستعمل حقا لمدينة، ويترتب علي هذا التكييف، لن يكون الاختصام للمجوز عليه الزاميا، وسوف يكون للحاجز إثبات حق المحجوز عليه

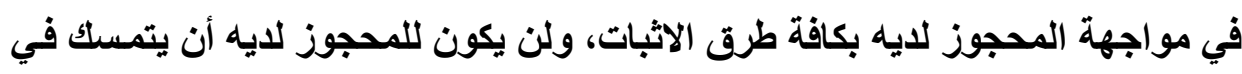


مواجهـة العـاجز بـالأوراق العرفيـة إلا إذا كانـت ثابتـهـه التـاريخ باسـثنـاء المخالـصات وبشرط عدم التواطؤ (1).

ويري البعض أنه يجوز للحساجز إقامـة الدليل علي مديونية المحجوز لايـه بكل

$$
\text { طرق الإثبات علي اعتبار أنه يتعذر عليه الحصول علي دليل كتابي(؟) }
$$

ويبرر هذا الاتجـاه موقفه بـأن الدائن بمجرد توقيعه للحجز لا يمكن اعتبـاره ممثلا لمدينه، إذا يصبح صاحب حق ذاتي يجعله من الغير بالنسبة لكل تصرفات هذا الدين(")، فالحاجز لا يستعمل حقه في الدعوي الغير مباشرة، حيث لا تتوافر في هذا لنوع من الحجوز شرائط استخدامها، كمـا أنـه يباشر الحجز باسمه ولحسـابه الخـاص

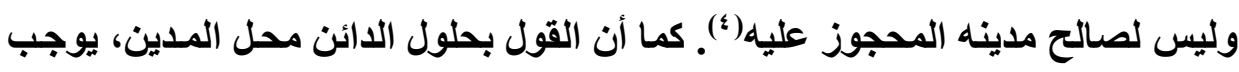
اعتبار الحكم الصادر في المنازعة حجة علـي مدين أيضا، فضلا عن قيامسه بمـوالاة الدعوي أصالة عن نفسه وهذا قول لا يسلم بـه الفقه والقضاء ومن ثم يقسط التبرير المتقدم.

نجد أن السلطة التي خولها القانون للحسجز في توقيع الحجز مـا للمدين للاي الغير الأي يعتبر في الأصل من الغير بالنسبة له، ترجع إلـي أن القانون قد أقام علاقة مباشر بين الحاجز والغير. فهذا الاخير لا تربطه بالحاجز ايـة رابطة قانونية. فالحسجز

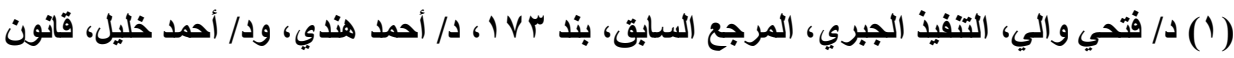

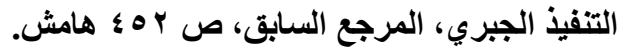
(ץ) د/ أحمد ابو الوفا، إجراءات التنفيذ بمقتضي قانون أصول المحاكمات اللبناني الجديد، ط؟،

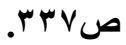

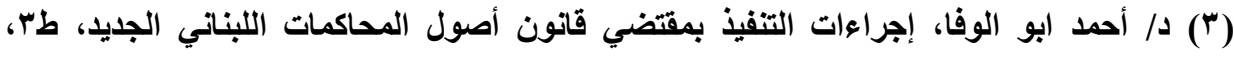

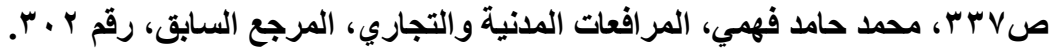

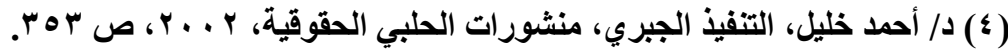




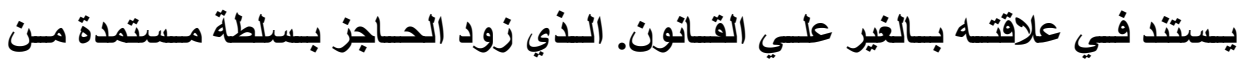
علاقته بمدينة الأصلي المحجوز عليه. وأجـاز بنـاء علـي هذه السلطة إلقـاء الحساجز

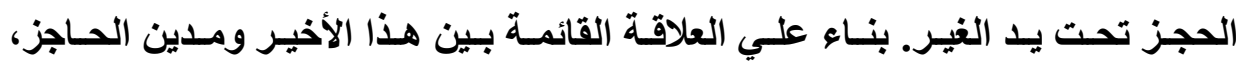

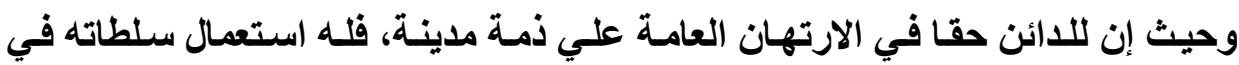
توقيع الحجز علـي هذه العناصـر كمـا لـو كانت قائمسة في ذمـة المحجوز عليـه ذاتـه. والقانون يقتحم هذه الروابط مقيما رباطا اصطناعيا بين الدائن الأصلي ومدين مدينهـ الثخص الثالثــ ممكنا الأول من إلقاء الحجز علي ما في ذمـة الشخص الثالث لحساب مدينه الأصلي (1)

\section{الاتجاه الثاني: للحاجز استعمال طرق إثبات المتاحة للمجهوز عليه:}

يذهب الرأي الراجح في مصر وفي فرنسا إلى أن الحاجز ليس من الغير(؟)، بـل يحل محل المحجوز عليه في الإثبات(")، حيث يري الفقه الحاجزين في دعوي التقرير بما في الأمة أنه لا يعتبر من الغير من حيث الأدلة الجـائزة في إثبات الدعوي أو نفيها

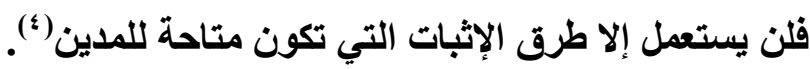

إذن الحاجز يحل محل مدينه المحجوز عليه في المطالبة بحقه، فلا يجوز لـه أن يسلك من طرق الإثبات إلا ما كان جائزا للمحجوز عليه، ومن ثم لا يجوز لـه أن يثبت دين المحجوز عليه في ذمة المحجوز لايه بالقرائن وشهادة الثهود إذا لم يكن الإثبات

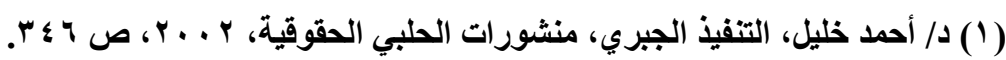

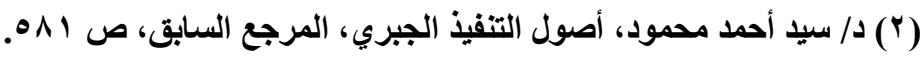

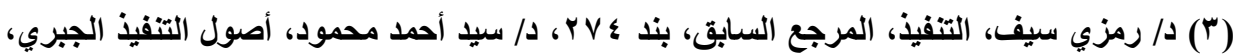

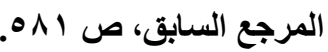

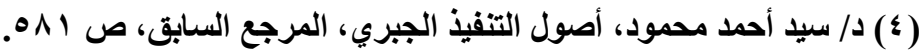


بهذين الطريقين جائزا للمحجـوز علي نفسه(')، وذلك لأن الحساجز يستمد حقة في دعوي المنازعة من مدينه المحجوز عليه، فيسلك فيها من طرق الإثبات مـا يجوز للأخير أن يسلكه فيها، فإن كان الدين يتجاوز نصاب البينة، فلا يجوز للائن التائن الحاجز

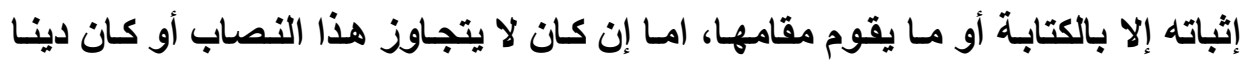
تجاريا أو توافر المانع الأدبي من الحصول علي دليل كتابي، جاز للحاجز الإثبات بكافة الإنة

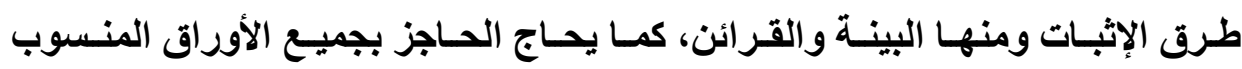

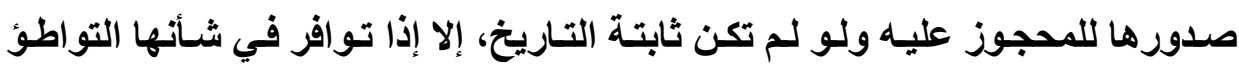

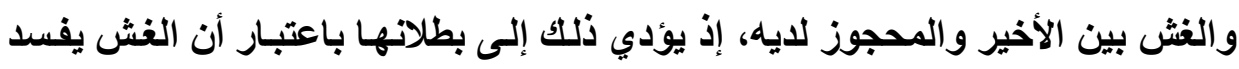

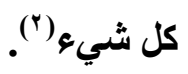

ذهبت بعض أحكام القضاء القرنسي إلى أن الحاجز ليس من الغير في معني

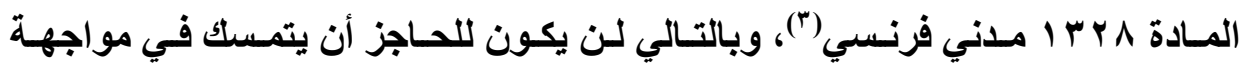

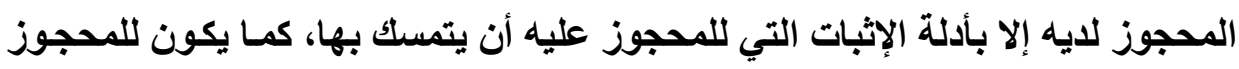

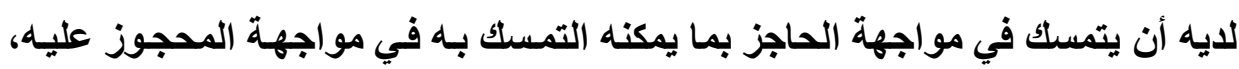
وبصفة خاصة الاحتجاج عليه بالورقة العرفية، ولو لم تكن ثابته التاريخ.

قد ذهبت بعض الأحكام إلى أنه يجوز للمحجوز لديه أن يحتج علي الحاجز في دعوي المنازعة في التقرير بالأوراق العرفية الصادرة من المحجوز عليه ولو لم يكن تاريخـا ثابتا قبل الحجز، والاحتجـاج علي الحاجز بـالأوراق غير الثابتة التاريخ قبل التبل

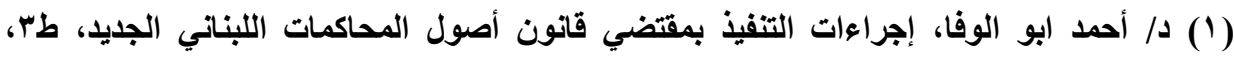

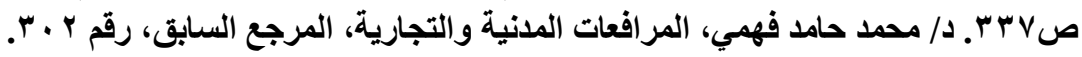

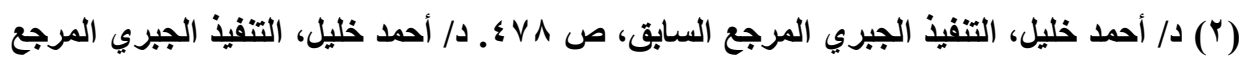

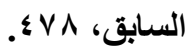

(3) Cass. 29 octobre 1890, siry, 1891, I, p. 305.

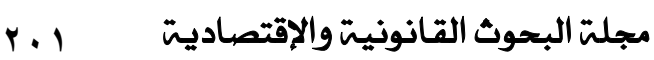


الحجز مشروط بانتفاء الفش، ومن ثم يجوز لـه أن ينكر حجية هذه الأوراق متي أثبت

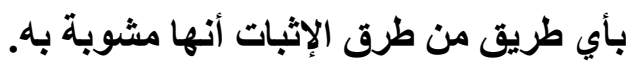

اختلف الشراح في تبرير اتجاه الرأي المتقدم، فقيل إن الحاجز حين مطالبته

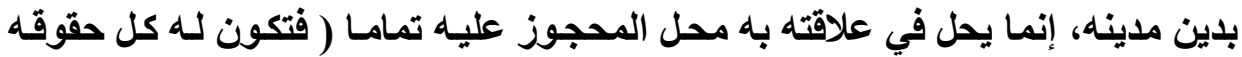

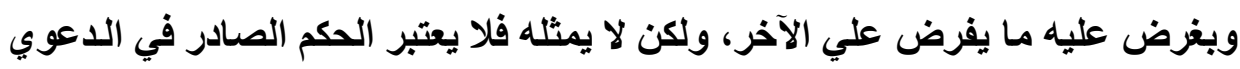

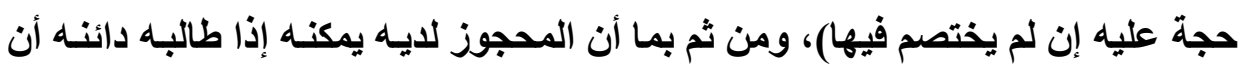
يحتج عليه بالأوراق الصادرة منه ولو كان تاريخها غير ثابت، يجب ألا يتغير مركزه وألا يضار بسبب طارئ لا شأن له فيه وهو حصول المطالبة من دائن دائنه بلا من الهن دائنه، ويترتب علي هذا التبرير أن المحجوز لديه يعفي في جميع الأحوال من تقديم أوراق ثابته التاريخ.

وييرر البصض هذا الاتجاه علي اساس اعتبار هذه دعوي غير مباشرة يحل فيها

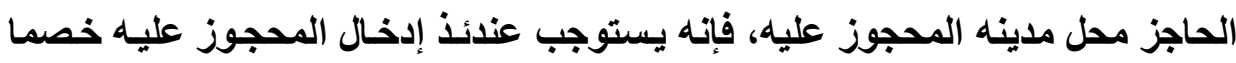

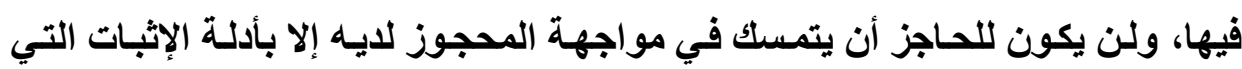
للمحجوز عليه أن يتمسك بها، كما يكون للمحجوز لديه أن يتمسك في مواجهة الحساجز

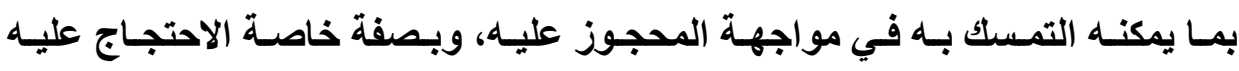
بالورقة العرفية، ولو لم تكن ثابته التاريخ. ويري أنصار هذه الاتجاه أنه يترتب علي اعتبار الحاجز من الغير إلحاق ضرر بـالمجوز لايسه وقد يكون جسيما إذ يسهل علـي الحساجز إحضار شـاهدين يقرران بمديونية المحجوز لايه،، كما أن هذا الرأي لم يستند إلى قاعدة قانونية تقرر اعتبار

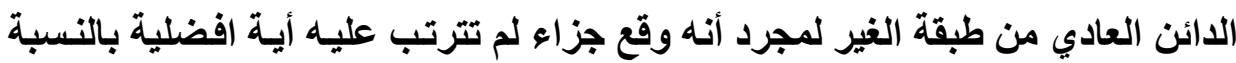
له ولم يجر له حق تتيع المحجوزات في حالة التصرف فيها لحائز حسن النية. 
أما هذا الرأي هو الذي يتفق والقواعد القانونية العامة التي تجعل الدائن العادي ممثلا في شخص مدينه وتتعدي إليه حجية الحكم الأي يصدر ضد الأخير، وأنها يستمد حقه من مدينة ولولا علاقة الدائنيه لامتنع توقيع الحجز.

رأي الباحث:

في الواقع لا يعتبر حجز ما للمدين لاي الغير صورة من استعمال الدائن لحقوق

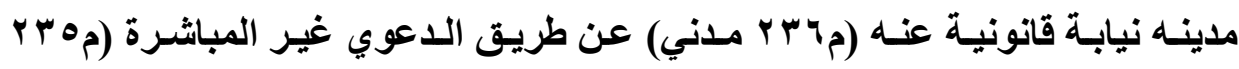
مدني)، حيث إن الحجز مستقل عن الدعوي غير المباشرة، لأن الدائن الحساجز يستعمل حقه في مواجهة مدين المدين (م ا آ مرافعات) وليس حقوق مدينه في مواجهة مدين

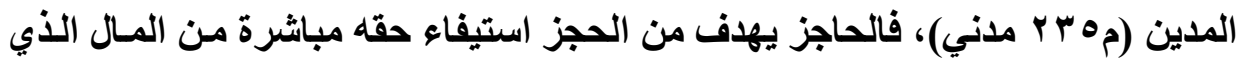
تحت يد الغير أو من ثمن بيع هذه المنقولات، وليس مجرد إدخال هذه المنقولات أو تحصيل هذه الديون لإدخالها ضمن أموال المدين أي في الأمـة الماليـة للمدين كنتيجة للحكم في الدعوي غير المباشرة، لتكون معا ضمانا عاما له ولغيره من الدائنين. كما أن حجز مـا للمدين لـدي الغير يؤدي إلى منـع الغير من الوفـاء بمـا في ذمته للمـدين أو

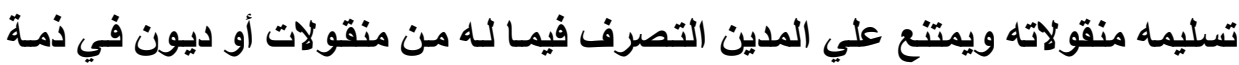
الغير، بعكس استعمال حقوق مدينهـ للدي الغير بالدعوي غير المباشـرة، حيث يملك

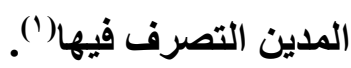
إذن الدائن الحاجز يستعمل حقا خاصا به، ونظمه المشرع، كجزاء علي الإخـلال بالواجب القانوني المفروض علي الغير المحجوز لايهاه. ونري أن الحـاجز في دعوي الالزام الشخصي، يمارس حقا خاصا باه، منحه إياه القانون تجـاه المحجوز لايسه، وهذا 
الحق مستقل عن المحجوز عليه، فالقانون يعاقب المحجوز لايه علي تقصيره في عمل ألزمه به المشرع، وهو الاخلال بواجب التقرير بمـا في الأمسة، لذا يمكن توقيع الجزاء حتي لو لم يكن المحجوز لايـه مدينا فعليا للمحجوز عليه. كمـا أن الحسجز لا يمـارس الاعوي غير المباشرة، وذلك لأن الحكم الصادر لا يكون حجة علي المحجوز عليه. كمـا أن الهـف من الدعوي غير المباشر والدعوي الإلزامية الشخصية مختلف، فـالأولي تهدف إلى الحفاظ علي الضمان العام، أما الثانية فتهدف إلى مجازاة المحجوز لايه، فقد الإندائ يخسر الحاجز دعواه ومع ذلك يرفع المحجوز عليه دعوي علي المحجوز لايهه ويكسب

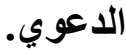

لذا نري أن الحاجز يعتبر من الغير بالنسبة للعلاقة بين المحجوز عليه والحاجز، وبالتـالي يمكن لله أن يتمسك بجميع طريق الإثبات الجـائز للغير أن يتمسك بها طبقا لأحكام قانون الإثبات سواء بشهادة الثهود أو القرائن.

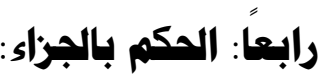

إذا توافرت الثروط السابقة فالمحكمـة ليست ملزمـة بتوقيع الجزاء الذي نص عليه المشرع و إنمـا تتمتع في هذا الصدد بسلطة تقديريـه، وإذا حكمت بـالجزاء، فلها توقيعه كاملا أو علي نحو جزئي بحسب مدي خطورة مسلك المحجوز لايه وسوء نيته. وتجـدر الاشــارة إلـى أن القضاء والفقـه فـي فرنسـا يمسيلان إلـى القـول بعـدم إعمـال الجزاء إلا عند ثبوت اصرار المحجوز لايسه علـي المخالفة، بحيث إذا اتخذ مـا أوجبـه عليـه المشرع قبـل صـدور حكم حـائز لقوة الشيء المحكوم بـه امتــع توقيع الجزاع (').

(1) Cass. 6 juill. 1903, D.,1905, I., p. 506.

مجلت البحوث القانونيت والإقتصاديت ب 
وفي بعض القوانين مثل القـانون اللبنـاني لا تحكم المحكمة بـالجزاء إذا أبـدي المحجوز لايه عذر مقبولا تقديره المحكمة، وانما إذا أخفي الحقيقة وثبت ذلك بصدور الحكم في الاعوي، وكان ذلك عن عمد، الزم بـالتعويض طبقا لقواعد المسئولية فضلا عن الحكم عليه بدين الحاجز.

وإذا لـم يحكم القاضسي علي المحجوز لايـه بـالجزاء الذي نص عليـه المشرع، وإنما حكم عليه بمصاريف الاعوي والتضمينات المترتبة علي تقصيره أو تـأخيره في تقايم التصريح أو علي إخفائهه الحقيقة فمـا يحكم بـه للحسجز لا يشاركه فيه غيره من الحاجزين، الحكم الصادر لا يكون حجة إلا علي أطرافه، فعندما يتعدد الحاجزون ولـم ترفع الدعوي إلا من أحدهم فإن هذا الأخير لا يعد ممثلا لهم و إنمـا يعدل لحساب نفسه. وهو يقبل الطعن فيه طبقا للقواعد العامـة في استئناف الأحكام الصادرة في منازعات التتفيذ الموضوعية الصادرة من قاضي التنفيذ.

ولا يجـوز للمجسوز لايسه الرجـوع بـه علـي المحجـوز عليـه لأن مـا يحكـم بـه

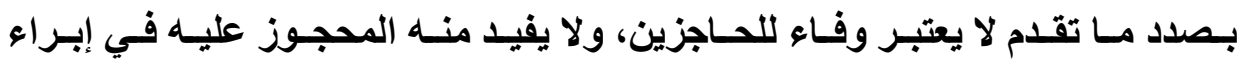

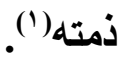

وتنص المادة ror مر بافعات علي أنه يعاقب المحجوز لديه بالعقوبة المنصوص

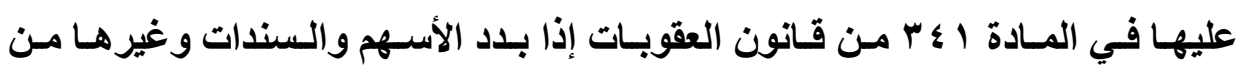
المنقولات المحجوز عليها تحت يده إضرارا بالحاجز. 


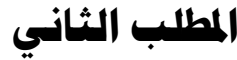 \\ التزام الغير بالمافظة علي المال المجهز عليه}

قد يكون الغير مكلفا بحراسة المال، فيجب عليه المحافظة علي المـال المحجوز عليه، ويعاقب مدنيا وجنائيا إذا اخل بواجباته. سنشير إلى التزامات الحارس، وجزاء مخالفة هذه الواجبات، وذلك في الفروع

\section{الفرع الأول \\ التزاهات الهارس}

يعتبر الحسارس من أعوان القضاء، فهو ليس وكيلا عن الحاجز أو المحجوز

عليه، ويؤدي الحارس خدمة عامة، ويأخذ بذلك حكم الحارس القضائي ('). والواقع أن الحراسة في القانون المصري لا تعد لازمة لتوقيع الحجز أو إجراء متمم أو مكمل لـه، ولكنها ليست سوي أثر من آثاره وهي ليست أثرا متمماب(؟)

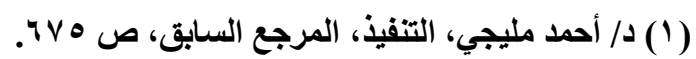

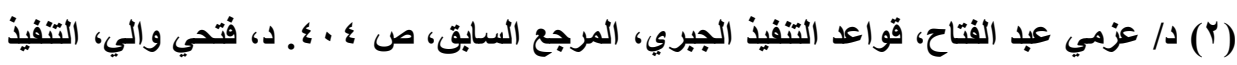

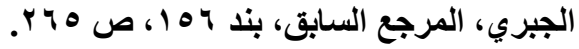




\section{بمقتضي تعيين الحارس، فإنه يلترزم بالواجبات الآتية:}

ا - التوقيه علي هصضر العبز:

يجب علي الحسارس طبقـا لنص المسادة צ ب مر افعـات أن يوقع علي محضر

الحجز وتسلم لـه صسورة منـه، فبإن امتـع عن التوقيع علـي محضر الحجز أو رفض

استلام صورته وجب علي المحضر أن يسلم صورة المحضر في اليوم ذاتـه إلى جهة الإدارة، وأن يخطر الحسارس بـللك خلال أربع وعشرين سـاعه بكتـاب مسجل، وعلي المحضر إثبات ذللك في المحضر.

\section{r- الالتزام بالاستمرار في الحراسة حتي يوم البيع:}

تنص المادة 9 جس مرافعات علـي أنـه "لا يجوز للحسارس أن يطلب إعفـاءه من الحراسـة قبـل اليوم المحدد للبيع إلا لأسـباب توجب ذلـك"، فالحسـارس بقبولـه القيـام بالحراسة يلتزم بالاستمرار فيها إلى يوم البيع')، ولكن قد تكون هنالك ظروف يقدرها قاضي التنفيذ تعفي الحارس من التزامسه بالحارسـة، كـأن يصاب بمرض أو يسافر إلى الخـارج، وإذا لـم يجد القاضـي عدم معقولية الأسباب التي استتل اليها الــارس، فإنـه يحكم برفض طلب التنحي من الحراسـة، وإذا اصر الحسارس عدم القيـام بواجبه، فإنـه يحكـم عليـه بالغزامـة التهـيليـة، وإذا لـم يـستجيب يحكـم بعزل الحسارس مــع الزامـه بالتعويض. 
ويرفع الطلب الإعفـاء من الحراسـة بتكليف المحجوز عليهه والحاجز الحضور أمسام قاضـي التنفيذ بميعـاد يوم واحد، فيلاحظ أن المشرع أضفى علي طلب الحسارس وصف الاستعجال، فقد نص علي رفعه بميعـاد حضور يوم واحد، وهو ميعاد حضور سـابق علـي يـوم الجلسة المحددة لنظره أمسام قاضسي التنفيذ والواجب انقضاؤه بـين التكليف بالحضور وبين الجلسة المحدة بهـ.

وتعتبر دعوي الاعفاء من الحراسة مرفوعة بـالإعلان المحجوز عليه والحساجز بعريضة التكليف بالحضور، خلافا للإجراءات المعتادة لرفع اللدعاوي والتي بموجبها تعتبر اللدعوي مرفوعة بمجرد إيداع صحيفتها قلم الكتاب، ويكون المشرع قد حدد طريقا لرفع الدعوي المتعلقة بإعفاء الحارس مغاير للطريق المعتاد ('). إذا قضي بإعفاء الحسارس، تعين علي قاضسي التفيذ تعيين حارس آخر، وقد نصت المادة 9 ج مرافعات علي أن هذا الحكم غير قابل للاعتر اض عليه بـأي طريق من طرق الطعن، ويجرد المعاون الأثياء المحجوزة عند تسليم الحارس الجديد مهمته، ويشبت هذا الجرد في محضر يوقع عليه هذا الحارس ويسلم صورة منه.

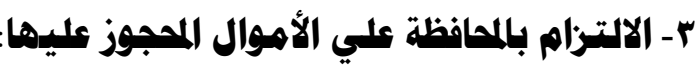

الواجب الأسساسي علي الحسارس باعتبـاره من أعوان قاضسي التتفيذ المحافظة علي الأشياء المحجوزة إلى وقت البيع أو انتهاء الحجز بـأي سبب آخر(")، وتقديمها يـوم البيع، ويلتزم في ذلـك بكل مـا يلتزم بـهـ الحسارس القضائي(ّ)، وهـو يتقاضسى 
أجراً عن حراسته، ولهذا فإنه يلتزم بأن يبذل في حفظ الأثياء المحجوزة عناية الرجل

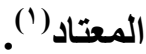

فيتعين علي الحارس القيام بأعمال الحراسة علي نحو يحفظ الأشياء المحجوز

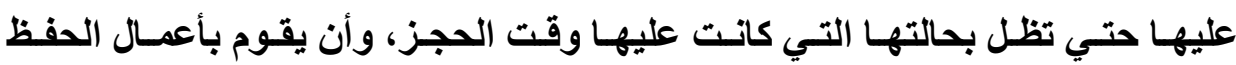
والصياتة اللازمة كما لو كاتت معدات يلزم تثغيلها من وقت لآخر، بحيث إذا قصر في ذلك تعرضت للتلف، فيصبح ملتزما في مواجهة أطراف التنفيذ بكل الأعمال التي تساهم في المحافظة علي الأشياء. ويلتزم الحسارس في حالـة حجز ثـان علي نفس الأمسوال المحجوزة، أن يقدم صوره من محضر الحجز السابق ويقدم الأثياء المحجوزة. يثار التساؤل عن التزام الحارس هل هو التزام ببذل عناية؟ أم أنه التزام بتحقيق نتيجة؟ يري الفقـه أن الحسارس يلتزم في حراسته عنايـة الرجل المعتـاد، وذلكت طبقـا لنص المادة ؛ VY مدني(")، وقد قضي في فرنسا بمسئولية الحارس عن تحطم مركب-

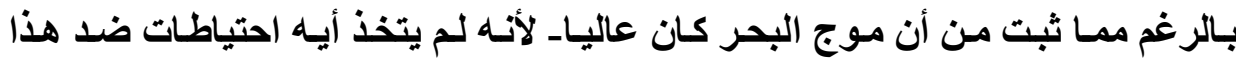

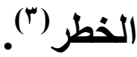

$$
\begin{aligned}
& \text { (1) د/ عزمي عبد الفتاح، قواعد التنفيذ الجبري، المرجع السابق، ص ^ م ـ؛. }
\end{aligned}
$$

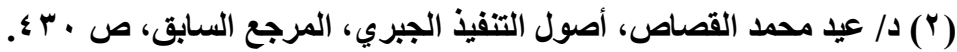

(3) Cass. Com, 6 mars `973, D., '973, p. 544.

مجلت البحوث القانونيت والإقتصاديت 


\section{§- التزام الحارس بعدم استعمال أو استغلال المال المجوز عليه:}

لا يجوز للحارس أن يستعمل الأشياء المحجوز عليها أو يستظها أو يعيرها وإلا

حرم من أجرة الحراسة فضلا عن التعويض(') ل

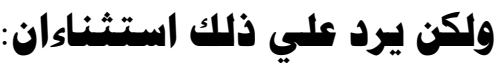

أ ـ إذا كان الحسارس ماكسا لها أو صـاحب حق انتفاع عيها فلـه أن يستعملها فيمـا

$$
\text { حصصت له (") }
$$

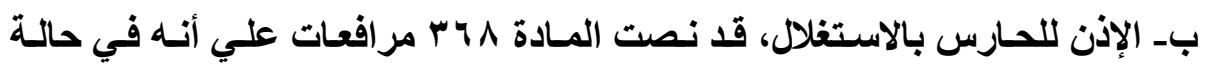
الحجز علـي ماشية أو عروض أو منقولات أو آلات لازمسة لإدارة أو استخفلال

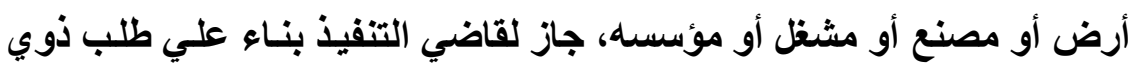
الشأن أن يكلف الحسارس الإدارة أو الاستغلال أو يستبال بـه حارسـا آخر يقوم

بذلك.

وبالتالي يمكن للحاجز أو المحجوز عليه إذا كان الحجز علي ماثيه أو آلات أو

مصنع أو أي مال يحتاج إلى استغلال رفع دعوي تنفيذ مستعجل بتكليف الحارس بإدارة

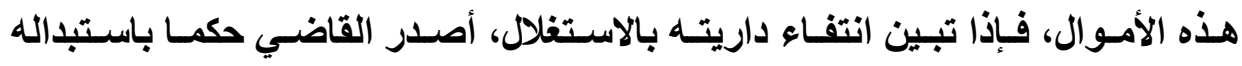

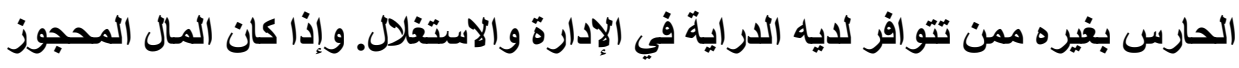

(1) ذهبت محكمة النقض إلى أن "مقتضي الحجز أيا كان نوعه وضع المال المحجوز تحت أمر القضاء

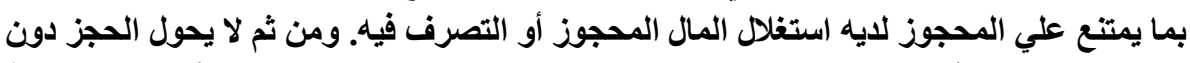

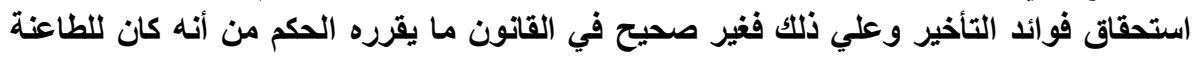

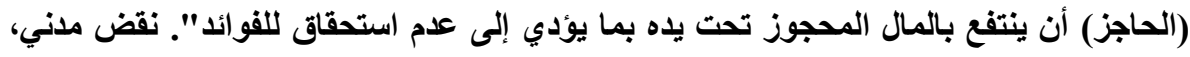

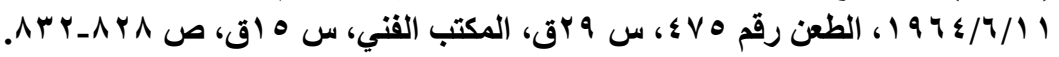




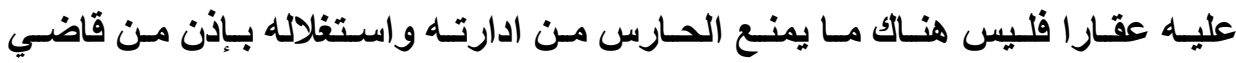

(التنفيذ) (1)

ويمكن للحسارس طبقا لنص المـادة • م مر افعـات أن يطلب الإذن مسن قاضسي

التنفيذ بجنـي أو حصاد النـاتج عن الاموال المحجوز عليها وذلك بعريضة تقدم إلى

$$
\text { القاضي أو من ذوي الشأن. }
$$

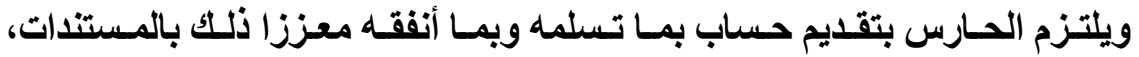

ويلتزم بتقديم هذا الحساب في نهايـة مهتـه في الحراسـة علـي الأكثر. ويمكن أن يـأمر

القاضي الحارس باتخاذ دفاتر حساب منتظمة موقع عليها من قاضي التنفيذ(؟).

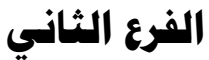 \\ جزاء هخالفة واجبات الحارس}

يلتزم الحسارس بالمسئولية الملقـاة علـي عاتقـه وفي حالـة اتـلاف أو فقدان أو

اختلاس للأشياء المحجوز عليها أو إخفاءها أو امتناع عن تسليمها، يرتب مسئولية قد تكون مدنية وجنائية، ولا يعفي من العقاب لو اعتقد بطلان الحجز لأن القصد الجنـائي في الجريمـة هو العبث بإجراعات التنفيذ القضائية، لا الاعتداء علـي ملكيـة الأشياء

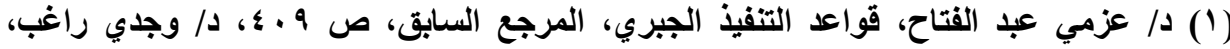

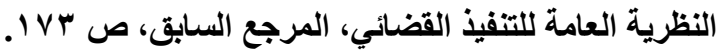

(ץ) د د عزمي عبد الفتاح، الإثارة السابقة. 
المحجوزة، لأنه لم يكن قد حكم ببطلان الحجز، إذا كان يجب اللجوء إلي القضاء للحكم

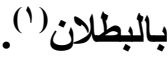

ويجوز رفع دعوي مستعجلة باتتهاء الحراسـة مسن جانب الغير، إذا فرضـ الحراسـة خطـأ علـي أعيـان مملوكـة لـه لا للخصوم، أو فرضـت علـي أعيانـهـ بطريـق التواطؤ بين الخصوم، وتقتصر المحكمة علي فحص ظاهر المستثلات فإذا استبان لها صحة ذللك قضت برفع الحراسة(؟). والواقـع أن الحسارس يعفـي مسن المسئولية إذا ثبـت أن الأضـرار التــي لحقــ

بالأشياء المحجوزة كاتت نتيجة لقوة قاهرة(؟).

\section{تنقسم الجزاءات الموقعة علي الهارس المخل بواجبه إلي نوعين:}

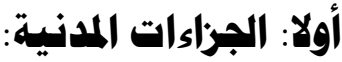

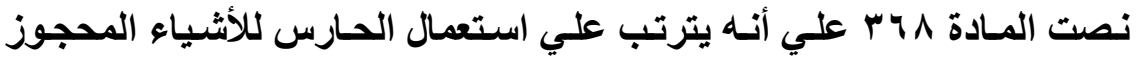
عليها أو قام بإعارتها للغير حرمانه من الأجر بالإضافة إلى إلزامه بالتعويضات. ويلاحظ أن هذا الجزاء مقرر لمصلحة طرفي التثفيذ، فيجب أن يطلب بـه الحسجز أو المحجوز عليه، ولا يحكم به القاضي من تلقاء نفسه، ويختص قاضسي التنفيذ بنظر هذه المنازعة وترفع لله في شكل دعوي موضوعية.

(1) د/ أحمد ابو الوفا، إجراءات التنفيذ بمقتضي قانون أصول المحاكمات اللبناني الجديد، ط؟،

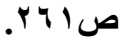

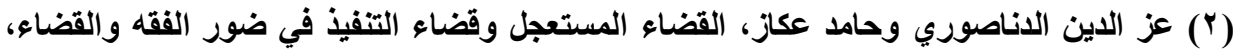

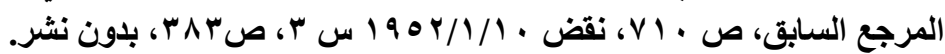

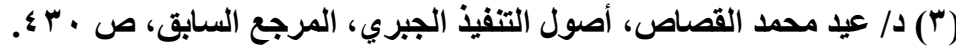




\section{ثانيا: الجرزاءات الجنائية:}

إذا بـد الحسارس الأشسياء المحجوزة عوقب بعقوبـة خيانـة الأمانـة، ولـو كـان هـو

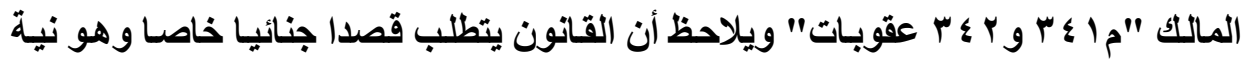
عرقلة التنفيذ، لأن الغرض من حماية قانون العقوبـات للمـال المحجوز ليس حماية الملكية و إنما المحافظة علي المال المحجوز لأغراض التنفيذ(')

وقد نصت المادة س مر مرافعات علي أنه يعاقب الحارس بعقوبة التبايد إذا تعدد عدم إبراز صورة محضر الحجز لمعاون التنفيذ، وترتب علي ذلك الإضرار بـأي من الحاجزين.

\section{الإطلب الثالث \\ التزام الغير بتسيير إجراءات التنفيذ}

توجـــ مجموعـة مـن الالتزامــات التـي تقـع علــي رجـال الـسلطة القـضائية والتنفيذيـة أثتاء التنفيذ الجبري، كمـا أن مخالفـة هذه الالتزامـات يترتب عليهـا بعض

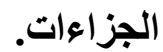

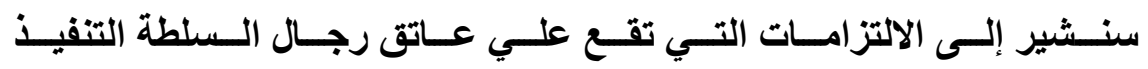

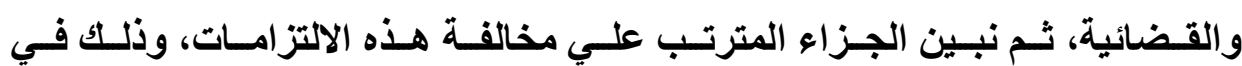

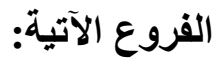




\section{الفرع الأول \\ الالتراهات التي تقع علي رجال السلطة القضائية والتنفيذية الهية}

لقد نص المشرع المصري علي مجموعة من الالتزامات تقع علي رجال السلطة القضائية والتنفيذية أثناء إجراء التنفيذ الجبري، وتتمثل في الآتي:

\section{ا - التزام المعاون بهباشرة التنفيذ إذا طلب ذلك.}

تنص المـادة rVq مرافعـات علي أنه يجري التنفيذ بواسطة معساوني التنفيذ،

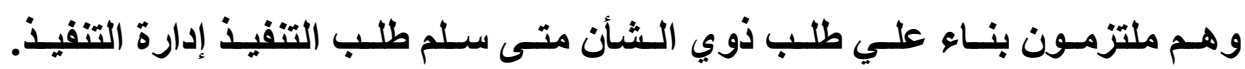
وإذا امتــع المعـاون عن القيـام بـأي إجراء مـن إجراءات التنفيذ كـان لصاحب الشأن أن يرفع الأمر بعريضة إلى مدير إدارة التنفيذ، وبنـاء علـي ذلك فِإن المعاون يستطيع

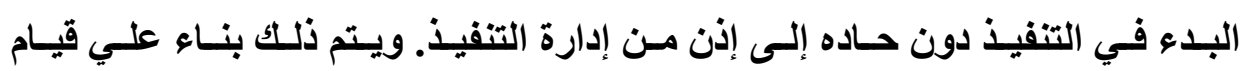
طالب التنفيذ بتحريك الجهاز القضائي للقبام بالتنفيذ الجبري عن طريق تقديم السند التنفيذي.

يشغل المعساون وهو موظف عـام يحلق بـإدارة التتفيذ مركزا هامـا في قانون المرافعات، فهو وحده المختص بإجراعات التتفيذ، ويقوم معاون التنفيذ بمعاونـة إدارة التنفيذذفي عمليـة التنفـذ، وفي الواقـع أن الذي يقوم بأغلب إجراعات التنفيذ هـو المعاون، ولكن تحت رقابة وإشراف إدارة التنفيذ، ويباشر المعاون إجراءات التنفيذ أيـا كـان طريقته، سـواء كـان تنفيذا مباشـرا أو غير مباثـر عن طريق الحجز، وقد أورد المشرع عدة نصوص اسند فيها القانون إلي المعاون بعض الواجبات أثناء التنفيذ، ويجب علي المعاون عرض ملف التنفيذ علي إدارة التنفيذ عقب كل إجراء لتأمر بمـا تزاه مناسبا. 
ويرتب عن ذلك أن المعساون يلتزم بـإجراء التنفيذ وفق الأوضساع والشروط المقررة في القانون منى طلب منه ذلك، فإذا امتنع دون الاستناد إلي حجة قانونية تبرر ذلك، كان مسئولا عن امتناعه وجاز لطالب التنفيذ أن يرفع أمره إلي مدير إدارة التنفيذ لجبره علي القيام بالتنفيذ أو اتخاذ الإجراء، أما اذا كان امتناعا مبنيا علي حجة قانونية كان له عرض الأمر علي ادارة التنفيذ لتفصل في الأمر('). ولكن يلتزم المعساون بعدم التعرض لمدي جديـة الإثكال في التنفيذ المرفوع أمامه(؟)، وإنما يترك هذا لتقدير قاضـي التنفيذ المختص تحقيقا للحكمة التي توخاهـا القانون من النص علي أن رفع الإثكال الوقتي يكون أمام قاضي التنفيذ باعتباره قاضيا للأمور المستعلة، ولا يجوز للمعاون الاطلاع علي مستتدات المستشكل، ويجب علي المعاون التحري عن سابقة الحجز علي ذات المنقولات المراد حجزهـا، ولا يلتفت إلى الأوراق غير الرسمية عند الحجز، ويقوم المعاون بإثبات كل ما يقدم إليهه من اعتر اض أثنـاء التففيذ، ويجب علي المعاون تعيين الأمكنة التي يجري فيها التنفيذ بالمحاضر وإفراد محضر للك منها.

\section{r- الالترزام بالإشراف علي أعمشال التنفيذ}

لقد حدد المشرع المصري اختصاص قاضي التنفيذ قبل تعديل قانون المرافعات بالقانون رقم V V لسنة V . . . . حيث نـص في المسادة ه PV علي أن يختص قاضسي التنفيذ، بجميع المسائل التي تتعلق بالتنفيذ الجبري، سواء أشـراف علي إجراءات التنفيذ أو كان الاختصاص بالفصل في منازعات التنفيـ. وذلتك في المواد ؟ ؟V إلي 
مرافعات. إلا ان ما جاء به المشرع من تعديل قصر اختصاص قاضي التفيذ علي الفصل في منازعات التنفيذ.

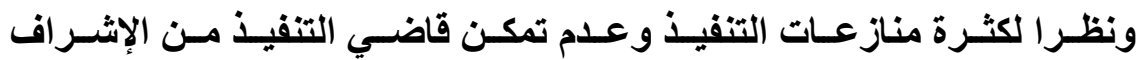

الكامل علي إجراعات التنفيذ، عمد بالمشرع إلـي تعديل نظام السلطة المختصة بالقيام

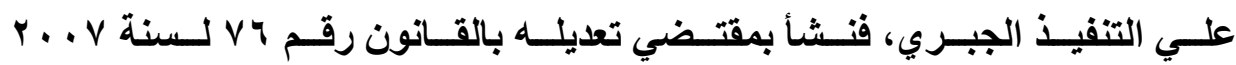
ما يسمي بإدارة التنفيذ للإشراف علي إجراعات التنفيذ الجبري، ولم يعد لقاضي التنفيذ دور إلا فيمـا يتعلق بالفـصل فـي المنازعـات الموضـوعية والوقتيـة المتعلقـة بالتنفيــ. حيث تتولي إدارة التنفيذ الإشراف والرقابـة علي إجراعات التنفيذ التي تتم وبواسطة المعاون.

\section{r- الالتزام بالفصل في هنازعات التنفيذ}

نص قـانون المرافعـات علـي اختصاص قاضسي التنفيذ في المسادة ه PV، حيث "يختص قاضسى التنفيذ دون غيره بالفصل فـ جميع منازعـات التنفيذ الموضـوعية والوقتية أياً كانت قيمتها. ويفصل قاضسى التنفيذ فى منازعات التنفيذ الوقتية بوصفة قاضياً للأمور المستعجلة". فقد قضت محكمة النقض بأنـه "مفــاد نص المـادة ه ا بمـن قـانون المرافعـاتـ وعلى مـا جرى بـه قضاء هذه المحكمةــ أن قاضسى التنفيذ يختص دون غيره بإصدار القرارات والأوامر المتعلقة بالتتفيذ وبالفصل فى جميع المنازعـات المتعلقة بـه سواء أكانت مناز عة موضوعية أم وقتية سواء أكانت من الخصوم أم من الغير ممـا مقتضاه 
أن قاضس التنفيذ اصبح دون غيره المختص نوعيا بجميع منازعات التنفيذ الوقتية

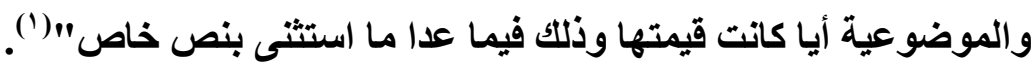
يختص قاضي التنفيذ نوعيا بمنازعات التنفيذ، فإذا تحقق صفة التنفيذ في مسألة أو المنازعة المثارة أنعقد الاختصاص بها لقاضي التنفيذ. في الواقع قاضي التنفيذ لا يعد

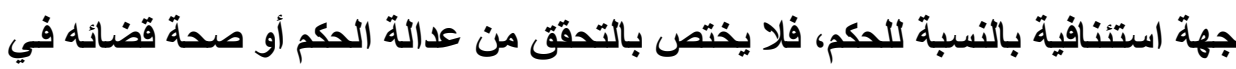

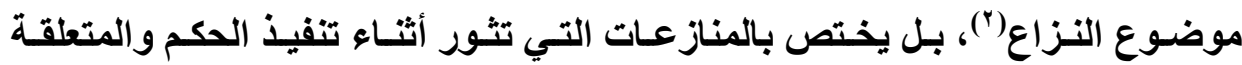
بإجراءات التنفيذ.

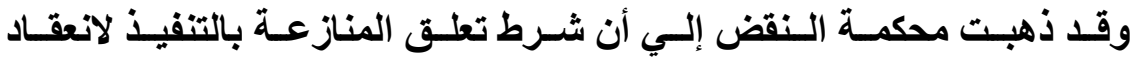
الاختصاص لقاضي التنفيذ يقصد به أن تكون منصبة علي أجراء من إجراءات التتفيذ او مؤثرة في سير التنفيذ وإجراء(ته(")، وان يكون التنفيذ جبرياً(). §- الالتزام باستخدام القوة إذا وجدت عقبة هادية أهام التنفيذ: يقتضي إجراءات التنفيذ الجبري تلذخل السلطة التنفيذ لمساعدة القضاء علي

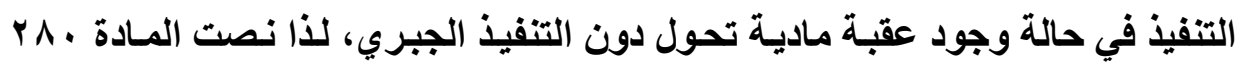

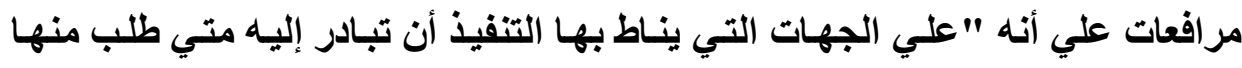
وعلي السلطات المختصة أن تعين علي إجرائه ولو باستعمال القوة متي طلب منها

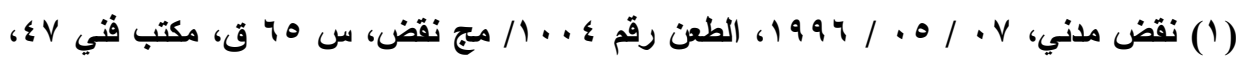

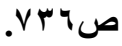

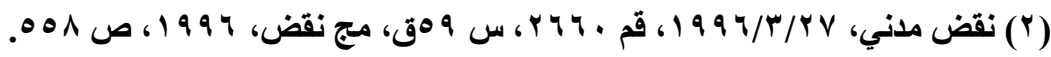

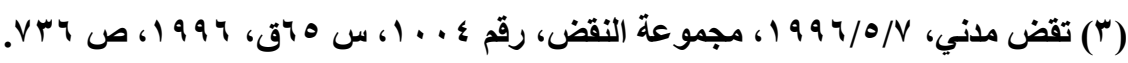

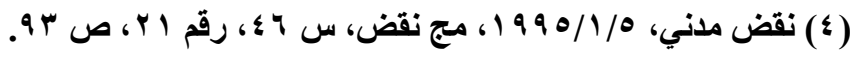


ذلك". والصيغة التنفيذية تتضمن أمر للمعاون بإجراء التنفيذ وأمر إلى رجال السلطة العامة بمعاونتهم، وهي تكتب حرفيا عند تحرير الصورة التنفيذية.

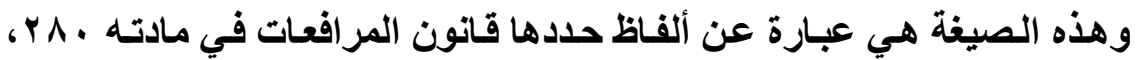
وهي توضع علي صورة السند في شكل ختم مستطيل بعبارة تهدف إلي منح الدائن الحق في التنفيذ بواسطة السلطة العامـة، وذلك باستخدام القوة الجبريـة إذا كـان هنـاك حاجة لذلك. وهذه الصورة تختلف عن أمر التنفيذ الذي يصدر بواسطة قاضي التنفيذ ليسبغ علي بعض الأوراق صفة السند التنفيذي. مثال ذلك أحكام المحكمين والأحكام الأجنبية والتي يراد تنفيذها في مصر، والحصول علي أمر التنفيذ هذا لا يغني عن

ضرورة وضع الصيغة التنفيذية علي السند التنفيذي حتي يمكن التنفيذ('). وتنص المادة rVq علي أنه إذا وقعت مقاومة أو تعد علي معاون التفيذ وجب عليه أن يتخذ جميع الوسائل التحفظية وله في سبيل ذلك- بعد عرض الأمر علي مدير إدارة التفيذ- أن يطلب معونة رجال السلطة العامة أو السلطة المحلية من أجل استخدام

\section{الفرع الثاني \\ جزاء الإخلال بالالتزاهات بتسيير إجراءات التنفيذ}

سنشير إلي الجزاعات التي تترتب علـي اخلال رجـال السلطة العامـةـ القضائية والتفيذيةـ بمباشرة إجراعات التفيذ، ثم نبين بعض أوجه القصور في هذه الجزاعات،

$$
\text { وذلك علي النحو التالي: }
$$




\section{أولا: الجزاءات علي الإخلال بهاجبات رجال السلطة العاهة:}

ا - المسئولية المدنية والتأديبية:

معاون التنفيـ يكون مسئولا عن خطئة قبـل أصـحاب الشأن إذا لـم يراعي مـا أوجبه القانون، وتكون الاولة مسئولة عن خطئة قبلهم أيضا، وذلك يكون المعساون

مسئولا مسئولية تأديبية التي يخضع لها موظفي الدولئ.

وإذا كان معاون التفيذ يؤدي عمله بناء علي طلب طالب التنفيذ، وإلا أنه موظفا

عامـا، فإنـه يخضع لقواعد المسئولية التأديبية التي تحكم الموظف العـام، وقد نظمت المواد \& 179 ـ1 19 من قانون السلطة القضائية المسئولية التأديبية للمحضر والمعاون. وذلك اذا أرتكب خطأ وظيفيا حتي ولم يسبب هذا الخطأ ضررا لخصم معين('). فإذا امتنع المعاون عن القيام بالتنفيذ بالرغم من صدور قرار من قاضـي التنفيذ فإنـه يكون محل المسئولية التأديبية. وقد يخضع المحضر للمسئولية المدنية اذا ارتكب خطأ سبب ضرراً للغير. وكذلك تكون الدولة مسئوله عن خطأ المحضر علي أساس مسئولية المتبوع عن أعمال التابع، وللمضرور رفع دعوي تعويض عن الضرر علي الحكومة والمحضر(). ويجوز للاولة الرجوع علي المحضر لأنها ليست مسئولة معه.

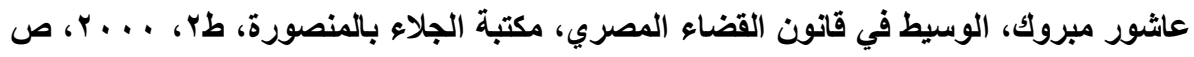


لقد نص قانون المرافعات علي بعض الأعمال التي تؤدي إلي مسئولية المعاون من ذللك ما نصت عليه المادة بr ؛ مرافعات اذا تسبب المعاون في تأجيل البيع أو إعادة الإعلان تكون مصاريف الإعادة علي حسابه، وإذا قام المعاون بتعيين حارس ثم اتضح أنـه غير مقتدر أو غير أمين وكـان المحضر سـيء النيـة أي يعلم بهذه الصفات وقت تعيينه، فإن المعاون يكون مسئولا قبل الخصوم بتعويضهم عن الأضرار التي تتتج عن هذا التعيين، كذلك إذا قام بتعيين من منع المشرع تعيينهم مخالفـا المسادة ؛ ؟ب مر افعـات فانـه يكـون مسسئولا قبـل الخـصوم بتعويـضهم عـن الأضـرار التـي قـ تنـتج مـن هـذا

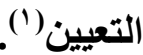
والخلاصة أن المعاون لا يسأل إلا عن خطئه في تأدية عمله، وهو يسأل مدنيا وجنائيا وتأديبيا، ويعفي المعاون من المسئولية، إذا قامت قوة قاهرة تؤدي إلى استحالة قيامه بالتنفيذ الجبري(") كحالة حرب، أو فتته أو كوارث طبيعية أو اعتبارات الملائمسة، وتقوم مسئولية الدولة في بعض الأحوال عن امتناع المعاون عن التنفيذ، مثال ذلك رفض الدولـة بـل معاونتهـا للمعـاون في تـليل العقبـات الماديـة التي تعترض التنفيذ الجبري، أو رفض الحكومـة المعـاون قد يرجـع إلى أسباب تقدرها كمـا لـو أدركت أن التتفيذ يؤدي إلى الإخلال بالأمن العام، كما لا تتعقد مسئولية المعاون إذا كان المتسبب في عدم التنفيذ هو نفسه طالب التنفيذ. 


\section{r- الهكم علي القاضي بجريمة إنكار العدالة:}

كذلك لا يجوز للقاضسي أن يمتتع عن الفصل في الدعاوي التنفيذ، إلا للأسباب

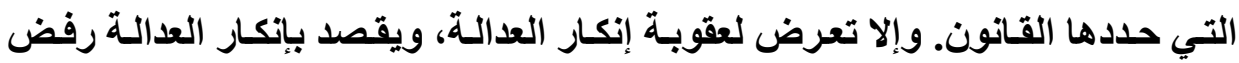
القاضـي صراحة أو ضـناً الفصل في الـدعوي أو تـأخير الفصل فيهـا رغم صـلاحيتها

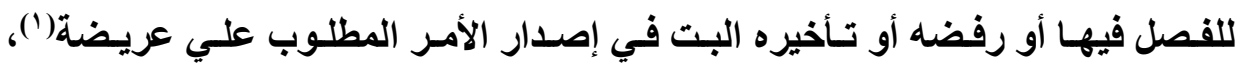
ويذهب الفقه إلى أن المهم هو إثبات واقعة الامتناع بصرف النظر عن إرادة القاضي

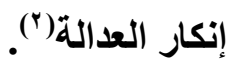

ومن الثابت أن القاضي لا يجوز لله الامتناع عن الفصل في الدعوي بحجة عدم

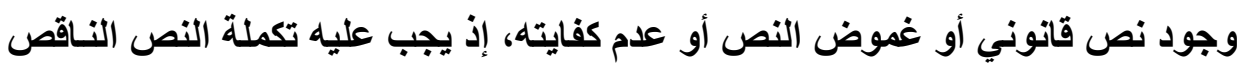
أو تفسير النص الغامض أو البحث عن القاعدة الواجبة التطبيق عند عدم النص. وهنايك بعض الحالات يكون تأخر القاضسي في الفصل في اللاعوي لله مـا يبرره قانوناً كما لو كاتت الدعوي تثير مشكلة معقدة تتطلب وقتا للتفكير في حلها، أو كاتت الاعوي لم ينته التحقيق فيها بعد، أو كان القاضي مريضا. ويخضع إثبات إنكار القاضسي للعدالة لقواعد خاصـة، فيجب لكي يعد القاضسي منكراً للعدالة أن يعذر القاضي مرتين علي يا محضر يفصل بين الإعذارين ميعاد أربعة وعشرين سـاعة بالنسبة للأوامـر علـي عرائض، وثثلاثة أيسام في الـدعاوي الجزئيـة والمستعجلة والتجاريـة، وثمانية أيسام في الدعاوي الأخرى، ولا يعتبر القاضسي منكراً

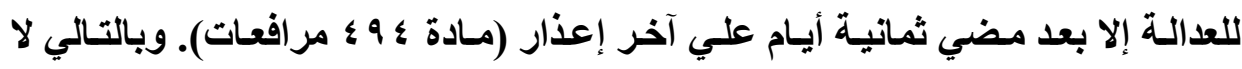

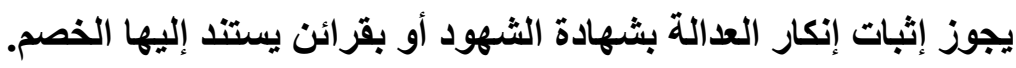

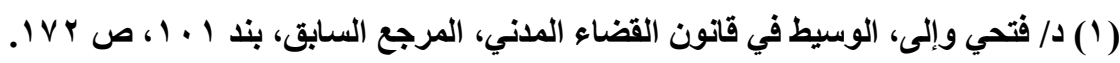

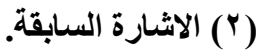


وإذا رفعت اللدعوي وأثنـاء نظر الخصومة أصدر القاضسي الحكم أو الأمر قبل صدور الحكم بقبول دعوي المخاصمة، تكون المصلحة من المخاصمة قد أنتفت ويحكم بعلم قبول دعوي المخاصمة، حيث يجب تـوافر شـرط المصلحة عنــــف رفع الـدعوي واستمرار ذلك حتى صدور الحكم فيها'('). r- الهكم بعقوبة الهبس والعزل للهموظف: إذا قام أي موظف بأي فعل سواء كان هذا الفعل الإيجابي أو السلبي قد أدي إلى عدم تنفيذ الأحكام أو التراخي في تنفيذها، فإنـه يشكل عملا غير مشروع يسأل فاعلـه عن التعويض كما تسأل الحكومة علي أساس مسئولية المتبوع عن أعمال تابعه(؟). هذا بالإضافة إلى المسئولية الجنائية.

فحرصسا من جانب المشرع علي تحقيق التنفيذ الجبري وتحقيق استقلاله في مواجهة السلطة التنفيذية(")، فقد نصت المـادة ب r ا من نفس القانون علي أن يعاقب بالحبس والعزل كل موظف استغل سلطة وظيفته في وقف تنفيذ حكم أو أمر صـادر من المحكمة، أو امتتع عمدا عن تنفيذ حكم أو أمر بعد مضي ثمانية أيام من إنذاره علي يـا محضر، إذا كان تنفيذ الأمر أو الحكم داخلا في اختصاص الموظف. وهذا النص يعزز استقلال القضاء، ويمنع السلطة التنفيذية من التذخل في شئون القضاء عن طريق منع تنفيذ أحكام القضاء.

(1) د/ عزمي عبد الفتاح حسن، قانون القضاء المدني المصري، طه، ه99 19، دار النهضة العربية، صץ"9.

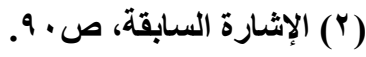

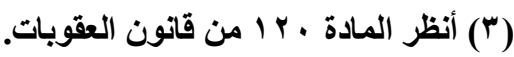


وقد نصت المادة آبr من قانون العقوبات اللبناني علي أن كل موظف يستعمل سلطته أو نفوذه مباشرة أو غير مباشرة ليعوق أو يؤخر تطبيق القانون أو الأنظمـة أو

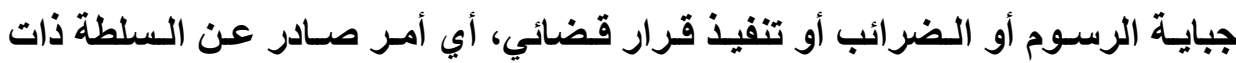

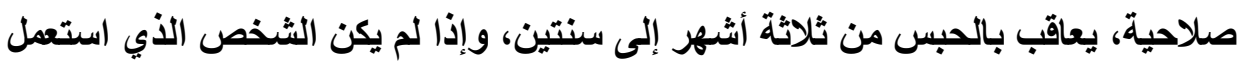
سلطته أو نفوذه موظفا عاما، فلا تتجاوز العقوبة السنة.

ويلاحظ أن عبارة الموظف تشمل المعين أو المنتخب، وسواء أكسان دائمسا أم مؤقتا. والجرم يقوم إذا استعمل الموظف نفوذه ليحول دون تنفيذ الحكم القضائي، وقد

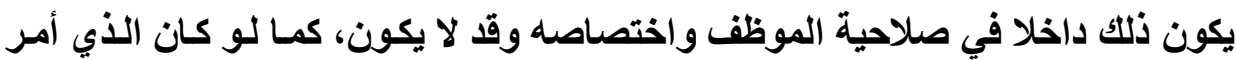
بعد التنفيذ رئيسا للموظف المختص بالتنفيذ. ويجب تو افر القصد لدي الموظف، وهو ألا يكون لديه سبب مشروع لعدم تنفيذ الحكم أو تأخير تنفيذه، والسبب المشروع كما لو كان الحكم قد اعتراه الغموض أو شابه لهابه الإبهام، وكان من الضروري إزالة هذا الغموض أو الإبهام قبل التنفيذ. ثانيا: بعض أوجه القصور في الجزاءات. 1 - قد نصت المادة ؟ و و والمـادة rVN مرافعات والمتعلقة بإنشاء ملف للتنفيذ ويعرض علي إدارة التنفيذ، لم ينص علي الجزاء المترتب علي مخالفة هذا

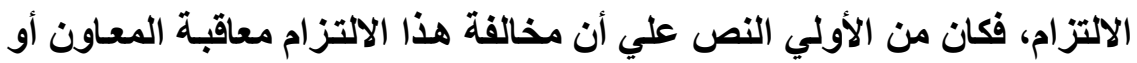

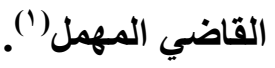


r - نظام إشراف إدارة التففيذ يتميز بأنه مراقبه لاحقة للقيام بالإجراء وليست رقابة سابقة علي عمل المعاون، والأي يكون له أثر كبير في تفادي بطلان الإجراءات التي يمكن أن يخطأ فيها المعاون أو إعادة القيام بالإجراء.

ب- في الواقع لم ينص المشرع علي جزاء علي امتــاع السلطة العامـة عن معاونـة

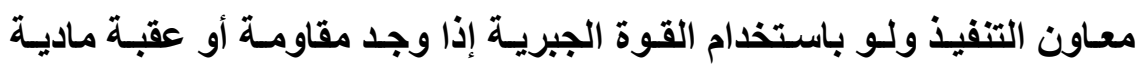

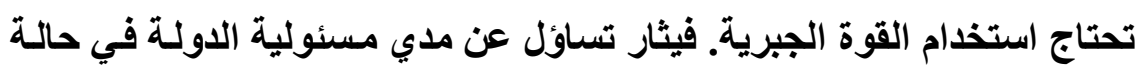

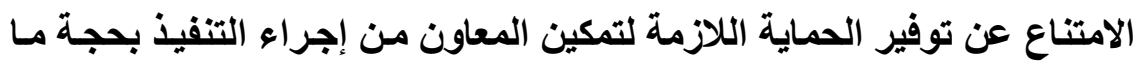
قد يؤدي إليه التنفيذ من تهديد للنظام والأمن العام. ذهب البعض من الفقهه والقضاء إلـي إمكانيـة امتنـاع جهة الإدارة عن مساعدة

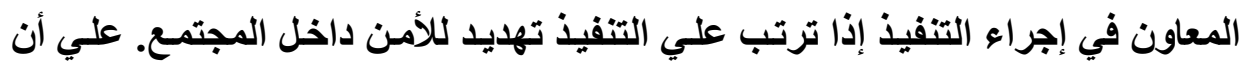
يكون للمحكوم له الحق في طلب التعويض عن الأضرار التي لحقته من عدم التنفيذ('). والحق في التعويض يكون علي أساس مبدأ المساواة بين الأفراد أمسام الأعباء العامـة.

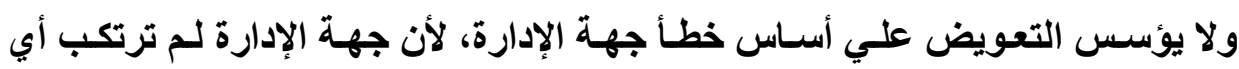

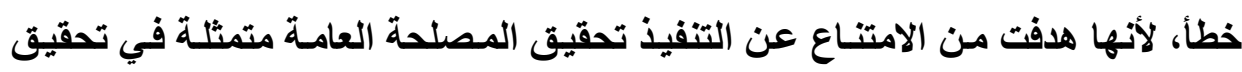
الأمن داخل المجتمع(؟). واذا كاتت الحكومة مسئولة عن امتنـاع موظفيها أو تقصريهم أو تراخيهم في إجراء التتفيذ، ولكن يجوز لها الامتتساع بدون مسئولية إذا وجدت قوة

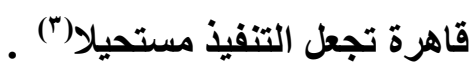

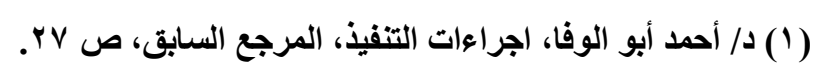

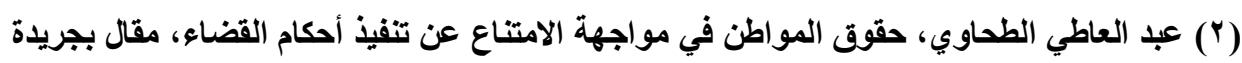

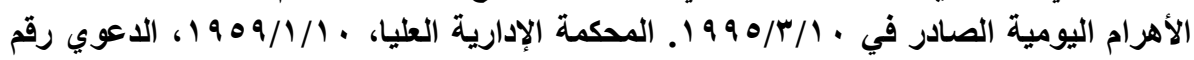




\section{الباب الثاني \\ وسائل حماية الغير في التنفيذ الببري}

قد يصدر السند التنفيذي في شكل حكم قضائيا، وقد يمس بحقوق الغير، لذا نظم المشرعين حق للغير في الاعتراض علي السند التنفيذ، وذلك بهدف منع تنفيذ السند

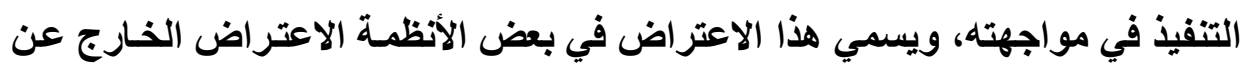
الخصومة، ويسمي في أنظمة أخري التماس إعادة النظر.

في الواقع يجب أن يكون الحجز علي أموال المدين فقط، ولا يجوز المساس بأموال الغير، و إذا تم الحجز علي أموال غير مملوكه للمحجوز عليه، وذلك نظرا لكونها في حيازته، أو في حيازة الغير ولكن اختط علي طالب التنفيذ تحديد أموال المدين، فبان هذا الحجز يكون باطل، ولكنه لكي يتقرر بطلانه لا بد من رفع دعوي أمام قاضي التنفيذ

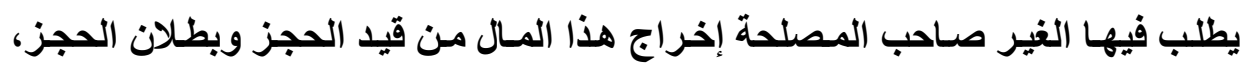

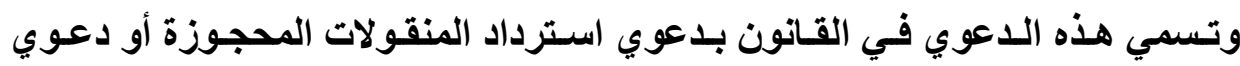

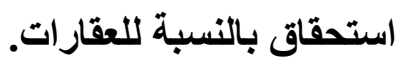

تقتضي حماية الغير في التنفيذ الجبري، تمكينه من الاعتراض علي السند التنفيذي، وحق الغير في الاعتراض علي إجراءات التنفيذ الجبري، وسنشير إلي ذلكت لكني

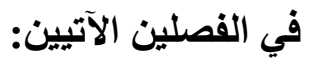




\section{الفصل الأول \\ حق الغير في الاعتراض علي السند التنفيذي}

تقتضـي قواعد العدالـة والانـصاف أن حجيـة السند التنفيـي وقوتـهـ التنفيذيـة

تقتصر علـي أطراف النزاع دون غيرهم، والقول بغير ذلكت يخل بقواعد العدالـة(')، فالحكم لا يعني بالنسبة للغير أكثر من كونه ورقة بيضاء، فإذا مس الحكم حقوق الغير، فإنه يحق لله الاعتر اض عليه، وذلك بهـف منـع تنفيذه في مواجهته ومنـع الاحتجـاج عليه بهذا الحكم، عن طريق سحبه أو تعديله أثناء الاعتراض عليه. في الواقع اختلفت الأنظمة القانونيـة في بيان طرق اعتراض الغير علي الحكم

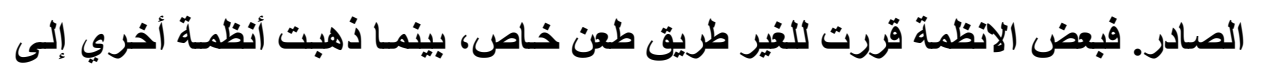
تنظيم طرق طعن مشتركه بين الغير والخصوم.

سنشير إلى حق الغير في الاعتراض علي الحكم في القانون المصري، وذلك في المبحث الأول، ونعـالج حق الغير في الاعتراض في القـانون المقـارن، وذلك في المبحث الثاني، أمسا المبحث الثالث، فيخصص لموقف الفقه من اعتراض الغير علي الحكم. 


\section{المبحث الأول \\ اعتراض الغير علي المكم في القانون المري}

سنشير إلى ماهيـة اعتر اض الغير علـي الحكم، وشروط اعتراض الغير علي

الحكم، وذلك في المطالب الآتية:

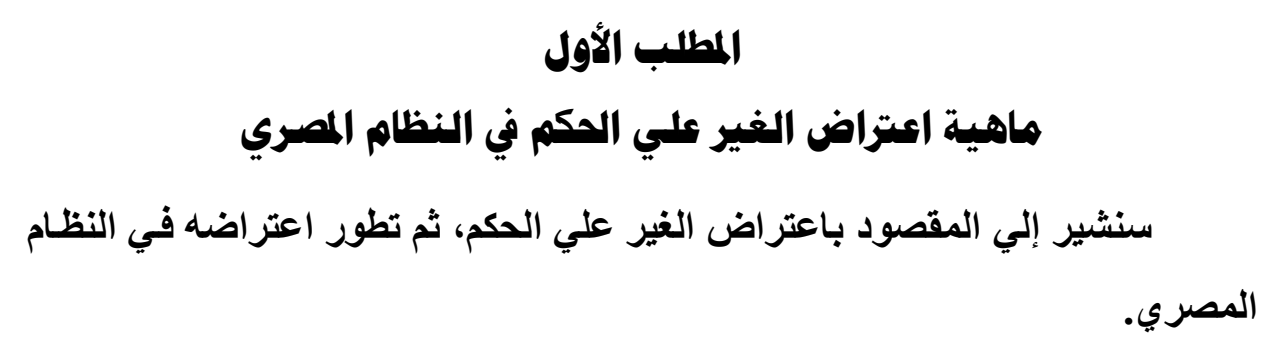

الفرع الأول

المقصود باعتراض الغير علي المكم الهم

هذا الطريق كان يقصد به في قانون المرافعات السابق، الاعتراض الخارج عن

الخصومة وهو الطعن في الحكم من شخص لـم يكن طرفا فيه لا بنفسه ولا بالنيابـة ولا بالوكالة، إذا كان هذا الحكم يمس حقا من حقوقه فيتعدى أمره إليه ولو أنه لم يظهر في القضية التي صدر الحكم فيها (مV V ؛ مختلط). والأثخاص الذين يجوز لهم الطعن بهذه الطريقة في ظل هذه القوانين ينقسمون إلى قسمين، قسم لا يستمد حقـه من خصم، ولا يمكن تنفيذ الحكم عليه، وهم غير الأننين ممن يجوز أن يعود عليهم ضرر من الحكم، 
وقسم يستمد حقه من خصم فهو ممثل في الحكم ولا يمكنه ايقاف تثفيذه وهم الـائنون إذا صدر الحكم بتواطؤ مدينهم مع الغيرالمحكوم له('). واعتراض الغير علي الحكم في ظل قانون المرافعات الحالي يـخل ضمن حالات التماس إعادة النظر، يمكن تعريف التماس إعادة النظر بأنه، طريق طعن غير عادي في الأحكام النهائية أمام نفس المحكمة التي أصدرت الحكم المطعون فيه إذا توافرت اسباب الالتمساس، وقد يكون الطعن امسام نفس القضاة الذين أصدر الحكم الملتمس فيـه. إذاً اعتراض الغير في قانون المرافعات الحالي، هو طعن غير عادي يتقدم بـه شـص أضر الحكم بمصلحته ولا يعد خصما ولا مختصما في الاعوي، وذلك في الأحوال المقرر في

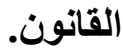

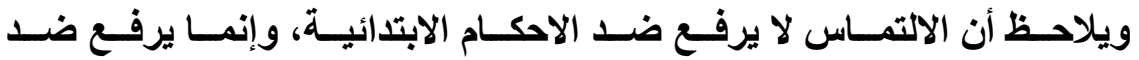
الأحكـام الـصادرة بـصفه انتهائيـة، سـواء صــادره مـن محساكم الاسـتئناف أو المحسكم الابتدائية أو المحاكم الجزئية، وأسباب الالتماس منصوص عليها علي سبيل الحصر في

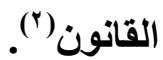




\section{الفرع الثاني \\ تطور نظام اعتزاض الغير في القانون المري}

أولا: اعتراض الغير في النظام المصري السابق.

في الواقع لا يعرف قانون المرافعات الأهلي هذا الطريق من الطعن، حيث كـان ينظم من طرق الطعن غير العادية التماس إعادة النظر والطعن في الحكم بالنقض فقط، ففي قانون المرافعات الاهلي، لمن يتضرر من الحكم أما أن يرفع دعوي علي من يري

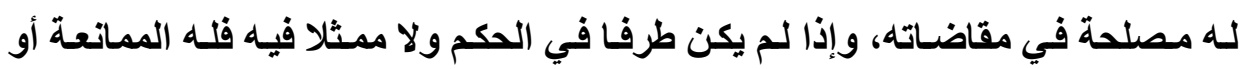
الاستثكال في تنفيذ الحكم إذا كان يضره تتفيذه(').

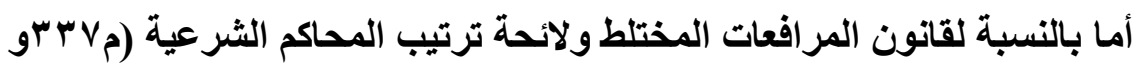

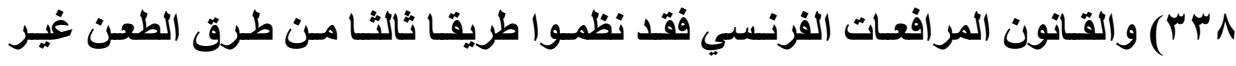

العادية، هو طريق معارضة الخصم الثالث أو الطعن في الحكم ممن يتعدى إليه.

وقد رأي المشرع في ظل قـانون المرافعات السابق بعض مزايـا هذا النظـام،

فاقتبسه بعض صوره فقط، حيث لم يأخذ بهذا النظام كما في القوانين التي اقتبسه منها، بل عدل في احكامه بحيث يجعله مقصورا علي طائفة معينة من الطاعنين.

والواقع أن القوانين المختلفة قد أفردت تسميات عده لتظيم حق الغير في

الاعتراض علـي الحكم، فالقـانون المختلط والقـانون الفرنسـي أفرد تسمية معارضـة

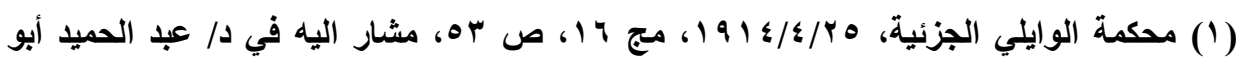

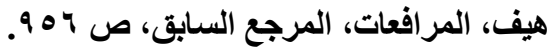


الخصم الثالث، وقـانون أصـول المحاكمـات المدنيـة اللبنـاني فضل مسسمي اعتراض

الغير، وبالنسبة للائحة الشرعية فقد فضلت مسمي الطعن في الحكم ممن يتعدى إليه. ويلاحظ أن المشرع المصري في قانون المرافعات السابق نبذ هذه التسميات وتخير اسـما مناسبا لطبيعـة الدلالـة علـي هذا الطعن، حيـ يهـدف إلـي منـع امتـداد

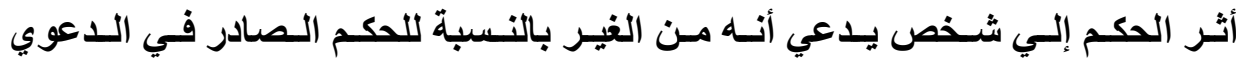

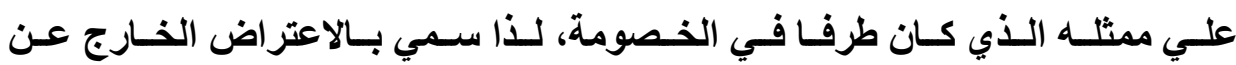

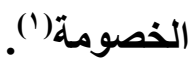

ويقصد بالاعتراض الخارج عن الخصومة، طعن الغير علي الحكم، وذلك بهدف سحب الحكم أو تعديله لمصلحة الغير، حيث نصت المـادة ب ^هـ من قانون المرافعات القديم علي أن " اعتراض الغير يهدف إلى سحب الحكم أو تعديله لمصلحة الغير الذي طعن فيه". يلاحظ أن الاعتراض المقدم من الخـارج عن الخصومة، طريق يسلكه من يتعدى إليه الحكم باعتباره ممثلا في الخصومة، ويقصد بـه منـع امتداد أثر الحكم إليه والتقريز بأنه ليس لله حجية عليه. بالرغم من أن المشرع المصري أفرد لهذا الطريق من الاعثراض علي الحكم بابا خاصا بعد أن فرغ من تنظيم وسائل الطعن بنوعيه العادي وغير العادي(؟)، وذلك

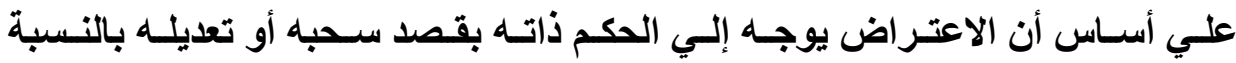
للمعترض. إلا أن الفقه يري أن هذا الاعتراض طريق خاص من طرق الطعن في الحكم، ويسري عليه ما يسري علي الطعون من أحكام عامة.

( (1) د/ عبد المنعم الثرقاوي، الوجيز في المرافعات المدنية والتجارية، المرجع السابق، ص هـهـ.

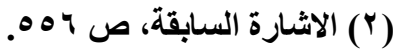

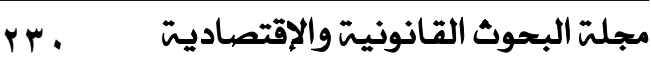


ونري أن الاعتراض الخارج عن الخصومة، طريق طعن غير عادي، يطبق عليه الأحكـام العامـة لطرق الطعن الغير عاديـة، وتنظيم المشرع لـه في بابـا خـاص وذلكـ لخصوصية هذا الطريق، وتمييزه ببعض الخصائص، حيث يتقلم بـالطعن شخص من الغير، وهذا لا يمنع من كونه طريق طعن غير عادي علي الحكم. والواقع أن الطعن المرفوع من الغير لا يفيد إلا هذا الشخص، بمعني إذا قبل الطعن فلا يعدل الحكم إلا بقدر مـا يوافق مصلحة الطاعن، ولا ينظر لمصلحة من لم يطعن إلا إذا كان الموضوع غير قابل للتجزئة، فحينئذ يفيد الطعن كل من له مصلحة فيه

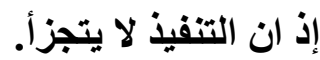

\section{ثانيا: أعتزاض الغير في النظام الصري الحالي}

لقد الغـي المشرع المـصري في قـانون المرافعـات الحسالي الاعتراض الخـارج

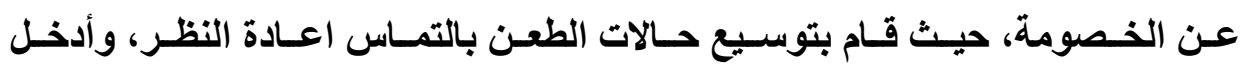
فيها حـالات الاعتراض الخـارج عـن الخـصومة، فلـم يعـد المـشرع المـصري الحسالي

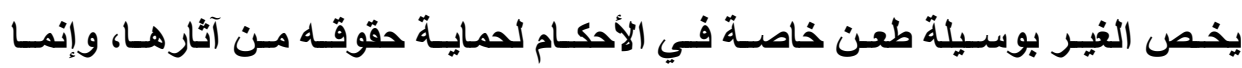
اكتفي في ذلك بقاعدة النسبية في بعض الحالات، وأجساز للغير الطعن بأحد الطرق المقررة للخصوم وهو التماس إعادة النظر في بعض الحالات. وذلك علي عكس بعض القـوانين الأخـرى التـي تفـرد للغيـر طريقـا خاصــا للاعتـر اض مثل القـانون الفرنسـي واللبناني.

لو نظرنـا لموقف المشرع المصري سنجد أنها صدي لرأي الفقـه التقليدي في فرنسا والذي نـادي بـه الققيه شوفوchauvean ومقتضاه أن الغير ليس بحاجة إلى تنظيم طريق طعن خـاص بـه لحمايـة حقوقه من آثر الأحكام. وعلي أسـاس أن حالات 
الاعتراض من الغير تعتبر تظلمـا من حكم صدر علي شخص من الغير، ولكنه اعتبر

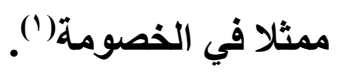

إذن جعل المشرع حالات الاعتراض الخارج عن الخصومة سببا لالتمساس إعـادة النظر، فنصت المـادة إ؟ مرافعات علي أنسه "للخصوم أن يلتمسوا إعادة النظر في الأحكام الصادرة بصفة انتهاعيـه في الأحوال الآتيـة... لمن يعتبر الحكم الصادر في الدعوي حجة عليه ولم يكن قد تلخل أو أدخل فيها بشرط إثبات غش من كـان يمثله أو إهماله أو تواطئه. كمـا نص علي أنـه من بين أحوال التمـاس إعادة النظر حالة " إذا صدر الحكم علي شخص طبيعي أو اعتباري لم يكن ممثلا تمثيلا صحيحا وذلك فيما عدا

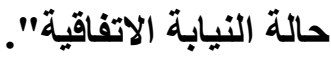
ويمكن القول بأن المشرع المصري في القانون الحالي قد نظم حقا للطعن للغير، إذا قدر أن الحكم الصادر في خصومة معينة بين طرفيها قد أضر به، وأن يدعي ضد هذا الحكم بصيغة اعتراض ليتمكن من رفع الضرر الذي قد يتعرض لله نتيجة هذا الحكم الأي لا حجية له عليه، ولا يمتد إليه أثر. 


\section{الاطلب الثاني \\ شروط طعن الغير بالتمهاس إعادة النظر وأثاره في القانون المصري}

سنشير إلـي شـروط الطعن بالتمـاس اعـادة النظر مـن الغير، و وآثـار الطعن

بالتماس علي التنفيذ الجبري، وذلك في الفروع الآتية:

\section{الفرع الأول \\ شروط طعن الغيز بالتمهاس إعادة النظر}

طبقا للقواعد العامة يجب لقبول التماس إعـادة النظر أن يتوافر للغير مصلحة، ويقصد بذلك أن يعود عليه ضرر من الحكم الصادر، حيث أنه لا يمكن قبول أي طلب أو دفع أو طعن إلا إذا كـان لـصاحبه فيـه مسلحة قائمسة ومسشروعله وشخصية، وتتمثل مصلحة الغير الملتمس في دفع الضرر الذي سيصيبه مـن الاحتجـاج عليه بـالحكم. ويشترط ألا يكون الغير قـ سبث وقبل الحكم، حيث يفقد حقهه في الالتمـاس بـالقبول لانتفاء مصلحته في الطعن في الحكم. طبقا لنص المادة إ؟ مرافعات يشترط لطعن الغير بالتماس إعادة النظر توافر

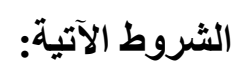

الشرط الأول: صفة الغير الملتمس في الحكم. الشرط الثاني: أن يكون الحكام يقبلالتماس إعادة النظر. 


\section{يمكن تفميل هذه الشروط علي النحو التالي:} الشرط الأول: أن يكون الطاعن هن الغير

طبقا لنص المادة إ؟ بمرافعات يمكن للغير أن يطعن في الحكم بالتمساس إعـادة النظر إذا فقد الثخص تمثيلة في الاعوي.

يلاحظ أن نص المـادة إ؟ مرافعـات قصر اعتراض الغير علي طائفتين مـن

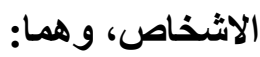

الطائفة الأولي: الشخص الطبيعي أو الاعتباري الذي لم يكن ممثلا في الدعوي

تمثيلا صحيحا:

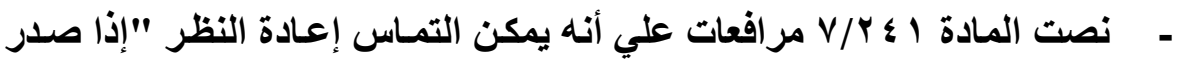
الحكم علي شخص طبيعي أو اعتباري لم يكن ممثلا تمثيلا صحيحا في الدعوي

وذلك فيما عدا حالة النيابة الاتفاقية".

وهذا الثرط هو الأي يبرر إدراج هذه الحالة في حالات التماس إعادة النظر من الغير، وليس من الخصوم، فعدم التمثيل الصحيح يترتب عليه أن يصير الطرف الأصلي من الغير بالنسبة للحكم الأي صدر في مواجهة الممثل. ويفترض هذه الحالـة أن يكون الشخص ممتثلا في الخصومة بنص القـانون كالقاصر أو المريض مرضا عقليا، أو بحكم قضائي، كالمحجوز عليه والمفلس، ولكن تمثيله لم يتم بصورة صحيحة طبقا للقانون. كما يجب ألا يكون طرفا شخصيا فيها' '. (1) د/ بشندي عبد العظيم أحمد، حماية الغير في قانون المرافعات، المرجع السابق، ص ץ ـ ه. 
ويكون المثيل غير صحيح قانونا إذا قام به شخص آخر غير صـاحب الصفة في مباشرة إجراءات الخصومة باسم الاصيل، كما لو صدر الحكم في مواجهة شخص آخر غير الولي أو الوصي صاحب السلطة في تمثيل القاصر أو السنديك الذي يمثل المفلس أو الشخص الأي حدده القانون لتمثيل الثخص الاعتباري. كمـا تشمل هذه الحالـة أيضا تجـاوز الممثل لحدود تمثيله كمـا لـو تعدي مدير الثركة الحدود التي وضعها القانون أو اللائحسة لقيامـة بتمثيل الشركة في الخصومات القضائية، وأيضا صدور الحكم في مواجهة الخصم رغم وجوب تمثيلة في الإجراعات، كمـا لوحكم علي القاصر أو المحجور عليه دون علم الوصسي أو الـولي، وكذلك الحكم علي الورثة دون قيام مصفي التركة بتمثليهم (') كذلك لا يكون التمثيل صحيحا إلا إذا ارتكب الممثل غشـا أو تواطئس للإضرار بحقوق الأصيل، فالغش يفسد كل شيء والقاعدة أن من غشك لا يمثلك، ونتيجة لذلك يصير الطرف الأصيل من الغير بالنسبة للحكم الصادر في مواجهة ممثله.

\section{وهن ثم يخرج عن هذه الطائفة:}

ا - مـن كـان طرفـا في الخصومة بشخصه سـواء أكسان مـدعيا أو مـدعيا عليـه أو متلخخلا.

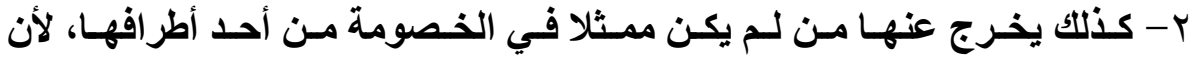
الاعتر اض يقصد به دفع أثر الحكم عمن يعتبر حجة عليها، فمن لا يسر عليه الحكم قانونا لا يكون اعتراضه مقبولا، ويكفيه أن يدفع تنفيذ الحكم إذا أضر بـه 
نسبية الأحكام. وأنه لم يكن طرفا في الخصومة التي صدر فيها الحكم لا بنفسه ولا بمن يمثله. كما يكون له أن يطلب حقه بدعوي مبتدئه متجاهلاً صدور الحكم في الدعوي التي لم يكن طرفا فيها.

\section{الطائفة الثانية: هن يعتبر المكم حبة عليه ولم يكن قد أدخل أو تدخل فيهها.}

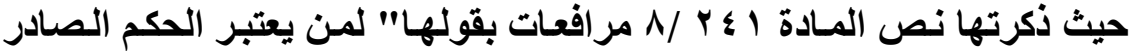
في الدعوي حجة عليه لم يكن قد أدخل أو تلخل فيها بشرط إثبات غش من كان يمثله أو تواطئه او إهماله الجسيم". وهؤلاء الأثخاص يعتبرون ممثلين في الخصومة، ولكن هناك غش أو تواطؤ أو إهمال جسيم من ممثلهم.

\section{وبمب توافر الصفة الأتية في الطاعن:}

ا - يجب أن يكون الطاعن من الغير بالنسبة للحكم المطعون فيه، فلا يقبل التمـاس إعادة النظر طبقا لهذه الحالة إذا كان طالبه طرفا في الخصومة التي صدر فيها الحكم المطعون فيه، سواء كان طرفا أصليا أم متلخلا أم مدخلا في إجراءاتها('). ץ- أن يكون الطاعن ممن يحتج بالحكم المطعون فيه في مواجهتهم، ويكون ذلك في حالة الخلف أو الدائن للمحكوم عليه، حيث يحوزن مركزا تابعا ومستمدا من مركز الخصوم، ولالكك يكون الحكم في مواجهة هذا الخصم نافذا في مواجهتهم. فيمـا عـادة هـؤلاءـ كالـدائنين أو المــينين المتـضامنين مـع المحكـوم عليـهـ أو الثركاء معه في مال غير قابل للقسمةـ فلا يجوز لهم التماس إعادة النظر، لأن هؤلاء في مركز مستقل عن المحكوم عليه ولا ينفذ الحكم الصادر ضده في 
مـواجهتهم، وقد رأي المشرع أنـه يكفي لحمايـة حقوقهم مـن آثـار هذا الحكم الاستناد إلى قاعدة النسبية الواردة في المادة 1 ـ 1 من قانون الإثبات.

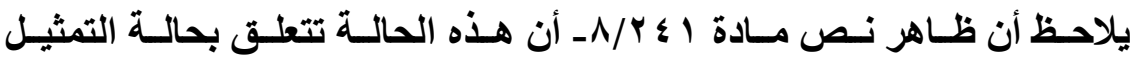
الإجرائي، أي أن الملتمس يجب أن يكون طرفا ممثّلا في الخصومة، فِان الحقيقة غير ذلك، لأن صفة الطرف في الخصومة لا تتفق مع عبارتي التدخل والإدخال الواردتين في النص السابق. لذا يري البعض أن هذه الفقرة تتعلق بالحالات التي يحتج فيها بالحكم في

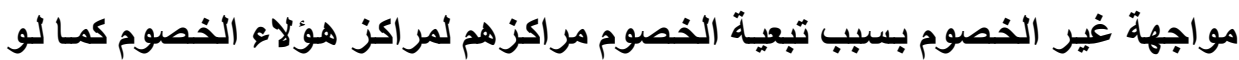

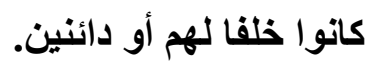

و الواقع نري أن هذه الصياغة تحتاج إلى تعديل، وذلك لأن في بداية الفقرة يشير

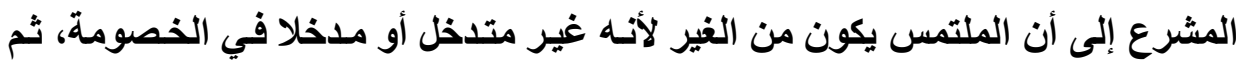
بعد ذلك يشير إلى أنه من الخصوم، باعتباره ممثُلا في الخصومة، ولكنه فقط التمثيل بسبب الغش أو التواطؤ أو الاهمال الجسيح.

ويمكن تفسير هذه الفقرة علي اسـاس أن المشرع قصر الالتمساس علي الخصم الذي فقد تمثيله مني كان هذا الخصم خصما اصليا، وليس خصما متدخل او مدخلا في الخصومة، ولا يكون بالنسبة للخصم الذي يمثل شخصه في لخدي الخصومة، كما يمكن أن تنطبق علي خلف الخصم و الائنين له، وذلك باعتباره ممثلا لهم في الخصومة. ويثار التساؤل لو كان هذا الخصم متذخل أو مدخل في الخصومة له ممثل، وفقد هذا التمثيل لفش المثثل او اهماله الجسيم، فهل يحق له الاعتراض علي الحكم بالتماس لواس

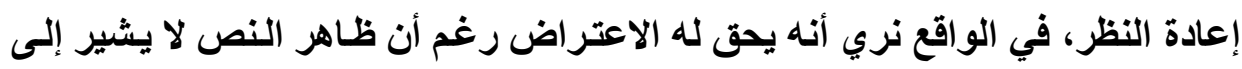

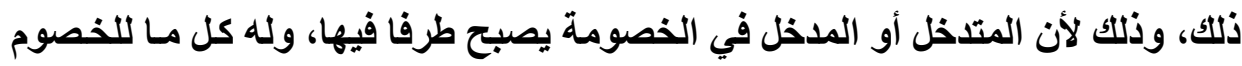


من حقوق وعليه ما يجب عليهم من واجبات، ويحتج بالحكم في مواجهته. لذا يكون من العدالة أن يحق له الاعتراض علي الحكم بالتماس إعادة النظر إذا توافر ت شروطه. وتتمثل هذه الشروط في الآتي:

ا - ثبوت الغش أو التواطؤ أو الاهمـال الجسيم، لأن ذلك يقطع التبعية بين مركز

الطاعن والمحكوم عليه. وتقدير ذلك يخضع لسلطة قاضي الموضوع دون رقابـة عليه من محكمة النقض مادام قد بني قراره علي أسباب سـائغة تؤدي إليهـ('). ويجب قيام رابطة النسبية بين غش المحكوم عليه أو تواطئه أو إهماله والحكم

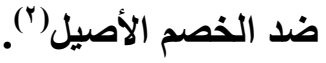

ونـري أن المقـصود بـالفش أو التواطـؤ، تـصرف الممثل بقـصد وسـوء نيـة للأضرار بحقوق من يمثله، أو لتحقيق مصلحة شخصية أو لترجيح كافة الخصم الأخر. ويقصد بالخطأ الجسيم، هو الخطأ الجسيم الذي مـا كـان ينساق اليهله لو اهتم بواجباتهـ الإهمال العادي للأمر، ولا يشترط هنا سوء نية الممثل. ويجب أن يؤدي الغش إلي منع الخصم من حريـة الدفاع وأن يتوجه الغش إلى احد مصادر معلومات القاضي ولم يتح للمحكمة أن تتحرز عن اخذها به بسبب عدم قيام المحكوم عليه بلحضه وتنويرهـا في حقيقة شـانه لجهله بـه وخفاء امره عليه بحيث يستحيل كشفه. ويجب أن يكون الغش حافيا علي الملتمس طوال نظر الدعوي بحيث لم تتح لله الفرصة لتقليم دفاعه فيه وتنوير حقيقته للمحكمة فتأثر به الحكم("). 


\section{ז- أن يكون الطاعن قد لهقة ضرر هن الهكم المععون فيه.}

ويلاحظ أن الضرر لا يعود علي الملتمس بصورة مباشرة، ولكن بطريق غير

مباشرة أو بطريق الانعكاس نتيجة الاحتجاج بـالحكم في مواجهته بسبب تبعية مركزه لمركز الخصم المحكوم ضـده. ولا يـشترط أن يكون الضرر حسالا، بـل كفي أن يكون

ويجب أن يكون التقدير الذي اشتثل عليه الحكم قد تحدد استنـادا إلى التمثيل المزيف للحقيقة الراجع إلى الغش بحيث أنه بغير هذا الغش ما صدر الحكم بالمضمون

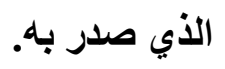

ويثور التساؤل عن مدي قبول التماس فرعي قياسا علي الاستئناف الفرعي؟ في الواقع لـم ينص القـانون علي جواز رفع التمـاس فرعي كمـا فعل بالنسبة للنص علي الاستئناف الفرعي، لذا نري أنه لا يجوز رفع هذا الالتماس.

\section{الشرط الثاني: أن يكون المكم يقبل التماس إعادة النظر:}

تنص المادة إ؟ مرافعات علي أنه للغير وللخصوم " أن يلتمسوا إعادة النظر في الأحكام الصادرة بصفة انتهائيه في الأحوال الآتية:...". يتضح من النص أن الشرط الوحيد بالنسبة للأحكام التي تقبل التمـاس إعـادة النظر هي أن تكون انتهائيه. ويكون الحكم انتهائي في الأحوال الآتية:

ا - إذا كان صادرا من محاكم الدرجة الثانية، سواء كان قابلا للطعن بالنقض أم لا. r - الأحكام الصادرة من محاكم الدرجة الأول في حدود نصابها الانتهائي. r- الأحكام التي اتفق الخصوم علي عدم الطعن في الحكم. 
ع - الأحكام التي فات الطعن فيها بالاستنناف أو حكم بعدم قبول الاستتناف أو زال الاستئنف بأي طريق.

وبالتالي إذا كان الحكم يقبل الطعن بالاستئناف فاته لا يكون قابلا لالتماس إعادة النظر، وذلك لعدم الحاجة إلى هذا الطريق، إذ يمكن معالجة الخطأ المنسوب إليه في

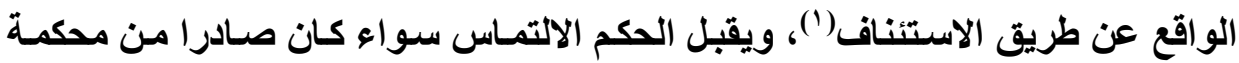
عادية أو استثنائية، حكما منشأ أو تقريريا، صادرا بقبول الدعوي أم عدم قبولها، منهيا للخصومة. ويجوز الطعن بالالتماس في الاحكام الغيابية الصادرة في الاحوال الثخصية ما دام غير قابل للطعن فيه بالاستنـاف. ويجوز استثناء الطعن في الاحكام الانتهائية

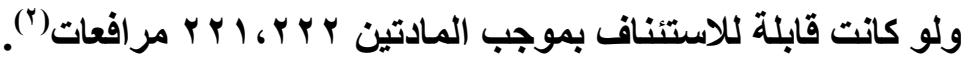
ويثور التساؤل إذا كان المشرع نص علي اثشتراط أن يكون الحكم نهائيا للطعن عليه بالتماس إعادة النظر، فهل كل الاحكام النهائية تقبل هذا الطعن؟ في الواقع هناك أحكام نهائية لا يجوز فيها الطعن بالالتمساس ولو قام بها سبب

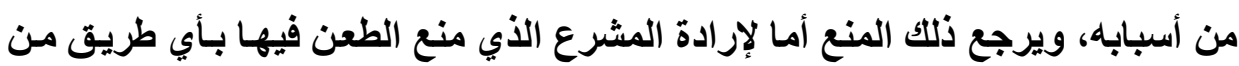
طرق الطعن وأما لنص المشرع علي منع الطعن فيها بالالتماس، ويتمثل ذلك في الآتي:

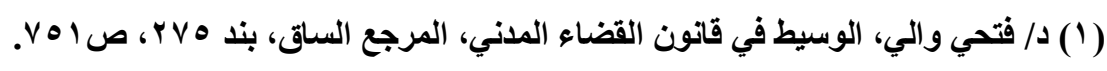

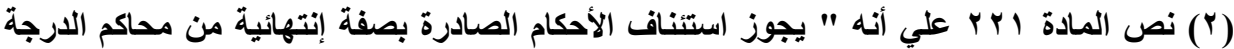
الأولى بسبب مخالفة قواعد الاختصاص المتعلقة بالنظام العام، أو وقوع بطلان في الحكم أو بطلان في الإجراءات أثر في الحكم.

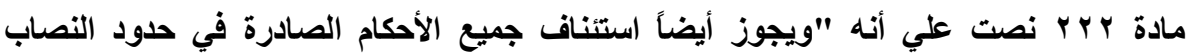

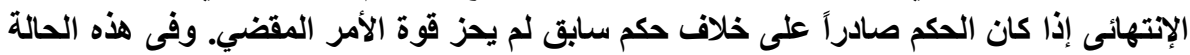
يعتبر الحكم السابق مستأنفا بقوة القانون إذا لم يكن قد صار انتهائي غذد رفع الاستناف. 


\section{ا - الاحكام الصادرة هن همكمة النقض:}

في الواقع الأحكام الصـادرة مـن محكمة النقض لا يجوز الطعن عليها بـأي طريق من طرق الطعن، سواء كان طعن عادي أو غير عـادي، وحتي ولو كانت فاصلة في الموضوع .

الاستثناء الوحيد علي القاعدة السابقة هو سحب حكم النقض لعدم صلاحية أحد القضاة الأين أصدروا الحكم، حيث ذهبت محكمة النقض إلى أن "الطعن على الحكم الصادر من محكمة النقض لا يجوز بأي طريق عادى أو غير عادى بما في ذلك التمـاس إعادة النظر.

الاستثناء الوحيد على القاعدة السابقة هو سحب حكم النقض لعدم صـلاحية أحـ القضاة الذين أصدروا الحكم نقض محكمة النقض للحكم وتصديها للفصل في موضوعه في الأحوال المقررة لا يجعل الحكم الصـادر من محكمة استئنافـ بـل هو حكم محكمة نقض"('). r- الأمكام الصادرة برفض الالتمهاس والصادرة بعدم قبول الالتمهاس: إذا قدم التماس وحكم في الالتمـاس بـالرفض أو بعد القبول ثم ظهرت بعد ذلك اسباب جديدة قوية، فلا يجوز رفع التماس جديد، وذلك عملا بالقاعدة في فقه المرافعات الالتماس لا يجوز بعد الالتماس، ولو كان الطعن الثاني مبنيا علي اسباب جديدة ولو كانـت لـم تظهر إلا بعـد الحكـم بقبـول الالتمـاس الاول أو رفضه، مـع ملاحظة أن منـع 
الالتماس لا يسري إلا علي الملتمس أمام المدعي عليه في طعن بالالتماس فيجوز له ان يرفع التماسا إذا كان ميعاد الالتماس ممتد. حيث ذهبت محكمـة النقض إلى أن التمساس إعـادة النظر في حكم صـادر في التماس إعادة النظر غير جائز ولو كسان مبنيا على أسباب جديدة. الحكم الصادر في

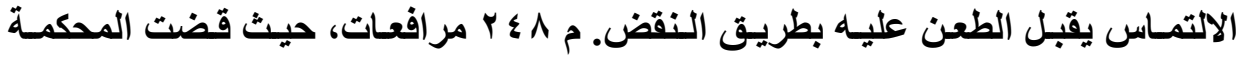
بالآتي: " المادة V Y من قانون المرافعات تنص على أن الحكم الذى يصدر برفض الالتماس وكذلك الذى يصدر في موضوع الدعوى بعد قبول الالتمساس لا يجوز الطعن عليهما بطريق التماس إعادة النظر مره ثانية حتى ولو كـان الطعن الثاني مبنيا على أسباب جليدة. يفيد أن مـا حظره الشارع في هذه الحالة هو الطعن بالالتمساس للمرة الثانية أي رفع التماس بعد التماس وفيما عدا ذلك يترك أمر الطعن في الأحكام الصادرة في الالتماس للقواعد العامة. لما كان ذلك وكان التماس إعادة النظر طريق غير عادى للطعن في الحكم النهائي يرفع إلى نفس المحكمة التي أصدرته متى توافر سبب من أسباب الالتماس التي بينها القانون بيـان حصر. وكـان صدور الحكم الملتمس فيه من محكمة الاستئناف يستلزم رفع الالتماس إليها فإن القضاء فيه يعتبر حكما صـادرا منها وبالتالي يقبل الطعن عليه بطريق النقض إعمالا لنص المادة ^ ؟ ب مرافعات التي تجيز الطعن بـالنقض في الأحكام الصادرة من محسكم الاستئناف بمـا يكون معـه الدفع بعدم جواز الطعن غير سديد" (') 


\section{r- الأحكام المستعبلة التي تصدر بصفة نهائية:}

حيث ذهب الرأي الغالب إلى أن هذه الأحكام لا تقبل الطعن فيها، لأنها ذات حجية

$$
\text { وقتية، وليس لها أثز علي الحكم في الموضوع)' }
$$

وعلي العكس من ذلك ذهب بعض الفقهاء إلى جواز الطعن بالتماس إعادة النظر في الأحكام المستعجلة التي تصدر بصفة انتهاعيه()، وقد استتد هؤلاء الفقهاء إلى أن نص المادة إ؟ مرافعات جاء عاما بالنسبة لجميع الأحكام الانتهائية، وليس هنـاك مـا يمنع تطبيقه بالنسبة للأحكام المستعجلة، كمـا لا يمكن التمسكك بالصفة الوقتية لهذه الأحكام، لأن محكمة الطعن تتقيد بنفس سلطات القاضي المستعجل ومنها عدم المساس بالحق وضرورة توافر ركن الاستعجال. كمـا أن الأحكام المستعجلة يجوز الطعن فهيا بالنقض، فبالتالي لا يكون هناك مانع للطعن فيها بالالتماس.

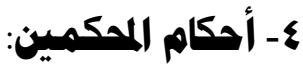

هي دائما انتهائية لأنها لا تقبل الطعن بالاستئناف، ولذلك يري البعض أنها تقبل الطعن بالتماس إعادة النظر، ويرفع الالتماس في هذه الحالة إلى المحكمة التي كان من اختصاصها أصلا نظر الدعوي(").

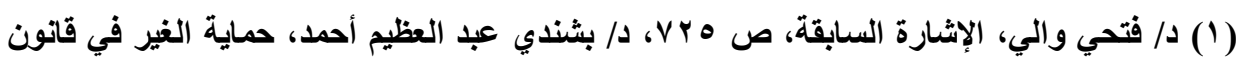

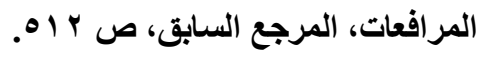

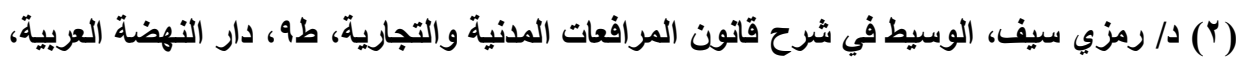

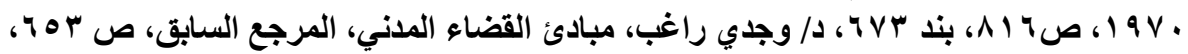

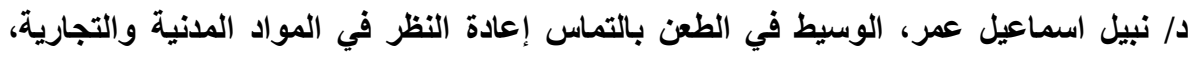

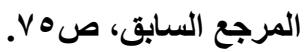
(r) د/ بشندي عبد العظيم أحمد، حماية الغير في قانون المرافعات، المرجع السابق، ص ـ ـ10. 


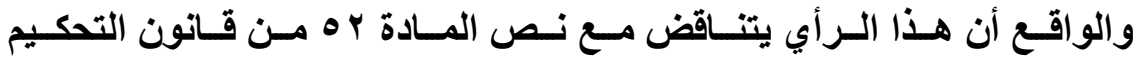
والتي تنص علي أنه "لا تقبل أحكام التحكيم التي تصدر طبقا لأحكام هذا القانون الطعن فيهـا بـأي طريـق مسن طرق الطعن المنصوص عليهـا في قـانون المرافعـات المدنيـة والتجاريـة، وبالتالي فلا يجوز الطعن فيها بطريق التمـاس إعـادة النظر أو النقص أو الاستئناف.

ونرى أنه يمكن الطعن بالتماس إعادة النظر في الحكم الصادر من محكمة الطعن بالبطلان، وذلك في الحالات التي نص عليها المشرع بالنسبة للغير.

\section{الفزرع الثانتي \\ آثار الطعن بالتماس إعادة النظر علي التنفيذ}

يرفع الالتماس امام المحكمة التي اصدرت الحكم بصحيفة تودع قلم كتابها وفقا للأوضاع المقررة لرفع اللدعوى ويجب ان تشتمل صحيفته على بيـان الحكم الملتمس فيه وتاريخه واسباب الالتماس والا كاتت باطلة ويجب على رافع الالتماس في الحالتين المنصوص عليهمـا في الفقرتين السابعة والثامنـة مـن المـادة الب ؛ ان يـودع خزانـة المحكمة مبلغ عشرة جنيهات على سبيل الكفالة ولا يقبل قلم الكتاب صحيفة الالتمـاس اذا لم تصحب بما يثبت الايداع. ويجوز ان تكون المحكمة التي تنظر الالتماس مؤلفة من نفس القضاة الذين اصدروها الحكم ويرفع الالتماس بصحيفة تودع قلم كتاب المحكمة التي اصدرت الحكم المراد الالتماس فيه ويكون رفع الالتمساس طبقا للأوضـاع المقررة في المسادة با من قانون

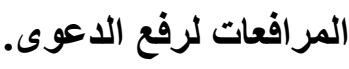


ينظر التمـاس إعـادة النظر علـي مرحلتين أولاهمـا التحقق مـن شـرائط قبولـهـ

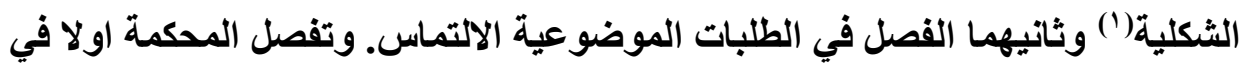

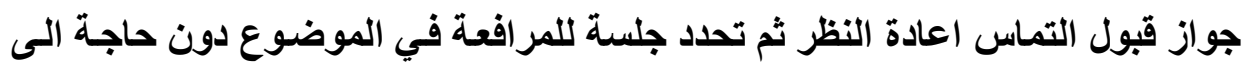

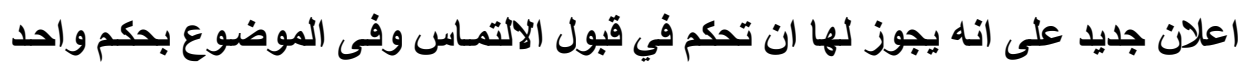

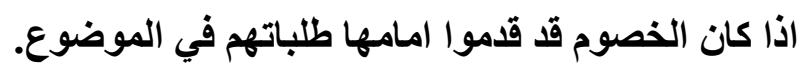
سنشير إلى آثار رفع الالتماس علي تنفيذ الحكم، وآثار قبول ورفض الالتماس علي التنفيذ، وذلك في النقاط الآتية: أولا: آثار رفع الالتهماس علي تنفيذ المكم: تنص المادة ؛ ؛ ؟ مرافعات علي أنه" لا يترتب علي رفع الالتماس وقف تنفيذ،

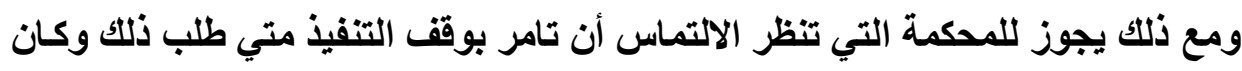
يخشي من التنفيذ وقوع ضرر جسيم يتعذر تداركه".

\section{ويتضح هن ذلك أنه يترتب علي رفع الالتهاس ها يلي:}

ا - القاعدة: عدم الوقف القانوذي للتنفيذ

لا يرتب علي رفع الالتماس وقف تتفيذ الحكم المطعون فيه، فلم يرتب القانون علي مجرد رفع الالتماس وقف تنفيذ الحكم، ولذلك فمن الجائز أن يقوم المحكوم لـه بتنفيذ الحكم رغم الطعن فيه بالالتماس، ولا شك ذلكت يتفق مع طبيعة الالتماس باعتباره

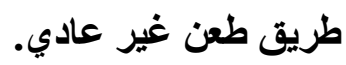

(1) ويكفى للفصل في قبول الالتماس أن تتحقق المحكمة من توافر الاوضاع الثكلية فيه من حيث

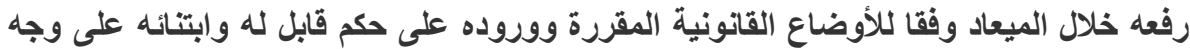

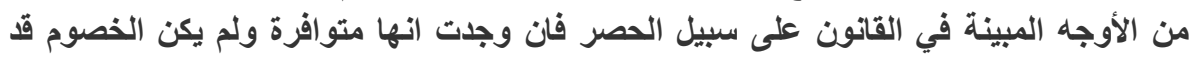

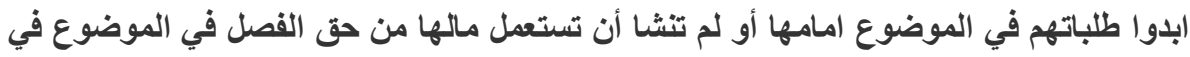
هذه الحالة قضت بقبول الالتماس وجدلت جلسة للمرافعة في الموضوع دون حاجة الباعل إعلان جديد. 
ولكن قد يترتب علي الاستمرار في التنفيذ أضرارا بـالمحكوم عليه، ويصعب

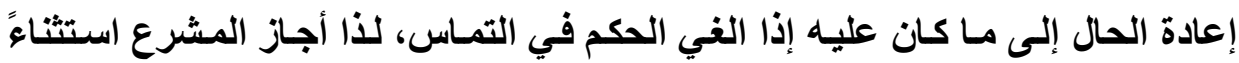

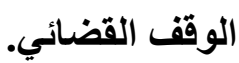

\section{r- الاستثناء: الوقف القضائي للتنفيذ:}

خروجـا علي القاعدة السابقة وهي عدم الوقف القـانوني للتفيذ بسبب رفع

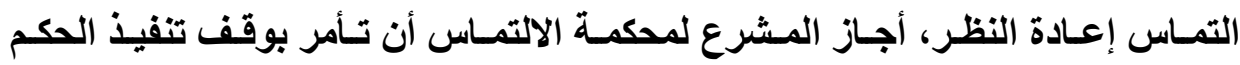

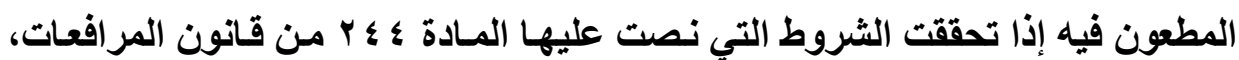

$$
\text { و التي تتثمل في الآتي: }
$$

\section{الشرط الأول: أن يطلب وقف التنفيذ هن المكمة:}

فلا تقضي به محكمة الالتماس من تلقاء نفسها دون طلب الملتمس، ولا تشترط

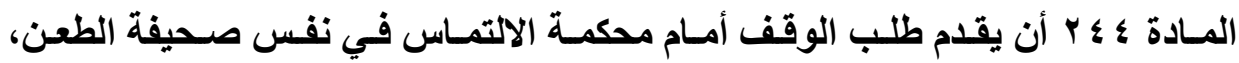
وبالتالي يجوز تقديم طلب وقف التتفيذ أمام محكمة الالتماس في شكل طلب مستقل عن التحن

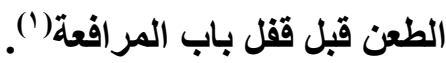
ويري البعض جواز تقليم طلب الوقف ثم الطعن بالالتماس، لأن رفع الالتمساس

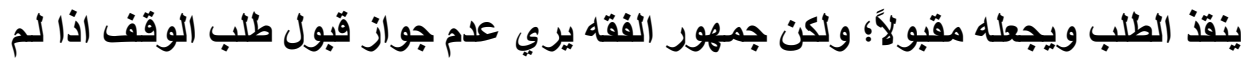

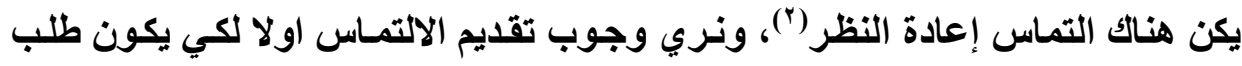
الوقف مقبو لاًا.

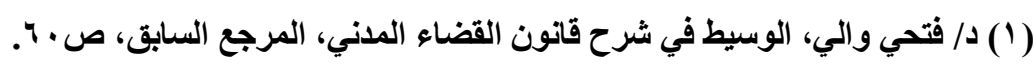

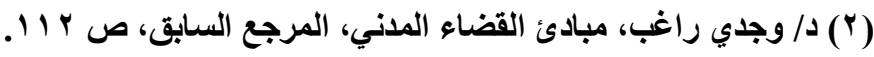


وإجراءات وقف التنفيذ امسام محكمة الالتمساس هي نفس اجراءات المعتادة في طلب وقف التنفيذ امام محكمة الاستئناف بتحديد جلسة لنظر الطلب واعلان الخصوم والمرافعة ثم حكم المحكمة ووقف التتفيذ هو سلطة تقديرية للمحكمة في حالة رفض طلب الوقف لعدم توافر شروطه، فهل يمكن إعادة رفع الطلب متي توافرت شروطه؟ لقد اختلف الرأي حول هذه المسألة. ذهب جانب من الفقه إلـي ضرورة التقيد بميعاد الالتمـاس لأن طلب الوقف في حقيقته طعن علي الحكم من حيث صلاحيته للتنفيذ(') وبالتالي لا يمكن تقديم الطلب مره ثانية لفوت الميعاد كما هو الثأن في الطعن بالنقض. وفي حقيقة الأمر هذا الرأي يـأتي بتقيد لم يرد بشأنه نص فلم ينص المشرع علي وجوب تقديم الطلب في الميعاد ولو أراد المشرع ذلك لنص صراحة كما فعل بالنسبة لوقف التففيذ أمام محكمة النقض. وقد ذهب رأي آخر إلي أن طلب الوقف ليس طريقا للطعن علي الحكم و إنما هو طلب وقتي يتعلق بـالقوة التنفيذية للحكم، وبالتالي لا يشترط تقديمـه في ميعـاد الطعن

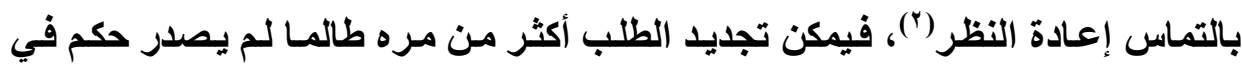
الالتماس، وهذا ما نؤيده.

(1) د/ رمزي سيف، قواعد تنفيذ الاحكام والعقود الرسمية في قانون المرافعات الجديد، طو، مطبعة

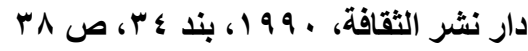

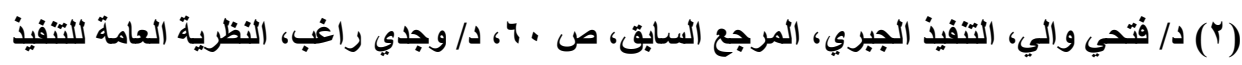
القضائي، المرجع السابق، ص بـ 9. 


\section{الشرط الثاني: تقديم طلب وقف التنفيذ قبل تهام التنفيذ:}

يجب أن يتم تقديم الطلب قبل أن يتم تنفيذ الحكم فعلا، فإذا تم التنفيذ قبل تقديم

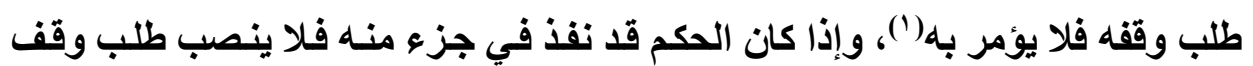

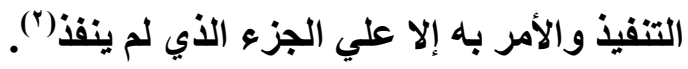

والحكمة من ذلك أن تمام التنفيذ يجعل الحماية الوقتية غير ممكنة، ويستفاد من نص المادة اهب أن العبرة بتمام التنفيذ أو عدمه هي بوقت تقديم الطلب، فالقاعدة أن

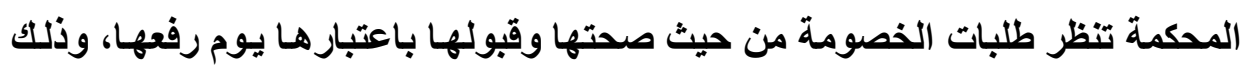

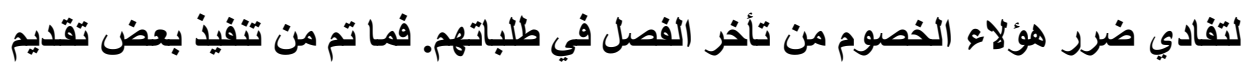
الطلب، ينسب أثر الحكم الصادر بالوقف علي إجراءات التنفيذ من وقت تقديم الطلب، وبالتالي يجوز اللجوء إلي قاضي التنفيذ بطلب إعادة الحال إلي ما كان عليه وقت تقديم طلب الوقف وذلك تنفيذا لحكم المحكمة بوقف التنفيذ. ولهذا إذا كان الملتمس قد طلب وقف تنفيذ الحكم المطعون فيه سواء قبل بدء هذا التنفيذ أو قبل تمامه، فإنه يجب ألا يضار من تأخير نظر هذا الطلب، فيقضي فيه وفيه باعتبار يوم رفعه ويقف التنفيذ ولو تمت إجراءاته بعد تقديم طلبه وقبل النظر فيه.

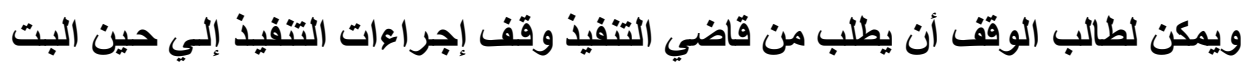
في طلب الوقف أمام محكمة الالتماس. 
ويلاحظظ أنسه لا يجـوز لمحكمـة الالتمـاس أن تقض بـالوقف وبطـلان إجراءات التنفيذ، وذلك لأن طلب الخصم هو الوقف، كمـا أن اختصاص محكمة الالتمـاس الوقف

$$
\text { وليس بطلان الإجراءات(') - ولئ. }
$$

\section{الشرط الثالث: أن يششي هن التنفيذ وقوع ضرر جسيم يتعذر تداركه.}

للحكم بوقف التنفيذ يجب أن يخشي وقوع ضرر جسيم يتعذر تداركه، ويقصد بالضرر هنا هو الضرر غير العادي الأي يقع جراء التنفيذ علي مال ذي قيمة خاصـة أو

استثنائية، مما قد يؤدي إلي التأثير في حالة المدين المالية أو الأدبية لدرجة كبيرة(؟). ومتى قدرت المحكمة أن التنفيذ سيترتب عليه ضرر جسيم يتعذر تداركه، قررت وقف التنفيذ، ويستوي أن يكون الضرر أدبياً أو مالياً، ولا يشترط أن يكون الضرر مؤكداً، ولكن يكفي أن يكون محتملا وقوعه بلرجة كبيرة. ويجب أن يكون الضرر متعذراً تداركه، أي يصعب إعادة الحال إلي ما كاتت عليه قبل التنفيذ، وفي حقيقة الأمر لم يشترط المشرع أن يكون إعادة الحال مستحيلا، ولكن يكفي أن يكون من الصعب إعادة الحال، فمثلا يتعذر تدارك الضرر عند تنفيذ الحكم بهام

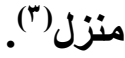


والواقع أن وقف التنفيذ هو نـوع من أنـواع الحمايـة الوقتيـة، ولذلك يجب أن يتوفر لها شرط الاستعجال الذي ييرر الأمر بها، ويتوافر هذا الشرط إذا كان يترتب علي تأخيرها- أي تنفيذ الحكم- احتمال حدوث ضرر بالملتمس يكون من المتعذر علاجه. وبمب علي القاضي للمكم بالوقف أن يبحث العناصر الآتية: 1 ـ احتمال حدوث ضرر بحقوق الملتمس من تنفيذ الحكم:

وهذا العنصر خاص بالحالة التي يقلم فيها الالتمـاس من الغير الذي يحتج في مواجهته بالحكم (م ا ؟ r مرافعات) لأن تنفيذ الحكم وإن كان يضر دائمسا بالمحكوم عليه فإنه ليس كذلك بالنسبة للغير، فمثلا لا يؤدي تنفيذ حم علي المدين لصالح أحد دائنيه إلى الإضرار بحقوق دائن آخر إذا كاتت أموال المدين كافيه للوفاء بجميع ديونه. ولم يشترط المشرع أن يكون هذا الضرر مؤكدا بـل يكفي أن يكون محتملا أن تتولا في نفس القاضي الخثية من وقوعه، فوقف التنفيذ هو نوع من الحمايـة الوقتية التي يتطلبها تفـادي خطر التأخير، ومن ثم يكفي الامر بها أن يستشف القاضي هذا الخطر من ظاهر الأمسور ودون تعمق في بحث الموضوع، ولكن يجب أن تكون درجة احتمـال وقوع الضرر كبيرة، ولا فرق بين مـا إذا كـان هذا الضرر المحتمل ماديـا أو معنويا.

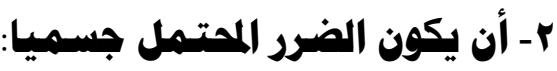

فقد وازن المشرع بين مصلحة المحكوم لله، فهو يستمد حقه في التنفيذ من حكم انتهائي حسائز لقوة الأمر المقضي، ومصلحة الملتمس في وقف التنفيذ، فلم يكتف باحتمال الضرر العادي وإنما تطلب أن يكون هذا الضرر جسيما، بمعني أن يؤدي تنفيذ 
المكم إلي التأثثير علي حقوق الملتمس الماديـة أو المعنويـة بلرجة تفوق الفائدة التي

تعود علي المحكوم له من جراء ذلك (').

وجسامة الضرر ليست مسألة موضوعية، بل تختلف من شخص لآخر، فالضرر

الذي يحتمل قد يكون بسيطا بالنسبة لشخص وجسميا في الوقت ذاتهه بالنسبة لشخص آخر، ولذلك يجب النظر في تقدير جسامة الضرر إلي الظروف الخاصـة بالشخص الذي قـ يعود عليه، وكذلك فإن جسامة الضرر تتأثر بالظروف الاقتصادية في زمن معين ومكان معين(). فهذا التقدير لا يخضع لمعيار موضوعي وإنمـا يخضع لمعيار شخص، فتختلف من شخص لآخر.

\section{r- أن يكون هذا الضرر همتعذرا تداركه إذا وقع فعلا:}

فلم يشترط المشرع أن يكون تدارك الضرر مستحيلا بـل يكفي أن يكون متعذرا بمعني أنه إذا تم سحب الحكم تكون هناك صعوبة كبيرة في إعادة الحالة إلى مـا كانت عليه قبل تنفيذه، ولذلك فقد حكم بـأن الضرر يعتبر ممـا يتعذر تداركه إذا كـان إعـادة الحالة تتطلب وقتا طويلا أو مصاريف باهظة، ويعتبر متعذرا تداركه إذا كان المحكوم عليه معسرا، إذ أن إعادة الحال هنا تكون مستحيلة("). وقد حكمت محكمة النقض المصرية بأنه إذا كان طلب وقف التنفيذ قد بني علي أن المطعون ضدهم معدمون بدليل عجزهم عن دفع باقي الرسوم المستحقة عليهم لقلم 
الكتاب، ولم يقلم المطعون ضدهم مـا يثبت ملاعمتهم، فِان في هذه الظروف مـا يبرر وقف تنفيذ الحكم المطعون فيه(').

\section{الشرط الرابع: ترجيح إلغاء الحكم}

بالرغم من عدم النص علي هذا الشرط في المـادة اهب مرافعات، فقد ذهب

البعض إلـي أنسه لا يشترط تـوافره لأن المشرع نـص عليـه في المـادة ب ج ج مرافعـات الخاص بوقف التفقيذ أمام محكمة النقض، وأغقله في المـادة ؟ ؛ ب مرافعات، وأن هذه المغايرة تلال علي تعدد المشرع تجاهل هذا الثرط. ولكن جمهور الفقهاء ذهب إلي ضرورة توافر هذا الشرط علي أسـاس القواعد العامة في الحمايـة الوقتية، ورجحان إلغـاء الحكم يخضع للسلطة التقديريـة للمحكمة، و هي تستطيع أن تستثف مدي إلغاء الحكم من جديـة الأسباب التـي بني عليها الطعن بالالتماس.

\section{الشرط الخاهس : أن تأهر همكمة الالتهاس بوقف التنفيذ:}

لم يرتب المشرع علي تقديم طلب وقف التنفيذ وإثبات وقوع ضرر جسيم يتعذر تداركه في حالة تنفيذ الحكم، أن يتم وقف هذا التنفيذ بقوة القانون وإنمـا استوجب أن يكون ذلك بناء علي أمر من محكمة الالتماس. ولكن هل يكون للمحكمة سـلطة تقديريـة في الأمـر بوقف التنفيذ إذا تـوافرت شروطه؟ 
د/ طلعت يوسف خاطر

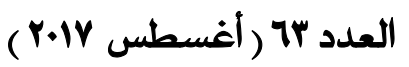

يلاحظ أن المحكمة ليس لها سلطة تقديريـة فيمـا يتعلق باثـتراط قيام الملتمس بطلب وقف تنفيذ الحكم قبـل البـدء فيـه أو قبـل إتمامسه، فهذا شـرط جامـد ولا يمكن الاختلاف في تحديد عناصره.

وبالنسبة للشرط الثاني، وهو الخثية من قوع ضرر جسيم يتعذر تداركه نتيجة التنفيذ، فهذا شرط مرن يتيح للمحكمة الحرية في تقديره. وإذا قدرت المحكمة تـوافر الشروط، فهل يجـوز للمحكمة أن تمتتـع عن الأمـر بوقف التنفيذ رغم ذلك؟

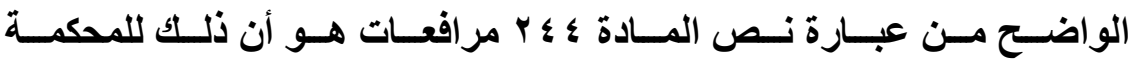

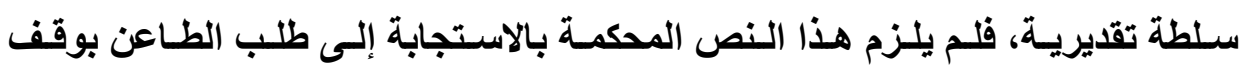
تنفيذا إذا تحققت شـروطه، حيث جعل لها سـلطة جوازيـه، فيكون لهـا أن تمتنـع عن

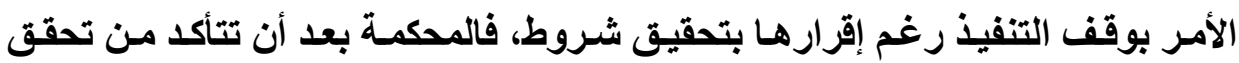
هذه الشروط تقوم بتقدير الموقف تقديرا كـاملا، فتراعي مقتضيات العدالة، وتصدر قراراها بما يحقق الموازنة بين مصلحة الملتمس في وقف التنفيذ ومصلحة المحكوم له في استمراره، ولذلك فقد أجـاز لها القانون عندما تـأمر بوقف التنفيذ أن توجب تقديم

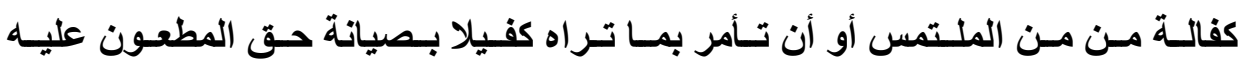

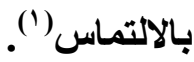

ويجب نظر الطلب قبل الفصل في موضوع الطعن. وإلا أصبح لا محل له، كمـا أن لمحكمة الالتماس السلطة التقديرية عند النظر في وقف التنفيذ، فلها أن تأمر بمـا تراه (1) د/ بشندي عبد العظيم أحمد، حماية الغير في قانون المرافعات، المرجع السابق، ص ا به. 
كفيلا بحماية حق المطعون ضده. كما لا يجب إبلاغ النيابة العامة بطلب وقف التتفيذ كما هو الحال بالنسبة لطلب الوقف أمام محكمة النقض.

\section{ثانيا: آثار الحكم بقبول الالتهاس:}

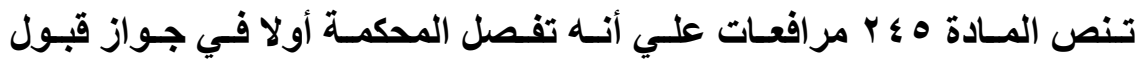
الالتماس ثم تحدد جلسة للمر افعة في الموضوع دون حاجة إلى إعلان جديد، وبالتـالي قبول الالتماس يستوجب أن تصدر المحكمة حكما أخر وتفصل من جديد في الموضوع. الالتماس وسيلة تهذف إلى سحب الحكم وليس إحلال حكم جليد محله، ومن ثم فإن قبوله يؤدي إلى إلغاء الحكم المطعون فيه، وجعله كـأن لـم يكن ثم إعـادة النظر في الموضوع من جميع عناصره الواقعية والقانونية بعد ذلك، ويؤدي إلغاء الحكم المطعون فيه إلى زوال جميع الأثثار القاتونية التي تترتب عليه، بحيث يعود الخصوم إلى نفس مراكزهم التي كاتت قبل صدور هذا الحكم. إذا كان الحكم المطعون فيه قد نفذ فإن قبول الالتماس يؤدي إلى التزام المحكوم له برد جميع الحقوق التي سلمت له نتيجة هذا التنفيذ، وكذلك رد الثمـار الناتجة عنها خلال المدة اللاحقة لتفيذ الحكم دون بحث في حسن نيـة المحكوم لـه أو سوئها في تحصيل هذه الثمار ('). 


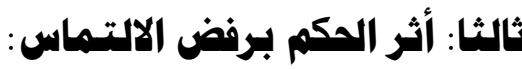

يؤدي الحكم برفض الالتمساس إلى انتهاء الخصومة، ويمكن للمحكوم لـه أن

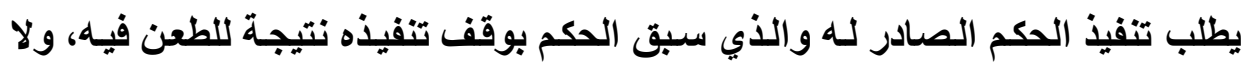
يجوز للملتمس إعادة رفعه من جديد.

في حالـة رفع موضسوع الالتمساس المقدم من الغير يمكن للمحكسة أن تقضي بمصادرة الكفالة كلها أو بعضها التي سبق له إيداعها عند رفع الالتمساس، وذلكت تبعا

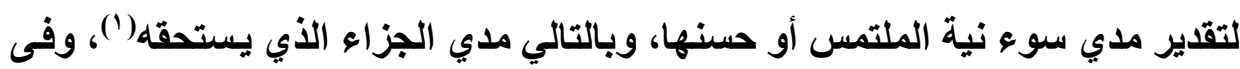
جميع الأحوال يجوز الحكم بالتعويضات إن كان لها وجهاء

وفي فرنسا يترتب علي رفض الالتمساس المرفوع بشكل تعسفي إلى الحكم

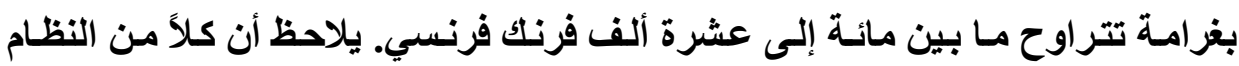

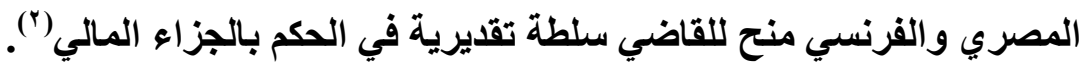
وقد نصت المادة V Y مرافعات علي أنه الحكم الصادر في الالتمساس لا يجوز

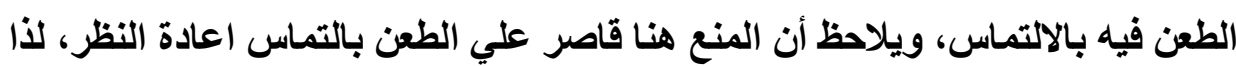
يجوز الطعن الطرق الأخرى، فيجوز الطعن بالنقص إن كان له وجه. ويثور التساؤل عن مدي جواز رفع التماس ثاني إذا وجت أسباب جيدةّ

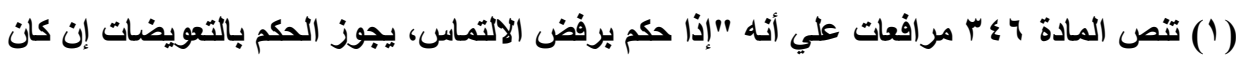

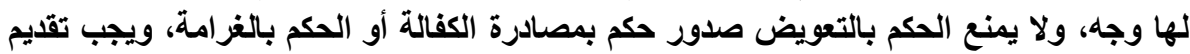

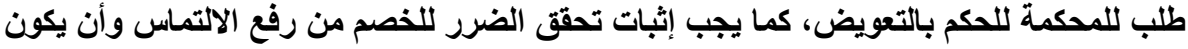
ناتجا عن تعف أو سوء استعمدل الحق الطعن".

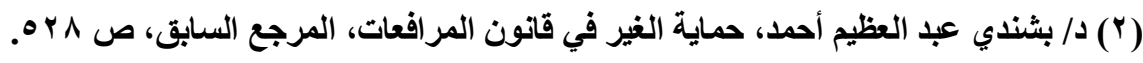


طبقا لنص المادة V \ من قانون المرافعات المصري، لا يجوز تقديم التمساس ثان، وذلك في حالـة رفض الالتمـاس أو الحكم في الموضوع. ولكن القانون الفرنسي

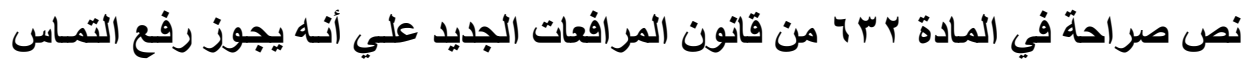
ثان إذا كاتت هناك أسباب جليدة. والواقع إذا كان المشرع المصري لم ينص علي حكم مشابه للقانون الفرنسي، ولكن يجب الأخـذ بـالنص الفرنسي، وبالتـالي لا يجوز رفض الالتمساس الثـاني، لأنـه الحجية تنصب علي الأطراف والموضوع والسبب، وفي حالة الالتمـاس الجديد تكون

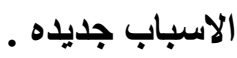




\section{المبحث الثاني \\ هوقف القانون المقارن هن اعتراض الغير علي الهكم}

سنثير إلى حق الغير في الاعتراض علي الحكم في الأنظمة المقارنة، وآثار اعتراض الغير علي الحكم في القانون الفرنسي، وذلك في المطالب الآتية:

\section{المطاب الأول \\ حق الغير في الاعتراض علي الحكم في الأنظمة المقارنة}

سنعالج وسائل الغير في الاعتراض علي الحكم في القانون المقارن، وشروط

اعتراض الغير علي الحكم في القانون الفرنسي، وذلك في الفروع الآتية:

\section{الفرع الأول \\ وسائل الغير في الاعتراض علي المكم في القانون المقارن}

لقد ذهبت النظم القانونية إلي ضرورة حماية الغير، فقد نظمت بعض القوانين حق الغير في الاعتراض علي الحكم عن طريق طعن خاص بالغير، والبعض نص علي لفي

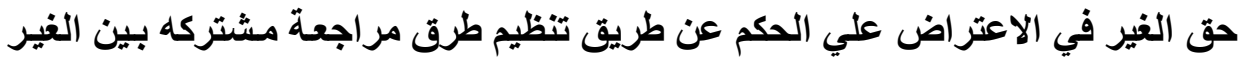
و الخصوم، ولم ينظم للغير طريقا خاصا به.

فمن الانظمة التي قررت للغير حقا خاص به للاعتراض علي الحكم، مـا نصت

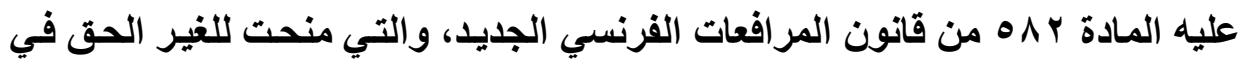


الاعتراض الخارج عن الخصومة، ويقصد بـه طريق طعن مقرر لمصلحة الغير بهدف تعديل الحكم أو إلغاءه، وبمقتضي هذا الطعن يعاد بحث الحكم من جديد من حيث الواقع

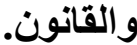

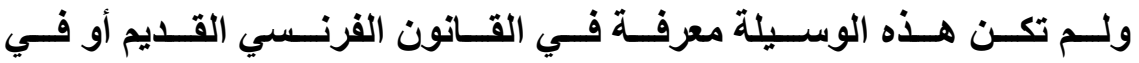

القـانون الرومساني، وإنمـا نص عليهـا لأول مـرة في اللـوائح الـصادرة سـنة ل 77 ا، ومنها انتقلت إلى القوانين المتعاقبة حتي نص عليها في قانون المرافعات الفرنسي

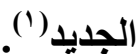

وقد اخذت بعض الانظمـة بـفس منهج القـانون الفرنسي، وذلك بمنتح الغير

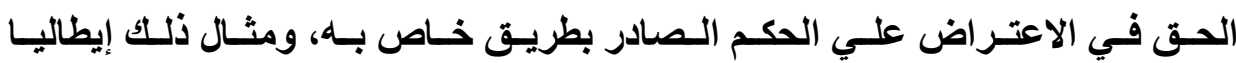

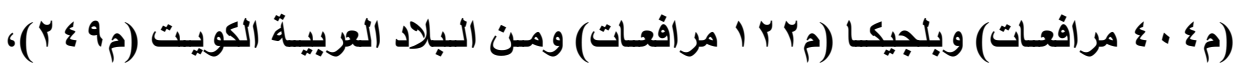
ولبنان (م اهـ من أصول المحاكمات) وقانون المرافعات المصري الملفي (م • ـ ؛)،

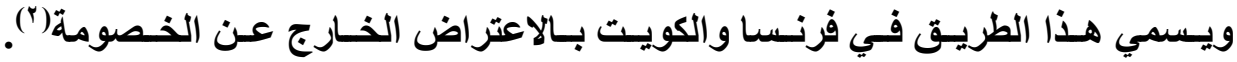
ويسمي في ايطاليـا ولبنـان بـاعتراض الغير، وفي السويد بالاسـتئناف غير العسادي للغير (") وقد نظمت قوانين اخرى طريقا أخر للغير، حيث ذهبت بعض التشريعات إلى تنظيم طرق للاعتراض علي الحكم من الأشخاص الممثلين في اللاعوي، وذلك بإضفاء صفة الغير عليهم إذا بني الحكم علي غش من كان يمثلهم في الدعوي أو تواطئه، فلم

(1) A. tissier, théorie et pratique de la tiers opposition, op. cit., $\mathrm{n}^{\circ}$ 6, p.11 et s.

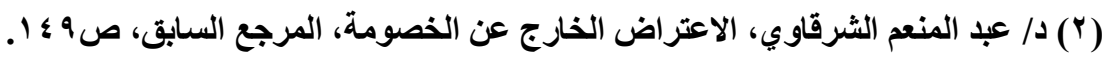

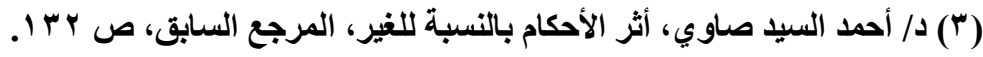


تسمح لكل من لله مصلحة من الغير أن يعترض علي الحكم، بل قصر ذلك علي طوائف معينـة من الغير. فنجد في القـانون السويسري مـا يسمي بدعوي الرجوع أو دعوي الاسترداد (مو س م مرافعات)، والتي تجيز للاائن أن يطلب إعادة النظر في الحكم الضار بحقوقه إذا بني علي غش أو تدليس. ونلاحظ في بعض القوانين، مثل القـانون الألمساني، إذا أضر الغير من الحكم، وكان ذلك نتيجة للتواطؤ بين الخصوم، فله أن يتمسك بالدفع بالتدليس، وإذا نجح في ذلــك امتــع الاحتجـاج عليـهـ بـالحكم. وفـي بعض القـوانين الأخرى، مثـل دول أمريكـا اللاتينيـة، نـصت قوانينهـا علـي بطلان الأعمـال الإجرائيسة التـي بنيـت علـي الغش أو التلليس(')

\section{الفزرع الثثاني \\ شروط اعتراض الغير علي الهكم في النظام الفرنسي}

نصت المـادة بره مـن قـانون المرافعـات الجديد علـي وجوب أن يكون للغير مصلحة في الاعتراض علي الحكم. وهذا النص يعتبر تطبيقا للقواعد العامـة، والتي تستوجب توافر المصلحة لقبول أي طلب أو دعوي قضائية. 
ويلاحظ أن ضابط المصلحة بالنسبة للغير يتمثل في الضرر الذي يعود عليه من

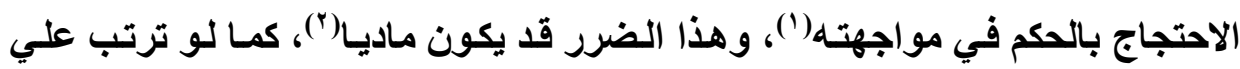

الحكم علي المدين إعساره مما يضر بحقوق الدائنين، وقد يكون هذا الضرر معنويـ(")،

فيجوز للورثة في النظام الفرنسي الاعتراض علي الحكم المتعلق بتحديد المسئول عن رعاية الأطفال بعد تطليق الوالدين.

ويكفي أن يكـون الـضرر النـاتج عـن الحكـم محـتملا لتحقيـق المـصلحة فـي الاعتراض، وليس ضررا حالأ؛)، ويظهر ذلك إذا كان حق الغير ليس حال الأداء وقت

ويمكن أن يتحقق الضرر المحتمـل وبالتـالي المصلحة في الاعتراض إذا كـان

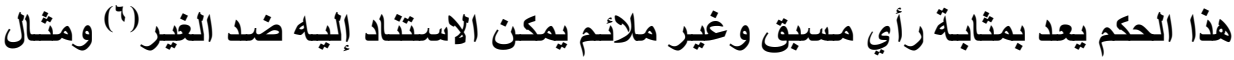
ذلك مصلحة أحد الموصي لهم في الاعتراض علي الحكم الصادر ضد موصسي لله آخر

(1) A. Tissier, théorie et pratique de la tiers opposition, op. cit., no 132, p. 211 et s., vincent et guinchard, procédure civile, op. cit., no 1010, p. 888, Cass. Civ., 17 mai 1977, Bull. civ, 1977, 3, $\mathrm{n}^{\circ}$ 215, Gaz pal, 1977, 2, somm, 311.

(2) Cass. Civ., 27 Avril 1966, Bull. Civ., 1966, 2, no 492, Cass. Com, 1er December 1969, Bull. Civ., 1969, 4, no 357.

(3) Chevet $M$, de la représentation en justice ( droit romain) des personnes qui peuvent intervenir ou former tierce opposition, thèse paris, 1892, $\mathrm{A}$. tissier, théorie et pratique de la tiers opposition, op. cit., $n^{\circ} 138$, p. 222

(4) Cass. Civ, 29 mai 1953, D., 1953, 515.

(5) Cass. Civ. 22 nov. 1859, DP, 1860, 1, 288.

(6) CA Paris, 23 mars 1956, JCP 1956, $2,9332$. 
ببطلان الوصية المشتركة، أو كان من الممكن الاستناد إليه كأساس للاعوي أخري ضد الغير (')، كمصلحة المسئول مدنيا في الاعتراض علي الحكم الصادر ضد مرتكب الفعل (r) (الضار)

سنعالج الثروط الواجب توافر لاعتراض الغير علي الحكم في القانون الفرنسي، والتي تتمثل في اشتراط صفة الغير، وأن يكون الحكم قابلا للاعتراض عليه من الغير،

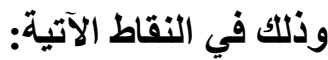

\section{الشرط الأول: أن يكون المعترض هن الغير:}

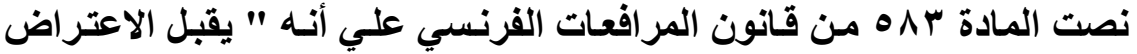

علي الحكم من كل ذي مصلحة لم يكن طرفا أو ممثلا في الحكم الذي يعترض عليه"(")، وبالتالي يشترط في الشخص الذي يعترض علي الحكم أن يكون من الغير، فيجب ألا يكون الشخص طرفا في الخصومة التي انتهت بصدور الحكم لا بنفسه ولا عن طريق ليق ممثل له في إجراء|تها(؛)، وذلك لأن أطراف الخصومة لهم الحق في الطعن بالطرق

(1) Ca Lyon, 30 decembre, 1947, D., 1948, somm., 23.

(2) Cass. Civ, 7 juillet 1910, DP, 1913, 1, 43, CA Lyon 30 décembre 1947, D. 1948, somm. 23, CA Montpellier, 31 mars 1982, JCP 1983, G, 4, 325.

(3) Art 583 dispose que «Est recevable a former tiers opposition toute personne qui $y$ a interet, a la condition au elle $n$ ait été ni partie ni représentée au jugement qu'elle attaque».

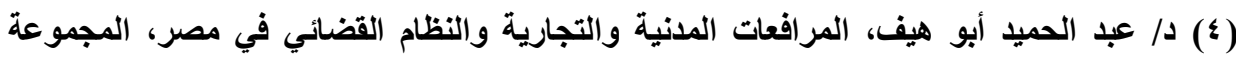

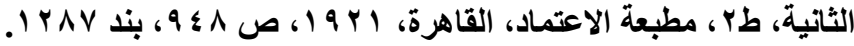


العادية والطرق غير العادية، ولا يجوز للخصم اتباع طريق الاعتراض علي الحكم حتي لو لم يشارك في الخصومة، وصدر حكم غيابي ضده('). ويثور تساؤل عن مـدي جـواز اعتراض كل مـن لـه صفة الغير علـي الاحكـام الصادرة من القضاء؟ في الواقع توجد حالات لا يمكن للغير الاعتراض فيها علي الحكم الصادر، وحالات اخري حدد المشرع شروط معينة في الغير المعترض علي الحكم، ويتمثل ذلك في الآتي:

\section{ا - الهالات التي هنه فيها المشرع اعتزاض الغير علي الهكم:}

ويتمثـل ذلــك فـي الــدعاوي التــي يقـصر المسشرع رفعهــا علــي اشــخاص معينين بالذات، حيث نجد في بعض اللدعاوي يقصر القانون الحق في رفع الدعوي علـي أثــخاص معينـين بالــذات مثـل دعـاوي الحجـر علــي الأثــخاص والتطليـق والتـصل مـن النسب...، وفي هذه الحساتلات فِان الصفة في الاعتراض علـي الحكم تقتصر علـي هـؤلاء الاشـخاص الــين أجـاز لهم القـانون رفـع الـدعوي، أمسا غيرهم فـلا يجـوز لهــم الاعتـر اض لأنهــم ممنوعـون قانونــا مـن مناقـشة موضـوع النـزاع، وبالتـالي لو كـان كل الأشخاص الذين يجوز لهم رفع الدعوي قد صساروا أطرافـا في الخصومة فإن الحكم الذي صدر يحتج به في مواجهة الكافة. ولا يقبل الاعتراض عليه من أي شخص آخر ممنوع من رفع اللاعوي حتي لا يحصل هؤلاء علي حق لا يجوز

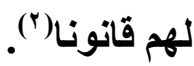

(1) TGI Lille 9 mai 1947, Gaz Pal, 1947, 2, 131

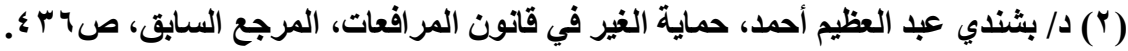




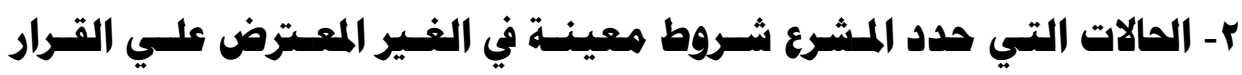
الصادر هن القاضي:

\section{الغير المعترض علي الاعمال الولائية:}

نصت المسادة rمه من قانون المرافعات الفرنسي علي أنه لا يقبل الاعتراض

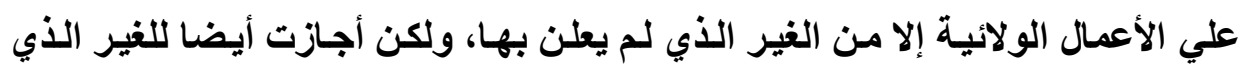
أعلن بالعمل الولائي أن يعترض عليه إذا كان قرار القاضي بثأنه غير قابل للطعن فيه الآنه بالاستنناف، فقد حدد القانون الفرنسي أثخاصا معينين من الغير يمكنهم الاعتراض علي القرار القضائي المتعلق بأحد الأعمال الولائية، ولا يكون هذا الاعتراض مقبولا إذا قدم من غير هؤلاء الأشخاص. الممثل في الخصوهة ليس بشخصه:

يجوز لمن كان ممثلا في الخصومة أن يعترض علي الحكم ضد ممثله إذا أثبت أنـه كـان نتيجة غش أو تواطئ للإضـرار بحقوقه أو أنـه تجـاوز ممثله حدود التمثيل

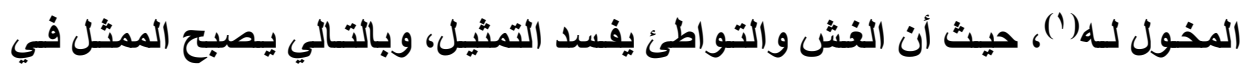
الخصومة كأنه من الغير.

وللاانتين والخلف الخاص الحق في الطعن إذا بني الحكم علي غش أو كانت

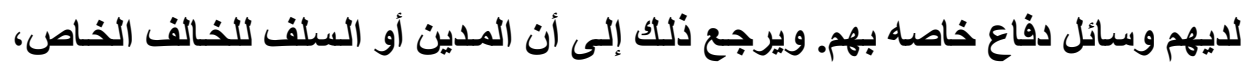

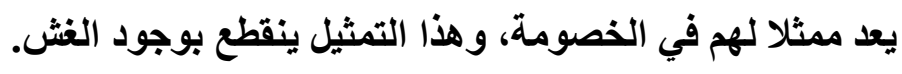

(1) A. tissier, théorie et pratique de la tiers opposition, op. cit., $\mathrm{n}^{\circ} 118, \mathrm{p}$. 193. 


\section{تغيير صفة النصم في الدعوي:}

كـذلك يجـوز للطـرف الاعتـراض علــي الحكــم إذا تغيـرت صــفته التـي كـان مساثلا بها، واعتبر بنـاء علي الصفة الجديدة من الغير بالنسبة للحكم، وفقد صفته كطرف (1) - (1)

\section{الشرط الثاني: أن يكون المكم قابلا للاعتراض عليه هن الغير}

تنص المسادة ه^ه مرافعـات علـي أن "كلل حكم يقبل اعتراض الغير مـالـم

ينص القانون علي خلاف ذلك". فيستفاد من هذه المـادة أن جميع الأحكام القضائية تقبل الطعن فيها بـالاعتر اض الغير(r)، فلا فرق في ذلتك بين الأحكام التي تصدر من محكمة أول درجة وتلك التي تصدر من محكمة الاستئناف، وسـواء كانت صسادرة من جهـة عاديـة أم اسـتثنائية أو هيئة ذات اختصاص قضائي (")، فكل هذه الأحكـام قابلـة

(1) د/ بشندي عبد العظيم أحمد، حماية الغير في قانون المرافعات، رسالة حقوق القاهرة، .99 19، ص ص

(2) J. Vincent et s. Guinchard, procédure civile, op. cit., p. 891.

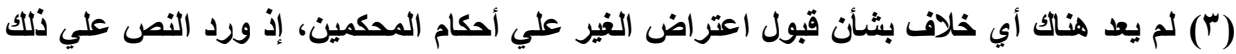

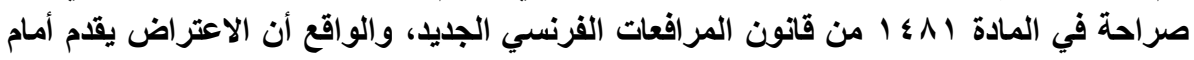

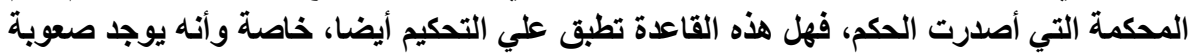

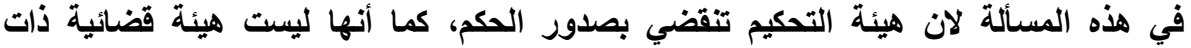

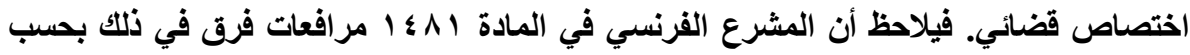

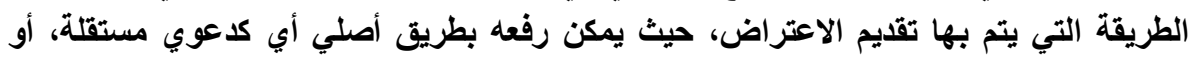

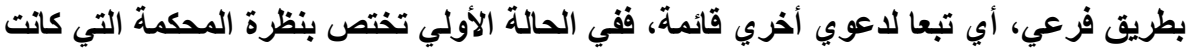

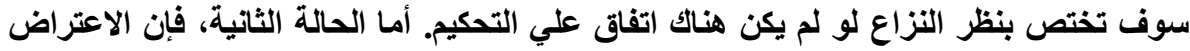

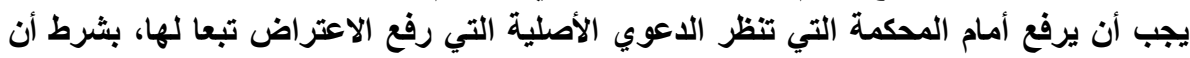

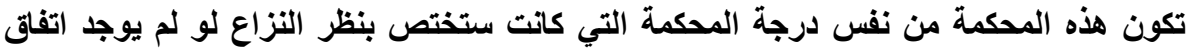
علي التحكيم أو في درجة أعلي منها، حتي لا يكون هناك خروج علي قواعد الت الاختصاص. 
للاعتراض عليها من الغير، سواء طعن فيها من الخصوم أم لا، وسواء كانت حضورية

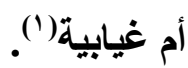

وبالرغم من النص العام علي جواز الاعتراض علي كافة الأحكام إلا أن الفقه

الفرنسي اختلفت كلمته حول بعض الأحكام، ويتمثل ذلك في الآتي:

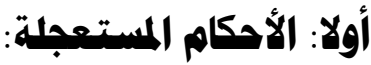

اختلف الفقهاء الفرنسيون في قبول اعتراض الغير علي الأحكام التي يصدرها قاضي الأمور المستعجلة، وذلك علي النحو التالي:

\section{الرأي الأول: عدم جواز اعتراض الغير علي الأحكام المستعبلة:}

ذهب جانب من الفقه يؤيده بعض أحكام القضاء إلى علم جواز الاعتراض علي

هذه الأحكام(")، واستتد أنصار هذا الاتجاه الأسانيد الآتية:

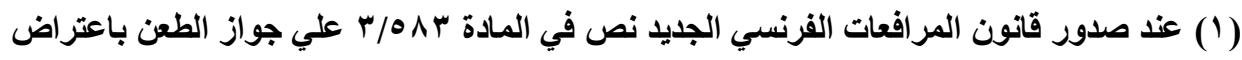

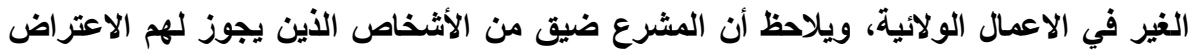

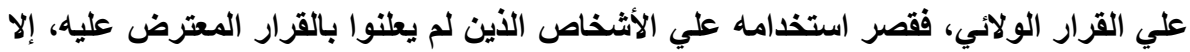

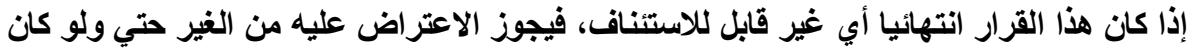

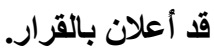

(2) Tostivint $\mathrm{R}$, «de la tiers opposition aux décision émanant des tribunaux ordinaires ", thèse Rennes, 1905, p.119,A. tissier, théorie et pratique de la tierce opposition, thèse paris, op. cité, $n^{\circ}$ 59, p. 104, CA Paris, 21 avril 1921, DP, 1921, 2, 76. 
د/ طلعت يوسف خاطر

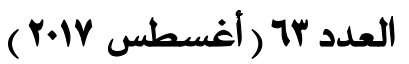

\section{ا - صعوبة تحقيقه هن الناحية العملية وعدم الفائدة هن تقريره.}

وذلـك لأن الحكم المستعجل لا يـؤدي إلـى الإضـرار بحقـوق الغيـر، ولا يحـوز

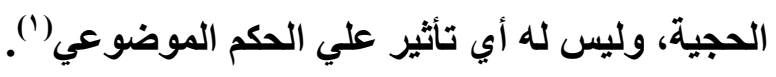

\section{r- لا يمكن هن الناحية القانونية قبول اعتراض الغير وذلك لسببين:}

السبب الأول: نص قانون المر افعات الفرنسي علي عدم قبول معارضة الخصم

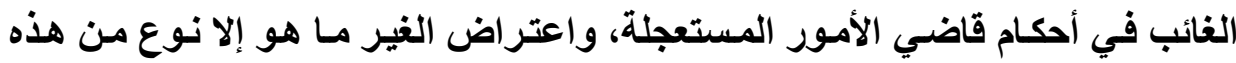

$$
\text { المعارضة فيكون غير مقبول أيضا. }
$$

السبب الثـاني: قبول الاعتراض يتعارض مي صفة الاستعجال التي تبرر

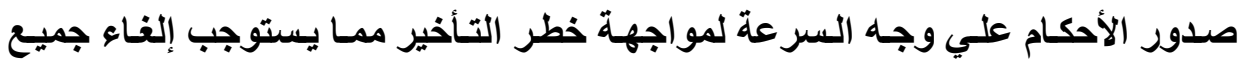

$$
\text { العوارض التي قد تعوق صدورها. }
$$

\section{الرأي الثاني: جواز اعتراض الغير علي الأحكام المستعبلة:}

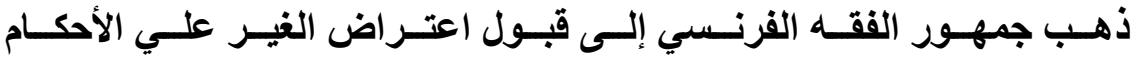

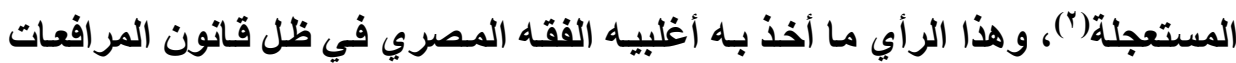

$$
\text { المختلط وقانون المرافعات السابق. }
$$

(1) إذا كان الإضرار بحقوق الغير ناتجا عن تنفيذ الحكم المستعجل، فإنه يمكن علاج ذلك بؤئل بوسائل

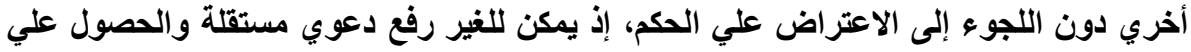

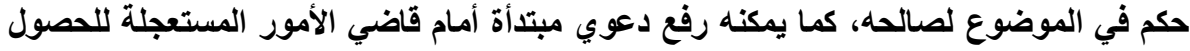

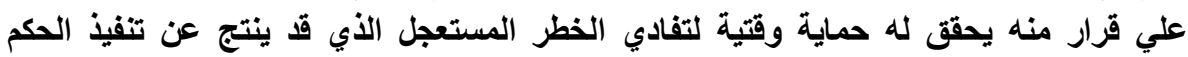
المستعجل الصادر لمصلحة شخص آخر، وأخيرا فإنه يجوز له تفادي ذلك بتقليم استثكال في تنفيذ

(2) Glasson $E$, tissier $A$, et Morel $R$, traite théorique et pratique de l'organisation judiciaire, de compétence et de procédure civile, 3ed, $=$ 
واستتل انصار هذا الاتجاه إلى أن النص علي اعتراض الغير علي الأحكام جاء

عاما بالنسبة لجميع الأحكام القضائية، وهو ما ينطبق علي الأحكام المستعجلة (').

sirey, 1925-1036, t3, no 958, p. 550, Costes $M$, de la protection des droit de tiers spécialement devant le juge de référé, RTD, civ, 1924, p. 277. Cass. Civ, 7 juill, 1910, D., 1913, 1, 43, CA Paris, 24 juin 1929, DP, 1931, 2, 15, CA Nancy, 1er fev, 1946, D,1946, p. 146.

انظر د/ عبد المنعم الثرقاوي، اعتراض الخارج عن الخصومة علي الحكم الصادر فيها، المرجع

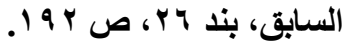
(1) وقد حاول أنصار هذا الاتجاه الرد علي حجج الرأي الأول، وذلك علي النحو التالي: 1 ـ بالنسبة للفائدة العملية من قبول الاعتراض:

الأحكام المستعجلة لها حجية ولكنها وقتيه، وبالتالي ينطبق عليها ما ينطبق لألئ علي الأحكام

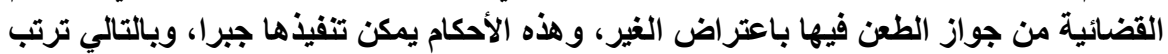

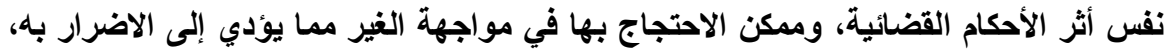

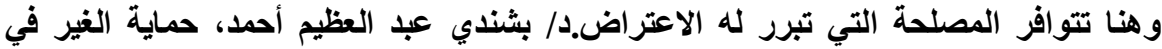

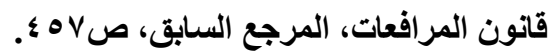

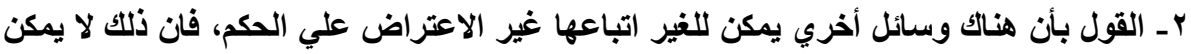

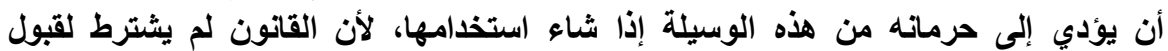

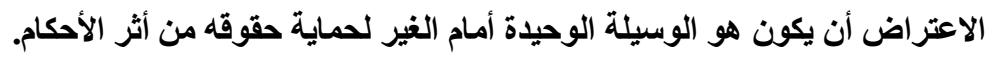

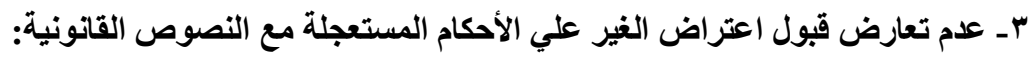

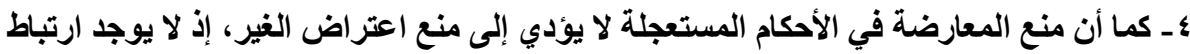

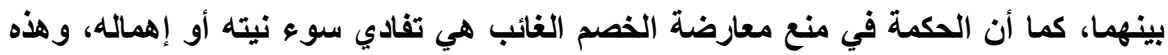
الحكمة غير موجودة بالنسبة للغير الذي لم يعلن بارضة الخصومة.

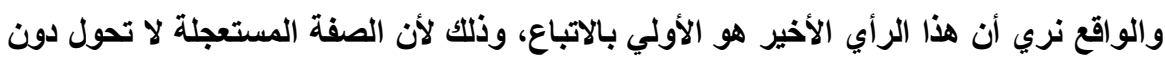

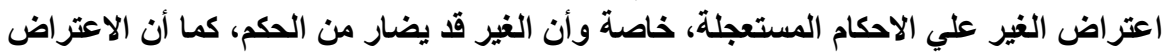

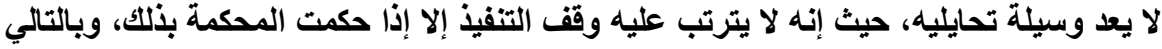
لا يؤثر ذلك على تنفيذ الحكم. لايلمة 


\section{ثانيا: أحكام همكمة النقض}

لقد اختلف الفقه الفرنسي في مدي جواز اعتراض الغير علي الأحكام الصادرة من محكمة النقض، ويمكن أجمالي هذا الاختلاف إلى اتجاهين:

\section{الاتجاه الأول: جماز اعتزاض الغير علي أحكام همكمة النقض:}

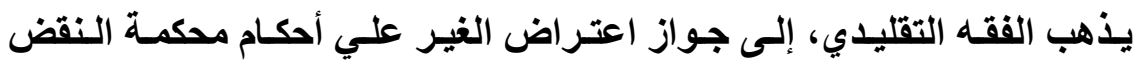
استنادا إلى أن هذه الأحكام قد يترتب عليها ضرر بحقوق الغير، فإذا قضي بنقض الحكم ترتب علي ذلك ضرر بحقوق الغير الذين تربطهم مصالح بهذا الحكم، وبالتالي يكون لهم الحق في الطعن أمام محكمة النقض باعتر اض الغير (')

\section{الاتجاه الثاني: عدم جواز اعتراض الغير علي أحكام همكمة النقض:}

ذهب رأي أخر في الفقه الفرنسي إلـي عدم جواز اعتراض الغير علي أحكام

محكمة النقض، وذلك لأن أحكام هذه المحكمة ذات طبيعة خاصة، فموضوعها هو الحكم المطعون فيه، أي أنها تقضي في الحكم وليس النزاع، وبالتالي لا يمكن تصور بحث طلب الغير والفصل في اعتر اضه دون تعارض مع طبيعة دور محكمة النقض باعتبار هـا

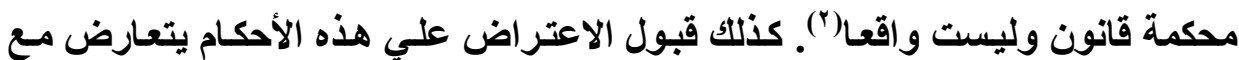
الوحدة والثبات اللازمين لهذه الأحكام.

(1) A. Tissier, théorie et pratique de la tiers opposition, op. cit., n 66, p. 117.

(2) Glasson et tissier et morel $R \quad R$, traite théorique et pratique de l'organisation judiciaire, de compétence et de procédure civile, op. ci., no 987, p. 552, J. Bonnecase et $M$. Larborde, Lacost, précis élémentaire de procédure civile et voies d'exécution, siry, 1932, no 806, p. 335. 
كما أن أحكام محكمة النقض لا يمكن أن تضر بحقوق الغير، وبالتالي لا يوجد مصلحة في الاعتراض(')، لأن المحكمة أما أن تقرر رفض الطعن أو قبوله والإحالة إلي المحكمة المختصة، ففي الحالة الأولسي يكون لـه الحق في رفع الاعتر اض ضد الحكم الأول أي الأي رفضت محكمة النقض الطعن فيه، وفي الحالة الثانية فإن للغير أن ينتظر حتي تصدر هذه المحكمة حكمها ثم يعترض عليهه إذا اضر بحقوقه، ولم يكن قد تدخل في الخصومة التي انتهت بصدوره(؟).

\section{الاطلبب الثاني \\ آثار اعتراض الغير علي التنفيذ في النظام الفرنسي}

تنقسم آثار الاعتراض المقلم من الغير إلى آثار رفعه علي التنفيذ، وأثثار الحكم فيه، وذلك في الفروع الآتية:

(1) د/ بشندي عبد العظيم أحمد، حماية الغير في قانون المرافعات، المرجع السابق، ص • V؛.

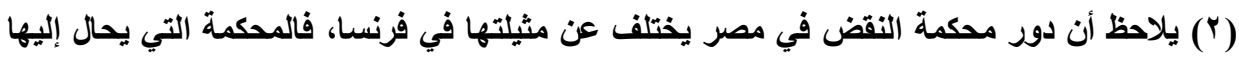

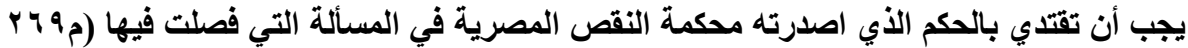
مرافعات) كما أن دور محكمة النقض في مصر لا يقتصر علي إثبات مدي مطابقة الحكم المطعون

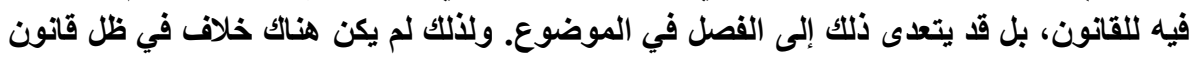

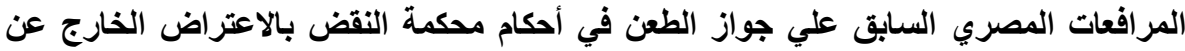




\section{الفرع الأول \\ آثار رفع الاعتراض علي التنفيذ الجبري}

لا يؤدي رفع الاعتراض إلي وقف التفيذ بقوة القانون، ولكن يجوز للمحكمة التي تنظر الاعتراض أن تقضي بوقف التنفيذ إذا توافرت شروط معينة، وعدم وقف التنفيذ بقوة القـانون يرجع اساسـه لنص المسادة وه ل مرافعـات فرنسي، حيث وردت كقاعدة عامة بالنسبة لطرق الطعن غير العادية، والتي يعتبر اعتراض الغير إحداها طبقا للقانون الفرنسي. ولعل الهدف من عدم وقف تنفيذ الحكم بمجرد اعتراض الغير عليه هو منع استخدامه كوسيلة يلجأ إليها الخصم لعرقلة تنفيذ الحكم عن طريق الإيعاز إلى شخص من الغير بتقليم اعتراض عليه(')، وحتي لا يساء استخدام طريق الاعتراض الخـارج عن الخصوم لوقف التنفيذ، عن طريق تحايـل الخصوم الذين استنفدوا طرق الطعن بالإيحاء لأصدقائهم بالطعن في الحكم، لذلك نصت بعض التشريعات علي عدم ترتيب وقف التفيذ علي رفع الطعن من الغير مثل القانون المصري والفرنسي، وإعطاء سلطة تقديرية للقاضي للحكم بقوة التنفيذ. كذلك نصت بعض الأنظمة علي جزاء علي رفع الطعن بسوء نية، مثال ذلك القانون الكويتي حيث يجـاز الطاعن بالغرامـة والتضمينات

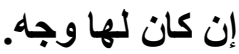

ويشترط لوقف التنفيذ بقرار من القاضسي المختص بنظر اعتراض الغير طبقا لنص المسادة ـ وه من قانون المرافعات الفرنسي الجديد أن يتقدم الغير بطلب لوقف 
التنفيذ، أن يترتب علي التنفيذ ضرر جسيم(')، ويجب ألا يكون التنفيذ قد تم، وأن تحكم

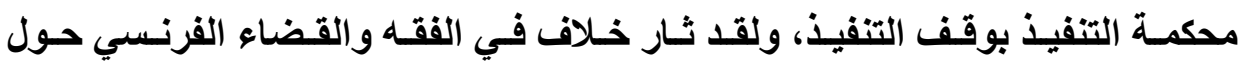
اختصاص قاضي الأمور المستعجلة في الأمر بوقف التنفيذ، ويري الرأي الراجح في

الفقه هو عدم اختصاص قاضي الامور المستعجلة بوقف التنفيذ(؟). وإذا نجح الطاعن في الاعتراض علي الحكم في وقف التنفيذ، فإنه لا يستفيا منه إلا هو، وبالتالي يصبح الحكم ملزما لأطر افه، ما لم يكن بني علي غش.

\section{الفرع الثاني أثار المكم في اعتراض الغير}

يؤدي رفع اعتراض الغير علي الحكم إلى إعادة طرح القضية بجميع عناصرها

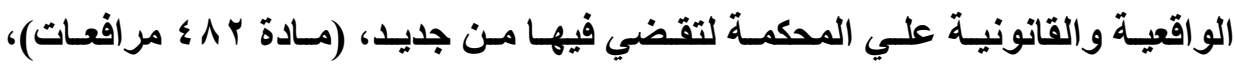

(1) TGI civ., sein, 19 mars 1958, D., 1958, somm., 92.

فالقاضسي يقوم بوزن مصلحة المدعي عليه في الاستمرار في تنفيذ الحكم أو البداء في التنفيذ،

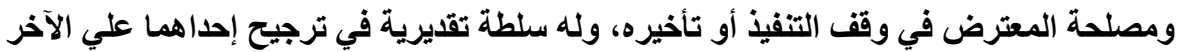

(2) A. tissier, théorie et pratique de la tiers opposition, op. cit., no 170, p. 263, CA Paris ref, 6 aout '976, JCP, 1977, 2, 18534, note JJH..

CA Angres ref, 25 janv. 1973, D. 1973, 647, RTD civ, 1973, 398, obs., Raynaud.

يلاحظ أن النص الفرنسي صريح في قصر سلطة الأمر بوقف التنفيذ علي المحكمة المختصة بنظر

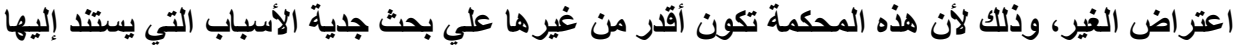

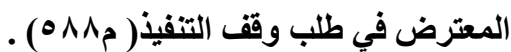


ويسمي هـا بـالأثر الناقـل لاعتراض الغير. ولا يتحقق هذا الأثر إلا بالنسبة للغيـر المعترض فقط لأنه هو الأي لم يسمع دفاعه، أما طرفا الخصومة التي صدر فيها الحكم المعترض عليـه، فرغم أن الاعتراض يوجـه إليهمــا معـا، إلا أنـهـ لا يجـوز لأي منهمـا المطالبة بتعديل الحكم فيمـا يكون قد قضي بـه عليه، لأن وسيلة ذلكك بالنسبة لـه هي الطعن في الحكم بالطرق العادية وغير العادية وليس اعتراض الغير('). ويصدر الحكم إما بقبول اعتراض الغير، أو رفض الاعتراض.

\section{ا - الآثار الملترتبة علي قبول اعتزاض الغير:}

يترب علي قبول الاعتر اض أن يصبح الحكم غير محتج بـه في مواجهة الغير، وقد عبر القانون الفرنسي في المادة ب مه و ا هـ من قانون المرافعات الجديد علي هذا الأثر بأنه سحب الحكم المعترض عليه أو تعديله أو إبطالهه، وذلك علي حسب المحكمة التي تنظر الاعتراض هل هـي المحكمة التي أصدرته أم محكمـة أخري، ويلاحظ أن التعبير الأدق هو عدم الاحتجاج بالحكم المعترض عليه، وذلك لأنـه هدف المعترض هو عدم الاحتجـاج عليه بـالحكم، فهو يختلف عن وسـائل الطعن الأخرى، فـلا يؤدي إلي سحب الحكم أو تعديله عن طريق المحكمة، ولكن يظل الحكم قائمـا كمـا هو، ولكن لا يحتج به في مواجهة المعترض(`).

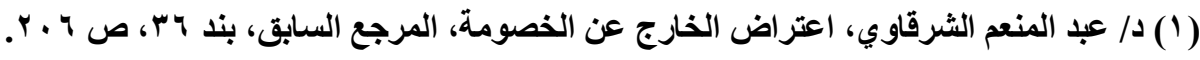

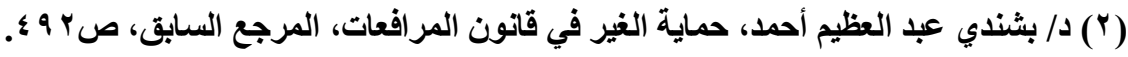


ولا يكون لعدم الاحتجـاج بـالحكم المترتب علـي قبـول الاعتر اض سـوي نطـاق نسبي، سواء من حيث الأشخاص أو من حيث الموضوع. بمعني لا يؤثر القرار الصادر في الاعتر اض إلا علي أطر اف الاعتراض فقط( م اوهه مرافعات).

r- آثار الصكم بعدم قبول الاعتزاض:

يؤدي الحكم بعدم القبول أن يصير الحكم المعترض حجة علي الغير المعترض، ويمكن تنفيذ الحكم في مواجهته، دون أن يكون لـه الاعتراض عليه مرة أخري، لأن حجية الحكم السابق بعدم قبول الاعتر اض تمنعه من إعادة رفعه مرة أخري. كذلك يترتب علي رفض الاعتراض، الحكم علي المعترض بغرامـة من مائة إلى عثرة آلاف فرنك فرنسي، وذلك دون المساس بما قد يطلب منه من تعويضات (م اليه مر (فعات).

ويلاحظ أن توقيع الغرامة لا يترتب تلقائيا بمجرد رفض اعتراض علي الدكم، ولكن إذا تبين أن القصد من الاعتراض المماطلة وتعقيد الإجراءات القضائية أو كـان ذات طـابع تعسفي (') لـا يجب علـي المحكمة أن تبحث مـدي توافر سـوء النيـة لـدي المعترض، فهل يريد منع الاحتجاج بالحكم حماية لحقوقه؟ أم أنه يهذف إلى الكيد لطرف الحكم ؟ فللقاضي سلطة تقديرية في الحكم بالغرامة. ويلاحظ أن الحكم بالغرامة لا يترتب عليه أي مساس بالتعويض الأي قد يحكم به علي المعترض بسبب الاضرار التي لحقت بالخصوم الاصلين نتيجة هذا الاعتراض، والتي يخضع في تقدير ها لسلطة التقديرية للمحكمة.

(1) Cass. Civ., 1 re, 29 oct. 1979, Bull. Civ., I, no 260. 
د/ طلعت يوسف خاطر

العدد rا7 (أغسطس Y.IV) 


\section{المبحث الثالث \\ هوقف الفته هن اعتزاض الغير علي المكم}

موقف المشرع المصري الحسالي يثير تساؤلا حهل مـا إذا كسان مـن المككن الاستغناء عن الاعتراض الغير الخارج عن الخصومة والوصول إلي الدور الذي يؤديه بطرق أخري قد يكون استخدامها أكثر سهولة ويسرا. فنجد أن كلمة الفقه اختلفت بين مؤيد ومعارض لإلغاء الاعتراض اعتراض الغير

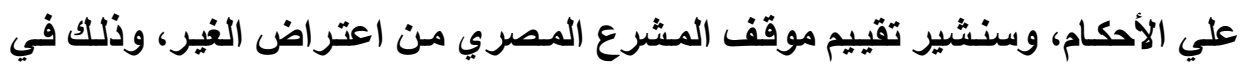

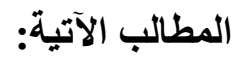

\section{المطاب الأول \\ الاتجاهات الفقيهة بين التأييد والرفض لاعتراض الغير علي المكم الاول}

سنثير إلى الاتجاه المؤيد لإلغاء اعتراض الغير، والاتجاه المعارض لاعتراض

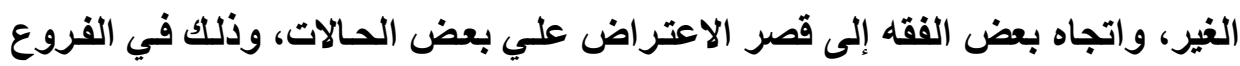

\section{الفرع الأول}

الرأي المؤيد لإلغاء الاعتزاض الخارج عن الخصوهة

أيــ البعض مـن الفقه موقف المشرع المـصري مـن إلغـاء طريق الاعتراض

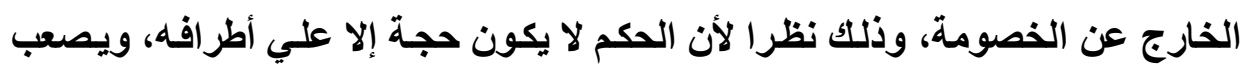


علي الغير إثبات الضرر الذي لحقه من الحكم، لذا يفضل إلغاء هذا الطريق لأنه لا يعدوا أن يكون تزيدا في قانون غير قابل لتطبيق، وإذا افترض وأصيب الغير بضرر بسبب

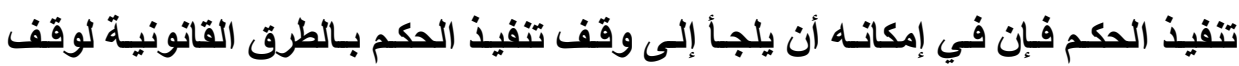
(التنفيذ) وقد انتقد بعض الفقه موقف المشرع الفرنسي في النص علي اعتراض الغير طريق طعن غير عـادي، ووصفه بأنه وسيلة طعن غير قابلة للتطبيق ومن الممكن

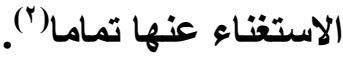

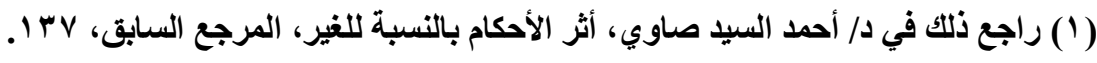

(2) Carre et Chauveau, Lois procédure civile et commercial, t3, et 4, 5ed, $1880, n^{\circ} 1709$, p. 265.

1 - 2 - عدم القابلية للتطبيق:

قرر الفقيه شوفو أن هذه الوسيلة مشروطة بأن يترتب علي الحكم ضرر بحقوق الغير، وهذا لأنا

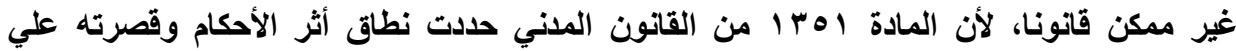

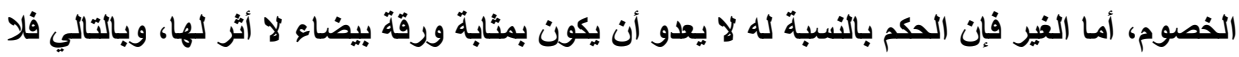

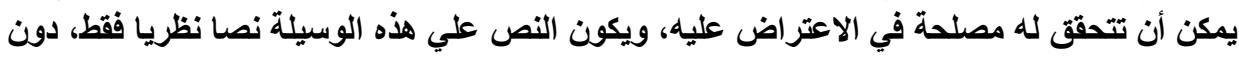

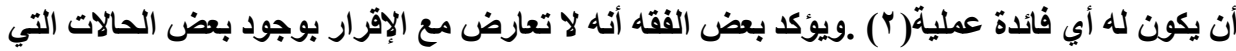

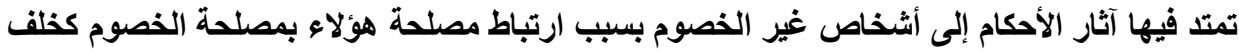

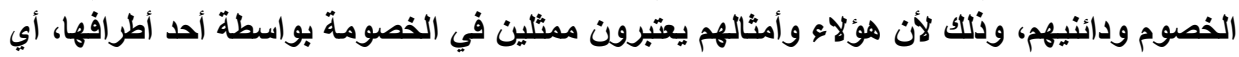

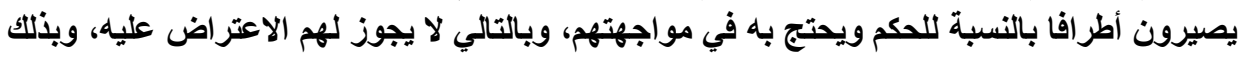

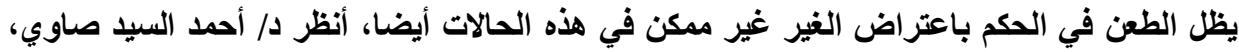
أثر الأحكام بالنسبة للغير ، المرجع السابق.

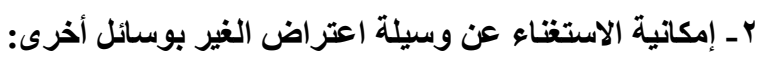

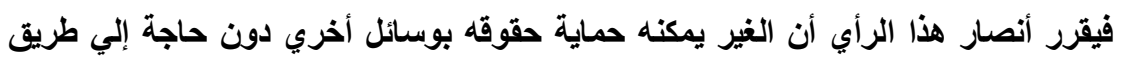
اعتراض الغير علي الحكم، وهذه الوسائل تتمثل في الآتي:

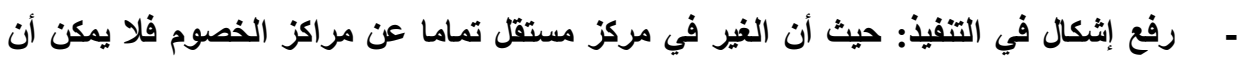
يضار إلا من تنفيذ الحكم، وفي هذه الحالة يمكنه دفع هذا الضرر برفع إثكال في التنفيذ. $=$ 


\section{الفرع الثاني \\ الرأي المعارض لإلغاء اعتراض الغير علي المكم}

ينتقد بعض الفقهـ موقف المشرع المصري من إلغـاء الاعتراض الخـارج عن

الخصومة، وذلك للأسباب الآتية:

ا - موقف المـشرع المـصري ينطـوي علـي خلط بـين الحجيـة والقـوة الثبوتيـة،

فـالحكم يحـوز الحجيـة بـين أطرافـه، ولكنـه كقـوة ثبوتيـه يمكن أن يحتبج بـهـ

علـي الكافـة، فكون الحكم غير ملزم للغير لا يعنـي أنـه لـيس دليل إثبـات في مواجهته، وبالتالي فالتمسك بالحجية النسبية لا يغتي عن اعتراض الخارج عن الخصومة، فكلاهما له وظيفة مستقلة، فالغير يهدف من التمسك بالنسبية إلى هي تفسير الحكم الذي يحتج به عليه، وذلك بالحصول علي تقرير قضائي بأنها من الغير، بينما يهدف الاعتراض إلي إلغاء الحكم أو تعديله في الحدود التي لا تضر بحقوق المعترض، وعليه فإن الغير لا يمكنه الدفاع عن نفسه أن يتمسك بمبدأ النسبة، وإنمـا عليـه أن يلجـأ إلـي الطعن في الحكـم بـالاعتراض الخـارج عن

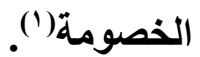

- رفع التماس إعادة النظر : إذا كان الغير ممثلا في الخصوم وصدر الحكم نتيجة غش أو أو تواطؤ علي الأضرار بحقوقه، فيمكنه التخلص من هذا الحكم عن طريق الطعن فيه بالتماس إعلى العادة النظر.

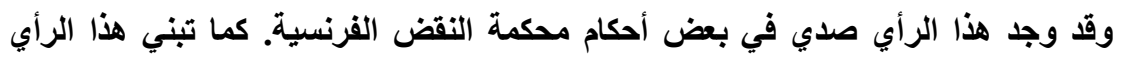

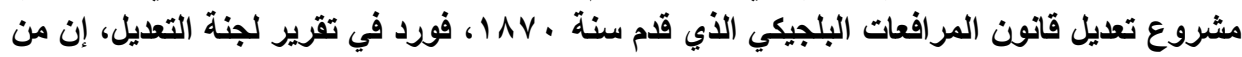

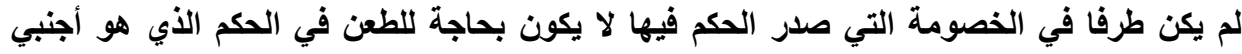
عنه (Cass. Civ., 23 mai 1882, S, 1883, 1, 97.

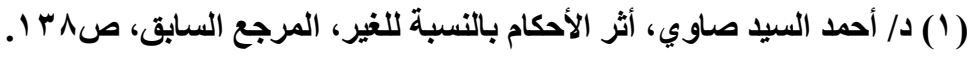


r- إلى جانب أن الحكم القضائي عمل رسمي يجب علي السلطة القضائية والتفيذية

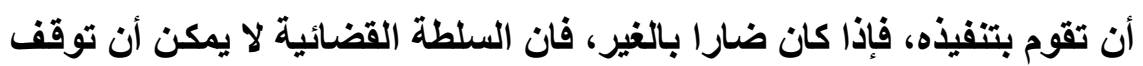
تنفيذه لمجرد أنـه يضير بحقوق الغير، لذا يجب تقديم طريق قـانوني للغير للاعتراض علي السند الذي يمس بحقوقه أمام القضاء بهذف تقييد تنفيذ الحكم

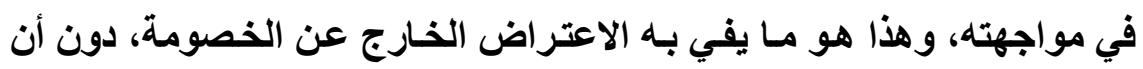
يثكل هذا المبدأ أي ازدواجية في الوظيفة مع مبدأ نسبية الأحكام. r- كما أن الالتماس لا يقدم إلا من كان طرفا في الخصومة، متي تعرض لغش أو

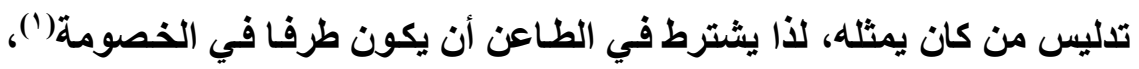
والقول بأن الخصم يصبح من الغير إذا تعرض لغش ممثله، فكيف لله الطعن في الحكم، فالطعن لا يكون إلا من الخصوم. ع - ويؤكد جاتب من الفقه علي تائيد موقف المشرع الفرنسي في الإبقاء علي اعتراض الغير علي الحكم، حيث يكون من السهل الرد علي هذه الحجج التي لتي استتل اليها معارضو اعتراض الغير علي الحكم، بل إثبات عكسها(").

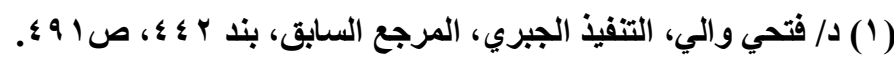

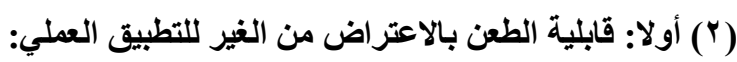

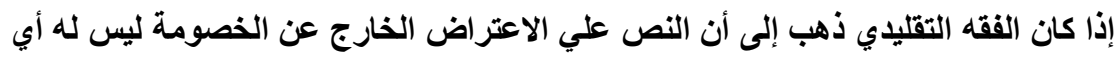

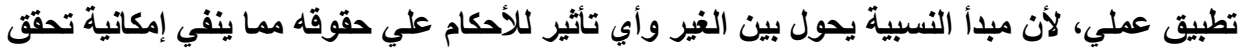

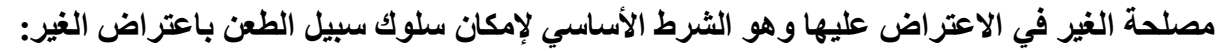

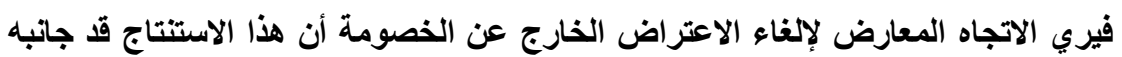

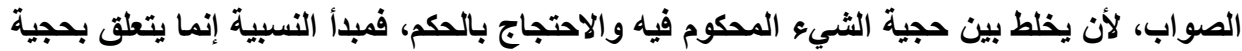

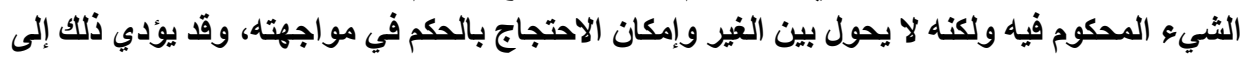

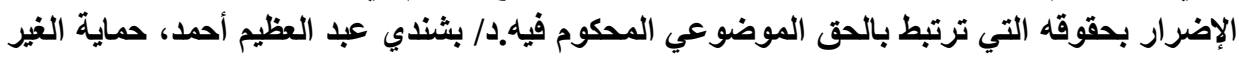

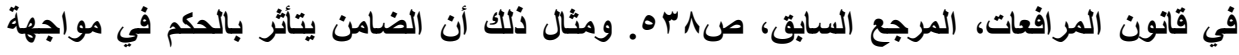
$=$ 
صاحب الضمان والورثة لابد أن يتأثرون بالحكم الصادر بصحة أو بطلان وصايا مورثهم، والائن

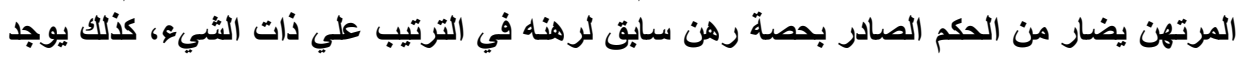

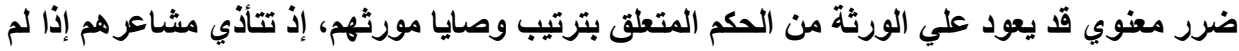

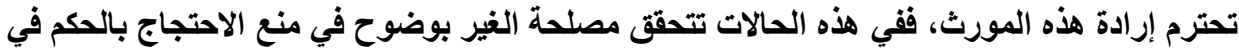

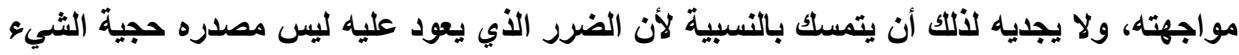

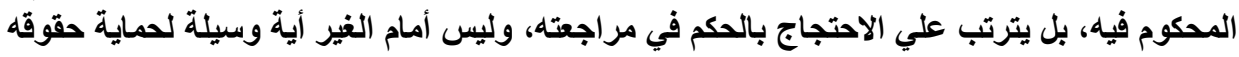

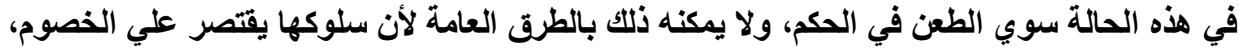

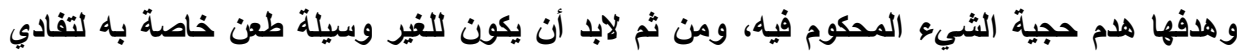
الاحتجاج بالحكم في مواجهته و هذه الوسيلة هي اعتر فئ فئ لاض الغير أنون

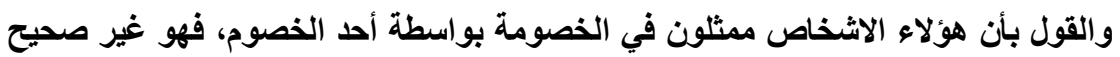

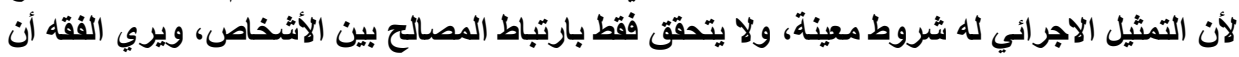

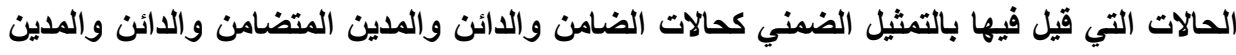

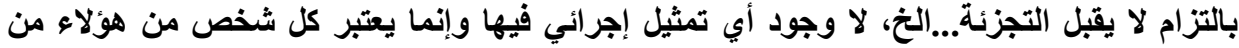

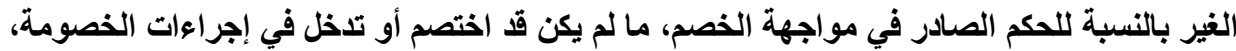

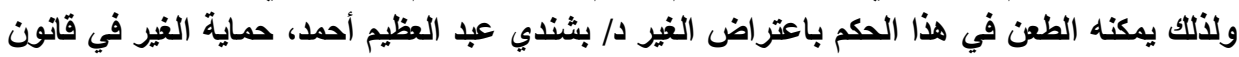

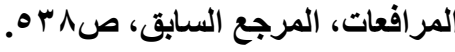

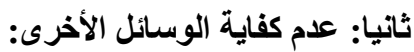

كذلك فإن الوسائل الأخرى التي طرحها الرأي المؤيد لإلفاء الاعتراض الخارج عن الخصومة

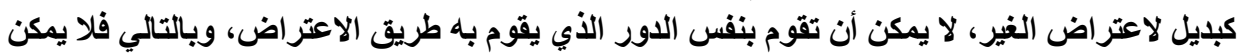

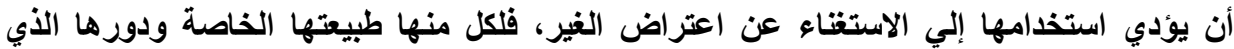
يختلف عن غير ها من الوسائل دون أن يتعارض معه بل يكمله.

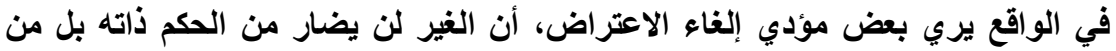

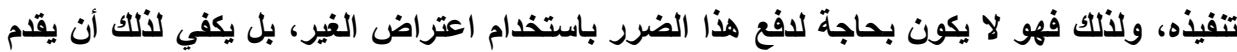
إثكالا في تنفيذه هذا الحكم. في الواقع هذا الرأي بعيد عن الصواب، سواء من حيث مضمونه أو النتيجة التي انتهي

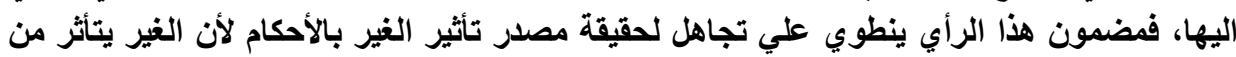

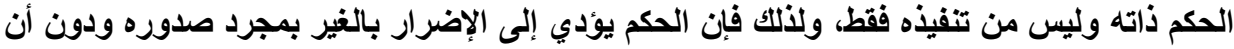

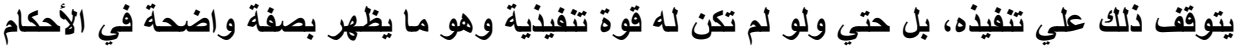

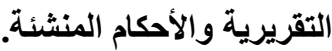


وقد نص المشرع الفرنسي علي جواز الطعن باعتراض الغير علي حكم التحكيم دون أن يتوقف ذلك علي صدور الأمر بالتتفيذ(')، بـل إنـه أجـاز اعتراض الغير علي الأعمال الولائية رغم أنها ليست أحكاما بالمعني الدقيق.

ويظهر ذلك مدي قصور إشكالات التنفيذ عن تحقيق حماية حقوق الغير بنفس الدرجة التي يحققها الاعتر اض علـي الحكم حتي تكون بـلا يمكن بـه الاستغناء عن الطعن في الحكم بواسطة الغير. فإذا صدر حكم بثبوت نسب طقل إلي أبيه المتوفي، فهذا الحكم يضر بالورثة، ولا يمكن حمايـة حقوقهم برفع الإشكال في التنفيذ لأن الحكم هنـا تقريري، وبالتالي لا يكون أمام الوارث الأي لـم يتدخل أو أختصم في الخصومة إذا مـا أراد منع الاحتجـاج بهذا الحكم في مواجهته سوي الطعن فيهه بـاعتراض الغير، كذلك الحسال أيضا بالنسبة للشخص المصاب في حادث في حالة صدور حكم في مواجهة مصاب آخر في نفس الحادث، بعدم مسئولية الفاعل عن الضرر اللاحق بـه نتيجة هذه الحادثة، فهذا الحكم يعتبر دليلا يستند إليه المحكوم له في مواجهة هذا المصداب الآخر ولا يجدي هذا الأخير أن يدفع ذلك برفع إثكال في تثفيذ الحكم فذلك غير ممكن.

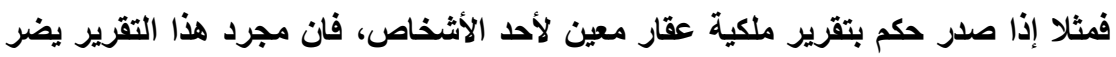

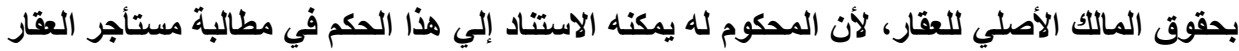

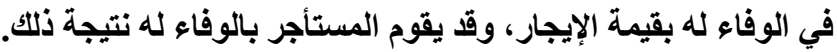

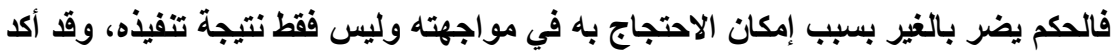

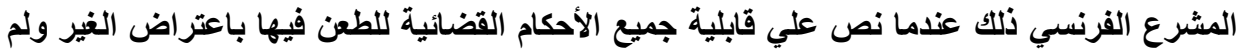

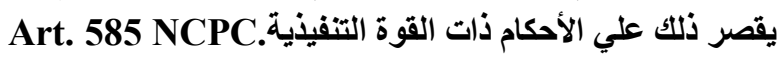

(1) Art. 1481 NCPC, dispose que "la sentence arbitrale n'est pas susceptible d'opposition ni de pourvoi en cassation elle peut être frappe de tierce opposition devant la juridiction qui eut été compétente a défaut d'arbitrage...." 
وقد يرفع الغير الاشكال ومع ذلك يظل ذلك غير كاف لحمايـة حقوقه من الآثار

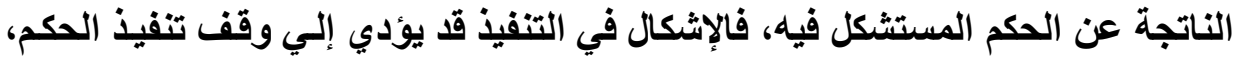

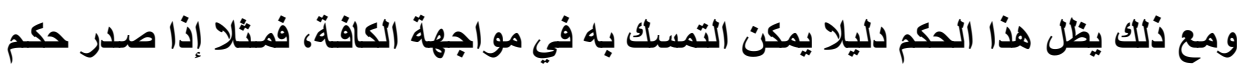

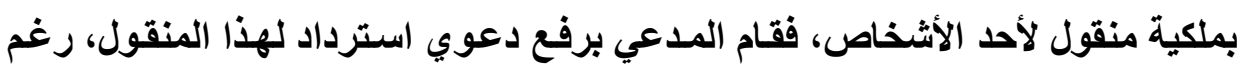

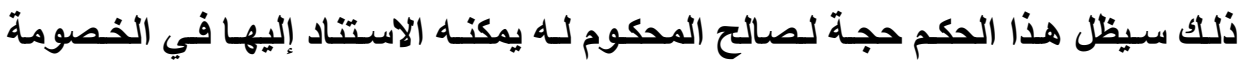

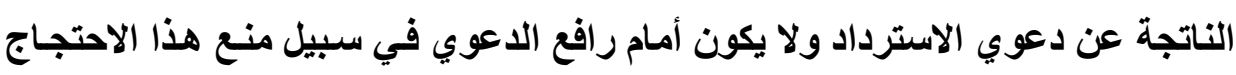

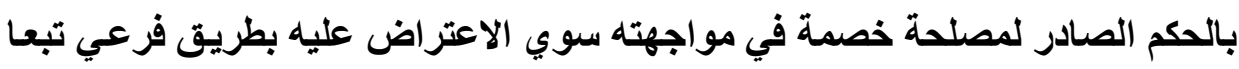

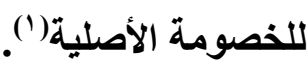

\section{الفرع الثالث \\ الرأي المؤيد لقصر اعتراض الخارج عن الخصوهة بحالات همددة}

يري بعض الققه أن اعتراض الغير وسيلة لا غني عنها لحماية حقوق الغير من

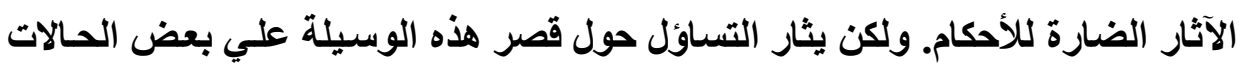
دون البعض الآخر، في الواقع اختلف الفقه الفرنسي بشأن تحديد الحساتات التي يكون اللجوء فيها إلـي اعتراض الغير ضروريا، وانقسم في ذلكك إلى عدة اراء أهمهــا

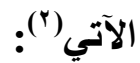

(1) د/ بشندي عبد العظيم أحمد، حماية الغير في قانون المرافعات، المرجع السابق، ص م • ؛ ه.

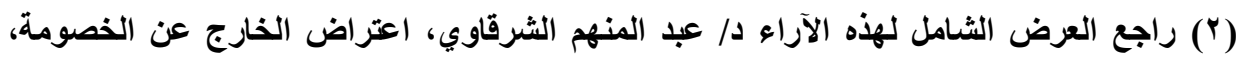

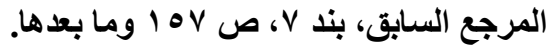


الرأي الأول: الاعتزاض يكون هجديا لضهمان حماية الغير هـن الأضـرار الناتجـة

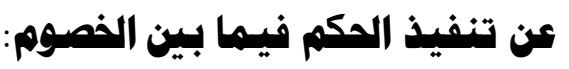

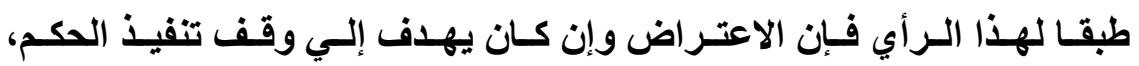

وذلك لمنع الضرر الواقعي الذي يعود علي الغير نتيجة هذا التنفيذ، إلا أنه ليس هو

الوسيلة الوحيدة لتحقيق هذا الهدف في جميع الأحوال، وإنمـا يجب التفرقة بحسب مـا

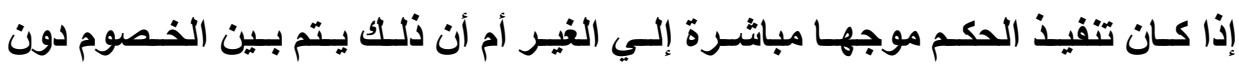
تلخله، ففي الحالة الأولي لا يكون الغير مجبرا علي اللجوء إلى الاعتراض على الحكم لوقف تنفيذه، بل يمكنه حماية حقوقه بالاستناد إلي قاعدة النسبية، فمقتضاها لا يكون للحكم أي اثر في مواجهته، أما في الحالة الثانية فإن قاعدة النسبية غير مجدية لحمايـة حقـوق الغيـر، ويكـون اللجـوء إلـي الاعتـراض علــي الحكـم ضـروريا لتحقيـق هـــه

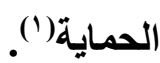

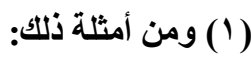

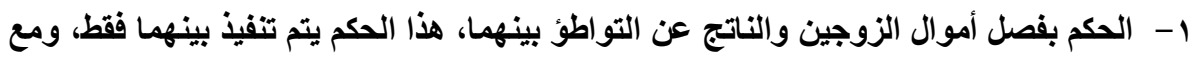

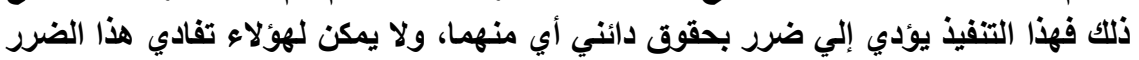
بالاستناد إلي مبدأ النسبية، والوسيلة الوحيدة لذلك هي وقف تنفيذ التفيذ هذا الحكم عن طريق الطعن فيه باعتر اض الغير.

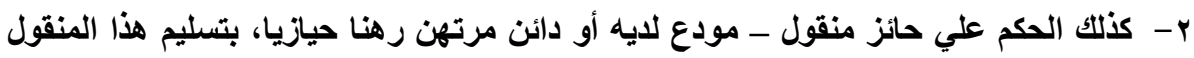

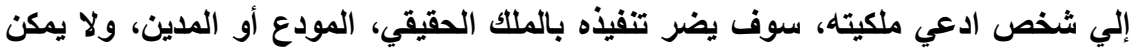

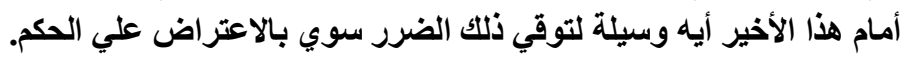

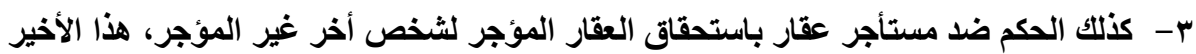

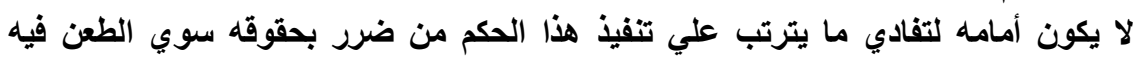
باعتراض الغير. , Boitard, leçons de procédure civile, paris, 1890, no 719 مانه .et s. cite au Rolin, chose jugée et tierce opposition, Thèse, p. 44 


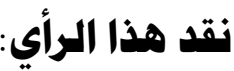

يـري هـذا الاتجـاه أن اعتـراض الغير قـــــــون ضـروريا في بعض الحسالات واختياريا في حالات أخري، وهذا القول لا يمكن التسليم به وذلك للآتي:

ا - عدم جواز استبدال النسبية بـاعتراض الغير، يري أنصار هذا الاتجـاه أن للغير الخيار بين اللجوء إلي الطعن بالاعتراض علي الحكم أو الدفع بالنسبة إذا بـاء

\section{التنفيذ في مواجهته.}

والقول بأن اللجوء إلـي الاعتراض اختباري دائمسا، لأن الغير يمكن الاستغناء عنها بالدفع بالنسبية، فالاعتر اض والنسبية وجهين لعملة واحدة، والواقع أن القـول بالخيـار أو المفاضـلة بـين النسبية واعتـراض الغيـر علـي الحكم غيـر صحيح، لأن المفاضلة تكون بين أمور متشابهة في مميزاتها وعيوبها بحيث يجد الثخص نفسه مترددا في تفضيل إحداهما علي الأخرى، الاعتراض نجده يأخذ الغير موقف المـدعي وعليـه يقع عبء الإثبـات، كمـا انـه يتقاضسى أمسام محكمة غير محكمته الأصلية. وهو مهدد بدفع الغرامة إذا حكم ضده. أما النسبية فليس عليه سوي الوقف موقفا سلبيا معلنا أنه من الغير دون أي أعباء أخري. وتختلف النسبية عن الاعتراض من حيث طبيعتها والهدف منها، فالاعتر اض وسيلة طعن خاصة بالغير تهدف إلي سحب الحكم أو تعديله بالنسبة للمعترض، وفن وفئل في حين أن النسبية دفع يهدف إلى عدم امتداد حجية الشيء المحكوم فيهه إلي ني

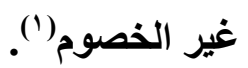

(1) ولكل منهما مجاله الذي يعمل فيه. ولا يمكن الاستغناء عن طريق الاعتراض واستبداله بالنسبية في أي حالة. لأنه ضروري لحماية حقوق الغير. فمثلا إذا صدر حكم بملكية منقول في حيازة الأني $=$ 
r- عدم تبرير ضرورة الاعتراض في حالة التنفيذ بين الخصوم، للافع بالنسبة بدلا من الاعتراض، فالأمثلة التي قالوا بها غير كافية الدلاية.

r- السبب الأساسي للأخطاء التي وفع فيها أنصار هذا الرأي يظهر فيما ذهبوا إليه. من النظر إلي الاعتراض علي اعتباره نوعا من إثكالات التنفيذ، فحصروا دوره في وقف التنفيذ فقط. والحقيقة أن دوره لا يتوقف عند هذا الحد، بـل يهـف إلـي

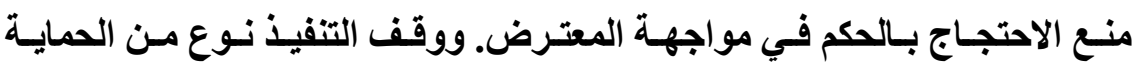
الوقتية التي قا يحققها الاعتر اض بالنسبة لحقوق الغير

الرأي الثاني: الاعتراض يكون ضروري لهماية هقوق الغير في هواجهة الهمية الاملقة للأحكام التبي تفمل في هنازعات هوضورية:

يـري جانـب مـن الفقـهـ(') ضـرورة الاعتـراض تثتوقـف عــي طبيعـة الحـق

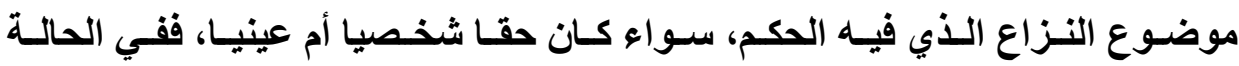
الاولي يكون الاعتراض علي الحكم اختياريـا أمـا في الحالـة الثانيـة فيكون الاعتر اض

وذلك لأن الحكم الأي يفصل في حق شخص تكون حجية نسبية فلا تمتد آثاره إلي الغير، لذا لا يكون الغير بحاجة إلي الاعتر اض ولكن يمكن أن يتمسك بالنسبية، أمسا

شخص آخر، مستأجر أو مودع لايه، غير المحكوم عليه، فهذا الحكم يعتبر دليلا يمكن للمحكوم له اله

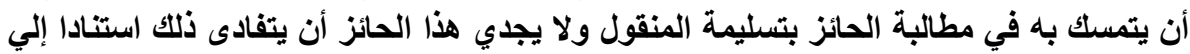
النسبية، بل عليه إذا أراد دفع الاحتجاج بهذا الحكم في مواجهته أن يطعن فيه باعتراض الغيل الغير.

(1) GARSONNET E ET DESS ERTEUX M., traite de procédure civile et commercial, DIJON, 1926, T 3, n 705 NOTE 2. 
الحكم الذي يفصل في حق عيني فإنه يحوز حجية في مواجهة الكافة، ولا يجوز للغير دفع أثارة إلا بالاعتراض.

\section{نقد هذا الرأي:}

لقد انتقد الفقه الفرنسي هذا الرأي(')، ويرجع ذلك إلى الأسباب الآتية: ا ـ التفرقة التي بني عليه هذا الرأي غير صحيحه لأن طبيعة موضوع النزع ليس لها أي تأثثير علي نطاق حجية الحكم الذي يفصل فيه، فالحكم وحده واحدة، ولـه

$$
\text { نطاق حجية واحده في جميع الحالات. }
$$

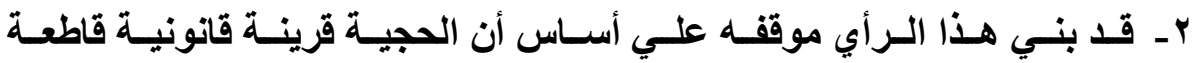

بالنسبة للخصوم وبسيطة بالنسبة للغير، وهذا الرأي منتقد لأن الحجية ليست

قرينـة قانونيـة بـل قاعدة موضـوعية وليست قاعدة إثبـات وهـي لا تكـون إلا

$$
\text { نسبية) (r) (ن) }
$$

الرأي الثالث: الاعتراض ضروري إذا كان المكم قد صدر نتيجـة غسش المكـمم عاليه أو تواطئه علي الاضرار بمقوق الغير:

هـا الـرأي تبنـاه الفقيـه تيسيه TISSIER، ويـري أنـه يوجـ طـائفتين مـن

$$
\text { الأشخاص يمكن لهم الاعتر اض علي الحكم: }
$$

الطائفــة الأولي: وهـم الأشـخاص الـذين يكونـون مـن الغيـر تمامــا بالنسبة

للخصومة، ولكن يعود عليهم ضـرر واقعي نتيجة تنفيذ الحكم، ولذلك فقد حق لهم

(1) ROLIN, chose jugée et tierce opposition, op. cit., $n^{\circ}$ 30, P. 48.

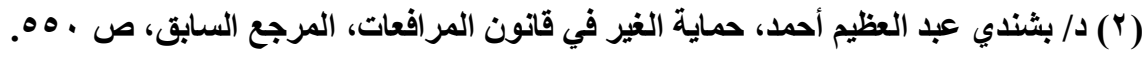




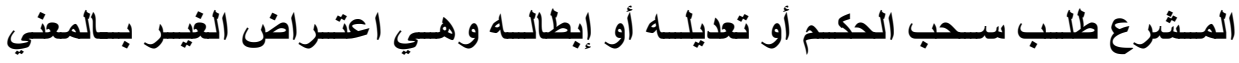
الــقيق. ولكن هـذا الـضرر يمكن دفعـه عن طريـق الإستشكال في التنفيذ أو الـدفع بالنسبية.

الطائفــة الثانيسة: وهم الأشـخاص الذي كـانوا ممثلين في الخصومة سـواء بتوكيل منهم أو نتيجة خلافتهم لأحد الخصوم، وصدر الحكم ضدهم نتيجة عش الممثل أو تواطئه علي الأضرار بحقوقهم، فهؤلاء يمكنهم دفع هذا الضرر والتخلص من آثار تمثيلهم عن طريق الطعن في الحكم بـالاعتراض الغير. وهو الوسيلة الوحيدة لسحب الحكم الضار بحقوقهم أو تعديله أو إبطاله، فلا يمكن الدفع بالنسبية في هذه الحالة. لأنهم ممثلون في الخصومة

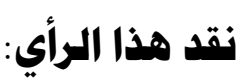

الواقع أن هذا الرأي يساوي بين الاعتراض والنسبية والإشكال، وقد ثبت لنـا خطأ هذا التصور حيث تختلف كل وسيلة من حيث طبيعتها ودورهـا ولا يمكن استبدال إحداهما بالأخر.

\section{الامطلب الثاني \\ تقييهيم هوقف المشرع المسري هن الغاء طريق اعتراض الغير}

سنـشير إلـى اعتـراض الغيـر علـي الحكـم وسـيلة لحمايتهـه مسن آثـار تنفيـذه، والانتقادات الموجهة لإلغاء طريق اعتراض الغير في القانون المصري، وذلك في الفرع 


\section{الفرع الاول \\ اعتراض الغير علي المكم وسيلة لحمايته هن آثار المكم}

الواقع أن عدم تخصيص الغير بوسيلة طعن خاصـة بـه إنمـا ينطوي علي إنكار

لطبيعة آثار الأحكام بالنسبة له، والتي تختلف عن آثارها بالنسبة للخصوم(')، ونري أن المشرع المصري قد جانبه الصواب عندما ألغى نظام اعتراض الخـارج عن الخصومة، و هو طريتق الطعن الخـاص بـالغير، والذي كـان منصوصـا عليهه في القـانون السابق، ويقابله اعتراض الغير في القانون الفرنسي.

إذا كـان المشرع المسري نـص علـي إلغـاء الاعتراض علـي أسـاس أن السند التنفيذي لا يحوز سوي حجية نسبية بين اطرافه، ولكن يلاحظ أن الغير قد يضار من الحكم بالرغم من أنه ليس طرفا فيه، وذلك يرجع إلى تشابك العلاقات القانونية بحيث يصعب فصل بعضها عن بعض، فالقاضسي المختص بالفصل في النزاع بين طرفين لا يمكنه أن يمتنع عن الفصل في الاعوي بحجة أنها تهم شخصا من الغير، ذلك أنه مقيد بحدود الدعوي المطروحة عليه، الأمر الذي يترتب عليها إمكانية تضرره من السند التنفيذي رغم أنه لم يكن طرفا فيه. وبالتالي فيمكن أن يؤثر الحكم علي حقوق الغير، فلا يجوز تجاهل حقوق الغير علي أسناس نسبية آثار الحكم().

الاعتر اض الخارج عن الخصومة هو طريق اجرائي لإثبات عكس قرينة الحقيقة الناتجة عن الحكم، فيجب قصر حق الغير علي طريق الاعتراض الخارج عن الخصومة، وعدم السماح لـه برفع دعوي جليدة يطالب فيها بحقه وتجاهل الحكم السابق، لأن

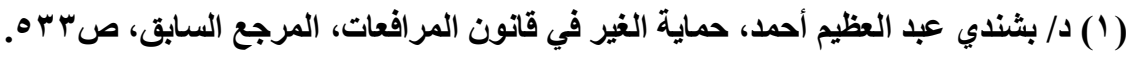

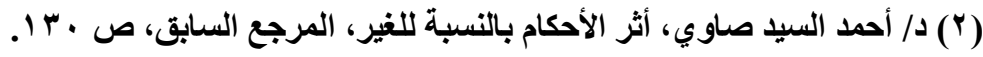


استصدار حمم أخر يثبت عكس ما أثبته الحكم الأول، بحيث يصعب تنفيذ الحكمين معا، وهذا يؤدي إلى تـاقض الأحكام، لذا يكون من الافضل أن يلجأ الغير فقط إلى طريق الاعتر اض لإلغاء الحكم أو تعديله(').

ونري أنها يجب أن يترتب علي الاعتراض الخـارج عن الخصومة وقف تنفيذ

الحكم إلا إذا حكم القاضي بالاستمرار في التفيذ، وذلك تحقيقا لمصلحة الغير، حيث إن فكرة وقف التنفيذ تقوم بدور وقائي ضد مخاطر الخضوع أو استمرار الخضوع لتنفيذ، معرض للإلغاء، وبالتالي ضد مخاطر استحالة إعادة الحال إلى ما كان عليه، وغير ذلك من النتائج غير المرغوية التي قد يفرزها هذا التنفيذ. فإذا لاحظنا هذا الدور المستمد من طبيعة الوقف ذاته، فيكون من الأفضل أن ينص عليه المشرع في ترتيب أثره في أسرع وقت ممكن- وهو ما يستمد من طبيعته أيضا- ومن عموميـة في التطبيق- وهو أمر منطقي حيث لا يوجد ما ياعو لغير ذلكـ ليتبين لنا مـا ولقف التنفيذ من وقت رفع الاعتر اض من أهمية بالغة وضرورة حتمية في مواجهة ظاهرة حتمية أيضا هي إمكانية التنفيذ رغم قابليته للإلغاء.

\section{الفزرع الثاني \\ انتقاد هوقف المشرع المصري هن إلغاء اعتراض الغير}

في حقيقة الأمر لا نؤيد إلغاء اعتراض الغير من جاتب المشرع المصري، وذلك لأن تنظيم المشرع المصري فيما يتعلق بحق الغير في التماس إعادة النظر والمنصوص 


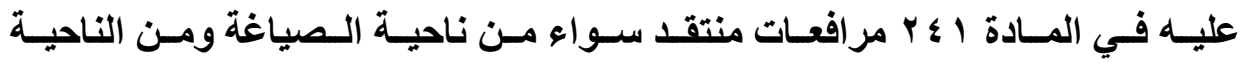
القانونيـة، وكـللك مـن ناحيـة القصور فـي تـوفير الحمايـة للغيـر، وذلـك علـي التحو

1 - من ناحية الصياغة: يلاحظ أن عبارة الفقرة الثامنة من المـادة إ؟ مر افعات غير متفقة مع بعضها البعض، فقد أوحت في البدايـة أن يكون الطاعن من الغير، لأنها اشترطت استبعاد حدوث التدخل أو الاختصام في الإجراعات بالنسبة لهذا الشخص، وهما نظامان خاصان بالغير وليس الخصوم، ولكنها اشترطت إثبات غش ممثل هذا الشخص أو تواطئهـه أو اهمـال جسيم، وهذا يـل علـي أن الطـاعن طرفـا ممثلا في الخصومة وليس من الغير، وهذا يناقض الشث الاول من الفقرة. ويرجع هذا الخطأ إلى تمسك المشرع بـالمفهوم التقليدي لمعني النسبية، فلم

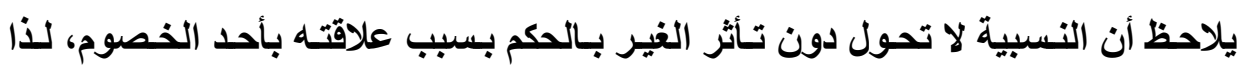
استند إلى فكرة التمثيل الضمني في الخصومة، وهي فكرة منتقدة من الفقه('). r - ومـن الناحيـة القانونيـة: الطعن بالتمـاس إعـادة النظر طريـق خـاص بالخصوم، والحسالات التـي وردت فـي الفقـرتين السـابعة والثامنـة مسن المسادة إ؟ تتعلق بأثـخاص مـن الغير وبالتـالي فليس لهم صـفة في الطعن بهذا الطريق، وعلي المشرع أن يبحث لهم عن وسيلة أخري لحمايـة حقوقهم التي تتأثر بـالحكم تكون متفقة مع مركزهم بالنسبة للخصومة، وليست هنـاك وسيلة أجدي من الطعن في الحكم بطريق خاص بهؤلاء الأشخاص وهو اعتر اض الغير. 
وقد ذهب بعض الفقه أن إمكان فتح طريق الاستئناف كاستثناء لهذه الحالات طبقـا لنص المـادة I Y مر افعـات أو توسيع حساتات الطعن بـالنقض لكي تشمل هذه

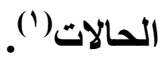

r- أما من ناحية قصور القـانون المصري عن تحقيق الحمايـة الكافية لحقوق الغير، فنجد أن المشرع المصري قصر حالات الطعن بالتمـاس إعـادة النظر علي حالات معينة، فلـم يصل في ذلك إلـي المـدي الذي نص عليـه القـانون الفرنسي أو حتي القانون المرافعات السابق من حيث نطاق الحالات التي تشملها الحمايـة، فطبقا لمـا ورد في النص الحالي تظل معظم حالات الغير بـلا أي وسيلة للحمايـة، اللهم إلا في حالات الافع بالنسبية، وهو دفع لا يفيد في بعض الحالات، فمثلا إذا صدر حكم ضد دائن أو مدين أو مدين متضامن، فالنسبة لاائن أو مدين أخر متضامن معه لا يجديه في ذلك أن يدفع بنسبية هذا الحكم، ورغم هذا فِان القانون لـم يسمح لـه بـالطعن بالتماس إعادة النظر في هذا الحكم(؟). كذلك فِان الطعن لا يكون إلا بالنسبة للأحكام الانتهائيـه، وهو مـا قد لا يكون متحققا في بعض الحالات، مما يحرم الغير من حماية حقوقه. 
ونظرا لما قد يصيب الغير من ضرر نتيجة لحكم لم يكن طرفا فيها تبدو ضرورة حمايته من آثار السند التنفيذي(')، عن طريق تمكينه من الاعتراض الغير علي الحكم بطريق خاص به، لذا نري ضرورة العود إلى طريق لحماية الغير متمثلا في الاعتراض الخارج عن الخصومة. وضرورة بسط الاعتراض لكل من له مصلحة، ولا يجوز قصره علي بعض الغير وترك الأخرين كمـا كـان منصوصا عليهه في المـادة ـ ه ؛ مرافعـات ملغي. وهذا ما قرره المشرع الفرنسي في قانون المر افعات الجديد.

(1) Charels Debbasch, Procedure administrative contentieuse et procedure civile, op. cit., $\mathrm{n}^{\circ} 144$. 
د/ طلعت يوسف خاطر

العدد rا7 (أغسطس Y.IV) 


\section{الفصل الثاني \\ اعتراض الغير علي إجراءات التنفيذ الجبري}

بالرغم من أن الغير ليس طرفا في الحق في التنفيذ()، إلا أن المشرع المصري

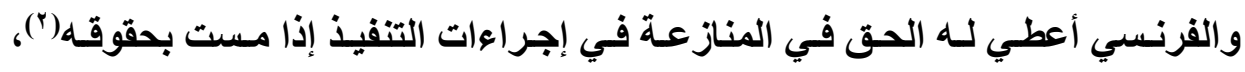
ويهذف الغير من اللجوء إلى منازعات التنفيذ مجابهة إجراءات التنفيذ المزميع اتخاذها

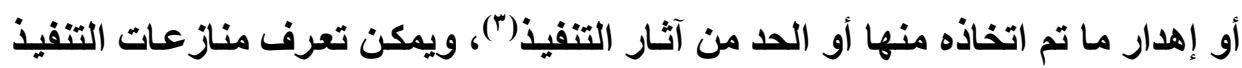

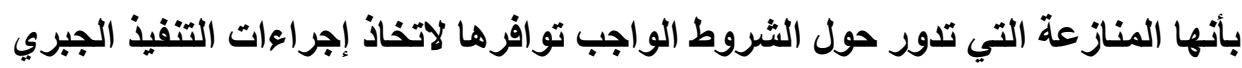

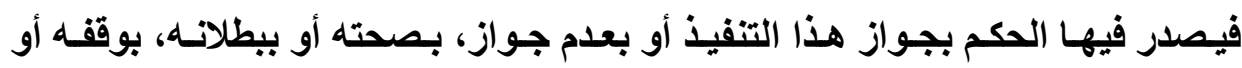

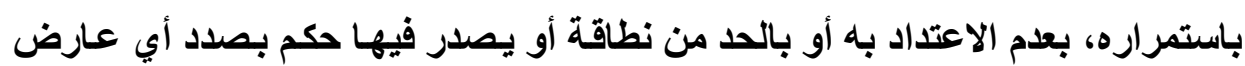

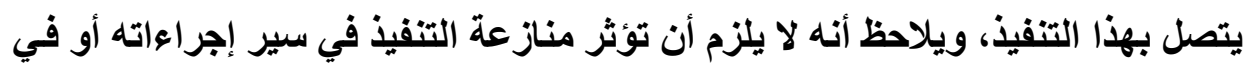

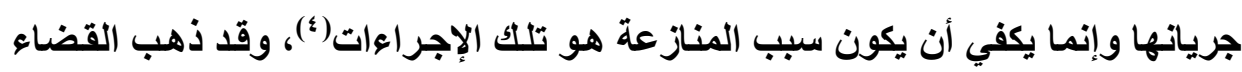

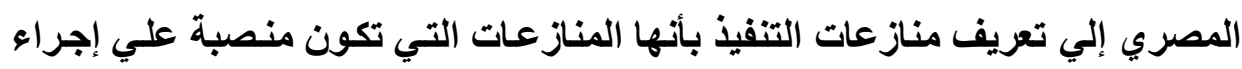

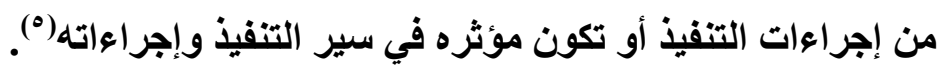

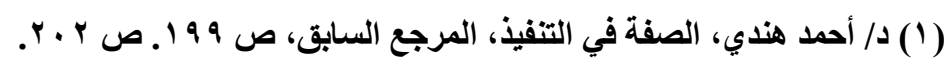

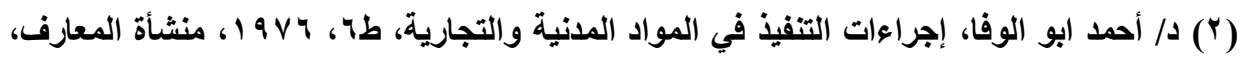

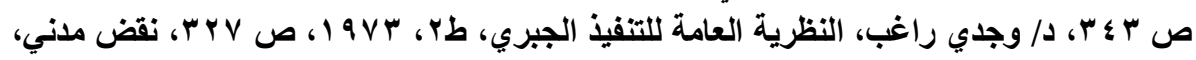

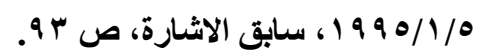

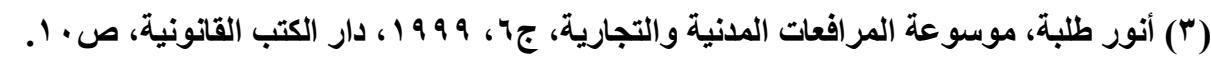

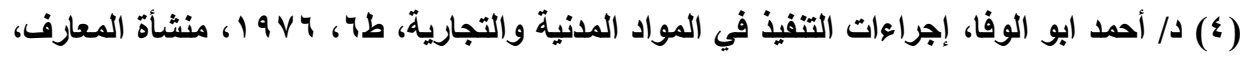

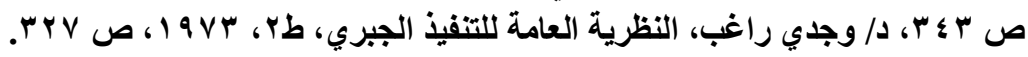

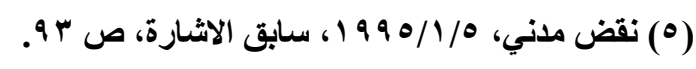


و المنازعة في التنفيذ عقبة قانونية تعترض التنفيذ، تنشأ بسبيه وتدور حول

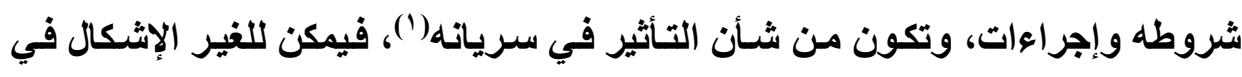

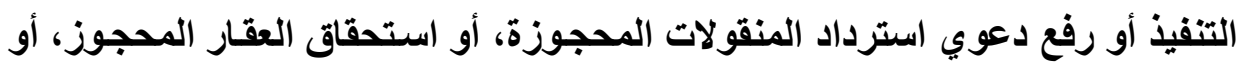
الاعتراض علي قائمة شروط البيع، أو طلب بطلان حكم رسو المزاد. سنثير إلى حق الغير في رفع مناز عة وقتية في التنفيذ، ثم نعالج حق الغير في رفع مناز عة موضوعية في التنفيذ، وذلك في المباحث الأتية: 


\section{المبحث الأول \\ حق الغير في رفع هنازعة وقتية

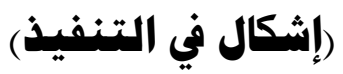

قد يمس التنفيذ الجبري بحقوق الغير، فيكون لـه الحق في الاعتراض على التي

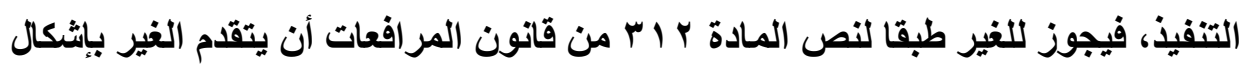

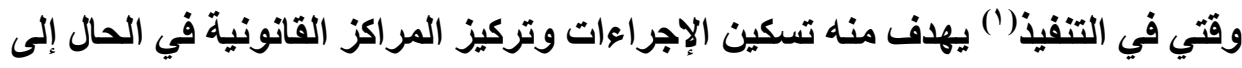

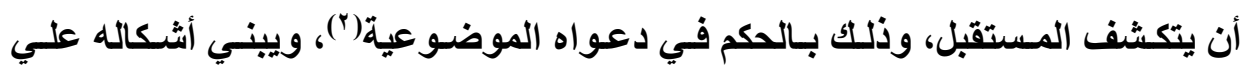
أسباب تتسمم بالجدية كان يدعي أنها يملك العين المراد التنفيذ عليها، أو يحق لـهـ

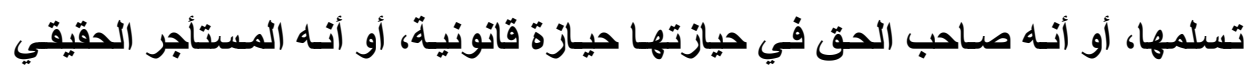
للعين المقضي بإخلائها أو تسليمها، ففي هذه الحالات يختص قاضي التنفيذ بالحكم

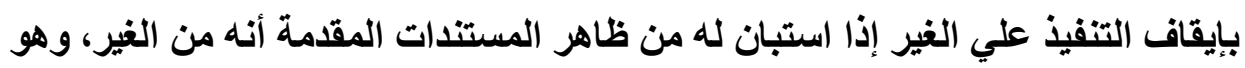

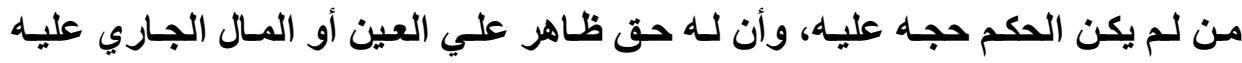

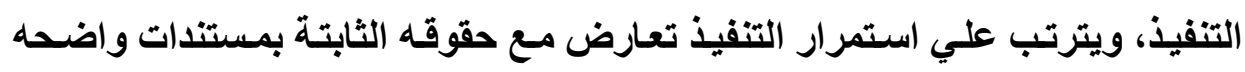

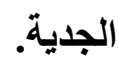

و الإشكال في التنفيذ هو دعوي قضائية تطرح علي قاضي التنفيذ، وتتضمن قيام خطر داهم يحتاج إلى حكم وقتي للوقاية من هذا الخطر (")، ويهدف الغير من فئ الاشكال 
إلى وقف إجراءات التنفيذ وفقا مؤقتا، أو إهدار ما اتخذ منها إهدارا مؤقتا، فالغير يطلب تحقيق حماية وقتية(') لا يطلب حسم التزاع ولا تتضمن طلباته المساس بالموضوع(). وبالتالي إذا كان هدف الغير من المنازعة هو وقف أو إهدار إجراعات التفيذ بصفة دائمة، فنكون أمام منازعة موضوعية وليست منازعة وقتية. سنشير إلى رفع الغير اشكال في التنفيذ، وذلك في المطلب الأول، أمسا المطلب الثاني، فيخصص لأثار إثكال الغير في التنفيذ، ونعالج تقييم حق الغير في رفع الاشكال في التنفيذ، وذلك في المطلب الثالث.

\section{المطلب الأول \\ رفع الغيز اشكال في التنفيذ}

تنص المسادة ه PV مرافعـات علـي أن قاضـي التنفيذ هو المختص دون غيره بالفصل في جميع منازعات التنفيذ الوقتية بصفة مستعجلة، وذلك مـا لم ينص علي خلافه؛ وهذا الاختصاص النـوعي يتعلق بالنظام العام الذي لا يجوز الاتفـاق علـي مـا يخالفه. حيث يقوم الغير برفع الاشكال أمام قاضي التنفيذ المختص.

تعد إثكالات التنفيذ من المنازعات المستعجلة، فيجب اتباع الاجراعات الخاصة بهذه اللدعوي فضلا عن الاجراعات المقررة للدعاوي العاديـة، لذا فقد أجساز المشرع رفعها بأحس طريقين: الطريـق العـادي لرفع الـدعوي، والطريـق الخـاص بالإثـكالات 
الوقتية (')، فبجاتب الطريق العـادي لرفع الاشكال بإيداع الصحيفة قلم كتاب المحكمة يجيز المشرع رفعه بطريق استثنائي من اجل التيسير علي الخصوم وهو ابداؤه شفاهه

سنعالج في هذا المطلب، صفة أطراف الاشكال، وكذلك شروط قبول الاشكال،

$$
\text { وذللك في الفروع الآتية: }
$$

\section{الفرع الأول \\ صفة أطراف الإشكال الاقدم هن الغير}

\section{أولا: صفة الغير المدوي في الإشكال:}

لقد نصت المادة r ا M مرافعات علي أنه يجوز أبداء اشكالات التنفيذ من أطراف التنفيذ(") أو من الغير، وينصب لطلبات الغير علي الحكم بوقف التنفيذ(")، والغير في مثل هذه الحالات ليس هو المنفذ أو المنفذ ضده أو الخلف العام أو الخـاص لأحدهما، وإنما هو شخص ياعي تعلق حق له بالتنفيذ المشروع في اتخاذه(ْ). وكل مـا يطلبه هو إجراء وقتي بوقف التنفيذ مؤقتا إلى أن يحصل علي السند التنفيذي الذي يؤكد أنها هو

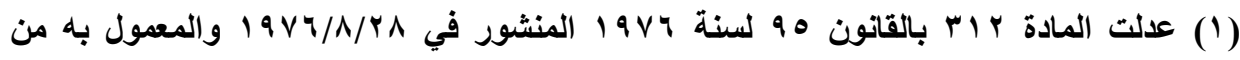

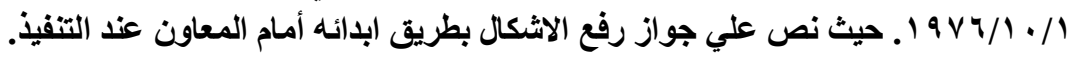

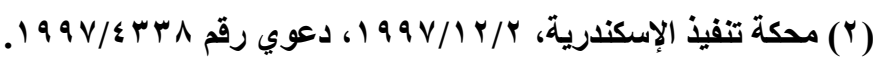

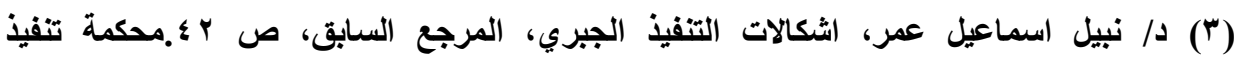

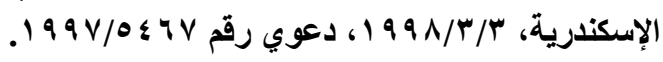

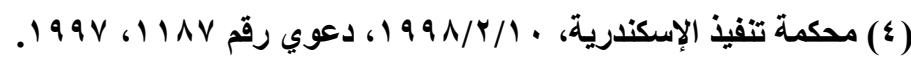

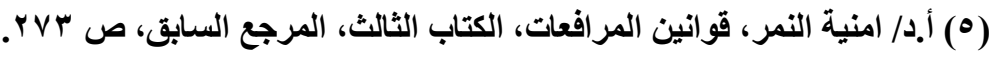


صاحب الحق المدعي به، فالغير المدعي في الإشكال هو الذي لا يكون طرفا في الحق في التنفيذ ولكنه طرفا في خصومة التنفيذ(').

وقد ذهب بعض الفقه إلى بعض الاشخاص من الغير لا يمكن لهم رفع الاشكال الوقتي في التنفيذ، وذلك لان سلطتهم تنحصر أما في حيازة المال الجاري التنفيذ عيه أو في إدارته، وذلك مثل الحارس القضائي والمحجوز لايه(؟)، ونري أنـه لا يمكن التسليم بهذا الاتجاه، حيث يملك كلا من الغير المحجوز لايسه والحسرس أن يرفعان اشكالا في التنفيذ إذا كانت لهم مصلحة، حيث لا يوجد نص يمنعهم مـن رفع الاشكال، فكمـا أنـه يجوز للمحجوز لايسه رفع إثـكال، خاصـة إذا كـان الحكم غير واجب النفـاذ، أو بسبب بطلان في إجراءاته.

\section{ثانيا: صفة المدعي عليه في الإشكال:}

المـدعي عليـه في الإشـكال المقدم مـن الغيـر هـو الــائن الحـاجز أو الــائنين

الحساجزين، والمــين المحجـوز عليـه، حيـث اسـتلزم المسشرع المـصري فـي قـانون المرافعات لقبول الإثكال الوقتي المقدم من الغير أن يختصم المدين المحجوز عليه، فقد نصت المـادة Y ا M مرافعـات علـي أنـه"يجب اختصام الطرف الملتزم في السند في الإشكال إذا كـان مرفوعـا من غيره" وإذا لـم يختصم الغير من يجب اختصامهم في الإشكال وجب علي المحكمة أن تكلف الغير باختصامه في ميعاد تحدده له، فإذا لم ينفذ ما أمرت به جاز الحكم بعدم قبول الإشكال، ويلاحظ علي هذه المسادة أنسه يجب في حالـة رفع الإشكال مـن الغير أن يختصم الطرف الملتزم في السند التنفيذي في الإثـكال،

( (1) د/ نبيل اسماعيل عمر، اشكالات التفيذ الجبري، المرجع السابق، ص ^ ^؛.

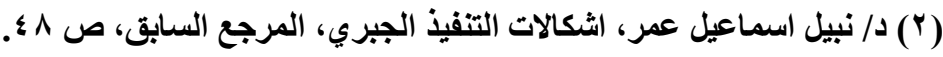


وأيـا كانـت طريقـة رفعـه سـواء بإبدائسه أمسام المعـاون أو بـالإجراءات المعتـادة لرفع

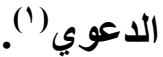

ويمكن للقاضسي أن يـخل المـدين الملتزم في السند مسن تلقـاء نفسـه، حيـث نصت المـادة 11 ا مرافعـات علي أنسه للمحكـة ولو من تلقاء نفسها أن تـأمر بإدخـال من تري إدخاله لمصلحة العدالـة أو لإظهار الحقيقة، وتملك المحكمة أن تحدد الخصم الذذي يقوم بإذخالـه وتعين ميعـاد لا يجـاوز ثلاثـة اسـابيع لحضور مـن تـأمر بإخالـه، ويكون ذلـك بـالإجراءات المعتـادة لرفع الـدعوي، وتنطبق هـذه القاعدة سـواء كسان الاشكال مرفوعا بإيداع الصحيفة فلم كتاب المحكمة أو كان مرفوعا بإبدائهـ أمسام معاون

ويهدف المشرع من نص المادة ب آ// إلى تفـادي الاشكالات الكيايـة نظر لمـا يرتبه القانون علي الاشكال الوقتي من أثر موقف للتنفيذ إذا كانت اشكالا اول()؛ فهذه

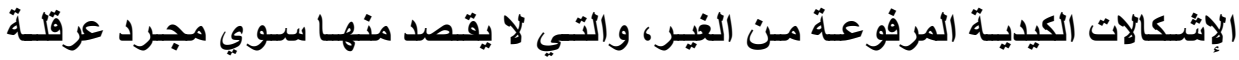
إجراءات التفيذ لمصلحة الطرف الملتزم في السند التنفيذي، ولا تطبيق هذا الجزاء علي الإشكالات الجدية التي قد يتعذر فيها علي المستشكل اختصام الطرف الملتزم في السند التنفيذي تنفيذا لما أمرت به المحكمة لسبب خارج عن إرادته، وتحقيق ذلك منوط بالمحكمة علي ضوء ما تستظهره من الأوراق فيكون لها أن تحكم بعدم قبول الإشكال في الحالات التي وضع النص لمواجهتها بمـا يحقق الفرض منـه أو لا تحكم بعدم قبول 
الإشكال فيما عدا ذلك(')؛ وكنا نفضل أن يقام المشرع على مرحلة أبعد من ذلكت ويجعل

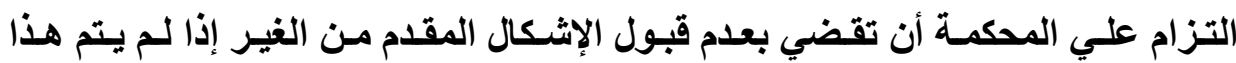
الاختصام.

ويقتصر نطاق تطبيق المادة ץ ا ب مرافعات الخاص باختصام الطرف الملتزم في السند التنفيذي علي الاشكالات الوقتية في التنفيذ الجبري الذي يجري تحت اشراف قاضي التنفيذ، والتي تتعلق بجميع السندات التنفيذية ويمـا فيها حكم التحكيم، وتفريعا علي ذلك، لا يجب اختصام الطرف الملتزم في السند التنفيذي في حالات اشكالات التنفيذ

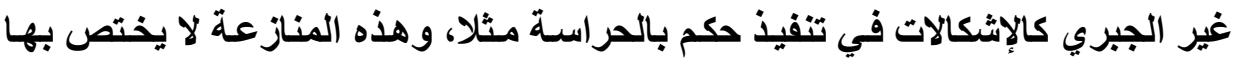
قاضي التنفيذ، وكذلك لا يختصم الطرف الملتزم في السند في اثُكالات التنفيذ في الحجز

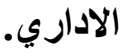

ويرجع ذلك إلى أن هذه القاعدة المنصوص عليها في المـادة ب اب ليست من القو اعد العامة في قانون المرافعات التي تطبق علي الحجز الاداري(")، وإنما هي قاعدة

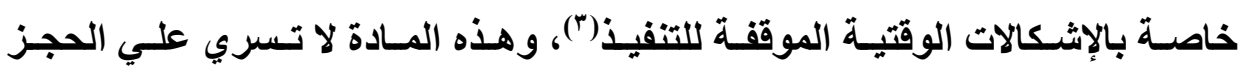

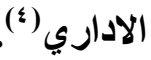

ويلاحظ أن الجزاء اللذي نصت عليهه المسادة ب اب والذي يتمثل بعدم قبول الاشكال لإصرار الغير علي عدم اختصام المدين الملتزم في السند جوازيا للقاضي،

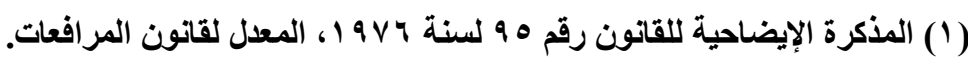

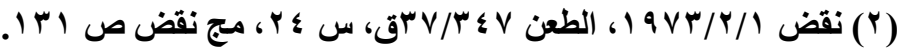

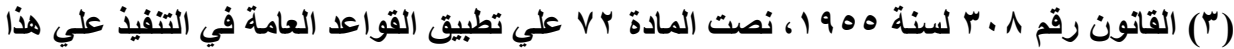

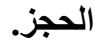
( ) د/ امنية النمر ، قوانين المرافعات، الكتاب الثلث، المرجع السابق، ص \&^؟广. 
ويلاحظ أنها لم ينص المشرع علي اعمـال الجزاء المنصوص عليهه في المـادة 9 9/9 مرافعات التي تخول المحكمة وقف الدعوي جزاء لمدة شـهر الي أن يقوم المدعي بمـا كلقتهـه بـه المحكمة، وذلتك لأن اعمـال هذا النص يفترض وجـود دعوي موضـوعية،

والاشكال الوقتي لا يتحمل الوقف(')

وفي رأينا لا يوجد ما يمنع من إعمال الجزاء المنصوص عليه في المـادة 99/9

مرافعـات حيـث ورد في القـانون دون تحديـــ ولا تقييـد، وبالتـالي يمكن اعمالـه علـي الاشكالات، وإذا انقضت مدة الوقف ولم يختصم المستشكل المدين الملتزم في السند حكمت المحكمة باعتبار الاشكال كأن لم يكن.

ويصدر القاضي حكم بعدم قبول الاشكال إذا لم تتوافر شروطه، ولا يصدر حكمـا بالرفض، لأنه الرفض هو قضاء في الطلب موضوع الدعوي، ولكن عدم القبول يتعلق بشروط قبول الدعوي؛ كما أنه لا يصدر قرار بعدم الاختصاص بنظر الاشكال، لأن هذه الشروط مناطهـا مسسائل متعلقـة بسماع الـدعوي أمسام المحكمـة مثـل تمـام التنفيذا أو اختصام الغير، ولا تتعلق بالاختصاص(")، ويترتب علـي الحكم بعدم القبول انقضاء الخصومة في الاشكال امـام المحكمة وزوال الآثار التي تترتب عليها، والواقع أن هذا الشرط يقتضي وحدة السند والأموال والأطراف، ففي حالة تعدد هذه العناصر، فإنتا نكون بصدد عمليـات تنفيذ مستقله لكل عمليـة إثكالاتها. ويتم التمسك بالدفع بعدم القبول وهو دفع يبدي في أي حالة تكون عليها الإجراءات، كما تملك المحكمة أن تحكم من تقاع نفيها بعدم القبول لتعلق ذلك بالنظام العام. 


\section{الفرع الثاني \\ شروط قبول الاشكال المقدم هن الغير في التنفيذ}

لقبول الإثكال المقدم من الغير أن يقوم علي أسباب تتسم بالجدية، كأن يدعي

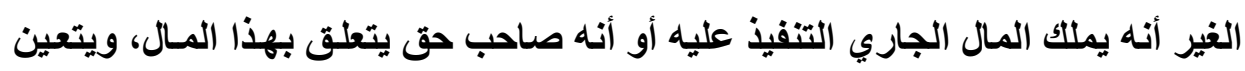

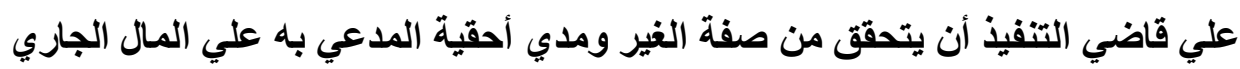

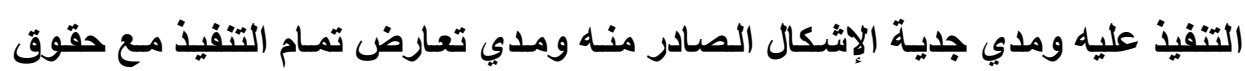
الغير الثابتة بمستندات المقدمة امام القاضي. ويشترط لقبول الإثكال المقدم مـن الغير، توافر المصلحة للغير، وأن يرفع

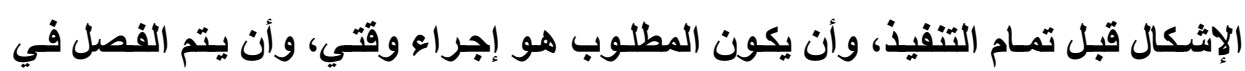
الاشكال قبل الفصل في النزاع الموضوعي، وسنشير إلى هذه الثشروط على النحو الندو

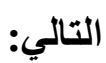

\section{الشرط الأول: أن يكون للغير هصلحة:}

الإثكال منازعة وقتية تعرض علي القضاء لاستصدار حكم فيها، وبالتالي يلزم

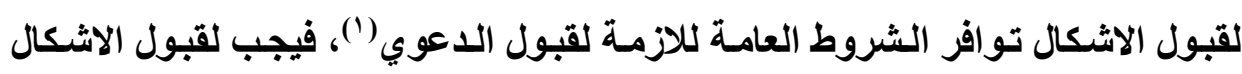

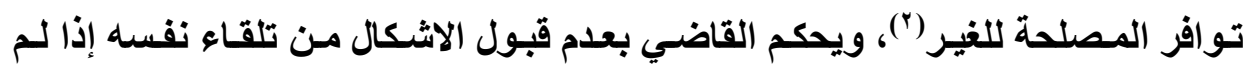

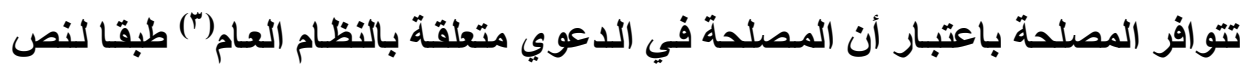

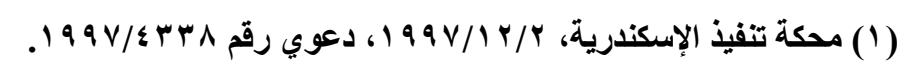

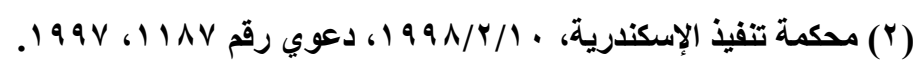

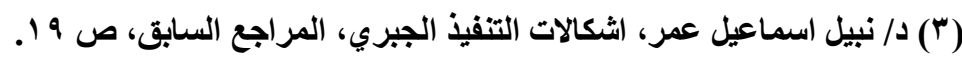

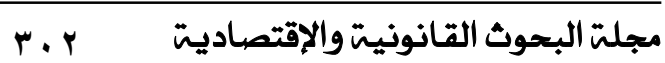


المادة الثالثة من قانون المرافعات، وذلك لأن الامر يتعلق بالحاجة إلى الحماية القانونية

وسلطة المحكمة في منح هذه الحماية لمن يحتاج اليها من الاشخاص(").

ويشترط كذلك أن يكون هنـاك ضرر سيلحق بـالغير من الاستمرار في التتفيذ،

وهذا ما يطلق عليه شرط الاستعجال(؟)، والواقع أن المشرع المصري لم ينص صراحة

علي ضرورة توافر شرط الاستعجال لقبول الإشكال، وذلك لأن إثكالات التنفيذ الوقتية

تعتبر مناز عة مستعجلة بطبيعتها تتوافر فيها الاستعجال، فالاستعجال مفترض من قبل

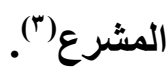

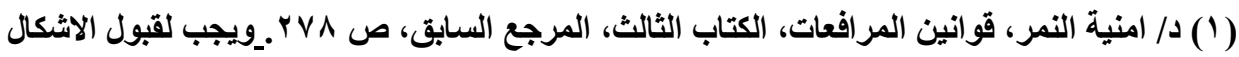

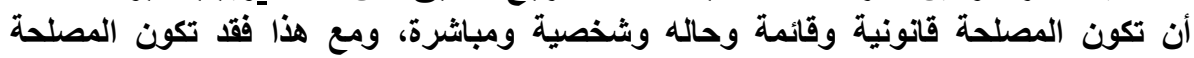

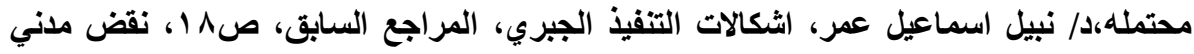

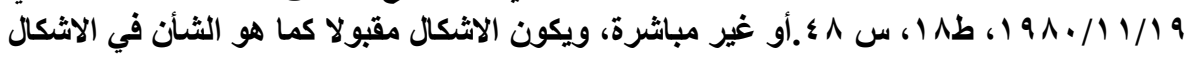

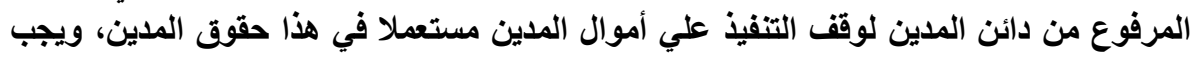

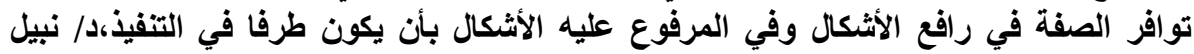

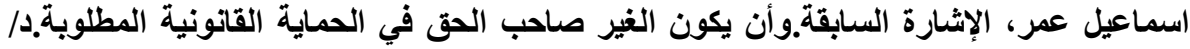

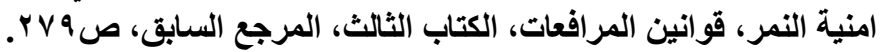

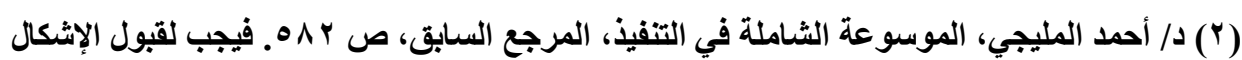

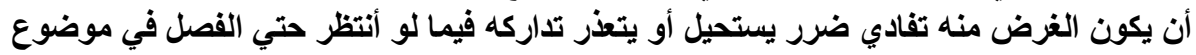

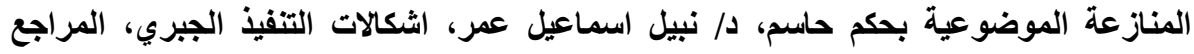

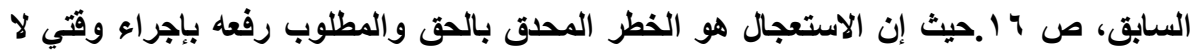

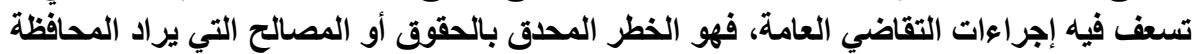

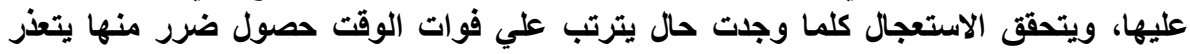

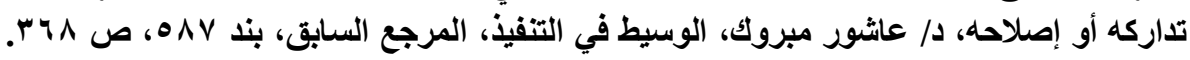

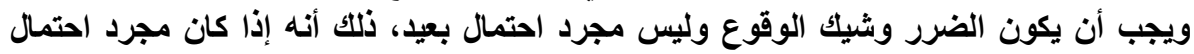

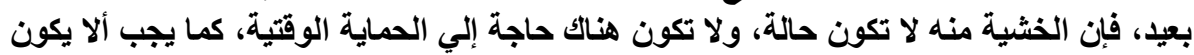

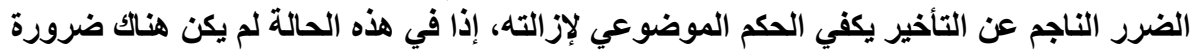

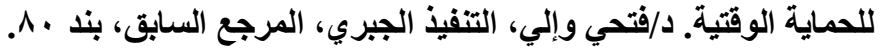

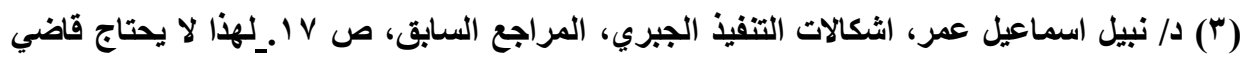

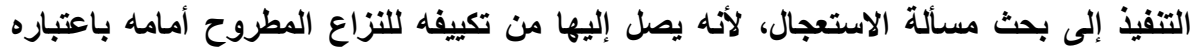
$=$ 


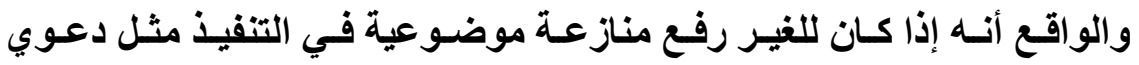

الاسترداد أو الاستحقاق، ولكن نظرا لأنها قد تستغرق وقتا طويلا في العادة، ممـا قد

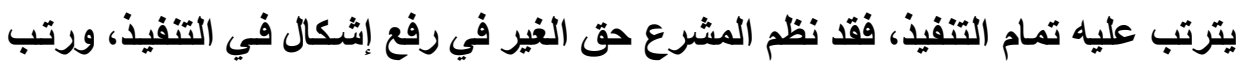
علي رفعه وقف التنفيذ بقوة القانون إذا كان الإثكال الأول، فمفاد ذلتك أن الإشكال يعتبر في الغالب أداه للغير للافاع بها عن مصالحه، وذلك بهدف الوصل إلى وقف التتفيذان.

\section{الشرط الثاني: أن يطلب الغير إجراء وقتيا:}

الإثكال في التنفيذ يعتبر المنازعة وقتية، وبالتالي فيجب أن يكون المطلوب

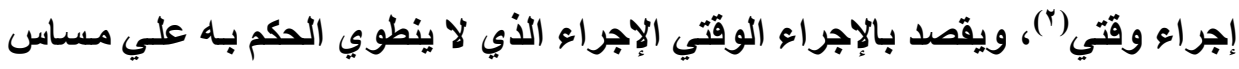

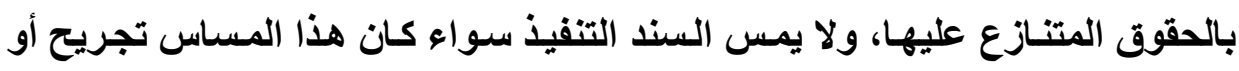

إثكالا وقتيا في التنفيذ(ّ) ،الإثارة السابقة، والعبرة في تحديد وصف المنازعة هي بتكييف

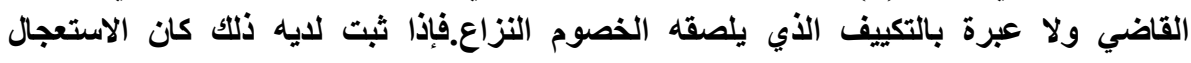

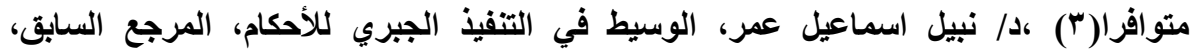

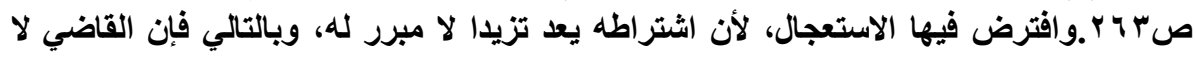

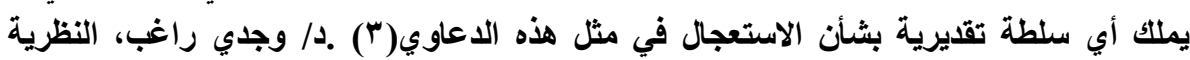

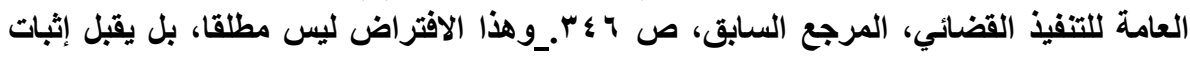

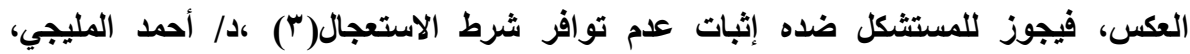

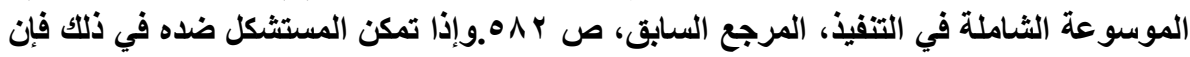
القاضي لن يقبل الاشكال المقدم من الغير.

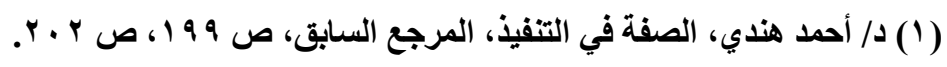

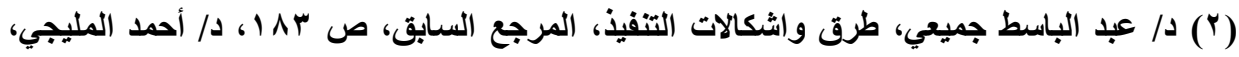

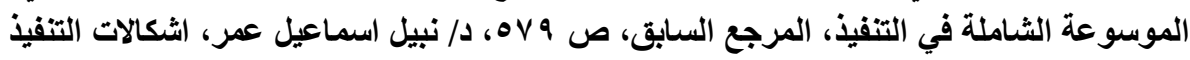

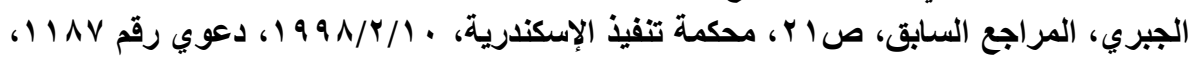

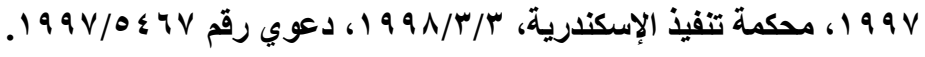

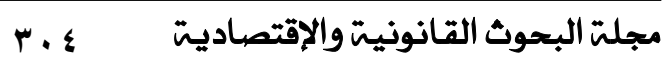


تفسير أو تصحيح أو طعنا عليه(')، فلا يتضمن الاشكال قضاءً بوجود الحق أو عدمـه، لذلك يجب أن يكون المطلوب الحكم بإجر اء مؤقت يحمي مصلحة الغير، ويرجع ذلك إلى أن هنـاكك دعـوي موضـوعية أخري معروضـه علـي القضاء سيفصل فيهـا فيمـا بعد، وبالتـالي يهـف المستشكل إلى وقف التفيذ مؤقتا إلى أن يفصل في هذه الـدعوي

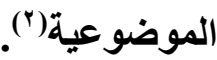

الهذف من الإجراء الوقتي تحديد مركز الخصوم تحديدا مؤقتاً أو توفير حمايـة مؤقتة إلي أن يحسم الأمر نهائيا من قبل القضاء الموضوعي("). ويلاحظ أن كون المطلوب اتخاذه إجراء وقتيا، فالحكم فيه يحدد مراكز الخصوم مؤقتا، ولكن لا يعني أن نتائجه يجب أن تكون متداركة دائمسا، فيمكن لقاضسي التنفيذ أن يأمر بصفة مستعجلة بالاستمرار في التنفيذ علي المنقولات المحجوزة حتي ولو أدي ذلكـ إلـي توصسيل الخصوم إلـي مركز يستحيل أو يتعذر تغييره فيمـا بعد، أي يمكن الوصول إلي بيع المنقول المحجوز عليها، وتكون مملوكة للغير، وهذا أمر لا رجوع فيه فيما لو تبين بطلان الحجز، فلا يمكن أن يعيده الخصوم في الإشكال إلي الحالـة التي كانوا عليها فيما قبل البيع، فلا سبيل سوي التعويض في هذه الحالة.

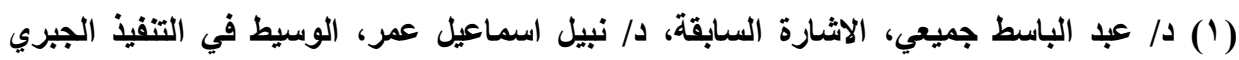

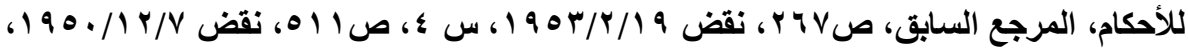

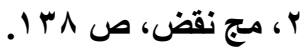

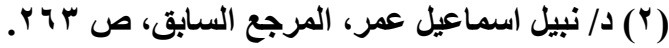

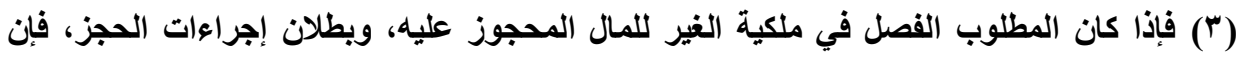

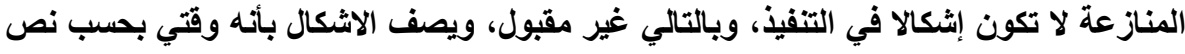
القانون ولا يعتد بتكيفات الخصوم لله إذا كاتت مخالفة للقانون. 
وإذا كان الإجراء المطلوب يجب ألا يمس أصل موضوع النزاع(')، ولكن يجب أن يكون متعلقا بمنازعة موضوعية في التنفيذ يرمي الإشكال إلـي مساعدتها(؟) في الواقع كثيرا مـا يعجز القاضسي عن الفصل في النزاع المعروض عليهه دون بحث أو تفسير عرضي يتحس به ما يحتمل لأول نظرة أن يكون هو وجـه الصواب في النزاع

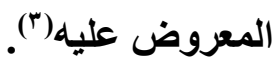

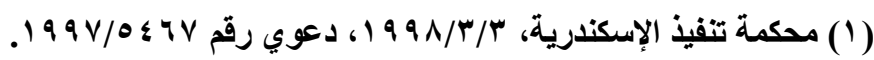

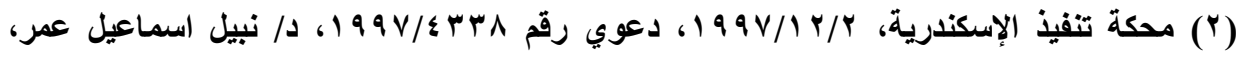

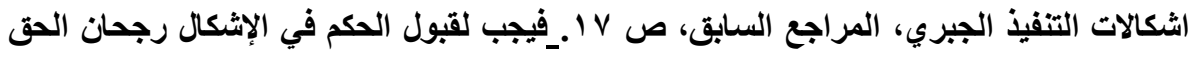

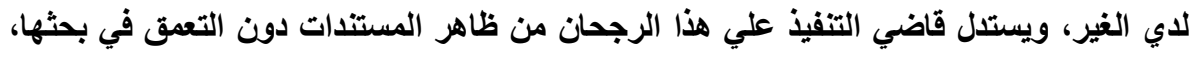

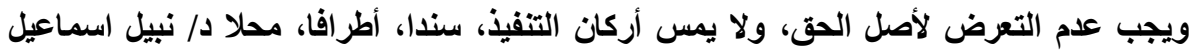

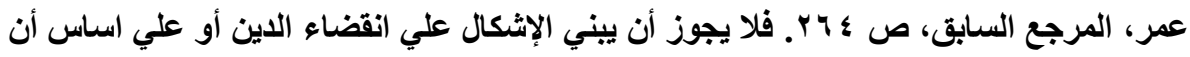

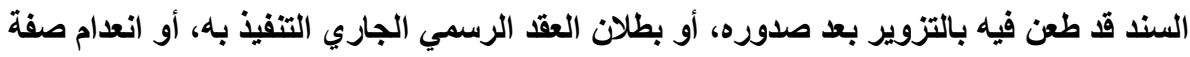

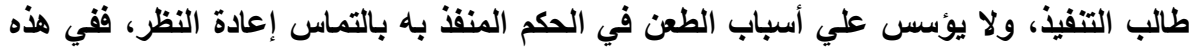

الحالات يجب الحكم برفض الإنكال.

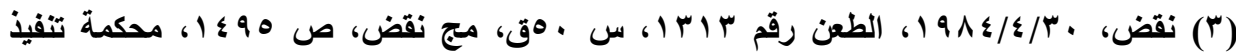

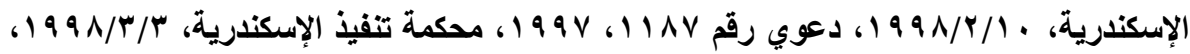

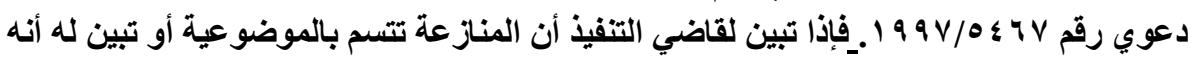

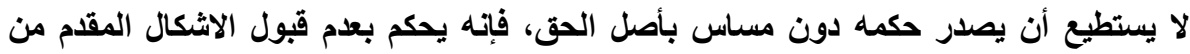

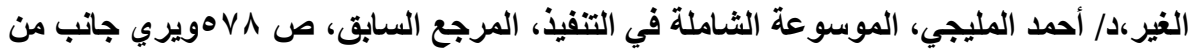

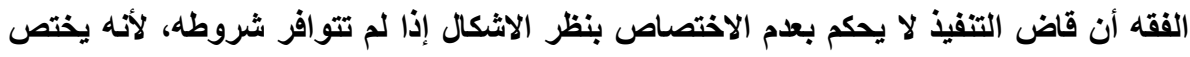

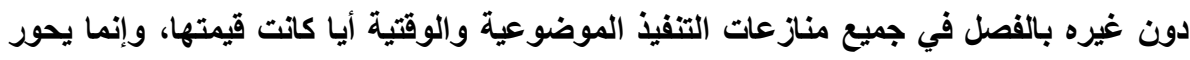

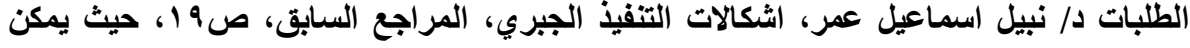

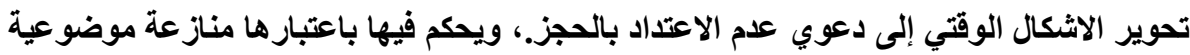

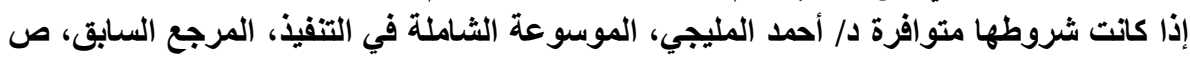

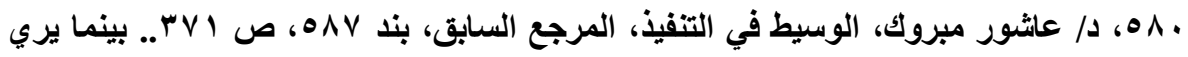

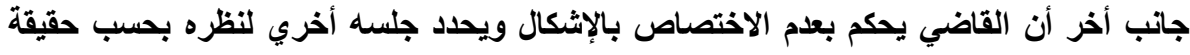
$=$ 


\section{الشرط الثالث: رفع الإشكال قبل تمام التنفيذ:}

يثترط لقبول الإثكال المقدم من الغير أن يكون رفع الإثكال قبل تمام التنفيذ(')،

ويرجع ذلك إلى أن هدف الاشكال هو دفع خطر المضي في التنفيذ، وذلك عن طريق الحصول علي حكم بوقف التنفيذ، وبالتـالي إذا تم التنفيذ فتنتفي المصلحة في رفع

الاشكال في الدعوي(؟)، حيث أن وقف التنفيذ يرد علي الإجراءات المستقبلية وليس إلغاء الإجراءات التي تمت(")، فتمسام الإجراءات يعطي الحق في رفع دعوي ببطلان

الإجراءات عن طريق إثارة منازعة موضوعية في التنفيذ(؛).

الطلب فيه، أي وفقا للتكييف الصحيح للطلب إذا كان منازعة موضوعية.د/ امنية النمر، قوانين

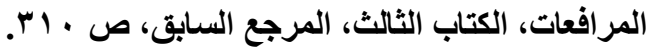

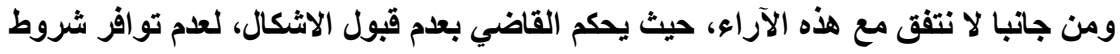

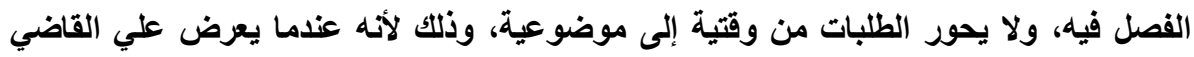

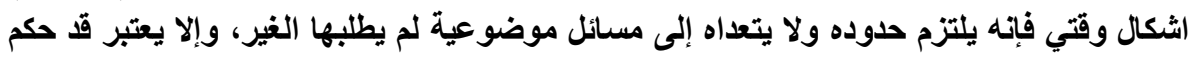

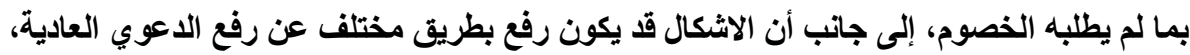

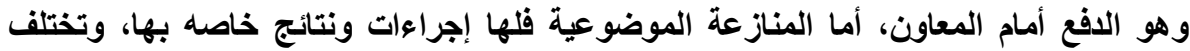
جذريا عن الإثكال الوقتي.

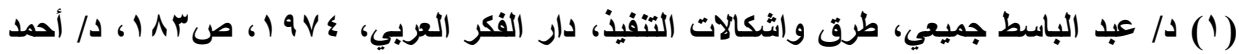

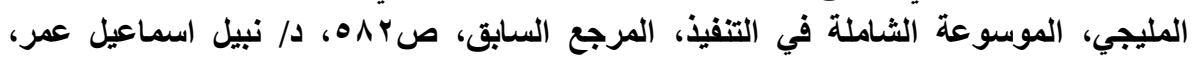

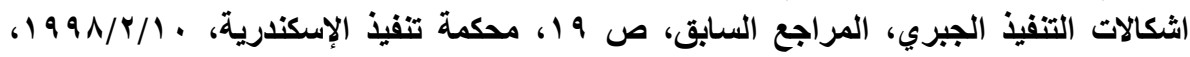

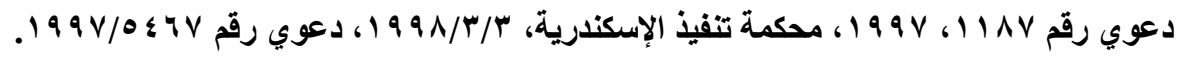

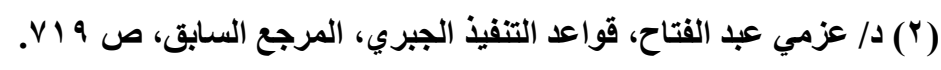

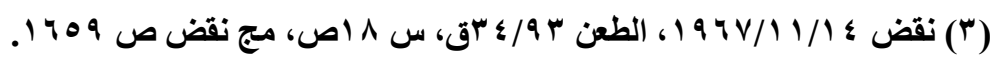

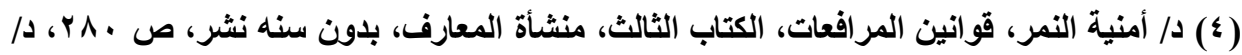

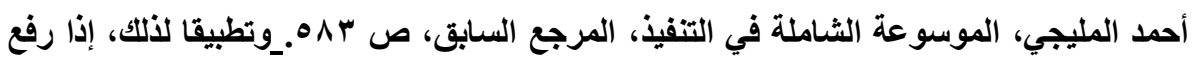

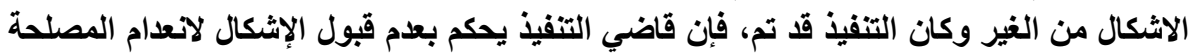

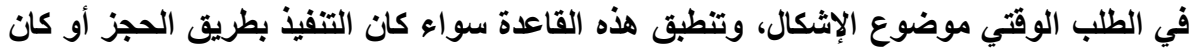
$=$ 
والواقع أنه من الصعوبة تحديد اللحظة التي يمكن فيها القول بأن التنفيذ قد تم، وبالذات إذا كان يتم علي عدة مراحل، أو علي عدة أموال أو بعدة سندات تنفيذيـة، أو يتعدد فيه الحاجزين، والنظر إلي تمام التنفيذ من عدمه يجب أن ينظر إلي كل عمل علي هي حدة'(')، فبإذا كـان قد تـم عمل فـلا يقبل وقف تنفيذه، وإنمـا يطلب وقف مـا يليهله مـن إجراءات، فـإذا كـان الحجز علي الأموال الذي يتم علي مراحل متتابعة مستقلة منها توقيع الحجز والإعلان عن البيع والبيع، فإذا تم توقيع الحجز فلا يجوز رفع الإشكال الوقتي لوقفه ولكن يجوز رفع الإثكال لوقف البيع قبل إجرائه، وإذا تمت كل إجراءات الحجز بالفعل فلا يمكن طلب وقف التنفيذ، والعبرة هنا بتمام التنفيذ وليس بتمام الحجز، وتمام التنفيذ يكون البيع الجبري(). ويرى جانب مـن الفقـه أن العبر في قبـول الإشكال بضرورة تقديمـه قبـل تمـام الحجز وليس قبل تمـام التنفيذ لأن التنفيذ يتم تمامـا بالبيع وتوزيع حصيلة التنفيذ(")، والواقع لا نتفق مع هذا الرأي حيث أن العبرة هي بتمـام التنفيذ وليس بتمـام الحجز، وذلك لأن المشرع في المادة r آ استخدم عبارة التنفيذ ولم يستخدم الحجز. والواقع أنه يترتب علي رفع الإشكال من الغير وكان الاشكال الأول، وقف التنفيذ بقوة القانون، وبالتـالي من لحظة تقديم الاشكال يوقف التنفيذ، ولكن إذا كـان اشكالا

تنفيذا مباشرا، والواقع أن شرط رفع الإشكال قبل تمام التنفيذ هو شرط من النظام العام تقضي

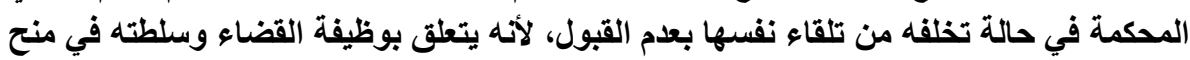

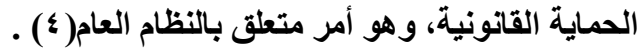
(1) (1) د/ أحمد المليجي، الإشارة السابقة.

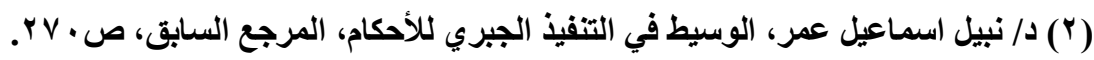

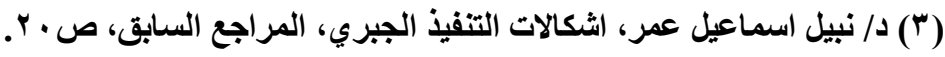


ثانيـا، فـلا يترتب عليـه وقف التنفيـذ بقوة القـانون، وإنمــا يتوقف ذلــك علـي حكم قاضي التفيذ، وفي هذا الفرض الاخير، يثور تساؤل عن الوقت الذي ينظر فيه من

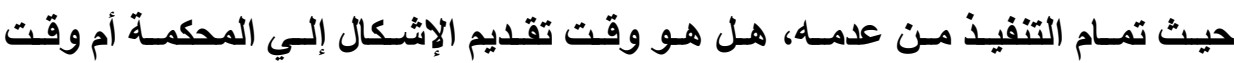
صدور الحكم بوقف التنفيذ من القاضـي، يلاحظ أن الفقه اختلف في الإجابـة علي هذا

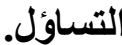

يـرى جانـب مـن الفقـهـ(') أن العبرة هـي بلحظـة الحكم في الاشـكال قبـل تمـام التنفيـذ، ومرجـع ذلــك إلسى أن شـرط المسصلحة كقبـول للـــوي هـو شـرط مستمر،

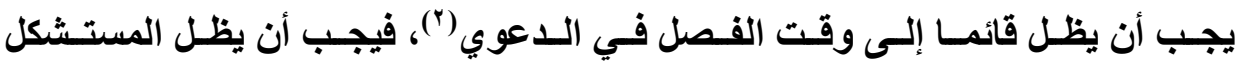
في حاجة إلى الحماية القانونية إلى وقت صدور الحكم، وبالتالي يجوز لقاضسي التنفيذ أن يحكم بعدم قبول الاشكال إذا تم التنفيذ قبل صدور الحكم. والقول بغير ذلك يؤيد إلى أن الحكم بوقف التنفيذ يمتــ أثره إلى الماضـي ولـيس مـن وقت الحكم بـه. كمــا أن المقصود مـن الإشـكال الـوقتي هـو طلب وقف التنفيذ مؤقتـا، والتففيذ قـــــم عمـلا قبل الجلسة المحددة للحكم في هذا الاشكال، ومـا تم لا يوقف وإنمـا يلفي، وبالتـالي لا يجـوز الحكم بوقف التنفيذ، ويـري البعض مـن هذا الاتجـاه(ّ) أنـه يمكن للغير أن يحور طلباته الواردة في الإشكال ويجعله طلبا بعدم الاعتداد بالحجز، وإذا ما حكم له يتم زوال التنفيذ الأي تم.

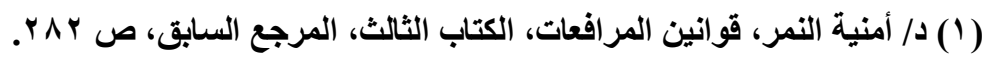

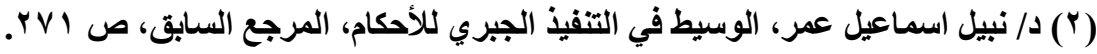

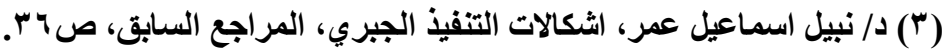


بينما يري جانب أخري من الفقه أن العبرة هي وقت رفع الاثكال لأن العبرة في قبوله أو عدمه باعتبار يوم رفعه(')، أي أن تمام التنفيذ بعد رفع المنازعة لا يمنع من الحكم بقبولها، وفي هذه الحالة كان الطلب مقبولا لحظة رفعه،، لأن الاخذ بـالرأي الأول يؤدي إلى الإضرار بـالغير المستشكل ضررا بليغا، حيث أنها رفع الاشكال في الوقت

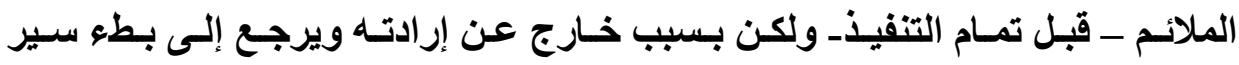
الإجراءات أمام المحكمة تم التنفيذ قبل الفصل في الاشكال، فبإذا حكم بعدم القبول فِان

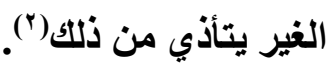
ويعترض علي هذا الرأي بأنه يوجد استحالة واقعية، لأنـه لو اجيب هذا الطلب وحكم بوقف التنفيذ فإنه يكون من المستحيل تنفيذه لأنه لا يوجد تنفيذ قائم يمكن وقفه، وبالتالي تتتفي المصلحة في الإبقاء علي هذا الطلب. والواقع نري أن العبرة هي بوقت الحكم من قاضـي التنفيذ إذا كـان الاشكال لا يترتب علـي رفعه وقف التنفيذ، وذلكك لأنسه وقت الحكم ينظر القاضـي مـدي تـوافر المصلحة في الاشكال، كما أنه ليس لحكم القاضسي أثر رجعي علي مـا تم من اجراعات التنفيذ، بالإضـافة إلى أن المشرع لـم ينص علـي أن قرار القاضـي بوقف التنفيذ في الاشكال لـه أثُر رجعي من لحظة تقديم الطلب، ولهو رغب المشرع لنص علـي ذلك

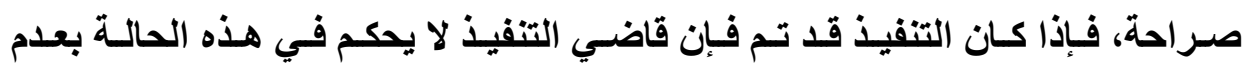
الاختصاص لأنه مختص، ولكنه يحكم بعدم القبول.

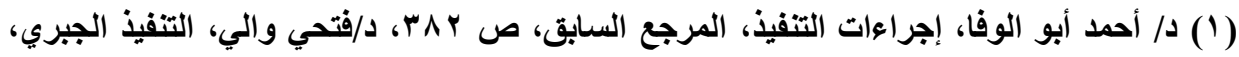

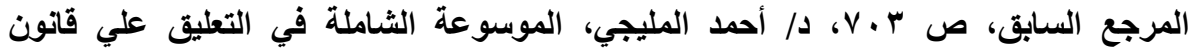

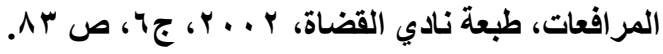

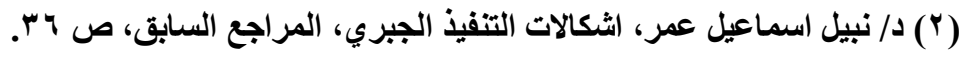

مجلة البحوث القانونيت والإقتصاديت 


\section{الشرط الرابع: عدم الفصل في النزاع الموضوعي:}

في الواقع أن الحماية الوقتية لا يكون لها أهمية إذا كان النزاع الموضوعي قد حسم بحم، وبالتالي إذا فصل في موضوع الاثكال من الناحية الموضوعية فلا يقبل

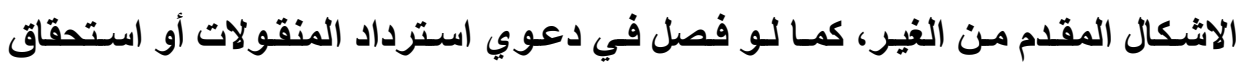
العقار، حيث لا يكون هناك حاجه إلى إجراء وقتي ('). ويرجع ذلك إلى أن الاثكال المقدم من الغير يقصد بـه تحديد مركز الخصوم

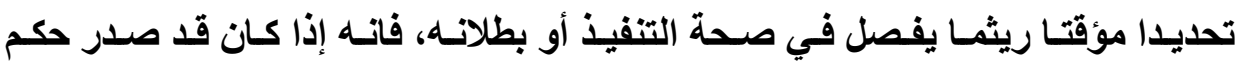
موضوعي في هذا الثأن عند الفصل في الاشكال الوقتي، لا يحكم القاضي في الإشكال، لأن الحكم الموضوعي يفني عن الحكم في الاشكال بحسب القو اعد العامة("). وهنـا يثُور التساؤل، هل يكفي للحكم بعدم قبول الاثـكال أن يكون الحكم الموضوعي حائز لحجية الامر ألمقضي أم لقوة الأمر المقضي؟ يري البعض من الفقه

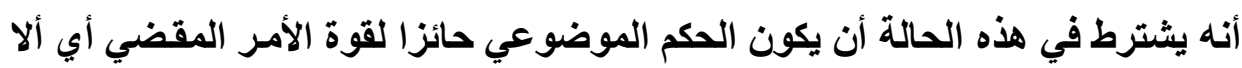

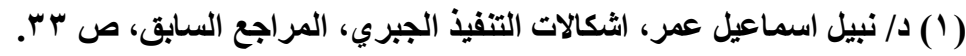

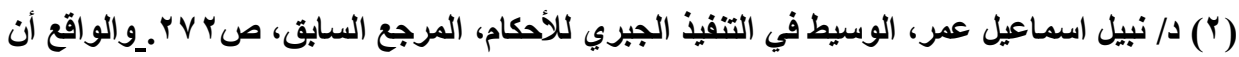

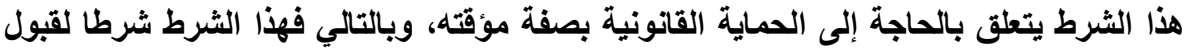

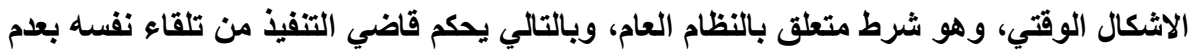

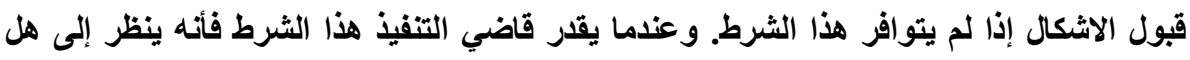

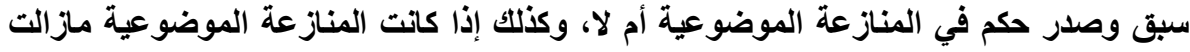
منظورة أمام القضاء، فإنه يجب أن ينصب تقديره علي أن الأشكال سيصدر الحكم فيه في المستقبل

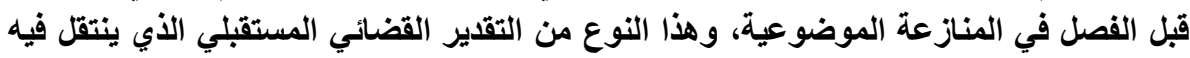

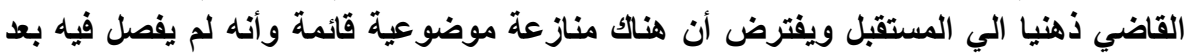


يكون قابلا للطعن بالاستئناف('). ومن جاتبا لا نتفق مـع هذا الاتجـاه، ونري أنها يحكم القاضي بعدم قبول الاشكال إذا كـان الحكم الموضوعي حاز حجية الامر المقضي، ولا يـشترط أن يحـوز الحكـم قـوة الأمـر المقضي، حيـث أن حكم أول درجـة الــي يحسم الموضوع يجب احترامه، وبالتالي لا يجوز اهدار مركز الخصوم في حكم أول درجه عن طريق استخدام طرق الحماية المؤقتة.

\section{الشرط الخاهس : أن يكون سبب الاشكال قد جد بعد صدور السند:}

يشترط لقبول الاشكال الوقتي أن يكون سببه قد جد بعد صدور الدكم، واسـاس ذلك أن الإشكال وهو ينصب علي إجراعات التنفيذ الجبري يكون مبنـاه دائمسا وقائع لاحقه علي صدور الحكم وليست سـابقة عليه والا كـان الاشكال بمثابـة طعن في الحكم بغير الطريق القانوني. فمن المؤكد أن إشكالات التنفيذ المقدمـة من الغير ليست طريقا من طرق الطعن في الحكم الذي يجري التنفيذ بمقتضاه(؟)، وإنما هي تظلم من إجراءات التنفيذ مستنده إلي وقائع لاحقة علي صدور الحكم(")، فلا يمكن لقاضي التنفيذ أن يبحث مسائل متعلقة بصحة الحكم الصـادر أو متعلقة بـإجراعات اللـعوي لمسا في ذلكـ مـن مساس بحجية الأحكام القضائية(؛)

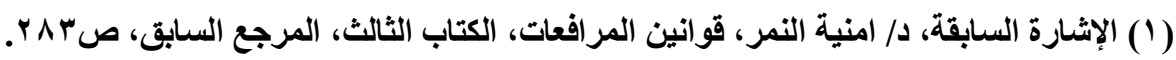

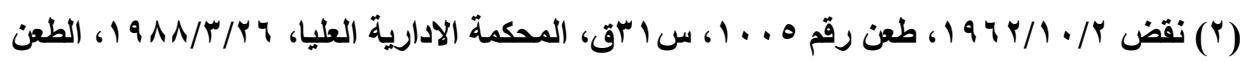

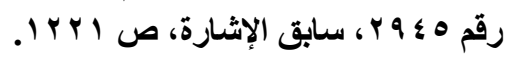

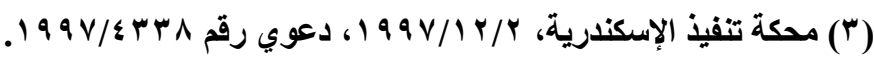

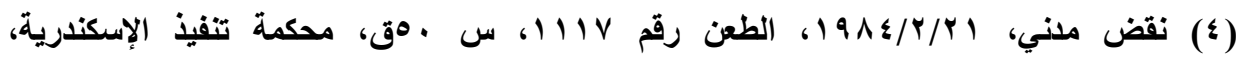

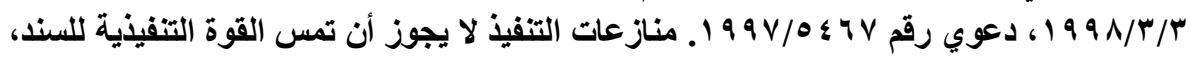

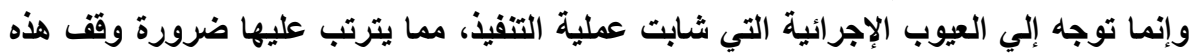

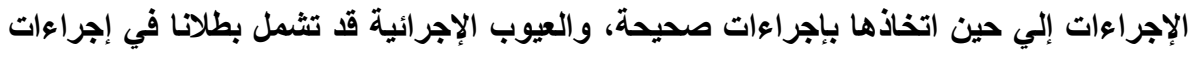
$=$ 
والواقع أنـه إذا كـان السند التنفيذي في مواجهة الغير منعدما، فـلا يكون لـه حجية، حيث أن الحجية نسبية بين الأطراف فقط، وبالتالي يمكن للغير أن يستتد إلى انعدام السند التنفيذي(')، لأسباب سابقة علي صدوره(؟)، فيجب علي القاضسي أن يحكم بوقف التفيذ(")، بعد أن يفحص ظاهر المستندات التي قدمها الخصوم لكي يستشف صحة المنازعة وجديتها وأن الأسباب التي يبني عليها الإثكال لـم يصدر فيها قضاء صريح أو ضمني، كما لو استتـد إلى غش أو تواطؤ ممثلـهـ أو إذا كـان الحكم مزورا أو مرفوع دعوي تزوير بشأنه، فيمكن الحكم بوقف التنفيذ، ويلاحظ أنه نظرا لجسامة العيب المنسوب إلى الحكم المنعدم، وبالتـالي يجور للمحكمـة التنفيذ أن تـأمر بوقف التنفيذ، ولا يعد ذلك مخالفة لاختصاص قاضـي التنفيذ بالمنازعـات الوقتية، حيث أن قاضي التفيذ يختص بالعيوب اللاحقة للسند إذا كان السند التتفيذ موجودا، ولكن في حالة انعدامه، فإنه ينظر عيوب السند السابقة علي تحريره.

الحجز، مثل عيوب في تحرير محضر الحجز، أو الحجز علي الحجز علي أموال غير مملوكه للمدين، أو غير ذلك من الإجراءات التي تطلبها المشرع وتمس فير حق الغير التير.

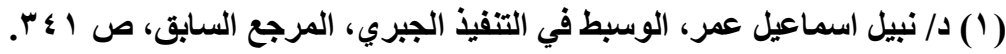

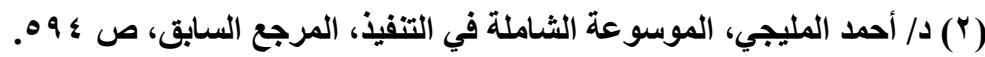

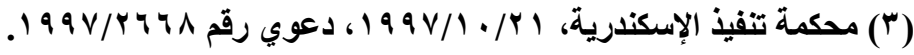




\section{المالب الثاني \\ آثار اشكال الغير}

يعتبر الإثكال مرفوعا بمجرد تقديمه للمعاون وإثباته بالمحضر أو بمجرد تقديم صحيفة الدعوي قلم كتاب محكمة التنفيذ، ويعتبر منتجاً لآثاره القانونية المترتبة علي رفعه، فإذا قصر المعاون في رفعه إلي قاضي التنفيذ، فإنه يجوز للمستثكل تحريك هذا الإشكال بتكليف خصمه بالحضور أمسام قاضسي التنفيذ المختص، ولا يعتبر ذلك إشكالا

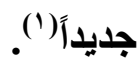

$$
\text { في الإثكال، وذلك في الفروع الأتية: إلى الآثار التي تترتب علي رفع الإشكال، والآثار التي تترتب علي الحكم }
$$

\section{الفرع الأول \\ الآثار التي تثرتب علي رفع الإشكال المقدم هن الغير}

نص المشرع المصري صراحة علي أن للإثكال آثرا موقفا للتففيذ بقوة القانون

بمجرد رفع الاشكال، ولكن هذا الاثر ليس مطلقا يترتب في جميع الاشكالات الوقتية

$$
\text { وانما يترتب فحسب في حالات الاشكال الأول. }
$$

سنشير إلى وقف التنفيذ بقوة القـانون والوقف القضائي، وزوال الأثر الواقف

للإشكال، وذلك في النقاط الآتية:

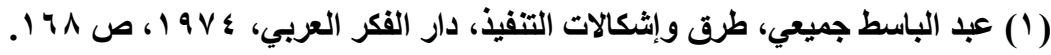

مجلتّ البحوث القانونيت والإقتصاديت 


\section{أولا: وقف التنفيذ بقوة القانون والوقف القضائي}

نصت المـادة ب اس مرافعـات علـي أن الإشكال الـوقتي في التنفيذ يؤدي مجرد

رفعه إلي وقف التنفيذ(')، ولكن يشترط أن يكون اشكالا أول، وأن يجري تحت اشراف قاضي التفيذ، ويستوي أن يقدم الإشكال أمام المعاون عند التنفيذ أو يرفع مباشر أمسام قاضي التنفيذ، ويكون الأمر كذلك ولو رفع الإثكال أمام محكمة غير مختصة(؟)، ويظل هذا الأثر باقيا مـا بقيت صحيفة الاشكال قائمسة ولا يزول إلا بصدور حكم يترتب عليه

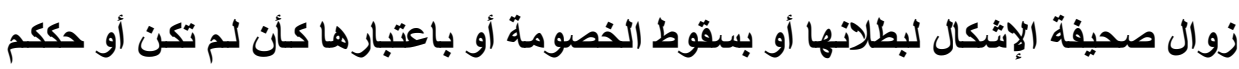
بشطب الإشكال، كما يستوي أن يتعلق الإشكال بحجز تحفظي أو بحجز تنفيذي، وأن

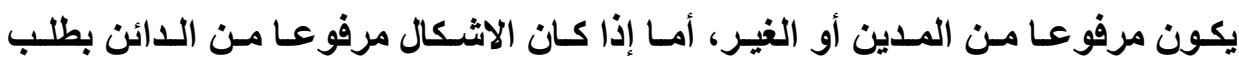
الاستمرار في التتفيذ، فلا تثور بثأنه مسألة وقف التنفيذ.

ويقصد بوقف التنفيــن نتيجـة للإشـكال الـوقتي المقـدم مـن الغيـر عـدم اتخــاذ الاجراءات التي تعتبر من اجراءات التنفيذ وهي الاجراءات التي تبدأ في الحجز علي المنقول بتوقيع الحجز وتنتهي بيع المنقولات وتبدأ في التنفيذ علي العقار بتنبيه نزع الملكية وتنتهي بصدور الحكم بإيقاع البيع.

ويجب أن ينصب الاشكال علي التفيذ الذي يجري بواسطة معاون التفيذ، لأن المشرع منح سلطات في المـادة ب ا ب مر افعات لمعـاون التنفيذ في شـأن رفع الاشكال

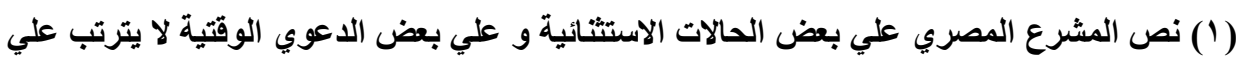

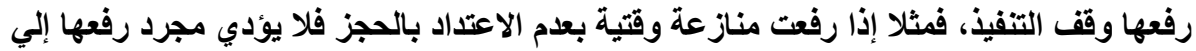
وقف الإجراءات التالية للحجز.

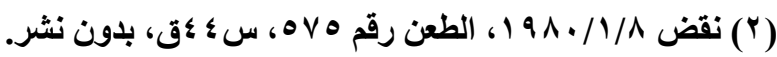


والتكليف بالحـضور وعرض النـزاع علـي القاضـي وهـذه الـسلطات لا يجـوز القول بمنحها لغير المعاونين طالما لم يرد نص خاص بهذه السلطات، وبالتالي لا يترتب علي الاشـكال فـي الحجـز الاداري وقف التنفيـذ(')، لأن التففيـ لا يجـري بواسـة معساون

التنفيذ(r)

فباذا قدم الغير الإشكال أمسام المعاون، فهو بالخيـار إمـا أن يوقف التنفيذ أو أن

يستمر فيه علي سبيل الاحتياط، ولكن إذا استمر في التنفيذ فلا يجوز لله أن يتمه قبل أن يصدر القاضـي حكمـه في الإثـكال، وبالتـالي إذا كـان العمل المعترض عليهه هو نهايـة التنفيذ فليس للمعاون أن يقوم به، وذلك لأن قيامه به يعني تمام التنفيذ، لأن المشرع قد

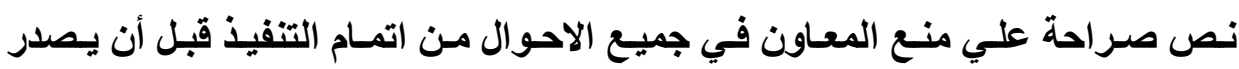
القاضي حكمه في الاشكال. والمقصود بنهايـة التنفيذ هو البيع في حالة التففيذ بنزع الملكية، والواقع أن سلطة المعاون في الاستمرار في التنفيذ لا تعني المضي فيهه إلـي تمامه بل تعني فقط اتخاذ الإجراءات التحفظية، فيجوز للمعاون الاستمرار في الحجز إذا كان يخشي تهريب المنقولات المحجوزة(")، وبنـاء علي ذلك لا يكون للمعاون سلطة تقديريـة في الاستمرار في الاجراعات إذا كـان التنفيذ يتم في مرحلة واحدة، كمـا هو الحال في التنفيذ العيني تعين عليه وقف التنفيذ فور تقديم الإشكال من الغير، كمـا هو الثأن في حالات التفيذ المباشر بإخلاء عقار. ولا تكون له سلطة إذا ابدي الاثكال عند بيع الاموال المحجوزة، لأنه بإتمام البيع يتم التنفيذ. 
واستثناء من قاعدة الأثر الموقف للإشكال الأول فقد نص قانون رقم و 1 لسنة

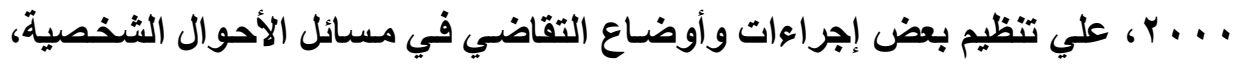
حيث إنه لا يترتب علي الإشكال المقدم من المحكوم عليه في تنفيذ أحكام نفقة الزوجة

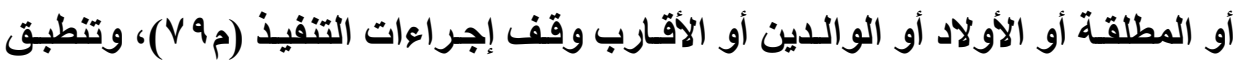
هذه القاعدة سواء كان الاشكال اول أو لم يكن كذلك، وبالتـالي فإن الإشكال المقدم من الغير في مسائل الاحوال الشخصية يترتب عليه وقف التنفيذ إذا كـان إثـكالات أول، وذلك لأن نص المادة V V استثناء من القاعدة العامة الواردة في المسادة ب اب مرافعـات

$$
\text { ولا يجوز التوسع في تفسير الاستثناء ولا القياس عليه('). }
$$

وخلاصة القول، يترتب علي الاشكال وقف التنفيذ متي كان التنفيذ يجري تحت اشـراف قاضـي التنفيذ ويواسطة معـان التنفيذ، وكـان اشكال أول، فبإذا وقف المعـاون التنفيـذ خلافـا للقـانون يجـوز لطالب التنفيـذ أن يطلب مـن المحكمة المختصة الحكم بالاستمرار في التنفيذ. ويجب ملاحظة أن وقف التنفيذ ينصرف إلى وقف سير الإجراعات التنفيذية، ولا يمس هذا الوقف القوة التنفيذية الكامنة في السند التنفيذي، وبالتالي يظل السند صـالحا رغم قيام الوقف، لإجراء تنفيذ جبري جديد، أو إعادة التنفيذ علي ذات الأموال الموقف التنفيذ عليها، لأن الدائن يملك بسند تنفيذي واحد إجراء حجوزات مختلفة، والذي يقف هو سير الإجراعات وليس صلاحية السند التففيذي(؟)، حتي لو كان سبب الوقف يتعلق

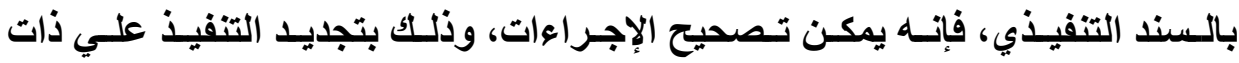


الأموال(')، فمثثلا لو قضي بوقف التنفيذ لأنـه المـال مملوك للغير لحظة الحجز، فأنهـ يمكن تجديد الحجز علي نفس المال إذا تملكه المدين، ويتنازل الحاجز عن الحجز الأول. يثور التساؤل متي يعتبر الاشكال الوقتي اشكالا اول يترتب عليه وقف التنفيذ؟ سنشير إلى مفهوم الإثـكال الأول المقدم مـن الغير وآثـاره، ثـم نبحث مفهوم الإشكال الثاني وآثاره، وذلك في النقاط الآتية:

\section{ا- هفهوم الإشكال الأول المقدم هن الغير وآثاره:}

لقد نص قانون المرافعات السابق في المـادة . ^ ـ علـي أن الاشكال الاول هو الذي يترتب عليه وقف التفيذ بقوة القانون، والاشكال الأول هو الذي لم يسبقه اشكالا أخر، ويثار التساؤل عن الاشكال يكون اشكالا ثانيا إذا رفع بعد رفع الاشكال الأول أم

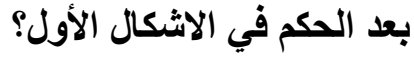

في الواقع ذهب المشرع المصري في قانون المرافعات السابق في المسادة ـ ـ ؛ علي أن الاشكال الثاني وهو الذي يرفع بعد صدور حكم في الاثكال الأول(؟)، وهو الذي لا يكون له الأثر الموقف للتنفيذ، وبالتـالي فالإثكال الذي يرفع قبل صدور الحكم في الاشكال الأول، يكون له آثر في وقف التنفيذ ويعتبر كأنه اشكالا أول، ومن شـأنه إبقاء التفيذ موقوفـارغم صدور الحكم بالاستمرار في التتفيذ في الاشكال الأول. وقد أدي تطبيق المادة ـ ^ ؛ مرافعات علي النحو السابق إلى بعض السلبيات فقد شجع الخصوم علي التحايل، فكان الدائن يكلف غيره برفع اشكال وقتي يقف التنفيذ بقوة القانون حتي

(1) د/ نبيل اسماعيل عمر، الوسيط في التففيذ الجبري للأحكام، المرجع السابق، ص ه^ץ.

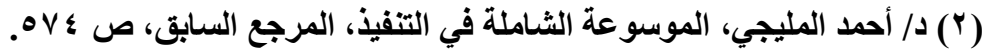


اذا حكم فيه بالاستمرار في التنفيذ لا يقف التنفيذ مره ثانية نتيجة لاي اثكال آخر يرفع

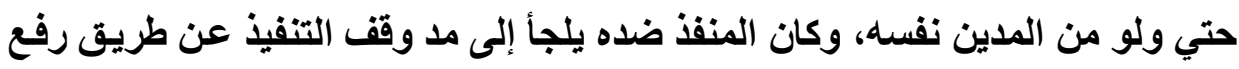
عدة اشكالات حتي إذا حكم في احداها بالاستمرار في التنفيذ فان التنفيذ يظل موقوفا نتيجة للإشكالات الأخرى المرفوعة قبل الحكم بالاستمرار في التنفيذ.

و هذا الوضع قد تغير بصدور قانون المرافعات الحسالي، فقد نصت المـادة ب اب علي أن الاشكال الأول وهو الذي يقف التنفيذ، سواء رفع من المدين أو الغير، فإذا رفع اشكال آخر بعده يكون اشكالا ثانيا، الذي لا يوقف التنفيذ بقوة القانون، وتنطبق هذه

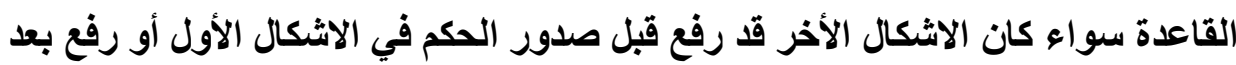
صدور الحكم بالاستمرار في التنفيذ. والإثكال الأول هو أول إنـكال يقدم في عملية التنفيذ أيـا كـان الخصم الذي

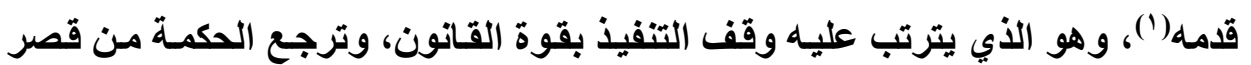
وقف التنفيذ علي الاثكال اول إلى أن المشرع لاحظ استغلال المدينين أو الغير سيء النية ما يترتب علي رفع الإثكال من أثر في وقف التنفيذ، فكان المدين أو الغير يقدم إثكالا أمام المعاون يوقف التنفيذ، فإذا حكم فيه برفضه أو انتهت الخصومة بغير حكم، التهان وشرع المعاون في إتمام التنفيذ، عاد المدين أو الغير إلي تقديم إثكال آخر يوقف

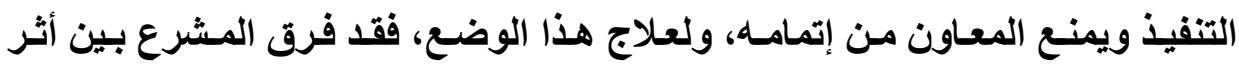
الأثكال الأول وأثر الأثكال الثاني، حيث نص علي الاثر الواقف بقوة القانون للإثكال الأول فقط.

( ) د/ نبيل اسماعيل عمر، الوسيط في التنفيذ الجبري للأحكام، المرجع السابق، ص • ^؟.

مجلة البحوث القانونيت والإقتصاديت 
والواقع أنه يمكن تصور وقف إجراءات التنفيذ وقفـا قانونيـا رغم صدور الحكم في الاشكال الأول بالاستمرار في التنفيذ، ويتحقق ذلتك في حالة مـا كـان الاشكال اول مقدم من الغير، ورفع دعوي استرداد المنقولات المحجوزة بعد الحكم بالاستمرار في التنفيذ في الاشكال اول، فقي هذه الحالة يقف التنفيذ ثانية بقوة القانون؛ أو يكون قد رفع دعوي الاسترداد قبل الحكم في الاشكال اول، فاذا صدر الحكم في هذه الاشكال أول، فان التنفيذ يظل موقوفا نتيجة لدعوي الاسترداد المرفوعة امام المحكمة. ويجب علي المعاون عدم اتمام التتفيذ قبل أن يصدر القاضسي حكمه في الاشكال الأول، وقد منتح المشرع للمعـاون في نص المسادة ب اب مرافعـات سلطة تقديريـة في الاستمرار في اجراءات التنفيذ رغم الوقف القانوني الذي ترتب علي الاشكال، غير أن المعاون عندما يقوم بالاستمرار في الاجراءات يكون ذلك علي سبيل الاحتياط، بمعني تكون هذه الاجراءات وقتية يتوقف مصير ها علي الحكم في الاثكال، فاذا رفض الاشكال أو انتهت الخصومة فيه دون حكم تستقر اجراعات التنفيذ التي يكون المعاون قد اتخذها علي سبيل الاحتياط رغم الاشكال، وإذا حكم في الاشكال بوقف التنفيذ فـان هذا الحكم يكـون ملغيـا للإجراءات التـي اتخذها المعـاون، وتعبـر كـأن لـم تكن دون حاجـة إلى استصدار حكم بهذا.

\section{r- - مفهوم الإشكال الثاني المقدم هن الغير وآثاره:}

نصت المادة r ا M مرافعات علي أنه لا يترتب علي تقديم أي إشكال آخر وقف التنفيذ ما لم يحكم القاضـي بـالوقف، وبالتـالي فِان أي إثكال آخر علـي خلاف الإشكال الأول لا يترتب علي تقديمه وقف التنفيذ بقوة القانون، وذلك لأن المشرع افترض في 
رافعه سوء النية والرغبة في عرقلة التنفيذ، لذا أخضع وقف التنفيذ لتقدير قاضي التنفيذ.

ويقصد بالإثـكال الآخـر أو الثـاني، الإثـكال الـذي سـبقه إثـكال، والأسبقية

هنا تكون في رفع الإثكال سواء صدر الحكم في الإثكال الأول أو لم يصدر، وسواء كان مرفوعا من المستشكل الأول أو من غيره؛ وتحسب الأسبقية بالنظر إلـي تاريخ الإول

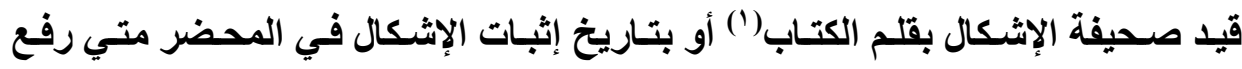
أمام المعاون(")، وقد يرفع الاشكال في شكل عارض، فيتحدال من تاريخ تقديم صحيفة

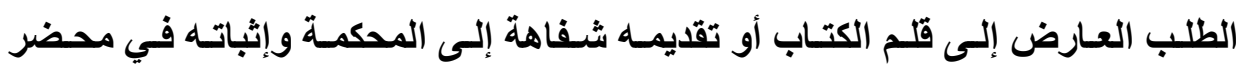

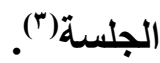

كمـا يشترط لاعتبـار الإثكال ثانيـا أن ينصب علـي ذات التنفيذ محل الإثكال

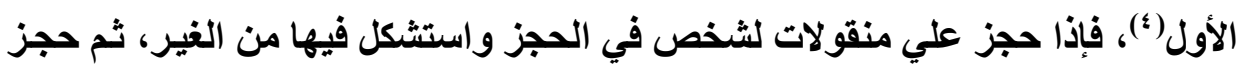
علي منقولات أخري له، واستثكل الغير في الحجز الثاني، فإن إثكاله يعتبر إثكالا أولا يوقف التنفيذ ولو كان الحجزان قد تما بموجب نفس السند التنفيذي (ه).

(1) ويعتبر الاشكال مرفوعا من تاريخ تقليم أوراقه بعد دفع الرسوم وقيد هذه الأوراق في قلم الكتاب.

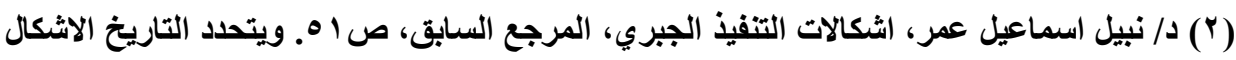

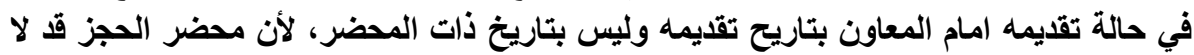
ينتهي في نفس يوم تقليم الآثكال بل قل يستمر مدة اططول.

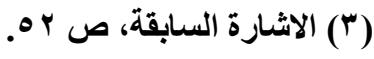

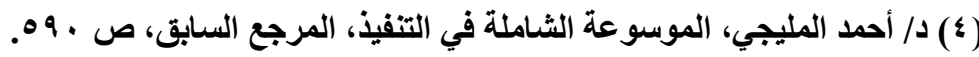

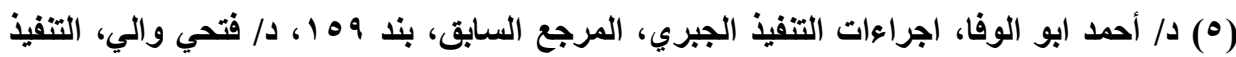

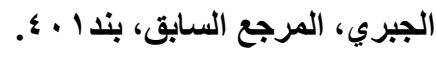

مجلتّ البحوث القانونيتّ والإقتصاديت 
فقد استحدث قانون المرافعات الحالي حكما جديدا وهو أن الأشكال الذي يثيره الملتزم في السند التنفيذي لأول مره يوقف التنفيذ إذا لم يكون قد اختصم في الأثكال اول المقدم من الغير (')، وذلك علي أسساس سـ باب التحايل الذي كشف عنه الواقع العملي(")، حيث كان طالب التنفيذ يوعز إلي شخص من الغير برفع إثكال قبل أن يرفع الملتزم في السند التنفيذي إثكاله، ثم ينتهي الأثر الواقف لهذا الإثكال، ومن ثم يبدأ التنفيذ أو يستمر، فإذا رفع الملتزم في السند إنكالا فإنه لا يوقف التنفيذ بمجرد رفعها لأنه بعد إثكالا ثانيًا(")، ومن أجل ذلك فقد نص المشرع المصري علي أن الإشكال الأي يرفعه الملتزم في السند التنفيذي يوقف التنفيذ علي أساس أن حقيقته هو أثنكال أول إذا لم يختصم في الإثكال الأول الذي رفع من قبل بواسطة الغير(")، وبالتالي إذا كان التتفيذ

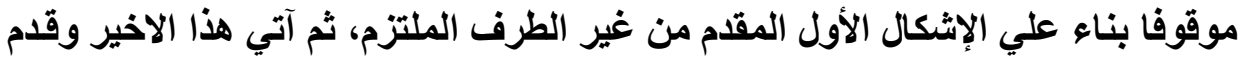

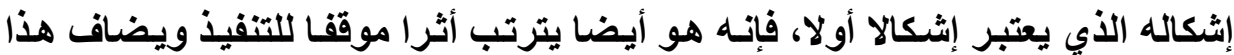
الأثر الموقف إلى الأثر الموقف الأول بحيث إذا زال هذا الأخير لأي سبب نشط الثاني

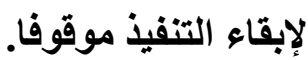

لا شك أن هذه الضمانة تهدف إلي حماية مصلحة الملتزم في السند التنفيذي، غير أن السند قد يكون الملتزم فيه شخص وينفذ ضد شخص آخر، مثل الحكم الذي

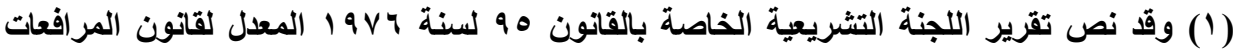

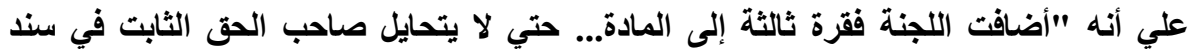
تنفيذي علي القانون فيوعز إلى شخص آخر برفع إثكال قبل أن يرفع الملتزم في السند إشكاله

ويمنع بذلك وقق التتفيذ".

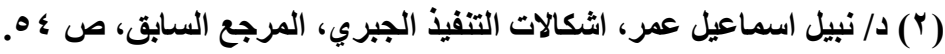

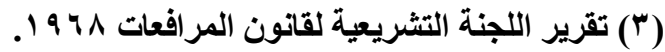

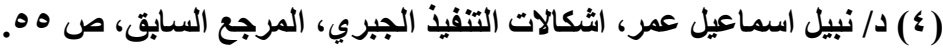

مجلت البحوث القانونيت والإقتصاديت 
يصدر في مواجهة مستأجر وهمي ويجري في الواقع ضـ شخص آخر وهو شـاغل العين، وقد يكون الحكم الصادر بصحة ونفاذ عقد بيع وتمكين المشتري من إقامـة بنـاء علي الأرض التي اشـتراها، ويكون هذا الحكم صسادر بـالتواطؤ بين البائع والمشتري إضرار بحق من لله حق ارتفاق علي الأرض المبيوعة، ففي هذه الحالة قد يقدم إثـكالا من ذات الملتزم ( و هو خصم وهمي متواطئ مع المحكوم عليه). فإذا استشكل صساحب حق الارتفاق أو شاغل العين فإن إثكاله يعد ثانيا لا يوقف التنفيذ بمجرد رفعه ولا يلزم اختصامه لأنه ليس ملتزما في السند التنفيذي مـع أن التنفيذ يجري ضده في الواقع، لألك يجب تعديل النص بحيث يلغي عبارة الملتزم في السند ويحل محلها عبارة المنفذ ضـده دفعـا للتواطؤ الذّي قد يحدث بين دائن ومـدين عن طريـق اصطناع خصومة للإضرار بالمنفذ ضده(')؛ كما لو صدر حكم ضد المستأجر الأصلي ونفذ في مواجهة المستأجر من الباطن، حيث ذهب جاتب من الفقه إلى اعتبار المستأجر من البـاطن ليس

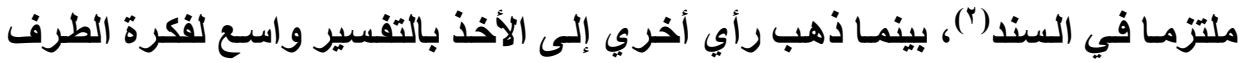
الملتزم في السند التنفيذي، حيث يمتـد حجيـة الحكم إلـى المستأجر مـن البـاطن لأنـه الحجية لا تمتد فقد إلى المحكوم عليه بل تمتد إلى من يوجد في مركز قانوني يعتمد علي

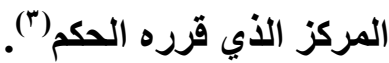

وقد يحدث في الواقع العلمي أن يقوم الملتزم في السند من أجل عرقلة التنفيذ أن يوعز لشخص من الغير برفع إثكال في التنفيذ يوقف التنفيذ، ثم ينتظر حتي صدور

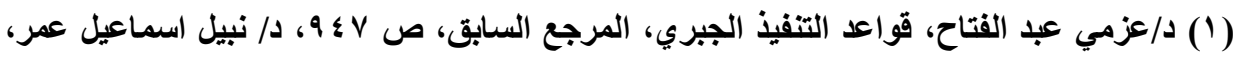
الإثارة السابقة، ص صن هـ

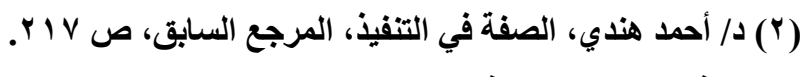

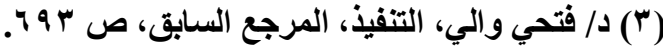


الحكم في الإثكال ويرفع إثكاله هو ليوقف التنفيذ، لأنه لم يختصم في الإثكال الأول

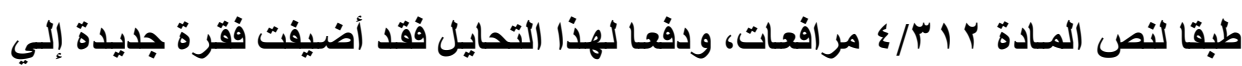
المسادة ץ ا ب استلزمت ضرورة اختصام الطرف الملتزم في السند التنفيذي إذا كـان الإشكال مرفوعا من غيره سواء كان الإثكال قد رفع أمام المعاون أو بـالطريق العادي، وقد أوجب النص علي القاضي إذا تبين لهه أن الملتزم في السند لم يختصم أن يكلف التف

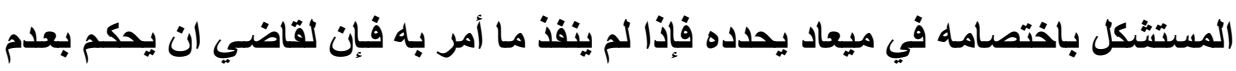
قبول الإثكال، ومنح هذه السلطة التقديرية للقاضي لكي يتأكد من جدية الغير والذي قد لـ

$$
\text { لا يتمكن من اختصام الملتزم في السند لسبب خارج عن إرادته ('). }
$$

ويثار تساؤل حول مسألة أنه إذا وجد أكثر من سبب أو واقعة يمكن بناء الإشكال الوقتي عليها أو رفح اشكالات بناء علي احد هذه الوقائع، فهل يجوز رفع إثكال ثناني

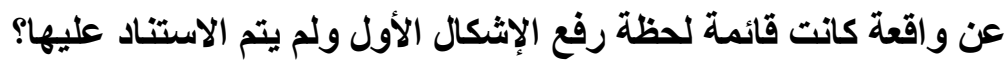
في الواقع اختلف الفقه في الاجابة علي هذا التساؤل، فقد ذهب جانب من الفقه إلى القول بأن الحكم في الإثكال الوقتي يمنع من رفع أي إثكال أخر عن سبب كان النان

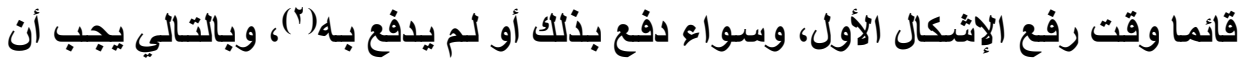
يكون سبب الاثكال الثاني لاحقا علي صدور الحكم في الإثكال الأول؛ ويري جانب أخر الخر من الفقه أنه يمكن أن يبني الأثكال الثاني علي اسباب كانت قائمة لحظة تقديم الاثكال

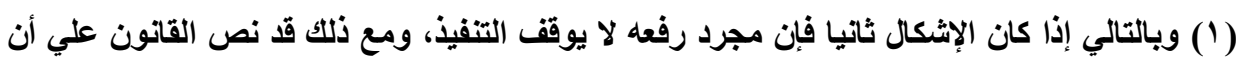

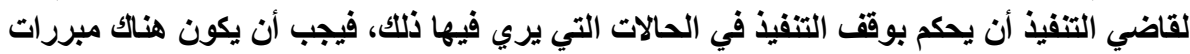

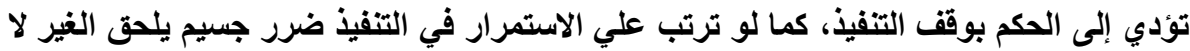

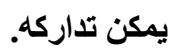

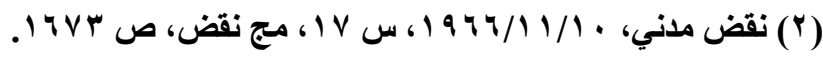


الأول، وينتقد هذا الرأي الاتجـاه الاول، وذلك لأن الحكم في الإشكال الوقتي هو قضاء مؤقت لا يمسس أصـل الحـق، ولا شـأن لـه بـصحة الإجراءات أو ببطلانهـا، ولمـاكــان المشرع لا يوجب إبداء جميع الاسباب التي تبرر وقف التنفيذ في وقت واحد عند رفع الإثكال وإلا سقط الحق في التمكك بما لم يبدي منها، ولمـا كان الحكم في الإثكال لا يتصور أن يعتبر قضاء في أسباب لم تطرح علي القضاء فلا يتصور التسليم بوجهة

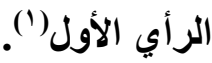

ومن جانبا نري أنه يمكن رفع اشكالا جديدا طالما كانت اسباب الأشكال لم تثار من قبل، حيث أن الحجية المؤقتة للحكم الصادر في الاشكال تتعلق بوحدة الخصوم والموضوع والأسباب، فإذا اختلف أحدهم فيمكن رفع اشكالا جديدا. ثانيا: زوال الأثر الواقف المتزتب علي رفع اشكال الغير: الإثكال يظل موقف للتففيذ طالمـا بقيت الخصومة في هذا الاشكال قائمـة أمسام قاضي التنفيذ، ولكن هذا الوقف يزول إذا حكم برفض الاشكال أو إذا الغي الحكم في الاشكال في الاستتناف أو تم تعديله نتيجة لتغير الظروف التي دعت إلى اصداره أو صدر حكم موضوعي مخالف له، أو حكم بسقوط خصومة الاشكال، او باعتباره كأن لم يكن، أو بطلان صحيفة الدعوي. قد نص المشرع المصري في المادة ؛ اب مرافعات علي أن غياب الخصوم في الإشكال الوقتي يؤدي إلى شطب الإشكال، وذلك يرجع إلى أن المشرع قدر عدم جديـة 
المستشكل الذي رفع الإثكال(')، ويلاحظ أن المشرع ولـ نتيجة خاصـة لشطب هذا

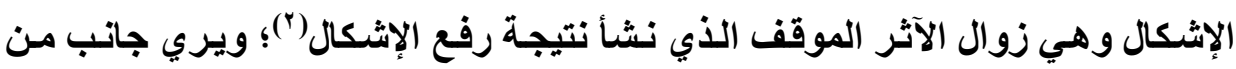
الفقه أن هذا النص يوجه وبصفة عامـة مطلقة في حالة غياب الخصوم في أي جلسه يكون(")؛ ومن جانبا نري أن هذا الشطب لا يكون إلا في حالة الغياب في أول جلسه وكان الاشكال غير صالح للحكم فيه.

والواقع أن إثكالات التنفيذ الوقتية هي دعوي بالمعني الفني، وبالتالي يخضع

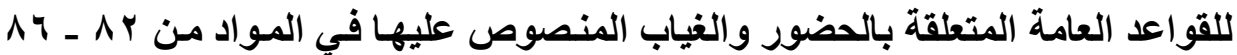
مرافعات، حيث نصت هذه القواعد علي أن غياب جميع الخصوم وعدم تقديم مذكرات مـن أي منهه، و ألا تكون الـعوي صـالحة للفصل فيها، وألا يكون الإعلان قد سلم لثخص المعلن اليه، يؤدي إلى الثطب، وهذا الشطب هو استبعاد الدعوي من جدول

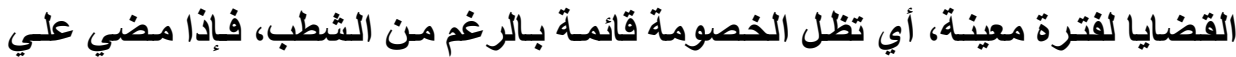
الشطب ستين يوما، ولم يطلب أحل من الخصوم السير فيها أو لم يحضر الطرفان بعد السير فيها تعتبر اللدعوي كأن لـم تكن، وهنـا تعتبر الخصومة قد سقطت وتزول

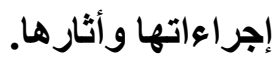

وتطبيق هذه الأحكام علي المنازعة الوقتية يستوجب القول بأن الحكم بشطب الدعوي لا يؤثر علي استمرار وقف التنفيذ الذي ترتب علي رفعها، غير أن المشرع النهان

$$
\text { (1) د/ نبيل اسماعيل عمر، اشكالات التنفيذ الجبري، المرجع السابق، ص } 9 \text { هـ. }
$$

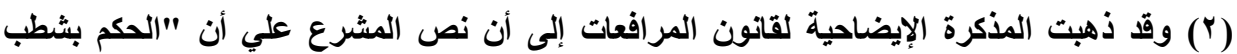

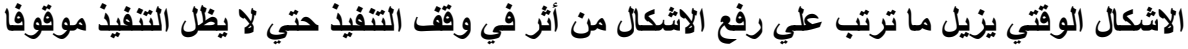

بسبب إثكالا لم يطن الخصوم بالحضور فيه فحكم بثطبه فئه

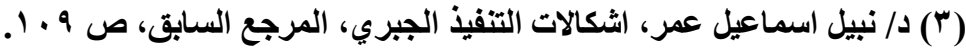


رأي أن ذلك يؤدي إلي المماطلة في تنفيذ الأحكام، فقد نص علي حكم مخالف للقواعد

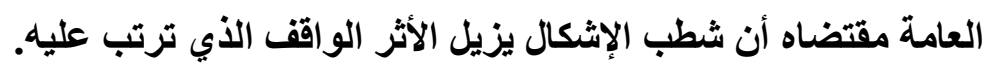
ويري جاتب من الفقه أن نص المادة ؛ الب مرافعات المتعق بزوال الأثر الواقف بالثطب نص استثنائي يتعلق بمناز عات التنفيذ الوقتيةة(')، فلا يطبق علي المنازعات

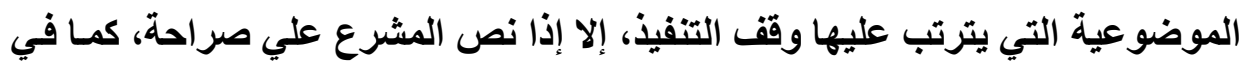
نص المـادة ه ه ب مرافعات بالنسبة للدعوي استرداد المنقولات المحجوزة، وبالتالي شطب الاثكال يؤدي إلى زوال الآثار التي تكون قد ترتبت عليه دون انتظار لأن تعتبر الاعوي كأن لم تكن بعد ستين يوما من الشطب فتستمر اجراءات التنفيذ من المرحلة

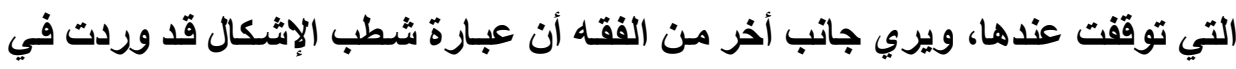
نص المـادة ؛ اب مطلقة من أي قيد وبالتالي لا يجوز تقيدها بغير مقيد، كمـا أن ذات الحكمة من زوال الآثر الموقف تتواجد في أي إثكال موضوعي ينص القانون علي أن

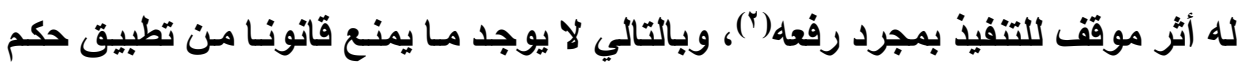

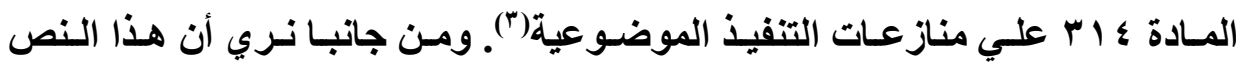
استثناء من القواعد العامة، وبالتالي لا يجوز تطبيقه علي منازعات التنفيذ الموضوعية إلا إذا نص المشرع صراحة علي ذلك. والواقع أن هذه القاعدة لا تترتب إلا في حالة الاشكال الذي يترتب علي رفعه وقف بقوة القانون لإجراءات التنفيذ، أما إذا كان وقف التنفيذ قد تقرر بحكم من قاضي

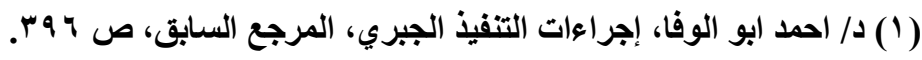

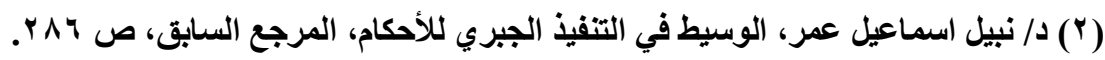

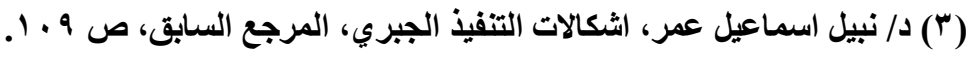


التنفيذ قبل الحكم في الاشكال ذاته وشطب هذا الاشكال فان هذا الوقف لا يزول بمجرد الثطب، وإنما بعد اعتبار الخصومة كأن لم تكن بنقضاء ستين يومـا من تـاريخ الشطب عملا بالمـادة r م م مرافعات. وهـذا الـنص يطبـق فقط علـي السشب في حالـة الإستششكال دون عـوارض الخصومة الأخرى مثل الحكم بالوقف لاي سبب من الأسباب، فإذا حكم بعدم الاختصاص بنظر الأشكال والإحالـة إلى قاضسي تنفيذ اخر، فإن الحكم لا يكون لـه أثثر علي وقف التنفيذ، لأن صحيفة الإثكال والأثر الواقف لها يظل قائمسا بعد الحكم بعدم الاختصاص والإحالة(')، ولكن يلاحظ أن حكم بعدم الاختصاص والاحالة إلى المحكمة المختصة بـه من غير قضاة التنفيذ فإنه يزول الاثر الموقف للإثكال(؟). وإذا تم تعجيل الإشكال المشطوب قبل انقضاء ستين يومـاً فـلا يعود إليه الأثر الواقف بقوة القـانون، ولكن يمكن للقاضي أن يحكم بـالوقف(")، ولكن إذا تغيب الغير المستثكل وقررت المحكمة شطب الإشكال ثم حضر الغير قبل انتهاء الجلسة وقررت المحكمة اعتبـار قرار الشطب كـأن لـم يكن فـإن الأثر المترتب علـي شطب الإشكال لا يتحقق ويظل الإشكال موقفا للتنفيذ. 


\section{الفرع الثاني \\ الآثار التي تتزتب علي المكم في الإشكال}

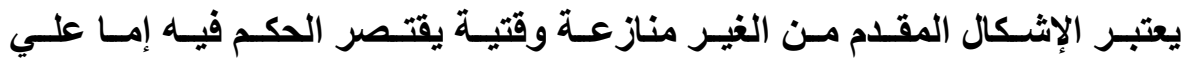

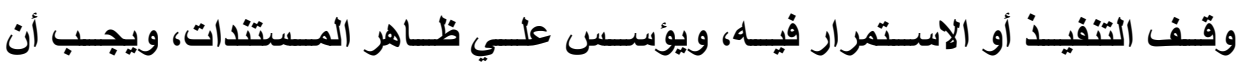
يفحص القاضـي مـدي رجــان وجـود الحقى(')، وإذا تغيب الخصوم فالقاضـي يـأمر بشطب الإشكال(") طبقا للقواعد العامـة، ولا يجوز للقاضـي التعرض لأصل الحق(")، ولا يجـوز أن يؤسسس الاثـكال علـي وقـائع سـابقة علـي صـدور السند التنفيذي(؛)؛، ولا أن يتضمن طعنـا علـي الحكم (o)، فـلا يجـوز للقاضـي أن يبنـي حكسه بوقف التنفيذ علي علم جواز التنفيذ، والحكم الصادر لا يقيد المحكمة عند نظرها موضوع النزاع بـل

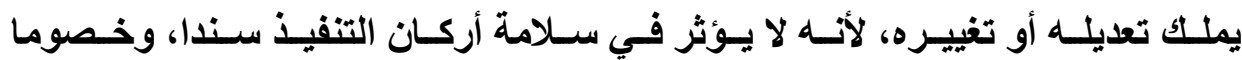
وموضوعا(").

وإذا زال وصف تعلق الاشكال بالتنفيذ أثناء نظر القاضي للمنازعة، فيري جانب من الفقه أن قاضي التنفيذ يحكم بعدم الاختصاص والإحالة إلى المحكمة المختصة، كمـا لو زالت المصلحة أو الصفة أو زال الخطر الداهم المبرر لاتخذا الإجراء التحفظي(v). في

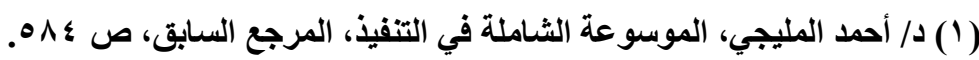

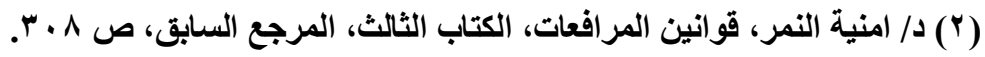

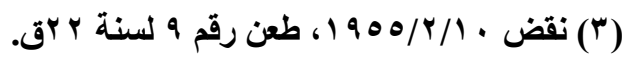
(£) د/ أحمد المليجي، الموسوعة الثاملة في التنفيذ، المرجع السابق، ص ع ـهـ.

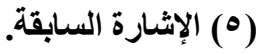

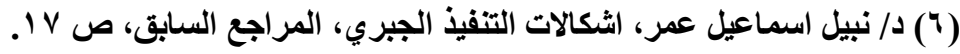

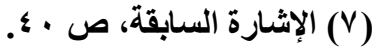


الواقع نري أنه في هذه الحالة يحكم القاضي بعدم قبول الاثكال، كما لو أقيم استشكال في التنفيذ، وأثناء نظره وقبل الحكم فيه، تنازل الحاجز عن الحجز أو حكم نهائيا ببطلان

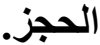

و الحكم في الإثكال الوقتي هو حكم مستعجل يخضع للقو اعد العامـة الخاصـة بهذه الاحكام (1)، فلـه حجية مؤقته، ويكون نافذا نفـاذا معجـلا بقوة القـانون، ويكون النفاذ المعجل بدون كفالة إلا إذا تطلبها قاضي التتفيذ في الحكم، وذلك طبقا لنص المادة

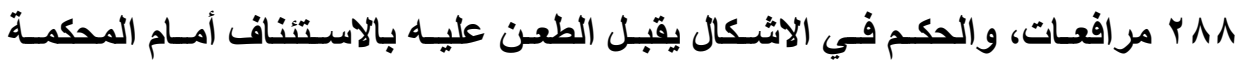

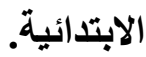

ويثور تساؤل هل يجوز الإستشكال في الحكم الصادر من قاضسي التنفيذ في إثكال آخر؟ يري الفقه أنه لا يجوز قانونا أن يرد الإثكال علي حكم صـادر في إثكال، لأن هذا الأخير لا يعتبر سندا تنفيذيا(")، وقد ذهب القضاء المصري إلى أن الحكم الذي يصدر من قاضي التنفيذ في الإثكال الوقتي سواء بوقف التنفيذ أو الاستمرار فيه لا يعد سندا تنفيذيا علي غرار الاحكام المعتبرة كذلك، لأنه مرهون بالظروف التي صدر فيها، ومن ثم فلا يترتب علي الإثكال الوقتي في الحكم الصادر في اشكال سابق وجوب وقف لإنف

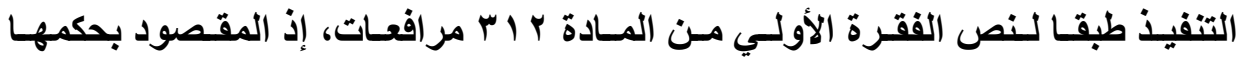
الوجوبي هو الإشكال الوقتي الأول في السند التنفيذي(").

(1) د/ أحمد المليجي، الموسوعة الثاملة في التنفيذ، المرجع السابق، ص 4 ـ ب.

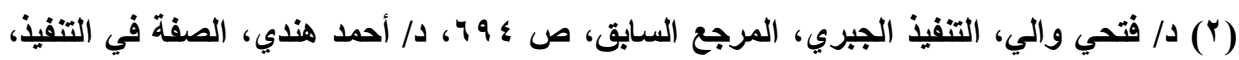

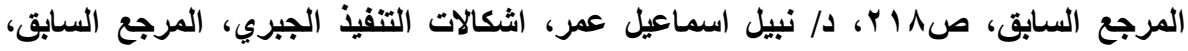


ومن جانبا نؤيد هذا الاتجاه، وذلك لأن السماح بالإشكال في الأحكام الصادرة في

إثكالات التنفيذ يؤيد إلى اتساع منازعة التنفيذ وعرقلة العملية التنفيذية، إلى جانب أن الحكم الصادر لصالح الغير بوقف إجراءات التنفيذ هو حكم وقتي لا يتضمن أي التزام بأداء شئ أو القيام بعل وإنما فقط بعدم الاستمرار في التنفيذ مؤقتا، وطالمسا أن هذه الاحكـام منشـأة فهي لا تحمل القوة التففيذيـة، ولا يعتبر حـائزة لقوة الأمـر المقضي،

\section{وبالتالي لا يعد هذه الاحكام سندات تنفيذية.}

وإذا رفع إثكال من الغير وقضت المحكمة فيه بعدم الاختصاص والإحالة فإنـه لا يترتب علي هذا الحكم إنهاء الخصومة في الإشكال وليس من شـأنه أن يزيل صحيفته، وتنظر المحكمة المحال اليها الإشكال بالحتـه من حيث انتهت إجراعاتـه أمـام المحكمة التـي أحالته، ويعتبر مسا اتخـذ مسن الإجراءات صـحيح بمـا في ذلـك وقف إجراءات

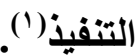
والواقع أنـه يمكن للغير أن يجمـع بين الطعن في الحكم بالتمـساس إعـادة النظر وبين رفع الإشكال أمام قاضي التنفيذ، بل يجوز له حتي لو تقلم الغير بطلب وقف النفاذ

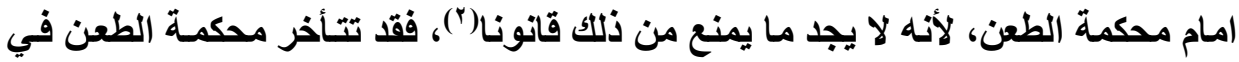
نظر طلب وقف النفاذ ويفضل الغير أن يتدارك هذا التأخير برفع إشكال لقاضسي التفيذ يطلب فيهه وقف تنفيذ، وإذا اصدر قاضسي التنفيذ حكمـا بـالوقف التنفيذ، بينمـا حكمـ محكمة الطعن برفض طلب الوقف، فبان الحكم الوقتي الصادر في هذا الطلب لا يمس الحكم الصادر من قاضي التنفيذ، فيظل التنفيذ موقوفا إعمالا للحكم السابق. ويظل حكم

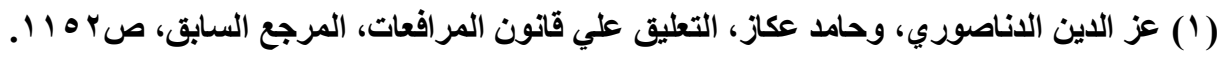

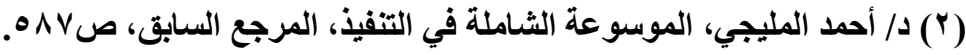

مجلت البحوث القانونيت والإقتصاديت اسبr 
قاضي التنفيذ قائما غير متأثر بحكم محكمة الطعن. لأن الظروف الذي نشأت أمام قاضي التتفيذ لم تتغير (') بينما إذا صدر حكم من محكمة الطعن بوقف التتفيذ، فإنه يرد علي تنفيذ موقوف، وبالتالي لا يمكن قاضي التتفيذ بعد ذلك أن يأمر بالاستمرار في التنفيذ إذا تغيرت الظروف، وذلك لوجود حكم من محكمة التماس إعادة النظر. وقد ذهبت بعض الأحكام إلى أن قيام النزاع أثناء نظر الإثكال في التنفيذ علي الحق المطلوب حمايته لا يحول دون أن يتناول القاضي بحث هذا النزاع بصفة وقتية ليفصل في الإجراء الوقتي الذي يري الأمر به، ويكون تقديرا وقتيا لا يؤثر علي الحق

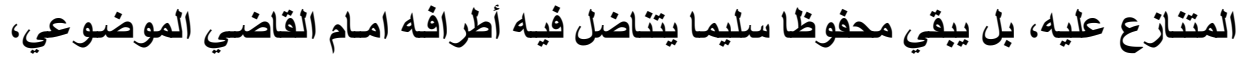
وللذا لا يحكم القاضسي بعدم الاختصاص، وإنمسا يـأمر بمـا يراه من إجراء وقتي كفيل

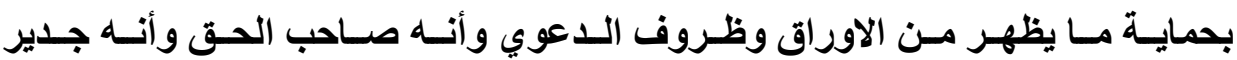
بالحماية(') والو اقع أنتا نري أنه إذا كانت طالبات الغير تتعلق بالموضوع فلا يجوز للقاضي أن يحكم بإجراء وقتي، ويجب علي القاضي أن يحمم بعدم قبول الإشكال. وحكم القاضي في الاشكال، إها برنضه أو قبوله، وذلك علي النحو التالي:

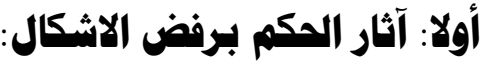

إذا خسر الغير اشكاله، فيمكن له رفع اشكال أخر إذا تغيرت الظروف، حيث لا

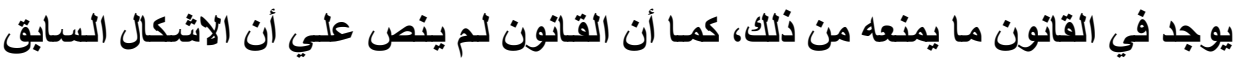

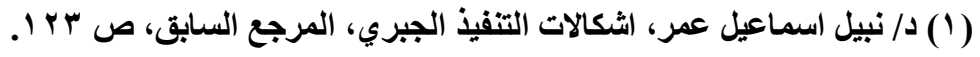

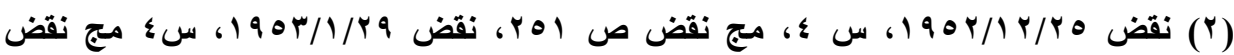


مجرد تقديمه يؤدي إلى استغراقه لجميع الوقائع التي كانت قائمسة لحظة رفعه ولو لـم يستند إليها المستثكل(')

ورغبة مـن المشرع في ضمان جديـة الاشكال فقد نص المـادة ه اب مرافعات علي أنه إذا خسر المستشكل دعواه جاز الحكم عليه بغرامة لا تقل عن مـائتين جنية ولا تزيد علي ثمنمائة جنية مع الحكم بالتعويض إن كان لله وجه(؟). ويمكن لأي مسن طرفي التنفيذ طلب التعـويض عن التعسف الغير في رفـع الاشكال، ويختص قاضـي التنفيذ بـالحكم بهذه التعويضات طالمـا تم التقدم بها بطلب عارض(")، أما إذا تم التقدم بها بلدعوي مبتدأه فإنها تخضع للقواعد العامة للاختصاص

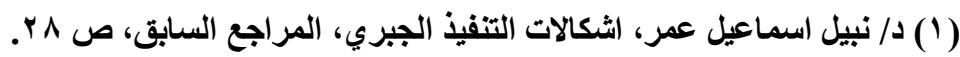

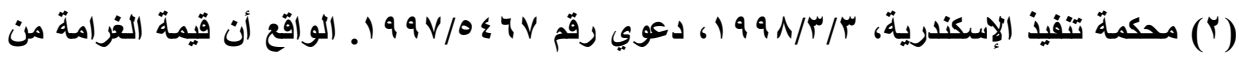

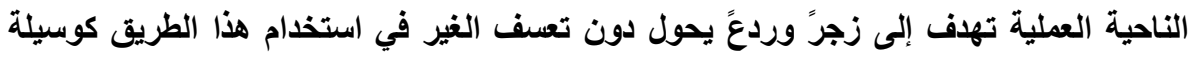

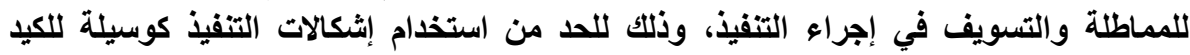

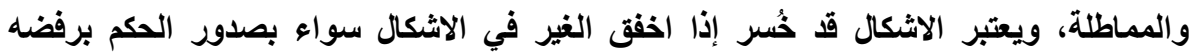

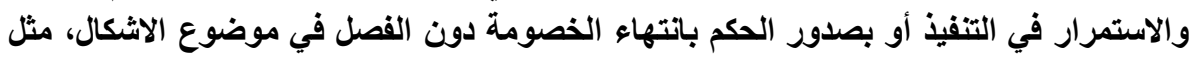

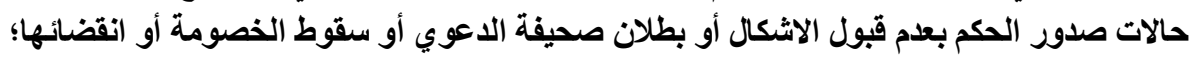

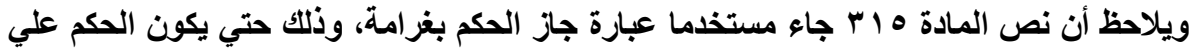

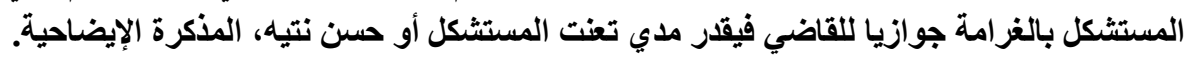

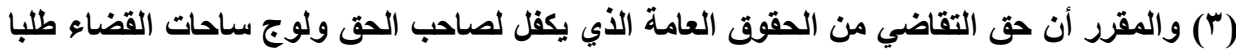

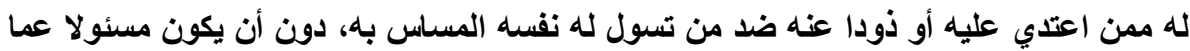

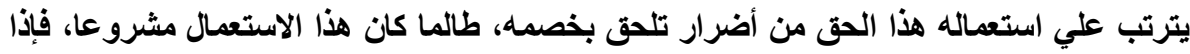

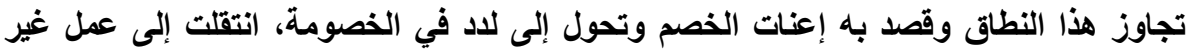

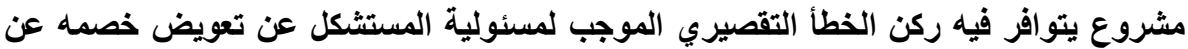

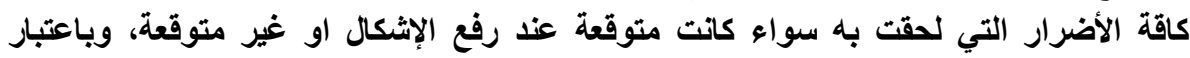

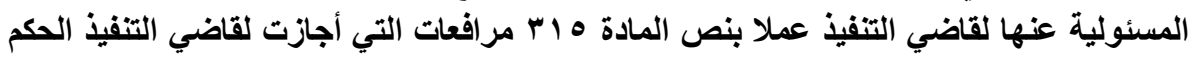

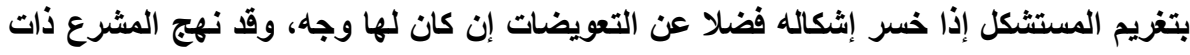
$=$ 
بعيدا عن قاضي التنفيذ، وإنما لمحكمة الموضوع وفقا للقواعد العامـة في الاختصاص

وترفع دعوي المسئولية عن الإثكال الكيدي طبقا لنص المـادة 1^^ا مرافعـات،

بطلب عـارض يثبـت في محضر جلسة الإثـكال ويـصدر فيهـا قاضسي التنفيـذ حكمـا

موضوعيا بعد أن يحكم في الطلب الوقتي برفض الإشكال، وينعقد الاختصاص لـه أيـ

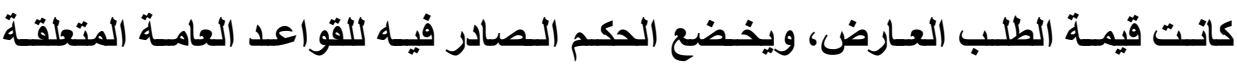

بالطعن (')

ويري جاتب من الفقه أن الحكم بالغزامـة لا يجوز إلا في حالـة اشكالات التنفيذ

التي يترتب علي رفعها وقف التنفيذ بقوة القـانون، وذلتك علـي اعتبـار أن الغرامـة

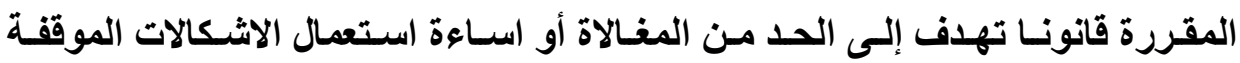

للتنفيذ، أما الاشكال الذي لا يؤدي إلى وقف التنفيذ فلا يخضع لهذه القاعدة، فلا يجوز

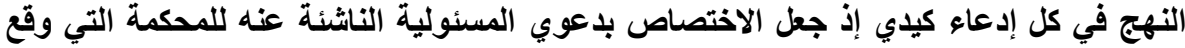

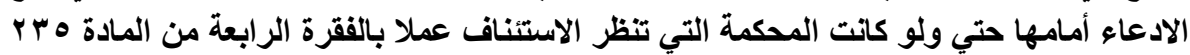

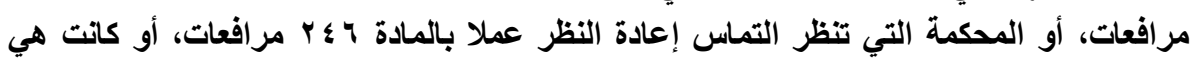

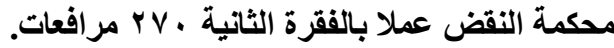

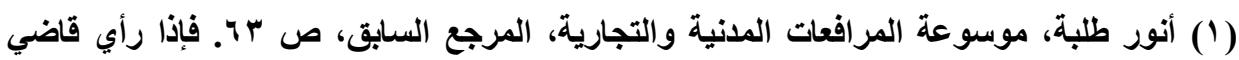

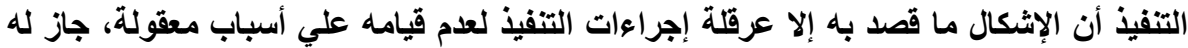

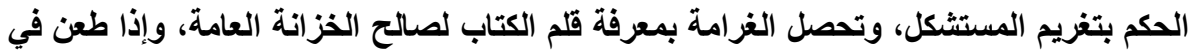

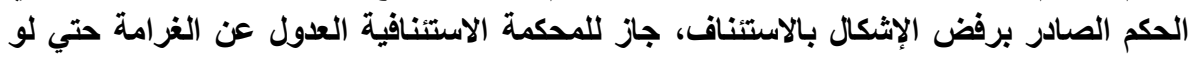

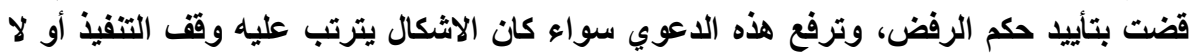
يترتب عليه ذلك. 
الحكم بالغرامة إذا كان اشكالا ثانيا لا يوقف التنفيذ(')، وذلك علي اساس أن الاخفاق في الالتجاء إلى القضاء ليس خطأ موجبا للمسئولية. ومن جاتب لا نتقى مع هذا الرأي، وذلك لأن النص المسادة 0 اب مرافعات جاء

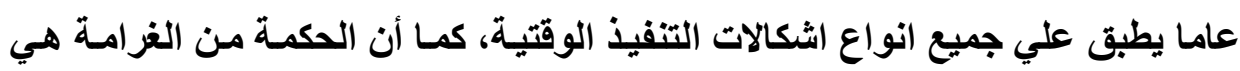
الحد من اساءة استخدام اشكالات التنفيذ بصرف النظر عن اثارة، بالإضافة أن الاشكال

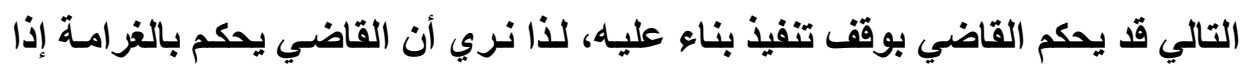
خسر الغير اشكاله سواء كان الاشكال الاول أو التالي.

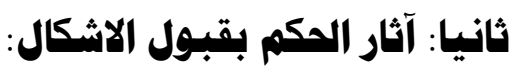

يمكن لقاضي التتفيذ بعد استتاده إلي ظاهر الأوراق دون المساس بـالحق(")، أن

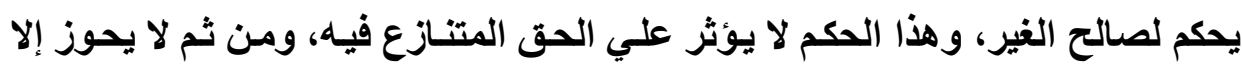

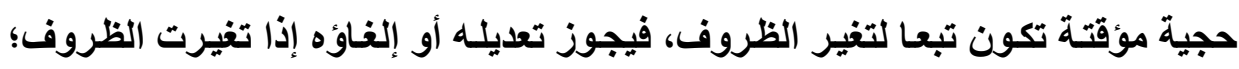

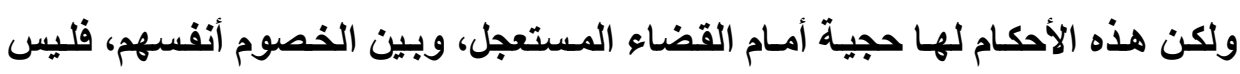

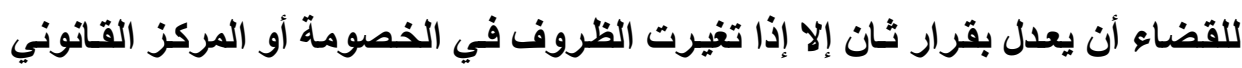
للخصم، ففي هذه الحالة يجوز لقاضي التتفيذ الرجوع عما صدر منه وإصدار حكم معدل

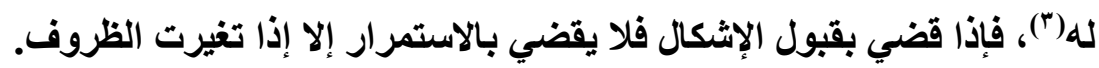
والأحكام الصادرة في منازعـات التنفيذ تكون مشمولة بالنفـاذ المعجل بقوة القانون وبدون كفالة ما لم ينص القانون علي غير ذلك، والحكم الصادر في الإثكال لا

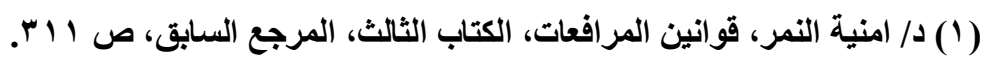

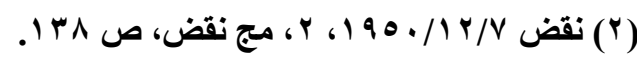

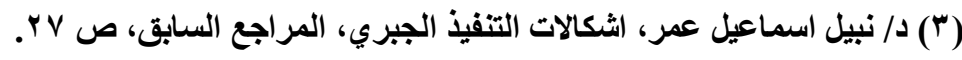


يؤثر علي عملية التنفيذ، فإجراءات التنفيذ تظل قائمة، ومراكز الخصوم تظل كمـا هي، والآثار المتولدة من التففيذ تظل علي حالهاب(')، وذلك لأن هدف الغير من الإثكال هو وقف الإجراءات وليس إلغاء التنفيذ.

ونظرا لأن قاضي التنفيذ في مركز القاضي الجزئسي، فقد نص قانون المرافعات

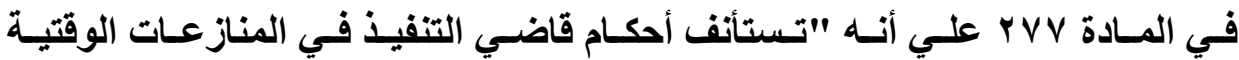

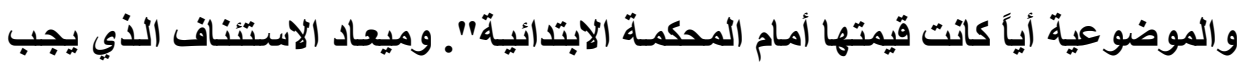

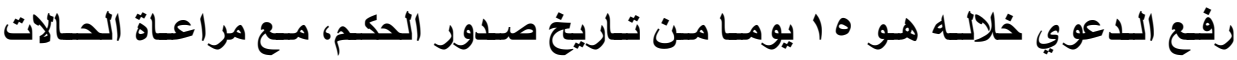

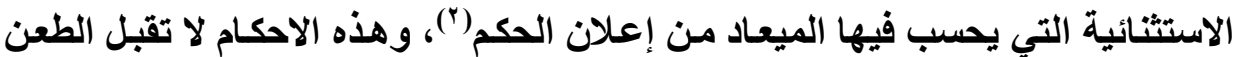

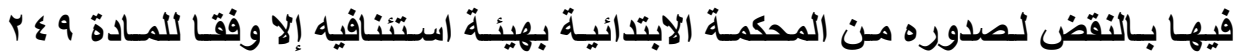

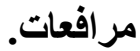

وإذا صدر حكم من القاضي في الإشكال بوقف التفيذ، فلا يجوز السير في هذا التنفيذ إلا بمقتضي حكم قطعي من محكمة الموضوع، أو حكم وقتي أخر يبني علي غير الاعتبارات التي بني عليها الحكم الأول.

\section{الامطاب الثالث}

\section{تقييم حق الغير في رفع الاشكال في التنفيذ}

في الواقع قد ثار خلافـا في الفقه حول حق الغير في اشكال في الحجز الواقع علي أمواله الخاصة، بدلا من رفع دعوي استرداد أو استحقاق المال المحجوز عليه. 
سنشير الي موقف الفقه من حق الغير في رفع الاشكال، ثم موقف الباحث، وذلك

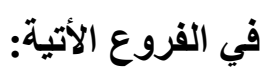

\section{الفرع الاول \\ هوقف الفقه هن حق الغير في رفع الاشكال}

لقد انقسم الفقه بين مؤيد ومعارض في حق الغير في رفع اشكال امسام قاضسي التنفيذ في حالة رفع دعوي الاسترداد او الاستحقاق.

ويمكن لنا تقسيم هذا الخلاف إلى ثلاثة اتجاهات(').

\section{الاتجاه الأول: عدم جهاز رفع إشكال في التنفيذ:}

يذهب جانب من الفقه إلـى أنسه لا يجوز للغير رفع إثـكال أمسام قاضسي التتفيذ بصفته مستعجلة، وذلك لأنه لا تتوافر للغير صفة في رفع الإثكال، لأن القانون رسم لـه طريقا خاصا وهو دعوى استرداد المنقولات فليس له أن يطرق هذا الطريق ولجـأ إلي الإثـكال، حيـث يقتــر حقـه عــي رفـع دعـوي الاسـترداد، ويرفعهـا بـصفة نـزاع موضوعي، ويترتب علي هذه الدعوي إيقاف بيع الأموال المحجوز عليها، طبقا لنص

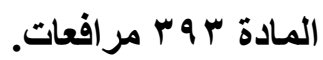

وبالتالي إذا وقع الحجز علي المنقولات يدعي الغير ملكيتها له، فلا يجوز للأخير الممانعة في بيعها بإثكال يرفع أمام قاضي التنفيذ، وإنما له الحق في دعوي الاسترداد 
التي يرفعها أمام قاضي التنفيذ بصفته محكمة الموضوع المختصة، ويترتب علي رفع الدعوي وقف التنفيذ، فلا يكون الغير في حاجة إلى اشكال في التنفيذ. كمـا لا يجوز للغير رفع دعوي مستعجلة بأحقيته للمنقولات المحجوز عليها وإلغاء الحجز الموقع عليها لمساس الفصل فيها بالموضوع أو أصل الحق لتعلق الفصل فيها بحق الملكية والحق الأي يترتب للحاجز علي توقيع الحجز (').

\section{الاتجاه الثاني: جواز الاشكال إذا كان الغير حاضرا أثناء التنفيذ}

ذهب بعض الفقهـ إلي أن ليس للغير الاشكال في التنفيذ إلا في حسال حضوره

أثناء الحجز()، حيث يستثكل في السند أمام معاون التنفيذ، ممـا قد يترتب عليه وقف ، التنفيذ، أما إذا تم الحجز فلا تتوافر فيه هذه الصفة لرفع الاشكال بطريق العـادي أمسام

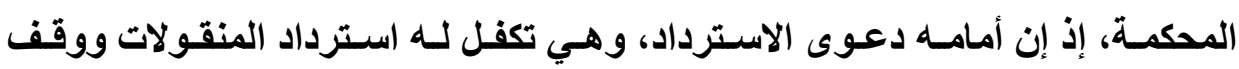

التنفيذ)

\section{فهذا الرأي يفرق بين حالتين:}

الحالة الأولي: أن يكون الغير موجودا عند الثروع في الحجز علي المنقولات، فهنا يقبل منه رفع الإشكال الوقتي بإبدائه أمام المعاون، وذلك لأن رفع الإشكال الوقتي

(1) دماب، وحمد علي راتب، محمد نصر الدين، محمد فاروق راتب، قضاء الأمور المستعجلة، ط؛، عالم

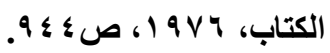

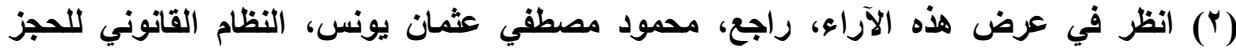

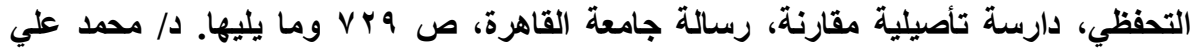

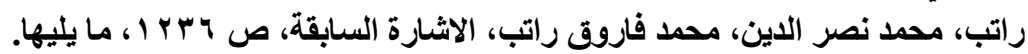

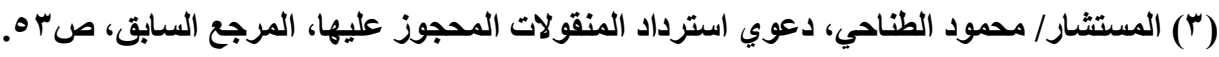


يحقق له مصلحة لا يحققها رفع دعوي الاسترداد، إذ يترتب علي تقديمسه الإشكال وقف إجراعات التنفيذ، وهي نتيجة لا يحققها رفع دعوي الاسترداد التي لا يؤثر رفعها في

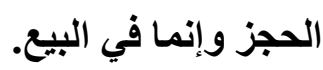

الحالة الثانية: إذا لم يكن الغير حاضرا وقت إجراء الحجز، وبالتالي لـم يبدي الاشكال أمام المعاون، وتم الحجز، فلا يقبل الاشكال الوقتي برفعه أمسام قاضي التتفيذ، لانعدام المصلحة لأن رفع الأثكال في هذه الحالة لن يؤثر علي الحجز، وإنمـا هو يقف البيع، وهذ الغرض يتحقق برفع دعوي الاسترداد('). والحكمة في هذه التفرقة أنه بعد تمام الحجز لا تتوافر لدي الغير المصلحة التي تبرر المنازعة الوقتيـة، فالمصلحة في هذه المنازعة هي الحصول علي حكم وقتي لتحقيق حماية عاجلة لا يحققها الالتجاء إلى القضاء بدعوي موضوعية، فإذا كان مجرد رفع الدعوي الموضوعية يحقق وقف التنفيذ، وبالتالي يحقق حمايـة عاجلة للغير، فلا تكون هناك مصلحة في رفع الدعوي المستعجلة، ويجب علي قاضسي التنفيذ كقاضي الأمور المستعجلة أن بحكم بعدم قبول الاشكال.

وبالتـالي قاضسي التنفيذ يختص بإشكال الغير إذا مـا أدلـي بـه وقت الحجز أمسام المعاون، أما إذ رفع بعد توقيع الحجز فلا اختصاص لله بـه علي اعتبـار أن المشرع قد رسم طريقا خاصا للمطالبة بملكية الأشياء المحجوزة وبطلان إجراءات الحجز، وأن هذا

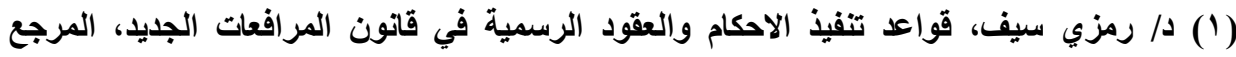

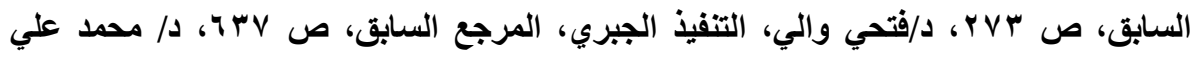

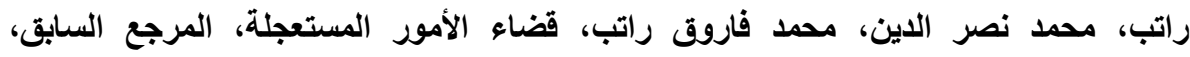
صז"ب إب، وما يليها. 
السبيل يوقف إجراعات الحجز اذا بُدت جديـة الطلب، ويجب الالتزام بمـا نص عليها المشرع من أوضـاع ومواعيد وإجراءات، فضلا عن أن دعوي الاسترداد تحقق آثثار الاشكال وهو وقف التنفيذ(')

\section{الاتجاه الثالث: حق الغير في رفع الإشكال:}

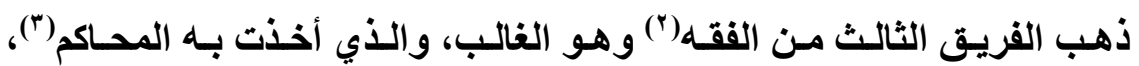

إلي القول بأن للغير رفع الاشكال في أيـة مرحلة كان عليها التنفيذ، لأن النص ب اب إ مر افعـات نـص عـام لا يفـرق بـين المــين والغيـر، فضلا على أن دعـوى الاسـترداد دعـوى موضـوعيه، تتـضمن طلب موضـوعي بالملكيـة وبطـلان اجـراعات التتفيـذ، والإثـكال منـازعـه وقتيـه، والقاعـدة أن الـدعوى الموضـوعية لا تــول دون اللجـوء

$$
\text { لبلإجراء الوقتي. }
$$

فـالغير مـدعي ملكيـة الأثـياء المحجـوزة يملـك الاعتر اض علـي الحجز برفـع

إثـكال وقتي، وهذا الاشكال يوقف أو لا يوقف البيع بحسب القواعد العامـة، فيؤدي إلسى وقف التنفيـذ إذا كـان هـو الإشـكال الأول، والقاضـي لـه مطلـق تقدير الأمـر في

(1) داب، محد علي راتب، محمد نصر الدين، محمد فاروق راتب، قضاء الأمور المستعجلة، المرجع

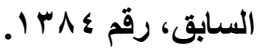

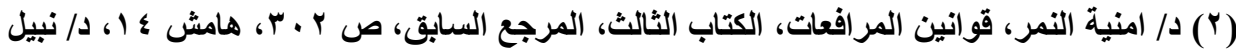

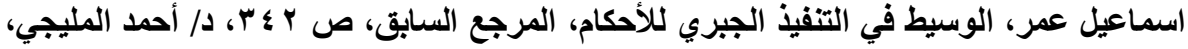

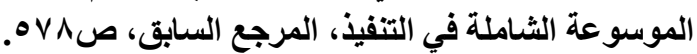

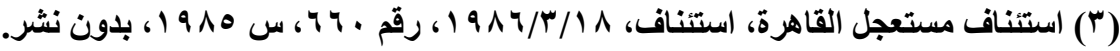

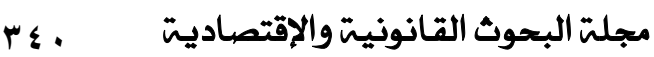


رفض الإشكال إذا ساوره شك في ما يدعيه المستثكل طالب الملكية، وذلك لأن المشرع قـ نظم له سبيلا خاصا، ومما يستوجب أن يأخذ دعواه بالحذر والحيطة(').

\section{ويستند أنصار هذا الاتجاه إلى العجج الآتية:}

ا ـ دعوي الاسترداد هي إثكال موضوعي، أمـا الإشكال الوقتي فهو مقبول دائمـا وفي

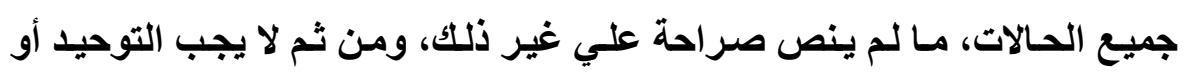
الخلط بين الاشكال الوقتي والإشكال الموضوعي().

أن النص المادة ب ا ب مرافعـات جـاء شـاملا لكل اعتر اض قدم أمسام المعاون أو صحيفة مبتدأه، سواء كان ذلك مقدم من المدين أو الدائن أو الغير مدعي الملكية أو أي حق يتعلق بها"). فللغير أن يرفع إثـكالا، وذلك لأن نص المـادة ب اب مرافعات يسري علي الإشكال المرفوع من الخصوم وعلي الإشكال المرفوع من الغير، إذ لا يوجد مـانع

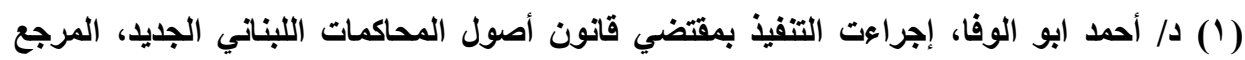

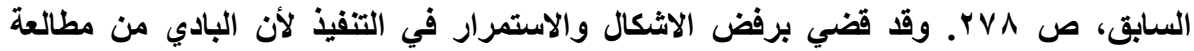

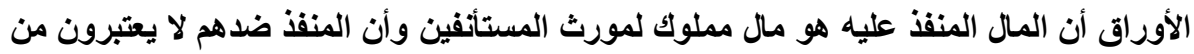

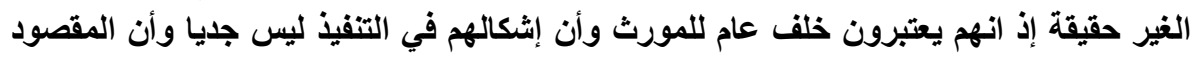

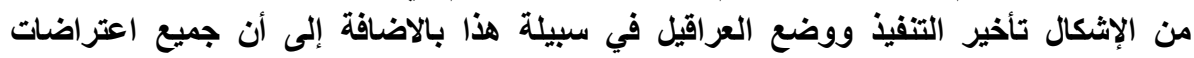

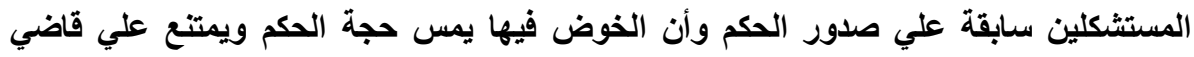

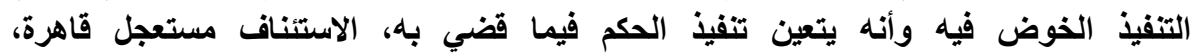

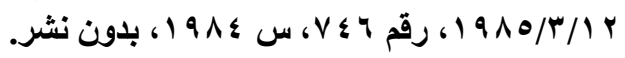

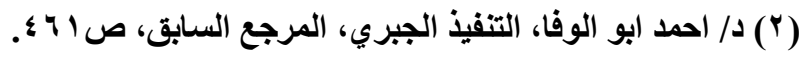

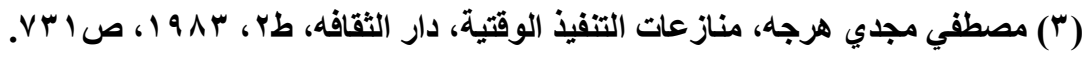


في القـانون مسن اختصاص قاضــي التنفيـذ بإثـكال وقتـي إلسى جانـب قيـام المنازعـة الموضوعية وهي دعوي الاسترداد('). r ـ انعدم السند القانوني للاتجاه الذي يفرق بين الإشكال قبل أو بعد الحجز، ومن ناحية ثانية أنه يقيد اختصاص قاضي التنفيذ بصفة مستعجلة بغير نص. يمكن للغيـر مـدعي الملكيـة أو أي حق يتعلق بهـا، رفـع دعـوي الاسـترداد، ولا ينفي حقه في رفع إثـكال وقتي في التنفيذ، وكذلك جـواز الجمـع بـين الطريقين فـي وقـت واحـد، وذلــك لابتنائسه علـي أسسس قانونيـة صــيحه ولـسلامة حجبـة وأدلته(r)

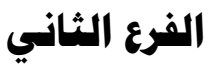 \\ رأي الباحث في حق الغير في رفع الاشكال \\ في الواقع نري أنه يجب التفرقة بين أهرين:}

الأهمر الأول: إذا كان الغير قد رفع دعوي الاسترداد أولا، فليس للغير الحق رفع

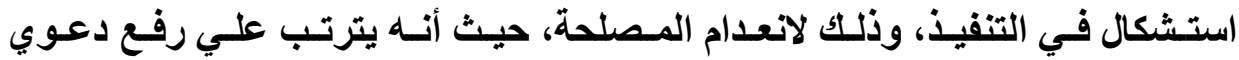
الاسـترداد وقف إجراءات التنفيذ، وهو الهـف مـن الاشكال، فمن بـاب الاقتصاد في

(1) د/ أحمد ابو الوفا، التنفيذ الجبري، المرجع السابق، ص 9 ه ؛.

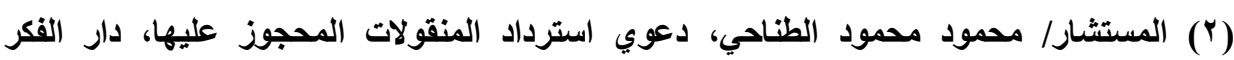

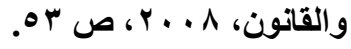


د/ طلعت يوسف خاطر

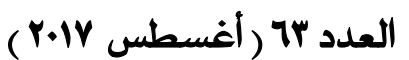

الاجـراءات، فـلا يجـوز القيـام برفـع الاشـكال بعـد رفـع دعـوي الاسـترداد، لأن وقـف

$$
\text { الإجراعات سيترتب علي الوسيلتين. }
$$

الأهـر الثاني: إذا لم يكن الغير قد رفع دعوي الاسترداد، فإنـه يكون لـه الحق في رفع الاثكال سواء أمسام المعاون أو أمسام قاضسي التنفيذ، وذلك لأن لـه مصلحة في وقف الإجراءات إلى أن يقوم برفع دعوي الاسترداد.

- والواقع أن الغير قـ يفضل اللجوء إلي الاثكال في التنفيذ حتي يوقف التنفيذ إلي أن يتم الفصل في دعواه الموضوعية، حتي لا يتم التففيذ ويصبح من الصعب إعـادة الحسال إلـي مـاكـان عليهل بعد الفصل في اللدعوي الموضوعية. ويالتـالي يكون الاستمرار في التنفيذ يتعارض مع حقوق الغير الثابتة علي الشئ المنفذ عليه، وإذا اتضح لقاضـي التفيذ خلاف ذلك، وأن الإشكال مقصود منـه تـأخير التنفيذ أو وضع العراقيل في سبيله، فأنه يقضي برفض الأثكال والاستمرار في التنفيذ:

ويشترط أن يكون هدف الغير من الاشكال هو الاعتراض علي التنفيذ، بهدف وقف إجراءات التنفيذ، وذلك لوجود عيب في إجراءات التنفيذ يمس بحقوق الغير(')، فيجب أن يكون للغير حق ظاهر علي العين أو الشئ الجاري التنفيذ عليه يتعارض مـع إجراعات التفيذ، كما لو كان المال المراد التنفيذ عليه مال مملوكا للغير أو كـان لـه حق عليه سواء كان حق انتفاع أو وضع يد. 
ويلاحظ أن المشرع أعطي للمعاون سلطة عند رفع الاشكال من الغير أمامـه،

وهذه السلطة تنتقص من سلطة قاضي التنفيذ، وهذا الأمر منتقد، حيث أنه يتولا عن إعـال لهذه السلطة العديد من الآثار المتمثلة في وقف الإجراعات، لأن المعاون هو الأي سوف يقدر عند قبوله للإثكال ما إذا كان مقدمه هو طرف ملتزم في السند أم لا، وما إذا كان الإثكال هو أول إثكال يقدم في التنفيذ أم لا، ومـا إذا كـان قدم تم اختصام الملتزم في إثكال سابق أم لا، وفي مثل هذه الحالات قد أعمل المعاون سلطته ولا يملك قاضي التنفيذ إعمال أي جزاء عليه('). 


\section{المبحث الثاني \\ حق الغير في رفع هنازعة هوضوعية في التنفيذ}

قد يكون تحديـ المنقولات أو العقـارات التي تم الحجز عليهـا أكتنفـه شـئ مـن الصعوبة والغموض، وبالذات معرفة من هو مالكها، لأن المدين قد يزعم أمسام المعاون

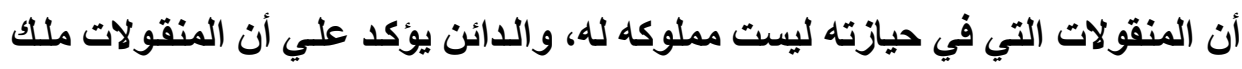
للمدين، مثال ذلك أثاث المنزل فهو يكون ملك المؤجر وليس المستأجر في السكن، ويقوم المعاون بالحجز عليه لاين علي المستأجر. وقد يعتري حيازة المال التباس نـاتج عن الحيـازة المشتركة للمنقول- مثال ذللك منقولات الأشخاص الذين يعيشون معيشة مشتركة كـالزوجين، ففي هذه الحسات يجب علـي المعـاون أن يتصل بقاضسي التنفيذ للسؤال عن التعليمات، أو يقوم بتوقيع الحجز، وعلي مدعي الملكية من الغير أن يرفع دعوي باسـتردادها، إذا كـان محل الحجز منقول، أو باستحقاقها إذا كـان محل الحجز

إذن للغيـر الحـق فـي اللجـوء إلــى رفــع الاسـترداد المنقـولات المحجـوزة،

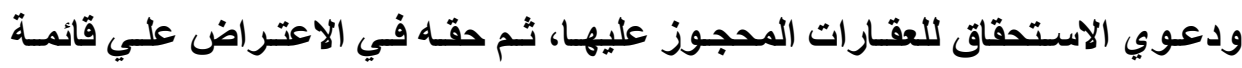
شروط البيع، ورفع دعوي بطلان حكم رسو المزاد، وسنشير إلى ذلك في المطالب 


\section{المطلب الأول \\ دعوي استرداد المنقولات المجوزة}

دعوي الاسترداد هي دعاوي موضوعية يرفعها مدعى ملكية الأشياء المحجوزة طلبا فيها الحكم له بملكية هذه الأشياء و إلغاء الحجز الموقع عليها. إذ هي ادعاء بتخلف شرط من شروط التنفيذ ألا وهو ملكية المدين للمـال المحجوز عليه، لو صـح لكـان من شأنه ذلك منع التنفيذ، وهذه دعاوي متعلقة بالتنفيذ، وترفع بعد توقيع الحجز وقبل البيع، والفرض الأي أراد المشرع أن يوجهه بهذه الدعوي يتمثل في أن حجزا قد وقع علي مال منقول غير مملوك للمدين المحجوز عليه(')، ولذلك بات من الضروري حمايـة المالك الحقيقي لهذا المال.

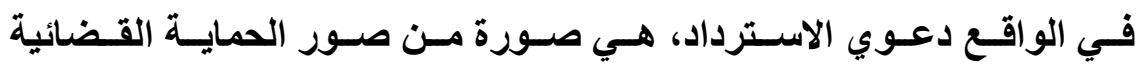

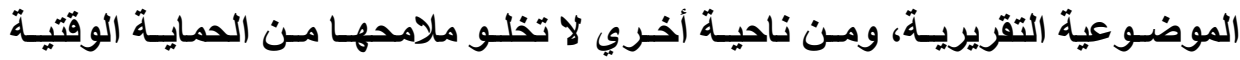
بحسبان مـا تهدف إليه مـن وقف البيع المنقولات المحجوزة مؤقتا إلى حين الفصل

يجب أن تتضمن الدعوي، طلبين، الاول: ملكية المسال، والثاني: بطلان الحجز، فبإذا اقتصرت الدعوي علـي أحد الهدفين، فـلا نكون بصدد دعوي استرداد منقولات محجوزة، فقد نكون بصدد دعوي ملكية أو دعوي ببطلان إجراءات الحجز. ولن تكون

(1) فيجب أن يكون المال محل الحجز في دعوي الاسترداد منقولا، ويستبعد من نطاق الحجز العقار

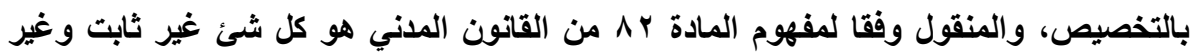

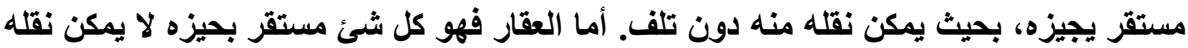

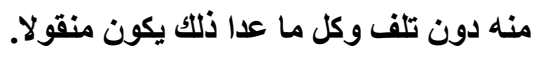

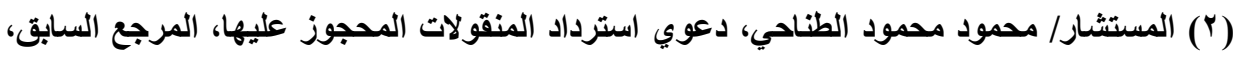
• 
مقبولة لرفعها من غير ذي صفة وذلك لعدم تأسيسها علي ملكية المنقولات المحجوزة

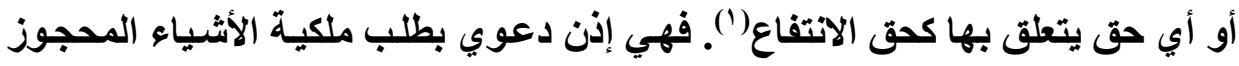

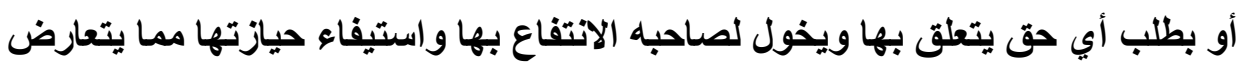
مع الحجز عليها ومـا يقتضيه هذا من بيعها علي المدين وتسليمها إلى من يشتريها

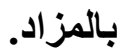

ولتلافي هذا الوضع ولدفع هذا الضرر الذي حدث أورد المشرع القواعد الخاصة

بلدعوي الاسترداد في الفصل الأول من الباب الثالث المتعلق بـالحجز التنفيذي على التي

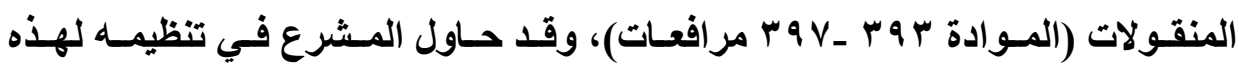
الاعاوي أن يوفق بين مصلحتين متعارضتين: المصلحة الاولي: مصلحة من يرفع هذه هـاه

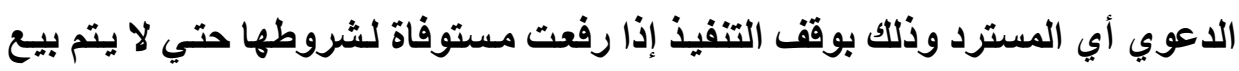
المنقولات، ويحوزها مشتر حسن النية مما يضر بالمسترد ضررا بليغا إذا كان محقا في

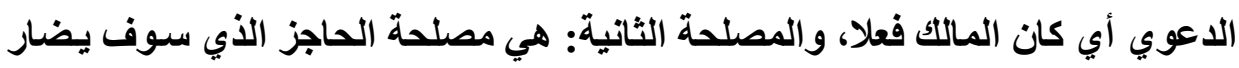
من وقف التنفيذ الذي يترتب علي رفع هذه الدعوي الذي قد يتبين عدم صحتها، ومن ثم

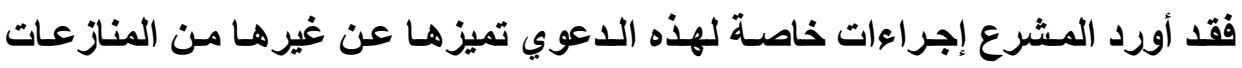

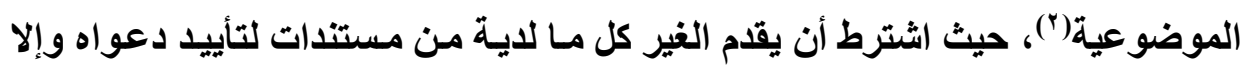
إلغي استمر في التنفيذ. وإذا كان الفقه تتاول بالثرح والتعليق علي النظام الإجرائي للدعوي الاسترداد، إلا أننا أردنا أن نلقي الضوء علي بعض قواعد هذه الدعاوي ومفرداتها وخصوصيتها، 
وإظهار المشكلات العملية الكثيرة، والآراء الفقهية المتضاربة المتعلقة بها، والعلول المناسبة. سنشير إلى شروط رفع دعوي الاسترداد وآثارها، وذلك في الفروع الآتية:

\section{الفرع الأول \\ شروط رفع دعوي الاسترداد وآثارها}

دعوي الاسترداد منازعة موضـوعية تتعلق بالتنفيذ علـي المنقول، ترفع مـن

الغير الأي يطلب فيها الحكم لـه بملكية المنقولات المحجوزة أو تقرير حق عيني آخر يتعلق بها، كما يطلب فيها وقف التففيذ لبطلان الحجز لعدم توافر الثروط اللازمة لمحل الحجز (')، وعرفت أيضا بأنها الدعوي الموضوعية التي يرفعها من يدعي ملكية الشئ المحجوز قبل بيعه، ويوجهها إلي الحاجز والمحجوز عليه بطلب ملكيته و إلغاء الحجز الموقع عليه()، فهي اللاعوي التي يرفعها شخص من الغير يلدعي ملكية المنقولات المادية المحجوزة أو أي حق يتعلق بها، وذلك علي كل من الحاجز والمحجوز عليه، ويطلب فيها تقرير حقه علي هذه المنقولات و إلغاء الحجز الموقع عليها").

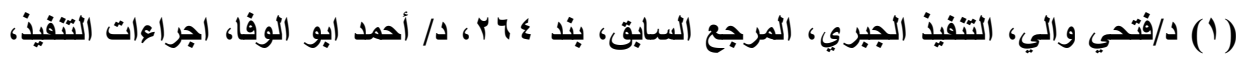

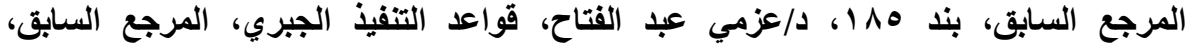

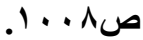

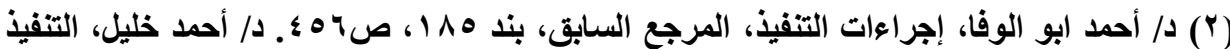

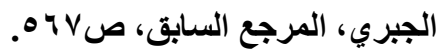

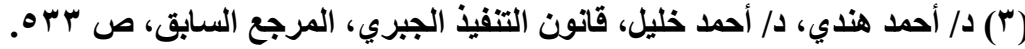


نلاحظ أن المشرع قد ميز دعوي الاسترداد بقواعد خاصـة ومميزة عن غيرهـا من دعـاوي التنفيذ، وذلك لمـا لها مـن أهميـة في الواقع العملي، باعتبارهـا من أهم اللدعاوي التي تحمسي حقوق الغير، حيث تخول هذه الدعوي حمايـة مزدوجـة للغير: حمايـة موضـوعية، حيث تهـدف موضسوعيا إلى تقريـر حقى للمـــي علـي الأثـياء المحجوزة، وتقريز بطلان الحجز لوقوعه علي غير محله، وبالتالي تخليص الأشياء المحجوزة من الحجز، وحماية وقتية، حيث ترمي إلى وقف آثار الحجز مؤقتا إلى حين الفصل في الموضوع.

لـم يحـد المسشرع بـصورة صـريحة محكمـة معينـة لنظر دعـوي الاسـترداد، ومع ذلك يجمع الفقه علي اختصاص قاضي التنفيذ- دون غيرهـ بنظرهـا إعمـالا للمـادة ه PV مرافعـات، والتـي تعقد لـه الاختصاص بكافـة منـازعـات التففيــ وقتيـة كانـت أم موضـوعية. ونظـرا لأن دعـوي الاسـترداد مـن منازعـات التنفيـذ الموضـوعية. فهــا فضلا عن إشارة المشرع إلى اختصاص قاضي التففيذ بهذه الدعوي في معرض تحديده للحكم باستمرار التنفيذ رغم رفع الـعوي الأولـي أو وقف التنفيذ رغم رفع دعوي

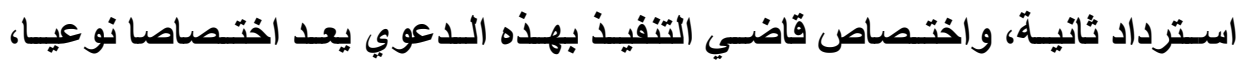
أما الاختصاص المحلي لقاضـي التتفيذ بهذه اللاعوي فإنـه يكون للمحكمة التي يجري

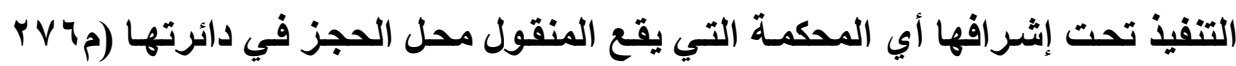
مرافعات). سنشير إلى شروط دعوي الاسترداد، ثم نعالج آثار ها وذلك في الفروع الآتية: 


\section{الفرع الثاني \\ شروط دعوي الاسترداد}

لم يشأ المشرع أن يخضع هذه الاعاوي من ناحية شروطها وآثار هـا للقو اعد

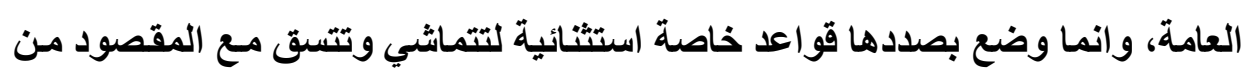

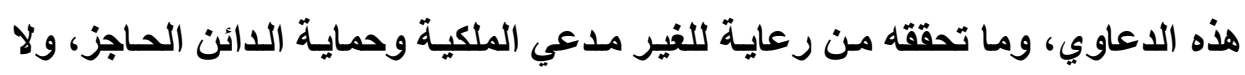

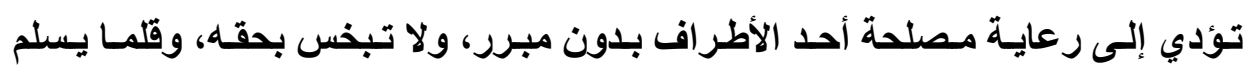
المشرع من الإفراط أو التفريط في هذا الصدد.

في الواقع، المشرع الفرنسي قد عالج المسألة بشكل مختلف، حيث قرر بصدد

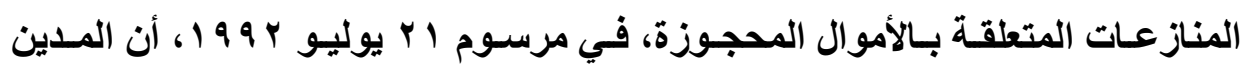

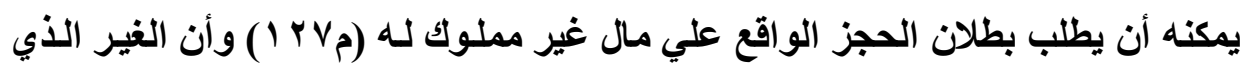

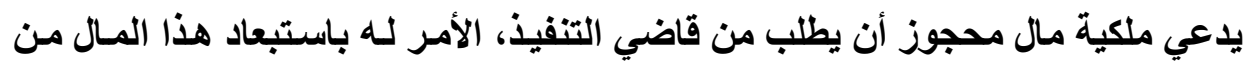
الحجز، La Distaqction، شريطة أن يوضح طلب الاستبعاد العناصر التي يبني

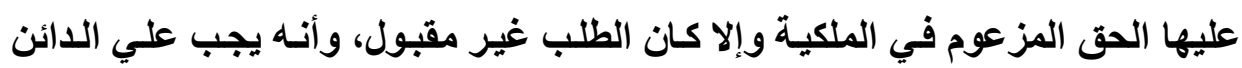

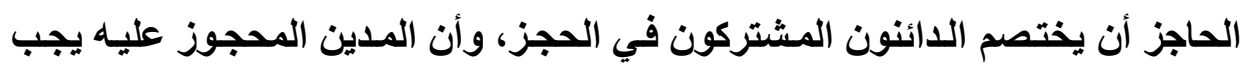
اختصامه كذلك أو يستدعي في الدعوي، واوضح المشرع الفرنسي أن دعوي استبعاد الاموال المحجوزة من الحجز تغذو غير مقبولة بعد بيع الأموال المحجوزة، وأنه يمكن

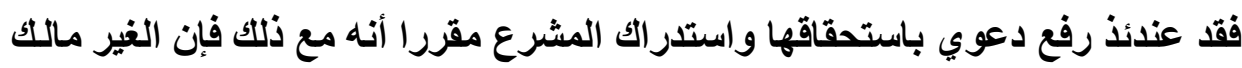

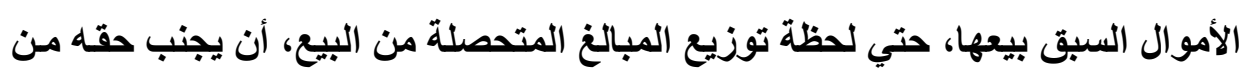

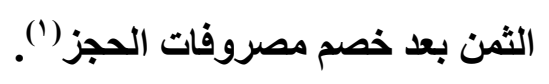




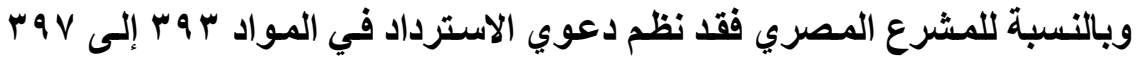
مسن قـانون المرافعـات، وذلـك في معرض تنظيمسه للتنفيذ بـالحجز علـي المنقولات لـدي المـدين، والواقع أن هذه اللـعوي مـن الـدعاوي التـي تكثر اسـتخدامها في العمـل كـأداة للمشاكسة وعرقلة السير الطبيعي للتنفيذ الجبري، ولذلك كانت الحاجة إلى ضبط قواعدها سواء من حيث نطاقها وشروطها وآثار اها. سنشير إلى الشروط المتعلقة بالنطاق الموضوعي للـعوي، والمتعلقة بالنطـق الثخصي، والمتعلقة بالنطاق الزمني، وذلك في المطالب الآتية: أولا: الشروط المتعلقة بالنطاق الموضوعي. يشترط لاعتبـار المنازعـة دعوي استرداد أن تتعلق بتنفيذ علـي منقول، وأن يجري التنفيذ بطريق الحجز. يترتب علي ذلك النتائج الآتية: النتيجة الأولي: يجب استبعاد دعوي الاسترداد من نطاق التنفيذ بـالحجز علي العقار، حيث نظم المشرع بالنسبة لهذا الطريق دعوي خاصـة هي دعوي الاستحقاق الفرعية. دعوي الاسترداد تهدف إلـي صدور حكم يحسم النزاع حول ملكيـة المنقولات المحجوز عليها، فيجب أن تتضمن هذه المنازعة هدفين، الأول الفصل في مسألة ملكية المنقول، والثاني في مدي صحة الحجز. النتيجة الثانيسة: يجب استبعاد دعوي الاسترداد من نطاق التفيذ المباشر، وذلـك لأن الأطراف السلبيين فـي دعـوي الاسـترداد هـم الحساجز، والمحجـوز عليـه، 
والحاجزون المتداخلون، كما يترتب علي رفعها وقف البيع، وهذا أو ذلك دليل علي أن التنفيذ بطريق الحجز وليس تنفيذاً مباشراً، وهذا ما يستفاد من تنظيم المشرع للاعوي

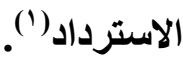

علي أن استبعاد دعوي الاسترداد من نطاق التنفيذ المباشر، لا يعني حرمـان الغير الذي يدعي ملكية الأموال المطلوب التنفيذ المباشر عليها من أدوات الحمايـة

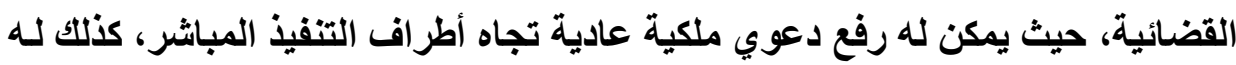
الحق في أن يرفع إثكالا وقتيا بطلب وقف التنفيذ المباشر لحين الفصل في دعوي الملكية، وذلك طبقا للمـادة ب آ مر افعات، ويستفيد بالتالي من الأثر الموقف للتنفيذ المترتب علي رفع الإشكال الوقتي("). النتيجة الثالثة: ثمة شكك يمكن أن يثور بثأن سريان قواعد دعوي الاسترداد

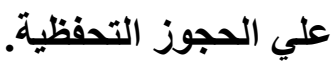
يرجع مصدر الثكك هنا إلى أن التظيم المشرع لهذه الدعوي في الفصل الخـاص

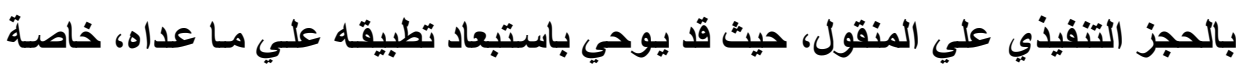
وأنه في الحجز التحفظي لا مصلحة للغير في الاستفادة من الأثر الواقف للبيع في دعوي الاسترداد، لعدم تحديد يوم للبيع أصلا في هذا النوع من الحجوز. في الواقع اختلفت كلمة الفقه في هذه المسألة، ويمكن أن نجمل هذا الاختلاف

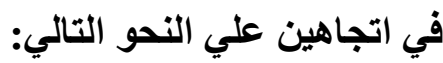

(1) انظر، د/ أحمد هندي، الحق في الإخلاء الجبري ونظامه الإجرائي، مجلة الحقوق، العدد الثالث

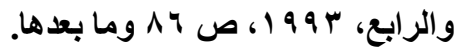

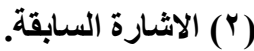




\section{الاتجاه الأول: تصر تطبيق الدعوي علي العجوز التنفيذية:}

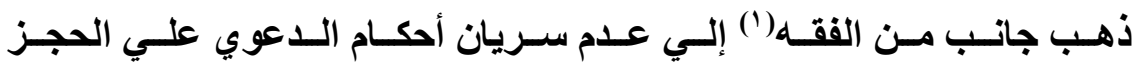

التحفظـي، حيث أن الـــوي التـي يرفعهـا الغيـر بالنسبة لهــا الحجـز هـي دعـوي حـق عاديـة ()، لا تنطبـق عليهــا قواعـد دعـوي الاســترداد مـن حيــث شـروطها وآثارهـا، وذلـك لأن دعوي الاسـترداد تقتصر علـي حالـة توقيـع حجز تنفيـي علـي

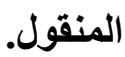

ويري بعض من أنصار هذا الاتجـاه، أن فكرة تحول الحجز التحفظي إلى حجز تنفيذي معيارا في بيان مدي انطباق قواعد دعوي الاسترداد، ولذلك فعند هذا الاتجاه إذا رفعت دعوي الاسترداد في الحجز التحفظي قبل تحول هذا الحجز إلى حجز تنفيذي فإنها لا تخضع لقواعد دعوي الاسترداد، أمسا إذا رفعت بعد هذا التحول فإنها تعتبر دعوي استرداد بمعني الكلمة(")

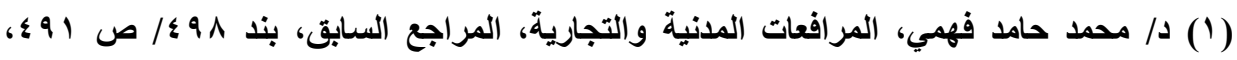

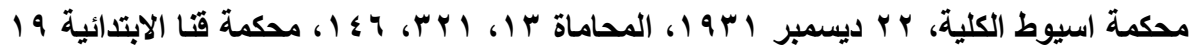

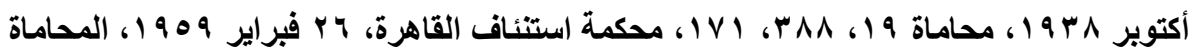

$$
\text { roo، orv }
$$

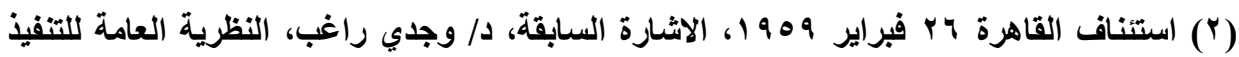

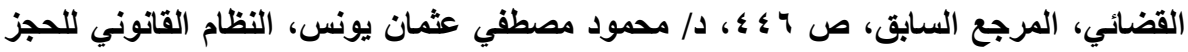

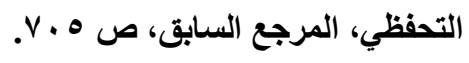

(ए) د/ محمد محمود فهمي، تنفيذ الأحكام والسندات التنفيذية والحجوزات التحفظية، المرجع السابق،

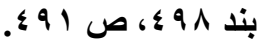

مجلت البحوث القانونيت والإقتصاديت 


\section{استند هذا الاتجاه إلى الأسانيد الآتية:}

1- أن القواعد الخاصة بدعوي الاسترداد، إنما هي قو اعد استثنائية ولم يرد ذكرها ضمن نصوص الحجز التحفظي، ونظمها المشرع في باب الحجز التنفيذي علي

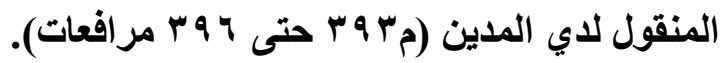
r- أن دعوي الاسـترداد هـي أداة قانونيـة لإثبـات حق المسترد علـي المنقولات

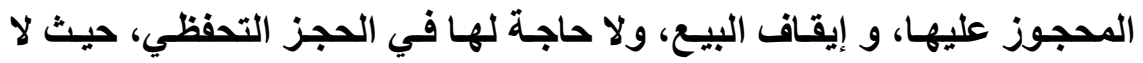
يرمي الدائن إلى البيع لاستيفاء حقه، حيث إن الحجوز التحفظية لا يتحدد فيها

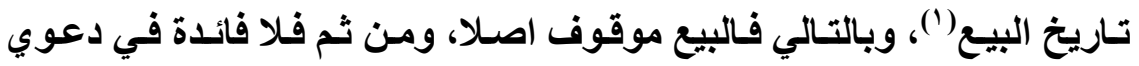

$$
\text { الاسترداد من ناحية وقف البيع. }
$$

الاتجـاه الثـاني: انطباق اللاعوي علي الحجز التحفظي والتنفيذي وحجز مـا

$$
\text { للمدين لاي الغير: }
$$

يـرى الـرأي الـراجح(") أن للغيـر الحـق في رفع دعـوي اسـترداد المنقولات المحجوز عليها، سواء كان الحجز بطريق تنفيذي أو تحفظي، وحجز مـا للمدين لدي الغير؛ وذلك لوحدة الغاية من هذه الحجوز وهي إجراء البيع.

(1) المادة ـ ـا مرافعات الواردة في الفصل الخاص بالحجز التحفظي تحيل إلى قواع وإجراءات الحجز التتفيذي ويستثي صر احة منها تحديد يوم البيع.

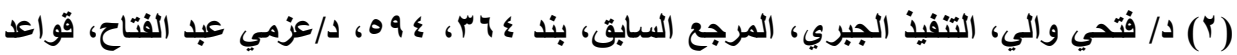

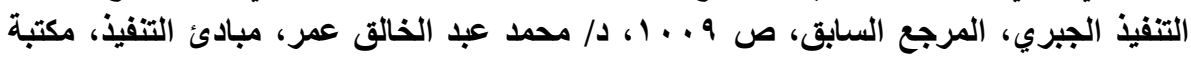

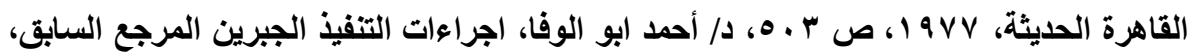




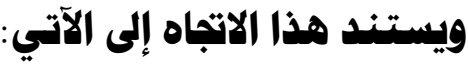

أولا: إذا كاتـت دعوي الاسترداد ترمسي إلى تقريـر حقى للغير بالنسبة للمـال المحجوز وإلى وقف البيع، وإلى بطلان الحجز، فهذه الأغراض تتحقق أيضا في الحجز

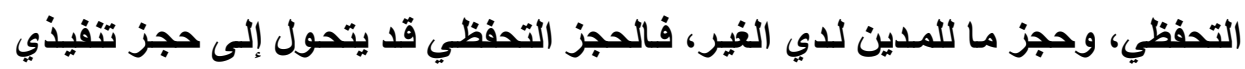

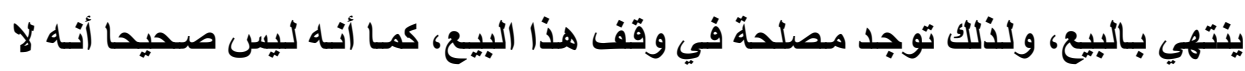
حاجة لوقف البيع في الحجز التحفظي، لأن الحجز التحفظي يرمي في النهاية إلى التنفيذ

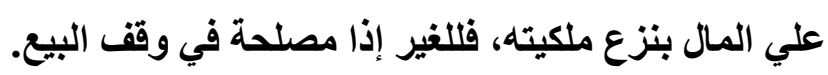

ثانيا: أن وضع النصوص الخاصة بدعوي الاسترداد في الفصل الخاص بالحجز

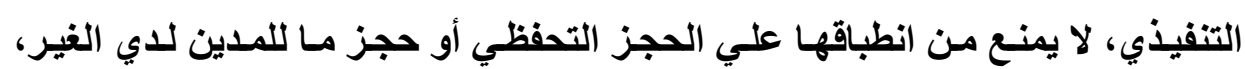
فالقاعدة هي أن يتبع في الحجز التحفظي النصوص الخاصـة بـالحجز التنفيذي (').

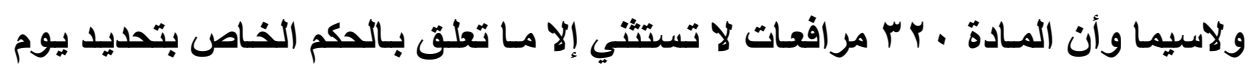

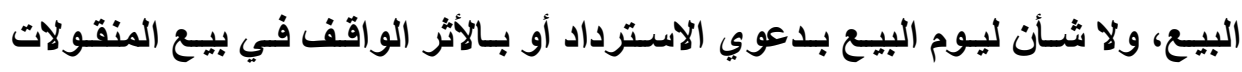

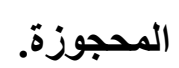

ثالثا: ليس هناك علاقة بين تحديد يوم البيع وبين الأثر الواقف للبيع في دعوي

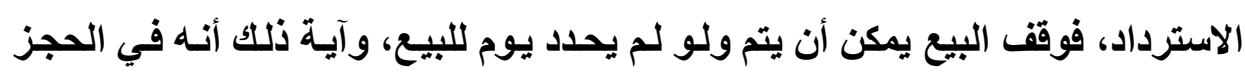

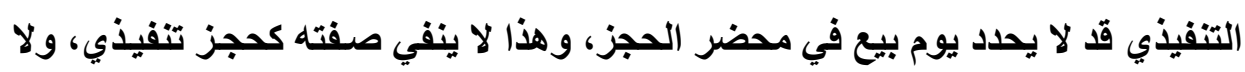
ينتفي عن دعوي الاسترداد التي ترفع قبل هذا التحديد، صفتها كدعوي استرداد أو ولاو

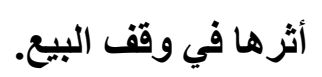

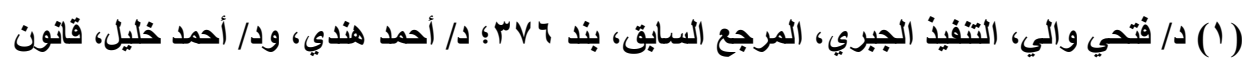

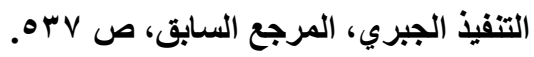


رابهـ" : أن الاتجـاه الـر افض لإعمـال قواعـد دعـوي الاسـترداد علـي الحجـوز

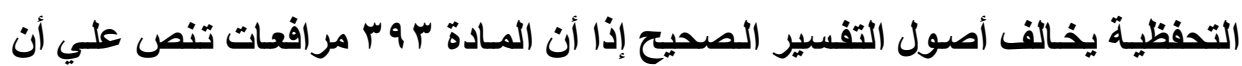
"رفعت دعوي لاسترداد الأشياء المحجوزة"، وذلك دون تخصيصها لطريق معين من طرق الحجز، فيكون قصر تطبيقها علي الحجز التتفيذي دون التحفظي تحصيص لعموم النص بغير مخصص وتقيد المطلق بغير مقيد '(') ونرى أن الرأي الثاني هو الأولي بـالترجيح، وذلك لأن ليس من شروط دعوي الاسترداد أن يكون هناك يوم محدد للبيع، ولكن تنطبق في حالة الحجز علي منقول، سواء كان حجزا تثفيذيا أو تحفظيا. النتيبـة الرابعة: هنـاك ثمـة شكك يمكن أن يثور أيضا بثأن سريان قواعد دعوي الاسترداد علي الحجز الاستحقاقي، وهو الحجز الذي يوقعه مالك المنقول أو صاحب حق عيني آخر عليه يخوله حق تتبعه، أو صساحب الحق في الحبس في يـ من يحوزه، تمهيدا لتسلمه، لأن هذا الحجز بطبيعته لا يؤدي إلى البيع، وإنمـا إلى التنفيذ المباشر، ولكن دعوي الاسترداد توجه حجزا ينتهي إلى البيع وتستهلف إيقافه(؟). النتيجة الخاهسة: لا ترفع دعوي الاسترداد بصدد التنفيذ الجمـاعي، فإذا رفع شخص دعوي بملكية محل تجـاري اتخذت بشأنه إجراعات قائمسة علي الحكم بإثـهار إفلاس المدين، فإن هذه الدعوي لا تخضع لقواعد دعوي الاسترداد(").

(1) المستشار/ محمود محمود الطناحي، دعوي استرداد المنقولات المحجوز عليها، المرجع السابق،

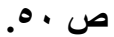

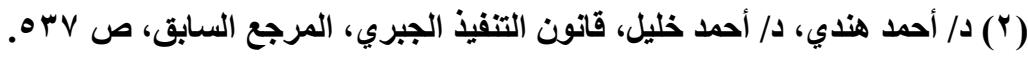

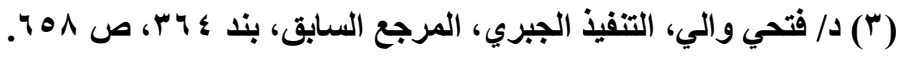




\section{ثانيا: الشروط المتعلقة بالنطاق الشخصي للدومي:}

يتعلق النطاق الشخصي في دعوي الاسترداد بأطراف الدعوي، حيث ترفع هذه اللاعوي من اشخاص نص المشرع علـي صفتهم، كمـا ترفع علـي أشـخاص معنيين. وستشير إلي ذلك في النقاط الآتية:

\section{أولا: المدوي في دعوي الاستزداد: الغير}

المدعي في الدعوي دعوي الاسترداد هو من شخص من الغير، وهو من ليس طرفا في السند التنفيذي، وينازع في التنفيذ، استنادا إلي أنه المالك للمنقول المحجوز عليه أو من له حق آخر علي المنقول يتعارض والحجز عليه(')، فالغير في هذه الاعوي يطلب ملكية المنقول المحجوز عليه، ووقف البيع وبطلانه.

ويري جاتب من الفقـه(؟) أن المدعي في دعوي استرداد المنقولات المحجوزة ليس من الغير لأنه طرف في دعوي الاسترداد، ولأنـه ينـازع في ملكيـة المـال المحجوز عليه، والواقع أن هذا الرأي لا يمكن التسليم به، وذلك لأن المدعي في دعوي الاسترداد

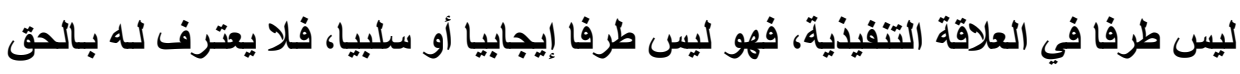
في التنفيذ ولا يلزمه التنفيذ بأداء ما، لذا فالمدعي في دعوي الاسترداد يعد من الغير

بالنسبة للعلاقة التنفيذية.

ويلاحظ أن المشرع لم يحدد صفة المدعي في تلكك الدعوي ولم يقصرها علي

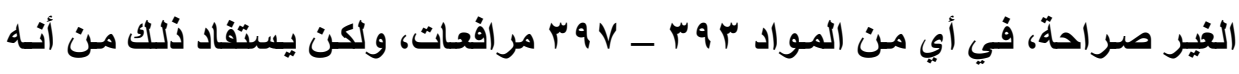

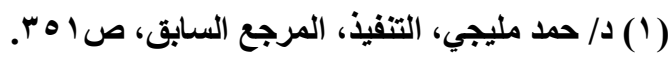

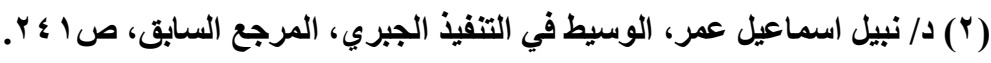


جعل المـدعي عليـه في هـذه الـدعوي الــائن الحساجز والمحجـوز عليـه والحساجزين المتلخلين، بمـا يعني أن أي من هؤلاء لا يصح أن تثبت لـه صفة المدعي في دعوي الاسترداد، بالإضافة إلى أن للغير مصلحة في رفع هذه الدعوي. ويمكـن أن يستجمع الـشخص لـصفتين فـي آن واحـد، الغيـر وممـثلا لاحــ أطراف التفيـذ كـالولي أو الوصسي أو نـاظر الوقف أو مـدير الشركة، فقد يكون أيهـ طرفا في التنفيذ بصفته ممثثلا لأحد اطراف التنفيذ، ومن الغير بصفه أخري، كمـا لو حجز علـي شـصص بصفته مـديرا لشركة، ويـدعي ملكيـة الأشـياء المحجوزة بـصفته الشخصية، ففي هذه الحالـة وأمثالها يكون لهذا الشخص بصفته مـن الغير ويرفع

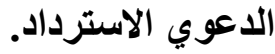
وينبغي أن يكون حق المقرر لغير يتعارض مـع التنفيذ علي المنقولات لـدي

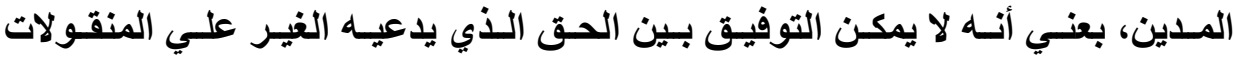
المحجوزة، وبين حجز هذه المنقولات الذي ينتهي ببيعها جبرا إلى الراسي عليه المزاد، فإذا أمكن التوفيق بنـي حق الغير وبين حق الراسـي عليه المزاد فـلا يكون هنـاك من مبرر لرفع دعوي الاسترداد التي ترمسي في النهايـة إلى منع بيع المنقولات جبر|(')؛ فهذه الدعوي تتعلق بطالب الغير تقرير ملكيته للمنقولات أو أي حق يتعلق بها مع إلغاء أو إبطـال الحجزز عليهـاـ لأنسه ورد علـي ملـك الغير- وذلـك فـي مواجهـة الحساجز أو الحاجزين (لإلغاء الحجز في مواجتهم) والمحجوز عليه (للاحتجاج بالملكية أو أي حق علي المنقولات في مواجهته). 
ولقد اختلف الفقه في مفهوم الغير في دعوي الاسترداد، ويمكن حصر هذا الخلاف في الاتجاهين الآتيين:

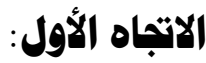

يذهب أنصار هذا الاتجـاه(') إلى أن الغير في دعوي الاسترداد هو كل من لـه حق يتعـارض مـع التنفيذ علـي المنقولات لـدي المـدين، كصاحب حق ملكيـة الأشـياء المحجوزة، وقد وجه جاتب من الفقه النقد لهذا الرأي بـأن هناك أشخاصـا لا تتعـارض

حقـوقهم مـع التنفيـذ، ومـع ذلــك يـستطيعون المنـازعـة فيـه، ولـيس بالـضرورة أن تأخذ هذه المنازعة صورة دعوي الاسترداد بـالمعني الدقيق، فقد لا يكون الغرض من المنازعة هو طلب بطلان التنفيذ، وإنما الاحتفاظ بحق الغير في مواجهة الراسي عليه

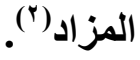

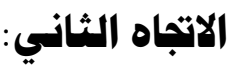

يـذهب إلى أن الغير هـ مـن لـه حق متعلق بالشئ محل الحجز يفضل حق

المشتري بالمزاد كصاحب حق الانتفاع عليها مثلا().

ومن جانبا نري أن الغير في دعوي الاسترداد هو كل شخص من الغير يدعى ملكيتهـ لكل أو بعض المنقولات التـي أوقع الحجز عليهـا أو يـــعى أن لـه حقـا عليهـا يتعارض مع حق الدائن في توقيع الحجز أو مع استمراره قائما(؛)، ويهدف من الدعوي

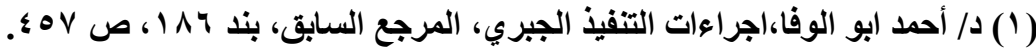

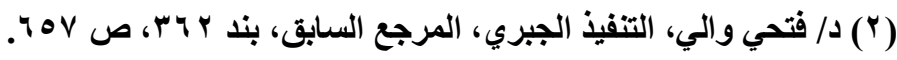

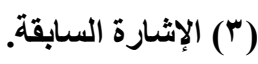

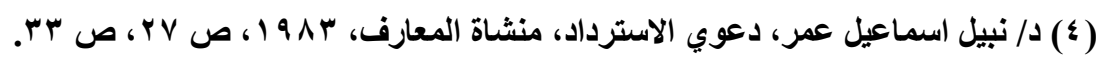


بطلان الحجز وتقرير حقه، فالغير يجد مصدر حقه في القانون الموضوعي الذي ينظم العلاقة بين هذا الغير، والمال الجـاري التنفيذ عليه، كمـا يجد مصدره أيضا في قانون المرافعات الذي أعطي لهذا الغير مجموعة من الأدوات القنية منهـا دعوي الاسترداد لحماية الحقوق التي للغير علي الأموال المتوقع عليها الحجز. ولا يمكن إثبات صفة الغير للمدين ذاته، حيث لا تقبل منه مثل هذه الدعوي، لأن المـال المحجوز إمـا أنسه مملـوك لـه فعلا وعندئــ يكون الحجز صحيحا، وإمـا أنـه غير مملوك له، ومن ثم لا تكون له صفه في إثبات ملكية الغير لهذا المسال(')، إذ أن المسال تم الحجز عليه لأنسه في حيازتـه، ويفترض بالتـالي أنـه مالكك لـه باعتبار أن الحيـازة في المنقول سند الملكية، فالمعاون يلتزم بالحجز علي كل المنقولات التي في حيازة المدين بفرض ملكيته لها حتي وإن كان الواقع غير ذلك، حيث إن المعاون لا يلقي بـالا إلى اعتراضات المدين لحظة توقيع الحجز، والتي تتضمن القول أن المـال المحجوز ليس

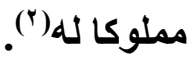
كما أن الغير ليس بطالب تنفيذ أو ممثلا عنه، فلا يتصور أن يكون الدائن طالب التنفيذ مدعيا في دعوي الاسترداد، لتعارض مركزه مـع أهداف هذه الدعوي، حيث أن مصلحته تتمثل في متابعة الحجز للحصول علي حقهه من ثمن المنقولات المحجوزة، بينمـا ترمسي هذه الـعوي للخـلاص مـن هذا الحجز، وإعـادة الأمسوال المحجـوزة إلى صاحبها الحقيقي. (1) وقد اخذ القانون الفرنسي بجواز للمدين رفع هذه الدعوي أنظر فتحي والي، التنفيذ الجبري،

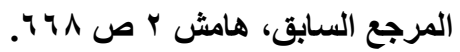

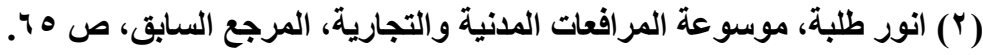


ولا يؤثر علي حق الغير في رفع دعوي الاسترداد أن المشرع يسمح لـه برفع

إثكال وقتي بطلب وقف التنفيذ طبقا للمـادة ب ا M مرافعات، فليس هنـاك تعـارض بين

الدعويين لاختلافهما موضو عا وسببا.

ويجب لرفع دعوي الاسترداد، ألا تكون المنقولات في حيازة المسترد، حيث أن

دعوي الاسترداد تفترض أن الحجز يقع علي منقولات في حيازة المدين أو في حيازة

مشتركه بين المدين والغير، فإذا انتقل المعاون واتضح أن المنقولات ليست في حيازة المدين، فانه يمتنع عن توقيع الحجز، و إذا أوقعه كان بـاطلا، ولو كانت هذه المنقولات مملوكة فعلا للمدين، وذلك لأن وسيلة الحجز في هذه الحالة تكون بحجز ما للمدين لدي الغير، ويكون لحائز المنقولات أن يرفع دعوي ببطلان الحجز، ويمكن الفصل في ملكية المنقول بطريق المنازعة في التقرير بمـا في الذمـة، ولا يلتزم برفع دعوي استرداد، حيث لا تكون له مصلحة(')، فلا يتطلب الأمر أن يثبت تملكه للمنقولات ويكفي أن يثبت أن الحجز علي المدين يقع علي مال في حيازته هو، وليس في حيازة المدين، وتثبت الحيازة باعتبار ها وقائع مادية بشهادة الشهود والقرائن مهمـا تكون قيمـة النزاع، كمـا يجوز نفيها بذات الطريق.

\section{ثانيا: المدوي عليه: الدائن الماجز والحاجزون المتدخلون والمجبوز عليه:}

نصت المـادة ؟ ؟ مرافعات علي أن المدعي عليه في هذه الدعوي هو طرفا

خصومة التنفيـ، أي المحجـوز عليـه، والـدائن الحساجز، والصـاجزين المتــلين، إذن المدعي ليس حرا في اختيار خصومه في دعوي الاسترداد، فقد ألزامـه المشرع برفع الدعوي علي اشخاص معينين. فمن ناحية أولي يجب رفع دعوي الاسترداد علي الدائن 
الحساجز، وهـو الحساجز الأول علـي المنقول، وكـللك علـي الحساجزين المتــلين، وهـم الأئنون الذين حجزوا علي المنقول بعد الحجز الأول، وعلة اختصام هؤلاء أنهم هم المدعي عليهم في الادعـاء ببطلان الحجز الواقع علي مـال غير مملوك للمدين، ومن ناحية ثانية يجب رفع دعوي الاسترداد علي المحجوز عليه، فهو المدعي عليه في الادعاء بالملكية والذي يعد الطلب الأصلي في دعوي الاسترداد، إذن في هذه الدعوي تعدد إجباريا في مركز المدعي عليه.

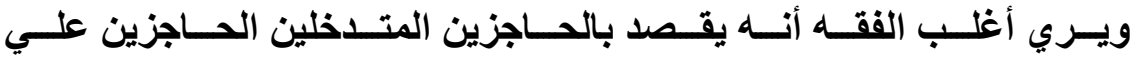

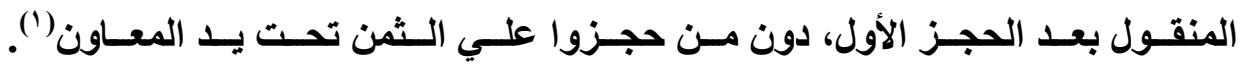
ولكن البعض() يري أن عبـارة الحاجزين المتـلين، وردت عامـة مطلقة، وبالتـالي لا يجوز تخصيصها أو تقييلها بغير مقتض، فباذا كـان الحاجز قد تـخلوا في الحجز عن طريق الحجوزات علي الثمن تحت يد المعاون فإنه يجب اختصامه، وذلك لأنه في ذات مركز الحاجز المتدخل بطريق محضر الجرد.

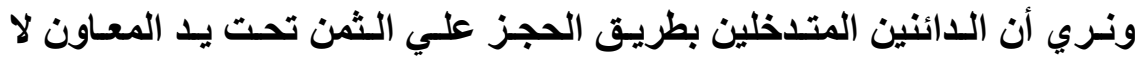
ضرورة لاختصامهم في هذه الدعوي، لأن حقهم لا يتعلق بالمنقولات محل الحجز، وإنما بحصيلة التنفيذ("). و إذا كـان المشرع قد تطلب اختصام العديد مـن الأشـخاص في مركز المـدعي عليه، فإنه لا يترتب علي عدم اختصام أي منهم بطلان أو عدم قبول الدعوي، وإنمـا 
رتب جزاء خاصا بهذه الدعوي، وهو وجوب الحكم بناء علي طلب الحسجز بالاستمرار في التنفيذ دون انتظار الفصل في الدعوي، ولا يشترط أن يطلب الاستمرار في التنفيذ من الحاجز الأول، بل يجوز لاحد الحاجزين المتدخلين أو المحجوز عليه أن يبدي هذا الطلب. والحكم الصادر بالتنفيذ غير قابل للطعن عليه بـأي طريق من طرق الطعن(')، كمـا أن الحكم الصادر في دعوي الاسترداد لا يكون الحكم حجـة علـي من لـ يختصم منهم. ولا يجوز للمكمة أن تقضي من تلقـاء نفسها بجزاء الاستمرار في التنفيذ(؟)، ويمكن أن يحكم القاضي بالتأجيل لإعلان من لم يعلن من الخصوم، كما يجوز للحاجز أن يطلب اختصام المحجوز عليه، اعمالا بالمـادة VIV مر افعات. ويجوز للقاضي بموجب المادة 11 ا أن يأمر باختصامه من تلقاء نفسه. ولذلك لـم يرتب المشرع كافة النتـائج المترتبة علي التعدد الاجبـاري بـالمعني الاقيق، فالجزاء الذي يترتب علي عدم اختصام بعض من يجب اختصامهم ليس عدم القبول وإنما يجب الحكم بالاستمر ار في التنفيذ بناء علي طلب الحاجز ("). علي أن إعمال هذا الجزاء يفترض أن الدعوي قد رفعت علي المدين المحجوز عليـه وأحـد الحساجزين علـي الأقل، أمـا إذا رفعت الـدعوي علـي المـدين دون أي مـن الحاجزين، ففي هذه الحالـة يستطيع أي حاجز أن يتدخل في الدعوي تدخلا هجوميا، ويطالب بإعمال الجزاء المقرر وهو الاستمرار في التنفيذ، أما إذا رفعت علي الحسجزين دون المدين، فإنها لا تعتبر في صحيح النظر دعوي استرداد، وكذلك من بـاب أولي إذا 
رفعت علـي أشـخاص آخرين غيـر المسدين والحساجزين، وعندئـن تكون الـدعوي غير مقبولة وفقا للقواعد العامة لرفعها علي غير ذي صفة، وبعبارة أخري، لا يتصور عدم اختصام المدين، لأن المطلب الأول في دعوي الاسترداد هو ملكية الأشياء المحجوزة، ولا صفة للحسجز في توجيه هذا الطلب اليه، وإنمـا الصفة تتوافر للمدين المحجوز

ولا شك في خطورة الجزاء الذي أورده المشرع عند عدم اختصام أحد الحاجزين

خاصة وأنه ليس للغير الوسيلة التي تمكنه أن يتعرف علي كافة الحاجزين، إذ يمكن أن يترتب علي هذا الجزاء أن يستمر التفيذ، ويتم البيع ثم يتبين بعد ذلك أن المسترد كـان علي حق، ولكنه لن يتمكن من استرداد المنقول بعد أن وقع في يد مشتر بـالمزاد حسن النيـة، ممـا يزيــ في خطورة المـادة ؛ ج ب مرافعـات النص علي عدم الطعن في الحكم الصادر بالاستمرار في التنفيذ، فضلا عن أنهـ ليس للقاضسي سلطة تقديريـة في الحكم بالجزاء أو عدم الحكم به، فالحكم هنا وجوبي.

لذلك يجب البحث عن وسيلة قانونية لتلافي مثل هذا الجزاء، ومن المتصور أن يتجه الذهن في هذه الحالة إلى نص المادة ه 11 مرافعات، والتي تعطي للقاضسي سلطة تأجيل الدعوي لإعلان ذي الصفة إذا تبين له انتفاء صفه المدعي عليه، ولكن هذا الحل

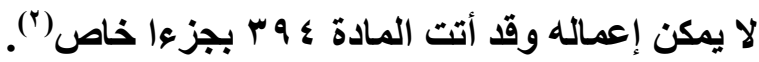

(1) د/ أحمد ابو الوفا، إجراعت التنفيذ بمقتضي قانون أصول المحاكمات اللبناني الجديد،المرجع

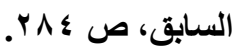
(r) د/ أحمد هندي، د/ أحمد خليل، قانون التنفيذ الجبري، المرجع السابق، وجه. 


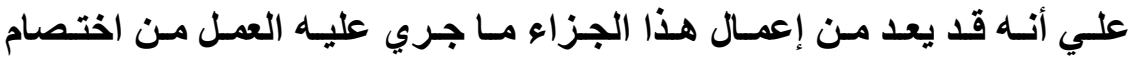
قلم المعاونين الذي أوقع الحجز، وذلك لبيـان حالـة جميع الحسجزين علي هذه الأموال، وذلك حتي يمتــع عن إجراء البيع، مـع العلم بأنسه لا يترتب علي عدم اختصامه أي

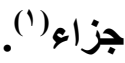

\section{الطبيعة القانونية لتعدد أطراف المدعي عليهم في دعوي الاسترداد:}

في دعوي الاسترداد يكون التعدد إجباريـا في مركز المدعي عليه، وقد حدث خلاف في الفقهـ حول تحديد طبيعيـة هذا التعدد، هل مصدره رابطة موضسوعية بين الخصوم؟ أم مصدره القانون؟

الاتجــاه الأول: التعدد الإجبـاري مبنـاه وجـود رابطة موضـوعية بين المـدعي

والمدعي عليهم)(r)

يذهب أنصار هذا الاتجاه إلى أن ثمة رابطة قانونية موضوعية واحدة بين مدعى الاسترداد والمدين المحجوز عليه، والدائنين الحساجزين، وأنـه يجب فهم هذه الرابطة علـي نحو أوسـع، بحيث لا تقتصر علـي رابطـة المديونيـة، إنمـا يجب فهمها لتشمل علاقات أخري، قـ تكون مبناها حقا من الحقوق الثخصية أو حقا من الحقوق العينية، فالادعاء بالملكية يقوم علـي أسـاس حق مطلق اتجـاه الكافة، ومـنهم المدعي عليهم، باعتبار أن الحجز يمثل اعتاءع علي حق المسترد، وبالتالي كان للمسترد أن يدافع عن

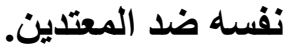

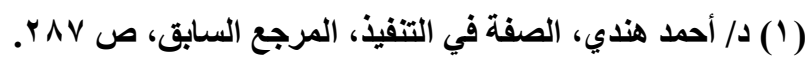

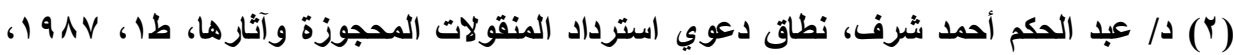
ص • ع وما بعدها. 


\section{الاتجاه الثاني: التعدد الإجباري هبناه إرادة المشرع وحده'(1)}

يـذهب أنـــار هذا الاتجـاه التعدد الإجبـاري في دعوي الاسـترداد ليس مبنـاه وجود رابطة قانونية موضوعية بين المدعي والمدعي عليهم التي هي منساط التعدد الإجباري كمـا هو معروف قانونـا، وإنمـا منشأة إرادة المشرع، ويستتد في ذلكك إلى

ا - أن العلاقة بين المدعي في تلكك الدعوي، وبين المدين المحجوز عليه لا يمكن أن تكون علاقة موضوعية بين دائن ومدين، إذ لو كـان الأمر كذلك لوجب علي المدعي الحصول علي سند تنفيذي، ومباشرة التنفيذ الجبري في مواجهة المدين وفقا لما تقضي به القواعد العامة، ولذلك وجب اختصام المدين باعتباره صاحب الـصفة الأساسـية فـي الادعـاء بـأن المسترد هـو صـاحب حـق علـي المـال

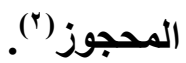
r - أن الحكمـة من اختصام الحساجز والحساجزين المتـخلين تكمن في أنهم أصحاب الصفة في الطلب الخاص ببطلان الحجز ()، وليس مبنـاه وجود رابطة قانونية موضوعية تجعل من المدعي مدينا أصليا لهؤلاء الحاجزين(؛).

(1) د/ فتحي والي، الوسيط في قانون القضاء المدني، مطبعة جامعة القاهرة، 999 19، ص1 آب،

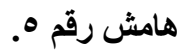

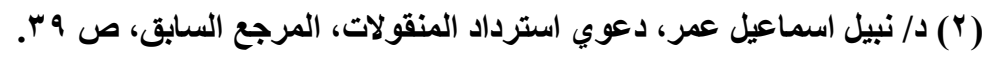

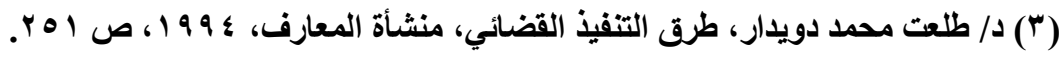

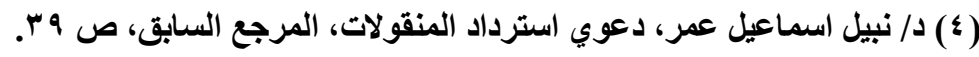


r- ونري أن الرأي الأول لا يستقيم لضعف حجبه، حيث لا يمكن التسليم بوجود رابطة موضوعية واحدة هي مناط التعدد الإجباري، كمـا أن الراي الأول اقتصر علي حق الملكية، ولكن لم يقلم حلولا بالحالة التي يـاعي فيها أنـه صـاحب حق عيني متفرع عن حق الملكيـة، ويمكن القول أن التعدد الاجبـاري هنـا مصدره القانون، وذلك من أجل الجمع بين الطلبات المرتبطة مع بعضها' '.

\section{ثالثا: الشروط المتهمقة بالنطاق الزهمي للدعوي الاسترداد:}

يجب لصحة دعوي استرداد أن ترفع بعد الحجز وقبل البيع، فباذا لـم ترفع خلال هذه القترة كانت دعوي ملكية عادية، لا يسري عليها النظام القانوني الخـاص بدعوي الاسترداد()، وترجع الحكمة من هذا الشرط الزمني إلى أن رفعت هذه الدعوي بقصد تخليص الأثـياء المحجوزة مـن الحجز الموقع عليها، وبالتـالي فـلا تعد مـن دعـاوي الاسترداد دعوي الملكية العادية التي ترفع قبل توقيع الحجز(") أو الدعوي التي تقام بعد تمام البيع أيا كانت طلبات المدعي فيها. ويرجع ذلك إلى أن المطلوب في دعوي الاسترداد هو ملكية المدعي للأموال المحجوزة، وبطلان الحجز، ويفيد ذلك اللزوم العقلي أن يكون هناتك تنفيذ قد بدأ بالفعلفي صورة حجز- حتي يكون لاعوي الاسترداد محل، فقبل حدوث الحجز ليس هناك مـال محجوز حتي يمكن المطالبة بملكيته، وبطلان الحجز الواقع عليه.

(1) المستثار/ محمود محمود الطناحي، دعوي استرداد المنقولات المحجوز عليها، المرجع السابق، ص.

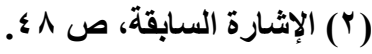
(r) د/ أحمد هندي، د/ أحمد خليل، قانون التنقيذ الجبري، المرجع السابق، ص هـهـ 
ودعوي الاسترداد تعد في جاتب منها من دعاوي الإلزام، إذ تستهدف استصدار قرار لا يثبت فقط ملكية المدعي للمال وإنما أيضا إلزام المحكوم عليه بتمكين المدعي من استرداد هذا المال، أو علي الأقل الامتتاع عن الاستمرار في التنفيذ عليه. ولن يكون

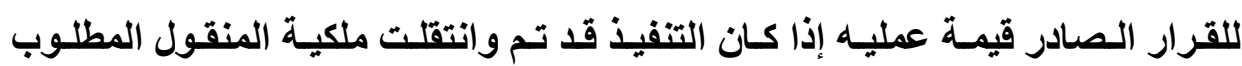
استرداده إلى المشتري بالمزاد حسن النية.

وتثثور الحاجة إلى تكييف اللعوي التي ترفع قبل البيع ولكن حدث البيع قبل الفصل فيها، في هذه الحالة سوف تحتفظ الدعوي بطبيعتها كدعوي استرداد، ولكن لن يكون للحكم الصـادر فيهـا حجيـة إلا تجـاه أطرافهـا، أي أنسه لـن يسري في مواجهـة المشتري بالمزاد لأنه لم يكن طرفا فيها، وحتي إذا رفع المحكوم لـه بالاسترداد دعوي في مواجهة المشتري بالمزاد فإن هذا الأخير يمكنه أن يدفع بقاعدة الحيازة في المنقول بحسن نيه سند الملكية(')

ولكن هل معني ذلك أن مدعى الاسترداد ليس لله حق في الحصول علي حماية

$$
\text { قضائية إذا تم البيع؟ }
$$

لا شك أن العدالة تتأذي لو أن القانون قـ حرم المالك الحقيقي للمـال المحجوز من حقه لمجرد حصول بيعه ورغم أنسه ليس هو المدين المحجوز عليه؛ إذ ليس من اللازم أن نتسب إليه تقصيرا متمثلا في تأخره في الاعتراض علي الحجز وهو لم يكن طرفا في المعاملة التنفيذية وبالتالي لا يعلم بالحجز وتعاقب الإجراءات اللاحقة عليه. 
ولكن ليس مستحبا في نفس الوقت أن نخل بالثقة في عملية البيع الجبري التي تمت ونهـد المشتري بـالمزاد بأن الملكية التي آلت إليه يمكن انتزاعها منهـ إذا ظهر المالك الحقيقي. فتفضيل حق الغير سـوف يجعل كثيرا مسن الـراغبين في المزايـدة يحجمون عن الاشتراك فيها، وسوف يعود هذا بالتالي بالضرر علي الحاجز والمحجوز عليه، رغم أن المال المحجوز والمعروض للبيع قد يكون مالكا خالصا للمحجوز عليه، ولن ينتزع بعد ذلك من المشتري.

للتوفيق بين الاعتبارين السابقين يمكن أن نجد الحل المناسب وهو جواز إقامـة الدعوي ولو بعد البيع ما دام المشتري سـئ النيـة، أي كـان عالمـا بـالواقع قبل الشراء، فهذا الحل يسمح للمالك الحقيقي للمـال المحجوز والمباع باستعادة حقه، وفي نفس الوقت لن يكون في هذا الاسترداد مفاجأة للمشتري، إذا كـان عالمـا بأنسه يشتري مـالا ليس مملوكا للمحجوز عليه، ويلاحظ أن حسن نية المشتري مفترض هنـا وعلي مدعي الملكية إثبات العكس. كمـا أنها يجب إثبات سوء نيـة المشتري لكي تقبل الدعوي بعد

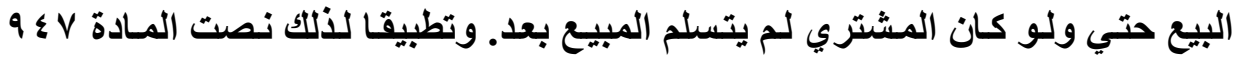
مدني علي أنها يجوز لمن يـدعي ملكية المـال المحجوز أن يقيم دعواه ولهو بعد البيع بالمزايدة إذا كـان المشتري سـئ النية('). وانمـا مشتري المنقول في المزايدة، يتملك بوجه بات إذا كان حسن النية ودفع الثمن كاملا (م هـ ه مدني).

(1) لا يجدي الطلب الموجه إلى المشتري حسن النية باسترداد المنقولات المحجوزة بعد بيعها لتمسكه

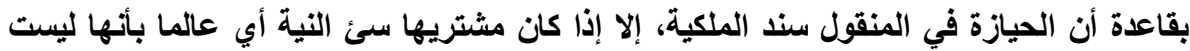

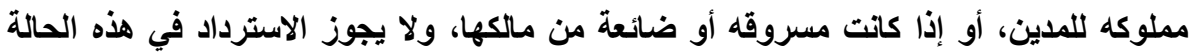

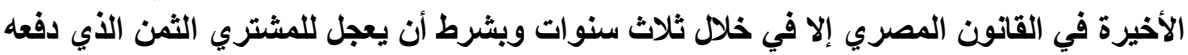

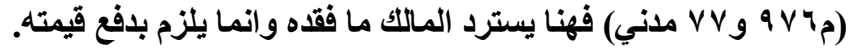


وإذا صدر الحكم لصالح مدعى الاستحقاق فسوف يسترد المنقول من المشنتري دون أن يدفع له مقابلا، ويكون للمشتري أن يرجع بعد ذلك علي المحجوز عليه الذي أثري- حيث تم الوفاء بلينها من الثمن الذي دفعه المشتري- بغير سبب ويسترد منـه

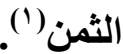

وإذا كـان المشتري حسن النيـة، جـاز لمـدعي الملكيـة أن يطالب بثمنهـا، وأن يختص بـه، دون الحاجزين، إذا لـم يكن قد دفع بعد لهم أو قسم بينهم، فِان كانوا قد استوفوا حقوقهم من الثمن، جاز لمدعي الملكية أن يرجع به علي المدين باعتبار أنه قد أثري بقدر ما سدد من ديونه علي حسابه وكثيرا ما لا يجدي الرجوع علي المدين بسبب

ويتجـه الرأي الراجح في فرنسا إلى عدم جواز الرجوع علي اللدائنين لأنهم قبضوا ديونهم التي لهم الحق في استيفائها، ولم يثروا بدون سبب مشروع ولم يتسلموا ما ليس مستحقا لهم(؟)، ولا يتصور ثمة خطأ ينسب لهم؛ ولكن إذا لم يكن الثمن قد وزع علي الحاجزين فإن من حق مدعي الملكية أن يعترض علي التوزيع ويقفه لحين الفصل في دعواه، وإذا ثبتت ملكيته للمنقول فِإن من حقـه استرداد الثمن ولن يوزع بالتـالي علي الحاجزين، وإنما عليهم حينئذ البحث عن أموال أخري للمدين لكي يبدأوا عملية حجز جديدة عليها من أجل استيفاء حقهم("). (1) د/ أحمد خليل، التنفيذ الجبري، المرجع السابق، ص ^^^ه. (2) Cass., 23mai 1945, s.1947,1,3. 
ونري مع البعض من الفقه أنه يجوز لمدعي الملكية الرجوع علي الدائنين، وإن كان لهم الحق في استيفاء ديونهم إلا أن هذا الوفاء يجب أن يكون من مال مدينهم، فاذا قبضوا ديونهم مما ليس مملوكا للمدين فهم قد اثروا بدون سبب مشروع، وهذا ولو لـ يتصور ثمـة خطأ ينسب لهم، أي ولـو كـانوا حسني النيـة، وعلـي اعتقـاد عنـــ مـوالاة إجراءات الحجز أنه يقع علي أموال يملكها فقط مدينهم (').

\section{الفرع الثالث \\ الآثار المترتبة علي دعوي الاسترداد}

ترفع دعوي الاسترداد بالإجراءات العادية لرفع الاعوي، وذلك بإيداع صحيفتها

قلم كتاب المحكمة، وأداء الرسم المقرر لها، وقيدها بالجدول، هذه الصحيفة تحتوي علي البيانـات العامـة بالإضـافة إلى بيـان خـاص بـدعوي الاسـترداد نصت عليها المسادة

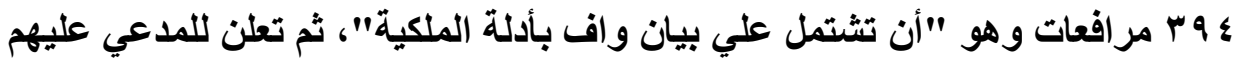
مع التكليف بالحضور(')، ويترتب علي عدم سلوك هذا الطريق، حق الخصم في الدفع

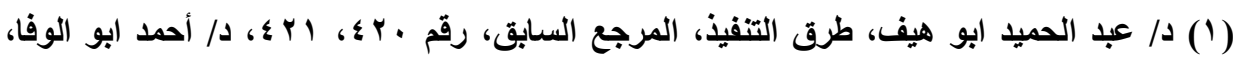

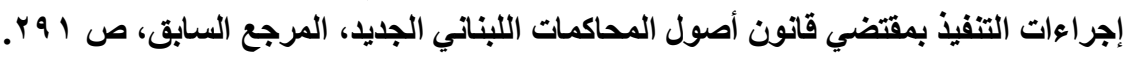

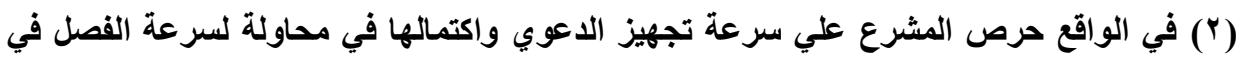

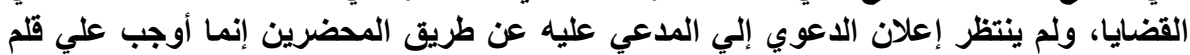

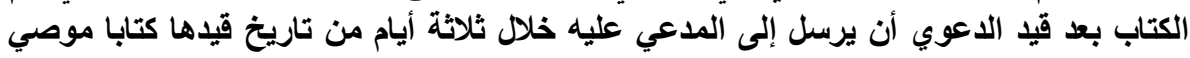

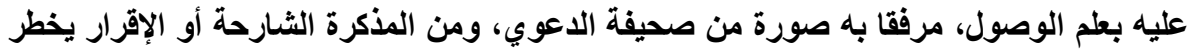

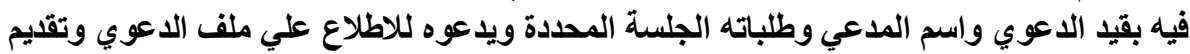

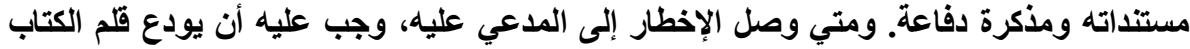

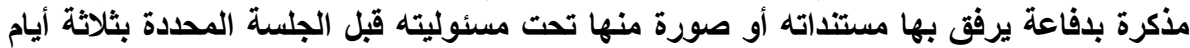

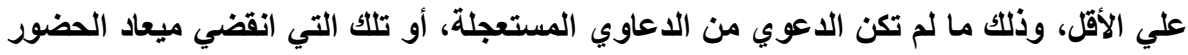
$=$ 
بـبطلان إجراءاتهـا وتقضضي المحكمـة بـذلك مسن تلقــاء نفسـها، باعتبـار أن إجـراءات التقاضي تتعلق بالنظام العام(')، وبالتالي لا يجوز رفع الدعوي بإبدائها أمسام المعاون وقت الحجز، ويحكم القاضسي بعدم قبول اللدعوي إذا رفعت بطريـق رفـع اشكال أمسام المعاون، وذلك لرفعها بغير الطريق الذي رسمه القانون(").

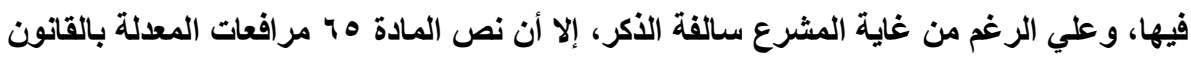

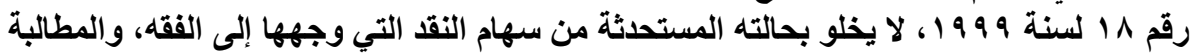

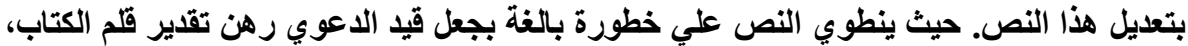

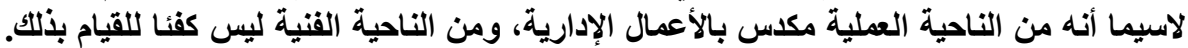

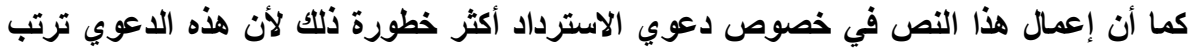

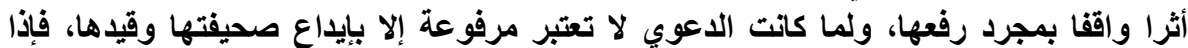

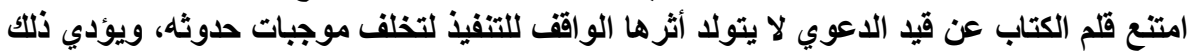

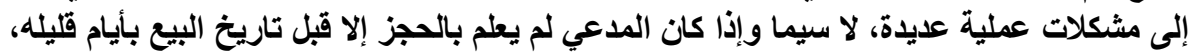

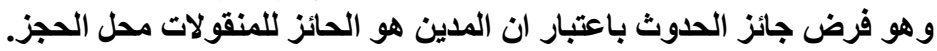

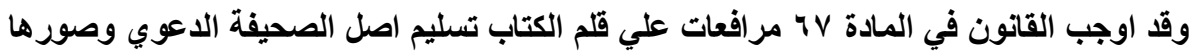

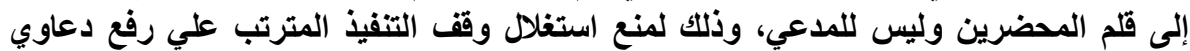

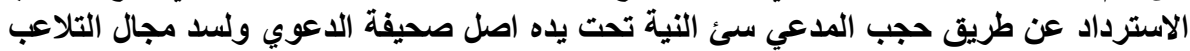

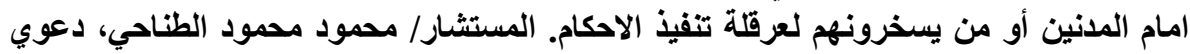

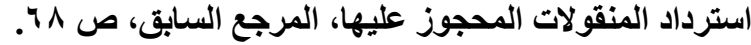

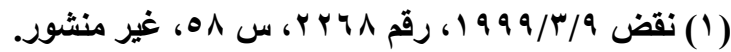

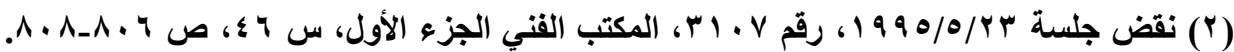

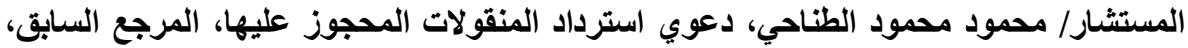

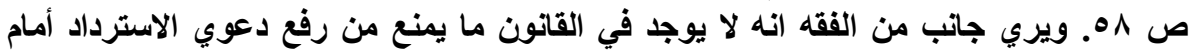

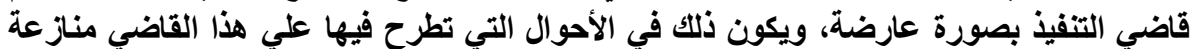

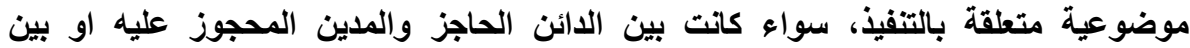

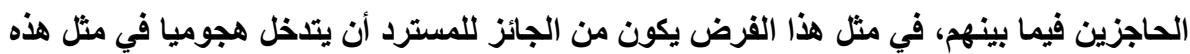

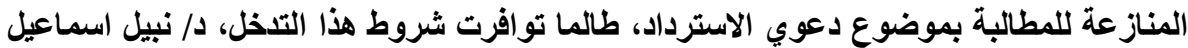

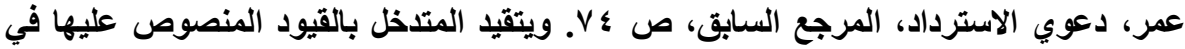

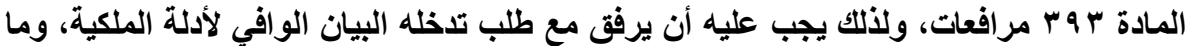

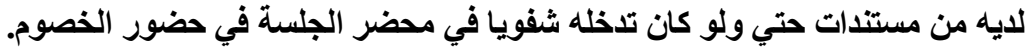


سنشير إلى الأثر المترتب علي رفع الدعوي، والآثار التي تترتب علـي الحكم

فيها، وذلك في النقاط الآتية:

\section{أولا: الأثر المترتب علي رفع دعوي الاسترداد:}

القاعـدة المقـرر أن رفـع الـدعاوي الموضــوعية لا يرتـب أثـرا فـي الحمايـة

المطلوبة، وإنما الحكم الصادر في الدعوي هو الذي ينتج عنه أثر (')، ولكن يلاحظ أن هذا القاعدة لم يقررها المشرع في دعوي الاسترداد، حيث إنـه بـالرغم من أن دعوي الاسترداد تعد منازعة موضوعية في التنفيذ، وبالتالي فالأصل لا يترتب علي رفعها أي

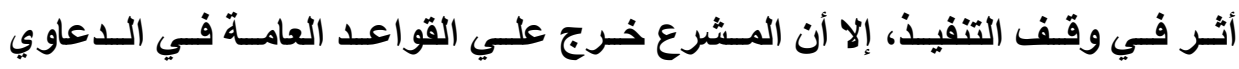
الموضوعية، ورتب علي رفع دعوي استرداد المنقولات المحجوزة، وقف إجراءات التنفيذ (مج ه م مرافعـات)، فوجـه الخصوصية في آثـار دعوي الاسـترداد، يتمثل في النص علي الأثر الواقف للتنفيذ(؟). فقد ساوي المشرع بين هذه المنازعة ويبين الإثكال الوقتي في الأثر المترتب علي أي منهمـا، والذي يتمثل في وقف التنفيذ بقوة القـانون دون حاجـة إلى طلبهـ ولا حاجة لصدور حكم به من القاضي، ويترتب الأثر الواقف بمجرد رفع الدعوي حتي ولو لـم يتم اختصام بـاقي الخصوم، ولو رفع من قبل اشكال ثم حكم بالاستمرار في 
ولكن هـا الأثتر تختلـف قـوة ترتيبـه بحسب مـا إذا كانـت دعـوي الاسـترداد المرفوعة تعد الدعوي الأولي، أم دعوي استرداد ثانية، وذلك علي النحو التالي: أولا: دعوي الاسترداد الأولي: يقصد بالدعوي الاسترداد الأولي، بأنها الاعوي التي لم تسبق بدعوي استرداد أخري بخصوص نفس المنقول، فعندما يتم الحجز علي منقول معين، فِإن أول دعوي استرداد ترفع بصدد هذا المنقول تعد دعوي استرداد أولى، وتظل دعوي الاسترداد بمثابة دعوي أولي ولو سبقتها دعوي استرداد أخري في نفس العملية التنفيذية، ولكن بخصوص منقول آخر (')، وللالك فِان اختلاف المحل يجعل أول دعوي استرداد تخص منقولا معنيا هي دعوي أولي.

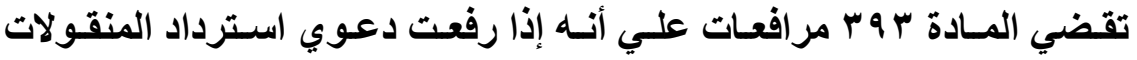
المحجوزة يقف التنفيذ، فهذا الجزاء يترتب بقوة القانون، ويهدف هذا الأثر إلي حمايـة المدعي من الاستمرار في التنفيذ وبيع المنقول، وانتقال حيازته إلي الغير حسن النية، مما لا يتمكن المدعي من استرداده بعد ذلك لتمسك المشتري حسن النية بالحيـازة في المنقول سند الملكية، فالحكمة من هذا الأثر الموقف للتنفيذ تلافي الأضرار الناجمة عن إتمام التتفيذ قبل الفصل في هذه الدعوي، فقد يكون الحكم الفاصل فيها لصالح مدعي الاسـترداد، وبالتـالي ثبـوت حقـه في اسـترداد المنقولات، ولكن سـوف يـصطدم هـذا

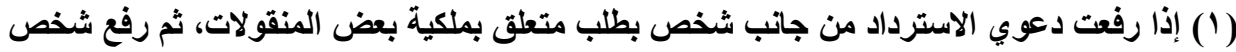

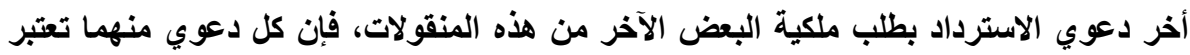

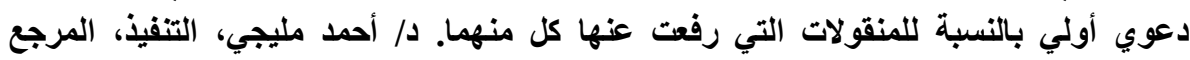

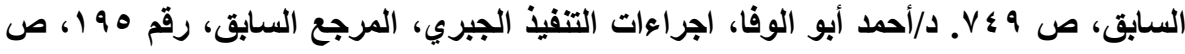


الاسترداد بعقبة، هي حصول البيع ووقوع المنقول في حيازة مشتر حسن النية بحسب الأصل، لذلك فإن وقف التنفيذ سيحول دون حصول البيع ويتوقى بالتالي أضرار إتمام

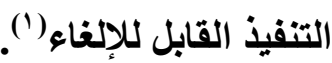
ويلاحظ أن المشرع افترض أن دعوي الاسترداد الأولي دعوي جدية، فقد يكون المسترد علي حق في دعواه فيصيبه الظلم من جراء تمـام التنفيذ، فأراد حمايته من خطر بيع المنقول، وانتقال الملكية إلى مشتر حسن النية، وإن كان المشرع لم يغفل من ناحية أخري مصير أطراف الحجز فرتب لهم العديد من الوسـائل التي يستطيعون بها التخلص من هذا الأثر الموقف(؟). ويترتب هذا الأثر ولو سبق وقف التنفيذ ثم استمر بنـاء علي إثكال وقتي أو حكم فيه أو حتي لو كان التنفيذ مـاز ال موقوفـا علي أثر هذا الإثكال أو الحكم؛ ففائدة

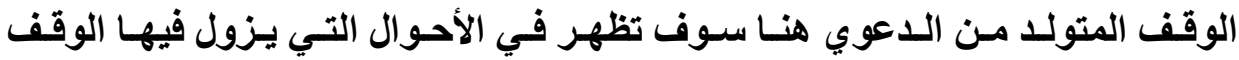
للإثكال لأي سبب كان، حيث سيظل التنفيذ موقوفا بالنظر إلى وجود دعوي الاسترداد

ويظل التنفيــ موقوفـا إلـي حين الفــل فـي دعـوي الاسـترداد بحكم جـائز التتفيذ()، ولكن يمكن الاستمرار في التنفيذ في حالات نص عليها المشرع تتمثل في لهي

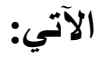

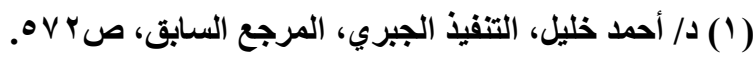
(广) المستثار/ محمود محمود الطناحي، دعوي استرداد المنقولات المحجوز عليها، المرجع السابق، ص 99

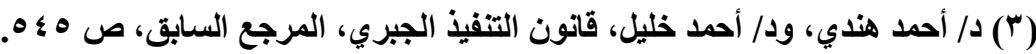

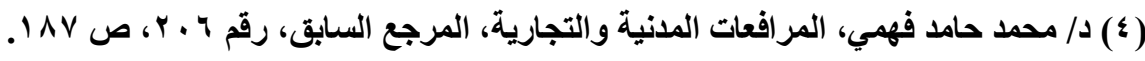


الحالة الأول: زوال الأثر الواقف بموجب حكم قضائي:

وتتضشن هذه الحالة فرضين:

الفرض الأول: حالات تكون للامكمة سلطة تقديرية بالاستهرار في التنفيذ

يجوز تقديم طلب الاستمرار في التنفيذ من الحسجز عند نظر دعوي الاسترداد

كطلب عارض، إما بـالإجراءات المعتادة لرفع الدعوي قبل يوم الجلسة أو بطلب يقدم شفاهية في الجلسة ويثبت في محضرها، وهو طلب وقتي، ولا يجوز تقديم هذا الطلب علـي هذا النحـو إلا أمسام محكـة الارجـة الأولى، ويخضع الحكم الـصادر في الطلب المستعجل للإجراءات والمواعيد المقررة في شأن الأحكام المستعجلة.

ويجب للحكم بالاستمرار في التنفيذ أن تكون هنـاك أسباب جديـة يستتد إليها

الحاجز في طلبه، وعلي القاضي باعتبار قاضي للأمور الوقتية فيما يتعلق بهذا الطلب أن يوازن بين مصلحة الحاجز والضرر الذي يصيبه نتيجة وقف البيع، وبين مصلحة المسترد والضرر الذي يلحقه من جراء الاستمرار في البيع، فبإذا اكتشف القاضسي عدم جدية مستندات الملكية من خلال البحث الظاهري للمستندات أمر بالاستمرار في التنفيذ، والواقع أن المحكمة تتمتع بسلطة تقديرية في الاستجابة للطلب أو رفضه، فلها أن تقدر مدي توافر رجحان حق الطالب، وذلك من خلال بحث سطحي لأدلة دعوي الاسترداد. وقد تقضي المحكمة بالاستمرار في التنفيذ، وفي ذات الوقت تهدف إلى حمايـة طالب الاسترداد، ولذلك أعطاها المشرع سلطة الحكم بالاستمرار في التنفيذ بشرط ايداع الثمن المتحصل مسن البيع خزانـة المحكمـة لحين انتهاء الخصومة، علـي أن تكون مفهوما أن هذا الشرط ليس لازمـا بالضرورة للحكم الاستمرار في التنفيذ، فللمحمـة سلطة الحكم بالاستمرار بشرط إيداع الثمن أو بلونه؛ والحكم الصادر يكون صـادرا في 
مــادة مسـتعجلة مسشملا بالنفــاذ المعجـل بقـوة القــاتون، وفــي نفس الوقـت قــابلا

لكلاستئناف(')

\section{الفرض الثاني: حالات يبب علي المكمة المكم بإلغاء وقف التنفيذ:}

قد يطلب أحد الحساجزين الاستـمرار في اجراءات التنفيذ، ويكون واجبـا علي القاضــ النطق بـه، يتصور ذلـك إذا رفعت دعوي الاسـترداد غير مطابقـة للنمـوذج القانوني المنصوص عليه في المـادة ؟ ج م مرافعات، وتحديدا إذا لـم يختصم فيها من يجب اختصامهم (وهم الحاجز أو الحاجزين والمحجوز عليه)، أو لم تشتمل صحيفتها علي بيان واف بأدلة الملكية، أو لم يودع عند تقديمها ما لادي المسترد من مستندات. وليس للمحكة في هذا الفرض سلطة تقديرية، حيث يجب علي محكمة التنفيذ المرفوع أمامها دعوي الاسترداد أن تحكم بناء علي طلب الحاجز بالاستمرار في التنفيذ دون انتظار الفصل في الدعوي؛ حيث إن دور المحمة في هذه الحالة هو التحقق من وجود المخالفـة(؟)، وأن القاضي هنـا لا يتمتع بأيسة سلطة تقديريـة، إذ يكفي أن تحدث المخالفة المنصوص عليها ويتقدم صـاحب المصلحة بطلب، بعدها يجب إصدار الحكم

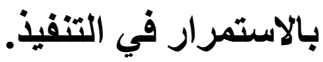

ويرفع الطلب بالاستمرار في التنفيذ من صساحب المصلحة هو أحد الحسجزين،

و إذا كان المشرع خص الحـاجز بهذا الطلب، فذلك راجع إلى أنـه الوضـع الشائع، ولا يحرم منه المدين فيمكن لله رفع الطلب(").

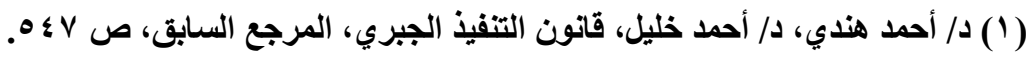

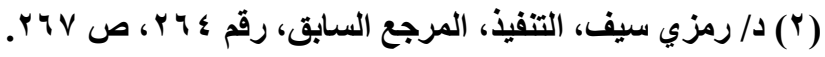

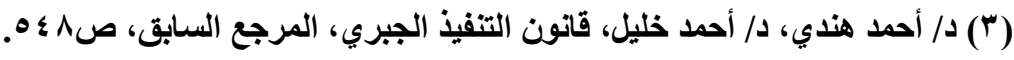


والحكم الصادر مـن المحكمة بالاستـمرار في التنفيذ لا يقبل الطعن عليهه بـأي طريق من طرق الطعن، أما الحكم الصادر برفض الاستمرار في التنفيذ فإنه يقبل الطعن وفقا للقواعد العامة.

ومـن جانبـا نـري أن المشرع لـم يسـاوي بـين أطراف الــعوي حيث كـان مـن الواجب أن يكون الحكم الصادر من قاضي التنفيذ يقبل الطعن في كافة الحالات، سواء كان صادرا برفض وقف التنفيذ أو بقبول الاستمرار في التنفيذ.

الحالة الثانية: زوال الأثر الواقف بقوة القانون هع بقاء الفصوهة:

يتحقق هذه الفرض إذا حكم بشطب الـدعوي أو وقفها، فـأثر الواقف يـزول بقوة القانون، فليس هناك حاجة لصدور حكم بذلك أو طلب من أصاحب المصلحة، ففي هذه الحالـة تظل الخصومة قائمسة، وإن كانت الـدعوي مستبعدة مسن جدول القضايا المتداولة.

والحكمة من ذلك عدم استفادة المدعي المهمل من الوقف، وحتي يمتثل المدعي لأحكام القانون ولأمر القاضي، فإذا تغيب المدعي شطبت دعواه وفقا لنص المـادة ب 1 ب مرافعات أو امتنع عن تنفيذ ما أمرت بـه المحكـة، ويقتصر هذه الحالة علـي الشطب، ولا ياخل ضمن حالات الاستمرار في التفيذ بقوة القانون حالة انقطاع الخصومة، لأنها ليست من الحسالات المنصوص عليها في المـادة ه9 ب مرافعات، والتي يترتب عليها زوال الأثر الواقف لدعوي الاسترداد. وقد نصت المادة ج9 ج علي أنه في حالة صدور حكم بعدم الاختصاص يعد سببا لعدم ترتيب دعوي الاسترداد أثرها في وقف التنفيذ، ويري البعض أن مجرد رفعها واعتبرهـا المشرع دعوي اسـترداد ثانيـة، ويتحقق ذلـك في حالـة عدم الاختصـاص 
الوظيفي أو النوعي، حيث إن لقاضسي التنفيذ أن يكيف الدعوي المرفوعة أمامـه علي أنها ليست دعوي استرداد اولي، ومن ثم فإنها لا ترتب الأثر الموقف لها، وأن رتبته خطأ، فإنه يزول بقوة القانون لأنه ليس من آثارها؛ أما في حالة الحكم بعد الاختصاص المحلي، فمعني ذلك أن الدعوي المرفوعة وفقا لتكييفها الصحيح دعوي استرداد، إلا أن المحكمة غير مختصة محليا، ومن ثم تقضي بعدم الاختصاص المحلي والإحالـة إلى المحكمة المختصة محليا، ففي هذه الحالة اعتبر المشرع الحكم الصادر في الدعوي بمثابة دعوي استرداد ثانية تشديدا علي المسترد، وعلي الرغم من مخالفته للقواعد العامة في الإحالة التي تقتضي نقل الدعوي بحالتها إلي المحكمة الأخرى(') والواقـع أنـه في حالـة الحكم بعـدم الاختصاص يصدر بالإحالـة إلـى المحكمـة

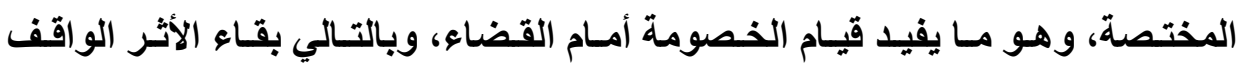
المترتب علي رفعها، إلا أن المشرع قد رتب علي الحكم بعدم الاختصاص مـا رتبه علي الشطب أو الوقف، فقرر هنـازوال الأثر الواقف لـدعوي الاسـترداد عنــ الحكم بعدم الاختصاص. ونري أن الحكمة من زوال الأثر الواقف في هذه الحالة، هي أن الدعوي المرفوعـة أمسام قاضــي التتفيـذ ليست دعـوي اسـترداد، وبالتـالي ليست داخلـه في

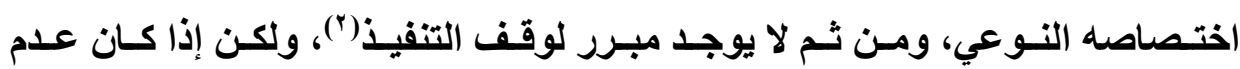
الاختصاص محليا، ففي هذه الحالة فقد قرر المشرع زوال الأثر الواقف عقابا علي خطأ المدعي في معرفة المحكمة المختصة(") مدهي

(1) المستثار/ محمود محمود الطناحي، دعوي استرداد المنقولات المحجوز عليها، المرجع السابق، سب +1.

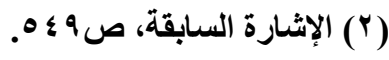

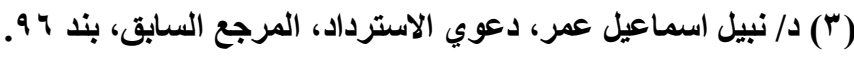




\section{الحالة الثالثة: زوال الأثر الواقف بقوة القانون بزوال الثصوهة:}

إذاز زالت الخصومة في دعوي الاسترداد لأي سبب من الأسباب زال مـا يترتب عليها من آثار، فإذا حكم باعتبار الخصومة كأن لم تكن أو حكم برفضها أو بعدم القبول أو ببطلان صحيفتها أو سقوطها أو بتركها.

ويزول الأثر الواقف للدعوي ولهو كـان الحكم بأحد هذه الأمسور السابقة قـابلا للطعن عليه بالاستئناف، كمـا أن زوال الأثر الواقف للاعوي في هذه الحالة لا يتوقف علي الحكم به، حيث يترتب بقوة القانون (') ثانيا: دعوي الاستزداد الثانية (ז):

تعتبر دعوي الاسترداد ثانية إذا رفعت في تاريخ لاحق لرفع الدعوي الأولي إذا اتحدا في محلا، وذلك في حالة كون المنقول المطلوب استرداده في الأولي هو المطلوب استرداده في الأخرى، يستوي بعد ذلك أن تكون الـاعوي التاليـة قد رفعت مـن ذات المسترد الأول أو من مسترد آخر("). وتعدد دعاوي الاسترداد قد ينطوي علي سوء نية وعرقلة التنفيذ، وانطلاقا من ذللك كان طبيعيا أن يعمد المشرع إلى قصر إعمـال الأثر الواقف علي دعوي الاسترداد

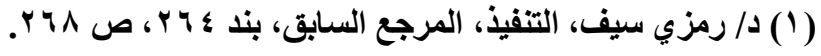

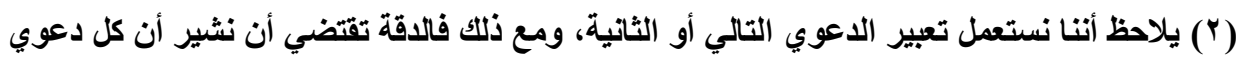

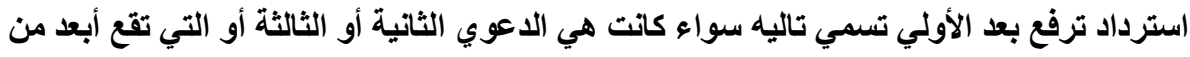

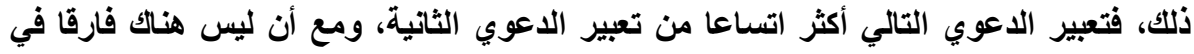


الأولسي فقط، دون الدعاوي التالية لها، وهو مـا يتفق - في نفس الوقتـ مـع الأصل

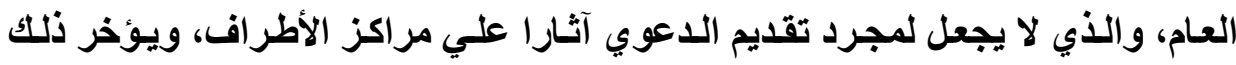

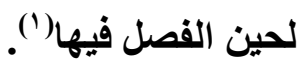
وقد نصت المـادة ج ج مرافعات علي أنه "إذا رفعت دعوي استرداد ثانية... فلا يوقف البيع إلا إذا حكم قاضي التنفيذ بوقفه لأسباب هامة". فطبقا لنص هذه المـادة لا يترتب علي رفع دعوي الاسترداد الثانية وقف التنفيذ بقوة القانون، وإنمـا يمكن لقاضي التنفيذ بناء علي طلب من المدعي، إذا وجدت أسباب هامة، أن يقضي بوقف

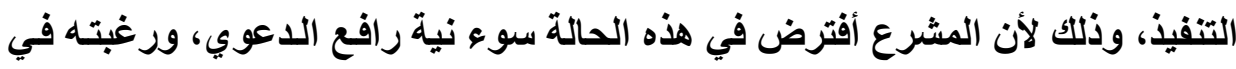
عرقلة سير التنفيذ، ولذلك نص علي عدم وقف التتفيذ بقوة القـانون، وإنمـا أجـاز للمحكمة أن تقضي بهذا الوقف.

إذا كان المشرع قد افترض تو افر سوء النية في رفع دعوي الاسترداد التالية، غير أن المشرع وازن بين مصالح الخصوم، فأدرك أن الاخذ بهذه النتيجة علي اطلاقها من شانه الحاق ضرر جسيم ببعض الاشخاص، لذا خول القاضي وقف التنفيذ بصفة مستعجلة بناء علي طلب صاحب المصلحة، وبالتالي إذا استبان لقاض أن طلب المسترد علي قرر من الاهمية، كأن يكون حسن النية وأن طبيعة المنقولات تستوجب التريث في

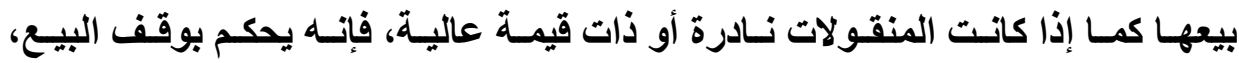
ولقاضي التنفيذ أن يأمر بايداع الثمن خزينة المحكمة، والحكم الصادر مستعجل، فينفذ بصورة مستعجلة، ويقبل الطعن بالاستنناف سواء كان قاضيا بالاستمرار في التنفيذ أو برفضه. (1) د/ أحمد هندي، د/ أحمد خليل، قانون التنفيذ الجبري، المرجع السابق، ص • هـ. 
وترجع الحكمة من الوقف القضائي لاعوي الاسترداد الثانية، إلى أنـا إذا جري البيع رغم استمرار نظر دعوي الاسترداد، فقد يصدر الحكم بعد ذلك لصالح المسترد، فلن يتمكن من استرداد المنقول بعد وقوعه في يد مشتر حسن النية، ولتلافي هذه النتيجة أعطى المشرع للمحكمة أن تحكم بوقف التنفيذ بناء علي طلب أحد ذوي الشأن، لأسباب هامة( مج 9 ب مرافعات) لحين الفصل في دعوي الاسترداد.

ويلاحظ أن دعوي الاسترداد الثانية تظهر في حالتين: الحالة الأولي: إذا رفعت هن شخص غير طالب الاسترداد في الدعوي الأولي: تعد دعوي الاسترداد ثانية إذا رفعت من غير طالب الاسترداد الأول، فقد يدعي شخص لأول مره باسترداده للمنقول إلا أن المشرع جعل دعواه بمثابـة دعوي ثانيـة

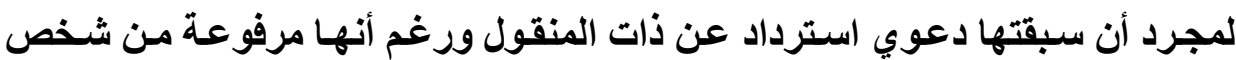

و الحكمة من هذا التكييف أن المشرع يفترض سوء نية رافع الاعوي الثانية، إذ إن القول بغير ذلك واعتبار الدعوي أولي لمجرد أن رافعها لم يسبق لـه أن رفع دعوي استرداد عن ذات المنقول في ذات عملية الحجز قد يفتح بابا لتحايل المدين المحجوز عليه، إذ يستطيع الاتفـق ميع أثخاص متعددين فيرفع أحدهم دعوي استرداد أيضا بمثابة دعوي أولى وبعد خسارتها يقوم آخر، برفع دعوي استرداد أخري تعد أيضا

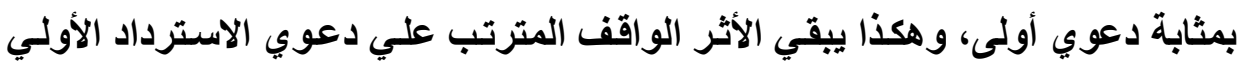

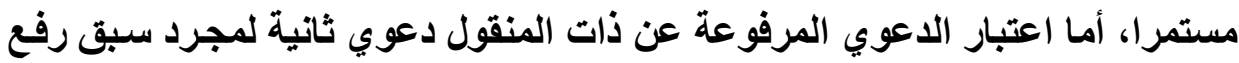


دعوي أخري عنها ولو مع اختلاف المدعي، وهو الحل الذي يتبنـاه المشرع، حيث إن تواطؤ المدين مع الغير لن يحقق لله الفائدة المرجوة '('). الواقع أن الصورة التي قصدها المشرع في الاعوي الاسترداد الثانية، هي التي ترفع بعد زوال الأثر الواقف للبيع الذي ترتب علي رفع دعوي الاسترداد الأولسي، وسواء تم ذلك بناء علي حكم نهائي أو حكم نافذ نفـاذا معجلا في هذه الدعوي أو علي دعوي تم رفعها بعد رفع دعوي سابقة، ولم ترتب أثرها في وقف البيع. وقد اختلف الفقه في مدي اعتبار دعوي الاسترداد ثانيـة إذا رفعت أثناء الأثر الواقف للاعوي الاسنرداد الاولي.

يري جاتب من الفقه أنـه يجب أن تكون هذه الدعوي قد رفعت بعد زوال الأثر الواقف المترتب علي الدعوي الأولي، وإذا رفعت أثناء سريان الأثر الواقف للدعوي السابقة، فإنها تعتبر دعوي استرداد أولي توقف التنفيذ، وذلك لأن افتراض سوء نية رافعها ورغبته في وقف البيع لا محل له في حالة رفع الدعوي في حالة رفعه للاعوي أثناء سريان الأثر الواقف للاعوي السابقة(؟). ويذهب الرأي الراجح إلـي أن الدعوي التي ترفع بعد سبق رفع دعوي أولـي تعتبر في جميع الأحوال دعوي ثانية، لا يترتب علي مجرد رفعها وقف التتفيذ سواء رفعت قبل زوال الأثر الواقف للاعوي الأولي أم لا؛ ومن جانبا نتفق مـع الراي الثاني،

وذلك للأسانيد الأتية.

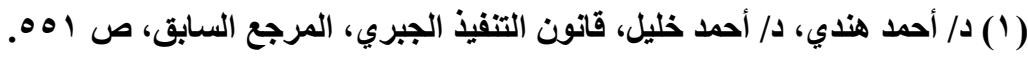

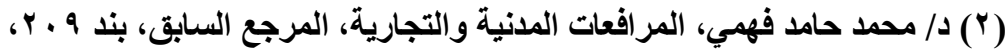

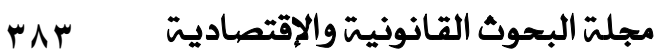


ا - الأخذ بـالر أي الأول يفتح بـاب التحايـل علـي القـانون بـأن يتواطـأ المـدعي مـع أشـخاص آخرين علي رفع دعـاوي استرداد متعددة ترفـع كل منها فور رفع الأخرى، بحيث يترتب عليها الاستمرار في وقف التنفيذ إلي ما لا نهاية('). r - أن نص المادة צ ج م مرافعات جاء صريحا بنصه علي أن الدعوي الثاتية هي التي ترفع من مسترد آخر، ومن ثم فلا يجوز تخصيصها بغير مخصص. r- أن نص القانون يبين أن العامل الزمنـي هو الذي يحدد عمـا إذا كانت الدعوي المرفوعة هي دعوي استرداد أولي أم دعوي استرداد ثانية(؟)

\section{المالة الثانية: رفع الدووي الثانية هن ذات المسترد في الدوهي الأولي:}

قد يقوم المسترد في الدعوي الأولـي، برفـع دعوي ثانيـة، بعد زوال دعواه الأولي، إذا انقضت خصومتها دون الفصل في الموضوع، وذلك لأنها اعتبرت كأن لـ تكن أو بعدم قبولها أو ببطلان صحيفتها أو بسقوط الخصومة فيها أو بقبول تركها؛ فانقضاء خصومة الدعوي الأولي دون الفصل في موضوعها يجعل الدعوي التالية إذا رفعت بعد ذلك من ذات المدعي (").

(1) د/ فتحي والي، التنفيذ الجبري، المرجع السابق، رقم rمبr، د/ احمد ابو الوفا، التتفيذ، المرجع

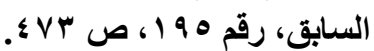

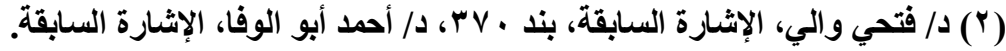

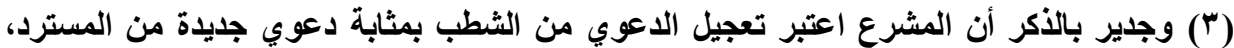

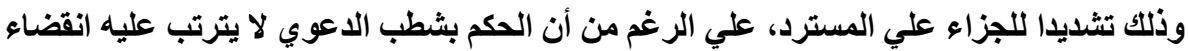

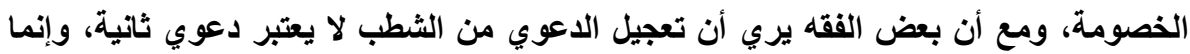

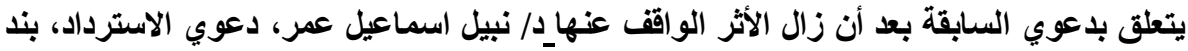


وترجع الحكمة من عدم وقف التنفيذ علي رفع الدعوي الثاتية من ذات المدعي أن المشرع يعتبر الدعوي الجديدة هنا مرفوعة بقصد عرقلة التتفيذ، ولذلك لم يعتبرهـا المشرع دعوي أولي رغم عدم سبق الفصل في موضوع الاعوي الاولي. يري جاتب من الفقه أنه إذا قضي قاضسي التنفيذ بوقف التنفيذ بنـاء علي طلب رافع الاعوي الاسترداد الثانية لوجود أسباب هامة، ثم زالت الخصومة في هذه الدعوي لأي سبب من الأسباب، فإن الأثر الواقف لا يزول بقوة القانون، بـل يلزم صدور حكم بالاستمرار في إجراعات التنفيذ من قاضي التنفيذ(') ونري أنه لا يمكن الأخذ بهذا الرأي وذلك لأن الأثر الواقف الذي حكم به القاضي كان نتيجة لاعوي الاسترداد الثاتية، فزوالها يؤدي إلي زوال الحكم الذي قضي بوقف التنفيذ دون حاجه إلي حكم جديد بالاستمرار في التتفيذ، لأن زوال الخصومة يتضمن ضمنيا زوال الأثر الواقف للتنفيذ، حيث لم يعد هناك حكمة من استمرار وقف التنفيذ.

\section{ثانيا: الهكم في الدعوي وآثاره:}

\section{ا - المكم في هوضوع دعوي الاسترداد:}

تنظر دعوي الاسـترداد ويفصل فيهـا باعتبار هـا مناز عـة موضسوعية، والحكم

الصادر فيها يحسم النزاع حول أصل الحق، وعلي القاضي عند الفصل في الدعوي أن يسبب حكمه، ويحكم القاضي في الدعوي- سواء كاتت دعوي الاسترداد أولي أم تاليةــ إذا لم يعترض خصومتها عارض يزيلها، ويقضي في طلب الملكية وطلب البطلان، فإذا انتهت المحكمة بعد بحث أدلة الإثبات إلى أحقيـة المدعي في المـال محل الحجز فإنها 
تحكم له به وأيضا ببطلان الحجز، أما إذا تبين عدم أحقيته في المال فإنها تقضي برفض طلب الملكية ودون حاجة إلى البحث في مدي صحة الحجز. القاعدة العامة أن الإثبات يقع علي المدعي، وليس المقصود بالمدعي هو رافع

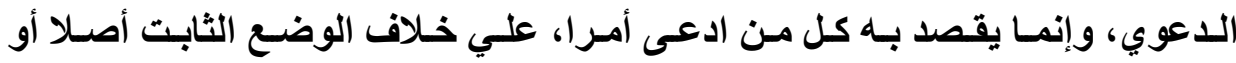

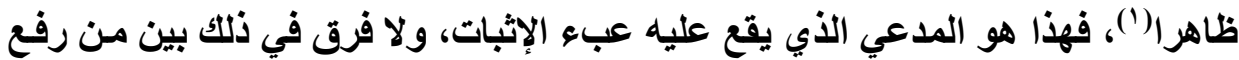
الاعوي ومن رفعت عليه الدعوي)("). لقد أثارت مسألة تحديد من يقع عليه عبء الإثبات في دعوي الاسترداد خلافا كبيرا في الفقه والقضاء، فهل يقع علي المسترد عبء إثبات ملكيته للأموال المحجوزة؟؟ أم يقع علي الائن الحاجز عبء الإثبات أن المنقولات المحجوزة تقع في ملكية المدين

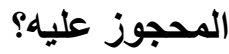

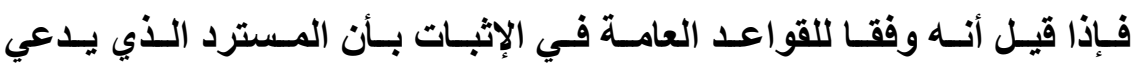
ملكيته للمنقولات المحجوزة يقع عليه عبء الإثبات، فإن ذلك يؤدي إلى إساءة استعمال الائن لحقه في التنفيذ، إذ يمكن أن يقوم بتوقيع الحجز علي أي مال سواء كان مملوكا للمدين أو للغير، ويقع علي هذا الأخير بعد ذلك رفع هذا الحجز الذي وقع، ولا شـأن لـه

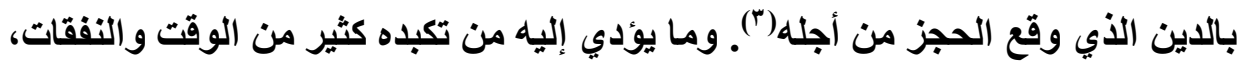

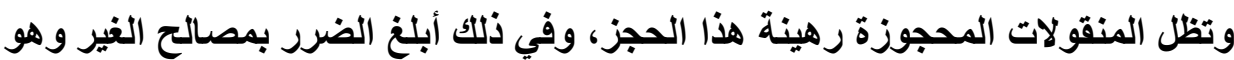
ما لا يتفق مع اعتبارات العدالة، إذا قلنا باتتفال عبء الإثبات إلى اللائن الحاجز، فعليه 
إثبات ملكية مدينة للمنقولات التي حجز عليها، فلا شك أن هذا الأمر شـاق وعسير لـه، إذ ليس من السهل عليه أن يقدم هذه المستندات، وكيف يحصل عليها وهي ليست تحت

$$
\text { (') }
$$

لقــ ذهـب الفقـهـه إلسى وضـع حـلا للإثبـات في دعـوي الاسـترداد هـو الاسـتناد علي الحيازة، التي تحدد من يقع عليه عبء الإثبات، وأساس ذلك ما نصت عليه المسادة ب 9 9 مدني من أن "من كان حائزا للحق اعتبر صـاحبه حتي يقوم الدليل علي عكس ذلكت".

لكن الاستناد إلى الحيازة ليس من السهل والبساطة في كل الأحوال بحيث يمكن الاعتماد عليها في تحديد عبء الإثبات، إذ أنه قد يبدو سهلا في حالة ما إذا كان الوضع الظاهر يال علي أن المنقولات الموجودة في حيازة المدين مملوكة له، إلا أن الامر يدق في حالة مـا إذا كـان الظـاهر يدل علي أن المنقولات الموجودة في حيازة المدين غير مملوكـة لـه، وتثثار الـصعوبة أيـضا فـي حالـة اشـتراك أكثر مسن شـخص في حيـازة المنقولات، كما في حالة الحيازة المشتركة.

\section{لذا يمب التفرقة بين الفروض الآتية:}

\section{الفرض الأول: إذا كان المنقول في حيازة المدين بمفردة وقت المبز:}

في هذا الفرض يوجد المنقول في حيازة المدين بمفرده وقت الحجز، فعلي من

يقع عبء الإثبات الملكية في هذه الحالة، في الواقع يجب التفرقة بين الحالات الآتية: 
الهالهة الأولي: إذا كـان الظـاهر يـدل علـي أن المنقـولات الموجـودة في حيـازة المهلين هملوكة له، فإن عبs الإثبات يقع علي عاتق المسترد:

إعمالا لنص المادة ؛ ج 9 مدني والتي تنص علي أن من يحوز المنقول حيـزة

مادية يفترض فيه أنه يحوزه حيازة قانونية، ومن يحوز يفترض فيه أنه مالكه ما لم يقم الاليل علي العكس، فإذا أراد المسترد إثبات خلاف الظاهر انتقل إليه عبء الإثبات، إذن

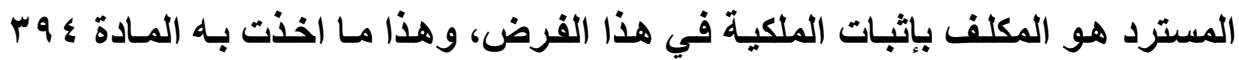
مرافعات، والتي أوجبت أن تثتمل صحيفة الدعوي علي بيان واف لأدلة الملكية('). يمكـن للمسـترد إثبــات الملكيــة بإثبــات التـصرف التــانوني الـــي يعطيـه

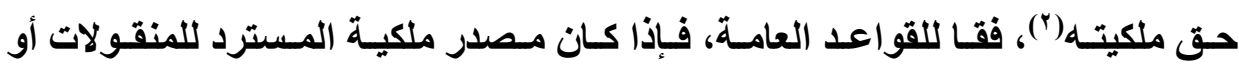
حقـه عليهـا هو واقعـة ماديـة، فيجوز لـه إثباتها بجميع طرق الإثبات(")، أمـا إذا كـان

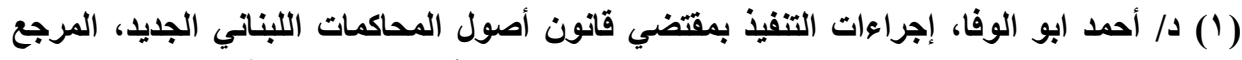

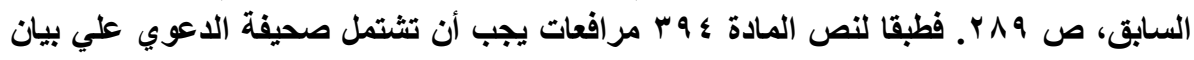

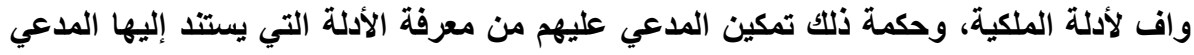

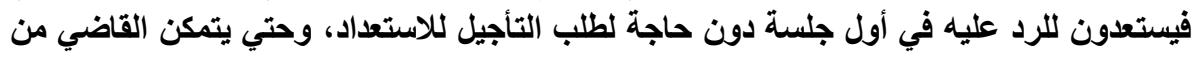

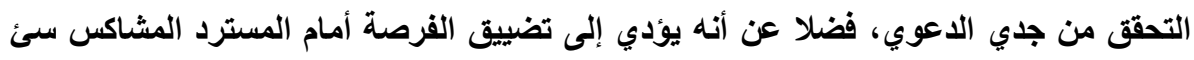

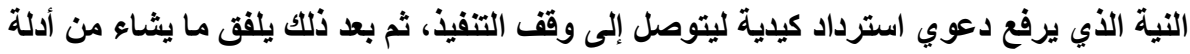

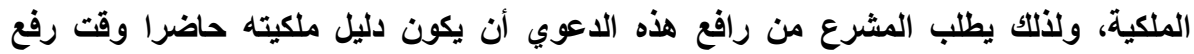

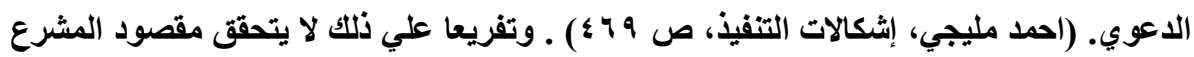

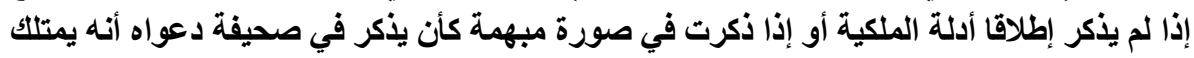

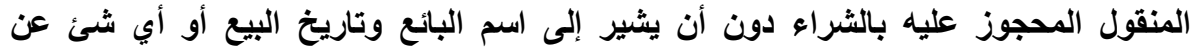

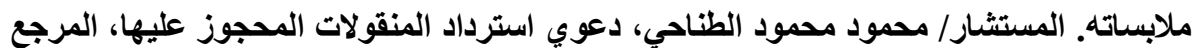


مصدر الملكية تصرفا قانونيـا، فـلا يجوز لله إثباتـه إلا بالكتابـة، إذا كانت قيمـة هذا التصرف تتجاوز نصاب الإثبات بثهادة، أو كان غير محدد القيمة، أو كان إثباته يخالف الثابت بالكتاب، وذلك مـا لم تتوافر في حقه حالة من حالات جواز الإثبات بالشهادة استثناء.

كما يمكن للمسترد أن التخلص من هذه القرينة بكافة طرق الإثبات، بأن يثبت حيازته هو للمنقو لات، فيعتبر هو المالك في هذه الحالة ولا يكلف بتقديم أدلة الملكية، و إنما ينتقل عبء الإثبات إلى غيره، أي إلي المدين أو الحاجز ('). وإذا كان الغير قد اكتسب المنقول من المدين وجب أن يكون الدليل ثابت التاريخ قبل

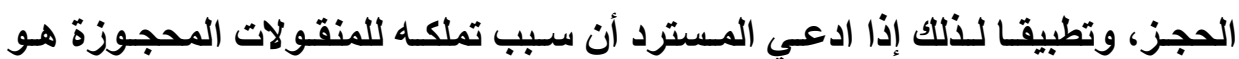
شراؤها من المدين، فإن عقد البيع يجب أن يكون ثابت التاريخ قبل الحجز (؟). الحالة الثانية: إذا كان الظاهر يال علي أن المنقولات الموجودة في حيازة المدين ليست مملوكه له، فإن عبء الإثبات يقع علي عاتق الدائن الحاجز: في الواقع، إلقاء عبء الإثبات علي عاتق المسترد يفترض أنه يدعي خلاف الظاهر، فإذا كان الظاهر أن المنقولات الموجودة في حيازة المدين ليست مملوكة لـه،

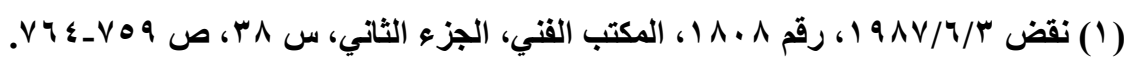

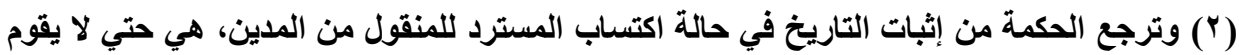

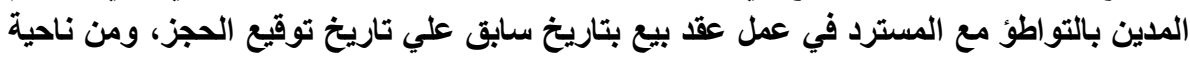

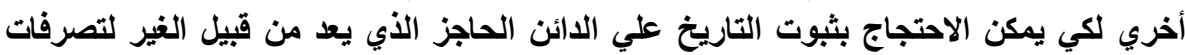


فإنه يكفي أن يثبت المسترد هذا الظاهر وعندئـ يقع علي عاتق الحساجز عبء إثبات ملكية المدين للمنقولات المحجوزة (')

حيازة المدين للمنقول ليست دائما قرينة علي الملكية، إذ إن هذه القرينـة قرينة بسيطة، ومن ثم فليس هناك ما يمنع أن تنفصل مسألة الملكية عن مسألة الحيازة، ويقع عبء الإثبات علي ملكية المدين للمنقولات التي يحوزها علي عاتق الدائن الحاجز، كما في حالة أن يوقع الحجز علي مدين صاحب محل أو مصنع لإصلاح أجهزة، فالظاهر يدل في هذه الحالات أن المنقولات المحجوز مملوكة للعملاء. ويري بعض الفقه أنه يمكن التمبيز بين حالتين: الأولي: إذا كان العقار الموجود بـه المنقولات المحجوزة ملكـا للمدين أو مستأجرا باسمه، فانـه يعتبر حسائزا لها، بـل المشرع يفترض أنه المالك إلى أن يثبت العكس، فالمادة ؛ ج 9 مدني تنص علي أنه من كان حائزا للحق اعتبر صاحبه حتي يقوم الدليل علي العكس، ومن ثم يقع عبء إثبات الملكية علي المسترد في هذه الحالـة. الثانيـة: إذا كـان العقار الموجود بـه المنقولات المحجوزة ملكا للمسترد- لا للمدين أو مستأجرا باسمه، فالمفروض أن الحجز يقع علي مال في حيازة الغير، وللأخير رفع دعوي بطلب بطلان الحجز (†)، وبالتالي يقع عبء الاثبات علي عاتق الحاجز.

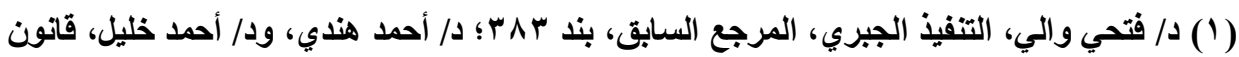
التنفيذ الجبري، المرجع السابق ص ص • ؛ ه. (r) د/ أحمد ابو الوفا، إجراعت التبفيذ الترجيذ بمقتضي قانون أصول المحاكمات اللبناني الجديد، المرجع

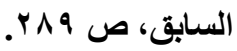

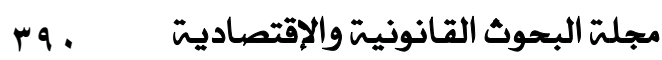


الفرض الثاني: إذا كان المدين والمسترد يحوزان المنقول حيازة هشتركه:

تثير مسسألة الإثبـات في دعوي الاسـترداد صـوبة بالنسبة لحسالات الحيـازة المشتركة، فما الحكم مثثلا إذا حجز دائن الزوج علي منقولات الزوجية الموجودة في منزل الزوجيـة، ورفعت الزوجـة دعوي استرداد، فهـل يمكنـه أن تستفيد مـن الوضـع الظاهر، وتلقي بعبء الإثبات العكسي علي الحسجز؟ فـإن لـم يقدم الدليل علي أن مدينهـ هو مالك للأثياء أو هو حائزها بنية التملتك، خسر الدعوي ولو لم يثبت المسترد من ناحيته أنه مالكك.

يلاحظ أن الحيـازة في هذه الحسالات يـشوبها نـوع مـن اللبس والغمـوض، لأن ضابط الحيازة لا يصلح قرينة علي الملكية، لأن كل منهمـا يعد حسائزا، وبالتـالي يستفيد من الوضع الظاهر المستمد من الحيازة. لقد اختلف الفقه والقضاء في حالة الحيازة المشتركة وينحصر هذا الاختلاف في

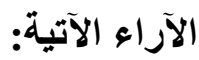

\section{الرأي الأول: عبs الإثبات يقع علي الدائن الحاجز:}

يذهب جانب من الفقه ويؤيده جانب من القضاء(') إلى أنه اذا كان الغير المسترد يثترك مع المدين في معيشة واحدة، فيقع عبء الإثبات علي الدائن الحسجز، باعتبار أنه المدعي، ويرمي إلى اقتضاء حقه، فعليه مولاة إجراءات الحجز، عليه إثبات صحة

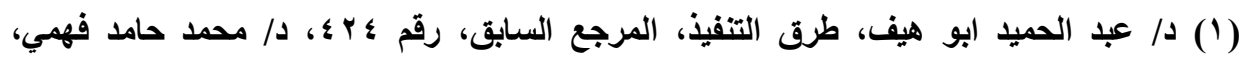

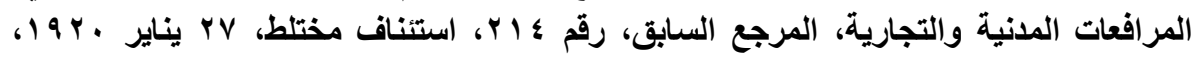

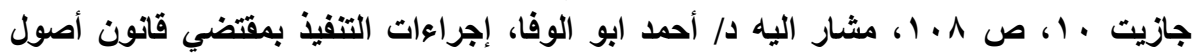

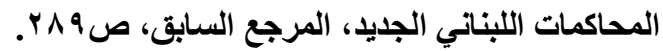


الإجراعات التي اتخذها في سبيل ذلك، فـإن لـم يقدم الدليل علي أن مدينـة هو مالكك المنقولات أو هو حائزها بينة التملك خسر دعواه، ذلك لأن الدائن الحاجز لا يجوز لله أن يقلب عبء الإثبات علي الغير، لاسيما وأن الحجز اجراه الحاجز بنفسه، لذلك يخسر

دعواه حتي ولو لم يثبت المسترد ملكيته للمال المحجوز عليه('). ويستند هذا الاتجـاه علـي أنـه يوجد وضـع ظـاهر لمصلحة الزوجة مستفاد من العرف الجـاري بـأن الزوجة مالكة لأثـاث المنزل(")، فبإذا هي رفعت دعوي الاسترداد فإنها تستفيا من هذا الظاهر، ويقع علي الحاجز عبء إثبات العكس، أما إذا ورد الحجز علي منقولات، مـا جري العرف علي شراء الزوج لها كـالأجهزة الكهربائية والمكتبة مثلا، فإن علي الزوجة أن تثبت ملكيتها لهذه المنقولات("). وينبغي ملاحظة أن القرينة القضائية المستمدة من العرف لا يستفيد منها إلا الزوجات المسلمات، وقد ألحق البعض كذلك القبطيات المصريات علي أسـاس مـا جرت بـه العـادة في مصر منـذ وقت بعيد في هذا الشأن(؛)، ولا يستطيع أحد غير الزوجـة الاستفادة من هذا العرف، فليس لوالديها أن يستفيدا، وليس للمرأة التي تعيش مع المدين في غير علاقة زواج أن تسفيد مـن هذه القرينـة، كذلك لا تستفيد من العرف

(1) د د محد محمود فهمي، تنفيذ الأحكام والسندات التنفيذية والحجوزات التحفظية، المرجع السابق،

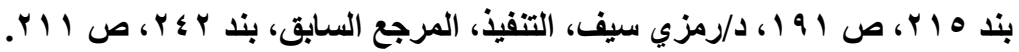

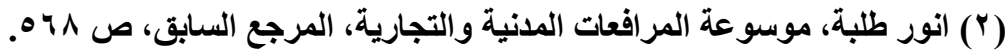

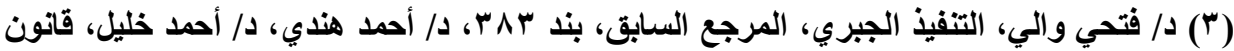

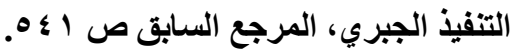

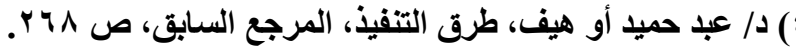


الزوجة التي لا تقيم مع زوجها في منزل منفصل للزوجة، كما لو كانت تقيم مـع والدها أو والا زوجها، وتوقع الحجز علي المنقول بالمنزل(')

\section{الرأي الثاني: التزام الغير المسترد بالإثبات:}

يذهب أنصار هذا الرأي إلى أن الغير يلتزم بإقامة الدليل علي ملكيته للمنقولات، وله أن يثبت ذلك بكافة طرق الإثبات(؟)، إذ إن الحاجز عندما قام بالحجز علي المنقولات الذي يـاعي الغير ملكيتها، لـم يرتكب ثمـة خطأ، لأن هذه المنقولات كانت في حيـازة

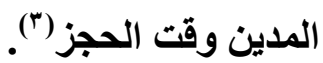

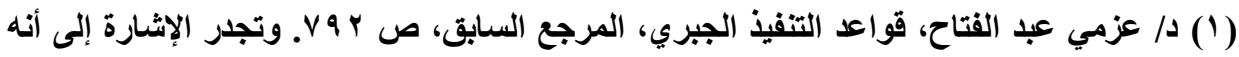

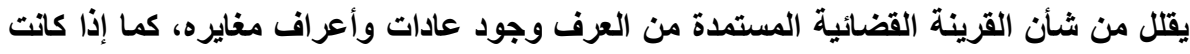

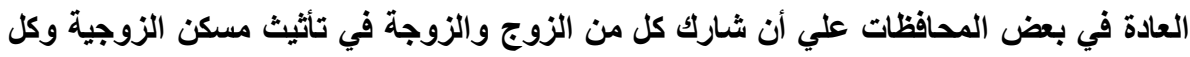

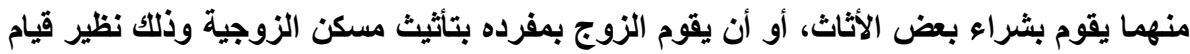

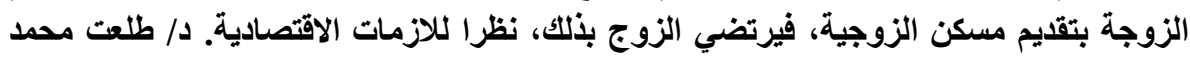

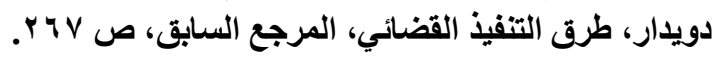

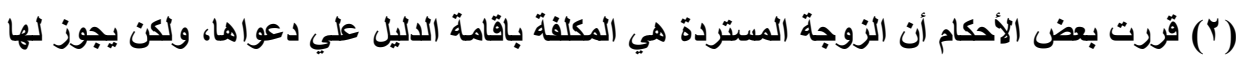

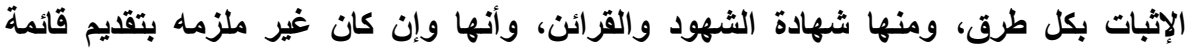

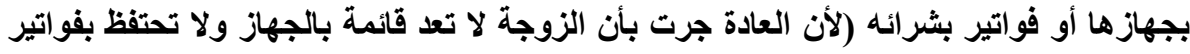

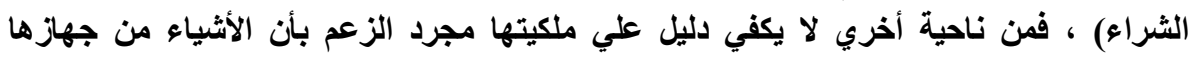

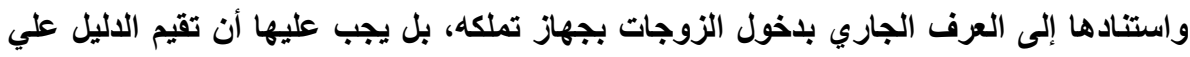

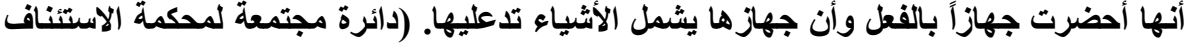

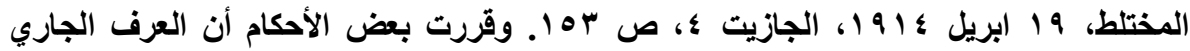

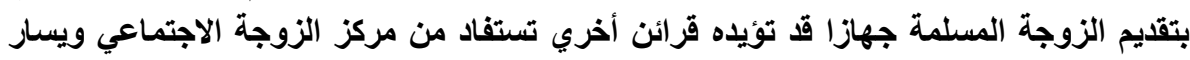

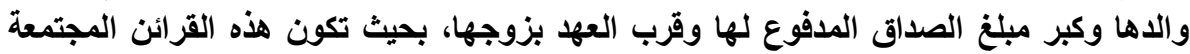
كافية لثبوت الملكية للزوجة، ويترك الامر لتقدير المحكمة بحسب الظروف، ولثها أن تطالب الزوجة

بقرائن أخري تؤيد ملكيتها.

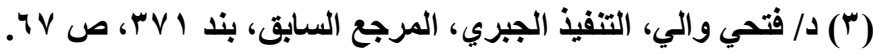


ويرجع أساس هذا الرأي إلي أنه في حالة الحيازة المشتركة يجب ألا يستفيد أحد

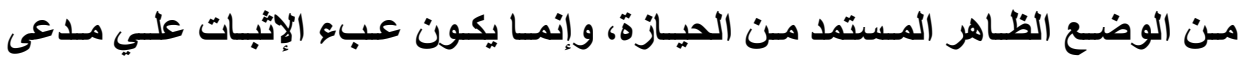
الاسترداد، إلا إذا وجد وضع ظاهر آخر يقلب عبء الإثبات. ويري البعض أن هذه قرينـة ملكيـة الزوجـة للأثناث، ليست كافيـة، وأنـه يجب إضافة قرائن أخري إليها لإثبات حقها، فالمسترد يقع عبء الإثبات ملكية المنقولات في جميع الحسالات الحيـازة المشتركة بـين المـدين والمسترد، حتـي المنقولات الزوجيـة المحجوز عليها بمنزل الزوجية، لأن القرينة القائمسة علي أن العرف جري علي دخول

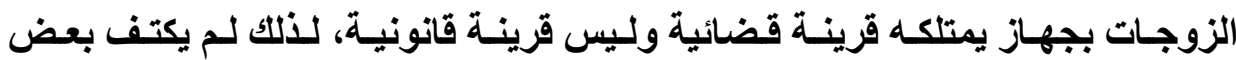
الفقه و القضاء بهذه القرينة، إنما استوجب أن تعززها قرائن أخرى تستقيد من مركز الزوجة الاجتماعي ويسار والدها بالمقابلة بحال الزوج، وقرب العهد بـالزواج بحيث لا يكون الزوج قد قام بتغير أثـاث المنزل أو أضساف إليهه الكثير، ومبلغن مهرهـا، وكذلك سكوتها فترة طويلة بعد الحجز قبل أن تفرع دعوي الاسترداد، وبطبيعة الحال يمكن الاستغناء عن كل هذه القرائن وإثبات الملكية عن طريث تقديم فواتير الشراء أو قائمـة

ونـري أنـهـه في حالـة الحيـازة المـشتركة، فيكفي الغيـر الاسـتـاد إلـى الحيـازة المشتركة، لكي ينتقل بعد ذلك عبء إثبات العكس علي عاتق الحاجز أو المحجوز عليه، وعلي المدعي أن يقرن دعواه بأدلة الإثبات الوافية لحيازته للمـال، لأن الحاجز يجب عليه أن يحجز علي مال مملوك للمدين وليس علي مـال الغير أو في حيـازة الغير، أمـا وسـائل الإثبات فتنطبق القواعد العامـة في قـانون الإثبات، فعبء الإثبـات ينتقل إلى الحاجز أو إلى المحجوز عليه أو الحساجزين المشاركين في الأحوال التي تكون حيازة 
المال فيها مشتركه بين مدين وطالب الاسترداد وأشخاص أخرين، لأن حيازة كل منهم

تعتبر حيازة غامضة' (1).

\section{الفرض الثالث: إذا كانت المنقولات في حيازة غير المدين:}

وفي حالة كون المنقولات في حيازة غير المدين، فإن طريق الحجز في هذه

الحالة هو حجز ما للمدين لدي الغير، ويري البعض أنه يستطيع حائز المنقولات رفع دعوي ببطلان الحجز دون حاجة إلي اللجوء إلي رفع دعوي استرداد، ولا يتطلب الأمر إثبات ملكيته للمنقولات، بل يكفي إثبات أن المنقولات في حيازته، وليست في حيازة

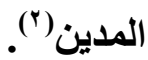

يثور التساؤل بالنسبة لإقرار المدين بحق الغير(")، فهل يكون نافذا في مواجهة الحاجز؟، وهل يعد دليلا كافيا علي الملكيةج يجمع الفقه علي أن الاقرار لا يسري في لهي

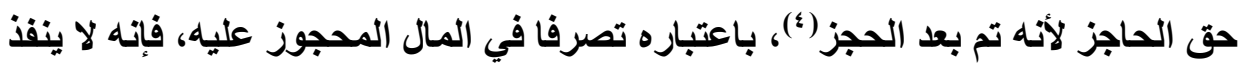

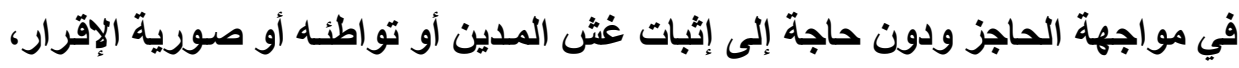
فهذا هو مصير كل تصرفات المدين بعد الحجز. أمسا الإقرار الصادر لصالح الغير قبل

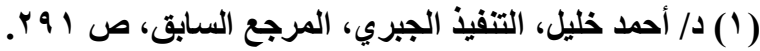

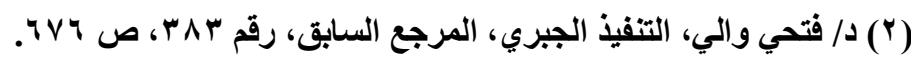

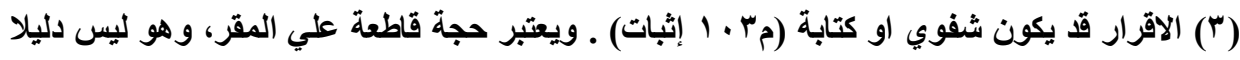

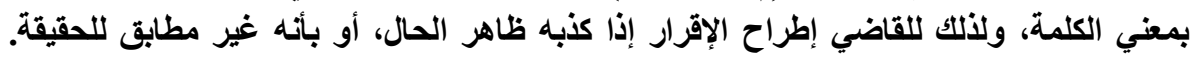

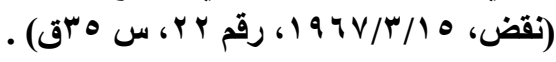

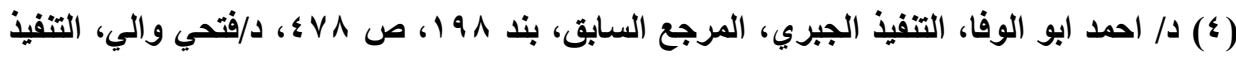

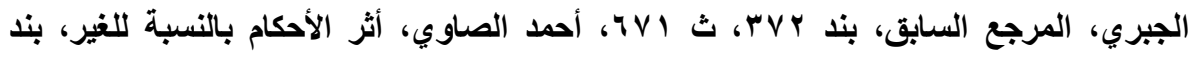


الحجز فيسري في مواجهة الحاجز وفقا لقواعد القانون المدني، إلا إذا أثبت الدائن

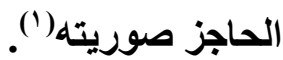

أما في العلاقة بين المدين والغير فلإقرار حجيته كاملة|(+)، ويناء علي ذلكك إذا

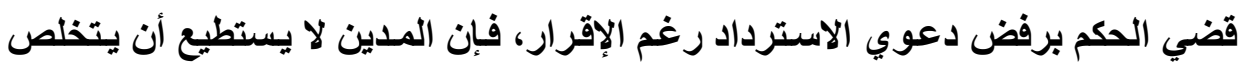
من نتيجة إقراره بالنسبة لعلاقته بالغير إلا إذا أثبت صوريته(ب). ويثار التساؤل عن مدي جواز توجيه المسترد اليمين الحاسـمة إلى اللدائن

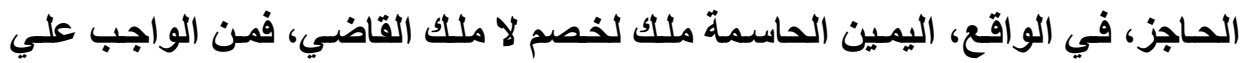

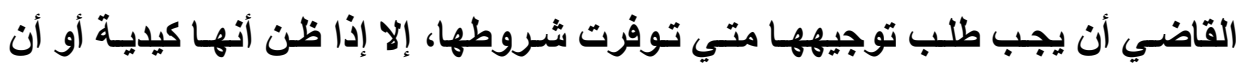
الخصم متعفف في توجيهها، فله أن يمتنع عن توجيه اليمين.

(1) د/ احمد السيد صاوي د/ اسامة المليجي، الإجراءات المدنية للتنفيذ الجبري، المرجع السابق،

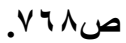

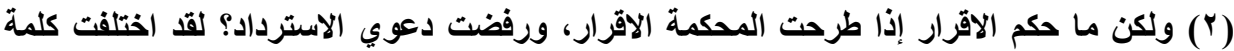

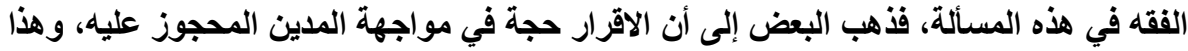

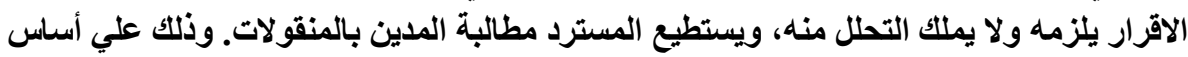

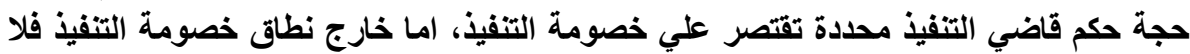

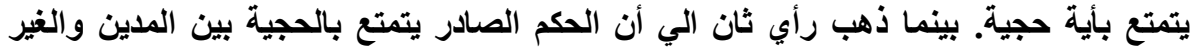

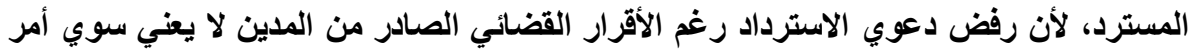

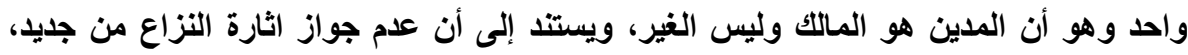

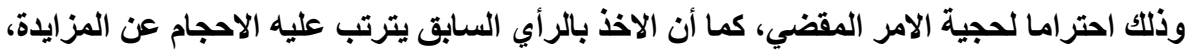

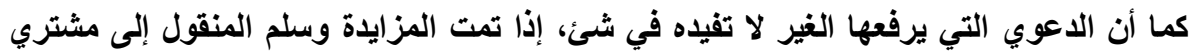

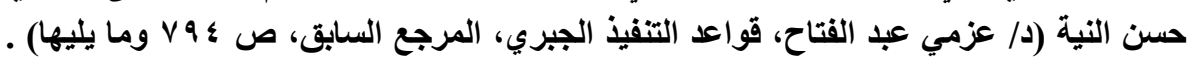

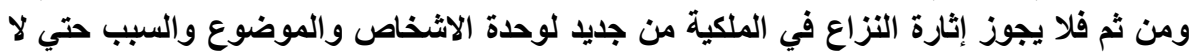
تهذر حجية الحكم الصادر في دعوي الاسترداد.

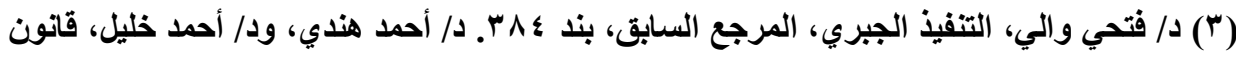

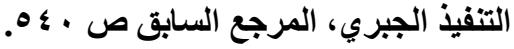


لا يجوز للمسترد توجيه اليمين الحاسمة للدائن الحسجز أو اللائنين الحسجزين

المتدخلين، لأن اليمين الحاسمة ليست حاسمة في هذا الشأن لأن ملكية المحجوزات بتنازعها شـص آخر هو المدين، إلا في فرض واحد وهو إذا كـان المـدين قد سـلم للمدعي- المسترد- بملكيته للمحجوزات(')

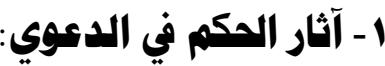

الحكم الصادر في دعوي الاسترداد حكما موضوعيا يحسم النزاع علي أصل

الحق، وإذا انتهت المحكمة إلي أحقية المدعي المسترد في المنقولات المحجوزة فإنها تحكم له بالملكية، وببطلان الحجز، وقد يتضمن حكمـا ضمنيا بإلغاء الحجز، وإذا تبين لها عدم أحقية المدعي في المـال المحجوز، فإنها تقضي برفض طلب الملكية، ودون بحث مدي صحة الحجز، ويكون الحكم الصادر في الدعوي حجة علي من اختصم فيها، فإذا لم يختصم بعض الحاجزين لم يكن للحكم حجية في مواجهتهم.

ويقبل الحكم الصادر في دعوي الاسترداد الطعن عليهه بالاستئناف، حيث أن المشرع نص في المـادة rVV مرافعات علـي أنـه "تستأنف أحكام قاضسى التنفيذ فى المنازعات الوقتية و الموضوعية أيا كاتت قيمتها أمام المحكمة الابتدائية". سنشبير إلى آثار الحكم بقبول الدعوي، وآثار الحكم برفض الدعوي، وذلك في

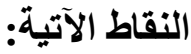




\section{ا - أثر المكم بقبول دعوي الاسترداد:}

إذا حكم بقبول الدعوي، فـإن الحجز يزول عن المنقولات المحجوزة، ولكن مـا الحكم في حالـة قبـول دعوي الاسترداد بعد زوال الآثر الواقف للدعوي، و تـم بيع

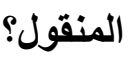

\section{البيان حكم هذه الفرض يجب التمييز بين الحالات الآتية:}

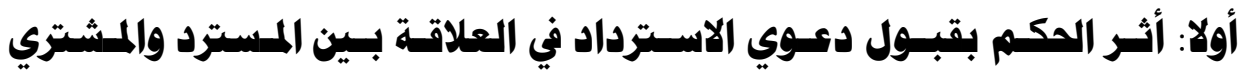

$$
\text { الراسي عليه المزاد: }
$$

في هذا الفرض يمكن للمشتري إذا كان حسن النية أن يتمسك بقاعدة الحيازة في المنقول سند الملكية، وبالتالي لا يستطيع الغير التنفيذ في مواجهته بتسلم المنقول، والمشتري يستتد لحقه علي محضر البيع الذي اشتري بمقتضاه تلك الأشياء('). ولكن إذا كان المشتري سـئ النيـة، فللغير الحق في استرداد المنقولات، كمـا يمكن الاسترداد في حالة السرقة أو كاتت ضائعة من مالكها، وذلك خلال ثلاث سنوات. ثانيا: أثر المكم بقبـول الدعوي في العلاقة بين المسترد والمدين والحاجزين: سنفرق هنا بين مجموعة من الافتراضات:

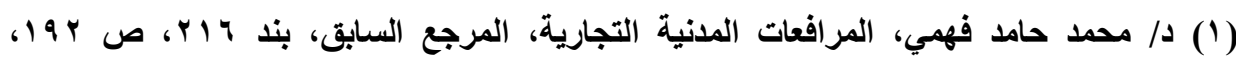

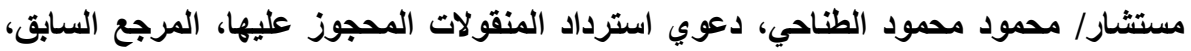




\section{الفرض الأول: إذا تم البيع ولم يوزع الثمن:}

يجمع الفقه علي استرداد الثمن(')، ويمكن للمحكمة أن تحكم بايداع الثمن خزانة

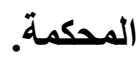

الفرض الثاني: إذا تم البيع وتم التوزيع:

فيمكن التنفيذ بطريق التعويض، لاستحالة التنفيذ العيني، وذلك بالرجوع علي المدين، باعتباره أثراً بقدر ما سدد من ديونه على حساب الغير، ولكن كثير ما لا يجدي

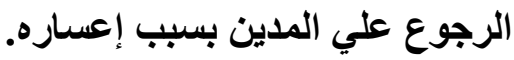

فهل يجوز الرجوع علي الحاجزين: علي أساس رد ما دفع بغير سبب؟

اختلف الفقه في هذه الحالة، فذهب رأي من الفقه إلى عدم جواز الرجوع علي

الدائنين لأنهم لم يثروا بدون وجه حق فما قبضوه هو استيفاء لحقوقهم الثابتة(").

فبينما ذهب رأي آخر إلى جواز الرجوع، وإن كان لهم الدق في استيفاء ديونهه إلا أن هذا الوفاء يجب أن يكون من مال مدينهم، الأي أثراء بلا سبب مشروع، ولو لم يتصور ثمة خطأ في حقهم، لو كانوا حسني النية(")، حيث يتو افر شروط الإثراء، والتي

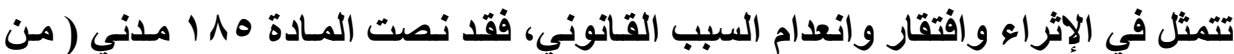
تسلم علي سبيل الوفاء ما ليس مستحقا لله وجب عليه رده، وحتي لو كان حسن النية،

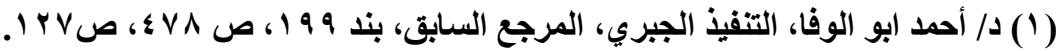

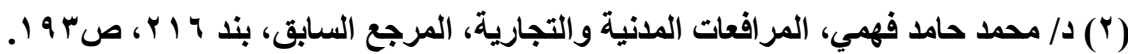

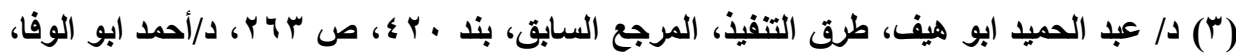

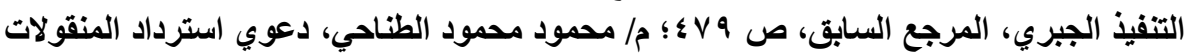

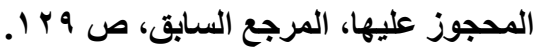


وكذلك نصت المادة ؟ 1 ا مدني علي أنسه ( لا محل لاسترداد غير المستحق إذا حصل الوفاء من غير المدين وترتب عليه أن الدائن، وهو حسن النية، قد تجرد من سند الدين أو مما حصل عليه من التأمينـات أو ترك دعواه قبل المدين الحقيقي تسقط بالتقادم، ويلتزم المدين الحقيقي في هذه الحالـة بتعويض الغير الذي قـام بالوفـاء" ويمفهوم

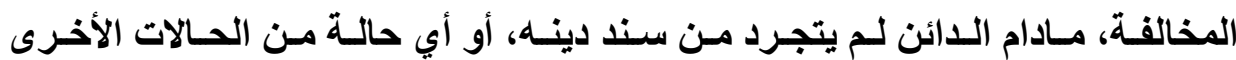
المنصوص عليها في المادة، فإن عليه رد ما دفع له بغير حق، فإن كـان تجرد م سنده، فإن المدين يلتزم بتعويض المحكوم له في دعوي الاسترداد(').

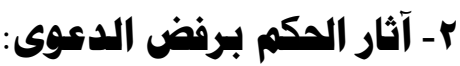
قد يحكم القاضي برفض دعوي الاسترداد وذلك لعدم اطمئنانه للأدلة التي قدمت من المسترد، كما لو قدم صوراً من فتورة الشراء ولم يقدم الأصل، أو عدم اطمئنـان القاضسي لشهادة الشهود، فـإذا رفض دعوي الاسترداد يعتبر حكمسا صسادرا لـصالح الحاجز، لذا يمكن للحاجز أن يطلب بالنفاذ المعجل، ويلاحظ أن النفاذ المعجل ليس بقوة القـانون ولكن بحكم القاضس، ويجوز شـول الحكم بالنفــاذ المعجل في جميع الأحول سواء كان الحكم بعدم قبول المنازعة او بعدم الاختصاص أو بطلان صحيفتها أو غير ذلك من حالات زوال الخصومة، وذلك لعموم نص القانون()، وحكمة هذا النص محاولة تفادي الآثار المترتبة علي مشاكسة الغير أو المنفذ ضده.

(1) المستثار/ محمود محمود الطناحي، دعوي استرداد المنقولات المحجوز عليها، المرجع السابق،

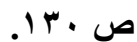

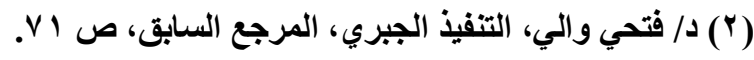


وفي حالة الحكم برفض دعوي الاسترداد يحكم بالغرامة، فقد نصت المسادة VQ مرافعات علـي انـه إذا خسر المسترد دعواه جـاز الحكم عليهه بغرامـة لا تقل عن مائة جنيه ولا تزيد علي أربعمائة جنيه تمنح كلها أو بعضها للائن، وذلك مـع عدم الإخلال بالتعويضات إذا لها وجـه(')، فيمكن للحاجز الرجوع بالتعويضات إن ترتب علي وقف

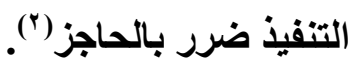
وترجـع الحكمـة مـن هذا النص هـي الحرص المسشرع علـي توجيـه الخصوم للحد من الاعاوي الكيدية، وذلك بمعاقبة المسترد سيئ النية الذي يرفع دعواه بقصد وقف إجراءات التنفيذ، ويري بعض الفقه أن الحكم بالغرامة سالفة الأكر لا يكون إلا في

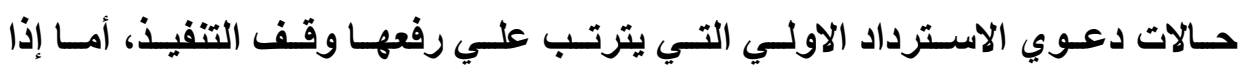
كانت إجراعات التنفيذ وقفت نتيجة لصدور حكم من القاضسي بهذا الوقف، ثم خسر المسترد دعواه، فلا يجوز الحكم عليها بالغزامـة، لأن إخفاق الخصم في دعواه ليس موجبـا لمسئوليته و الغرامسة أعمـالا لهذه المسئولية(") ونـري أن النص جـاء عامـا، فيطبق الجزاء علي جميع دعاوي الاسترداد سواء كانت الدعوي الاولـي أم الدعاوي التالية، كما أن الحكمة من الجزاء متوافره في جميع دعاوي الاسترداد، وهي الحد من رفع الدعاوي الكيديـة، والحكم بالغرامـة يمكن في كل حالـة خسر المسترد الدعوي حتـي دون الفـصل فـي الموضـوع، وهـو جـوازي للقاضـي، ويمكن للـائن أن يطلب بالتعويض.

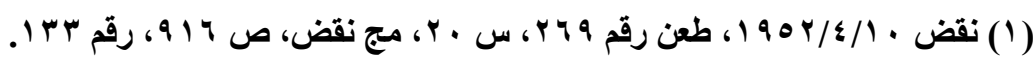

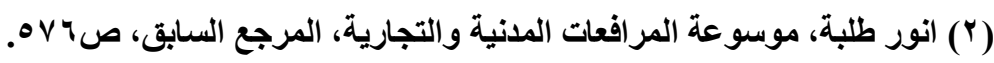

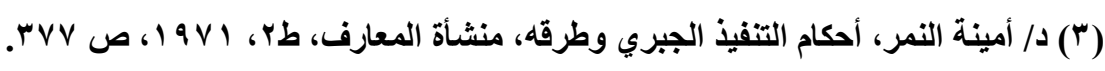


ولقد اختلف الفقه في طبيعة الغرامة، ذهب البعض إلى أنها نوع من الجزاء

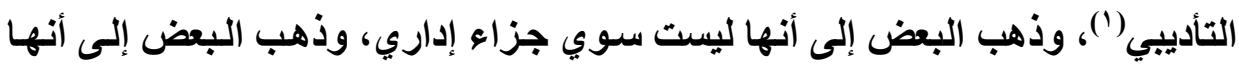
تعد عقوبة، وذهب رأي إلي أنها ذات طبيعة جزائية إجرائية تفرض علي الخصوم الذين

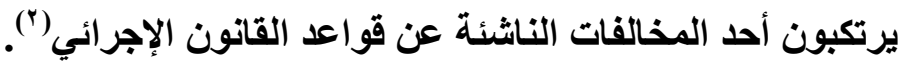

\section{المطالب الثاني \\ دعوي استحقاق العقارات العجوزة}

دعوي استحقاق العقار المحجوز هي دعاوي موضوعية يرفعها مدعى ملكية العقارات المحجوزة طلبا فيها الحكم لله بملكيتها و إلغاء الحجز الموقع عليها؛ فهي لهي ادعاء بتخلف شرط من شروط التتفيذ ألا وهو ملكية المدين للمال المحجوز عليه، وهذه دعوي متعلقة بالتفيذ، وترفع بعد توقيع الحجز وقبل البيع. فهذه الدعوي يرفعها الغير أثنـاء إجراءات التتفيذ علـي العقـار للمطالبـة بتقريـر ملكيته للعقـار أو الحق العينـي

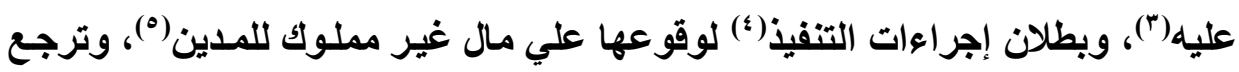

(1) د/ ابراهيم امين النفياوي، مسئولية الخصم عن الاجراءات، رسالة دكتوراه، كلية الحقوق- جامعة

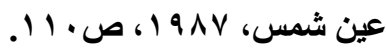

(r) د/ سيد أحمد محمود، د/ يوسف يوسف ابو زيد، التقاضي بقضية ويدون قضية في المواد المدنية

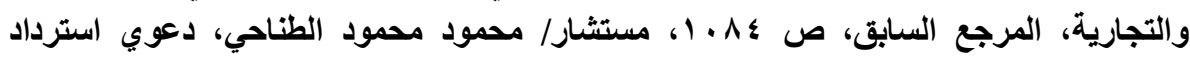

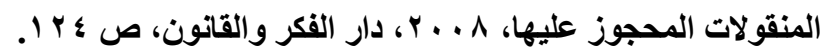

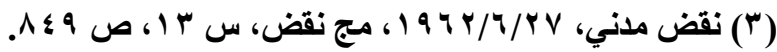

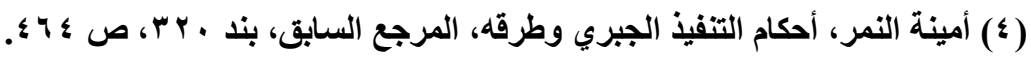

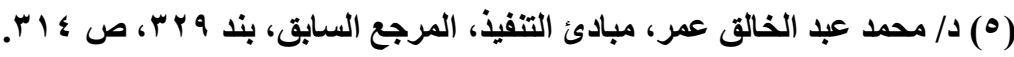


تسمية الدعوي بالاستحقاق الفرعية، إلى أن طلب استحقاق العقار المحجوز متفرع عن

التنفيذ، ومقترن بطلب بطلانه (')

والفرض الأي أراد المشرع أن يوجهه بهذه الدعوي يتمثل في أن حجزا قد وقع

علي عقـار غير مملوك للمدين المحجوز عليه()، ولذلكك بـات من الضروري حمايـة المالكك الحقيقي لهذا المـال، وهذه اللدعوي هي صسورة مـن صور الحمايـة القضائية الموضوعية التقريرية(")

وقـد أورد المسشرع القواعد الخاصـة بـدعوي الاسـتحقاق الفرعيـة في المـواد

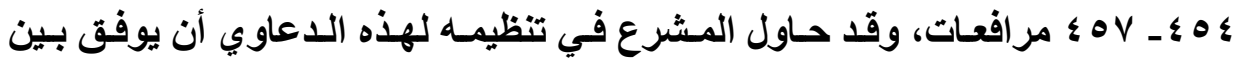
مصلحتين متعارضتين: المصلحة الاولي: مصلحة من يرفع هذه اللدعوي وذلك بمنح القاضي سلطة في وقف التفيذ إذا رفعت مستوفاة لثروطها حتي لا يتم بيع العقارات، والمصلحة الثانية: هي مصلحة الحاجز الذي سوف يضار من وقف التنفيذ الذي يترتب علي رفع هذه الدعوي الذي قد يتبين عدم صحتها، ومن ثم فقد أورد المشرع إجراعات خاصة لهذه الاعوي تميزها عن غيرها من المنازعات الموضوعية(؛)، حيث اشترط أن يقدم الغير كل ما لاية من مستتدات لتأييد دعواه. سنشير إلى شروط دعوي الاستحقاق، وآثارها وذلك في الفروع الآتية:

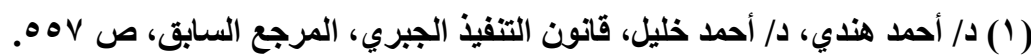

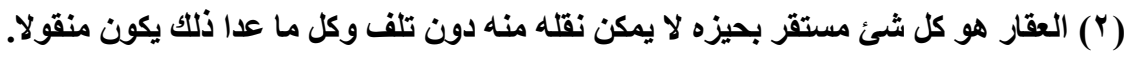

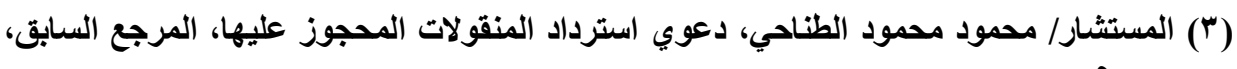




\section{الفرع الأول \\ شروط دعوي الاستمقاق الفرعية}

قد يبدوا غريبا أن يتم الحجز علي عقار غير مملوك للمدين، وذلك لأنه لا يحجز علي العقارات إلا بعد الاطلاع علي سجلات الثهر العقاري، والتي تمنـع الخطأ بالنسبة لما يملكه المدين، إلا أنه قد يحدث خطأ عند النقل من السجل أو قد يحدث تفسير مختلف لما في هذا السجل، لذا حمي المشرع مالك العقار بدعوي الاستحقاق الفرعية. ويمكن تقسيم شروط دعوي الاستحقاق إلى شروط متعلقة بالنطاق الموضوعي، وشروط متعلقة بالنطاق الشخصي، وشروط متعلقة بالنطاق الزماني، وذلك علي النحو التالي: - n

\section{أولا: الشروط المتعلقة بالنطاق الموضووي:}

دعوي الاستحقاق الفرعية، هي دعوي موضوعية يرفعها الغير- أثناء التنفيذمدعيا ملكية العقار المحجوز عليه طالبـا تقرير حقه علي العقـار أو جزء منـه، وكذلك بطلان إجراءات التنفيذ (لوقوعه علي مسال مملوك للغير)، وذلك بعد بـدء التنفيذ علي

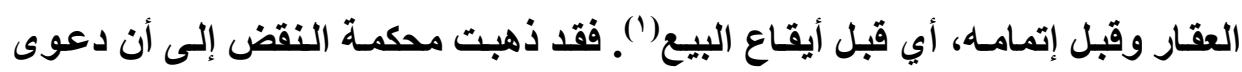
الاستحقاق يكون محلها المطالبة بملكية عقار ().

يجب لقبول دعوي الاستحقاق الفرعية أن تتضمن الاعوي طلبين، الاول: ملكية المال، والثاني: بطلان الحجز، فإذا اقتصرت الدعوي علي أحد الهدفين، فلا نكون بصدد

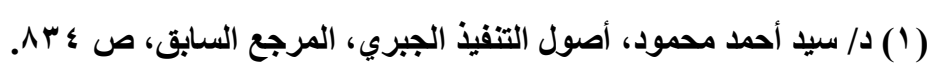

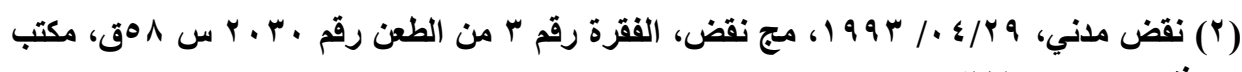

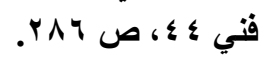

مجلتّ البحوث القانونيت والإقتصاديت 
دعوي استحقاق، فقد نكون بصدد دعوي ملكية أو دعوي ببطلان إجراءات الحجز، ولن تكون مقبولـة لرفعها مـن غير ذي صـفة، وذلتك لعدم تأسيسها علـي ملكيـة العقـارات المحجوزة أو أي حق يتعلق بها كحق الانتفاع|' فالشروط الموضوعية لدوعي الاستهقاق تتضمن الآتي: ا - أن يطلب الغيز هلكية العقار:

الطلب الأساسي في الدعوي، يجب أن تكون الملكية العقار، وبناء علي ذلك ليس للمشتري بموجب عقد بيع غير مسجل أن يرفع دعوي استحقاق إذا شرع دائن البائع في التنفيذ علي العقار المباع باعتباره مملوكا للبائع(؟)، وعلي العكس يمكن لواضع اليد الذي اكتسب ملكيـة العقـار بالتقـادم قبـل تسجيل تنبيـه نـزع الملكيـة أن يرفع دعوي الاستحقاق الفرعية، وإذا كان المطلوب هو ملكية، فيستوي بعد ذلك أن ترفع الدعوي بطلب ملكية العقار المحجوز كله أو ملكية جزء منه مفرزا أو شائعا فيه("). يجب أن ياعي المدعي بحق ملكية كامل علي العقار، أما إذا كان المدعي يطلب حقا آخر عينيا أصليا كالاتتفاع أو الارتفاق أن تبعيا كـالرهن أو الامتيـاز او الاختصاص

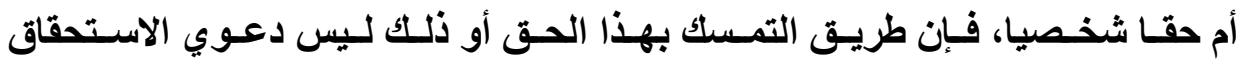
الفرعية(؛)، ويري البعض أنـه يمكن لصاحب حق الاتتفـاع أو الارتفـق في حالـة عدم 
التمسك بحق بطريق الاعتراض علي القائمة أن يرفع دعوي استحقاق فرعيـة(')، وذلك لأنه إذا كان التنفيذ يرد علي حق الانتفـاع، فيمكن لمن يكون لـه حق الانتفـاع أن يرفع دعوي استحقاق فرعية يطالب فيها بتقريز حقه علي العقار ()، ولكن بعض الفقه يري أنـه لا يجوز رفع هذه الدعوي حتي ولو انقضي ميعـاد أبـاء الملاحظـات، لأن البيع الجبري لا يطهر العقـار منـه، ويكون لله منازعة المشتري في حقه، بـأن يرفع دعوي تقرير عادية في مواجهة.

وقد ذهبت محكمة النقض إلي عدم جواز الحجز إلا علي مـال مملوك للأصيل وليس النائب، حيث يلتزم الأصيل بـأداء الديون المترتبـة في ذمته بنـاء علي تصرف النائب عنه، وبالتالي لا يجوز الحجز إلا علي مال مملوك للأصيل وليس النائب(")، واذا أثبتت ملكية الغير للشئ المحجوز عليه كـان الحجز بـاطلاً وتعتبر إجراءات التنفيذ منذ بدايتها باطلة.

\section{r- أن يطلب الغير بطلان إجراءات التنفيذ:}

بالنسبة لطلب بطلان إجراءات التنفيذ فهو طلب تبعي في الدعوي، ولكن لابد منه حتي نكون أمسام دعوي استحقاق فرعية، ويستتد هذا طلب إلى كون العقار غير مملـوك للمحجوز عليـه، ولا يجوز أن يستند إلى سبب آخر للبطلان، فبإذا لـم يطلب

(1) د/ أحمد هندي، د/ أحمد خليل، قانون التتفيذ الجبري، المرجع السابق، ص 9هـه.

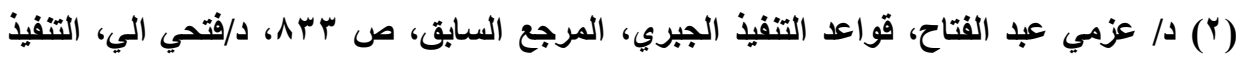

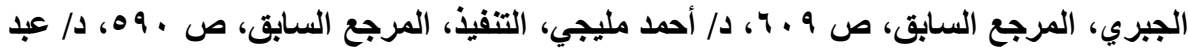

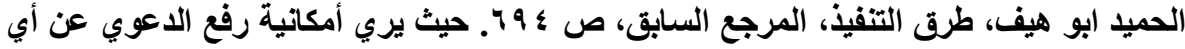
حق عيني.

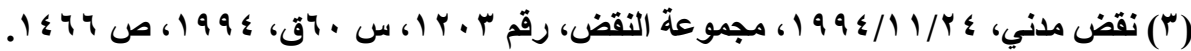


المدعي بطلان إجراعات التنفيذ، فلا نكون بصدد دعوي استحقاق فرعية، بل دعوي استحقاق أصلية"(')؛ وإذا زالت إجراءات التتفيذ لأي سبب، فإنـه لا يصبح هنـآك محل لبطلانها، وعندئذ تتحول الدعوي إلى دعوي استحقاق أصلية، ويجب علي القاضي أن يحكم بعدم الاختصاص والإحالـة، لأن الـدعوي في هذه الحالـة ليست مـن منازعـات التنفيذ؛

إذن يجب أن يطلب الغيـر بطـلان إجـراءات التنفيـذ مـع طلب الملكيـة العقــار المحجوز عليه أو بعضه ولو بعد انتهاء الميعاد المقرر للاعتراض علي قائمة شروط البيع، وذلك بلدعوي ترفع بالأوضاع المعتادة أمام قاضي التنفيذ ويختصم فيها من يباشر الإجراعات والمدين أو الحائز أو الكفيل العيني وأول الائنين المقيدين(؟). يلاحظ أن طلب بطلان إجـراءات التنفيذ طلب منـدمج في الطلب الأول وهـو الملكية، لأن مقتضي الحكم بالمليكة للمدعي، بطلان إجراءات التنفيذ، ويجب أن يستند مسدعي الاسـتحقاق إلـى طلـب الحكـم بـبطلان إلسى تخــف شـرط مـن شـروط التنفيـذ الموضوعية، وهو ملكية المدين للعقار، ومن ثم لا يجوز لـه الاستناد في طلب البطلان إلى سبب أخر كعدم إنذار الحائز أو التخلية. ثانيا: الشروط المتعلقة بالنطاق الشخصي: تتضمن دعوي الاستحقاق الفرعية، طرفين، المدعي، والمدعي عليه، ويجب أن تكون له صفه في التنفيذ. وذلك علي النحو التالي.

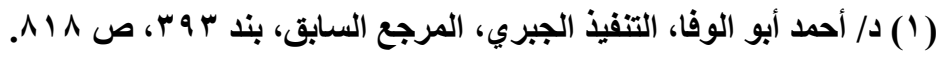

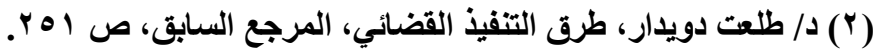


دعوي الاستحقاق هي طريق خصصه المشرع لغير أطراف التنفيذ للاعتر اض علي التنفيذ العقاري، حيث تثبت الصفة في تقديم هذه المنازعة للفير طبقا للمـادة ؛ ه ؛ مرافعات، ويمكن أن يكون الشخص رافع الدعوي متمتعـا بصفتين في نفس الوقت، فيعتبر غيراً، وطرفاً في إجراعات التفيذ، كما لو حجز علي شخص بصفته وليـا علي ابنه ـ فهو طرف في الاجراءاتـ فـادعي هذا الشخص ملكيـة العقار المحجوز بصفته الشخصية، كادعاء مدير الشركة أن العقار مملوكة لـه شخصيا، وكذلك الوارث الذي يستتد إلى حق ذاتي غير مستمد من مورثث. حيث يعتبر في تلكك الحالة الأخيرة من الغير، ولا يقال في هذا المجـال أنـه يبدي كل مالهه بجميع صفاته مرة واحدة بطريق الاعتراض ما دام قد أخبر بإجراءات التنفيذ بإحدى هذه الصفات، إذ في ذلك مصادرة لحقـه في اتخـاذ الوسيلة القانونيـة المناسبة في الوقت المناسب وفقـا لكل صفة من فن

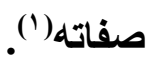

ويلاحظ أن الذي يعتبر طرفا في إجراعات التنفيذ، فوسيلة للتمسك بحق لـه علي العقـار هي الاعتراض علـي قائمـة شروط البيع، خـلال الميعـاد المحدد للاعتراض مـع مراعاة أنه إذا لم يخطر أحد من أطراف التففيذ الذين عددتهم المـادة V Vاء ، فإنـه يعتبر من الغير، ويمكنه أن يرفع دعوي الاستحقاق، ولا يكون الحكم الصادر ببيع العقار حجة

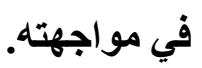
وبناء علي ذلك ترفع اللدعوي الاستحقاق من البائع الذي حكم لله بفسخ البيع لعدم دفع الثمن، لأنه يعتبر من الغير بالنسبة لإجراءات التنفيذ؛ ومن ثم لا يجوز رفعها

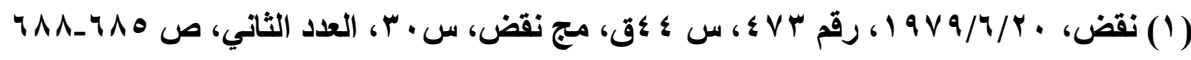


من الدائن المرتهن الأي يدعي أنه يملكك جزعاً من العقار ملكية خاصـة أو واضـع اليد الذي ليس له من الحقوق علي العقار سوي وضع اليد(')، وكذلك لا يجوز رفعها من البائع الذي رفع دعوي الفسخ ولم يحصل علي حكم به.

ا - المدوي عايسه في الدوعوي:

نظرا لأن دعوي الاستحقاق الفرعية تتضمن طلبين، طلب ملكية العقار وبطلان إجراءات الحجز، فقد استوجب المشرع في المادة ؛ ه ؛ مرافعات اختصام كلا من: اــ المدين أو الحائز أو الكفيل العيني إن وجد باعتبـاره الخصم الأصلي في دعوي

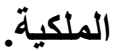

r- الدائن مباثر الإجراعات، وأول الدائنين أصحاب الحقوق المقيدة علي العقار، وذلك باعتباره صـاحب المصلحة الأولي والأهم من هؤلاء الدائنون، حيث أنـه يباشر الإجراءات في حالة إهمال الدائن في تسيير الإجراءات. وإذا كانت القاعدة هي حرية المدعي في اختيار خصومده، إلا أن المشرع خرج علي هذه القاعدة في دعوي الاسـتحقاق، وألزم المـدعي برفع دعواه قبل اشـخاص

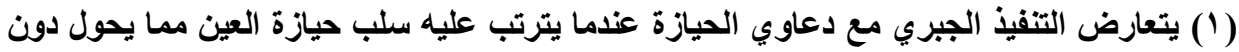

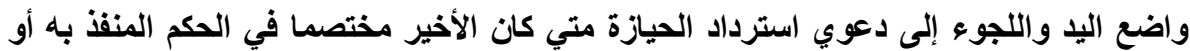

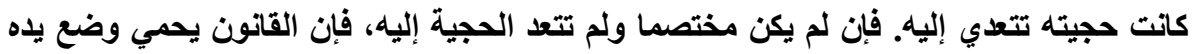

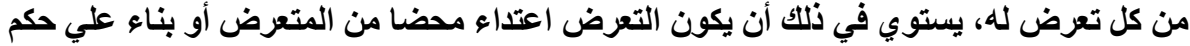

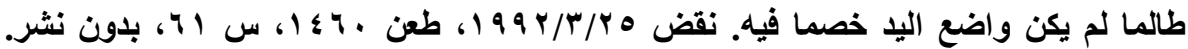

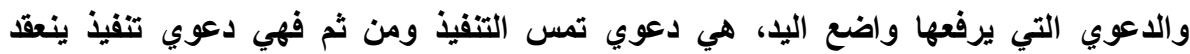

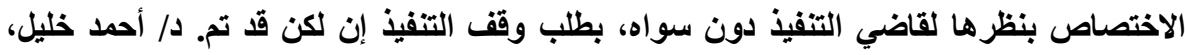

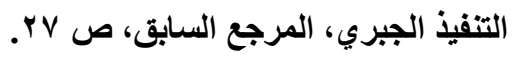


معينين بالذات، وقد ورد ذكرهم في نص المادة ؟ ؟ مر افعات؛ حيث إن صفة المدعي عليه في منازعة الاستحقاق الفرعية تثبت لأطر اف التنفيذ، وذلك أن الغير ينـازع ملكية العقـار ويطلب الحكم بإبطـال إجـراءات التتفيذ عليـه. وكــان المفترض أن توجـه تلكـ المنازعة إلى جميع هؤلاء الأطراف، ولكن المشرع قرر أنسه يختصم فيها من يباشر الإجراءات والمدين أو الحائز أو الكفيل العيني وأول الدائنين المقيدين (مسادة ؛ ؛ ؛)، ولا يغني مخاصمة مباشر الإجراءات عن مخاصمة الأئن المقيد الأول، فإذا كان مباشر

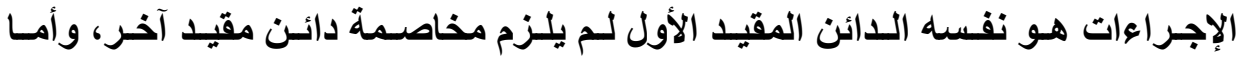
بالنسبة لباقي الـدائنين المقيدين فِان لهم الحق في التدخل في الـدعوي للدفاع عن مصالحهم. ويلاحظ أن المشرع لم يبين جزاء علم اختصام أحد ممن يجب اختصامهم، خلافا لما فعله في دعوي الاسترداد، ويري الفقهـ أن الدعوي لا تؤثر في وقف تنفيذ قياسـا علي دعوي الاسترداد(')، فدعوي الاستحقاق الفرعية تعامل علي أنها دعوي استحقاق عادية، لأن المشرع لم ينص علي جزاء لما نص عليه في دعوي الاسترداد، ولا وجـه للقياس لاختلاف الدعويين في أمور كثيره(×)، والإجماع منعقد علي أنه لا يترتب علي عدم الاختصام ممن يجب اختصامهم بطلان أو عدم قبول، و إنما الحكم الصادر لن يكون حجة إلا علي من اختصم فيها").

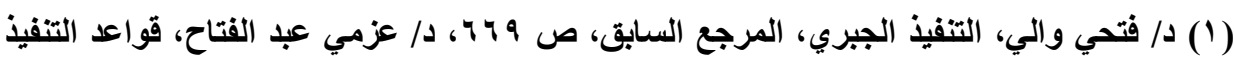

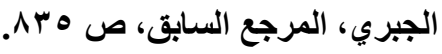

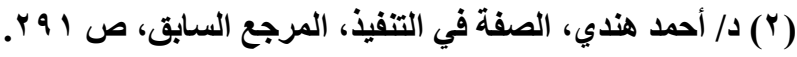

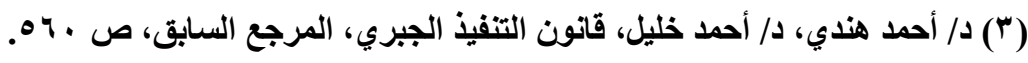




\section{ثالثا: الشروط المتعلقة بالنطاق الزهاني للدعوي:}

إذا كان المشرع لم يحدد ميعادا ميعنـا لرفع دعوي الاستحقاق الفرعية، إلا أن اسمها يفرض وقوعها في النطاق الزمني للعملية التنفيذية، ولما كان التنفيذ علي العقار يبدأ بإعلان التبيه بنزع الملكية، فإنه يمكن رفعها عقب هذا الإعلان ولو لم يكن التبيبه قد تم تسجيله بعد، وبالنسبة لانتهاء التتفيذ علي العقار فإنـه يتحدد بحكم إيقاع البيع، ولذلك فإن الدعوي لا تعد استحقاقا فرعيا إذا رفعت بعد صدور هذا القرار، ولكن إذا رفعت بعد اعتمـاد القاضسي لمن تقدم بـأكبر عطاء في جلسة البيع بـالمزاد فإنـه تعتبر مقبولة طالما أنه لم يكن قد صدر بعد حكم إيقاع البيع(')، وباعتبار المدعي في دعوي الاستحقاق الفرعية من الغير، فلا يلتزم عند رفع اللاعوي بالميعاد المقرر للاعتر اض علـي قائمسة شـروط البيع، إذ يجوز لـه رفعها في أي وقت و إلى مـا قبل الحكم بإيقاع

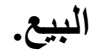

وبالتـالي إذا رفعت الدعوي قبل التنبيـه بنزع الملكية أو بعد إيقاع البيع فإنها

تعتبر دعوي ملكية عادية أو دعوي استحقاق أصلية، وذلك لأن هدف هذه الدعوي هو بطلان إجراءات الحجز، فإذا رفعت قبل بـد التنفيذ فلا يكون هنـاك بطلان لإجراءات التنفيذ، وإذا رفعت بعد تمام التنفيذ بالبيع، فإن قاضي التنفيذ لا يكون مختصا. ويلاحظ أنه اذا رفعت الاعوي بشأن عقارات وحكم بإيقاع البيع بالنسبة لبعضهم دون الآخرين، فإنهـا تعتبر دعوي اسـتحقاق أصلية بالنسبة للعقـارات التـي بيعـ، وفرعية بالنسبة للعقار ات التي لم تبع بعد. 
ويناء علي ذلك إذا رفعت دعوي الاستحقاق الفرعية أثناء إجراءات التنفيذ، ثم

زالت هذه الإجراءات لأي سبب من الأسباب، فإنه لا يصبح هناك محل لبطلانها وتتحول الاعوي إلى دعوي استحقاق أصلية.

\section{الفرع الثاني \\ الآثار المترتبة علي دعوي الاستحقاق الفرعية}

سنشير إلـي الآثـار المترتبـة علـي رفـع دعـوي الاستحقاق الفرعيـة، والآثـار المترتبة علي الحكم في الدعوي، وذلك في النقاط الآتية:

\section{أولا: الآثار المثزتبة على رفع دعوى الاستمقاق الفرعية:}

نظرا لأن دعوي الاستحقاق الفرعية دعوي موضوعية في التتفيذ، فالأصل ألا يترتب عليها وقف التتفيذ، ولكن المشرع رأي أنهه في بعض الحالات من الضروري وقف التنفيذ كأثر لرفع هذه الدعوي، ولكن هذا الأثر لا يترتب بقوة القانون، ولكن يجب علي المحكمة أن تقضي بـه، وفي هذا تختلف دعوي الاستحقاق الفرعية عن دعوي استرداد المنقولات المحجوزة؛ والمشرع في ذلك متسث في حكمه مع القاعدة العامة في أثخر رفـع الـدعاوي الموضـوعية، وسـبب الاختـلاف بـين دعـوي الاسـترداد ودعـوي الاستحقاق، في طول إجراءات التفقيذ علي العقار وتعقيدها.

وترجع الحكمة من الوقف القضائي، إمكانية تمام التنفيذ بالبيع، وبالتالي يصعب إلغاء الحكم بـالبيع إذا حكم لمصلحة المستحق، فرعايـة لمصلحة الغير رافع الدعوي أوجب المشرع علي القاضي بأن يحكم في أول جلسة بوقف إجراءات البيع إذا توافرت شروط الوقف. 
وقد اشترطت المـادة هـ ؛ مر افعـات لصدور حكم من القاضسي بوقف التنفيذ أن

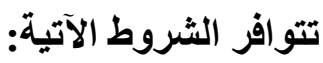

\section{ا - أن يكون رفع الدعوي هتفقا هع نهوذجها القانوني:}

ترفع دعوي الاستحقاق بالأوضاع العادية لرفع اللاعاوي، أي بإيداع صحيفتها

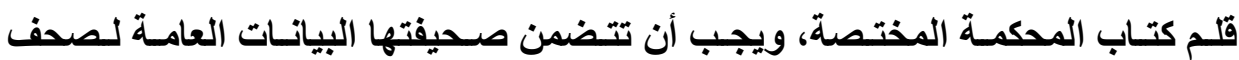
الدعاوي، فضلا علي اشتثمالها علي بيان المستندات المؤيدة للاعوي أو علي بيان دقيق لأدلة الملكية أو وقائع الحيازة التي تستتد إليها، وذلك للتأكد من جدية الدعوي، وتمكن المدعي عليهم من تحضير دفاعهم، ويتم إعلان صحيفة الدعوي طبقا للقواعد العامـة، ويترتب علي تخلف البيانـات العامـة لصحيفة اللدعوي البطلان، ولا يترتب جزاء علي تخلف بيان الأدلة والمستندات.

r - أن يكون المدعي قد أودع المبلع الذي يمب عليه إيداعه خزانة المككمة. ويتم إيداع فضلا عن مصارف الدعوي، المبلغخ الذي يقدره قلم الكتاب للوفاء بمقابل أتعاب المحاماة، فيجب أن يكون المدعي قد أودع خزانة المحكمة هذه المبالغ قبل الجلسة، وكذلك المصاريف اللازمة لإعادة الإجراعات في حالة الحكم برفض الدعوي أو بطلان صحيفتها أو اعتبارهـا كأن لم تكن أو غير ذلك من الأحكام المنهية للخصومة فيها '(' 


\section{r- أن يكون المدعي قد اختصم الأشخاص الذين يجب اختصاههم في الدعوي.}

ع- - تقديم طلب الوقف:

نصت المادة ه0 ؛ مرافعات علي أنها يحكم القاضسي في اول جلسة بوقف البيع

إذا اودع الطالب خزانة المحكمة بالإضافة إلى مصاريف الدعوي المبلغ الذي يقدر قلم

الكتاب....."، وهنا يثار تساؤل هل يجب تقديم طلب الوقف، أم أن القاضسي يحكم من

تلقاء نفسه بوقف التنفيذ؟ لقد ذهب الفقه إلى أنه يستفاد من نص المادة هـ ؛ مرافعات أنه إذا توافر الثروط المنصوص عليها في هذه المادة، علي المحكمة أن تحكم بـالوقف هـ دون سلطة تقديرية، حيث لم يشترط المشرع تقديم طلب الوقف من الغير('). ولكن إذا حل اليوم المعين لبيع العقار قبل أن يقضي القاضسي بـالوقف فلرافع الدعوي أن يطلب منه وقف البيع، وذلك قبل الجلسة المحددة للبيع بثلاثة أيام علي الأقل؛ ويقتصر دور المحكمة علي بحث مدي توافر شروط الوقف، فبإذا تبين لها توافرهـا تقضي بـالوقف دون أن يكون لها سلطة تقديرية في بحث مدي جدية الدعوي(). ويري جانب أخر من الفقه أنه يشترط تقديم طلب بوقف إجراءات البيع، لأن القاضي لا يحكم بشئ لـم يطلبه الخصوم مـا دام لا يتعلق بالنظام العـام("). ويذهب هذا الرأي إلى أنه يجب علي القاضي أن يحكم في الوقف إذا توافرت شروطه، فليس لـه أيـة سـلطة تقديريـة بـل يبحث فقط تـوافر شـروط الوقف أو عدم توافرهـا، فبإذا ثبت لايـة وجودها قضي بالوقف.

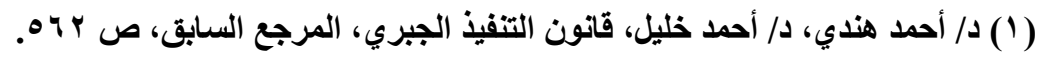

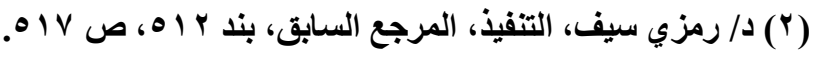

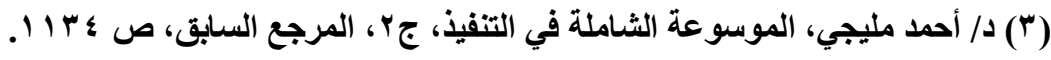


ونري أنه يجب تقديم طلب الوقف، وذلك لأن وقف التنفيذ لا يتعلق بالمصلحة العامة التي تقضي بـه المحكمة من تلقـاء نفسها، فيجب تقديمسه من صساحب المصلحة وهو الغير، وذلكك لأن المحكمة لا تستطيع أن تقضي بـالوقف من تلقاء نفسها، ويقدم الطلب أمسام قاضـي التنفيذ المختص، ويلاحظ أنه يستفاد من نص المـادة أن للقاضسي سلطة تقديريـه في الوقف في أول جلسه، وذلك لأن القاضسي يقارن بين مصالح ذوي الثأن ويبحث مدي جدية المستندات المتعلقة بالملكية أو بحقوق الغير علي العقار، فإذا تبين أن الهدف من رفع اللدعوي هو الكيد لأطراف الخصومة، فإنـه لا يحكم بـالوقف، وذلك لأن طلب الوقف هنا طلب مستعجل يخضع للقواعد العامة وقد نصت في الفقرة الثانية من هذه المـادة هـ ؛ مرافعـات علي أنسه " إذا حل اليوم المعين للبيع قبل أن يقضي بالإيقاف فلرافع اللاعوي أن يطلب منـه وقف البيع، وذلك قبل الجلسة المحددة للبيع بثلاثتة أيسام علي الأقل" ويفترض ذلك أن الجلسة المحددة للبيع حلت قبل أن يحكم القاضسي بـالوقف، فعلي القاضسي أن يـأمر بـالوقف إذا طلبه المدعي قبل الجلسة المحدة للبيع بثلاثة أيام علي الأقل. وإذا لـــ تتـــاول دعـوي الاسـتحقاق الفرعيـة إلا جـزعا مـن العقـار المحجـوزة، فإن الحكم الذي يصدر فيها يجب أن ينحصر في هذا الجزء وحده، سواء فيمـا يتعلق بالثق الموضوعي المتعلق ببطلان إجراءات البيع، ومن ثم تستمر الاجراءات بالنسبة للأجزاء الأخـرى مـن العقـار، ويمكن للقاضــي أن يـأمر بإيقـاف البيـع بالنسبة لبـاقي العقارات إذا طلب ذلك ذوو الثأن وكانت هناتك أسباب قويـة، كمـا لو كـان بيع العقارات علي صفقات يؤدي إلي بيعها بأقل من ثمنها، ممـا يسبب في خسارة بذوي الشأن(')، 
و إذا لم يطلب أحد إيقاف البيع بالنسبة إلى كل العقارات ممـا يوجب الاستمرار في بيع العقارات الأخرى، فإن قاضي التنفيذ يعدل الثمن الأساسي وفقا للفقرة الأولي من المسادة

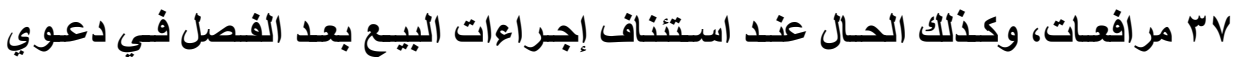
الاستحقاق.

ويستمر الأثر الواقف إلـي أن تقضي المحكمة في دعوي الاستحقاق، والحكم بالوقف لا يمنع ذوي الشأن من اتخاذ الإجراءات التحفظية والوقتية، كتعين حارس علي العقـار، ويـري بعض الفقهـ أن الأثر الواقف لا يـزول بقوة القـانون ببطلان صـيفة الاعوي أو بسقوط الخصومة، وإنما يشترط لذلك صدور حكم من القاضسي بالاستمرار في التنفيذ(') ومن جانبا لا نتفق مـع هذا الرأي علي أسساس أن الوقف يكون بسبب دعوي الاستحقاق، وإذا زالت هذه الدعوي لأي سبب، فلم يعد هناك حاجة لوقف التنفيذ، فيزول الأثر الواقف تلقائيا دون حاجة لصدور حكم. ونلاحظ أن المشرع نـص صـراحة في المـادة 7 هـ مر افعـات علـي أن الحكم الصادر بالوقف أو المضي في البيع لا يقبل الطعن فيه بأي طريق، فلا يقبل الطعن فيه بالاستقلال، ولكن الحكم صادر برفض طلب الوقف يمكن أن يطعن فيه مـع حكم إيقاع البيع الصادر بناء عليه خلال خمسة أيام من صدوره، وذلك لأن الحكم الصادر برفض طلب من طلبات الوقف الوجوبي. 
والواقع أنـه يمكن استثناء الطعن في الحكم الصادر بـالوقف الذي تنـاول كل الاعيان بالرغم من أن الدعوي تنصب علي جزء منها، ففي حالة طلب وقف بيع كل العقارات محل التنفيذ إذا كانت دعوي الاستحقاق ترد علي جزء منها فقط، فيان الحكم الصادر بالوقف أو برفضه يقبل الطعن فيه وفقا للقو اعد العامة، ولا يخضع للمادة 0 ـ مرافعات التي لا تجيز الطعن في حكم قاضي التنفيذ بوقف أو برفض وقف البيع في غير لهان هذه الحالة.

وأسـساس هـا الاستثناء يرجـع إلس ترتيب النصوص، ذلـك أن المسادة 07 ؛ والتي تنص علي منع الطعن في الحكم الصادر بـالوقف أو بـالرفض قد قصرت المنع علي الأحكام الصادرة وفقا للمادة الصابقة، وهو ما يعني أن حكمها لا يسري علي حكم

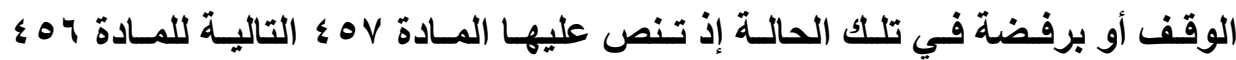

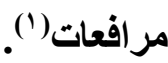

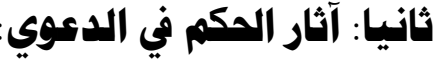

دعوي الاستحقاق، هي دعوي ملكية، ومن ثم فإنها ترد علي عناصر الملكية مجتمعة من استعمال واستغلال وتصرف، سواء وردت علي حصة مفرزة أو شـائعة،

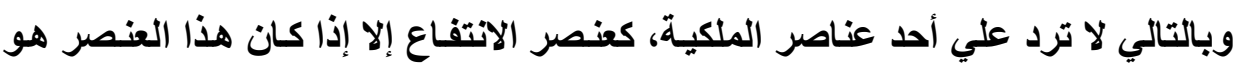
محل التففيذ العقاري، كما أنها تهاف إلى إلغاء جميع إجراءات التتفيذ. ويكون عبء الإثبات علـي عـاتق المدعي إلا إذا كـان واضـع يـده علـي العقـار ظاهرا فيكون علي الائن مباثر الإجراءات إثبات ملكية المدين للعقار، وتوجد إمكانية 
الاستناد إلى القرائن، مثل العقود ودفع المكلفة ودفع الأموال والعوايد، ولكن كلها قرائن يجوز دحضها بقرائن أقوي منها وتقدير ذلك متروك لقاضسي التنفيذ، فقد يكون دليل الملكية عقد بيع مسجل أو التقادم المكسب القصير أو الطويل أو الميراث؛ ويلاحظ أن القضاء يأخذ القرائن في إثبات الملكية، كسند تملك بصرف النظر عن كونهـه صسادراً من مالك أو غير مالك، ولا يشترط أن يكون مسجلا، وكذلك دفع الأموال والعوائد. ويتحدد نطاق بحث المحكمة في دعوي الاستحقاق حول سند الملكية، وبالتـالي تبطل إجراءات الحجز علي العقـار محل الدعوي إذا تـم إثبـات الملكية للمدعي؛ فِإذا رفضت المحكمة دعوي الاستحقاق فلا تتطرق إلي القصور في إجراءات التنفيذ، لأن هذه العيوب لها طرق لبحثها نص عليها المشرع، فلا يجوز مثلا للمحكمة أن تنظر عدم إنذار الحائز بالدفع أو التخلية. ولا يمكن بعد الحكم بالاستحقاق البدء من جديد في إجراءات جديد للتنفيذ علي ذات العقار من أحد الأشخاص المختصمين في الدعوي، وإذا تعلق الاستحقاق بجزء من العقـار، ألغيت الإجراءات بالنسبة لهذا الجزء فقط، دون الجزء الباقي الذي تستمر بالنسبة له الإجراءات علي أن يعدل القاضي الثمن الأساسي لهذا الجزء وفقا للقواعد العامة. ويمكن للمحكمة أن تقضي بشمول حكمها بالنفاذ العجل، في حالة رفض دعوي الاسـتحقاق الفرعيـة، وذلك طبقـا لنص المـادة ـ ج م مرافعـات الخـاص بجـواز شـمول الأحكام الصادرة لمصلحة طالب التنفيذ في المنازعات المتعلقة بـه باعتبار أن دعوي الاستحقاق الفرعية منازعة متعلقة بالتنفيذ والحكم الصادر فيها بـالرفض حكم صـادر لمصلحة طالب التنفيذ. 
وإذا خسر الغير الاعوي فيمكن الحكم عليه بالتعويض، حيث يجب علي الغير الذي اعترف لـه المشرع بحق الاعتراض علـي التنفيذ إذا مـا كـان ماسـا بحقوقهـ أو مصالحه أو ضار بها (')، ألا يتعسف فيه وألا يضر بأحد أطراف التنفيذ أو يعرقل سيره وإلا تعرض للمسئولية. حيث أن تجـاوز الحـ المعقول أو المسألوف في المنازعـة في التنفيذ يؤدي إلى اعتبار صـاحب الحق متعسفا مسيئا، حيث ذهب بعض الفقهـ إلى أن "بالتالي مسئولا عن استعمال الوسائل المتاحة له للافاع عن حقوقه أو مصالحه ـ في غير ما أعدت له أو علي خلاف الغاية التي من أجلها شرعتـ لأن الاتحراف بالحق عن غايته يقلبه إلى مفسدة أو مخبثة_ـ وكل شئ يزيد عن حده ينقلب إلى ضدة"(؟). والحكم الصادر في دعوي الاستحقاق الفرعية يقبل الطعن عليه بالاستئناف وفقا

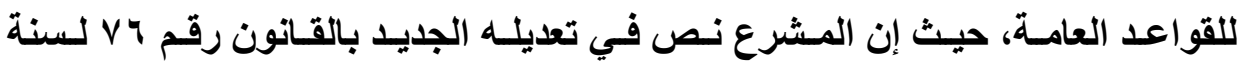

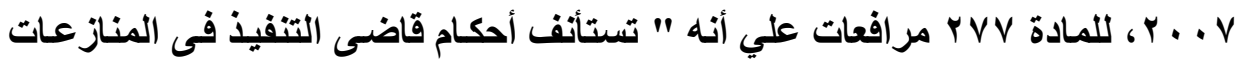
الوقتية و الموضوعية أيا كاتت قيمتها أمام المحكمة الابتدائية".

\section{الإطاب الثالث}

\section{اعتراض الغير علي قائمة شروط بيع العقار}

لم يطلق المشرع العنان للائن مباشر الإجراءات في اتخاذ إجراءات الحجز علي العقار، بل قد وضع القانون بعض الوسـائل التي تكفل إتاحة الفرصـة لذوي الشأن كي يباشروا رقابة لاحقه علي ما قام به الدائن من إجراعات، فهيأ لهم السبل للمنازعة في

(1) د/ عبد الباسط جميعي، الإساءة في التقاضي وفي التفقيذ، المرجع السابق، ص ه.

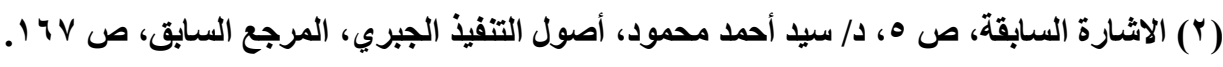


هـذه الإجـراعات فوضـع لـذلك نظامـا إجرائيـا خاصــا لنظـر هـذه المنازعـات بقصد حماية الغير وأطراف التنفيذ ومن تتعلق مصالحهم بإجراءات التنفيذ، وإذا تم الفصل في هـذه الاعتر اضــات بأحكـام نهائيـة، فإمــا أن تعـدل الإجـراعات أو يـصبح العقــار معــا للبيع وتبدأ إجراءات بيع العقار، هذا النظام يطلق عليه الاعتراض علي قائمة شروط

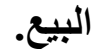

سنشير إلي شروط اعتراض الغير علي القائمة، وآثار اعتراض الغير، وذلك في

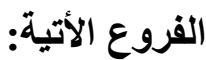

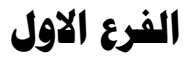 \\ شروط اعتزاض الغير علي القائمة}

سنشير إلي مصلحة الغير المعترض علي القائمة، وتقديم الاعتر اض في الشكل والإجراءات المنصوص عليها، وذلك في النقاط الآتية: الشرط الأول: هصلحة الغير المهترض علي القائمة:

الاعتراض علي قائمسة شروط البيع وهو المنازعة الموضوعية تتعلق بالتنفيذ علي العقار يقدمها ذوو الثأن من الأطراف أو من الغير، وتتعلق بصحة كل من مقدمات التنفيذ وما تم من إجراءات والثروط المدرجة بالقائمة'(1)؛ فهو طريق يهدف الغير من خلاله إلى التمسك بتعديل شروط البيع وبطلان إجراءات التنفيذ علي العقار لعيب يتعلق بالثكل أو بالموضوع أو الاعتراض عليها لأي سبب آخر، شريطة أن يكون هذا السبب 
مـؤثرا فـي طريـق التنفيذا أو في سـيره أو صــته أو بطلانـهـه أو في جـوازه أو عـدم جوازه(')، فيلاحظ أن هذه الاعتراضات لا تنصب علي قائمة شروط البيع وحدها، ولكن يمكن أن يتناول الأمور المتعلقة بصحة التنفيذ ذاته، حيث قد ينصب علي عدم توافر الثروط الموضوعية والثكلية للسند التنفيذي، كما لو كان المـال محل التففيذ لا يجوز الحجز عليه أو أن إجراءات التفيذ باطله.

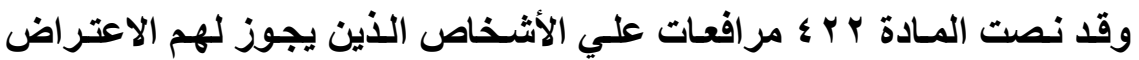
علي قائمة شروط البيع، وهم المدين أو الحائز أو الكفيل العيني والدائنون المشار إليهم في المادة Vائ وهم الدائنون أصحاب الحقوق المقيدة قبل تسجيل التببيه والدائنون الذين قاموا بتسجيل تنبيهاتهم، فيمكن لأي من هؤلاء الأشخاص تقديم اعتراض علي القائمة، سواء أخطروا بايداعها أو لم يخطروا بذلك(؟)، فعدم الإخطار لا يمنع من إثارة

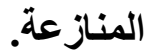
وقد نصت الفقرة الثانية من ذات المادة علي أنه يمكن لكل ذي مصلحة من غير من ورد ذكرهم في الفقرة السـابقة إبداء ما لايسه من أوجه البطلان أو الملاحظات علي القائمة بطريق الاعتراض عليها أو بطريق التخل في نظر الاعتراض، وطبقا للقواعد العامة، يجب أن يكون للغير مصلحة في الاعتراض علي قائمـة شروط البيع، من أمثلـه الغير مـن يكون دائنـا عاديـا للمدين أو من يكون قد قيــ حقـه بعد تسجيل تتبيـه نـزع الملكية، أو من يكون لله حق ارتفاق أو حق انتفاع علي العقار أو من يكون مستأجراً 
للعقار (') أو من يدعي ملكيته للعقار الذي يجري عليه التنفيذ، فلـه أن يعترض علي قائمة شروط بيع العقار.

\section{الشرط الثاني: تقديم الاعتراض في الشكل والميعاد المنصوص عليه قانونا:}

يعد الاعتراض علي قائمة شروط البيع خصومة ذات شكل خاص، حيث ترفع في ميعاد معين وفي شكل معين، فيقدم الاعتراض علي قائمة شروط البيع عن طريق تقرير في قلم كتاب محكمة التنفيذ، ولذلك لا يجوز تقديمه بالإجراءات المعتادة لرفع الدعوي، ويترتب علي عدم مراعاة الشكل سقوط الجلسة المحددة لنظر الاعتراضـات، وإذا تم التقريز فلا يلزم إعلانـه لذوي الشأن ولا تكليفهم بالحضور، لأنـه سبق إعلانـه بتـاريخ

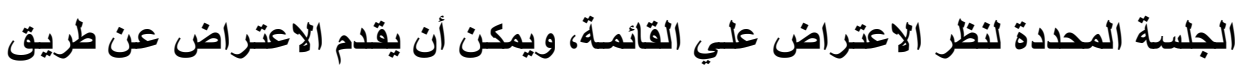
التدخل في اعتر اض آخر مقدم من معترض آخر حتي ولـو كان موضوع الاعتر اض

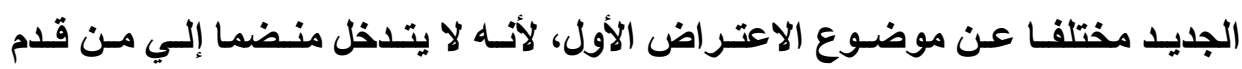

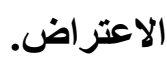

ويتخذ اعتراضات الغير علي قائمة شروط البيع العديد من الأشكال، منها مـا قـ يكون أوجه بطلان، والبعض يكون في صورة ملاحظات، وق يكون طلبـا بوقف البيع أو تأجيل الإجراءات، وقد يكون القصد من الاعتراض يتعلق بتقرير حث معين.

\section{أولاً: أوجه البططلان:}

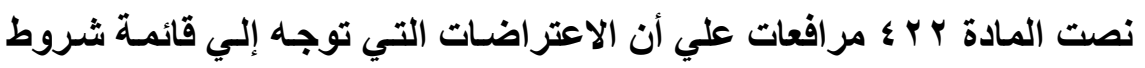
البيع، تتمثل في أوجـه البطلان في الإجراءات السابقة علي الجلسة المحددة لنظر

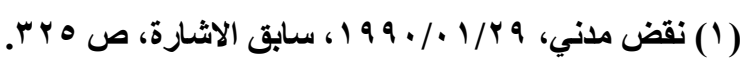


الاعتر اضات، ويقصد بأوجه البطلان، كل المنازعات المتعلقة بصحة التنفيذ سواء مـا يتعلق منها بالثكل أو بالموضوع.

وتنقسم أوجه البطلان إلي بطلان شكلي وبطلان موضوعي، حيث قد يبني علي

سبب يتعلق بالثكل، كما لو رجع ذلك إلي عدم اتبـاع القواعد الإجرائية المتعلقة بإنـار الحائز؛ وقا يتعلق موضوع الاعتراض بأوجه البطلان الموضوعية، كما لو تعلق بمحل التتفيذ، من ذلك أن يكون محل التتفيذ لا يجوز الحجز عليه لأنه عقار موقفا أو مشروطا عدم التصرف فيه، كذلك إذ كان العقـار المنفذ عليه غير مملوك للمـدين المنفذ ضده لخروجه من ملكه فى تاريخ سابق على تاريخ تنبيه نزع الملكية، فِان المنازعة بهذه المثابة تعتبر من أوجه البطلان التى يجوز إبداؤها بطريق الاعتراض على قائمة شروط البيع، و تؤدى إلى إلغاء إجراءات التنفيذ على العقار ('). وقد ذهبـت محكـة الـنض إلـي أن "المنازعـة في تخلف شـرط مسن الشروط الموضوعية لصحة التنفيذ، هي كون جزء من العقار المنفذ عليه مملوكا للمدين المنفذ ضدهـ الجزء الباقي مملوك للغير- تعتبر بهذه المثابـة مـن أوجه البطلان التى يجوز إبداؤها بطريق الاعتراض على قائمه شروط البيع، ومن حق المدين أن يتمسك بهاو تؤدى إن صحت إلى إلغاء إجراءات التنفيذ بالنسبة لهذا الجزء من العقار الذى خرج من ملكية المدين واستمراره بالنسبة للجزء الباقي"(")

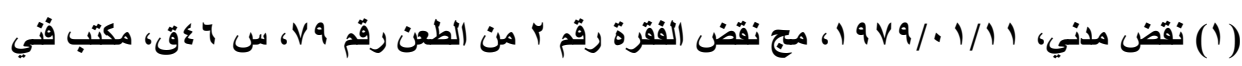
. r، ص 199.

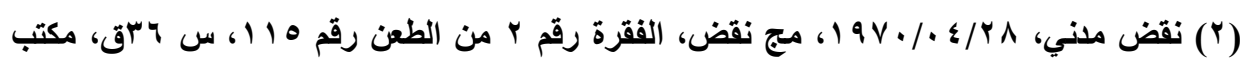

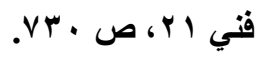


لقد سوي قانون المرافعات بين أوجه البطلان المتعلقة بالثكل و أوجهه المتعلقة بالموضوع وأوجب المشرع إباءوها جميعا بطريق الاعتراض على قائمة شروط البيع و إلا سقط الحق فيها؛ كما نصت المادة ؟ \ ج على أن تقدم الاعتر اضات على قائمة شروط البيع بالتقرير بها فى قلم كتاب محكمة التنفيذ، ولم تثترط أي من المـادتين المـكورتين

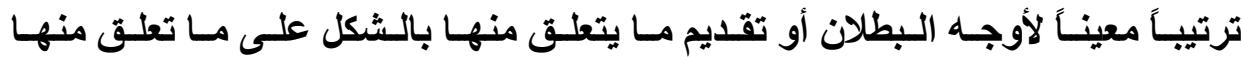

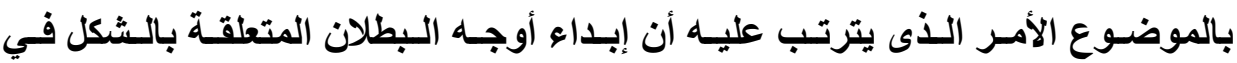
تقرير الاعتراض تاليـة لأوجـه البطلان المتعلقة بالموضوع لا يسقط الحق في الأوجه

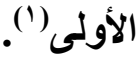

وتطبيقا لذلك قد حكمت محكمة النقض بأن "مفاد نصوص المواد ؛ اء ، 1 أ،

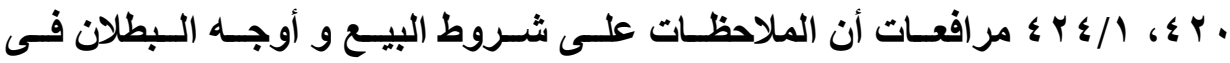
الإجراءات و فى صحة التنفيذ يجب إبداؤها بطريق الإعتراض على قائمـة شروط البيع و إلا سقط الحق فى التمسك بها"(`). ثانيا: أوجه الملاحظات:

يملك الغير توجيه بعض الملاحظات، وذلك بهدف حذف بعض الشروط أو إضافة شروط جديدة او تعديل القائمة، أو يوجه نقد إلي شروط البيع بقصد تعديلها أو تغييرهـا أو الإضافة إليها أو حذف بعضها، فالملاحظات التي يقدمها الغير هي كل مـا يطلب من

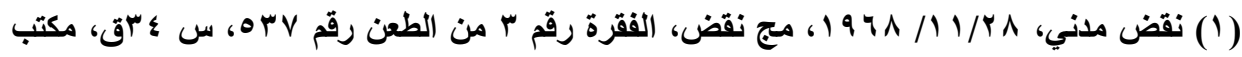

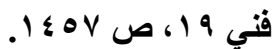

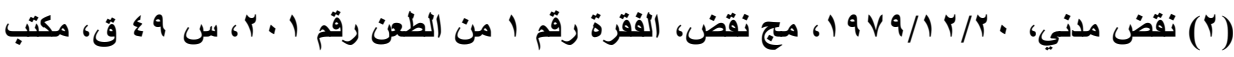

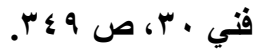


شروط تثضمن الإشارة إلي حق للغير، كأن يطلب صساحب حق الارتفاق أو الانتفاع أو المستأجر الإشارة إلي حقوقهم في القائمة حتى يتفادى كل نزاع بينه وبين المشتري في المزاد، ولو من قبيل التأكيا لأن هذه الحقوق ناقذة في مواجهة المشتري.

\section{ثالثا: تقديم الاعتراض في الميعاد المنصوص عليه قانونا}

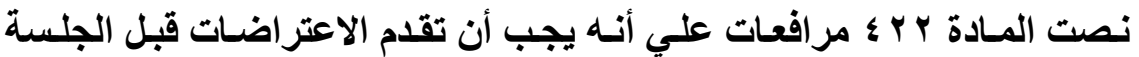

المحددة للنظر في الاعتراض علي قائمة شروط البيع بثلاثة أيسام علي الأقل وإلا سقط الحق في الاعتراض، وهذه الجلسة تحدد في محضر إيـاع قائمـة شروط البيع، ونص المشرع علي إلزام قلم الكتاب أن يحدد لنظر الاعتراضـات أول جلسة تحل بعد ثثلاثين يوما من انتهاء ميعاد الإخبار بالإيداع. ويلاحظ أن هذا الميعاد ملزم للمدين وللحسئز والكفيل العينـي والدائنين المشار اليهم في المسادة V V ، أمسا بالنسبة للغير فيمكن لـه تقديم الاعتراض في هذا الميعاد أو بطريق التدخل عند نظر الاعتراضـات المقدمـة من

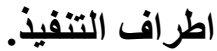

ولا يضاف إلي ميعاد الاعتراض علي قائمة شروط البيع ميعاد مسافة، إذ يتعلق الأمـر بميعـاد يجب اتخـاذ الإجراء قبله وهو ميعـاد مرتـ، ويترتب علـي فوات الميعاد سقوط الجلسة المحدة لنظر الاعتراضات وتستقر الجلسة المحددة لنظر البيع. يختص قاضي التنفيذ بالفصل في الاعتر اضـات علي قائمـة شروط البيع، وذلك لأنها من منازعات التنفيذ الموضوعية التي يختص بها قاضسي التنفيذ، وقاضسي التنفيذ المختص محليا هو القاضي الذي يقع العقار في نطاق اختصاصه. 


\section{الفرع الثاني \\ آثار اعتزاض الغير علي قائمة شروط البيع}

هناك أثاران يترتبان علي حق الغير في الاعتراض علي قائمة شروط البيع،

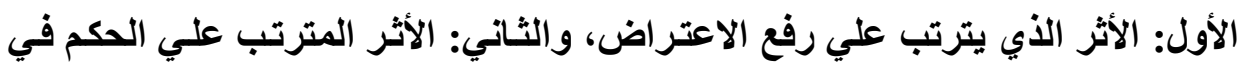

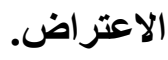

\section{أولا: الأثر المتزتب علي رفع الاعتزاض هن الغير}

$$
\text { يترتب علي تقديم الاعتراض علي قائمة شروط البيع الآثار الآتية: }
$$

\section{ا - سقوط البلسة المددة للبيع:}

يترتب علي تقديم الاعتراض من الغير سقوط الجلسة المحدد للبيع، ولا يـتم تحديد جلسة البيع إلا بعد أن يفصل قاضي التتفيذ في الاعتراضـات التي قدمت بأحكام واجبة التنفيذ.

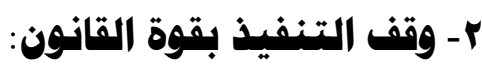
حيث يترتب علي تقديم الاعتراض بالشكل المنصوص عليه في القانون وقف التتفيذ، ويجب أن يتخذ الاعتراض شكل بطلان أو ملاحظة علي النحو السابق بيانه، ويمكن لقاضي التنفيذ أن يأمر بالاستمرار في الإجراءات، ولكن يجب في هذه الحالة أن يفصل في الاعتراض قبل صدور حكم بايقاع البيع'". 


\section{ثانيا: آثار المكم في الاعتراض علي قائمة شروط البيع:}

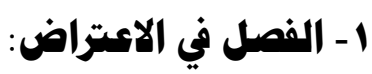

قـ يصدر قاضي التنفيذ حكم بقبول الاعتراض، أو برفضه، ويمكن له طبقا لنص

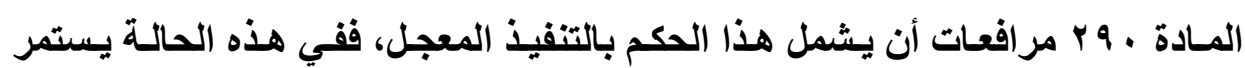
الحاجز في التنفيذ علي العقار.

و إذا أصدر القاضي حكما في الاعتراض- كليا أو جزئيا- فإنه يعدل قائمـة شروط البيع وفقا لما حكم به، والحكم الصادر في الاعتراض ينصرف أثره إلـي أطراف النزاع طبقا للقواعد العامة للمنازعات.

وقد حكمت محكمة النقض بأن "الحكم الصادر في الاعتراض على قائمـة شروط البيع- المؤسس على أوجه بطلان موضوعيةـ بالرفض و أياً كان وجه الرأي في تمثيل المعترض للورثة لا يتعدى إليهم و إنما أمره- وهو قضاء فى الموضوع قاطع- أن يحوز قبل المعترض وحده قوة الأمر المقضى فلا يملك أن يعود إلى الملكية التى فصل فيها فيؤسس عليها الدعوى المنظورة و هى دعوى الاستحقاق، وإذ اعتد الحكم المطعون فيه بحجيـة حكم الاعتر اض لا على المعترض وحده بـل على غيره مـن الطـاعنين أيضاً فإنـه يكون قد خالف القانون" (')

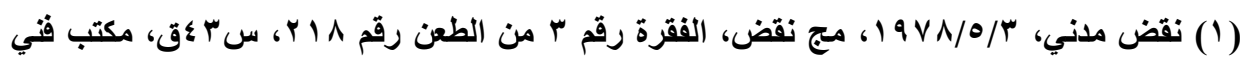
9ז، صזri 


\section{r- الطعن في الصكم الصادر في الاعتراض:}

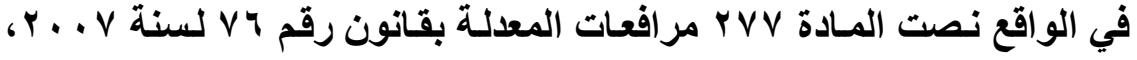

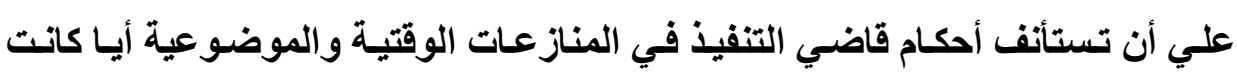
قيمتها أمام المحكمة الابتدائية".

لقد كان الوضع قبل التعديل الأخير، إمكانية الطعن في الحكم علي أسـاس قيمة

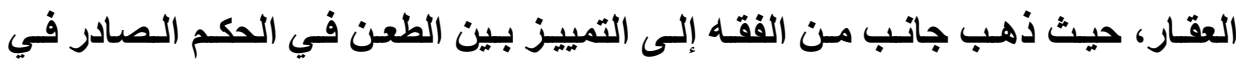
الملاحظة و الحكم الصادر في أوجه البطلان، فالنسبة للأحكام الصادرة في الملاحظات، فإنها تقبل الطعن في جميع الأحوال دون التقيد بالاختصاص القيمي، لأن الملاحظة لا لا

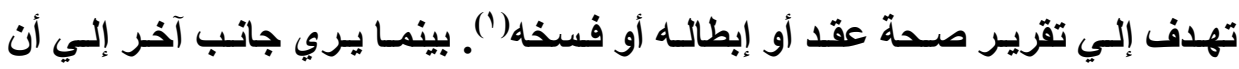
الملاحظة تقدر بقيمة العقار باعتبارها مناز عة موضوعية في التنفيذ(ه) وذلك لأن نص

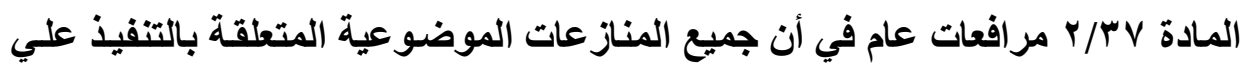
العقار تقار قيمتها بقيمة العقار (").

ويري البعض أنه إذا كان الحكم صـادراً في اعتراض مبني علي وجها بطلان،

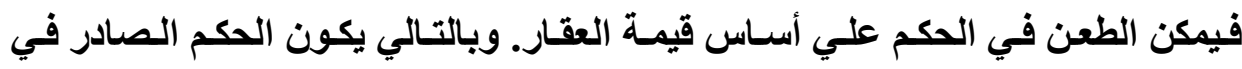

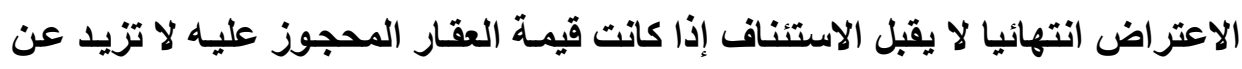
خمسة آلاف جنيه، ويكون قابلا للاستئناف أمام المحكمة الابتدائية إذا زادت قيمة العقار

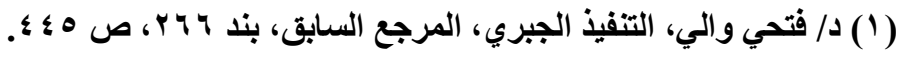

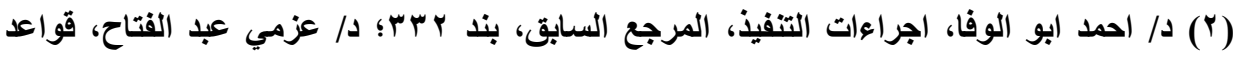

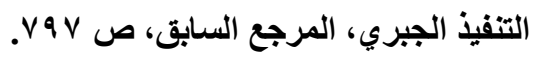
(") أحمد ابو الوفا، الإشارة السابقة، د/ عزمي عبد الفتاح، الاشارة السابقة، ص ـ ل117. 
علي خمسة آلاف جنية ولم تتجاوز أربعين ألف جنيه، وإلي محكمة الاستناف العالي إذا زادت علي ذلك.

وقد ذهبت محكمة النقض إلي أن الاعتراض على قائمة شروط بيع العقار الذى

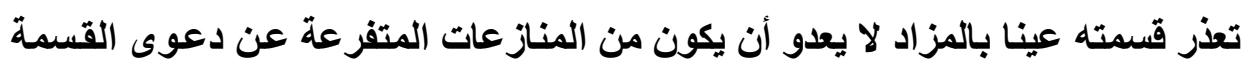
التى تختص بالفصل فيها المحكمة الجزئية ويكون استئناف الحكم الصادر في شـأنها

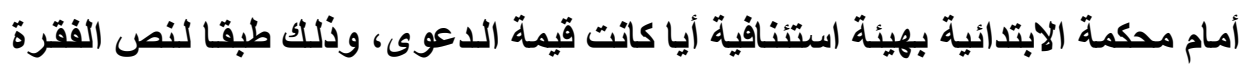

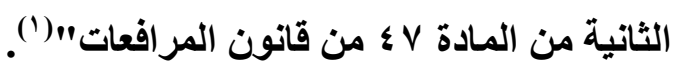

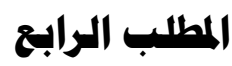 \\ رفع دعوي بطلان حكم رلسو المزاد}

في الواقع حكم رسوم المزاد لا ينثئ ملكية جديدة مبتدأة للراسي عليه المزاد، وإنما يكون من شأنه أن ينقل إليه ملكية العقار المبيع من العدين أو الحائز، ويمكن أن

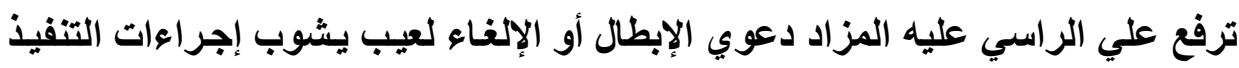

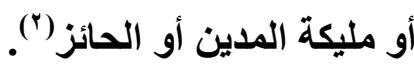

يمكن للغير أن يرفع دعوي أصلية ببطلان حكم إيقاع البيع، وتعتبر هذه الدعوي

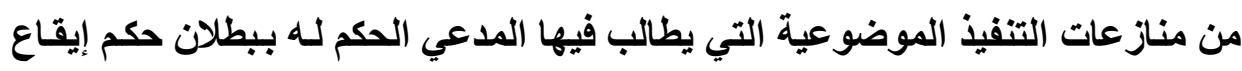

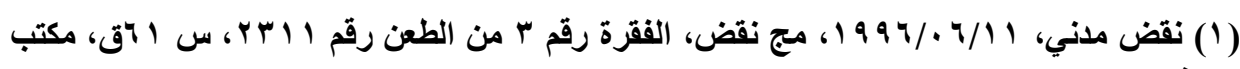

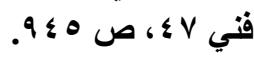

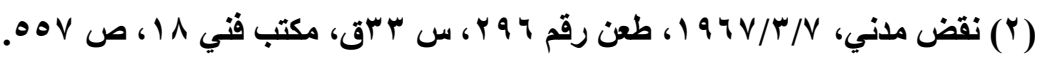


البيع(')، وترجيع الحكمـة من وجود هذه الدعوي إلـي أن حكم إيقاع البيع ليس حكمـا بالمعني القني، حيث إن الحكم صادر بايقاع البيع، ولم يتضمن فصل في الخصومة. ويختص قاضي التنفيذ بنظر هذه الدعوي باعتبار هـا من منازعات الموضوعية المتعلقة بالتنفيذ()، وترفع هذه المنازعة بالإجراعات العادية لرفع الدعوي، ويتم إعلان الاعوي بالإجراعات العادية للإعلان، ويمكن رفع هذه اللاعوي استنادا إلي أي سبب يتعلق بالإجراعات السابقة علي صدور الحكم بالبيع، أو أي سبب يتعلق بالحكم ذاتـه، أو

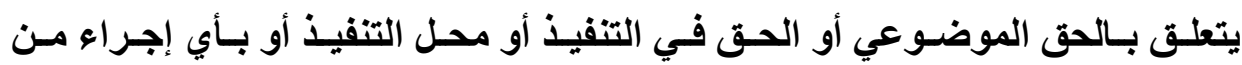

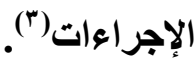

سنشير إلى شروط رفع هذه الدعوي، والآثار التي تترتب عليها، وذلك في الفروع الآتية: - م

\section{الفرع الأول \\ شروط دومي البطلان}

سنشير إلى اشتراط المصلحة في الاعوي وعدم سقوط الحق في رفع الدعوي، وذلك في النقاط الآتية:

(1) د/ عبد الباسط جميعي، د/ امال الفزايري، التنفيذ في المواد المدنية والتجارية، المرجع السابق،

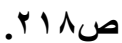
( )

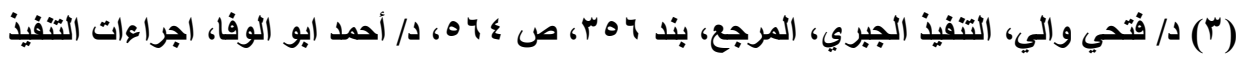

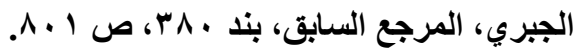

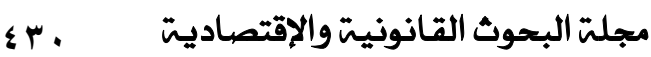




\section{الشرط الأول: توافر الصلحة للغير:}

يجوز لكل ذي مصلحة رفع دعوي بطلان حكم ايقاع البيع بشرط إثبات صفته، وترفع هذه الدعوي من جاتب الغير الذي لم يكن طرفا في إجراءات التنفيذ، وبالتالي لا يمك إلزامـه بمراعـاة المواعيد التي اوجبها القـانون المنازعـة في التففيذ خلالهـا(')، ويصدق ذلك علي كل شخص من الغير لم يكن يعلم بإجراءات التنفيذ، وذلك لأن الفرصة أمامه لم تتهيأ لإبداء أوجه البطلان في المراحل المختلفة لمراحل التفيذ العقاري، كمـا أنـه لا يملكك الاستئناف في الحكم، وبالتـالي يكون لـه الحق في تـدارك الأخطـاء أثنـاء الإجراعات التي لم يمثل فيها عن طريق دعوي البطلان(`). وتطبيقا لذلك يمكن لمالك العقار الذي لم يكن طرفا في إجراعات التنفيذ، والذي ليست لله صفة الحائز أو الكفيل العيني، يستطيع أن يرفع دعوي استحقاق أصلية يطلب فيها الحكم بيطلان حكم إيقاع البيع("). ويلاحظ أن أطراف التنفيذ لا يجوز لهم- من حيث الأصل- رفع دعوي أصلية ببطلان حكم إيقاع البيع، لأن المشرع نظم طرق التمسك ببطلان إجراءات التنفيذ علي نحو يؤدي إلى الاتتهاء من هذه المنازعات أولا بأول(؛)، فلأطراف الحق في الاعتراض علي قائمة شروط البيع قبل المزايدة، ولهم الحق في الاستتناف للحكم، ولكن استثناء

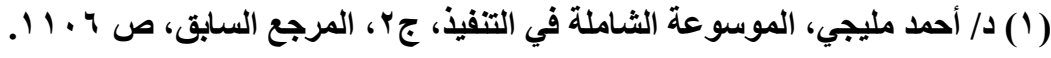

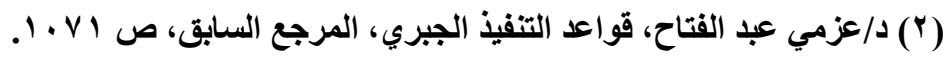

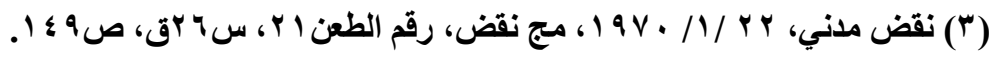

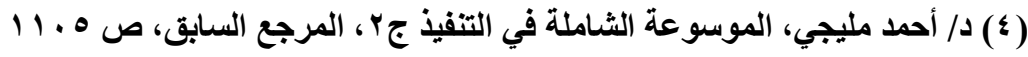


من ذلك يجوز رفع الدعوي من أطراف التنفيذ حيث اعتبرهم المشرع من فئة الغير،

$$
\text { ويظهر ذلك في الحالات الآتية: }
$$

\section{ا- إذا لم يتهكن أطراف خصومة التنفيذ هن العلم بالإجراءات:}

في الواقع يمكن رفع دعوي أصلية ببطلان حكم إيقاع البيع من جانب الداننين أصحاب الحقوق المقيدة قبل التسجيل تنبيه نزع الملكية و الذين لم يطلنوا بإيداع القائمة أو بجلسة البيع، أو من جاتب المدين نفسه إذا لم يكن قد أعلن بـالإجراءات إعلانـا صحيحًا')، كما يجوز للحائز الذي لم ينذر بالدفع او التظلية ولم يخبر بايداع قائمسة

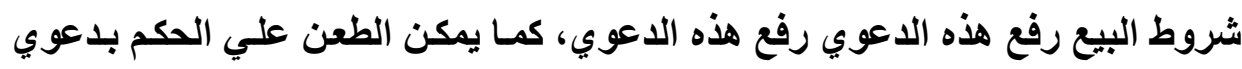

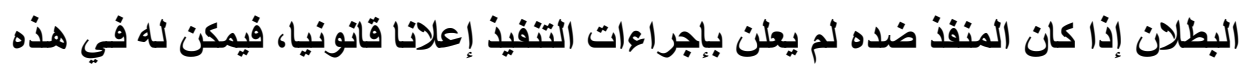

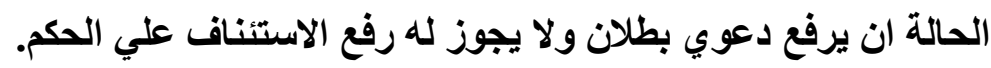
وقد قضت محكمة النقض بأن " على المدين إبداء أوجه البطلان فى الإجراءات

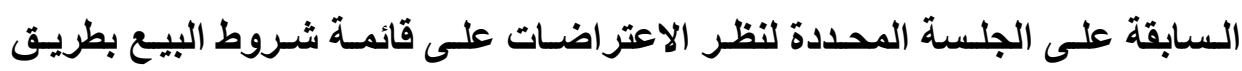
الاعتراض على القائمة و إلا سقط الحقى فى التمسك بها، إلا أن شرط ذلك ألك أن يكون

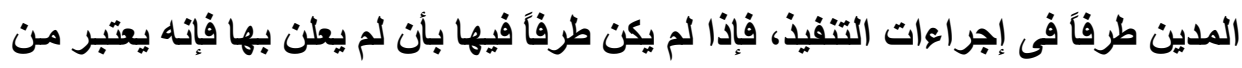

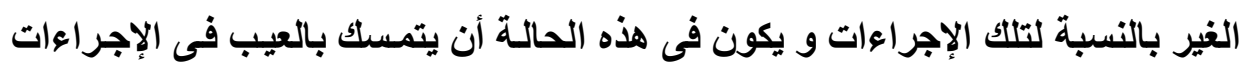
بما فيها حكم مرسى المزاد بطريق الدعوى الأصلية(").

(1) د/ عبد الباسط جميعي، د/ امال الفزايري، التتفيذ في المواد المدنية والتجارية، المرجع السابق، ص ای

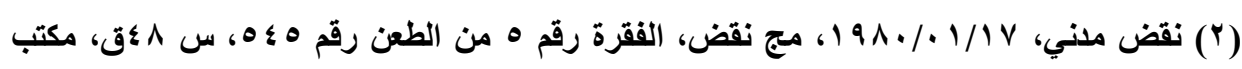
فني اسب، ص V V9 ال. 
r- إذا كان حكمه إيقـاع البيـع صـادراً بنساء علـى غـش أو كانـت الإجـراءات التنفيـذ

صورية (1) (1)

ويجب للتمسك بهذه الدعوي أن تكون المخالفة التي رفع بشأنها الدعوي مقرره

لمصلحة المدعي أو كانت متعلقة بالنظام العام(؟).

المدعي عليه في هذه الدعوي هو الدائن الذي يباشر الإجراعات والراسي عليه

المزاد، كمـا يجب اختصام جميع أصحاب المصلحة في هذه الـاعوي أي ممن تتأثر بحقوقهم بالحكم الذي يصدر فيها، وهم بـاقي أطراف الإجراءات غير المدعي في هذه الدعوي حتي تحسم جميع المنازعات بحكم واحل يصدر في مواجهتهم جميعا. وقد ذهبت محكمة النقض المصرية إلى أن " قاعدة الغش يبطل التصرفات هي قاعدة قانونية سليمه ولو لم يجري بها نص خاص في القانون وتقوم علي اعتبارات خلقيـة واجتماعيـه في محاربـة الغش والخديعة والاحتيـال وعدم الانحر اف عن جـادة حسن النية الواجب توافره في المعاقدات التصرفات والاجراءات عموما صيانه لمصلحة الأفراد والجامعات، فإذا كان الحكم قد اعتمد علي هذه القاعدة في قضائه ببطلان رسو المزاد فإنه لا يكون قد خالف القانون" (").

(1) وذلك علي أساس ان الفش يفسد كل شئ مما يجعل الحكم بدون أساس ويمكن الطعن عليه بدعوي البطلان الأصلية.

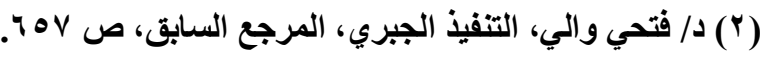

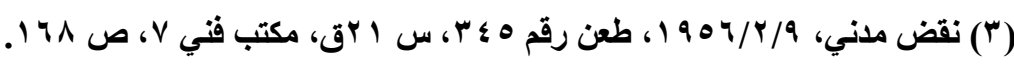




\section{r- إلغاء السند التنفيذي أو إبطاله:}

يتعلق مصير التنفيذ علي السند ذاته، فإن الغي السند او ابطل، امتنع المضي في التنفيذ وسقط ما يكون قد تم من إجراعاتـه، ووجب إعـادة الحال إلى مـا كـان عليه قبل مباشرته، ولا يمنه من ذلك سقوط حق المدين في التمسك ببطلان مـا تم من إجراءات بطريق الإعتراض علي قائمة شروط البيع البيع في الميعـاد المحدد لهه، لأنسه بـع إلغاء السند التنفيذي أو إبطالـه يصبح التنفيذ غير مستند إلى حق فتسقط إجراءاتـه نتيجة حتيمـه لزوال سنـده، ويكون للمدين بعد فوات الميعـاد المقرر قانونـا للإعتراض علي إجراءات التفيذ العقاري أن يطلب بدعوي أصلية إبطال هذه الإجراءات بما في ذلك حكم رسو المزاد، إلا إذا تعلق بها حق للغير بأن يكون العقار قد رسا مزاده علي غير طالب التنفيذ أو يكون هناك دائنون آخرون أعلنوا المدين بتتبيهه نزع الملكية أو دائنون من

$$
\text { أرباب الديون المسجلة كانوا طرفا في الإجراءات(') }
$$

فقد ذهبت محكمـة النقض المصرية إلى أن "قضاء هذه المحكمة قد دري بـأن للمدين المنزوعة ملكيتهـ بعد فوات مواعيد الطعن في إجراعات التنفيذ العقاري وبعد رسو المزادـ أن يطلب بدعوي أصليه إبطال هذه الإجراءات بمـا فيها حكم رسو المزاد

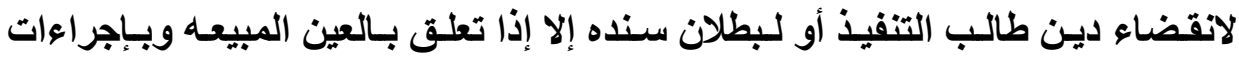
التنفيذ حق للغير، كـان تكون العين قد رسـا مزادهـا علـي غير الدائن طالب التنفيذ أو يكون هنـاك دائنون آخرون أعلنـوا بتنبيـه مزع الملكية أو دائنون من أربـاب الديون

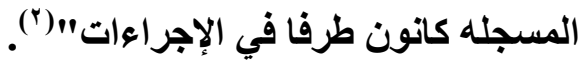

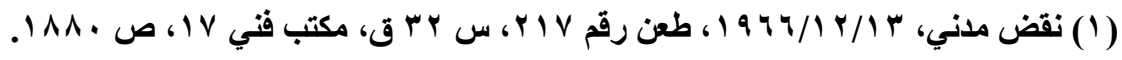

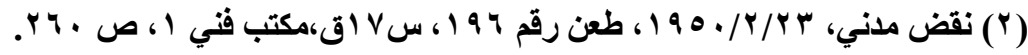




\section{الشرط الثاني: عدم سقوط الحق في رفع الدعوى:}

يجب لقبول دعوي البطلان ألا يكون حق المدعي قد انقضي بـأي سبب مـن

الأسباب، مثال ذلك أن يقوم برفع دعوي الاستحقاق أو الاسترداد، وقضي برفضها، أو ألا يتمسك المدعي بطريق الاعتراض علي قائمة شروط البيع قبل الجلسة المحددة للبيع بثثلاثة أيام علي الأقل رغم عدم إعلانـه بالإيداع وإخبـارهم بتـاريخ جلسة البيع ومكانـه؛ كذلك لو كان العيب يتعلق باجبراعات المزايدة، فان من له مصلحة يتعين عليه التمسك بالعيب بطريق استئناف حكم إيقاع البيع، فاذا لم يطعن خلال الميعاد، فلا يجوز لله رفع دعوي أصلية ببطلان إيقاع البيع('). أما إذا كان المال المحجوز عليه ملك الغير، فانه يجوز لله التمسك ببطلان الحكم في أي وقت دون التقيد بميعاد الاعتر اض أو الاستئناف. كذلك في حالة عدم استطاعة الثخص أن يتمسك بالعيب في الوقت المناسب وبالطريق الذي رسمه القانون، فان حقه في التمسك بهذا العيب بطريق دعوي البطلان الأصلية.

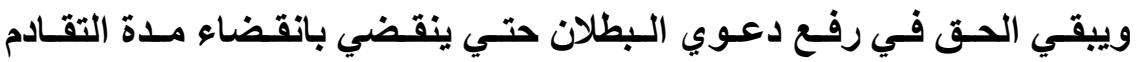

العادية(؟). ويرد علي مدة التقادم الانقطاع والوقف وفقا للقواعد العامة"("). 


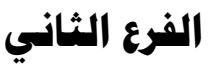 \\ آثار المكم في دعوي البطلان}

وإذا تحققت المحكمة من وجود عيب أصـاب إجراءات التتفيذ أو الحكم الصادر

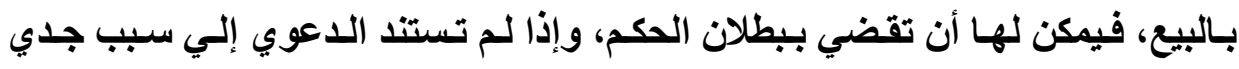
لبطلان الحكم رفضت المحكمة الدعوي.

يترتب علي الحكم ببطلان البيع إلغاء الآثار التي تترتب عليه، وإعادة الحال إلي ما كان عليه قبل صدوره، ويكون هذا الزوال من وقت إيقاعه شـأنه في ذلك شـأن البيع الاختياري الذي ينعطف أثر الحكم بيطلانه الي وقفت انعقاده(')، فيصبح المشتري كأن لم يمتلك العقار، وتعود الملكية إلي من انتزعت منه دون حاجة إلي تسجيل حكم ببطلان

$$
\text { البيع(") }
$$

حيث ذهبت محكمة النقض إلى أن "الحكم ببطلان حكم رسو المزاد إو إلغاءه يقرر انحلال البيع وزوالهه من قت ايقاعه، شـأنه في ذلكت شـأن البيع الاختياري الذي نعطف أثر الحكم ببطلانه أو بفسخه إلى وقت انعقاده")("). ويثار التساؤل عن مسئولية المشتري بالمزاد في مواجهة الغير، ومسئولية أطراف التنفيذ في مواجهة الغير؟ في الواقع يجب التفرقة في نطاق المسئولية بين الراسي عليه المزاد وبين أطراف التنفيذ، وذلك علي النحو التالي:

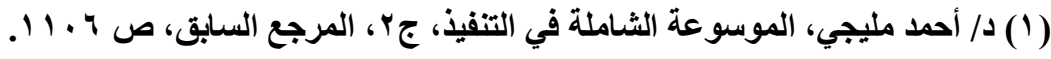

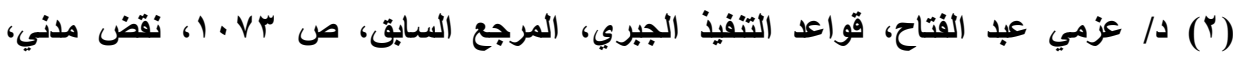
ا

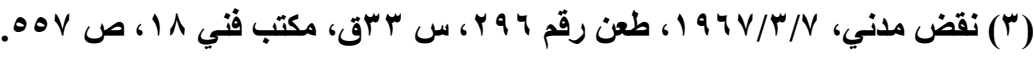




\section{أولا: هسئولية المشتري بالمزاد في هواجهة الغير:}

في الواقع ليس من شأن الحكم الصادر برسو المزاد أن ينقل إلى المشتري من

الحقوق أكثر مما كان للمدين المنزعة ملكيته، حيث ذهبت محكمة النقض المصرية إلي أنه متى كانت ارض المنزل موضوع النزاع جاريـة في وقف معين ومقررا عليها حكم للغير فان حكم رسو المزاد لا يلغي حق الوقف أمسا القول بأن الاستبدال يجب أن يكون لمالك المباني وحده فلا سند له من القانون ('). ونظرا لأن آثار الحكم بالبطلان تضر بمصلحة المشتري حسن النية، ولهذا ذهبت أحكام القضاء إلي التفرقة بين عدة فروض، أولها إذا كـان المشتري حسن النية ومن الغير، وثثانيا: و إذا كان المشتري الحاجز. الفرض الأول: إذا كان المشتزي هن الغير: في هذه الحالة يجب التفرقة بين حالتين:

الحالة الأولي: إذا كان المشتري حسن النية: في هذه الحالة لا تتأثر الملكية التي انتقلت بحكم إيقاع البيع وتسجيله، ويقصد بالمشتري حسن النية أن المشتري لا يعلم بسبب المنازعة، ويجب أن يكون المشتري من الغير أي غير الدائنين الحاجزين. فإذا تحققت هذه الحالةة، فإن مصلحة المشتري تغلب علي مصلحة الغير، وبالتالي لا يلغي حكم إيقاع البيع، ولكن يكون للغير الحق في

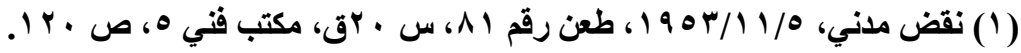


الرجوع علي مباشرة الإجراءات الاسترداد القيمة، أو الرجوع علي المدين علي أسساس الإثراء بلا سبب، وبالتعويض أن له سببا' '.

\section{الحالة الثانية: إذا كان المشتري سئ النية}

إذا اثبت المدعي سوء نية الغير يترتب علي ذلك الحكم ببطلان حكم إيقاع البيع وزوال ملكية المثتري بالرغم من أنه من الغير طالما أنه سئ النية. وتذهب بعض الأحكام إلي أنه يمكن للمدعي أن يرفع الدعوي ببطلان الحكم أيا كان السبب الذي يستتد إليه، فإذا حكم لصالحه ببطلان حكم إيقاع البيع فإنه يستطيع التمسك بحقه في مواجهة المشتري، ولو كان من الغير بصرف النظر عن حسن نيته أو

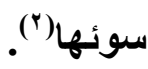
في الواقع لا نتفق مع هذا الحكم، لأته سيؤثر علي الثقة الواجب توافرها في نظام البيع بالمزاد العلني، حيث سيحجم الافراد عن الشراء بطريق المزاد العلني، حشيه من رفع دعوي بطلان في مواجهتهم مع حسن نيتهم. الفرض الثاني: إذا كان المشتري هو الدائن الحاجز إذا كان حكم البيع قد أوقع البيع علي الحاجز، فيمكن طلب إلغاء الحكم إيقاع البيع، وإذا قضت المحكمة بإلغاء الحكم زالت الملكية وعاد الحق إلي المدعي، وذلك التكاع بصرف النظر عن حسن أو سوء نية الائن المشتري(").

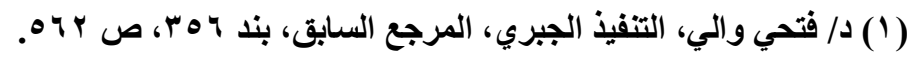

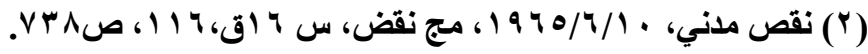

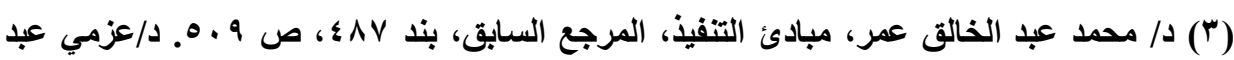

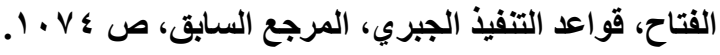


ويمكن الطعن في الحكم الصادر في الدعوي طبقا للقواعد العامـة للطعن في الأحكام الصادرة من قاضي التنفيذ في منازعات التنفيذ الموضوعية، والتي تشير إلي إمكانية الطعن في الحكم أمام المحكمة الابتدائية أيا كانت قيمة النزاع. ثانياً: المسئولية المدنية لأطراف التنفيذ في هواجهة الغير:

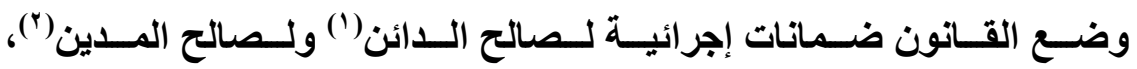

(1) كفل القانون للائن بسند تنفيذي الحق في التنفيذ الجبري بعد اتخاذ مقدماته علي أي مال من أموال

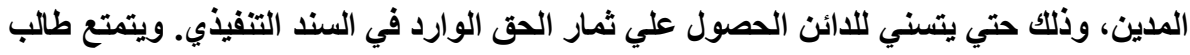

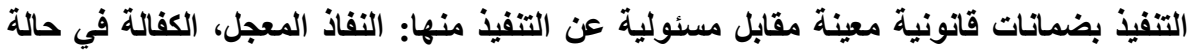

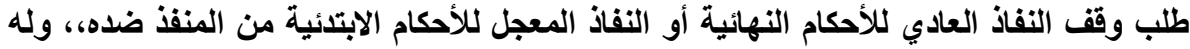

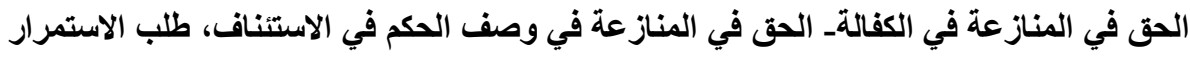

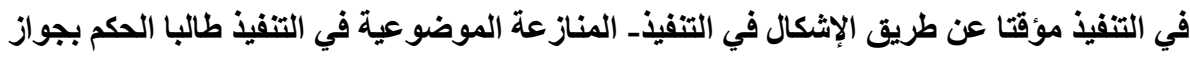

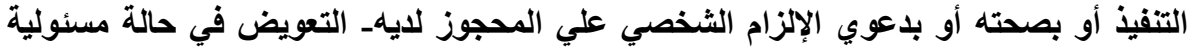
المدين عن منع التفيذ دون مبرر أو تعطيله.

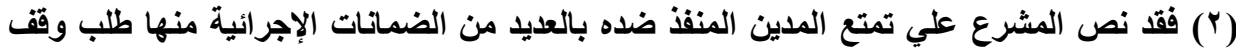

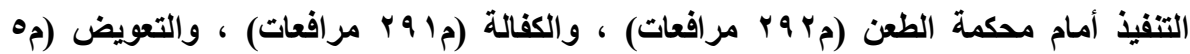

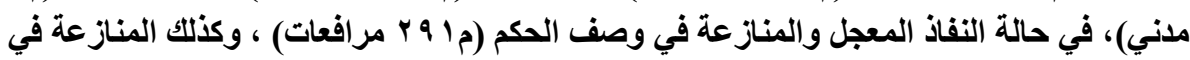

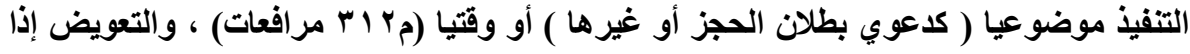

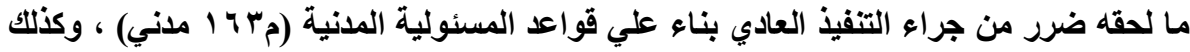

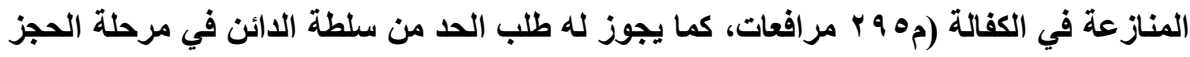

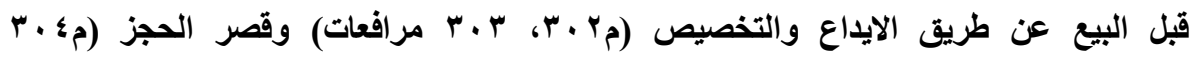

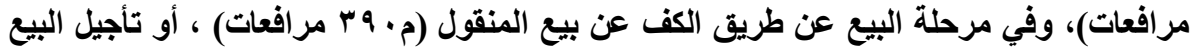

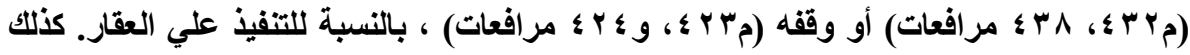

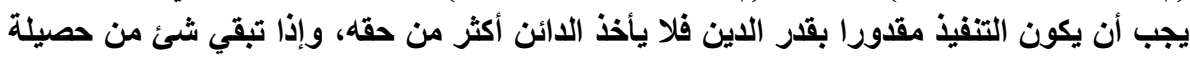

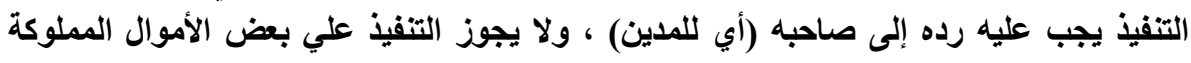
للمدين أو علي قدر أو نسبه معينة منها وذلك توفيرا للحد الأدني لحياة أو معيثة المدين الو الو أسرتها. 
وللغير (')، بمعني إذا كان متاحا للاائن الحجز علي أي مال من أموال المدين()، فِان هذا لا يمنع من مساءلة الدائن إذا تعف أو أساء في استعمال حقه في التنفيذ الجبري، لأن ممارسـة هـا الحقى مقيـة بـأن تكـون في الإطـار المرسـوم لـه قانونـا، وعدم تجـاوز المألوف، فلا يجوز له القيام بالحجز علي أموال مملوكة للغير. سنشير إلي تقرير مسئولية الحاجز في مواجهة الغير، وتقرير مسئولية المنفذ ضده، ومسئولية الغير، وذلك في النقاط الآتية:

\section{ا - تقرير هسئولية الحاجز في هماجهة الغير:}

إن التنفيذ علي أموال مملوكة للغير هو تنفيذ قلق غير مستقر يتعلق مصيره

بمصير إثبات الغير ملكيته للمال، فإذا أثبت الغير تضرره من التنفيذ، وذلك بإثبات أن محل التتفيذ مملوك للغير، وجب إعادة الحال إلى ما كاتت عليه قبل حصول التنفيذ بقدر ما يكون هذا ممكنا. وهنـا يثار التساؤل هل يلزم طالب التتفيذ فضلا عمـا تقدم بتعويض الـرر

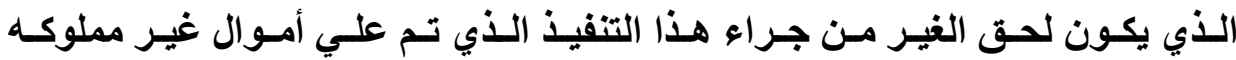
للمدين؟

(1) قد منح القانون للغير الحق في الاعتراض علي إجراءات التنفيذ وذلكك برفع دعوي الاسترداد

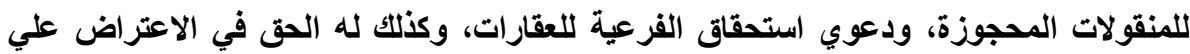
قائمة شروط البيع، ورفع دعوي بيطلان حكم ايقاع البيع.

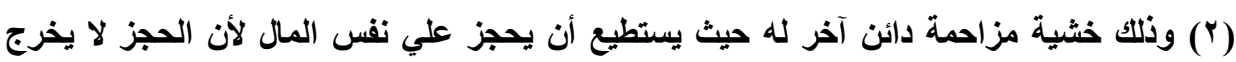

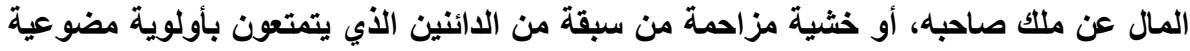

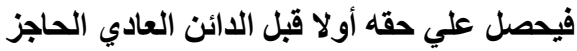


في الواقع إذا كان طالب التنفيذ سئ النيـة فإنها يلتزم بـالتعويض، وهذه القاعدة مسلم بها فقها وقضاء، وإنما إذا كان حسن النية فقد اختلف الفقه في تقرير مسئوليته،

$$
\text { وذلاك علي النحو التالي: }
$$

\section{الاتجاه الأول: التزام الحاجز بتعويض الضرر}

ذهب بعض أنه الحاجز يلتزم بتعويض الضرر الأي لحق الغير، لأنه ذلك يضمن حسن سير إجراءات التنفيذ الجبري، كما أنه يسأل لأن التنفيذ الذي يقوم بـه الحساجز، لا يخول من عدم التبصر الموجب لمسئولية الحاجز، لعلمه أن هذا الحكم، قد طعن فيه من الغير أو اعترض علي إجراءاته، وقد يلفي من محكمة المختصة، وكـان من الممكن أن يكتفي بتوقيع حجز تحفظي أو يوقف البيع لحين الفصل في حق الغير المتعلق

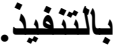
كما أن أقام الدائن علي تنفيذ حكم مشمولا بالنفـاذ المعجل وهو يعلم بأنـه حكم قلق يؤدي إلى مسئوليته عما يجريه من أعمال التنفيذ أو التزامه علي الأقل برد الحالـة إلى ما كاتت عليه قبل التنفيذ إذا ما ألغي هذا الحكم أو إجراءات تنفيذه نتيجة الاعتراض عليه(')، فإذا ابطل الغير إجراءات التنفيذ، يلغي مـا تم من إجراعات التنفيذ ويرد مـا قبض مـن أصسل وملحقــات وفوائـد بالإضـافة إلـى التعويـضيات، والمـصروفات التـي أنفقها الغير في اللجوء إلى القضاء، وقد ذهبت محكمة النقض إلى تقرير مسئولية اللائن المنفذ عن التنفيذ الذي يتم بمقتضي حكم مشمول بالنفـاذ المعجل إذا مـا ألغي

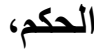

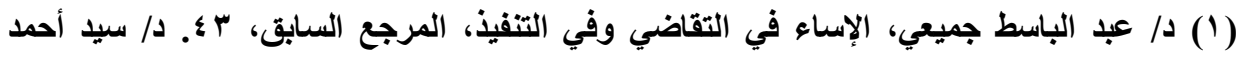

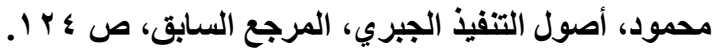


حيث ذهبت المحكمة إلى أن "تنفيذ الأحكام والقرارات الجـائز تنفيذها مؤقتـا يكون- علي ما جري به قضاء هذه المحكمةـ علي مسئولية طالب التنفيذ وحده، إذ يعد إجراءات التنفيذ مجرد رخصة للمحكوم لـه إن شـاء انتفع بها وإن شـاء تربص حتي يحوز الحكم قوة الثئ المحكوم فيه، إذا لـم يتريث المحكوم لـه وأقدم علي تنفيذ الحكم وهو يعلم أنه معرض للإلغاء عند الطعن فيه يكون قد قام بالتنفيذ علي مسئوليته بغير تبصر فيتحمل مخارطه إذا ما ألغي الحكم، ويصبح التنفيذ بغير سند من القانون بما يلزم طالب التنفيذ بإعـادة الحالـة إلى مـا كانت عليه وتعويض الضرر الذي قـ ينشأ عن التنفيذ، ولا يغير من ذلك أن يكون الدكم الذي جري التنفيذ بمقتضاه صادرا من القضاء المستعجل، إذ يقطع علي عاتق من بـادر بتنفيذه مسئولية هذا التنفيذ إذا مـا ألغي هذا الحكم في الاستثنتاف شـأنه في ذلك شـأن الأحكام الصادرة في الموضوع والمشمولة بالنفاذ المعجل. فطالب تنفيذ أحكام القضاء المستعجلـ كما يسأل في هذه الحالة_ يسأل عند الحصول علي قضاء في الموضوع بأن الحق لم يكن في جانبه"('). وقد ذهبت بعض الاحكام إلى أن تنفيذ الأحكام والقرارات الجـائز تنفيذها مؤقتـا يجري علي مسئولية طالب التنفيذ لأنه إباحة تنفيذها قبل أن تصبح نهائية هو مجرد رخصة للمحكوم له إن شاء انتفع بها وإن شاء تربص، وأقدم علي تنفيذه وهو يعلم أنها معرض للإلغـاء إذا مـا طعن فيسه فإنـه يتحمل مخـاطر هذا التنفيذ(؟). ولا يرجع أسـاس

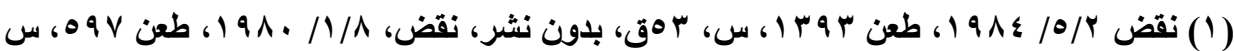

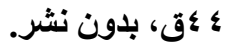

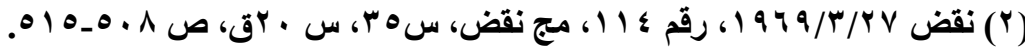


مسئولية المحكوم له في التنفيذ المعجل علي الخطأ، لأنه يستعمل حقا قانونية مشروعا لله ولكن علي أساس تحمل تبعة المخاطر (').

\section{الاتجاه الثاني: عدم التزام الحاجز بالتهويض}

يرى بعض الفقهـ أن الحساجز لا يكون مسئولا عن التعويض إذا جري التنفيذ

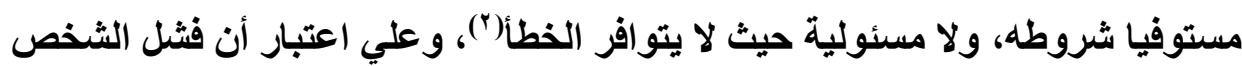
في التجائه إلى القضاء لا يعتبر في ذاتـه دليلا علي خطئه موجبا لمسئوليته وانمـا هو يسأل إذا كان سئ النية.

فالحجز جائز بلا مسئولية، لأن إجراعات التنفيذ الجبري من الحقوق المقررة

لحماية الحق، فيستطيع الدائن أن يقوم بإجرائه مهمـا كانت قيمـة الحق الثابت بالسند التتفيذي، ولو كان الباقي لـه في ذمـة المدين جزءا ضئيلا بـالنظر إلى هذا الحق، ولا يلتزم طالب التنفيذ بالتعويض المنفذ ضده أو الغير إذا ألغي الحكم (السند التنفيذي) عند الطعن فيه بالنقض أو التماس إعادة النظر، أو الغيت إجراءات التنفيذ، فبإذا كـان الحكم الأي أوقع به الحجز قـ تأييد إستئنافة أي نهائيا، ولكن الغي في التماس إعادة النظر المقدم من الغير لا يقوم حجة علي خطأ الدائن المنفذ، حيث إن المسألة في هذه الحالـة من الدقة وصعوبة التقدير من الوجهة القانونية بحيث يعد الدائن معذورا إذا عمد إلى ما

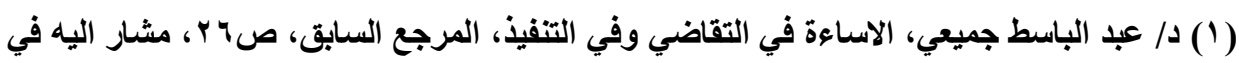

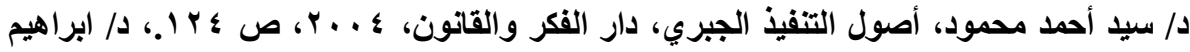

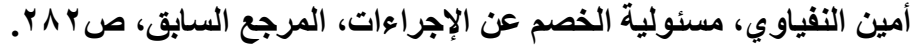

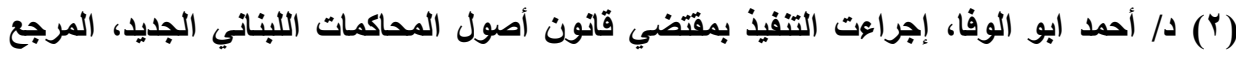

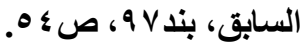


لله من حق قانوني في توقيعه الحجز للمحافظة علي حقوقه، يستوي في ذلك حجز المنقول لاي المدين أو حجز ما للمدين لاي الغير (').

إذا كان لكل شخص مطلق الحرية في الالتجاء إلى القضاء ليعرض عليه مزاعمه وإذا كان القانون لا يعتبر فشله دليلا علي خطئه موجبا لمسئوليته إلا إذا كان سئ النية، فمن باب أولى ذلك الذي يلجأ إلى القضاء أو يقوم بإجراء معين معتمدا علي حق ظاهر منحه نتيجة إياه حكم لم يستقر بعد لا يكون مسئولا إذا فثل في الدعوي في النهاية لأنه أولى بالرعايـة من الأول الذي لـم يستند إلى حق ظـاهر أو إلى حكم غير مستقر ()، وبالتالي فطالب التنفيذ هو صـاحب حق ظاهر يحميـه المشرع ويمنحه رعاية خاصـة فيبيح له اقتضاءه، وإذن يجب أن يكون شأنه شأن أي صاحب حق ظاهر يحمية القانون فلا يسأل إذا باشر هذا الحق، طالما كان حسن النية. وتطبيقا لذلك ذهبت محكمة النقض إلى أن "ولئن كـان اتخـاذ الدائن إجراءات التنفيذ القهري علي أموال مدينة، هو حق مقرر لـه لا يستوجب مسئوليته، إلا أن عليه أن يراعي الإجراعات التي فرضها القانون في التنفيذ علي أموال المدين ذاتها، بحيث لا يسند إليه الخطأ العمد أو الجسيم، فإن هو قارف ذلك ثبت في حقه ركن الخطأ الموجب للمسئولية عن هذه الاجراءات فيما لو ترتب عليها إلصاق الضرر بـالغير"("). وبالتـالي لو كان حسن النية ولم يرتكب أي خطأ فلا مسئوليه عليه، فقد ذهبت محكمة النقض إلى (1) د/ عبد العزيز خليل بديوي، الوجيز في قواعد وإجراءات التتفيذ الجبري والتحفظي في قانون

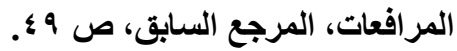
(ץ) د/ أحمد ابو الوفا، إجراءات التنفيذ بمقتضي قانون أصول المحاكمات اللبناني الجديد، المرجع

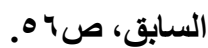

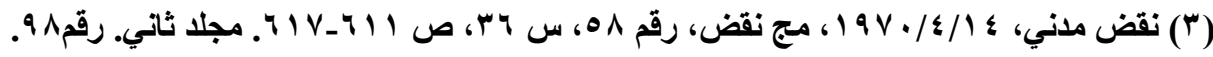


أن "المساعلة بالتعويض قوامها خطأ المسئول وإن كان مما أورده الحكم المطعون فيها لا يـؤدي إلـى تـوافر هـا العنصر مـن عناصـر المسئولية، لأن اسـتمرار الطـاعن في اجراءات التنفيذ بقبض جزءا من الدين الأي يدعيه لا يعد خطأ منه يستوجب المسئولية بـالتعويض لأن المشرع لـم يرتب علـي رفـع دعوي عدم الاعتداد بـالحجز أثرا موقفـا للاجراءات كـالأثر المترتب علي رفع الإثكال في التفيذ سواء من المدين أو الغير، خصوصا، وقد تمسك الطاعن بأن المحجوزات لايها سارعت إلى الوفاء بما هو مستحقى في ذمتها للمحجوز عليه عقب الحجز بوقف قصير وقبل صدور الحكم الانتهائي بعد الاعتداد باجر|اعت التنفيذ بمـا يرفع عنه مظنة الخطأ بعدم احترام حجية الأحكام فإنـه يكون قد أخطأ في تطبيق القانون"(')

ويري البعض أنه وإن كان طالب التنفيذ لا يعتبر مخطئسا بمجرد الحجز، إلا أنـه يسال بفوائد المبالغ التي قبضها من تاريخ مطالبته بها قضائيا، فإذا قام بتنفيذ السند، وطعن الغير في الحكم وطالب بفوائد المبالغ التي قبضها خصمه تنفيذ للحكم المطعون فيه فإن الاخير يكون ملزما بهذه الفوائد من تاريخ المطالبة بها، وهذه القاعدة بعمل بها سواء نفذ الحكم تنفيذ مؤقتـا أم نفذ عاديـا لأنه حـاز قوة الشئ المحكوم بـه إذ الفوائــ التأخيريـة تسري كقاعدة عامـة وعلـي الأقـل مـن وقت المطالبـة القضائية بهـا عمـلا بالقواعد العامـة، وكمـا يلزم المحكوم لله (الذي فشل في دعواه في النهايـة) بالفوائــ التأخيريـة يلزم أيضـا برد ثمـار العين التي كـان قد تسلمها مـن يوم قبضها إلى يوم 
وقد ذهبت محكمة النقض إلى "أن توقيع الأئن حجزا علي ما للمدين لدي الغير هو حق لا يستوجب مسئوليته إلا إذا كـان قد أسـاء استعماله بارتكاب خطأ لا يصح التسامح فيه، فإذا كانت المحكمة قد رفضت دعوي التعويض المرفوعة من المدين علي

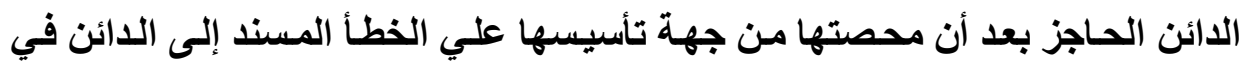
توقيعه الحجز تحت يده ويد غيره علي مبالغ مستحقة للمدين، وخلصت إلى الاقتناع بأن الحاجز كان لايه من المسوغات ما يبرر توقيعه الحجز بـليل تثبيته والحكم لله ابتدائيا واستننافيا علي المدين بالتعويض، وأنه إذا كانت محكمة النقض قد رأت بعد ذلك عدام استحقاق الادئن للتعويض فلا تأثير لهذا لأن الأمر كان من الدقة وصعوبة التقدير من

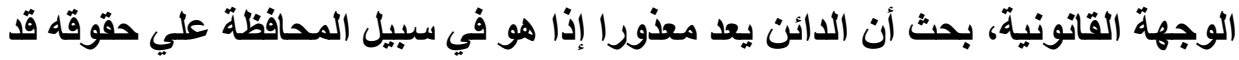

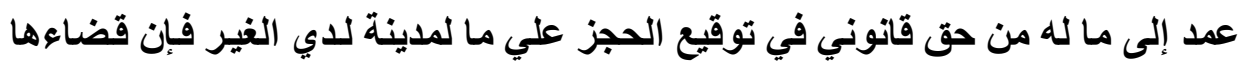

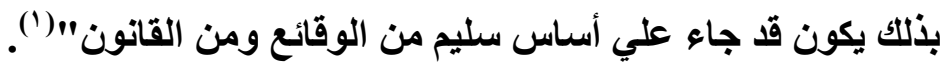

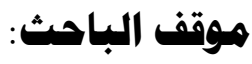

من وجهة نظرنـا، إذا تجـاوز الحساجز الحــ المعقول أو المسألوف في إجراءات

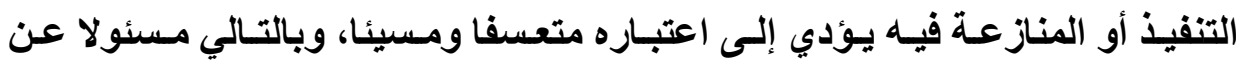

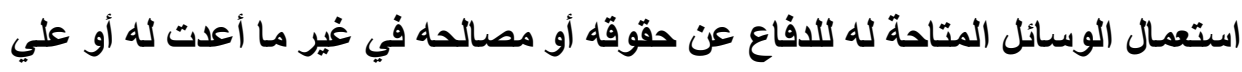
خلاف الغاية التي من أجلها شرعت، لأن الانحراف بالدق عن غايته يقلبه إلى مفسدة أو مخبثة، وكل شيء يزيد عن حده ينقلب إلى ضده. إذن لئن كان اتخاذ الدائن إجراءات التنفيذ القهري علي أموال مدينه هو حق

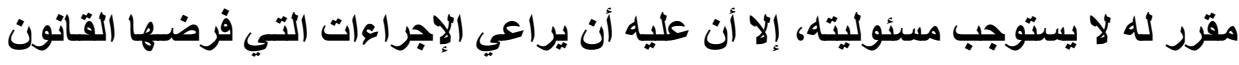

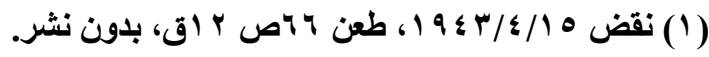


في التنفيذ علي أموال المدين ذاتها، بحيث لا يستند إليه الخطأ العددي أو الجسيم، فِان هو قارف ذلك ثبت في حقه ركن الخطأ الموجب للمسئولية عن هذه الإجراءات فيمـا لو ترتب عليها إلحاق الضرر بالغير ('). وقضت محكمـة النقض بـأن "مفـاد نـص المـادة السـابعة مـن قـانون المرافعات

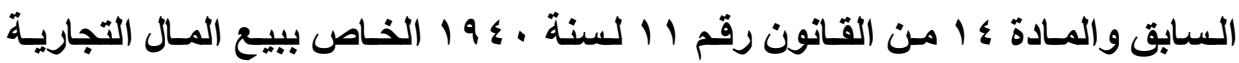
ورهنها، مرتبطين أن المحضر الذي يباشر التنفيذ أو غيره ممن أجاز القانون أن يجري التنفيذ الجبري بواسطته، إنما يقومون بذلك التنفيذ بناء علي توجيه من الخصوم لهذه الإجراءات، فإذا ما عين الخصوم إجراعات التنفيذ التي يطلبون اتخاذها اعتبر المحضر أو من يباشر إجراءات التنفيذ ممن أجاز لهم القانون ذلتك، وكلاء عن طالب التنفيذ الذي يسأل مسئولية مباشرة عن توجيه هذه الإجراءات فيما لو ترتب علي ذلك الإضرار

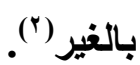

ويكون الحاجز مسئولا كذلك في حالة الحجز علي مـا للمدين للدي الغير إذا مـا

تبين أن الدائن قد أوقع الحجز وفـاء للدين متــازع فيه أو وفـاء لمبلـغ يزيد عن القدر الثابت له أو تحيل به ابتغاء مضارة خصمه أو الغير أو لجأ إلي الحجز بهذف الأذى، لأن

التحايل بالحق بقصد الإضرار، خطأ يستوجب المؤاخذة دون جدال(").

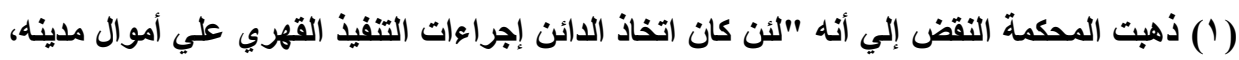

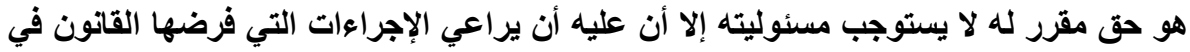

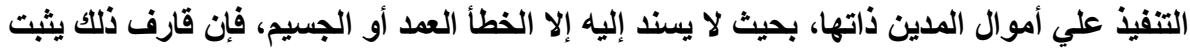

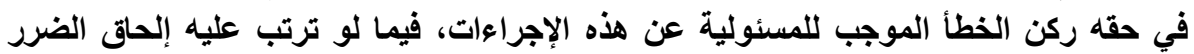

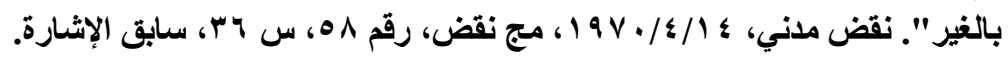

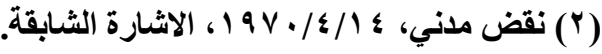

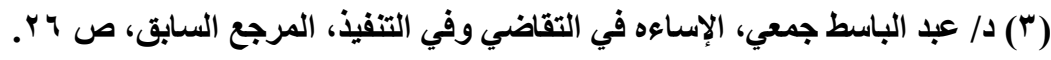


في الواقع استعمل الحق في الحجز مـا للاين لدي الغير دون مبرر جدي مـع وجود ضمانات قوية للوفاء بالدين أو أن حالة المدين وقدرته علي الوفاء ليست محل شك(')، وتطبيقا لذلك ذهب القضاء الفرنسي إلى أنه يساء استعمال الإجراءات التحفظية إذا كـان إجراؤهـا مصحوبا بسوء نيـة أو بقصد الإضـرار أو نتيجـة خطـأ جسيم مـواز

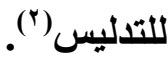

وبالتـالي إذا شـرع الدائن فـأوقع الحجز التحفظي علـي أمسوال مدينـة قبل حلول مواعيد الدفع أو في وقت كان المدين قد أودع في الخزينة ما لدائنـه كـان الحجز حاصـلا بقـصد المـشاغبة والنكايـة، ومتـي ثبـت أنسه سـبب للغيـر أضـرارا ماديـة وأدبيـه مثنل التشويش علـي سمعته بإظهاره في مظهر العـاجز عن الدفع أو إضـاعة وقته وتحملهـ. متاعب التقاضي وجب تعويضه عما لحقه من الضرر. ولقد جري القضاء الفرنسي علي اعتبار الدائن متعسفا في استعمال حقهـ في الحجز علي مدينة وذلك عند انعدام التناسب بين مدي الحجز وموجباته، أو عند انعدام التناسب بين أجزاء الحجز وضآلة الدين، أو عند وقوع حجز ما للمدين للدي الغير علي قدر كبير من أموال مدينه وتمكن بذلك من تجميد هذه الأموال فترة كبيرةـ نتيجة للحبس الكلى للأموال المحجوز عليها- وهو الأثر المرتب علي حجز ما للمدين لدي الغير- متي اتضح أن كان ضئيلا أو تافها أو لا وجود له في الحقيقة لانقضائه بأي سبب من أسباب الانقضاء، أو لإبطال سند المديونية أو لغير ذلك من الأسباب المؤديـة إلى تقرير زوال

$$
\text { (1) د/ ابراهيم النفياوي، مسئولية الخصم عن الاجراءات، المرجع السابق، ص rV^. }
$$

(2) Cass. 4 mars 1914, D., 1916, 1, 143.

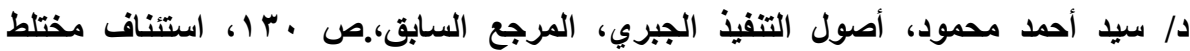
T 
الدين- أو عدم وجوه- بأثر رجعي نتيجة الحكم بالفسخ أو البطلان أو تزوير سند الدين أو غير ذلك مـن الأسباب) أو في حالـة عدم وجود مبرر قوي لذلك التجميد الطويـل

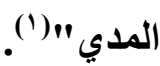

كما يعتبر من وسائل الغش التي تستوجب مسئولية الدائن أن يتبع في التتفيذ أسلوبا لا يتفق مع صحيح القانون كأن يتم التنفيذ علي غير المدين وهو عالمـا بذلك، فينفذ حكم علي شخص لم يكن طرفا فيه، ويستولي علي عقار من تحت يـده ممـا يؤدي إلى سلب حيازته بأسلوب لا يتفق مع الأوضاع السليمة مما يعطي الحق للثخص في أن يلجأ إلى القضاء طالبا رد حيازته المسلوبة، كأن يسخر شخص كي ترفع الدعوي ضده بزعم أنه مستأجر من الباطن فيقضي فيها للمدعي بالتسليم، ويقوم بتنفيذ الحكم ويستلم الأرض من مستأجر ها السابق (الحقيقي)(؟)

كذلك يعتبر تعسفا يستوجب التعويض أن يجري الدائن التفيذ علي أموال ليست مملوكة لمدينه(")، وقد نص القانون الفرنسي في 9 يوليه الو9 199 علـي أن الدائن لله حرية اختيار إجراءات التنفيذ، ولكن تنفيذ هذه الإجراءات لا يمكن أن يتجـاوز مـا يظهر لهري ضروريا من أجل الحصول علي الوفاء بـالالتزام (مץYY/ مرافعات)، وقاضسي التنفيذ

(1) J. Vincent et j. PREVAuLT, voies d'exécution et procédures de distribution, 17 éd., d., 1993, n $^{\circ} 60$ ets. pp. 41, J. VIDAL, essai d'une théorie générale de la fraude en droit français, D., 1957, préface G. marty.

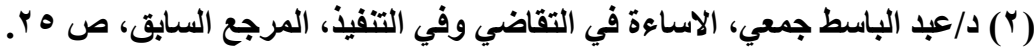

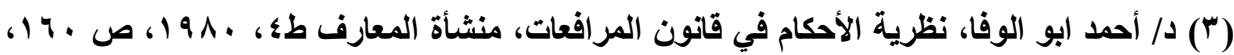


يملك سلطة الأمر برفع أو بشطب كل إجراء غير مفيد أو تعسفي ويحمم علي اللائن بالتعويض في حالة التعف في الحجز (م Y / I ) (')

ونري وجوب أن يكون هناك خطأوقع من الحاجز رتب ضرراً للغير، حيث ذهبت محكمة النقض إلى أنه "إذا كان الثابت بالحكم المطعون فيه أن الحجز الذي أوقعه بنتك التسليف زراعة قطعن هو حجز باطل لتوقيعة علي غير الزارع، وأن المحكمة حملت البنك المسئولية عن ذلك. ثم عن تبديد القطن المحجوز عليه علي أساس أنه لولا وقوع الحجز لما وقع التبديد، فإن هذا الحكم يكون باطلا لقصور أسبابه عن بيان السند الذي رتبت عليه المسئولية عن فعل التبديد، إذ إن تأسيس هذه المسئولية علي مجرد توقيع الحجز فيه غموض بين، لأن فعل التبديد مستقل عن الحجز، وقد تكون الصلة معدومـة بين المبدد ومن أوقع الحجز، فرابطة السببية إذن غير مبينة بيانا كافيا"(؟). ثانيا: تقرير هسئولية المدين المجبوز عليه تجاه الغير سنشير إلسي تقرير مسئولية المحجوز عليـه، وطرق الرجوع علي المحجوز عليه، وذلك في النقاط الآتية:

\section{ا - تقريز هسئولية المدين المجهوز عليه:}

يلاحظ أن المدين قد يرتكب غثا متمثلا في عدم إفصاحه أمام معاون التتفيذ عن ملكية الغير للمال، ومدعيا أنه ماله الخاص، مما يدفع الغير إلى رفع دعوي الاسترداد أو الاستحقاق، حيث يقصد مـن ذلك الإضرار بالـدائن والكيد للغير أو عرقلـة التنفيذ

(1) TGI Montpellier, 21 mai 1992, Rev. Huissiers, 1992, 1074, note Bourdillat.

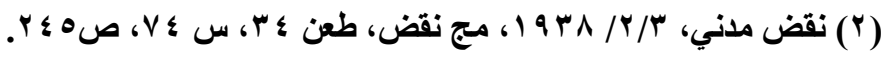

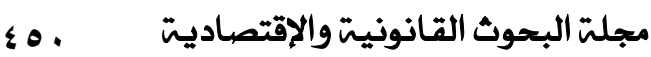


ووقفه أكبر فترة ممكنة، مما يوجب الحكم عليه بـالتعويض للغير أو للـائن عمـا أصسابه ضرر نتيجة لذلك.

خول المشرع المدين الحق في الاعتراض علي إجراءات التنفيذ سواء أكسان اعتراضه مبنيا علي أسباب موضوعية (منازعة موضوعية) أو مبنيا علي أسس وقتية (منازعة وقتية أو إثكال في التنفيذ) فإن المنازعة باعتبارها حقا إجرائيا يجب أن تكون ممارستها مقيدة بالغاية التي شرعت من أجلها وبالتـالي عدم التعسف أو الاسـاعة في استعمالها(')، بمـا يـؤدي إلى عدم الإضـرار بـالغير، وإلا وجبت مساءلة المـدين عن

والواقـع أنـه إذا مـا خرج صـاحب الحق في المنازعـة في التنفيذ عن الحدود المعقولة أو المألوفة في ممارسته قاصدا الاضرار بأحد أطراف التنفيذ، أو بـالغير أو مستخدما هذا الحق كوسيلة لأطال اجراعات أطول مدة ممكنة دون مبرر، فيكون الحكم بالتعويض، وذلك لتعسفه في حقه في اللجوء إلى القضاء. r ـ طرق الرجوع علي المحجوز عليه. يمكن للغير التففيذ بطريق التعويض علي المدين، لاستحالة التنفيذ العيني، وذلك بالرجوع علي المدين، باعتباره أثراً بقدر ما سـد من ديونـه علـي حساب الغير. ولكن كثير ما لا يجدي الرجوع علي المدين بسبب إعساره.

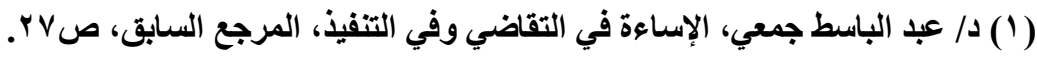

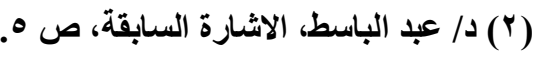


في الحالة التنفيذ علي عقار تحت يـ الحائز، فيمكن لـه الرجوع علي من تلقي منــه الملكيـة بـدعوي ضــان التعـرض والاسـتحقاق بمجـرد تسـلمه الإنـذار بالـدفع أو التخلية، ويكون للمحكمة الحق في وقف دعوي الضمان حتي الفصل في دعوي نزع الملكية، وموضوع الضمان هو تعويض الحائز عن كل مـا لحقهـ من ضرر، وليس فقط استرداد الثمن الذي رسـا بـه المزاد، إذ غالبـا مـا يكون هذا الثمن أقل مـن قيمة العقـار الحقيقية، ويشترط لقبول دعوي الضمان أن يكون انتقال الملكية قد تم بمقابل، وليس عن طريق الهبـة أو الوصية مـا لم يوجد اتفـاق علـي عدم الضمان أو مـالـم يحصل الاستحقاق بفعل الواهب، ويسقط حق الحائز في الرجوع إذا حصل الاستحقاق بتقصيره كما إذا أهمل في التمسك ببطلان الرهن أو انقضاء الدين. وللحـائز أيضا الرجوع علـي المـدين بالمبـالغ التي دفعها عنه سـواء للـدائنين مباشرة أو بسبب اتخاذ إجراعات التطهير أو إذا دفع الثمن في حالة رسو المزاد عليه، وذلك بمـا زاد عمـا هو مستحق في ذمتـه بمقتضي ســـ ملكيتهـ، ويحل الحسائز محل الدائنين الذين وفاهم حقوقهم، ويكون الرجوع بموجب دعوي الإثراء بلا سبب('). وإذا تعدد الحائزون لعدة عقارات مرهونـة لدين واحد وقام أحدهم بدفع الدين للـائن حل محلـه، وبموجب قاعدة عدم تجزئسة الرهن، يكون للحسائز الدي دفع الدين الرجوع علي أي من الحائزين، وإن تم الرجوع عليه، فلـه أن يرجـع بـوره علي غيره من الحائزين وهكذا، وهذه الطريقة مجحفة ومن ثم فللحائز أن ياخل باقي الحائزين في دعوي نزع الملكية، فإن لم يلخلهم ودفع الدين أو نزعت الملكية فيرجع علي كل حائز بنسبة قيمة العقار الحائز له بعد خصم الجزء الأي يخص عقاره. 


\section{ثالثا: مسئولية الغير تجاه أطراف التنفيذ:}

من أجل المحافظة علي حقوق الغير، فإن المشرع اعترف للغير بحق الاعتر اض علي التنفيذ إذا ما كان ماسا بحقوقه أو بمصالحة أو ضارا بها، فيجب عليه أيضا حينما يمـارس هـا الحـق ألا يتعسف فيـه، وألا يضر بأحـد أطراف التنفيذ، أو يعرقل سـير إجراءات التنفيذ، وإلا تعرض للمسئولية)(')

ويختص قاضسي التنفيذ بـالتعويض عن تعسف الغير في عرقلة سير إجراءات التتفيذ، وذلك إذا رفع الطلب أثناء نظره لمنازعـات التنفيذ، وممكن طلب التعويض بدعوي مستقلة ترفع بالإجراءات العادية لرفع الدعوي. خلاصة الباب الثاني

لقد نص المشرع المصري علي العديد من الضمانات التي تهدف إلى حماية الغير أثناء التنفيذ الجبري، وتتمثل في الآتي:

الضهانة الأولي: حق الغير في الطعن بالتمـاس إعـادة النظر وطلب وقف تنفيذ الحكم، فنلاحظ أن المشرع الفرنسي قد أخذ اتجاها ثابتا في هذا الشأن، فمنذ وقت طويل وحتي الأن مـازال يخص الغير بوسيلة طعن في الأحكـام وهـي اعتراض الغير، أمـا المشرع المصري، فإن موقفة متردد وليس مستقرا، فتارة يقرر للغير وسيلة خاصـة للطعن في الأحكام علي النحو الوارد في القانون الفرنسي، وتـارة يلفي هذه الوسيلة ويسمح للغير بالطعن بالتماس إعادة النظر مثله في ذلك مثل الخصوم.

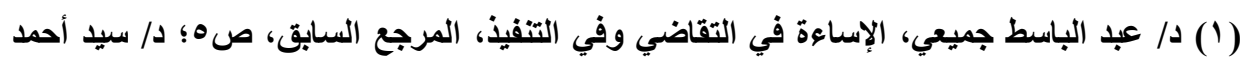

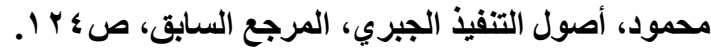


الضسمانة الثانية: حق الغير في الإثكال في التنفيذ؛ نص المشرع المصري علي حق الغير في الإشكال في التنفيذ، كمـا حمـاه المشرع بوقف التفيذ أثناء نظر الاشـكال سـواء كـان الوقف بقـوة القـانون إذا كـان اشـكالا أولا، أو كـان الوقف بحكم القاضي إذا كان اشكالا ثانيا. الضشمانة الثالثة: حق الغير في رفع دعوي الاسترداد والاستحقاق الفرعية، إذا حجزت علي أموال الغير سواء كانت عقارات أو منقولات فلـه الحق في رفع دعوي اسـتحقاق فرعيـة أو اسـترداد للمنقولات المحجـوزة، ويرتب علـي رفع هذه الـدعوي الأخير وقف تنفيذ إلي حين صدور حكم فيها، أم دعوي الاستحقاق الفرعية فلا يقف التنفيذ إلا بحكم من القاضي.

الـضهانة الرابعـة: حق الغير في الاعتراض علي قائمسة شروط البيع، نص المشرع علي أن للغير المنازعة في كل ما يتعلق بإجراءات التنفيذ التي مست حقوقه، الاعتراض علي القائمة طريق يهدف الغير من خلالهه إلى التمسك بتعديل شروط البيع وبطلان إجراءات التففيذ علي العقار لعيب يتعلق بالشكل أو بالموضوع أو الاعتراض عليها لأي سبب آخر، شريطة أن يكون هذا السبب مؤثرا في طريق التنفيذ أو في سيره أو صحته أو بطلانه أو في جوازه أو عدم جوازه. الـضمانة الخاهسسة: حق الغير في دعوي بطلان حكم إيقاع البيع، للغير أن يطالب في هذه الاعوي الحكم له ببطلان حكم إيقاع البيع(')، كما لهه الحق في استرداد 
المال الذي سلب منه إذا كان المشتري سئ النيه، أو الرجوع علي اطراف التنفيذ إذا

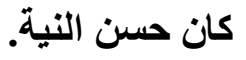

الضامنة السادسة: حق الغير في التعويض عما صابه من أضرار في مواجهة اطر اف التنفيذ.

\section{نتائج البمث}

نظرا لأن قيمة أي عمل تقدر بمـا يترتب عليه من نتائج، فِإن ذلك يقتضي أن نختم هذا البحث بتلخيص أهم النتائج التـي أمكن التوصل اليها مـن خلالـه، فيمكن الخروج بالعديد من الملاحظات علي دور الغير في التنفيذ الجبري وحمايته، كما يمكنتا إبداء التوصيات التي تعالج بعض القصور في نظام الغير في التنفيذ، وذلك علي النحو

\section{أولاً: ملاحظات علي نظام الغير في التنفيذ الببري:}

ا- لاحظنا من خلال هذا البحث أن المشرع المصري و المشرع الفرنسي لم يحدد

مغني الغير في مجال التنفيذ الجبري، وقد حاولنـا تحديد معني الغير في التنفيذ التيذ

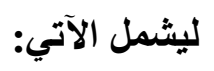

أ ـ كـل مـن يلزمسه القـانون- بسبب صـفته أو وظيفتـه أو علاقتـه بالخـصوم-

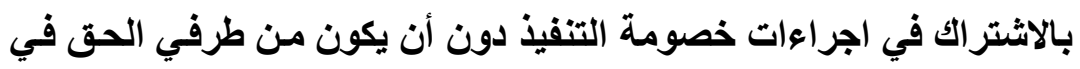
التنفيذ، فليس لله مصلحة شخصية بموضوع الحق المراد اقتضاءه، ولا

يعود عليه نفع أو ضرر من التنقيذ. 
بـ كذلك يتضمن معنـي الغير أي شـخص اجنبي عن التنفيذ، وقـ تـدخل في اجراءات التنفيذ بإرادته الخاصـة، وذلك دفاعـا عن حقوقه، مثل الغير في

$$
\text { دعوي الاسترداد ودعوي الاستحقاق. }
$$

r- ويلاحظ أن المشرع المصري لم يورد نصا عاما لتحديد صاحب الصفة في السند التتفيذي، في مختلف السندات، وإنما شرع نص خـاص بالأحكام باعتبارهـا أهم صور تلكك السندات، ويمكن حمله إلى سائر تلك الصور من السندات، حيث نص المشرع بطريقة عامة وغير مباشرة عن الخصم الذي لله صفة في طلب تنفيذ الحكم، فقد نصت المادة 1 ا 1 مرافعات علي أن الصورة التنفيذية للحكم لا تسلم إلا للخصم الذي تعود عليه منفعة من تنفيذ الحكم، وقد اختلف الفقه في تحديد معني المنفعة التي تعود علي الخصم من التنفيذ، فهل يقصد بها المصلحة أو يقصد معني أدق من المصلحة، أما المشرع الفرنسي فقد نص في المـادة ه ؟ ؛ مر افعـات علـي أنـه " يمكن لأي مـن الخصوم استتلام نسخة مـن الحكم مـزودة بالصيغة التنفيذية". كما نصت المادة 7 الت 11 مدني فرنسي علي حق الدائن في ممارسة كل الإجراعات التي تمكنه من الحصول علـي حقهه في مواجـه المدين

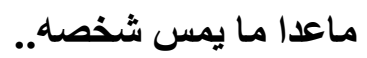

وتثبت الصفة للمدين في السند التنفيذي، وهو مـا يطلق عليه صساحب الصفة السلبية في التنفيذ، وهو الثخص الواجب التنفيذ في مواجتهـ، كما لاحظنـا أن أطراف التنفيذ ينـدرج فيهم مـن حل قانونـا أو اتفاقـا محل أطراف السند التنفيذي، كـالخلف 
r- لقد توصلنا من خلال هذا البحث إلي أن الغير يقوم بـور في اجراءات التنفيذ الجبري، ويتمثل ذلك في الادلاء بمعلومات كما في حالة التقرير بما في الذمة في حجز ما للمدين لاي الغير، وكذلك القيام بدور في المحافظة علي المـال، وكذلك المساهمة في تسيير اجراعات التنفيذ الجبري.

ـ ـ ونلاحظ في هذا البحث أن المشرع المصري والفرنسي شرعوا في حمايـة للغير أثناء التنفيذ الجبري، ويتمثل ذلك في الآتي: أ - المهاية الغير في هواجهة السند التنفيذ:

نظم المشرع المصري والمشرع الفرنسي اجراءات طعن الغير علي الحكم القضائي، وذلك كوسيلة ضرورية لحماية حقوق الغير من الاثار الضارة التي تلحق

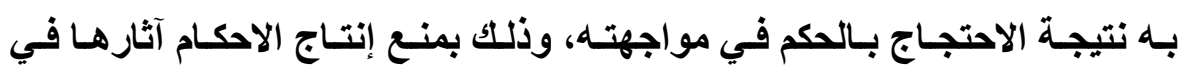
مواجهة الغير. وإذا كـان المشرعين المصري والفرنسي قد اهتمـا بحق الغير في الطعن في الأحكام، إلا أنهمـا اختلفـا في وسيلة هذا الاعتراض، فقد أجـاز المشرع la الفرنسي للغير الاعتراض علي الحكم بطريق خاص للغير، يسمي هذا الطعن (tiers opposition ( مr م ه مرافعات). أما المشرع المصري فقد مكن الغير من الطعن بالتمـاس اعـادة

\section{ب- حماية الغير في هواجهة إجراءات التنفيذ:}

نظم المشرعين المـصري والفرنسـي قواعد تهدف الـي حمايـة الغير اثنـاء

اجراءات التنفيذ الجبري، وتتمثل في حق الغير في الاشكال في التنفيذ الجبري، وحقه في رفع دعوي الاسترداد إذا تم الحجز علي منقولات ملكك الغير، وحقه في 
رفع دعوي الاستحقاق إذا حجز علـي عقـار خـاص بـالغير، وحقه في الاعتراض علي قائمة شروط البيع، إذا أثر التنفيذ علي العقار بحقوقه، وحق الغير في رفع دعوي بطلان ضد حكم ايقاع البيع.

وإذا كان يجب علي الغير أن يبني منازعته في التنفيذ علي أسباب لاحقه لوجود السند التنفيذي، إلا أنه استثناء من ذلك يجوز للغير أن يستند في منازعته إلى أسباب سابقة علي صدور السند متى كان السند التنفيذي منعدما بالنسبة له. كما يمكن للغير أن يجمع بين الطعن في الحكم بالتماس إعادة النظر وبين رفع الإثكال أمام قاضي التتفيذ، لأنه لا يجد ما يمنع من ذلك قانونا.

كما يمكن للغير مدعي ملكية المنقول المحجوز عليه أو أي حق يتعلق بها، رفع دعوي الاسترداد، ولا ينفي ذلك حقه في رفع إثكال وقتي في التنفيذ، وكذلك جواز الجمع بين الطريقين في وقت واحد، خاصـة إذا لـ يكن قد رفع دعوي الاسترداد أولا، فيحق لـه رفع الاشكال ثم رفع دعوي الاسترداد، أو كانت الدعوي قد فقدت آثارهـا الواقف للتنفيذ.

ونلاحظ في هذا البحث أنـه إذا كـان القـانون اعترف للغير بحمايـة حقوقه أثنـاء التنفيذ إلا أنه حمي أطراف التنفيذ أيضًا في مواجهة الغير، ويتمثل ذلك في الآتي: أ - جواز التنفيذ علي هال هملكك للغير، وذلك في حالتين:

الحالة الأولي: الحجز علي المنقولات المملوكة للغير الموجودة بـالعين المؤجرة من أجل دين الاجرة، بشرط عدم علم المؤجر وقت دخول المنقولات العين المؤجرة بملكية الغير لها. 
الحالة الثانية: الحجز علي المنقولات المملوكة للغير الموجودة بالفندق، بشرط ألا يكون صاحب الفندق علي علم بملكية الغير لها.

\section{ب- هسئولية الغير في هواجهة اطراف التنفيذ:}

إذا قام الغير أثناء التنفيذ بعمل يضر أطراف التنفيذ كان لهم الحق في التعويض في مواجهته، فإذا اخل الغير المحجوز لايسه عن الإدلاء بحقيقة التقرير بمـا في الأمـة، فأنه يلتزم بحق الأئن في أمواله الخاصة، وذلتك برفع عليه دعوي الإلزام الثخصي، ويلتزم المحجوز لديه بمصاريف الدعوي والتعويض المترتبة علي تقصيره أو تأخيره. كما يجوز لأطراف التفيذ أن يرفعوا دعوي مسئولية عن الإشكال الكيدي، وذلك طبقا لنص المادة ^^1 مر افعات، يجوز للقاضسي في حالة الإشكال الكيدي أن يحكم بتغريم المستشكل.

\section{ثانيا: الاقتراحات المتعلقة بالبمث:}

ا - في الواقع لم ينص المشرع المصري علي معيار محدد للغير في التنفيذ الجبري، وقد قصر الفقه معنس الغير علـي من يلزمسه القانون بالاشتراك في إجراءات التنفيذ دون أن يكون من طرفي التنفيذ، والواقع أن هذا الرأي قاصر، حيث إن معني الغير يشمل أيضا أي شخص أجنبي عن التنفيذ، وقد تدخل في إجراءات التنفيذ بإرادته الخاصة، وذلك دفاعا عن حقوقه، لذا نقترح أن يكون معيار الغير في التنفيذ الجبري، وبصفة عامـة يتحدد الغير بطريقة سلبيه، حيث أنـه ليس طرفا في الحق في التففي، ولا تعود عليه فائدة من السند التفيذي، ولا مسئولا عن الحق الثابت في السند، وقد يكون الغير ملزما بالاشتراك في التنفيذ، وينـاء 
علي ذلك ينقسم الغير في التنفيذ الجبري إلى نوعين: الغير الأجنبي عن التنفيذ،

$$
\text { والغير الطرف في الإجراءات. }
$$

ץ- يلاحظ أن المشرع المصري لم يورد نصا عاما لتحديد صاحب الصفة في السند التنفيذي، في مختلف السندات، وإنما يوجد نص خاص بالأحكام باعتبارهـا أهم صور تلك السندات ويمكن حمله إلى سائر تلك الصور الاخرى من السندات. ب- ونظرا لما قد يصيب الغير من ضرر نتيجة لحكم لم يكن طرفا فيه تبدو ضرورة حمايته من آثار السند التنفيذي، عن طريق تمكينه من الاعتراض الغير علي فرني الحكم بطريق خاص به، لذا نري ضرورة العود إلى طريق لحماية الغير متمثّلا في الاعتراض الخارج عن الخصومة. وضرورة بسط الاعتراض لكل من لـه مصلحة، ولا يجوز قصره علي بعض الغير وترك الأخرين كما كان منصوصا عليه في المادة . ه ؛ مرافعات ملغي. وهذا ما قرره المشرع الفرنسي في قانون

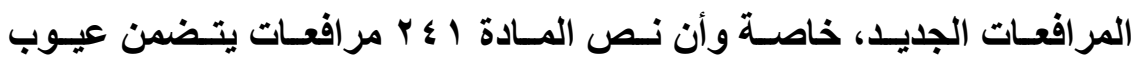

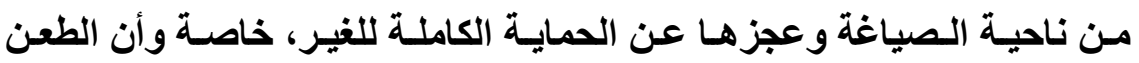
بالالتمساس لا يكون إلا بالنسبة للأحكام الانتهائية، وهو مـا قد لا يكون متحققا

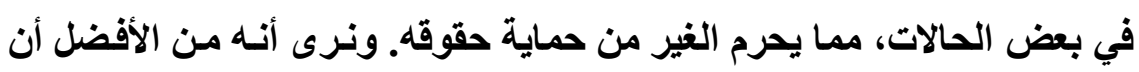

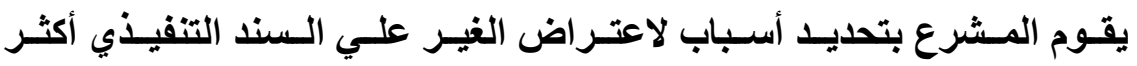

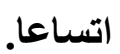
ع - لم ينص المشرع علي أحكام المسئولية المدنية للحاجز في حالة التنفيذ علي

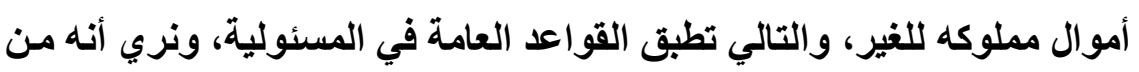
الافضل النص علي قواعد خاصة تحكم مسئولية اطراف التنفيذ في حالة الحجز 
علي مال مملوكه للغير، وجعل الاختصاص بنظر هذه المسئولية لقاضي التنفيذ، ويجب تثديد العقاب علي الدائن خاصة إذا كان سئ النية. ه- نظرا لأن طعن الغير في الحكم القضائي لا يوقف التنفيـذ إلا إذا طلبهـ وحكم القاضي بالوقف، ونقترح أن يترتب علي اعتراض الغير علي الحكم، وقف تنفيذ إلا إذا حكم القاضي بالاستمرار في التنفيذ، وذلك تحقيقا لمصلحة الغير، حيث أن فكرة وقف التنفيذ تقوم بدور وقائي ضد مخاطر الخضوع أو استمرار الخضوع لتنفيذ، معرض للإلغاء، وبالتالي ضد مخاطر استحالة إعـادة الحسال إلى مـا كـان عليه، فالحل الذي يجب تنظيمه في القانون- وإن لم يوجد فيجب إيجاده وتقنيهـ هو حل يجب أن يتضمن خصيتين: أولهمـا: تمكين الغير من الاعتراض علي التنفيذ، وطلب الغاءه سواء كان التفيذ علي عقار أو منقول أو تنفيذ عينـي أو بطريق الحجز. وثانيهما أن يكون حلا وقائيا يستهذف بصفة أصلية منع التنفيذ القابل للإلغــاء مـن أن يبـأ أو أن يستمر، وبـصفة احتياطيـة منـع إتمامـه، إذ لا يظهر مخاطر الخضوع لتتفيذ معرض للإلغاء علي نحو حـاد إلا عند إتمـام هذا التنفيذ عـادة، خاصـة علـي أمسوال غيـر مملوكـه للمـدين، حيث أنسه في كثير من الاحوال يصعب اعادة الحال إلى ما كان عليه، ويكون ذلك عن طريق ترتيب الاثر الواقف للتنفيذ بقـوة القـانون إذا اعتـرض الغيـر علـي الحكم القضائي بطريق التماس إعادة النظر. وهذا أمر منطقي حيث لا يوجد ما يدعو لغير ذلكليتبين لنا ما ولقف التنفيذ من وقت رفع الاعتر اض من أهمية بالغة وضرورة

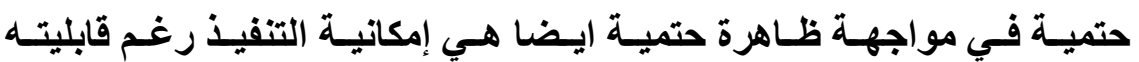

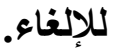


צ- في الواقع نلاحظ أن الحول التي نص المشرع عليها لحماية الغير بالإضافة إلى

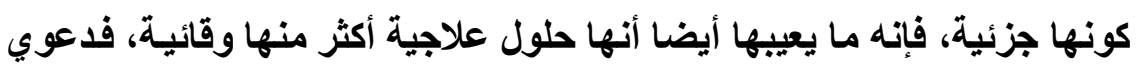
الاستحقاق لا يترتب عليها وقف التنفيذ بقوة القانون. ووقف التنفيذ المترتب علي رفع دعوي الاسترداد، لا تحول مطلقا دون التنفيذ و إتمامسه، حيث يمكن الغاء هذا الاثر، فإذا ما تم إلغاءه بعد ذلك وحكم للغير بالملكية، يصعب اصلاح الضرر الذي يصيب الغير، خاصة عذما يترتب علي التنفيذ استحالة إعادة الحال

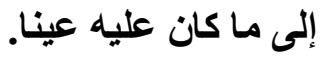
والذي يهمنا إبرازه هو باختصار مدي صلاحية فكرة وقف التنفيذ في ذاتها للوقاية من أضرار الخضوع لتنفيذ بالنسبة للغير، ومدي ملاعمتها للعمل مع طرق التنفيذ المختلفة واسباب الإلغاء المتعددة. إذ يراودنا الأمل في أن نجد في لهي هذه الفكرة الحل المثالي المنشود وهو الذي يجمع بين الشمولية والوقائية، حيث نقترح أن يترتب علي منازعة الغير في التنفيذ، وقف التنفيذ الجبري بقوة القانون بصرف النظر عن طريق التنفيذ، ومع منح القاضي سلطة تقديريه في في الحكم بالاستمرار في التنفيذ الجبري إذا كانت مزاعم الغير كايديه، ومع الزامـه بالتعويض إن كان له وجه،، وذلك مراعاة لأطراف التنفيذ الجبري.

V- و الواقع يلاحظ أن الجزاء الذي نصت عليه المادة ب ا ب والذي يتمثل بعدم قبول الاشكال لإصرار الغير علي عدم اختصام المدين الملتزم في السند جوازيـا للقاضي، ولم يرتب المشرع كافة النتائج المترتبة علي التعدد الاجباري بالمغني الدقيق، فنري أن ينص المشرع علي أن الجزاء الذي يترتب علي علم اختصام بعض من يجب اختصامهم ليس عدم القبول، وإنما يجب الحكم بالاستمرار في لئ التنفيذ بناء علي طلب الحاجز. 
ولا شك في خطورة الجزاء الذي أورده المشرع عند عدم اختصام أحد الحاجزين خاصة وأنه ليس للغير الوسيلة التي تمكنه أن يتعرف علي كافة الحاجزين، إذ يمكن أن يترتب علي هذا الجزاء أن يستمر التنفي، ويتم البيع ثم يتبين بعد ذلك أن المسترد كان علي حق، ولكنه لن يتمكن من استرداد المنقول بعد أن وقع في يا مشتر بالمزاد حسن النية. ( مما يزيد في خطورة المادة ؛ ؟ ب مرافعات النص علي عدم الطعن في الحكم الصـادر بالاستمرار في التتفيذ، فضلا عن أنها ليس للقاضي سلطة تقديرية في الحكم بالجزاء أو عدم الحكم به، فالحكم هناوجوبي). لذلك يجب البحث عن وسيلة قانونية لتلافي مثل هذا الجزاء، ومن المتصور أن يتجه الذهن في هذه الحالة إلى نص المادة هـ 11 مرافعات والتي تعطي للقاضي سلطة تأجيل الدعوي لإعلان ذي الصفة إذا تبين له انتفاء صفه المدعي عليه، ولكن هذا الحل لا يمكن إعماله وقد أتت المادة ؛ ج ب بجزعا خاص.

1- ونلاحظ أن التشريعات الحديثة تتجه إلى مساعدة الدائن في البحث عن أموال المدين، تحت يد أي شخص، وذلك بإجراءات مختصره تحافظ علي حقوق الغير والدائن معا، وتمكين المدين والغير من التظلم من هذه الإجراءات، فنقترح أن ينشئ المشرع نيابة مدنية لمساعد الدائن في تحديد اموال مدينه وتدير إجراعات التنفيذ الجبري وحتي لا يحجز علي أموال مملوكه للغير.

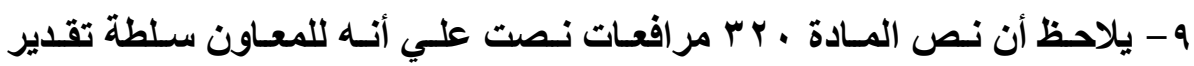
في مـدي قبول الاشـكال لأنـه يملـك تقدير شـروط قبـول الاشـكال المقدم اليـه، ونري أنه يجب ضبط صياغة هذه المسادة بحيث لا تتضمن أي سلطة التقديريـة

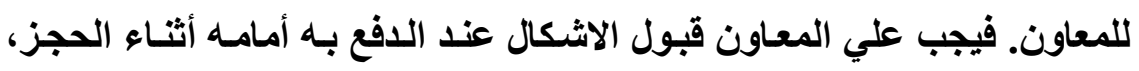


ولا يكون لـه سـلطة تقديريـه في ذلـك، وذلـك لأن هـا مـن اختصاص قاضسي

• 1 - نص قانون المرافعات علي أن الأشكال الذي يثيره الملتزم في السند التنفيذي لأول مره يوقف التنفيذ إذا لـم يكون قد اختصم في الأشكال اول المقدم من الغير، وذلك علي أسـاس سـد بـاب التحايل الذي كشف عنـه الواقع العملي، وهذه الضمانة تهذف إلي حماية مصلحة الملتزم في السند التنفيذي، غير أن السند قد يكون الملتزم فيه شخص وينفذ ضد شخص آخر، لذلك يجب تعديل النص بحيث يلغي عبارة الملتزم في السند ويحل محلها عبارة المنفذ ضده دفعـا للتواطؤ الذي قد يحدث بـين دائن وشـخص أخر عن طريـق اصطناع خصومة للإضرار بالمنفذ ضده.

يلاحظ أن الحكم الصادر من المحكمة التنفيذ بالاستمرار في التنفيذ في حالـة تقديم طلب بالاستمرار في التنفيذ من صاحب المصلحة في حالة رفع دعوي استرداد لا يقبل الطعن عليه بأي طريق من طرق الطعن، أمـا الحكم الصادر برفض الاستمرار في التنفيذ فإنه يقبل الطعن وفقا للقواعد العامة. و نري أن المشرع لم يساوي بين أطراف الاعوي حيث كان من الواجب أن يكون الحكم الصادر من قاضي التنفيذ يقبل الطعن في كافـة الحسالات، سـواء كـان صـادرا بـرفض وقـف التنفيــ أو بقبـول الاسـتمرار فـي 


\section{قائمة المراجع}

\section{أولا: المراجعة باللغة العربية:}

\section{أ- المؤلفات العاهة:}

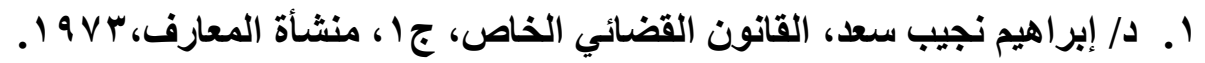

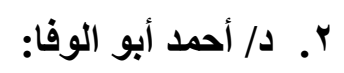

• إجراعات التنفيذ بمقتضي قانون أصول المحاكمـات اللبنـاني الجديد، طس، مكتبة

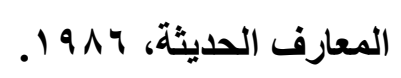

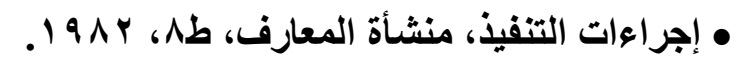

• المرافعات المدنية والتجارية، منشأة المعارف، ط؛ ا، 919 1 ـ r. د/ أحمد السيد صاوي، الوسيط في شرح قانون المرافعات المدنية والتجاريـة، دار

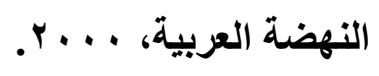

؛. د/ احمد السيد صاوي، د/ اسامة أحمد شوقي المليجي، الإجراءات المدنية للتنفيذ

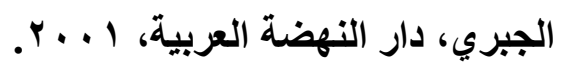

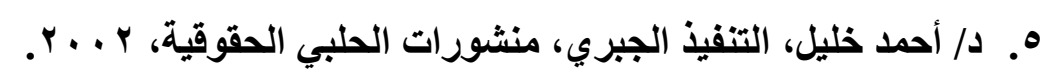

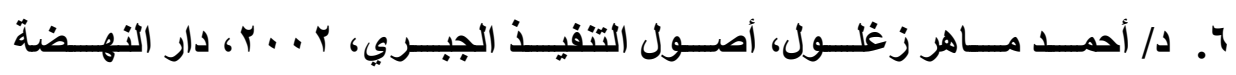

العربية. 


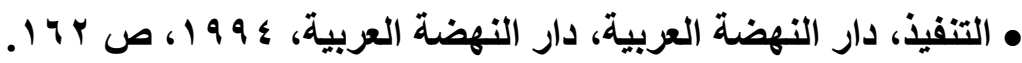

• الموسـوعة الشـاملة في التنفيذ، طه، المركز القـومي للإصـدارات القانونيـة،

$$
r . .1
$$

• الموسـوعة الشـاملة في التعليق علـي قانون المرافعـات، طبعة نـادي القضاة،

$$
r \ldots r
$$

^. د د/ أحمد هندي، ود/ أحمد خليل، قانون التتفيذ الجبري، دار المطبوعات الجامعية،

• أحكام التنفيذ الجبري وطرقه، منشأة المعارف، طץ، I9VI I I • قوانين المرافعات، الكتاب الثالث، منشأة المعارف، بدون سنة نشر. • أنور طلبة، موسوعة المرافعات المدنية والتجاريـة، دار الكتب القانونية، ج\،

• الوسـيط فــي شـرح قـانون المرافعـات المدنيـة والتجاريـة، طو، دار النهـضة

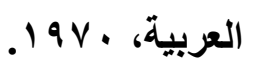

• قواعد تنفيذ الاحكام والعقود الرسمية في قانون المرافعات الجديد، طه، مطبعة دار نشر الثقافة، . 199 
1 |.د/ سليمان مرقس، شرح القانون المدني، ج1، الالتزامات، ؛ 9 ا 19

r ا.د/ سيد أحمد محمود، أصول التنفيذ الجبري، دار الفكر والقانون، ؟ . . . . r ا .د/ سيد أحمد محمود، ود/ يوسف يوسف أبو زيد، التقاضي بقضية وبدون قضية في المواد المدنية والتجارية، و . . . ب، بلون دار نشر.

؟ 1 ـد/ طلعت محمد دويدار، طرق التنفيذ القضائي، منشأة المعارف، ؛ 9 أ.

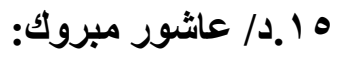

• الوسيط في التنفيذ، دار النهضة العربية، ع . . . .

• الوسيط في قانون القضاء المصري، مكتبة الجلاء بالمنصورة، طץ، . . . . .

1 ا.د/عبد الباسط جميعي، د/ امسال الفزايري، التنفيذ في المواد المدنية والتجاريـة،

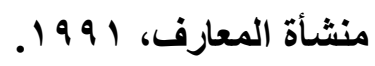

V . ا / عبد الحميد أبو هيف، المرافعات المدنية والتجارية والنظام القضائي في مصر،

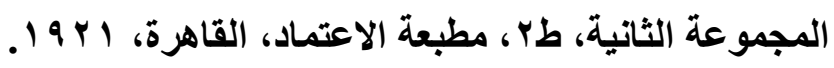

1 ا.د/ عبــ العزيـز خليـل بـديوي، الـوجيز في قواعـــ وإجـراعات التنفيـذ الجبـري

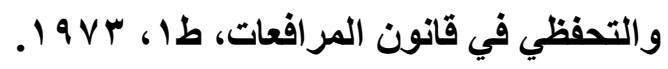

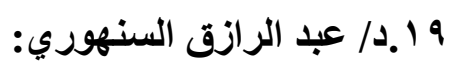

• الوسيط في شرح القانون المدني، 1، مصادر الالتزام، ؛ 9 ا 19

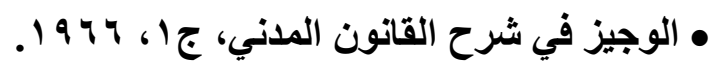

• الوسيط في شرح القانون المدني، جr، الإثبات، ط ب 9 ا ـ . 
• الوجيز في المرافعات المدنية والتجارية، مكتبة التهضة المصرية، ؛ 9 أ، ص . 570

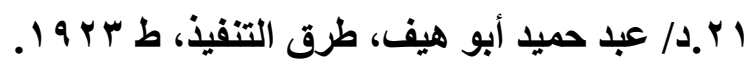
r r. عز الدين الدناصوري، حامد عكاز، التعليق علي قانون المرافعات، طا |، بدون دار نشر، بدون سنة نشر.

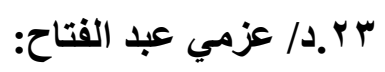
• قانون القضاء المدني المصري، دار النهضة العربية، طه، ه9 9 1.

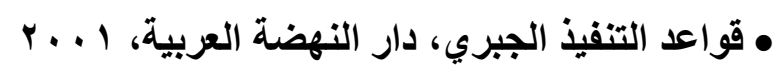

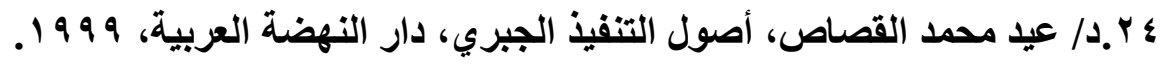

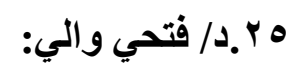

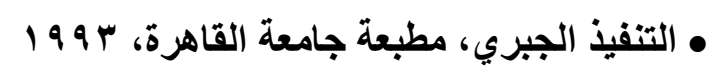

• الوسيط في قانون القضاء المدني، مطبعة جامعة القاهرة، 999 19.

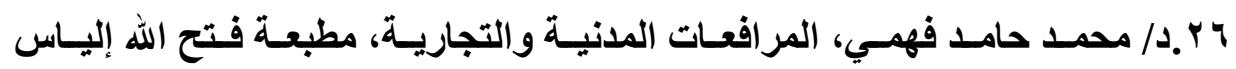

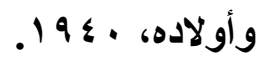

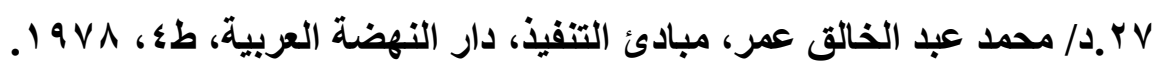




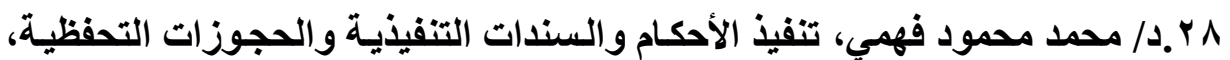

$$
\text { طب، دار النشر للجامعات المصرية. }
$$

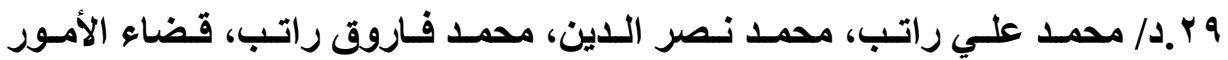

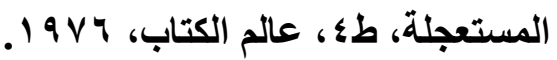

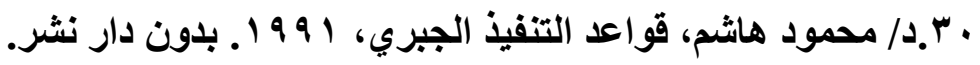

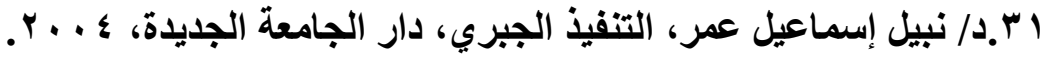

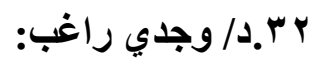

• النظرية العامة للتفيذ القضائي، طץ، ب Y Y I، بدون دار نشر.

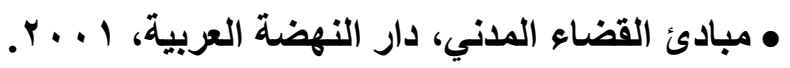

\section{ب- المراجع المتخصصة والرسائل:}

r r.د/ إبراهيم أمين النفياوي، مسئولية الخصم عن الإجراءات، رسـالة، جامعة عين

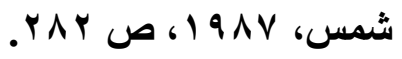

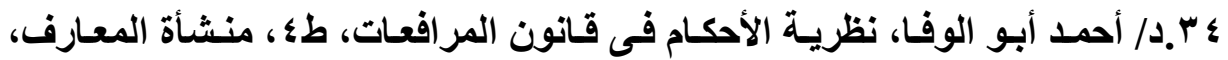

$$
191 \text {. }
$$

هـ ـد/ أحمد السبد صاوي، أثز الأحكام بالنسبة للغير، دار النهضة العربية، بدون سنة

$$
\text { نشر. }
$$

צr.د/ أحمد هندي، الصفة في التنفيذ، دار الجامعة الجديدة، .. . . .

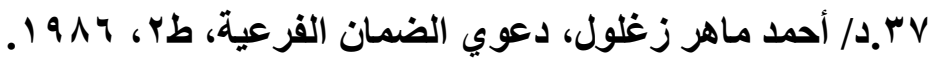


^ ץ.د/ بشندي عبدالعظيم أحمد، حمايـة الغير في قـانون مرافعـات، رسـالة، القـاهرة،

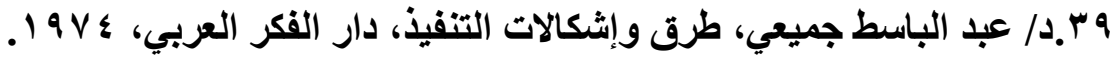
• ـ ـد/ عبد الحميـ الشواربي، حجيـة الأحكـام المدنيـة والجنائيـة، منشـأة المعسارف، $.1 \leqslant 1$ ص 61919

1؛ .د/ عبد الحكم أحمد شرف، نطاق دعوي استرداد المنقولات المحجوزة وآثارهـا،

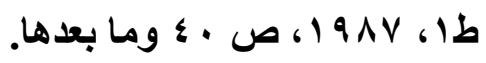
ץ § ـد/عبد المنعم حسني، منازعات التنفيذ، 999 19، بدون دار نشر.

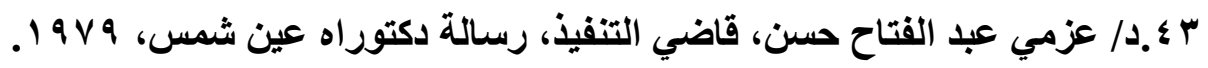
؟ ؛ .د/ عبد الباسط جميعي، الإسـاءة في التقاضسي وفي التنفيذ، خلاصـة محاضرات ألقاها في مصر علي طلبة دبلوم القانون الخـاص، دبلوم القانون المقارن، كلية

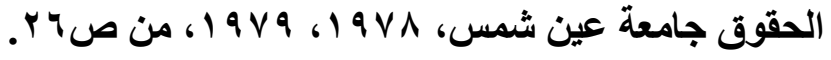
ه ؛ عز الدين الدناصوري وحامد عكاز، القضاء المستعجل وقضاء التتفيذ في ضوء

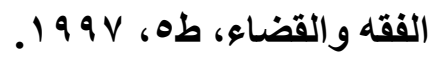

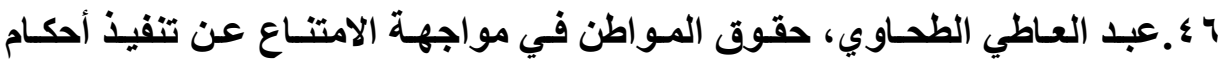

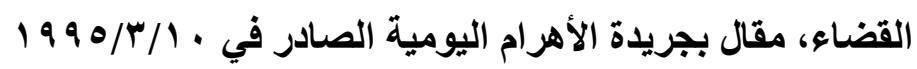

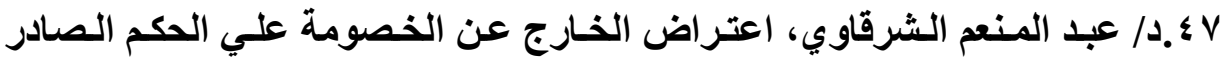
فيها، مجلة القانون والاقتصاد، س 9 ا، العددان الأول والثاني، مـارس و يونيه

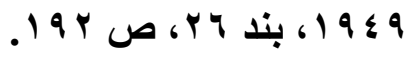


د/ طلعت يوسف خاطر

العدد rا7 ( أغسطس r.lY )

1 ؛ ـم/ محمود محمود الطناحي، دعوي استرداد المنقولات المحجوز عليها، دار الفكر

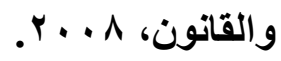

9 ؛ .محمود مصطفي عثمان يونس، النظام القانوني للحجز التحفظي، دارسـة تأصيلية

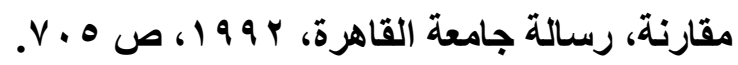

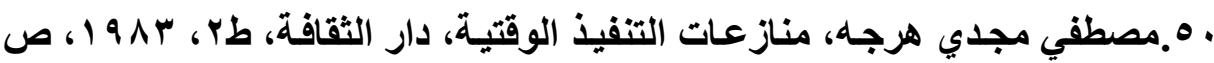

VMI

$$
\text { (1.01 }
$$

$$
\text { • الطعن بالاستئناف وإجراع|ته، منشأة المعارف، } 1 \text {. . ؟ . }
$$

• الوسيط في الطعن بالتماس إعادة النظر، دار الجامعة الجديدة، . . . ؟ .

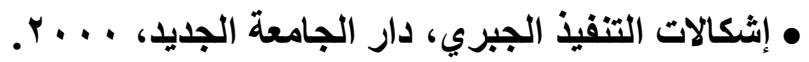

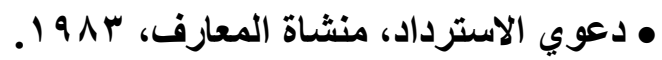

\section{ثانيا: المراجع بالاغة الفرنسية:}

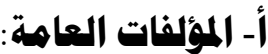

1. Aubry et Rau, Cours de droit civil français, T, XII, 5 ed, Paris, 1922.

2. Beudant $\mathrm{Ch}$., le droit civile français, $\mathbf{T} 10,5 \mathrm{ed}$.

3. Bonnier, traite théorique et pratique des preuves en droit civile et criminel, t2, 3e éd., paris, 1862. 
د/ طلعت يوسف خاطر

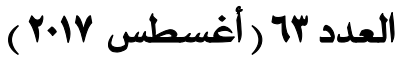

4. Bonnecase J. et M. Larborde, lacost, précis élémentaire de procédure civile et voies d'exécution, siry, 1932.

5. Boitard, leçons de procédure civile, paris, 1890 .

6. Carre G. et Chauveau A, Lois procédure civile et commercial, t3, et 4, 5ed, 1880 .

7. Debbasch Charels, Procedure administrative contentieuse et procedure civile, $1962, n^{\circ} 144$.

8. Garsonnet E et Cezar-Bru CH, traite théorique et pratique de procédure civile et commerciale, 9 col, 3 ed, siry, 1912, t. $6, n^{\circ} 545$ p. 907 .

9. GARSONNET E et DESS ERTEUX M., traite de procedure civile et commercial, dijon, 1926, T 3.

10. Glasson $E$, tissier $A$, et morel $R$, traite théorique et pratique de l'organisation judiciaire, de compétence et de procédure civile, 3ed, sirey, 1925-1036, t3.

11. GUINCHARD S. et MOUSSA T., droit et pratique des voies d'exécution, D. 2004.

12. Laurent, principes de droit civile français, $T, X X, 3$ ed., Paris, 1878. 
د/ طلعت يوسف خاطر

العدد rا7 ( أغسطس r.lY )

13. Perrot R., Cours de droit judiciaire prive, fasc. 2, paris, p. 733.

14. Perrot $R$. et thery, saisie attribution, la situation du tiers saisi, D. 2001, chron, 714.

15. Tiddeier, note au Rev. Trim. Civ. 1906, p. 644.

16. Vincent J., voies d'exécution et procédures de distribution, D., 19 éd, 1999.

17. Vincent J.et j. PREVAULT, voies d'exécution et procédures de distribution, 17 éd., D., 1993.

18. Vincent J. et s. Guinchard, procédure civile, D., 26 éd., 2001.

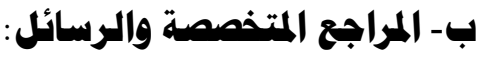

19. Chevet $M$, de la représentation en justice (droit romain) des personnes qui peuvent intervenir ou former tierce opposition, thèse paris, 1892.

20. CUNNY G., des tiers, thèse Nancy, 1889, p. 20,

21. Constantin Melinesco, Etude sur l'autorité de la chose jugée en matière civile, these, Paris, 1913, p. 106. 
د/ طلعت يوسف خاطر

العدد rا7 ( أغسطس r.lY )

22. Costes $M$, de la protection des droit de tiers spécialement devant le juge de referee, RTD, civ, 1924.

23. Coutant R., des créanciers chirographaires considères comme tiers, thèse Paris, 1906.

24. Dedessus-le-Moustier, I obligation de renseignement du tiers saisi dans la saisie attribution, JCP, 1998.

25. FRICERO N., "tierce opposition", ency. D. Rep. proc. Civ., 2e ed. T. 3.

26. Foyer J., De l'autorité de la chose juge en matière civile essai de l'une définition, thèse, 1954.

27. Griolet, L'autorité de la chose jugée en matière civile et en matière criminelle, Paris.

28. Lacoste paul, De la chose jugee en matrière civile, criminelle et administrative, 3e ed., sirey, 1914.

29. Madec P.D., L'autorité de la juge jugée et l'assureur en matière civile, thèse Rennes 1976.

30. M. AUSSEL J., essai sur la notion de tiers en droit civile français, thèse Montpellier, 1951. 
د/ طلعت يوسف خاطر

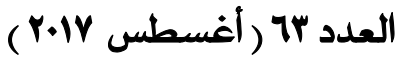

31. MOTULSKY H., Le droit naturel dans la pratique jurisprudentielle, le respect des droits de la défense, mélanges ROUBIER, 1961, T2.

32. Perrot Roger, "Autorité de la chose jugée au civile sur le civil", Juris classeur de procedure civile, fasc. A.C. proc.

33. ROLIN, chose jugée et tierce opposition, these., 2011.

34. Rrolond H., «chose jugée et tiers opposition», thèse Lyon, LGDJ, 1958.

35. Tissier A., théorie et pratique de la tierce opposition, thèse paris, 1889.

36. Tostivint $\mathrm{R}$, «de la tiers opposition aux décision émanant des tribunaux ordinaires», thèse, Rennes, 1905.

37. VIDAL J., essai d'une théorie générale de la fraude en droit français, D., 1957, préface G. marty.

38. Zarzycki J., De la demande en justice, Thèse, Caen, 1937. 